



Digitized by the Internet Archive in 2010 
DEPARTMENT OF AGRICULTURE.

SPECIAL REPORT-No. 12.

\title{
INVESTIGA'TION
}

Or

\section{DISEASES OF SWINE,}

AND

\section{INFECTIOUS AND CONTAGIOUS DISEASES}

\author{
INCIDENT TO
}

OTHER CLASSES OF DOMESTICATED ANIMALS. 


\section{FORTY-SLITH CONGRESS, FIRST SESSION.}

Resolved by the House of Representatives (the Senate concurring therein), That there bo printed 100,000 copies of Special Report No. 12 of the Commissioner of Agriculture, containing the reports of the examiners appointed to iurestigate the diseases of swino and contagious and infectious diseases incident to other classes of domesticated animals, of which 70,000 copies shall be printed for the use of members of the House, 25,000 for the use of members of the Senate, and 5,000 copies for the use of the Commissioner of Agriculture, 


\section{TABLE OF CONTENTS.}

Investigation of Swine-Plague-Introductory .................... Page.

Report of Dr. Detmers.......................................... 19

Report of Dr. Law ............................................... 56

Report of Dr. Voyles ........................................ 112

Report of Dr. Salmon ......................................... 123

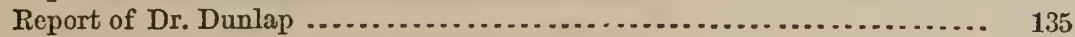

Report of Dr. Dyer............................................. 156

Report of Dr. Payne............................................ 165

Report of Dr. McNutt....................................... 173

Report of Dr. Hines ........................................ 177

Correspondence showing the prevalence of diseases among domesticated ani-

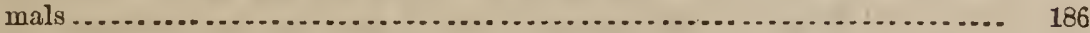

Correspondenco relating to tho moro common diseases affocting farm animals.. 211 Pleuro-pneumonia or contagious lung fever of cattle...................... 219

A strange disease among cattle in North Carolina....................... 253

Rinderpest, or Cattle Plague........................................ 255

Glanders............................................................ 257 


\section{LIST OF ILLUSTRATIONS.}

SwLie Plague.-Plate

Plato

Plate

Plate

Plate

Plate

Plato

Plite

1. Right lung (half-size) of experimental pig, No.

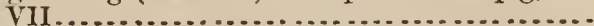

II. Enlarged section of right lung of same pig......

III. Ulcerous tumors on mucous membrane of intes-

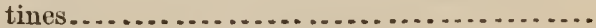

Plato IX. Fig. 1. Microscopic section through skiu and slough. Fig. 2. Microscopic section of skin in

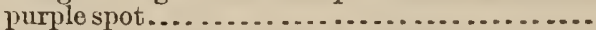

Plate X. Microseopic section showing exudation in the cxeal mucous membrane beneath an ulcer....

Microscopic seetion through skin, showing hair follielo containing etfused blood. 'The bristlo was detached in mounting ...................

Plate XI. Microscopic section of lung with exudato filling the air-cells, and thickening the alveolar walls.

Microscopic section of congested gut, showing villi with excess of gramular matter, stained iu hiematoxylon. Detached round cells.........

Plate XII. Microscopic section of lumg, showing thickened walls of air-cells; blocked resscls; exudate into cell-walls, and a few of the cells.........

Microscopic section from ear, showing cartilage and skin with broken surface, and crustentangling bristles.......................

Plate XIII. Forms assumed in rapid succession by bacterium; also head and tail of lung rorm .............

Plate XIV. Ora, hooks, and head and tail of lumg worms...

Plato XV. Fic. 1. Microscopic section of discased liver. Fig. 2. Microscopic section of lung in catarthal pueumonia. Fig 3. Microscopic section of intestino in "hog-cholera," showing healthy condition .................................

Glanders.-Plate I, Fig. I. Development of glanders-cells of comnective-tissue corpuscles in tho mucous membrane of the septum. Fig. II. Microseopic cut from gray-yellowish glanders. Fig. III. Development of glanderscells of cpithelium elements in the pnlmonal no-

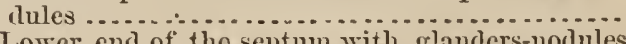

Plate II. Fig. IV. Lower end of tho septum with glanders-nodules aud ulcers (uatural size). Fig. V. Transiersal membrane of the septum (vatural sizo). Figr. VI. Piece of the lower border of a lung, cut surfice (natural sizo). l'ig. VII. Also a piece of tho lower border of a lung, cut surface (natural size) .... 


\section{INVESTIGATION OF SWINE PLAGUE.}

\section{INTRODUCTORY.}

Congress having previously appropriated the sum of $\$ 10,000$ for defrafing the expenses of a commission to investigate and determine the causes producing, and, if possible, discover remedies for, some of the more contagious and destructive diseases incident to domesticated animals, early in August last the Commissioner of Agriculture appointed examiners in the States of New York, Indiana, Illinois, Iowa, Kansas, Nissouri, and North Carolina, to concluct such investigation. Still later in the season, on receiving information that not only diseases among: swine were prevailing to an alarming extent in Virginia, but that a fatal disease resembling pleuro-pneumonia or contagious lung fever was destroying a good many valuable dairy cattle in some localities of that State, an additional examiner was appointed and instructed to investigate and report upon all the facts connected with the condition of both classes of animals in the infected districts of this State.

In the preliminary report of the Commissioner of Agriculture for 1877 , on the subject of diseases of domesticated animals, a tabular statement gives the total value of farm animals lost in the United States during that year, principally from infectious and contagious diseases, at $\$ 16,653,428$. These losses were based upon as accurate returns as could be obtained in the absence of an absolute census, but as they included data from but eleven hundred and twenty-fire counties (about one-half the whole number of counties in the United States), the above sum falls far below the aggregate losses for that year. About two-thirds of this sum was occasioned by the loss of swine by diseases presumed to be of an infectious and contagious character. Notwithstanding these maladies had their origin near a quarter of a century ago, and had rapidly spread from one State and one county to another, there was great diversity of opinion as to their contagious or non-contagious character. Many intelligent farmers and stock-growers insisted that they were not transmissible from one animal to another, while perhaps equally as large a number contended that the diseases were of a highly infectious and contagious nature. As this was regarded as one among the most important facts to be determined by the investigation, two of the examiners devoted most of their time to experiments looking to a solution of this problem.

As the number and value of the ammual losses among swine were much heavier than among all other classes of domesticated animals com- 
bined, the Commissioner deemed it best to devote the greater portion of the linited smm placed at his disposal to an investigation of the fatal diseases aflecting this class of farm animals.

The preliminary investigation instituted and conducted under the smpervision of this department, in the fall and winter of $187 i-78$, established the fact that diseases prevail amoug these animals much more extensirely dming the late summer and early fall months than at other seasons of the year, and for this reason the examiner's selected to conduct the investigation were emplosed for periods ranging from one to three months. It was assumed, and the subsequent listory of the disease prover the assumption to be well founded, that the reduced temperature of the late fall aud early winter months would cause an abatement of the disease, and in a measure deprire the examiners of subjects with which to eontinue their experiments. While, therefore, the rery severe weather of the past winter cansed a great rednction in the number of animals affected, the disease was not cradicated, nor did its fatality seem to be lessened. The sinear of the infeetion from one herd to another was greatly diminished; but, in infected lierds, where the malady was still prevailing when cold weather set in, there appeared but little difference in the rapidity of the transmission of the disease, from one animal to another, in the same herl. Dr. H. J. Detmers, V. S., of Chieago, who conducted his inrestigations and made his experiments in one of the worst infected of the many large hog-growing districts in Illinois, writing under date of Jamnary ith last, speaks as follows of the effects of severe frosts on the spread of the disease:

Since my last letter the weather has continued extremely cold. Wirere I now am, in Leo County, some five or six miles west of Dixon, the thermometer indieated at seven o'clock on the morniug of January 2, $28^{\circ}$ below zero, aud on the next morning $24^{\circ}$ below zero. At present-to-lay, yesterday and day befor-tho weather is a little milher. To-day it tried to snow a little; oflerwise the sky has been elear erexy day. 'The wind is, and has been, west, except yesterday afteruoon, when it was almost due south. Swine-plagne anring this cold weather does mot seem to spread either so readily or so rapidly from one farm to auother as a few months ago; but as to its spreading from one animal to another in the same herd in which it previonsly ex. isted no difference can be observed. It seems to be just as fatal as in August, aud its course, on the whole, is probably more acute, as severe affections of the lungs and of the heart are nore frequent, a fact easily explained in the labits of swine crowding together and lying on top of each other in their sleeping places when the temperature is very low.

1)r. James Law, of Ithaca, N. I., whose investigations were solely confined to experiments intended to further establish the contagious and infections character of the disease, the period of its incubation, E.e., confirms the statement of Dr. Detmers, $i$. c., that the serere frosts of winter do not destroy the germs of the malady but simply retard their conreyance from one herd to another. In a letter of recent date, forwarled since his report was completed, Dr. Law says :

I have demonstraicd that the freezing of the virnlent matter does not destroy its activity, and that the virus loses nothing in poteney by preservation for one or two 
months closely packed in dry bran. The same may be inferred of all other sitnations when it is closely packed and where the air has imperfect access. These two last points are of immense importance as bearing on the question of the prescrvation of the poison in infected pens and rards alike in wiuter aud in summer, to say mothing of its possible converance in fodder, \&c. The different modes in which the disease may be conveyed in the wet and dry condition, and in the bodies of rabbits, and probably sheep and other animals, speak in the strongest terms against keeping up the production of the poison by preserving sick animals, unless where they can be secluded in thoronghly disinfected bnildings in which even the air sliall be constantly charged with disinfectants.

In most of the States in which investigations have been made, the examiners have found the symptoms and post-mortem appearances of the disease the same, and hence agree as to the propriety of designating the affection under the head of a general disorder. Dr. Detmers has, therefore, giren the disease the name of "Srine-plagne," and Dr. Law has named it "Hog-ferer." While either designation would seem to be eminently proper, that of "Srine-plague" will no donbt be geuerally adopted.

As in almost all general disorders, a certain rariety of organs were foumd affected and diseased. Marked clianges and extrarasations in various parts of the body rere observed, and inflammation of the lungs aud large intestines ras usually present. The heart, the pleura, the eyes, the epidermis, and many other important organs showed either slight or more serious affections, and in almost erery case tested with the thermometer the temperature was found to be above normal heat before any other symptom of the disease was in the least apparent. In every herd where the disease had prevailed to ans considerable extent, no case was found where death had occurred from a local malady, but all the lesions and appearances ummistakably indicated the existence of the general disorder. In but few cases was deatl found to have resulted from the affection of any single organ, but on the contrary seemed to hare been the result of the varions organic changes obserred.

Dr. Detmers says that the morbid process, although in all cases essentially the same, is not restricted to a single part or organ, or to a set of organs, bnt can have its seat almost anywhere-in the tissue of the lungs; in the pleura and pericardinm; in the heart; in the lymphatic system; in the peritoneum; in all mucous membranes, especially in those of the intestines; in the liver; in the spleen, and eren in the skin. Only the pulmonal tissue and lymphatic glands are invariably affected.

The most constant and unvarying symptom of the disease is observed in the increased temperature of the body. Indeed, one of the examiners regards it as highly probable that a high temperature may exist sereral reeks before other symptoms are manifested, and that the disease may in some cases eren be confined to and run its course in the blood without a localization in any other organ or organs. A fer isolated cases are noted where this symptom was lacking, but it may have been pres. ent in a mild form before other symptoms were obserred. The external 
symptoms of the disease, which rere found to be almost identical in all the widely-separated localities in which examinations were made, were a dullness of the eyes, the lids of which are kept nearer closed than in health, with an accumulation of secretion in the corners. There is hanging of the head, with lopped ears, and an inclination to hide in the litter and to lie on the belly and keep quiet. As the disease adrances, the animal manifests more or less thirst, some cough, and a pink blush or rose-colored spots, and papular eruption appears on the skin, particularly along the belly, inside of the thighs and fore legs, and abont the ears. There is accelerated respiration and circulation, increased action of the flanks in breathing, tucked-up abdomen, arched back, strelling of the vulva in the female as in heat; occasionalls, also, of the sheath of the male, los of appetite, and tenderness of the abdomen, sometimes persistent diarrhea, but generally obstinate coustipation. In some cases large abraded spots are observed at the projecting points of the body, caused by separation and loss of the epidermis. In such cases a slight blow or friction on the skin is sufficient to produce such abrasions. In many cases the eruption, blush, and spots are entirely absent; petechire are formed in only about one-third of the cases. In some cases there is considerable inflammation of and discharge from the eyes. Some animals emit a very offensive odor even before death. In large herds, where the disease prevails extensively, this offensive effuvia can be detected for a great distance to windward. In nearly all cases there is a rrealnuess or partial paralysis of the posterior extremities, and occasionally this paralysis is so complete in the first stages of the disease as toprevent walking or standing.

As symptoms of special diagnostic valne, which are scarcely erer absent in any case, the following are mentioned: Drooping of the ears and of the head; more or less conghing; dull look of the ejes; staring appearance of the coat of hair; partial or total want of appetite for food; vitiated appetite for excrements; rapid emaciation; great debility; weak and undecided, and frequently staggering, gait; great indifference to surroundings; tendency to lie down in a dark corner, and to hide the mose and even the whole head in the bedding; the specific offensire smell, and the peculiar color of the excrements. This last symptom is always present, at least in an adranced stage of the disease, no matter whether constipation or diarrhea is exisiting. Among other characteristic symptoms, which are not present in every animal, may be mentioned frequent sneezing; bleeding from the nose; swelling of the eyelids; accumulation of muens in the inner canthi of the eyes; attempts to romit, or real romiting; accelerated and difficult breathing; thumping or spasmodic contraction of the abdominal muscles (flanks), and a peculiar, faint, and hoarse voice in the last stages of the disease.

The duration of the disease varies according to the violence and seat of the attack and the age and constitution of the patient. Where the attack is riolent, and its principal seat is located in one of the vital 
organs-such as the heart-the disease frequently terminates fatally in a fer days, and sometimes even within twenty-four hours; but when the attack is of a mild character, and the heart is not serionsly affected, and the animal is naturally strong and vigorous, one or two weeks usually interrene before death ensues. If the termination is not fatal, comvalescence requires an equal and not unfrequently a much longer time. A perfect recovery seldom occurs; in most cases some lasting disorder remains behind and more or less interferes with the growth and fattening of the animal. Those that do recover make but very poor returns for the food consumed; hencè from a pecuniary standpoint it makes but little difference to the owner whether the animal recovers or not. The attack is always more violent and fatal when large numbers of animals are closely confined together in small and dirty inclosures or in illy rentilated and filthy pens.

The disease can have its seat in many different organs or parts of the body, and therefore produces a great variety of morbid changes. This accounts for its different aspect in different animals. In some cases the principal seat of the disease may be in the organs of respiration and circulation, and in others in the intestinal canal and organs of digestion. Death may therefore be the result of different canses in different cases. In some cases it results from a cessation of the functions of the heart, the lungs, \&e., and in others it is in consequence of the inability of entirely different organs to perform their allotted functions. This being the case, the post-mortem appearances would necessarily greatly vary, but in all animals similarly affected the lesions and morbirl changes were found identical.

Perhaps the most important point to be determined by this inrestigation was the contagions or non-contagious character of the disease. In order to do this a series of experiments were instituterl and conducted solely with this end in view, by Drs. Detmers and Law. These experiments resulted in determining the fact that the disease is both infectious and contagious, and that it is not confined alone to sirine, but that other animals may contract it in a mild form and retransmit it to swine in its most virulent and malignant character.

On the 6th day of September, Dr. Detmers fed a portion of the stomach, the cxemn, and the spleen of a pig that had died on that day to tro healthy pigs. On the 19th of the same month they showed signs of illness, and the symptoms continued to grow in intensity until the $23 \mathrm{~d}$, when, finding that the animal must die in a few hours, one of them was killed by bleeding. The other pig was found dead in the pen on the morming of September 30. The symptoms and post mortem appearances were those of swine-plague, as they revealed the same lesions as those observed in an examination of the pig from which the diseased products lad been taken for the purpose of infection. On the 24th day of September, the day following the death of the first pig, a luealthy pig of 
mixed Polaud-China and Berkshire was confined in the same pen with the siek pig that died on the 30 th of that month. It showed no signs of sickness until the 2d dar of October, when the first srmptoms of the disease were observed. It contimned to grow rapidly worse, and was found dead in its pen on the morning of the 11th, nine days after the first srmptoms were observerl.

Experiments were male with a large number of other animals to test the infectious and contagious character of the plague. These experiments included the confinement of healthy with sick animals, and the inoculation of healthy animals with the diseased products of those suffering with the ferer. In almost every ease, as rrill be seen from his detailed report, Dr. Detmers was successful in transmitting the disease from sick to healthe animals.

The microscopic inrestigations of Dr. Defmers also revealed some important facts. His discorery of a new order of bacterin or bacillus, which he names bacillus suis, as it is common only to this disease of strine, and his failure to inoculate healthr animals with virus from which these gemus had been remored by filtration and otherwise, wonld lead to the conclusion that these microphytes are the true seeds of the hog ferer.

Dr. Detmers invariably found these germs, in one form or another, in all fluids. So constantly were they observed in the blood, urine, mucus, fluid exudations, \&-c., and in the excrements and in all morbidly affected tissues of diseased animals, that he regards them as the trne infeetions principle. Thes would seem to undergo sereral changes, and to require a certain length of time for further propagation; therefore, if introduced into the animal organism, a period of incubation or colonization must clapse before the morbid symptoms make their appearance. These germs were generally found in immense numbers in the fluids, but more especially in the blood and in the exudations of the diseased animals. With the proper temperature aud the presence of a sufficient amount of oxygen they soon derelop and grow lengthmise by a kind of budding process. A globular germ, coustantly observed under the microscope, budded and grew under a temperature of $700 \mathrm{~F}$. trice the original length in exactle two hours, and changed gradually to rod-bacteria or bacilli. Under farorable cireumstances these bacilli continue to grow in leugth until, when magnified S50 diameters, they appear from one to six inches loug. A knee or angle is first formed where a separation is to take place, and then a complete separation is effected by a swinging motion of both ends. After the dirision, which requires but a minute or two after this swinging motion commenees, the ends thus separated move apart in different directions. These long bacteria seem pregnant with new germs; their exterual envelope disappears or is dissolved, and then the numerous bacillus germs become free, and in this way effect propagation. Some of the bacilli or rod-bacteria move rery lapidls, while others are apparently motionless. A certain degree of heat rould seem to be neeessary for their propagation, as, under the microscope, the motion in- 
creases and becomes more lively if the rays of the light, thromn upon the slide by the mirror, are sufficiently concentrated to increase the temperature of the object. Another change obserred by Dr. Detmers, but the canse of which he was not able to determine, was observerl in the fact that the globular bacteria or bacillus germs commence to burl or grow, when, very suddenly, their further derelopment ceases, and partially developed bacilli and simple and budding germs congregate to colonies, agglutinate to each other, and form larger or smaller irregularly-shaped and apparently viscous elusters. These elusters are frequently found in the blood and in other fluids, and invariably in the exudations of the lungs; and in the lymplatic glands in pulnonal exurlation and in blood serum this formation can be observer nuler the microscope if the object remains unchanged for an hour or two. In the ulcerous tumors on the intestimal inncous membrane but few of these clusters will be found, but the fully-developer bacilli, many of which appear rery lively, are always exceedingly numerous. These tumors or morbid growths in the intestines seem to afford the most farorable conditions for the growth and derelopment of the bacilli and their germs. The presence of such immense numbers of these microplytes and their germs in the excrements and other morbid products of swine leads Dr. Detmers to regard them, beyond donbt, as the prineipal disseminators of the plague. Whether these colonies or viscous elusters are instrumental in bringing abont the extensire embolism of the lungs and other tissnes by merely closing the capillary ressels in a mechanical way, or whether the presence, growth, development, and propagation of the bacilli and thir germs produce peculiar elıenical changes in the composition of the blood, thereby disqualifying it from passing with facility through the capillaries, or which cause a clotting and retention of the same in the eapillary system, Dr. Detners is not able positively to decide. He is of the opinion, however, that these colonies or viscous elusters of bacillus germs and partially developed bacilli cause sufficient obstruction of the capillaries to produce fatal embolism.

The vitality of the bacilli and bacillus-germs is not very great, except where preserved in a substance or fluid not easily subject to decomposition; for instance, in water which contains a slight admixture of organic substances. Where contained in such a fluid and preserred in a rial with a glass stopper, they will remain for at least fire or six meeks in nearly the same condition, or develop very slowly, according to the amount of oxygen and degree of temperature maintained. In an open vessel the derelopment is a more rapid one. If oxygen is excluded, or the amount available is exhausted, no further change takes place. In the water of streamlets, brooks, ditches, ponds, \&c., their vitality is retained or preserved for some time. In fluids and substances subject to putrefaction, they lose their vitality and are destroyed in a comparatirely brief period; at least they disappear as soon as those fluids and substances undergo decomposition. In the blood they disappear as soon 
as the blood-corpuscles commence to decompose or putrefy. They are also destroyed if brought in contact with or acted upon by alcohol, carbolic acid, thymol, iodine, \&c. The destruction of these germs by decomposition would seem to account for the harmless nature of thoroughly putrid products when consumed by healthy animals. (See drawings, bacilli and bacillus-germs.)

Dr. Law also discorered bacteria in the blood of pigs suffering with the clisease, and in one ease, on the second day before death, he found the blood swarming with them, all showing very active morements. (See drawings, Plate xiii, Fig. 3.) The blood from another pig, which had been inoculated from this one, shotred the same living, actirels-moring germs in equal quantity. They were further found in the blood of a rabbit and of a sheep inoculated from the first-mentioned pig. In an abscess of a puppy, which had also been inoculated, the germs were abundant. In the examination of blood from healthy pigs the mieroscope failed to reveal the presence of these organisms. Dr. Law states that in his experiments the greatest precautions were taken to aroid the introduction of extraneous germs. The canstic potash employed mas first fused, then placed with reboiled distilled water in a stoppered bottle which had been heated to red heat. The glass slides and corerglasses were cleaned and burned, the skin of the animal cleaned and incised mith a knife that had just been heated in the flame of a lamp. The caustic solution and the distilled water for the immersion-lens were reboiled on each occasion before using, and finally the glass rods $\mathrm{cm}$ ployed to lift the latter were superheated before being dipped in them. On different occasions, when the animal was being killed, the blood from the flowing ressels was receired beneath the skin into a capillarr tube which had just been purified by burning in the flame of a lamp. With these precantions he thinks it might have been possible for one or two bacteria to get in from the atmosphere, but this would not account for the strarms foumd as soon as the blood was placed moler the micro. scope.

The most scrupulous care was observed by Dr. Law in his experiments in inoculation. The isolated and non-infected locality where the experiments were conducted offered special adrantages for a series of experiments of this character, as there were no large herds of diseased and exposed swine, and, consequently, no danger of accidental infection from other sources than the experimental pens. The number of animals subjected to experiment was limited by the necessity for the most perfect isolation of the healthy and diseased, for the employment of separate attendants for each, and for the disinfection of instruments used for scientific observations, and of the persons and clothes of those necessarily in attendance. The experimental pens were constructed ou high gromel in an open field, with nothing to impecle the free circulation of air. They were large and rooms, with abundant rentilation from back and front, with perfectly close walls, floors, and roofs, and in cases 
where two or more existed in the same building, the interrening walls were constructed of a double thickmess of matched boards, with building pasteboard between, so that no communication could possibly take place except thromgh the open air of the fields. When deemed necessary, disinfectants were placed at the rentilating orifices. On showing the first signs of illness, infeeted pigs were at once turned orer to the care of attendants delegated to take charge of these alone. The food, utensils, \&c., for the healthy and diseased animals were kept most carefilly apart. When passing from one to the other for scientific observations, the healthy were first attended, and afterward the diseased, as far as possible in the order of sererity. Disinfection was then resorted to, and no visit was paid to the healthy pigs until after a lapse of six $01^{\circ}$ eight hours, with free exposure to the air in the interval. In the pens the most scrupulous cleanliness was maintained, and deodorizing agents used in sufficient quantities to keep them perfeetly sweet.

The experiments of Dr. Law hare shown the period of incubation to vary greatly, though in a majority of eases it terminated in from three to seven days after inoculation. One animal sickened and died on the first day, three on the third, two on the fourth, one on the fifth, two on the sixth, four on the serenth, and one each on the eighth and thirteenth days respectively. Referring to experiments of others for determining: the period of ineubation, Dr. Law says that Dr. Sutton, observing the result of contact alone in autumn, sets the period at from thirteen to fourteen days; his own observations in Scotland, in summer, indicated from seren to fourteen days; Professor Axe, in summer, in London, concluded on from five to eight days; Dr. Budd, in summer, from four to five days; and Professor Osler, in antumn, at from four to six days. Dr. Detmers gires the period of incubation from fire to firteen days, or an arerage of about seven days. A comparison of these results would seem to iudicate that both extremes have been reached.

In experimenting in this direction, Dr. Law first sought to ascertain the tenacity of life of the dried virus. Some jears ago Professor Axe had successfully inoculater a pig with virus that had remained dried upon ivory points for trrenty-stx days. In order to carry this experiment still further, Dr. Law inoculated three pigs with virulent products that had been dried on quills for one day, one with virus dried on a quill for four days, one for five days, and one for six days. These quills had been sent from North Carolina and New Jersey, wrapped in a simple paper corering; and were in no way specially protected against the action of the air. Of the six inoculations, four took effect. In the two exceptional cases the quills had been treated with disinfeetants before inoculation, so that the failure ras anticipated.

Three pigs were inoculated with diseased intestine which had been dried for three and four days respectively. The intestine was dried in the free air and sum, and the process was necessarily slower than in the case of the quills, where the virus was in a very thin layer, hence there 
was more time allorred for septic changes. In all three eases the inocrlation prored successful. This experiment would prore that the morbid. products, even in comparatirely thick layers, may dry spontaneously, and retain their vitality sufficiently to trausmit the disease to the most distant States.

Another pig was inoculated with a portion of moist diseased intestine sent from Illinois in a closely-corked bottle. The material had been threo days from the pig, and smelt slightly putrid. The disease dereloped on the sixth day. A second pig was inocnlated with blood from a diseased pig that had been lept for eleren dass at $100^{\circ} \mathrm{F}$. in an isolation apparatus, the outlets of which were plugged with cotton wool. Hlness super. rened in trrenty-four hours.

A solitary experiment of Dr. Kilein's having appeared to support the idea that the blood was non-virulent, Dr. Law tested the matter by inoculating two pigs with the blood of one that had been sick for nine days. They sickened on the serenth and eighth days respectirely, and from one of these the disease was still further propagated by inoculating with the blood three other animals. Notrrithstanding the suecess of these three experiments, Dr. Law is still doubtful of the blood being virulent at all stages of the disease.

But one or two experiments were instituted by Dr. Law to test tho question of infection through the air alone. A healthy pig placed in a pen betreen trro infected ones, and with the rentilating orifices within a foot of each other, front and back, had an elerated temperature on the ninth, tenth, and elerenth days, with lameness in the right shoulder, eridently of a rheumatic character. On the twenty-fourth day the temperature rose two degrees, and remained $104^{\circ} \mathrm{F}$. and upward for six days, when it slowly declined to the natural standard.

A healthy pig was placed in a pen from which a sick one had been remored thirteen dass before. The pen had been simply swept ont, but subjected to no disinfection other than the free circulation of air, and as the pig was placed in the pen on December 19th, all moist objects had been frozen during the time the apartment had stood empty. The pig died on the fifteenth lay thereafter, withont having shown any rise of temperature, but with post-mortem lesions that showed the operation of the poison. Dr. Law refers to this ease as an example of the rapidly fatal action of the disease, the poison having fallen with prostrating effect on vital organs-the lungs and brain-and cut life short before there was time for the full derelopment of all the other lesions. It fully demonstrates the preservation of the poison in a covered building at a temperature below the freezing point.

Perhaps the most important cxperinents concheted by Dr. Law wero those relating to the inoculation of other animals than swine with the virus and morbid products of pigs sufferiug with the plague, and the transmission of the disease from these animals back to Inealthy hogs. A merimo wether, a tame rabbit, and a Newfotudlaud puppr were in- 
oculated with blood and pleural fluid containing numerous actively moving bacteria, taken from the right ventricle and pleuræ of a pig. that had died of the fered the same morning. Next day the temperature of all three was elerated. In the puppy it became normal on the third day, but on the eighth day a large abscess formed in the seat of inoculation and burst. The rabbit had elevated temperature for eight dass, lost appetite, became weak and purged, and its blood contained myriads of the characteristic bacteria. The wether had his temperature raised for an equal length of time, and had bacteria in his blood, though not so abundantly as in that of the rabbit. The sheep and rabbit had each been unsuccessfully inoculated on two former oceasions with the blood of sick pigs, in which no moving bacteria had been detected. Subsequently, after two inoculations with questionable results, made with the blood of sick pigs in which no microzymes had been obserred, Dr. Law succeeded in inoculating a rabbit with the pleural effusion of a pig that had died the night before, and in which were numerous actively moving bacteria. Next day the rabbit was very fererish and quite ill, and continued so for trenty-tro days, when it was killed and showed lesions in many respects resembling those of the sick pigs. The blood of the rab. bit contained actire microzymes like those of the pig. On the fourth day of sickness the blood of the rabbit containing bacteria was inoculated on a healthy pig, but for fifteen days the pig showed no signs of illness. It was then reinoculated, but this time with the discharge from an open sore which had formed orer an engorgement in the groin of the rabbit. Inness set in on the third day thereafter and continued for ten days, when the pig was destroyed and found to present the lesions of the rlisease in a moderate degree. A second pig, inoculated with frozen matter which had been taken from the open sore on the rabbit's groin, sickened on the thirteenth day thereafter, and remained ill for six days, when an imminent death was anticipated by destroying the animal. During life and after death it presented the phenomena of the plague in a very riolent form.

The results of these experiments have convinced Dr. Law, as they must convince others, that the rabbit is itself a victim of this clisease, and that the poison can be reproduced and multipliod in the body of this rodent and conreyed back with undiminished rirulence to the pig. Dr. Klein lad preriously demonstrated the susceptibility of mice and guinea pigs to the disease. The rabbit, and still more the mouse, is a frequent visitor of hog pens and yards. The latter eats from the same feeding troughs with the pig, hides under the same litter, and runs constant risk of infection. Once infected, they may carry the disease to long distances. During the progress of serere attacks of the disease, their reakness and inability to escape will make them an easy prey to the omnicorous hog; and thus sick and dead alike will be deroured by the doomed swine.

Dr. Law says that the infection of these rodents creates the strongest 
presumption that other genera of the same family may also eontract the disease, and by virtuo of au even closer relation to the pigs, may sneceed in conveying the malady to distant herds. The rat is suggested as being almost ubiquitous in piggeries, and more likely than any other rodent to contract and transmit the disease to distant furms. In order to test its susceptibility to the poison, Dr. Law inoculated a rat with the virus from a sick pig, but unfortmately the subject died on the seeond day thereafter. The body showed slight suspicious lesions, such as congested lungs with eonsiderable interlobular exudation, congested small intes. times, dried-ru eontents of the large intestines, and sainguinous discoloration of the tail from the seat of inoculation to the tip. With the fresh congested small intestine of the rat he inoenlated one pig, and with the frozen intestine one day later he inoculated a second. The first showed no rise of temperature, loss of appetite, or digestive disorder; but on the sixth day pink and violet eruptions, the size of a pin's head and up. wards, appeared on the teats and belly; and on the tenth day there was a manifest enlargement of the inguinal glands. In the second pig inoculated, the symptoms were too obscure to be of any real value. Dr. Law will continue his experiments with this rodent.

In addition to the above, Dr. Law experimented ou two sheep of different ages, an adult merino wether and a cross-breed lamb, and in both cases suceeeded in trausmitting the disease. With the muens from the anus of the wether he inoculated a healthy pig, which showed a slight elevation of temperature for five days, but withont any other marked symptoms of illness. Eleven days later it was reinoenlated with seab from the ear of the lamb, and again three clays later with anal mueus from the sheep. The day preeeding the last inoenlation it was noticed that the inguinal glands were much enlarged, and in six days theroafter the temperatiure was elevated and purple spots appeared on the belly. At the time that Dr. Law closed his report this ferer had lasted but a few days, but he regards the symptoms, taken in connection with the violent rash and the enlarged lymphatie glands, as satisfactory evidenee of the presence of the disease. It cau, therefore, be affirmed of the sheep as of the rabbit, that not only is it subject to this clisease, but that it can multiply the poison in its system and transmit it baek to tho pig.

Among the later experiments by Dr. Law was one inaugurated with the view of testing the vitality of frozen products of the disease. This point was briefly alluded to above, but its importance would seem to eall for further attention. In two eases healthy pigs were inoculated with virulent products which had been frozen hard for one and two days respectively. In both instances the resulting disease was of a very vio. lent type, and wonld have proved fatal had it been left to run its eom'se. The freezing had failed to impair the virulence of the product; on the contrury, it had only sealed it up to be opened and given free course on the recurrence of warm weather. Onee frozen no change conld take place 
nutil it was again thawed out, and if it was preserved for one night unchanged in its potency, it would be equally matfected atter the lapse of many months, provided its liquids had remained in the same crystalline condition thronghout. It is in this way, no doubt, that the virus is often preserved through the winter in pens and yards, as well as in cars and other conveyances, to break ont anew on returning spring. The import. ance of this cliscorery, as applied to preventive measures, camnot be orerestimated. Infected yards and other open and uncorered places may. not be considered safe until after two months' racation in summer, and not then if sufficient rain has not fallen during the interval to insure the soaking and putrid decomposition of all organic matter near the surfice. This will be made more apparent by reference to an experiment which resulted in the successful inoculation of pigs with virus that had been liept for a month in dry wheat bran. In winter, on the other hand, the yard or otler open and infeeted place may prove non-infecting for weeks and even months and yet retain the virus in readiness for a new and deadly course as soon as mild weather sets in. Safety under such cir. cumstances is contingent on a disuse of the premises so long as the frost continnes, and for at least one month or more thereafter. Even during the continuance of frost such places are dangerous, as the heat of the animal's body or of the rays of the sun at midlay may suffice to set the virus free.

Several of the examiners treat at length of hygienie and sanitary measures, and the attention of the reader is directed to their detailed reports, which will be found below, without further comment. 



\title{
INVESTIGATION OF SIVINE-PLAGUE.
}

\author{
REPOR' OF DR. H. J. DETMERS, V. S.
}

\section{Hon. WM. G. LeDUC,}

Commissioner of Agriculture:

Sir: Having been appointed by yon as one of tire inspectors to make an iuvestigation of the diseases prevailing among swine, I forwarded to you my witten acceptance, immeriately after I received my appointment, ou July $29,187 \mathrm{~s}$, and took at once the necessary steps to obtain reliable information as to the localities where the disease of swine, known to the farmers as "log-cholera," was at that time prevailing. I made also such other preparations as I deemed necessary to successful investigation, and provided nnyself with a good Hartnack microscope, divers chemicals and medicines, a clinical thermometer, \&c. Among all the places and localities at which the disease, as reported, was very frequent, I selecterl Champaign, Champaign County, Illinois, as afforiing the greatest ficilities for the intended investigation, or the most suitable basis for my operations, and repaired to that place on the second day of August. I found what I expected, i.c., numerous cases of disease in the vicinity of Champaign and Urbania, and offer's of assistance by F. IV. Prentice, M. D., aud M. R. C. V. S., who is lecturer on reterinary science in the Illinois Iudustrial University at Urbana, and of Piof. T. J. Burrill, M. A., who is professor of botans and microscopist in the same institution. Dr. Prentice had eren the kindness of offering to me, for experimental purposes, the free use of his veterinary infirmary buildings. That offer, of course, was accepted. Besides that, Dr. Prentice, who is a very able and well-educated reterinary surgeon, lias assisted me otherwise very essentially in my work, and tools charge of my cxperimental animals whenerer I was obliged to be absent for a short time. I am, theretore, very much indebted to him for his valuable help and lind assistance. Professor Burrill has assisted me in my microscolical examinations.

Arriver at Champaign I marle my plans as to the mamner in which to proceed with my iuvestigation. Knoriug that an eneny can ouly be conquered by being well kuown, I determined to ascertain first the real nature of the disease I had to deal with. That accomplished, I proposed to direet my atteution cxchnsively to investigating and ascertatining the cuuses, reasoning that, it the causes are known, it cannot be rery difficult to devise proper and eflicient means of prerention, and, perhaps, remedies that will effect a cure. At any rate, a knowlectege of the causes of a disease affords not only a sound, but in fact tir only basis of sncessful prevention and rational treatment. This plan I hare executed as far as circumstances and the time granted have perinitted me to do.

In order to become thoroughly acquainted with the nature of the socalled "hog-choiera," or more appropriatcly "swine-plague," called also typhoid, pig-trphoir, enteric terer, pneimo-enteric ferer, liog or swine disease, \&e., I lave made daring the time flom Angust 'und t? 
November 1, 5t risits to 26 rlfferent herds of diseased swine, and 53 post-mortem examinations, and have examined microseopically the blood, diverse other fluids, morbid products, and tissues of 42 sick or deal animals.

For the purpose of ascertaining the canse or canses of the disease, $J$ have also made numerons experiments, a detailed account of most of which will be found in this report. After having incquired into the canses, $I$ have made other experiments in regarl to prevention and treatment.

The following may be considered as the result of my investigations:

\section{DESCRIPTION OF STINE-PLAGUT.}

The disease, commonly known as "hog-cholera" to the fitrmers, but which may, more appropriately, be called swine-plagne-a mame which I shall use exchusively hereafter-is a disease sui generis, peculiar to swine, is neither cholera nor anthrax; it somewhat resembles the enteric ferer, or dothiuenteria, of man, but is not identical with the same; is communicated firom one animal to another by direct and indirect infection; has usually a subacute course; is extremely fatal, especially among young animals; and exempts neither sex, age, nor breed, but seems to prefer, in its attacks, for reasons hereatter to be explained, large herds, and is always most fatal in such sties, pens, and yards in which many animals are crowded together. Some inclividual animals seem to hare more predisposition to the disease than others. The morbid process, althongh in all cases essentially the same, is not restricted to a single part or organ, or to a set of organs, but can have its seat almost everywhere-in the tissne of the lings, in the plenra aud pericardinm, in the heart, in the lymphatie system, in the peritouenm, in all mucons nembranes, especially in those of the intestines, in the liver, in the spleen, and even in the skin. Only the pulmonal tissue and the lymphatic glands are invariably affected.

\section{TIIE SYMPTOMS.}

The symptoms, although presenting certain characteristics, observed more or less in the affected animals, vary considerably in different cases, even in one and the same herd, but still more so in different herds, and in different seasons and localities. The eanses of these differences will hereafter be fully explained.

To convey a better idea of the features of swine-plagne, as presented in the living animal, I shall first give an ontline of all the symptoms observed in a large number of hog's and pigs, and shall append, in order to show what combinations may oecur in an individual animal, a de. seription of the symptoms presented by some of my experimental pigs.

Swine-plagne amnounces its presence very often by a cold shivering, lasting from a few minntes to several hours, frequent sneezing; and more or less eougling. The symptoms of shivering and sneczing are generally noticel. At the beginning of the disease the temperature of the body seems to be increased. The thermoneter indicated from $104^{\circ}$ to 1060 T: Still, not mueh reliance can be placed on the temperature, as inclieated by the thermometer. In some cases it was found to be very high-in one case as high as $111^{\circ} \mathrm{H}$ - - ind in others below normal. It was always more or less variable, and has been found decreasing at the very height of the disease. I have come to the conchsion that in disases of swine thermometry is of a very donbtful practical value, be. 
canse to ascertain the temperature of a hog, that is not extremely low or in a rying condition, by introducing a thermometer into the rectum, requiles the use of force, because a hog or pig ean very selrlom be persuaded to submit to that operation without struggling and without being held; and struggliug, according to uny observation, increases the temperature of snch an irritable animal inmediately. The general appearance of the animal, if correctly analyzerl, is of muel more diagnostic and prognostic value than the differences of temperature as indieated ly the thermometer. In cliseases of swine the latter is, at best, a nico and interesting plaything in the hands of the inexperieneed.

The first symptoms are usually followed within a short time by a partial, and afterwarls by a total loss of appetite; a rough and somewhat staring appearance of the coat of hair; a drooping of the ears (characteristic); loss of vivacity; attempts to romit (in some cases); a tendency to root in the bedding, and to lie down in a clark and quiet corner; a dull look of the eyes, which not seldom become dim and injected; swelling of the hear (observed in several cases); ermptions on the ears and on other parts of the body (quite frequent); bleeding from the nose (in a few cases); swelling of the eyelids, and partial or total blindness (in five or six cases); dizziness or apparent pressure injon the brain; aecelerated and frequently laborious breathing; more or less constipation, or, in some cases, diarrhea; a gaunt appearance of the flanks; a pumping motion of the same at each breath; rapich emaciation; a vitiated appetite for doms, dirt, and saline substances; increased thirst (sometimes); accumulation of mucus in the eanthi of the eves (rery often at an early stage of the (lisease); more or less copious discluarges fiom the nose, de. The peculiar offensive and fetid smell of the exhalations and of the exerements may be consiclered as eluaracteristic of the disease. This odor is so penetrating as to announce the presence of the discase, especially if the held of swine is a large one, at a clistance of half a mile or even farther, provided the wind is farorable. If the animals are inclined to be costive, the dung is usually grapish or bromnish black, and haxd; if diarrhea is present the feces are semi-fluid, and of a grayish-green eolor, and contain, in some eases, an admixture of blood. In a large number of eases the more tender portions of the slin on the lower surface of the body, between the hind legs, behind the ears, and even on the nose and on the neck; cxhibit mumerous larger or smaller red spots, or (sometimes) a miform redness (Red Soldier of the English). Toward a fatal termination of the disease this redness changes frequently to purple. $\Lambda$ physical exploration of the thorax reveals, if pleuritis is existing, frenuently a plain rubloing somnd. As the morbid process promlesses the movements of the sick animal become wealier and slower; the gait becomes staggering and undecided; the steps made are short, as it the animal was mnable to advance its legs withont pain ; sometimes lameness, especially in a hind leg (not very often), and sometimes great weakness in the hind quarters, or partial paralysis (oftencr) make their appearance. The head, if the animal is on its legs, seems to be too heary to be carried, and is liept in a clrooping position with the nose almost tomehing the gromnd; but as a general rule the discased animals are usually found lying down in a dark and quict eorner with the nose hid in the bedding. If a fatal termination is approaching, a very fetid diarlhea (usually one or two days before (leath) takes the place of the previous costiveness; the roice becomes very peenliar, grows vely faint aud hoarse; the sick animal manifests a great indifference to its smroundings, and to what is going on; emaciation and general debility increase very fast; the skin (es- 
pecially if the disease has been of long duration) beemes minkled, hard, dry, parehment-like, and rery melean; a cold elammy sweat breakis nut (observed sereral times, once as early as forty-eight liours before (leath), aud death ensues either under couvilsions (companatirely rare), or gradually and withont any struggle. A peculiar symptom, which, however, has been observed only once, in a litter of nime pigs, abont a week old, at the beginning, or in the first stage of the lisease, may here be mentioned. It consisted in a peciliar and constant twitching of all roluntary muscles. All nine pigs clied, and I an sorry that I had no opportunity to make any post mortem examination.

In some cases mumerons eruptions (nlecrous nodnles) apleeared on the tender skin on the lorrer surface of the body between the legs and belind the ears, and in a ferr cases whole pieces of skin (in one case as large as a man's hand) were destroyed by the morbid process, sloughed off', and left behind a raw, nicerons surface. In anotlicr case a part of the lomer lip, of the gums, and of the lomer jam-bone had undergone ulcerous destruction.

Whererer pigs or hogs liad been ringed, the wounds thus made showed a great tendeney to ulcerate. In several cases the morbid process had caused sufficient ulcerons destruction to form an opening directly into the nasal carities large enough to euable the animal to breathe throngh, instead of through the nostrils, which had become nearly closed by strelling and by exndations and morbid prodnets adluering to their borders.

In those fer cases in which the disease has not a fatal termination the symptoms gradnally disappear, conghing becomes more frequent and easier; the discharges from the nose, for a day or two, become copions, but soon diminish, and finally cease altogether; appetite retmrns, and becomes normal; the offensire smell of the excrements disappears; sores or uleers that may happen to exist sirow a tendeney to heal; the animal becomes wore licelr, and gains, though slowly, in flesh and strength; but sone diffenlty of breathing, and a short, somewhat lioarse, hacking conglo remains for a long time.

Symptoms of special cascs. - Experimental pigs Nos. 5 and 6, both of the same litter, and abont fifteen weeks old, were fed on the sixth dlay. of September with the stomach, cnt in pieces, the cremu, and the spleen of experimental pig No. 2, which had clied the same day.

Sentemór 7.-Pig No. 5 coughs a litt!o, but eats rell ; pig No. 6 has a slight eaterrh: some yellow mucus in inuer canthns of one cye.

September S.-Both pies the same as yesturday.

September 9.-Both pigs have rery good appetite.

Scptember 10.-Both pigs seem to be as well as possible; consume all their food sreedily.

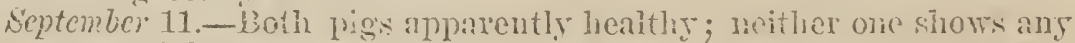
strmptoms of disease.

Sejtember 12.-Both piss evidently sick: they are tardy in thein mosements; their ears are dropiag; their appetite rlminished. T'ig No. is made attempt: to romit.

September 13.-Both pigs, but esperially pig To. 5, are rery sick; take searcely any food; show a tendeney to hide themselves in a cormer; coat of hair looks rough and staring; flanks are thin; acemmulation of mucus in the inner canthi of the eyes. No. 6 has discharges from the nose, especialiy from the right nostril.

Septomber 14.- Pig No. o, both eres nearly eloseil; is weak, though not rery; emaciates rapidly; appetite is poor. To. 6 has its eyes ret open; othermise about the same as No. 5. 


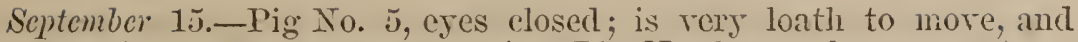
shows plain symptons of premmonia. Pig No. 6, too, shows symptoms of pnemmonia, but they are less pronounced; is witlont appetite, and just as much enlaciated as . To. 5 . The skin of both animals is hard and dry; and their coat of hair rough and staring; their borrels are costive; but little dung is roided. Both animals betray plain inclications of pain and suffering; neitler one seems to be rery thirsty.

Septcmber 16.-Pig No. J rery weak, breathes one hundred times per minnte; its flanks are worling foreibly; slight lameness in left hind leg. Pig No. 6 is also rery weak, but is yet able to rum; passed a large quantity of urine of a bright yellow color. The appetite of both pigs for food is reduced to nothing, but both exhibit a ritiater appetite, and eat each other's dung, or their own, as soon almost as it drops. The skin is rery hard to the tonch, parchment-like, and seems to stick to the bones. In the erening pig No. 5 is extremely weak; is searcely able to more; its breathing is difficult and distressing. No. 6 is abont the same as in the moming.

September 17.-Pig To. 5 shows symptoms of dropsy in the chest, and breathes with great difficulty, about one hundred times per minute. In the erening the pumping motion of the flanks is increased, bnt the respiration is slower-about fifty-six breaths per mimte. Pig No. 6 is a little more lively than No. 5 , but also rery sick, and has no appetite. Both pigs failed to roid any dung from $S$ o'clock a. m. to 6 o'clock 1 . m.

September 18.-Pig No. 5 exceedingly emaciated, some rattling noise in the respiratory passages. Pig No. 6 abont the same as resterday.

Septcmber 19.-Pig No. 5 emaciated to the ntmost, bit otherwise apparently not worse. Pig No. 6 shows apparent improrement; is a little livelier than before; has some appetite; consumed one car of cori during the last trenty-four hours. In the evening pig. No. 5 breathes with the greatest difficulty, one hundred and four times per minnte. No. 6 unchanged.

Septomber 20.-Pig No. 5 rery sick; breathes with great difficuity. No. 6 apparently improving

September 21.-Pig STo.5 just alire. Both pigs hare been lying nearly all day in one corner of their sty, their noses buried in the bedding. In the evening pig No. 5 is perspining; sweat cold aud clammy.

September 2.-Pig No. 5 breathes sixty-foul times per minute, with jerking motions of the flanks, and so far lias been nore or less constipated, but now has diarrhea; feces grayish-green, semi-fluid, and exceedingly fetid. Pig No. 6 is less emaciated than No. 5 , has no diamhea, and eats a little. Urine of No. 5, examined under the nicroscope, contained imnmerahle bacillus-germs (micrococei of Inallier), and a few bacilli suis** (See drawing I, fig. 1.)

Scptember 23.-Pin No. 5 a mere skeleton, and extremely weak; breathes only forty-eight times per minute. Pig No. 6 not quite so low; breathes only thirty-six times per mimnte. In aftermoon pig No. 5 too weak to stand on its legs; bieathes fifty-two times per minute; is sweating; the sweat cold and clammy. Seeing that the auimal could not possibly live till next moming, and desiring to make the post-mortem examination before putrefaction should set in, I lillerl pig . No. 5 by bleeding at 6 o'clock p. 11 . (As to result of post-inoricm examination, see chapter on Morbid Changes.)

September 2t.-Pig Lí. 6 rery sick; eats searcely anything.

*I have chosen the name "bacillus suis" because the bacilli, as will appear hereafter, secm to be peculiar to swine-plagne, aud have not been before named as far as I have been able to learn. 
Scptember 25.-Pig No. 6 slows slightly increased appetite, and fully as munch, if not more, liveliness than on any day last week. It almost seems as if some real improvement is going on, notwithstanding very serious morbirl changes must have taken place.

September 26.-L'Pig No. 6 eats some in the morning, but cloes not seem to care for any food at noon; appears to be a trifle bloated; droops its head, and liolds its nose to the ground.

September 27.-Pig No. 6 decidedly worse; breathes seventy-two times ber minnte; hearl drooping; nose to the ground; back arched; skin very dry and hard to the tonch; no appetite whaterer.

September 2S.-Pig No. 6, which was very low last night, has some. what reenperated, and is moving again; consumed some water, and also a little foocl.

September 29.-Pig No. 6 exceedingly emaciated and rery weak; breathes thirty-eight times per minute; holds its nose persistently to the ground, and has no appetite whatever:

September 30.-Fonnd pig No. 6, at 5 o'clock a. m., Tying dead in a colner of its sty. (See chapter ou Morbid Changes as to result of post mortem examination.)

It may be well to add a brief account of the symptoms and the progress of the disease, as observerl in experimental pig $\mathrm{B}$, a sow pig; abont fourteen weeks old, and of mixed Poland China and Berkshire stock. Pig B was put in pen No. 3, together with pig No. 6, on September 24. The same was and remained perfectly healthy until Oetober 2 , when the first symptoms of disease made their aplinearance. I find in my diary the following notes:

October 2.-Pig B shows symptoms of sickness; sneezes; has an eruption on both ears; is not quite as lively as it used to be; appetite is diminished; eurl is ont of its tail.

October 3.-Pig B has but little appetite; is decidedly- siek. In after. noon shows mumistakable symptoms of sickness; ears are drooping; no appetite; great tendeney to lie down in a corner; lides its nose in the bedling.

October 4.--Pig B about the same as yesterday; lias eaten a little.

October 5.-Pig B hides its nose in the bedding' ; las no appetite whaterer; emaciation has taken place. $B$, although a week ago a better and heavier pig than C, a full sister, and of the same litter, is now considerably lighter.

Octobcr 7.-Pig B very sick; still, seems to hare a desire to eat, but takes loold of an ear of corn so feebly as to make it appear that it has not sufficient strength in the jans to shell the corn; gave it, therefore, shelled.

October S. - Pig I3 very sick; lides in its corner; ears are cold ; other parts of the body warm; no appetite; great indifference to surroundings; emaciation rapid.

October 9.- Pig $B$ about the same as resterday.

October 10.-Pig B is getting worse; does not eat anything.

October 11.-Pig $B$ fond dead in its pen in the morling:

These three cases show that the symptoms rary in clifferent eases, and that those which are constant can scarcely be considered as rery characteristic. Still, if the varions symptoms presented by an indiridual animal are taken as a whole, a diagnostic mistake is seareely i possible.

The diagnosis is rery easy, especially if swine-plagne is known to be prevailing in the neighborlood, or has alrearly made its appearance in the herd, and if the anammesis, and the fact that many animals are 
attacked at once, or within a short time and in rapic succession, are taken into consideration. As symptoms of special diagnostic value, scarcely erel absent in any case, may be mentioned the droopins of the ears and of the head; more or less coughing; the dull look of the eres; the staring appearance of the coat of hair; the partial or total want of appetite for food; the vitiater appetite for exerements; the rapid emaciation; the great debility; the weak and molecided, fiequently stagerering, gait; the great indifterence to siuroundings; the tendener to lie down in a dark comer, and to hide the nose, or eren the whole head in the bedding, and particularly the specific, offensive smell, and the peculiar color of the exerements. 'This symptom is always present, at least in an adranced stage of the disease, no matter whether constipation or cliarrhea is existing. As other claracteristic symptoms, though not present. in erery amimal, deserve to be mentioned: frequent sneezing; bleeding from the nose; swelling of the ejelids; acemmlation of mucus in the innel canthi of the eyes; at. tempts to romit, or real romiting; accelerated and difienlt breathins; thumping or spasmodie contraction of the abclominal muscies (fianlis) at each breath, and a peculiar, faint and loarse roice in the last stages of the disease.

\section{THE PROGNOSIS AND TERIINATION.}

The prognosis is decidedly unfarorable, but is the more so the youncer the auimals or the lareer the herd. Among pigs less than three months old the mortality may be set down as from 90 to 100 per cent.; among animals from three to six or seren months old the same is from 75 to 90 per cent.; while among older animals that have been well kept and are in goorl condition, and maturally strong and vigorous, the mortality sometimes may not exceed 25 per cent., but may, on an average, reach 40 to 50 per cent. The prognosis is comparatirely farorable only in those few cases in which the morbid process is not very riolent; in which the seat of the disease is confined to the respiratory organs and to the slin; in which any thumping or pumpins motion of the fianks is absent; and in which the patient is, naturally, a strong, vigorous animal, not too young and in a good condition; further, in which but a fer, not more than two or three, animals are liept in the same pen or sty, and receive nothing but elean uncontaminated food and pure water for drinkins, and in which a frequent and thorough cleaning of the sty or pen prevents any consumption of exerements.

The duration of the disease varies according to the violence and the seat of the morbid process, the age and the constitution of the patient, and the treatment and keeping in general. Where the morbid process is violent, where its principal seat is in one of the most vital organsin the heart, for instance-where a large number of animals are kept together in one sty or pen, where sties and pens are rery dirty, or where the sick animals are very yommg, the disease frequently becomes fatal in a day or two, and sometimes even within trenty-four hours. On the other hand, where the morbicl process is not very violent or extensive, where the heart, for instance, is not seriously affected, and where the patients are naturally strong and vigorous, and well kept in every respect, it usmally takes from one to three weeks to cause death. if the termination is not a fatal one, the conralescence, at any rate, requires an equal and probably a much longer time. A perfect recorery seldom occurs; in wost cases some lasting disorders-morbiul changes 
Which can be repaired but slowly or not at all-remain belind, and interfere more or less with the growith and fattening of the animal.

From a jecuniary standpoint, it makes but little diflerence to the owner whether a pig affected with this plagne lecovers or dies, because those which do survive usually make very poor returns for the food consumed, unless the attack has been a rery mild one.

\section{MIORDW CIIANGES.}

The morbicl process, although everywhere essentially tire same (see chapter on Contagion, Causes, and Nature of Mínbid Process), can have its seat in many different or gans or parts of the boly, and prodnees, therefore, a great rariety of morbid changes. The discase, in consequence, repr often presents a somemlut different aspect in different animals. In some cases the principal seat of the morbicl process is in one organ or set of organs (organs of respiration and circulation, for instance), and in others in entirely different parts (intestinal canal and organs of digestion, \&c.) Death, therefore, lias very often a different cause in different cases; in some cases it results from a cessation of the functions of the heart, the lungs, \&c., and in others it is in consequence of the inability of entirely different organs to perform their functions, -of the digestive apparatus, for instance.

But few morbicl changes have erex been found entirely absent at any of the fifty-three post-mortem examinations made since August 2, and may, therefore, be considered as a coustant ocenrrence. All others have been found absent a larger or smaller mumber of times. These constant morbid changes consist-

1. In a more or less perfect hepatization of a larger or smaller portion of the lungs, or a more or less extensire aceumulation of blood, bloorserum and exudation in the pulmonal tissue. In some cases the morbid clianges (hepatization) found in tho lungs are so extensire as to cause the latter, if thrown iisto water, to sink like a rock, but in other cases the hepatization is limited to about one-sixth or one-eighth of the whole pulmonal tissue. In some eases, especially those in which the morbid cluanges rere of a recent origin, no real hepatization, fully dereloper, had yet been effected; the Inugs were merely gorgerl with exulation or blood-serum; the terine was not yet destroyed or sericusly changed, but inmumerible small red spots or specks, indicatino incipicnt embolism, were plainly risible to the nalied eye. (See photograpl, Plate 1, lialf-sizo lungs, right sicle of experimental pig No. VII, and plotograpl, Plate II, enlarged section of same lumgs.) In other cases a part of the exuchation liad clianged, or'ganizchl, or become a part of the tissue, and luad camsed the latter to become more or less perfectly impermealule to air. In some lungs hepatization was fomm only in certain insulated piaces, while in others the hepatization extended mintermptedly orer whole portions. In all these cases in which the hepatization was rery linited, it was fomd principally in the anterior lobes. In some animals (that is in those which had been sick for some time), old or so-called gray, more recent or brown, and rery new or red hepatization were frequently found side by side, or in more or less distinctly limited patehes, showing plainly that the morbicl changes had not been prodnced at once, but at several intervals. In othels, ustually the mplyer parts of the same lungs, the exudation or bloodserum had been recently deposited, and was yet in a fluid condition. The blood-serum, examined under the mieroscoje, invariably contained, besides blookl-eorpuscles, numerous bacilli suis, some moving and some mith. ont motion, and inmumerable bacillus-germs, of which some had budded, 
which can be repaired hut slowly or not at all-remain behind, and interfere more or less with the growith and fattening of the animal.

From a pecmiary standpoint, it makes but little difference to the owner whether "nis strontad with this mligne weorers or dies, because

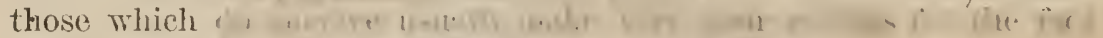

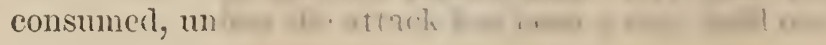

\section{S rint}

The morbi chapter on C

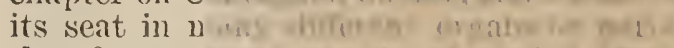

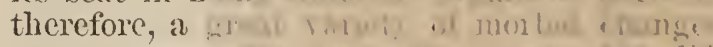

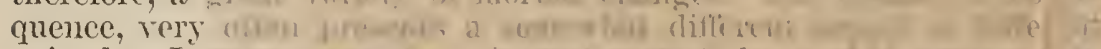

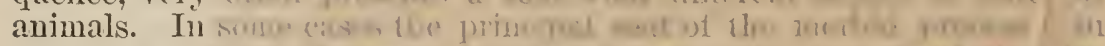

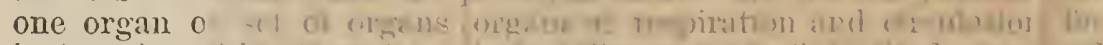

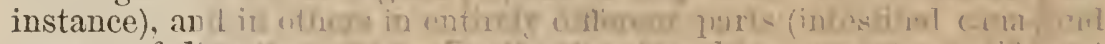

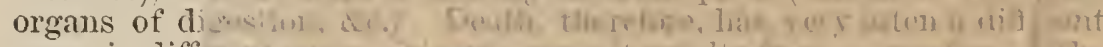

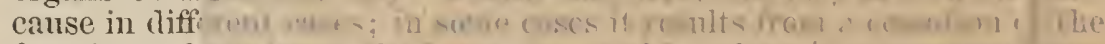

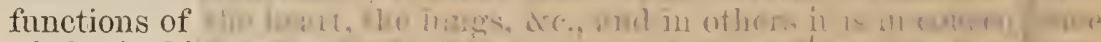

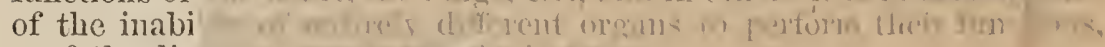
-of the dis

But few il of the fiftymay, theref been found : morbid clian

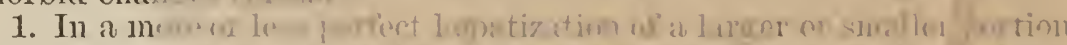

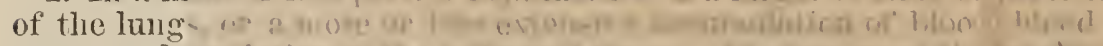

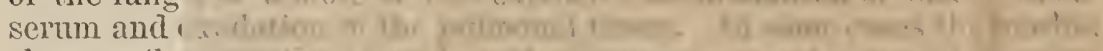

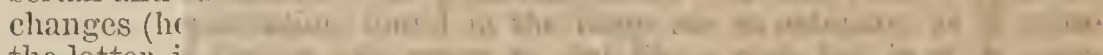
the latter, i the hepatiz pulmonal $t$ elianges we had yet be: blood-sermu but inmmus were plainl lmoss, righ enlarged s had cliang the latter lungs liep others the In all thes principall: lad been : and rery 1 in more or changes 1 other's, nsi serum har blood-seri silles bloo ont notic 


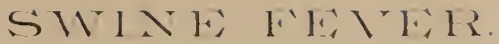

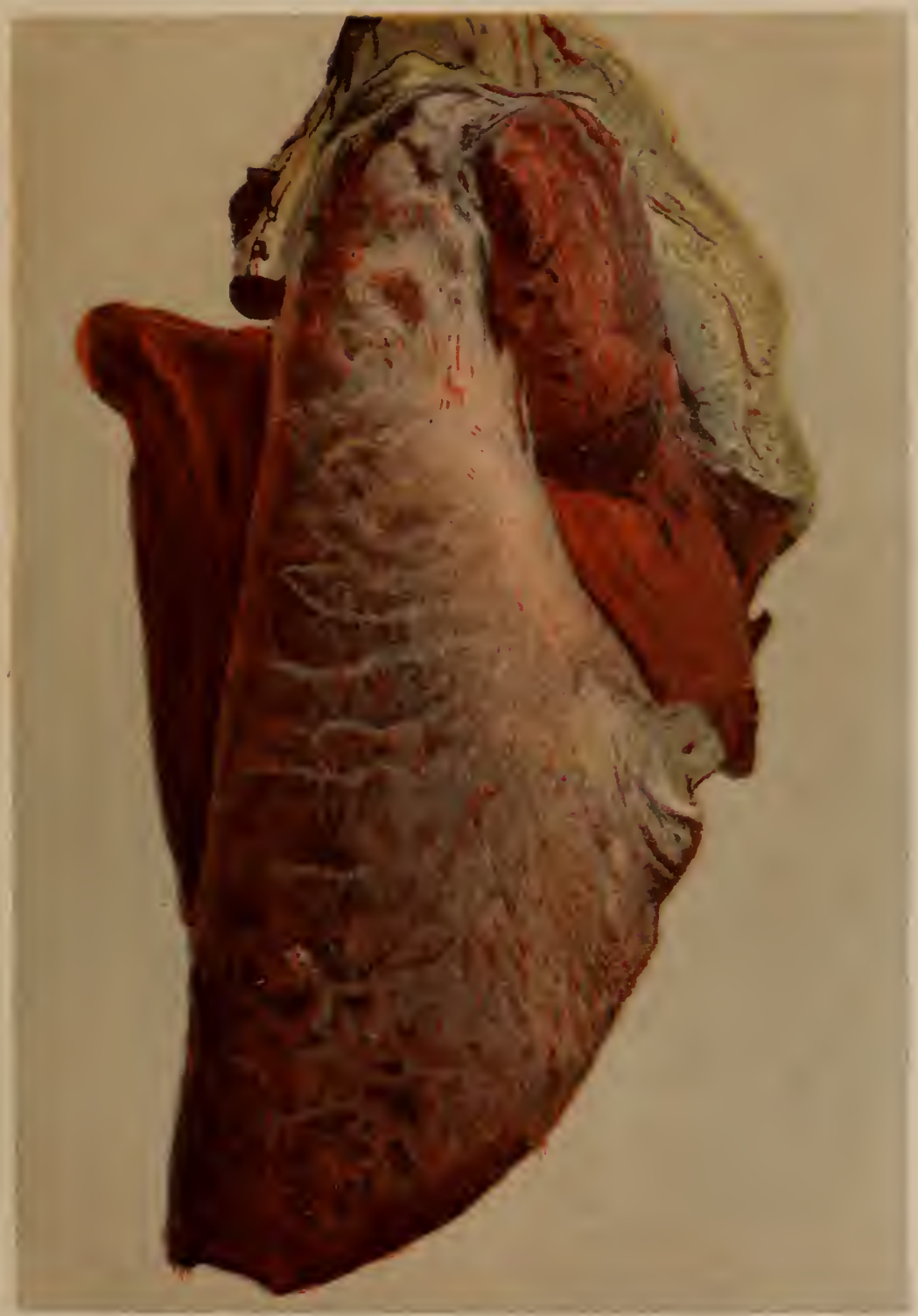



some were budding, ant others lat conglomerated. (Sce drawing II, figs. 3 and 4 , and diawing III, fig. 1.)

2. The lrmphatic and mesenteric glands were fomin invariably more or less enlarged. In some eases they presented eren a brownish or blackislu color, and contained not only deleterious matter, but even effnsious of blood in sufficient quantities to push aside the noimal glandular tissuc. Whether neoplastic formations (a proliferous growth of cells) had taken place I have not ascertained, but have not the least doubt that it liad. Under the microscope, partieles of lymph and glandular substance, taken from the interior of the lymphatic gland, presented, besides mormal tissue and lympll-eorpuscles, a fer blood-corpuscles, some granular detritus. and inmmerable bacilli and bacillıs-germs. (See

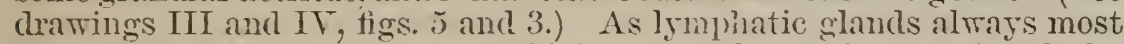
conspicuonsly eularged and morbidly clanged, may be mentioned the superficial and deep in grinal and the axillary glands, the bronchial and mediastinum glands in the chest, and the mesenteric, gastrie, gastroepiploic, and hepatic glands in the abdominal caritr.

3. The trachea and the bronchial tubes contrined in all cases more or less of a frothy mucus-in some cases the brouchial tubes riere full of it-which consisted, examined under the microscope, of brolien-down epithelium-cells, and contained a large number of bacillus-germs and bacilli. (See draming III, fig. 2.) The mucors membrane of the trachea and of the bronchial tubes appeared to be congested, and more or less strelled in erery case.

4. The pulmonal and costal plenm, the mediastinum, and the pericardinu presented almost inrariably some morbicl changes; only in a few cases no visible morbir? changes corlil be fonth. In some animals those membranes appeared to be smooth, but either the thoracic eavity or the pericardim, usually both, contained a smaller or larger quantity (from one ounce to one pint or more) of strarr-colored serum. In a great many cases one or more, and sometimes all, of those membranes were coated to some extent with plastic exudation. in sereral cases a more or less firm adlhesion betweein costal and puimotal plenra and mediastinum, betwecn pulmonal pletra and diaphragm, or between pulmonal pletira and pericardium, had been efiected. In a fer eases the whole surface of the lumgs appicared nore or less fimmly united with the walls of the tiomax. In one case the whole exterual sinface of the heart was firmls, and in another one partially, conlesced vith the inner surface of the pericardium. The pig (is fine animal about four montls old), in which the pericardinm adhered with its whole interior surface firmly and inseparable to the external surfize of the heart, lad severe conrulsions during life. It was lilled in my presence by a professional butcher, who stuck it in the msual may and severed the trunk of the carotides; only a fer drops of blood issued, but the pig diert immediately. The other morbid changes consisted in hepatization in the lungs, enlargement of the lympluatic giands, and the presence of large and numeroits morbicl groiths in the erecum and colon.

5. In nearly erery animal the heart itself has been found more or less afiecter in one way or another. In some animals it was flabby and dilated, but in most cases it was more or less congested. The capillary ressels, especially of the auricles. were, in a large number of cases, gorged with blood to such an extent as to give them a brownish-black appearance, almost similar to gangrene. On closer inspection, horrerer, it conld be seen rery plainly that the bromnish-black color was caused crelnsirely by an accumulation of hlood in the capillary ressels.

6. In forty-eight cases ont of fifty-three, characteristic morbid ehanges 
have been found in the exem and colon. The sume consist in peenliar morbid growths or ulcerous tumor's on the mucons membrane of those intestines. 'They are of various sizes, nearly romil or (sometimes) irregular in shape, nore or less elerated above the surface of the mucons membrane, and frequently, especially the older and larger ones, darkpigmented on their surface. 'Their size raries from that of a pin's head (incipient tumors or nodules) to that of a guarter of a clollar. The smaller ones are msually of an ocher color, and but slightly projecting. above the surfice of the mucons membrane (see photographi, l'late III), but the larger ones are of a grayish-black-brown (see pliotograph, Plate $\mathrm{IV}$,) or blackish eolor; project considerably abore the surface of the membrane, in some eases fully lalf an inch; have usually a slight conearity in the center, and frequently a plain neck or thick pedicle. (See photographs, Plates T, VI, and VII.) Under the microscope these morbid growths or exerescences appear to be composed, on their surfice, of a gramular detritus and morbid epithelimu cells, and contain immmerable bacilli suis, some of which have a very rapid motion. (Sce drawing $T$, fig. 1.) The stroma of these morbid growth consists mainly of a dense connertive tissne. In some cases these morbid growths, es. pecially the smaller ones, or those of a recent origin (see photograph, Plate III), are situated merely on the surfice of the mucous membrane, and are easily scraped off with the back of the sealpel. Thus remored they leare behind an uneren, excoriated surface, not dissimilar to grannlation. The older and larger tumors, howerer, cxtend deeper into the membranes of the intestine; they usually penetrate the mueons membrane, and extend into the musenlar coat, and eren penetrate the latter, and extend into the extermal or serons membrane. In some cases all three membranes of the cecum or colon have been found degenerated and destroyed beneath snch a morbid growth, so as to show perforation on the removal of the latter. The immediate surrounding of such at deep-seated degeneration presented some, but not rery much, inflammation. These morbid gronths, usually, were found most dereloped near the ileo-crecal ralre in the ceemm, but also in larger or' smaller mumbers, and of varions sizes, large and small, in all parts of the caemu and colon.

7. The same, or rery similar morbid growths, ocenrred also, thongh not so often, in other intestmes. In one ease (experimental pig No. VII) a diffuse, (lecaying morbid growth conted the whole interior surface of the jejumm for a length of seyeral feet. Examined muler the mieroseope it was fomd to consist of broken-rlown epithelium eells and a graunlar detritus, and contained numerous bacilli and bacillus-germs. (See drawing V"I, fig. 1.)

In another case one nleerous tumor was found on the monems membrane of the gall-bladder. In three eases the same, or at least rery similar morbid changes, presented themselves on the muens membrane of the stomach. (See pliotograph, Plate VIII.) In a few eases some ulcerons tmmors rere found in the duolenmm, and in one case eren in the right horn of the nterns. In a few eases similar morbid changessmall, knotty, tuberele-like, yellowish, or ocher-colored exerescences of the size of a small pea-were found on the surface of the spleen. In one case similar small excreseenees were also found on the extemal surface of the rena cava posterior. In two cases the liver was fomd to be derenerated by an lypertrophic condition of the eomective tissue, a morbid change which may or may not constitute a product of the morbirl process of sirine-plagine.

8. Morbid ehmges in the serous membranes of the abdominal earity. 
have been found in the cecum and colon. The morbicl growths or nleerous tumor's on the min intestiues. They are of rarions sizes, nearly regular in shape, more or less elevaterl shore + mes 7 y.

vig

(iii)

sin:

abo

but

IV,

mel.

carj

plio

bid

of a

mer:

dras

of a

peci:

Plat

and

they

ulati

mem

bran

and

threc

and

onl $\mathrm{tl}$

(teep-

tion.

the il

and

colon

7. '11

not si

TII) :

face o th.

miclo 


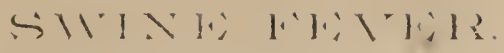

Repon fommasions of' Igriculture for 1878.

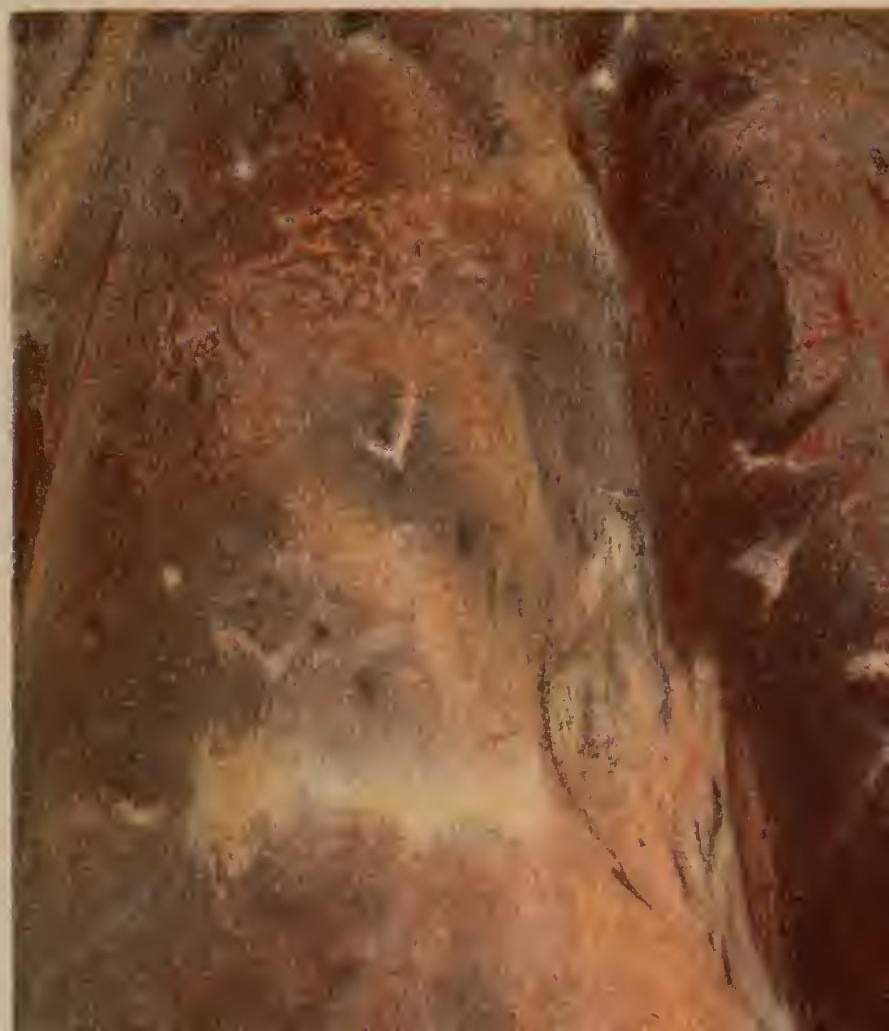



In some eases the peritonemm and the serous membranes of the intestines apreared to be perfeetly smooth, but a larger or smaller quantity of straw-colored serum, from two ounces to one quart or more, wals found in the abdominal cavity. In others, adhesions between the intestines: and the peritonemn, between the intestines themselves, or with other organs, had been efiected. More or less coalescence between cxem and colon, between crecum and ilium, or between the convolntes of the colon, sometimes not separable except by means of the knite, presenteri itself in almost every case, in which the nlcerous tumors or morbid growths in the exem and colon were extensire, large, and sufficiently deep-seated to affect the serons membrane.

9. The contents of the gall-bladder in a large number of eases were found to consist of a semi-solic, grannlar, and dirty brownish-eolored slibstance. In most of those enses, howerer, the inctus choledochus appeared to be thickened, and its membranes swelied; and so it inay be that the semi-solid condition of the bile was due, to some extent, to the partially or totally obstructed passage.

10. In one case a norbid enlargement or hypertrophy of the pancreas presented itselfi, and slight changes (congestion) were found in a f'ew eases in the lidners.

11. Morbid changes, similar in every respect to those occurring on the mucous membrane of the cremm and colon, presented themselves in tiro cases on the conjunctiva, or mucous membrane of the eye. But as the conjunctiva is exposerl more or less to the inflnence of the atmosphere, the morbid growth was not projecting in the same way as in the cecum and colon abore the surface of the membrane; the decay was more complete, and, perlielps, more rapid, so that instead of an excessive growth loss of tissue conld be noticer. In both cases the eyes themselves appeared congested, and the animals seemed to be perfectly blind.

12. In one case the gums of the lower jaw presented similar changes, but in these, too, considerable loss of tissue had taken placo. The morbid process extended into the lower jaw-bone, and enongh of it had been decayed and destroyed to expose the roots of the incisors, and to cause some of them to drop out.

13. Morbid changes, ulceration, and decay have been observed twice in one of the spermatic chords of pig's which had been eastrated a short time before the clisease was contracted. In both pig's an aloscess was found in the scrotum, the only instance in which real matter or pus was observed.

14. In nearly all those hogs and pigs which had been ringed to prevent them from rooting, the parts thus wounded presented more or less decay, in about a dozen eases to such an extent as to cause a formation of large holes direetly fiom the superior surface of the nose in to the nasil eavities. These holes presented very ragged or corroded borders, coated with a dirty-yellowish detritus, and were, in severul instances, sufficiently large to enable the animals to breathe throngh, instead of throngh the nostrils.

15. Morbid changes in the skin, bnt of a different character, were found to be of frequent ocenrrence. In three or four cases numerous sma!l morbid growths (ermptions) extending but slightly into the entis, but causing a complete degeneration of the epidermis, and leaving belind, if removed, an uneven, raw, or excoriated surfince, in appearabee not mulike granulation, were fomd on the comparatiresy fine slin on the lower surtace of the body, between the leas and bohind the ears. In two other cases whole pieces of degenerated and decared skin had sloughed off' and fallen out. 'The corroded borders and the hottom of 
the ulcerk, thus produced, were coated with a dirty-yellowish looking grimular detritus.

In at grent many cases, that is, in nearly half of tho whole number examined, red or puple spots and patchu, and cren contimuons er confluent redness, of a purple hue, presented themselves in the slin on the lower surfine of the hooly, between the legs, behind the ears, se. At the antopsy the slin and the snbentaneons tissue appeared to be congested, the eapillary vessels were gorged with blood, and more or less exuldation and small extrayatsations of blood were found to have falien place. In one case a latrge piece of skin on the lower surface of the body was mortitierl.

16. In two cases quite extensive extrarasations of blood presented themselves in the mucous membrane of the stomach and intestines.

17. The blood presented some quantitative and qualitative changes in every case. Its rnautity appeared to be diminished in erery animal, in some cases to such an extent that not more than, say, fomr or five ounees conld liave been collected if the animal had been lilled by bleediug. Still, the actual want of blood was never as great as it apieared to be, because a considerable quantity was locked ny in the tissues, especially in the lungs, and had become stamant in the eapillary ressels. The blood was dark-colored in all eases in which death had been cansed by extensive morbid changes in the lungs, or in which, on accomnt of those elamges, respiration hat been very imperfect; but it presented a normal color, and was perhaps a little lighter colored and thinner or more watery than in a healthy hog, in all eases in which death had been eansed by other morbid changes, or in which the affection of the hmos was comparatively mimportant. It invariably coagulated as soon ats it becime exposed to the influence of the atmosphere, to a loose and spongy elot, containing a considerable culuntity of serum. Henee, it must be supposed that it was rich in fibrinogen, but probably poor in fibrin, a condition due, nuquestionably, to the lact that during the disease the process of waste had been lingely in cxeess of that of repair.

Under the microscope the blood-corpuseles of fresh blood appeared sometimes nearly all normal or round, and sometimes nore or less angnlan and star-shatyed, lont after a while they all became more or less angular and of an irregular shape, and showed more or less tendeney to congregate in rows and elnsters. The fresh blood contained numerous bacillus-germs, many of them simple, small, romml boclies, some ju proeess of budkling, other's budked or donble, and still other's congregated

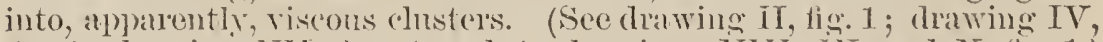
tig. 4; (lrawing VIl, figs. 1 and 4 ; (lrawings Vill, IX, and $\mathrm{X}$, fig. 1.) In a few ases finly developed bacilli suis were tombl in the fresh blood, but they were, compantitively, tew in mmber. In blood which hat been liept twenty-fonr hems or longer in well-elosed vials, becilli were always more muncrots, and sometimes were tomnd in large numbers. As soon,

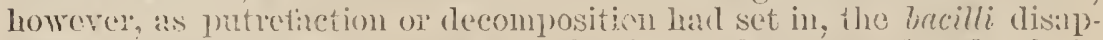
peared. White blood-eorjutiseles, is few in mumber, were found only in three or four cases.

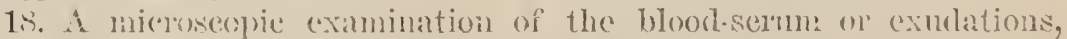
deposited in the pulnonal tissne, invariably revealed, besides some angonbre red hlomb-corpuscles, an immense mmber ot bacilli suis, and of barcillus-gernas in all stages of development, single, buthing, buded,

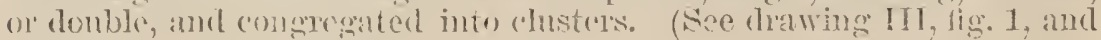
dlawing if, figs. : and t.)

That erery one of these morbid changes does not oecur in one and the 
the ulcerk, 1$\}$ :

gramular det

In al greitî examined, $x^{\prime}$ : fluent redine: lower surtiac antopsy the the capillar". tion and sm

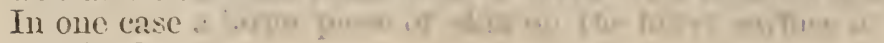
mortified.

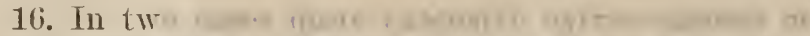

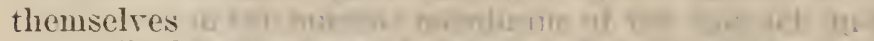

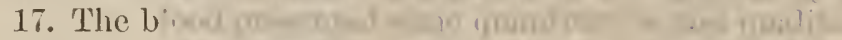
every case. in some cas ominees coul ing. Still, to be, beea especially i. sels. The caused by 1 connt of t] presented :

thinuer ol

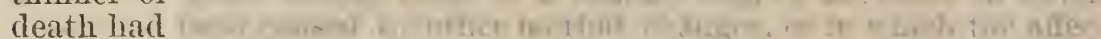

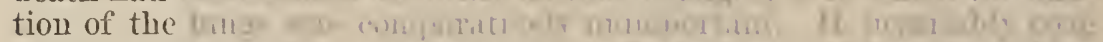

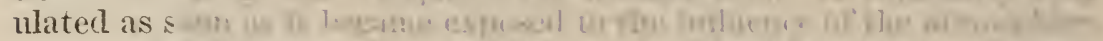

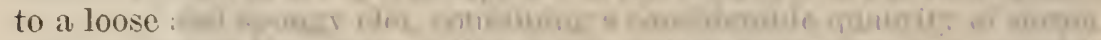

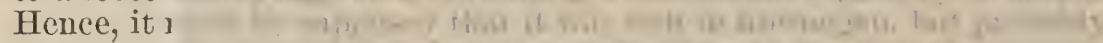
poor in fib the diseas repair.

Under $t$ sometimes,

lar and st: gular aud 1.1 wit or

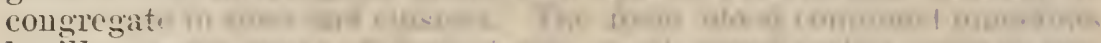
bicillus-g: cess of be into, appe fig. 4 ; dr In a few. but they liept twe? mole nitu however: peared. three or 1.5. A cleposites angular bacillus-

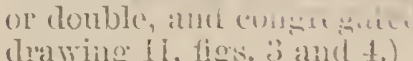

That every one of these morbid changes does not oceur in one and the 


\section{SIINH HH:VFR.}

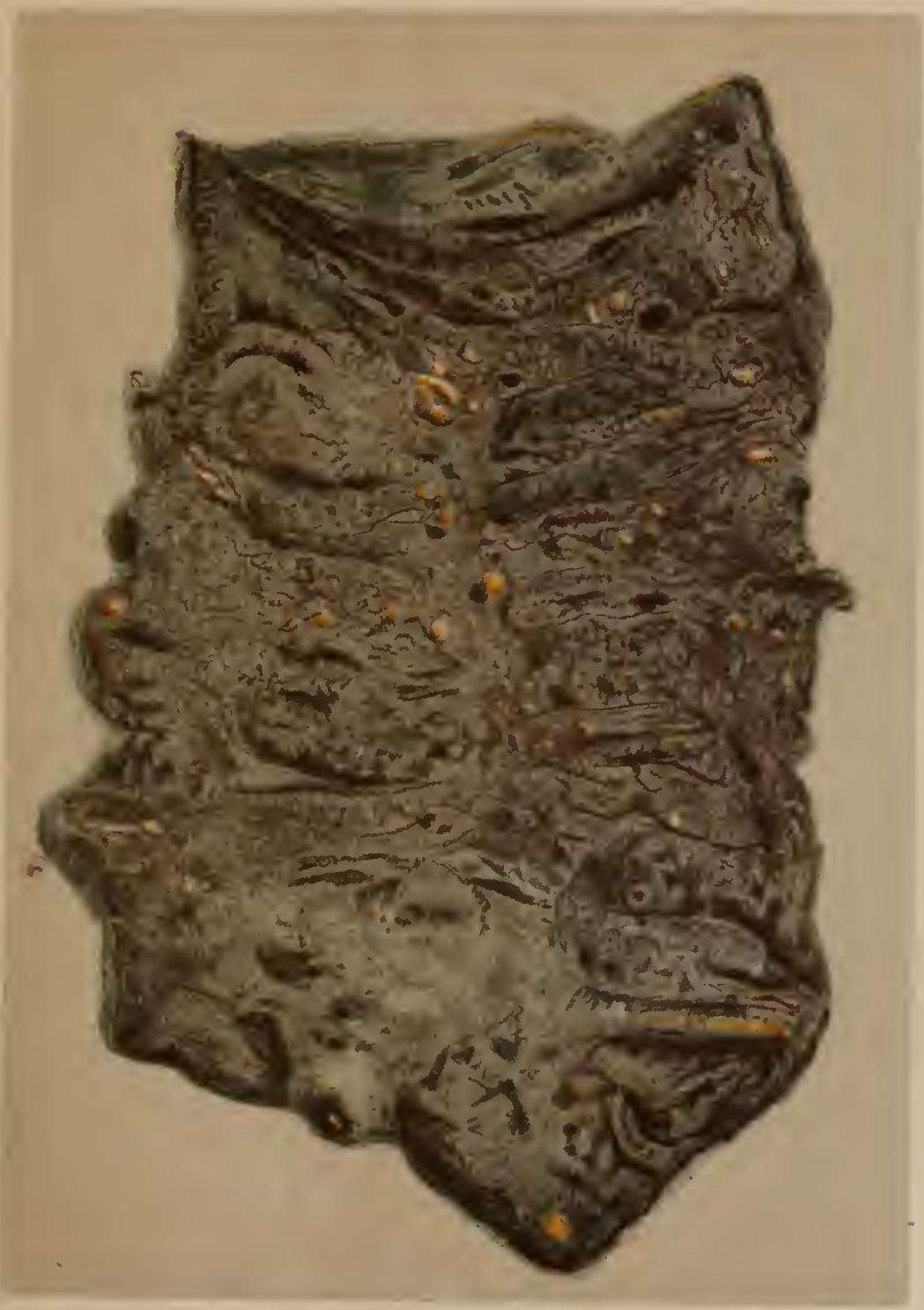

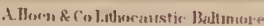

L Lerous tumors on mucous membrane of mtestmes. 

same animal, and that sometimes some and sometimes others are more dereloped and constitute the immediate canse of death, has already been indicated, and does not need any further explanation. 'To convey, however, a clearer iclea of the morbid features and clianges presented after death, I will colyr from my notes the result of the post-mortem examinations of a few of my experimental pigs. Of pigs Nos. 5 and 6 the symptoms, observed during life, have alreaty been noted.

Post-mortem excmination of $j$ ig No.5.-On opening the chest, the ribs, usually tough in a young animal, broke very easily, and seeued to be deficient in organic substances. No serum in the ehest; pulmonal pleura rough, patially coated with plastic exulation; lower half of both lobes of lumgs hepatized; no serum in the pericardiun, but apex of heart firmly coaleseed with the immer surfice of the pericardium; thick, white, and frothy mucus, but no strongili paradoxi in trachea and bronchial tubes. Caccum and colon firmly agolutinated to each otler with their external suffaces; adhesion separable only by means of the knife. Numerous large and small nieerous tumors or morbid growths in both crecum aucl colon. (See photograph, Plate V, which shows the caecum, and Plate VI, which shows the colou, natual size of pig No. 5.) Lymphatic and mesenteric glands enlarged. Ulcerous lecay in mucous membrane of the stomach. (See photograph, Plate VIII, which presents the iuterior surface of the stomich of pig No. 5, natmal size.) Besides those essential changes mentioned, one large nematoid was found in the ductus choledochus, extending from the duodenum through the choledochus and the gall-bladder into an hepatic duct. Another worm of the same kind was found in the eremm.

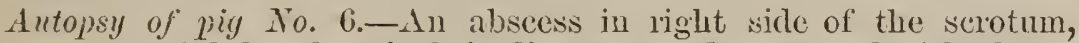
about seren-eighths of an inch in dianeter, and comected with ulceration in right spermatic chord. Inguinal and axillary lympluatic glands considerably enlarged. One-fouth of right aud one-fifth of left lobe of lungs hepatized; the rest gorged with blood-semem or exudation. Crecum and coìn agglutinated to each otler; cecum also adhering to peitoneum. Mesenteric glauds very much cularged; right spermatic chord nlcerated. (Pig had been castrater a few weeks before it contracted the disease.) Extensive morbid growth, in process of decay, in eaceum, and also a large number in colon. Some exudation on lower surface of spleen. Ulcerons decay in mucous membrane of anterior portion of stomach, and wine-colored infiltration and extravasations of blooal in mucous membraue of pyloric portion of same intestine.

Autopsy of pig B.- Some reduess between hind legs and on lower surface of the bohy; gieenish muens oozing from the nose; axillary and iilguinal g'ands very much enlarged; ribs deficient in organic substances, at any rate very brittle; both lumgs spotted all over, indicating plainly (ap)illary embolisn in early stage of flerelonment; licjatization limited, just commencing; lymphatic glands in chest vely much enlarged; the heart, but especialy the auricles, very much cougested anricles ahnost black; small (fuantity of straw-colored serum (uot exceeding two ounces) in thoracic carity, and still less in periearlinn. In the abdominal carity mucous nembrane of anturion part of stomach wine-colored; some chifuse morbirl growth, in process of cecar, in posterior (prloric) portion of sane membrane. To fool whaterer in stomach and intestines; bile thickened. semi-solirl; no nleelation nor any morbid growth whatever in erenu, colon, or any other intestine.

Results of post-mortem examination of experinacnial pig To. VI.-Decayinc biotches or nodules of the size of a fire-cent piece and smaller on skin of lower surface of body and between the legs; right spermatic 
chord ulecrated, amk an albseess the size of a licn's egw in right side of scrotum. Internally ail lymphatic and nesenteric whinds cnlarged; anterior portion of hoth limgs everywhere, with their whole external surfice, and posterior portion at some platees alliering (coalesced) to the costal plenra; muerons smaller and larger embolic tubereles, presenting tine appearance of incipient abscesses, in anterior portion of both lobes of the lumgs, but nore numerous and more developsed in right lobe than in the ledt : remainder-posterior parts of both lobes-gorsed with exulation; snall muantity of stram-colored serum in the chest aud in the pericardinm. In abdominal cavity, liver dather hard (sclerotic), its connective tissue apyarenty lypertrophied. One small tape-worm, not over one and a half inches long, in jejumun, and numerous small, incip). icnt morbid stowths or ocher-colored decaying nodules in crecum. (Sce photograpl, Plate III.) No other morbid changes.

Besides these numerons morbid changes, which must be looked upon as products of the morbid process of swine-plagne. some species of entozoa, a few of which have alrealy been mentioned, have occasionally been met witl, but as their presence is merely accidental, that is, hais nothing whaterer to do with the disease in question, a brief mention of this occurreuce will be sufficient. Strongilus paraloxus has been found in small numbers in the bronchial tubes of a few pigs in one herd onlyIrr. Bassetts. Trichocephalus crenatus (whip)-womiu) laus been found in small numbers in the blind end of the caecum of fonr animals, belonging to two ditierent herds. A small tape-worm was onee foum in the jejummm, as has been stated, and a few other entozoa (nematoids) were found in tour or five instances in the choledochus, gall-bladder, and hepatic ducts (in one case as many as twelve worms), and twice in other intestines.

What I hare so far related was comparativeiy easily ascertained. Nil. merons examinations of diseased animals, frequent visits to attected herds, aud fifty-three post-mortem examinations revealed the facts, and all that was necessary was to observe and talie notes. But the principal object of the investigation was to devise means to prevent the immense losses eansed every year by that most fatal disease, swine-plague. (I have adopted that name, because the clisease, if anything, is a real plague; and the name is sufficiently comprehensive to cover the whole mortid process, and so simple that I have no donbt it will soon supercede, even among farmers, that very inproper name of hog cholera.)

To ilerise snch means, a more reliable basis than a dnere knorledgo of the various features of the ciisease had to be gained. The real natme of the morbid process, aud the true canse or canses, had to be ascertained. Above all, it had to be decided as to whether swine-plasne is a contagions disease or not; and if contagions, the means hy which the contagion is eomvered firom one plater and nom one animal to awother; the manner in which it enter's the aninsal organism, and, if possible, the nature of the same. This conld not be rloue by simply visiting; diseased herds and examining sick and clead animals; it was necessary to make "xperiments and to observe and to record the results. This I lave done, and before I proceed any further it may be best to give. first, a condensed acconnt of the experiments which I lave matle for the purpose of settling those points, so as to gire othel's all oplortinnity to tom an opinion as to the correctness of the conclusions il have arrived at. I will mention again, that in making those experiments, in noting the results, and in maling the necessary and rery numereus microscopical examinations, I have been ably assisted by un friends, Dr. T. Wr. Prentice and Irof. T. J. Burrill, of the Illinois Indnstrial University. I commenced those experiments after I had gained con- 
14: 1 .

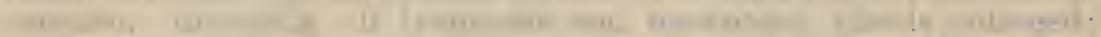
D.

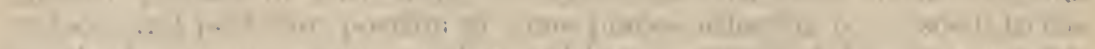

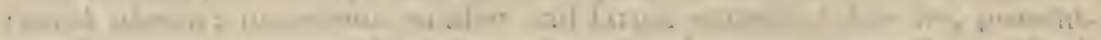

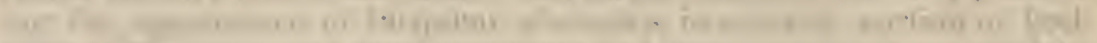

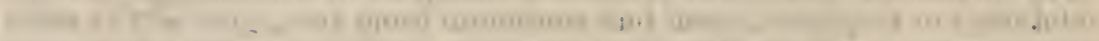

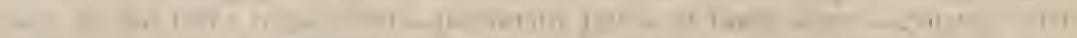

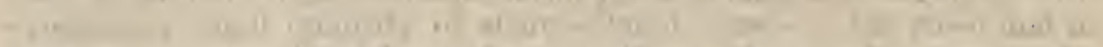

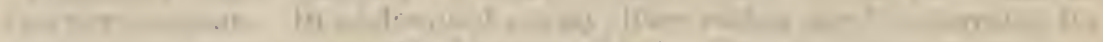

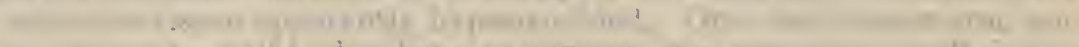

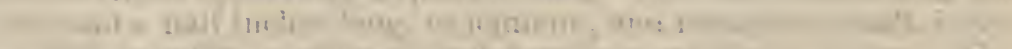

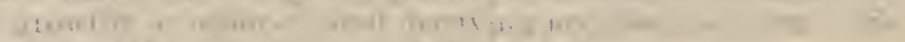

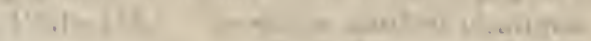

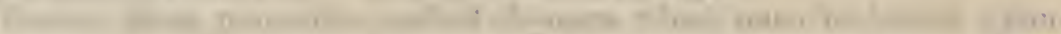

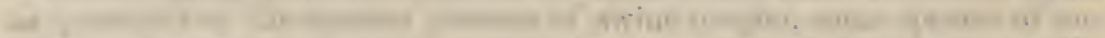

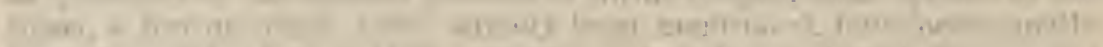

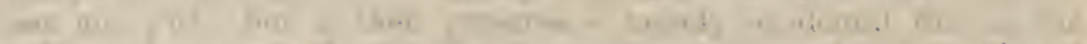

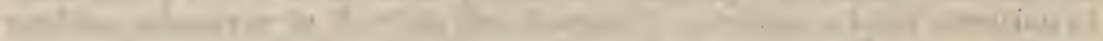

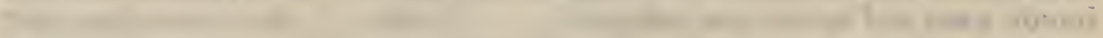

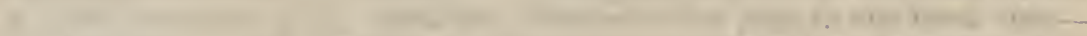

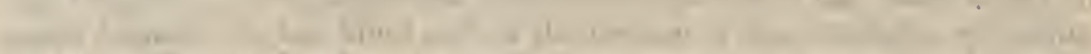

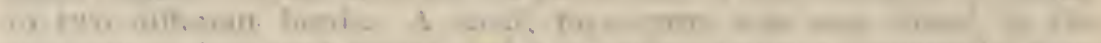

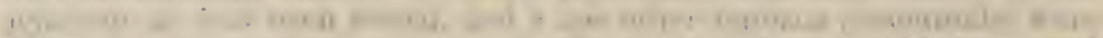

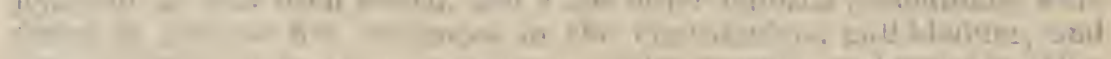

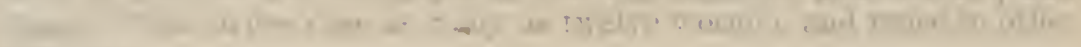
$1+$

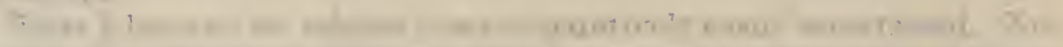

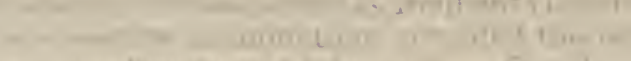

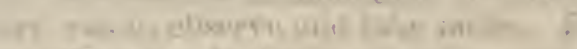

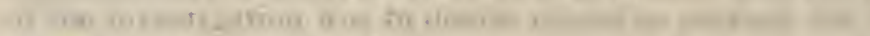

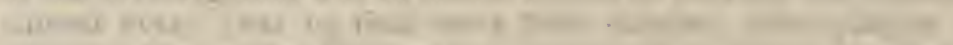

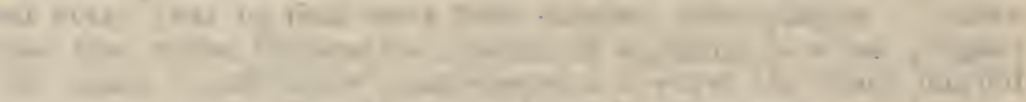

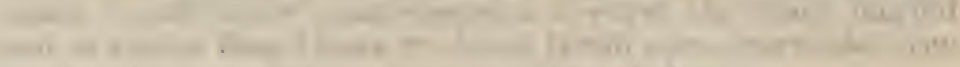

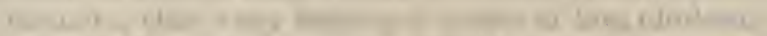

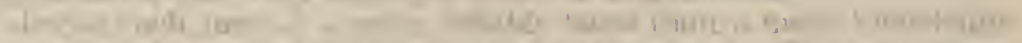

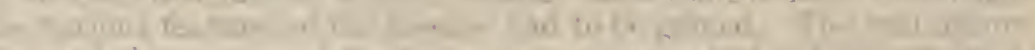

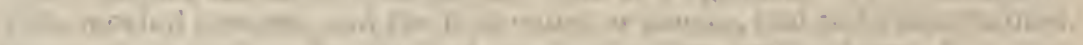

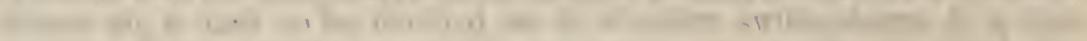

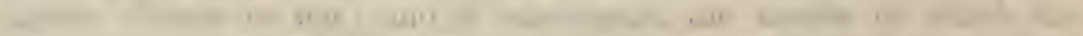

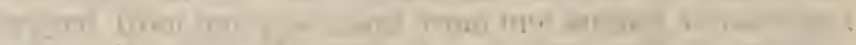

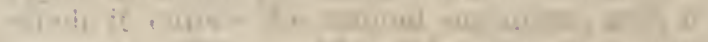

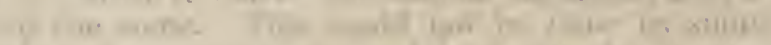

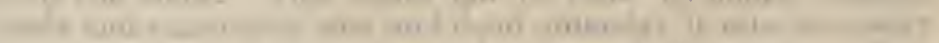
I im 5 :

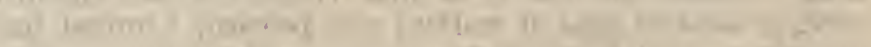

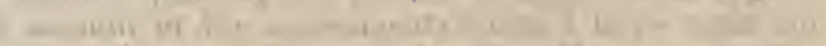

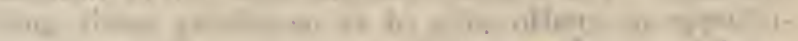

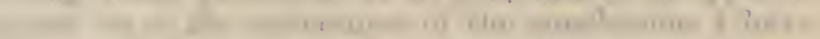
1.

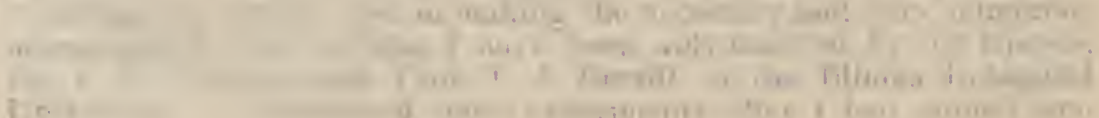




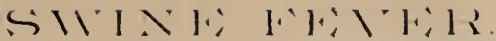

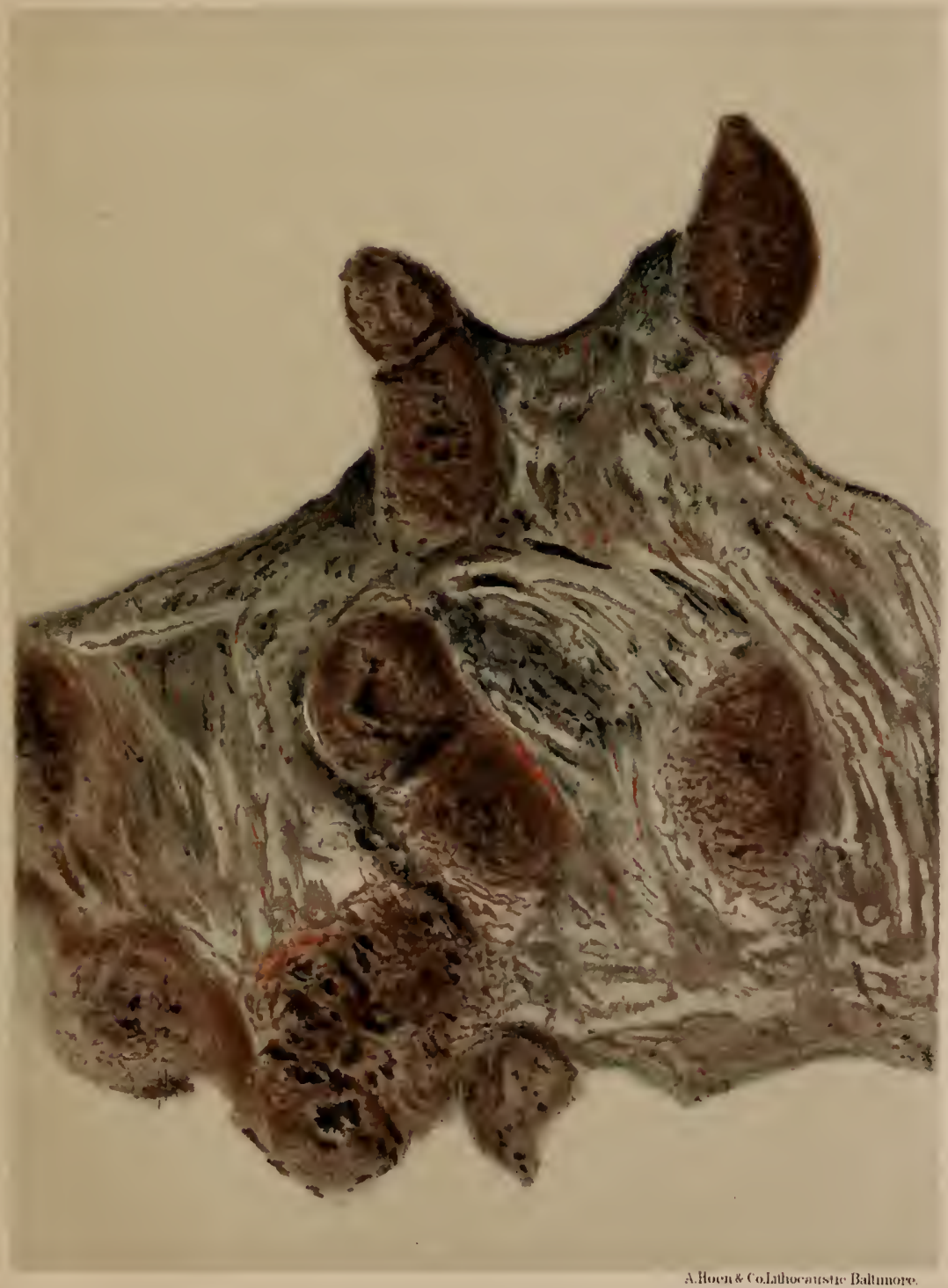

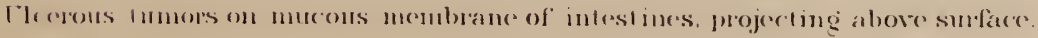



fiderable information as to the rarious features of the disease during life and after death, and as to the conditions and surroundings under which the same makes its appearance. The first series of experiments has been made for the purpose of settling the question as to the contagiousmess or non-cortagiousness of Swine-Plague. This was the more necessary from the fact that those who had suffered severe losses were decidedly divided on that question.

\section{FIRST SERIES OF EXPERIMENTS.}

After encountering considerable difficulty in findingindubitably healthy pigs, belonging to a perfectly healthy herd, which had never been in contact with diseased animals, I succeeded finally, on the 20th of August, in buying of Mr. Harris, south of Champaign, three Berkshire sow pigs about three aud a half months old, perfectly healthy, and withont any lesions whatever. I designated them as pigs Nos. 1, 2, and 3. Dr. Prentice, at the same time, had the kinduess of placing at my rlisposition two box-stalls in his reterinary hospital, a new building which had never been entered by any hog or pig. About one hundred and fifty yards east of the veteriuary hospital building, on a piece of ground never trodden by hogs, as far as known, I built of new lumber a pen eight feet square. This pen I designated pen No. 1, and the box-stalls, which are twelve feet square, as pens Nos. 2 and 3 respectively. Pig No. 1 was put in pen No. 1 , and pigs Nos. 2 and 3 together in pen No. 2 .

It may be well to state here that pen No. 1 having no floor, but resting on the ground, was moved to another place (each time its own width) every other day, usually at noon, in order to preserve cleanliness, and pens Nos. 2 and 3 were cleaned and swept once a day, except whero stated otherwise in the following pages. The food of all experimental pigs was the same, and consisted of corn in the ear, and occasionally a little green clover and purslane at noon or in the evening. The water for drinking was drawn three times a day from a well.

1. Account of pig No. 1.-On August 21 I procured from Mrr. Bassett, four miles north of Clımpaign, a diseased Chester white pig, four months oid (pig No. 4), which I put with pig No. 1 in pen No. 1. This diseased pig which arrived at 10.30 o'clock, a. m., exlibited plain and unmistakable symptoms of swine-plagme; its temperature was 1062 F., and its skin, on lower surface of the body, between the legs, \&c., was considerably reddemed. The temperature of pig No. 1, which objected to being examined and struggled hard, $\operatorname{mas} 104_{2}^{10} \mathrm{~F}$.

August 22.-Pig No. 1 all right; has vigorous appetite. Pig No. 4 at 8 o'clock a. m. very sick; has a peculiar, short, abrupt cough; at 1 o'clock, p. m., dead.

Post-mortem examination.-Capillary redness in the skin on lower surface of body and between the legs; considerable enlargement of lymphatic glands; more than two-thirds of the lungs hepatized and gorged with blood-serum; some straw-colored serum in thoracic cavity and pericardium; and morbid growths in process of decay (ulcerous tumors), iu cxcum and colon.

Received at 1 o'clock, p. m., three more pigs, each about three months old (eross of Berkshire and scrub), of Mr. Schumacher, a butcher in Champaign, who had bought the same of a farmer ten niles southeast of Champaign. I designated the same as pigs Nos. 5, 6, and 7. Pig's Nos. 5 and 6 appeared to be perfectly healthy, and were put together in pen No. 3. Pig No. 7 was apparently indisposed; it had been transported ten miles, crowded together with twenty others, most of them 
larger and older, and exposed for several hours to the burning rafs of the sun, in an open farm-wagon on a very hot day. It was panting for breath, and shorred symptoms of congestion of the lungs. It was put in pen No. 1 with pig No. 1, before dead pig No. 4 had been removed.

August 23.-Pig No. 1 perfectly healthly. Pig No. 7 rery sick; breathes ninety-two times per ininute; shows plain symptoms of plen. rites; has no apjetite, but is attentive and mores quickly when disturbed. It died at 8 o clock 1). $\mathrm{m}$. Post-mortem examination revealed pleurites aud pericarditis; the whole sturface of the lungs was loosely agglutinated to costal pleura, and the substance of the same was gorged with exudation. No other morbid changes vohatever. Whether this was a case of swine-plagne or not, I leare to my readers to decide for themselves. I am decidedly of the opinion it was not, because none of the other twenty pigs, except Tos. 5 and 6 (see account of them) liare, up to date, contracted the disease, as I have learned from a reliable source. It is true two other pigs of the same lot showed some indisposition ou the 24th, 25th, and 26th dars of August, but were all right again the next day, and are healthy jet.

August 21.-Pig No. 1 perfectly healthy; rigorous appetite.

August 25.-No change.

August 26. -No change.

August 27.-No change.

August 2S.- Weather very hot and sultry; in afternoon severe thunder-storm and rain, which eflected a sudden cooling of the atmosphere. Pig No. 1 in perfect health.

August 29.-Pig No. 1 coughed once; being exposed in an open pen to the changes of weather and temperature, it has possibly taken cold. August 30.-Pig No. 1 perfectly healthy; is very lively, and has vigorous appetite.

August 31.-The same.

September 1.-The same.

September 2.-The same.

September 3.-The same.

September 4.-Tho same. At 6.30 o'clock, p. m., diseased experimental pin No. 2 (see account of the same further dowu) was put in pen No. 1 with pig No. 1.

September 5.-Pig No. 1 perfectly healthy. Pig No. 2 eats nothing; shows plain symptoms of pmeumonia.

September 6.-P'ig No. 1. perfectly healthy. Pig No. 2 died at 6 o'clock, p. m. (For post-mortem examination, which was made immediately, see accorint of pig No. 2.)

September 7.-Liy No. 1 perfectly healthy, and has remained so up to date. Has always first-rate alpetite, has nerer refused a meal, and is to-day a strong, vigorons, and thriving pig. (Made use of the same for another experinent on November 13.)

2. Account of pigs Nos. 2 and 3.-August 21.-Both pigs are perfectly healthy; have good appetite, and are active and lively.

August 22.-Both pigs perfectly healthy. Inoculated both in right ear at 1.30 o'clock, p. m., with blood-serum from the lungs of pig No. 4 ,

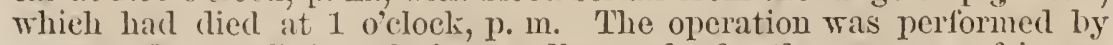
means of a small inoculation-needle, made for the purpose of inoculating sheep with the virus of sheep pox. Each pig receired two slight punctures on the external surface of the ear; the serum inoculated was less than one-fourth of a drop per animal. The blood-serum used was of a faiut reddish color, and almost limpid. Examined under tho 
in

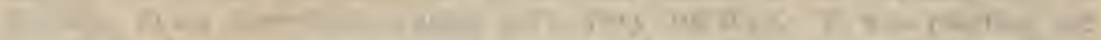

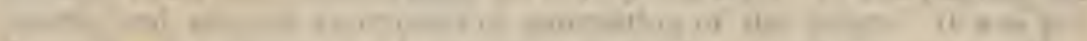

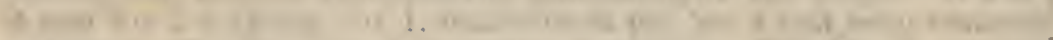

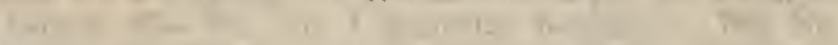

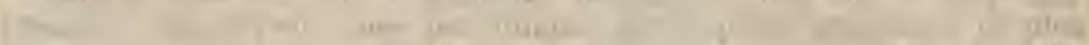

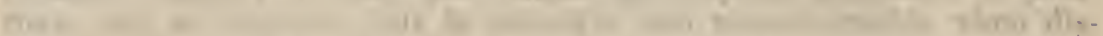

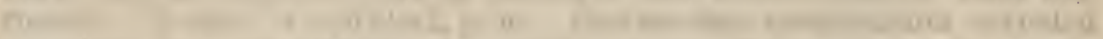

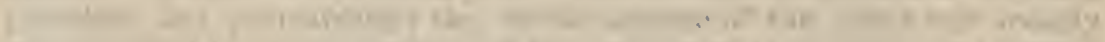

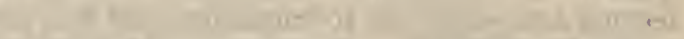

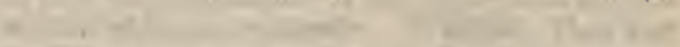

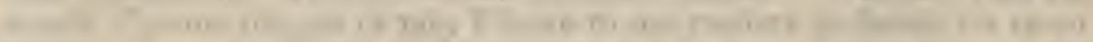

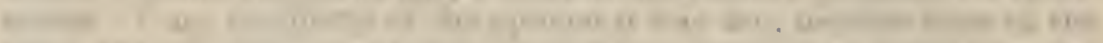

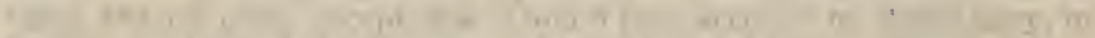
(1) W

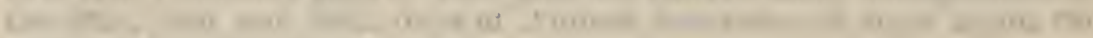
Li.

-

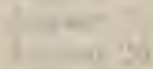

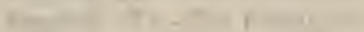

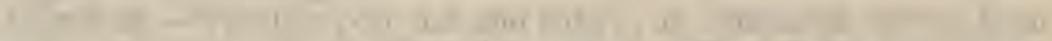

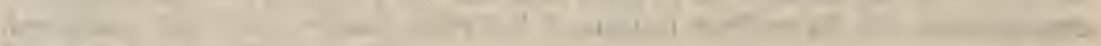

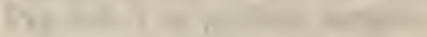

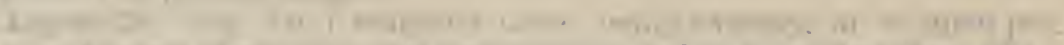

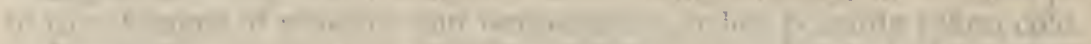
I

(1)

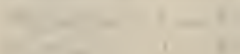

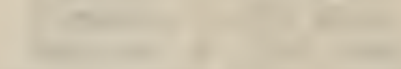

$x^{2}=$

for

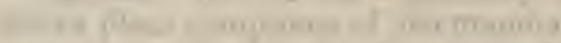

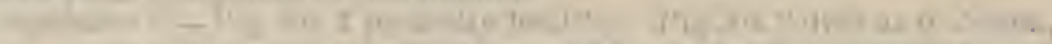

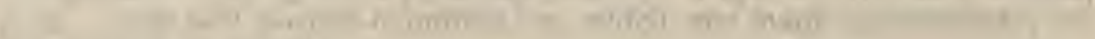

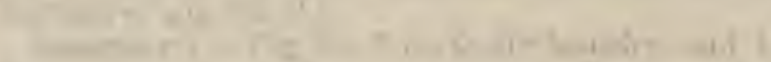

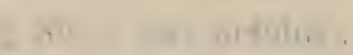

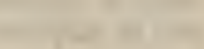

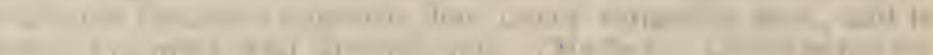

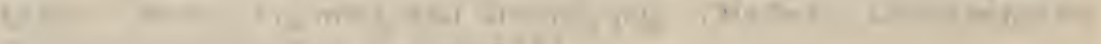

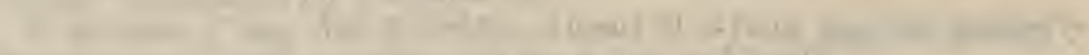

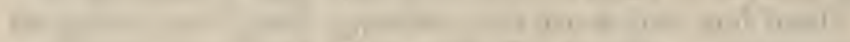

ming

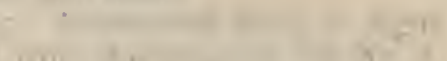

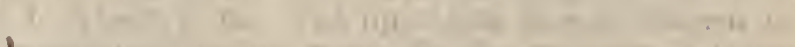

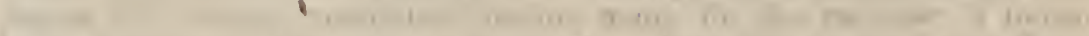

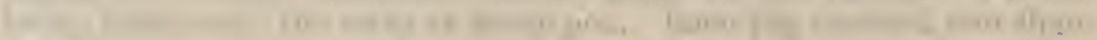
12

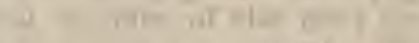
(1) 


\section{SWINE FEVER.}

Report Commissioner of Agriculture for 1878.

Plate 1 :

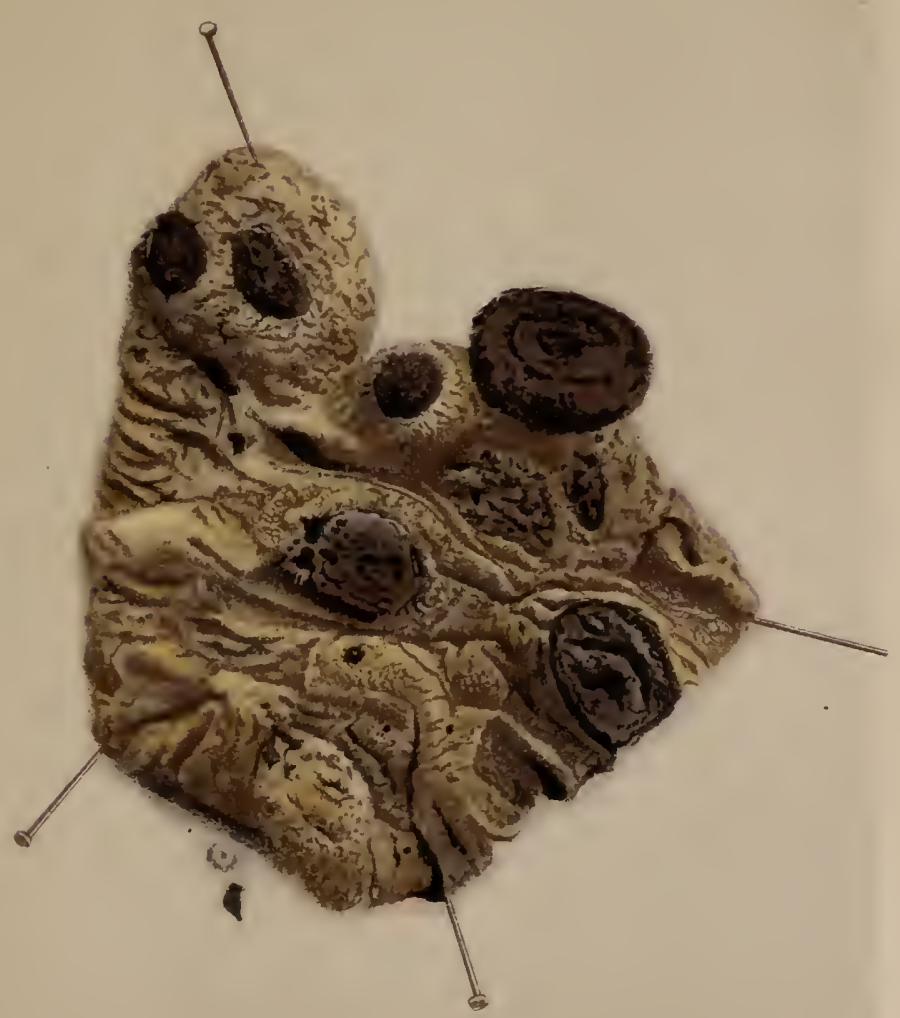

A.Joen \& Colhtheraustic. Baltumore

Dicerous tumors on mucous membrane of intestines, showing concavity in center. 

microscope it eontained a few red blood-corpuseles, numerons baeillusgerms, and some dereloped bacilli suis.

August 23.-Pigs Nos. 2 and 3 perfectly healthy. No visible reaction. August 21. - Both pigs perfectly healtliy; have rery good appetite.

August 25.-No cliange.

August 26.-No change.

August 27.-Pig No. 2 appears to be slightly indisposed. Pig No. 3 apparently healthy.

August 2S.-Both seem to be healthy; eat well.

August 29.-Pig No. 2 not quite as lirely as a healthy pig; does not seem to have very good appetite. Pig No. 3 shows no symptoms of disease. Temperature of pig No. 2, 105.4 F., and of To. 3, 10410 F. Both pigs struggled very much whilo being examined.

August 30.-Pig No. 2 not very lively, and shows a teudeney to lio down; does not eat as well as formerly; temperature, $104_{4}^{10} \mathrm{~F}$. At feeding time in the erening it did not arise, nor did it seem to eare for its food. Pig No. 3 apparently all right.

August 31.-Pig No. 2 shows plain symptoms of sickiness; arehes its back, and mores with short undecided steps. Pig No. 3 appears to bo less lively.

September 1.-Both pigs, Nos. 2 and 3, show plain symptoms of swine. plague.

September 2.-Pig No. 3 seems to be worse than pig No. 2. In afternoon the eyes of pig No. 3 appeared congesterl, and the conjunetiva infiltrated with blood. Appetite of both amimals rather poor. Both aro thirsty.

September 3.-Pigs Nos. 2 and 3 do not eat anything; are evidently very sick; show great indifference to surroundings, and do not like to come out of their corner. Both are very weak, and look as if they suffer from pressure upon the brain.

September 4.-Pigs Nos. 2 and 3 have not tonched any food; they huddle together in their corner, lie down, and will not get up unless compelled to do so. Both show increasing museular weakness and emaciation. At 6.30 o'elock, p. m., pig No. 2 was removed to pen No. 1. (See account of pig No. 1.)

September 5.-Pig No. 2 (now in pen No. 1) eats nothing; has plain symptoms of pneumonia. Pig No. 3 (in pen No.2) is getting rery weak; at 7 o'elock, p. m., is lying flat, and in a dying condition.

September 6.-Pig No. 2 (in pen No. 1) very sick. Pig No. 3 (in pen No. 2) dead in the morning, with well-marked rigor mortis.

Post-mortem examination.-Skin normal; lymphatie glauds enlarged; left lobe of lungs partially hepatized; right lobe the sane, but hepatization more extensive; no serum in thoracie cavity; about two drachms in pericardium; heart normal; spleen enlarged; partially eoalesced with peritoneum of abdominal wall, which shows traces of inflammation; some small ulcerous tumors on surface of spleen, and adhesion between the latter and the colon; mesenterie glands considerably enlarged; morbid growths or uleerous tumors, and a few worms (trichocephalus crenatus), the latter partially embedded in the smaller caceal mucous membrane in excum; blood extravasations, and capillary congestion in mucous membrane of crecum, colon, ilium, and stonach ; liver somewhat enlarged; kidneys normal. The blood, examined under the microseope, contained, besides red blood-corpuscles with ragged, irregular or starshaped outlines, a few white blood-conpuscles (fiom one to five in the field), numerous bacillus-germs in valious stages of derelopment, and a few developed bacilli suis. 
Pig No. 2 died at 6 o'clock, p. m. (Sce account of pig No. 1.)

Post-mortem cxamination.-Skin normal; lungs partially hepatized; hepatization most marked in anterior lobes; small quantity of serum in pericardium; liver enlarged; one nematoid in choledochus; abdominal cavity free from serum; ecchymoses on the external surface of colon and cxcum; capillary hyperæmia and swelling in cxcal mucous mem. brane; seieral small uleerous tumors in cacum, especially near the iliocacal valve; swelling, capillary congestion, and extravasations of blood in mucous membrane of colon and ilium; kidneys normal; bladder empty; mucous membrane of stomach similar in appearance to that of cæeum, colon, and ilium.

Account of pigs Nos. 5 and 6.-Pigs Nos. 5 and 6 , which arrived, as has been stated before, August 22, at 1 o'clock, p. m., were put in pen No. 3 , and at 1.30 o'clock, p. m., the colon, the heart, and a piece of the diseased lungs of pig No. 4 were given to them. They, however, touched neither colon, heart, nor piece of lung.

August 23.-Both pigs, Nos. 5 and 6 , in good health, and eat their food greedily, but have not touched the colou, heart, and piece of lung. The colon, having become very putrid, had to be removed; heart and piece of lung were thrown into the feed-trongh.

August 24.-Both pigs healthy. Heart and picee of lung have disappeared, but whether they hare been consumed by the pigs or by rats I ain not able to decide.

August 25.-Both pigs healthy; have good appetite, ant eat greedily. August 26.-The same.

August 27.-The same.

August 28.-The same. August 2Sth was a very hot clay, but a severe thunder-storm in the afternoon effected a sudden cooling of the atmosphere.

August 29.-Both pigs, Nos. 5 and 6, seem to have a slight catarrh, probably in consequence of the sudden rednction of temperature and change of weather. Both cough some.

August 30.-Both pigs, to all appearances, all right, except that oceasionally a slight cough can be heard. Both have first-rate appetites.

August 31.-Both pigs apparently in perfect health; appetite good.

September 1.-Both pigs all right.

September 2.-The same.

September 3.-The same. Pig No. 5 coughed once or twice, but has excellent appetite.

September 4.-Pig No. 5 coughs again a few times, but is lively, and has very good appetite. No. 6 is all right in every respeet.

September 5.-Both pigs all right.

September 6.-Both pigs hare good appetite, are very lively, and seem to enjoy good health. At 10.30 o'clock, a. m., the entire stomach, cut up into five pieces, the crecum, and the spleen of pig No. 3 were giren to them, and consumed immediately in the presence of Dr. Prentice.

September 7.-Both pigs, Nos. 5 and 6 , have very good appetite. No. 5 has a slight cough, and a slight accumulation of mucus in the inmer canthi of the eyes. (For further particulars see the aceomnts given of pigs Nos. 5 and 6 in the chapter on Symptoms and Morbid Changes.)

Having thus ascertained by experiments, just related, that swineplague is infeetious, and can be communicated by inoculation, and also through the digestive canal by a consumption of morbid tissues, I considered it to bo of great importance to ascertain, if possible, the nature of the infectious prineiple; that is, to decide by experiments whether it consists in something corporeal, endowed with life and power of propa- 


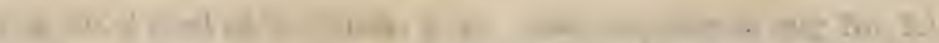

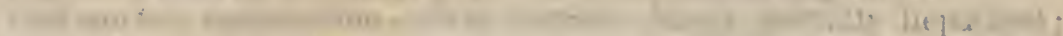

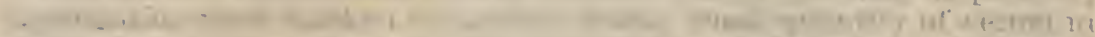

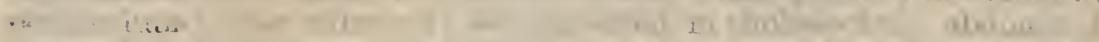

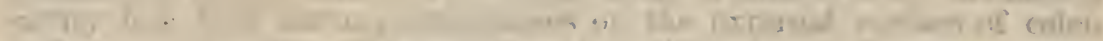

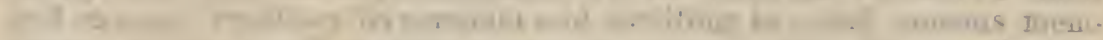

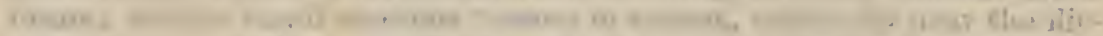

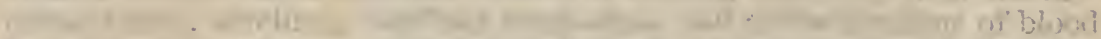

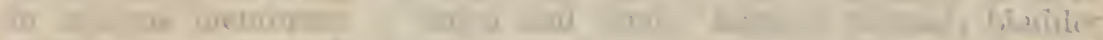

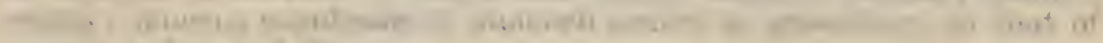

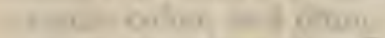

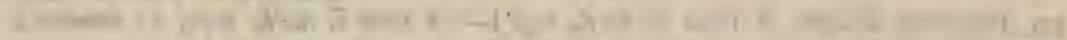

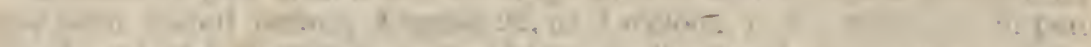

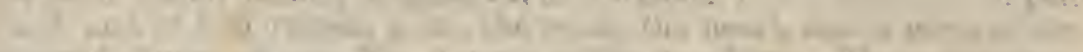

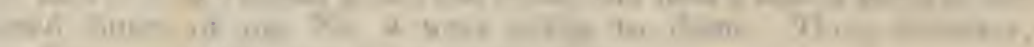

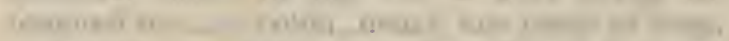

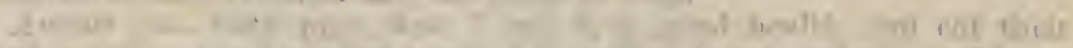

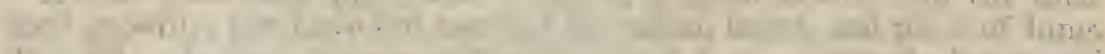

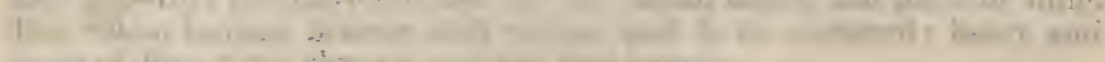

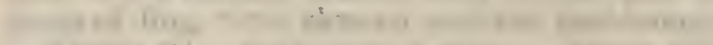

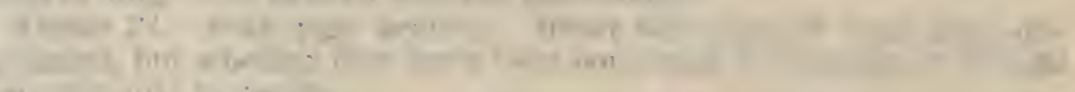

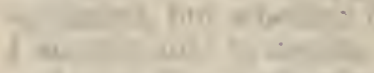

16.

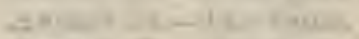

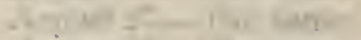

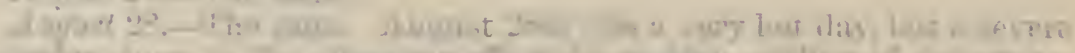
. $\cdot$

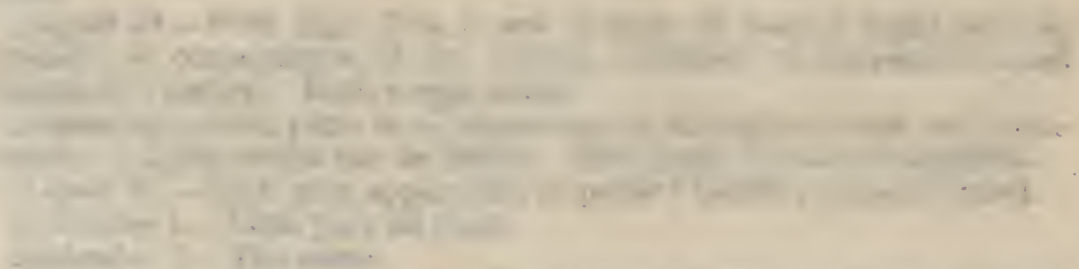

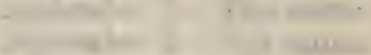

1,

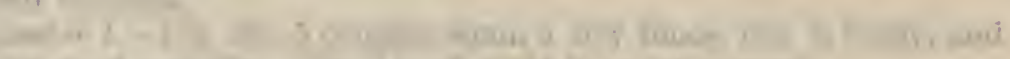

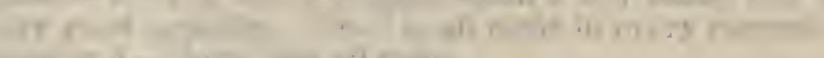

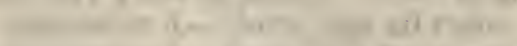

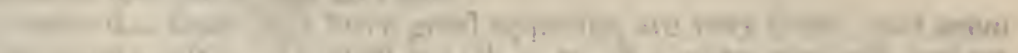

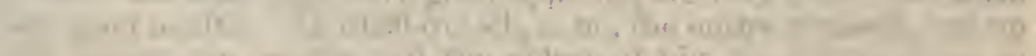

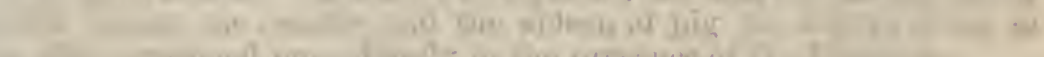

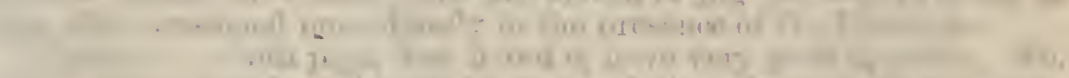

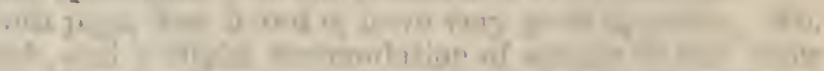

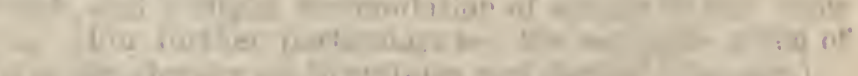

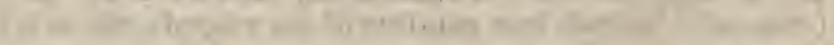

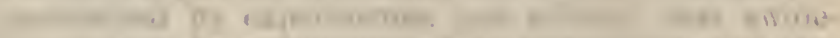
-

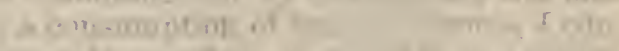

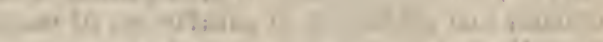

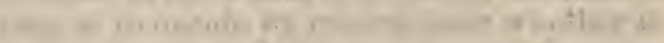

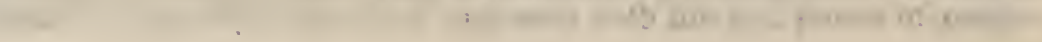




\section{SWINH: HWVHIR.}

Report Commissionex of Agriculture for 1878 .

Plate VI.

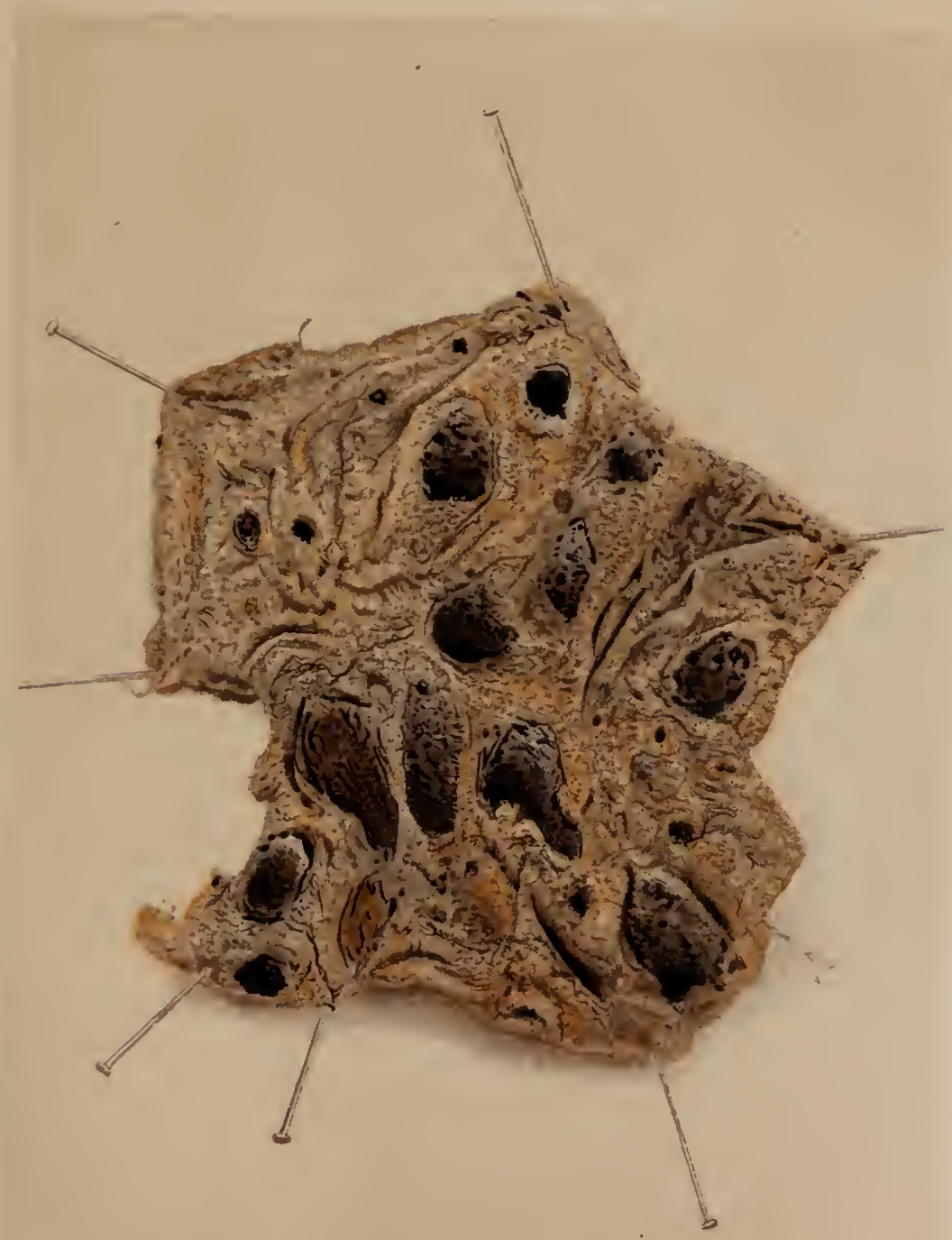

AHoen \& Colithocaustic Baltunore

Ulcerous tumors on mucous nembrane of intestines, showing different view 

gation, or in some invisible chemical agency or mysterious fluid, permeating, as has been supposed, the whole animal organism, and contained in, or clinging to, all those substances which possess infections properties, or constitute the bearers or vehicles of the contagion. As all microscopical examinations of the blood, morbid tissues, and morbid products of forty-two animals, which had been affected with swineplagne and had died of that disease or been killed by bleeding, and repeated microscopical examinations of the excretions (urine and excrements) of diseased animals, liare revealed in every case the presence of numerous bacillus-germs (micrococci of Hallier) and dereloped bacilli suis, I deemed it necessary to ascertain first, if possible, the relation which these extremely small microscopic bodies may have to the morbid process and to the infectious principle. For that puipose I com. menced another series of experiments, and bought again, on September 24 th, three very nice, perfectly healthy pigs, each a little over three months old, of IIr. Burton, residing four miles southeast of Champaign. I designated one of them, a nearly full-bred Berkshire barrow, as pig A; another one, a Poland-China sow, as pig B; and the third one, also a Poland-China sow, as pig $\mathbf{C}$.

Account of pigs $A, B$, and $C$.-The same arrived at 10 o'clock, a. $\mathrm{m}$. Pig A was put in pen No. 1 with pig No. 1 ; pig $B$ in pen No. 3 with pig No. 6 ; and pig $C$ by itself in the thoroughly cleaned and disinfected pen No. 2, formerly occupied by pigs Nos. 2 and 3. Pen No. 2 had been clean and empty since September 6 th, and was again disinfected with carbolic acid before pig $\mathbf{C}$ was put in.

September 25.-All three pigs, A, B, and C, perfectly healthy.

September 26.-All three pigs perfectly healthy; have good appetite.

September 27.-The same; inoculated pig C with cultivated bacilli and bacillus-germs. On September 23d, Professor Burrill charged two drachms of fresh cow-milk with a mere speck, smaller than a pin's head, of a decaying morbid growth, or ulcerous tumor of the cxcum of pig No. 5, and kept the vial well closed, at a temperature of $92^{\circ} \mathrm{F}$. On the evening of September 26th the milk was examined nuder the microscope, and was found to contain numerous bacilli suis and bacillusgerms (see drawing III, figs. 3 and 4), the same as found in the bloodserum, or exudation of diseased lungs, and in the decaying substance of the intestinal morbid growths. The inoculation with this millk was executed in the same way as the inoculations of pigs Nos. 2 and 3 ; two punctures were made on the external surface of the left ear.

Scptember 28.-All three pigs perfectly healthy. The inoculationpunctures on the ear of C slightly swelled.

September 29.-Pigs A, B, and C, all right.

september 30.-All three pigs perfectly healthy; 110 symptoms of disease.

October 1.-The same.

October 2.-Pig A perfectly healthy; pig B shows symptoms of sickness, sneezes, has eruption on the ears, diminished appetite, and is not as lively as formerly. As. a full account of pig $\mathrm{B}$ has already been given in the chapter on symptoms and morbid changes, it will not be necessary to repeat what has been said there, and pig $\mathrm{B}$ may be dropped. Pig $\mathrm{C}$ apparently all right in the morning. At noon, pig C, too, commences to sneeze; sneezes a good deal, and shirers like a man suffering from ague, but has good appetite.

October 3.-Pig A perfectly healthy. Pig C shows slightly diminished appetite and other plain symptoms of indisposition; is less lively, and has a tendency to lie down; the sneezing continnes. 
October 4.-Pig A in first-rate health. Pig C a little more lively; has fair appetite, but is not as greedy as formerly.

October 5.-Pig $\Lambda$ in fine condition, and all right in erery respect. Pig $\mathrm{C}$ shivers, and sneezes again a good deal, but does not show any other perceptible symptoms of disease, except some cruptions behind the cars, and on the external surface of the same.

October 6.-Pig $\mathrm{A}$ all right in every respect. Pig $\mathrm{C}$ abont the same as prececling day.

October 7.-Pig A perfectly healthy. Pig C lias good appetite, and with the exception of its coat of hair being a little rougher than usual, does not show any plain symptoms of disease.

Made two post-mortem examinations of pigs mhich had died of swineplagne at Mr. Hossack's place, fire miles southwest of Champaign. In the ereming I examined microscopically the blood.serum or exudations of the diseased lungs of one of MIr. Hossack's pigs, and found normal red blood-corpuseles, numerous bacilhus-germs in all stages of derelopment-single, budding, budded or double, and aggregated into clusters-and some developed bacilli suis.

October S.-Pig A all right. Pig C shirering again. In the forewoon I filtered some of the blood-sermm of the diseased lungs of $\mathrm{Mr}$. Hossack's pig throngh eight filters-the rery finest userl in the chemical laboratory of the I. I. University - for the purpose of freeing the serum from the bacilli and bacillns-germs; but notwithstanding that I hare taken all possible precantions, the filtrate, which was almost limpid, still contaimed, as examined under the microscope, a great many bacillus-germs. I preserved it in a rial with a tight-fitting ground-glass stop.

October 9.-Pig $A$ healthy. Pig $\mathrm{C}$ has fair appetite, but is not greedy. I filtrated the filtrate once more through two filters, and obtained a limpid fluid, which, howerer, at a microscopic examination, was found to still contain some bacillus-germs. Preserved the filtrate again in a clean vial, with a perfectly-fitting grouncl-glass stop.

October 10.-Dig A healthy. Pig $\mathrm{C}$ eats its food, but is rather slow at it.

October 11.- Pig $A$ healthy. Pig $\mathrm{C}$ about the same as on preceding day.

October 12.-Pig I healthy; pig C, no perceptible change.

October 13.-Dig $A$ all right in erery respect; pig $\mathrm{C}$ does not show any plain symptoms of disease in the morning, but is sneezing again in the evening.

Octoler 14.-Pig $\Lambda$ in perfect health; pig C sneezes a good deal, but has fair appetite. Took up) again the filtrated blood-sermm, and finding, on examination under the microscope, that the bacillus-germs had changed to bacilli (see drawing XI, figs. 1 and 2), I filtrated the same again througlt four papers. Dr. Prentice and myself examined the filtrate obtained uncler the microscope ( 850 cliameters), and neither of us being able to discorer any bacillus-germs, I inoculated pig $A$ on the left ear with the filtrate in the same manner in. Which the other pigs had been inoculated. Nade tro punctures, but used a needle a trifle larger than the one nsed before.

October 15.-Pig $A$ all right; no reaction whaterer. Pig $\mathrm{C}$ sneezing, but fair appetite.

October 16.-Pig A perfectly healthy, and has remained so up to date (Norember 11th). It has never refused a meal, and has been always rery actire and lively. It is now a rery fine pig and in a first-rate condition. (Made use of the same for another experiment on Norember 13th.) Pig 


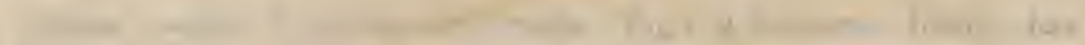

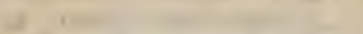

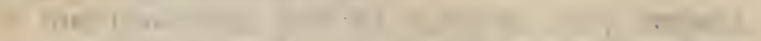

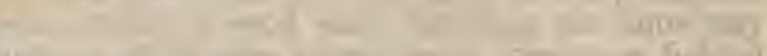
III. 2.

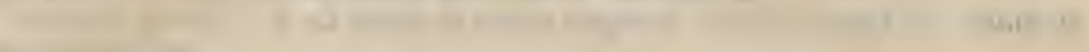

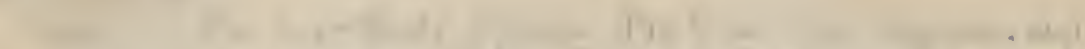

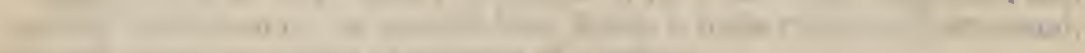

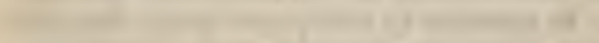

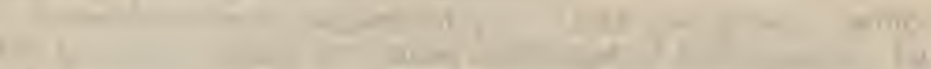

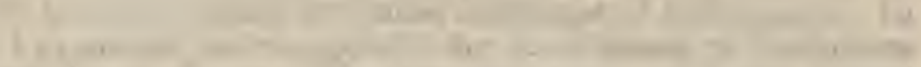

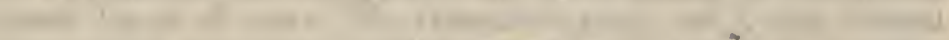

$$
\begin{aligned}
& \text { I1 }
\end{aligned}
$$

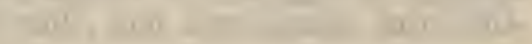

(20)

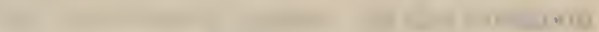
(2)

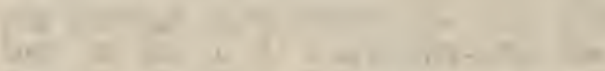

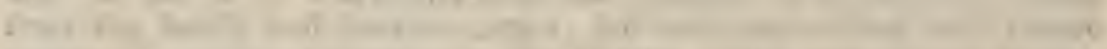

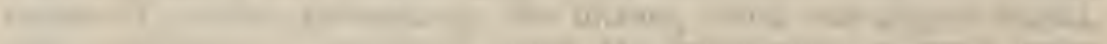

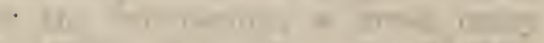

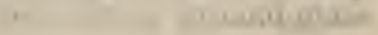

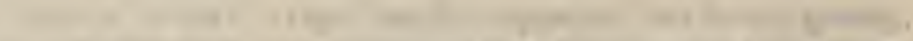

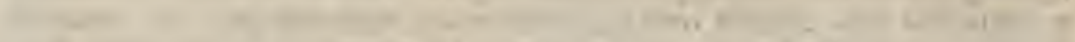

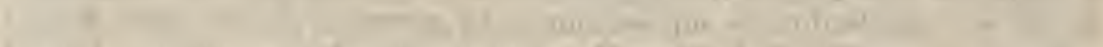

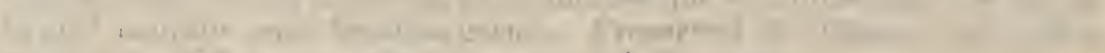

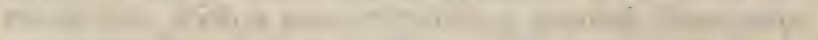

(20)

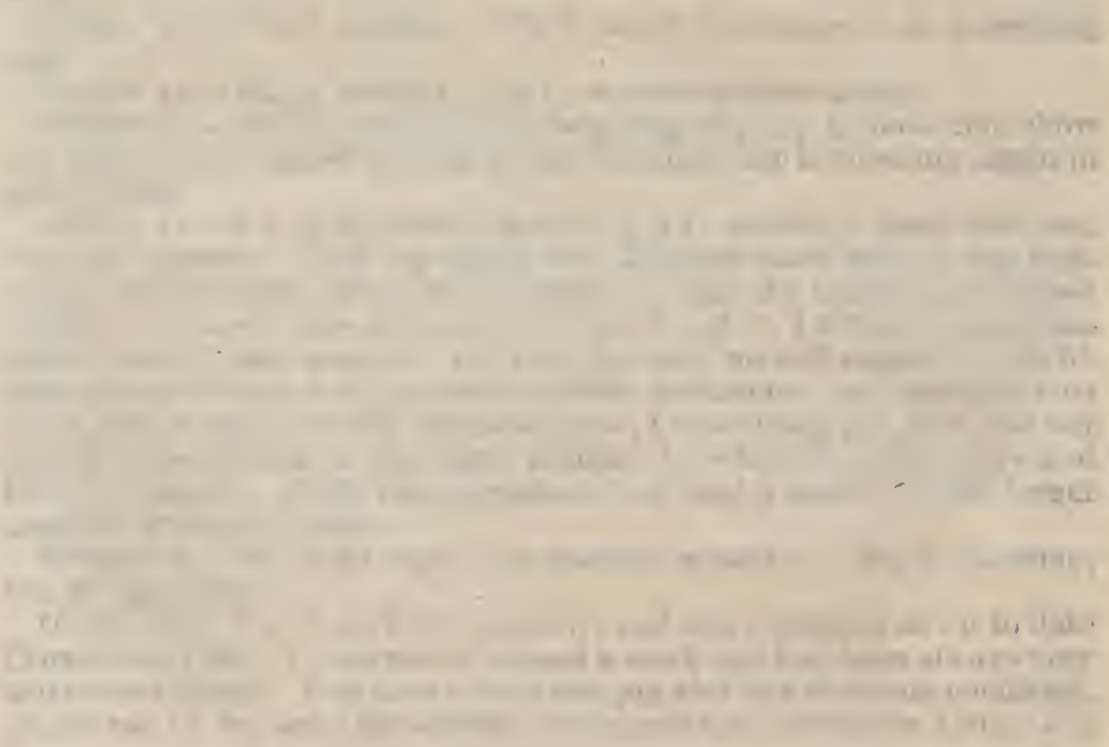




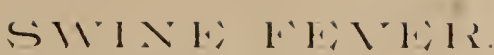

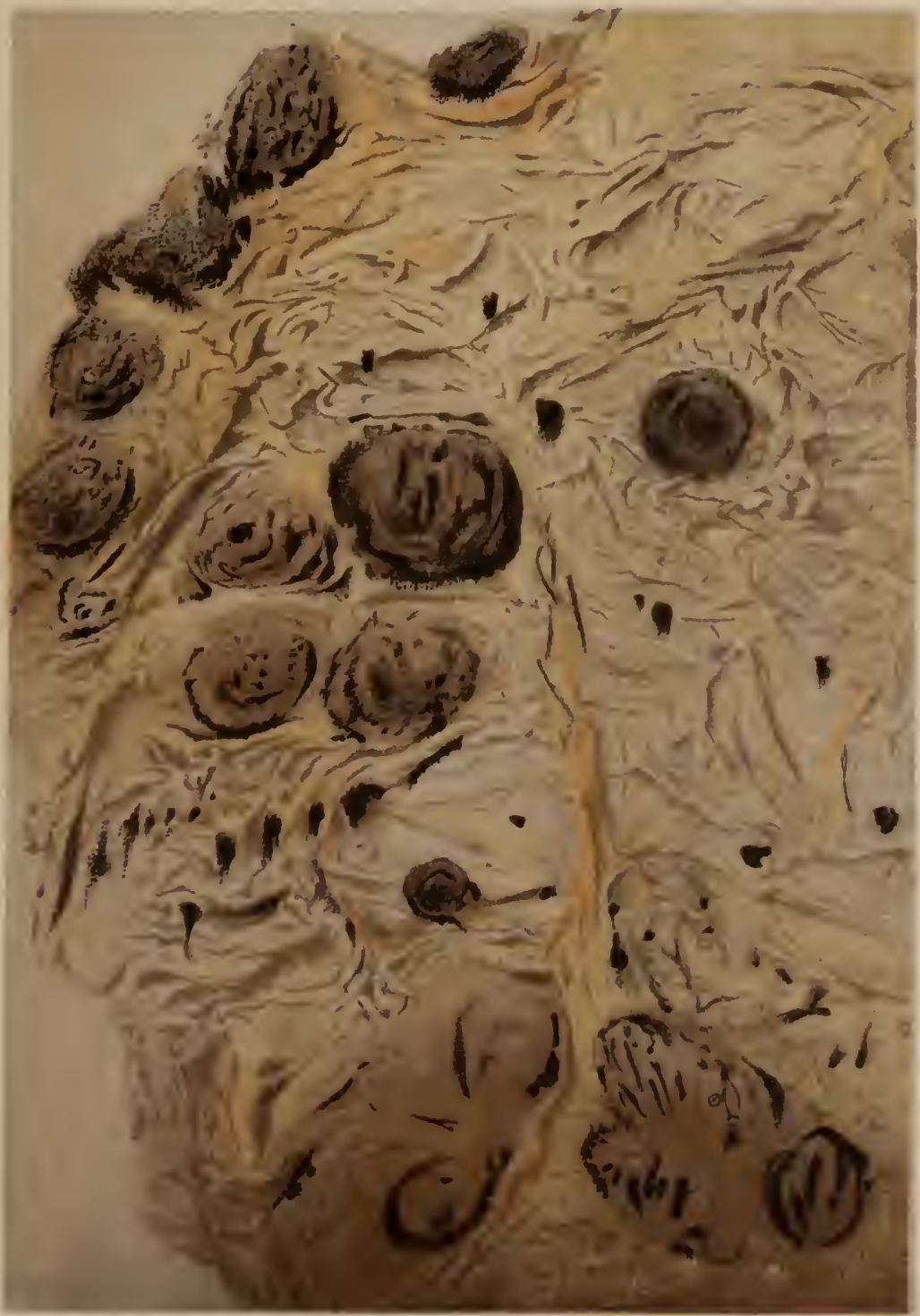

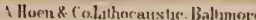



C shows plain symptoms of disease; its appetite is poor, and some emaciation has gradually taken place; at least $\mathrm{C}$ has not improved like $\boldsymbol{A}$, and weighs about half as much as the latter, notrithstanding $\boldsymbol{A}$ is in an open pen, exposed to the inclemencies of the weather, and $\mathrm{C}$ in a good, new building, with a shingled roof, in which it is amply protected against the changes of the weather.

October 17.-Pig C rather poor appetite; breathing a little accelerated, and coat of hair somewhat rough and staring.

October 18.-Pig $\mathrm{C}$ exhibits plain symptoms of swine-plagne; its breathing is accelerated; it sneezes a good cleal, and its appetite is poor. Eats some in the evening.

October 19.-Pig C improving; las better appetite.

October 20.-Pig C much improved; ents its food again, but is not greedy.

October 21.-No change.

October 22.-Pig $\mathrm{C}$ is lively again, and eats Fell-at any rate, seems to care more for its food. The sores on the ears are healing and disappearing.

October 23.-Pig C must be considered as fully recovered from its slight attack.

Up to date pig $\mathrm{C}$ has presented the appearance of a perfectly healthy pig. Its ears have healed, and are now (Norember 11th) perfectly smooth. It is lively and greely for its food, but has grown very little, and weighs to-day about half as much as pig $\mathrm{A}$. It can be seen very plainly that pig $\mathrm{C}$ has been sick. When I received A, B, and C, A was slightly the best pig. $\mathrm{B}$ came next, and $\mathrm{C}$ was the smallest, but the difference was only a trifling one.

The experiments just related show that the bacilli and their germs must have a causal conmection with the morbid process of swine-plague, because an inoculation with bacilli and bacillus-germs, cnltivated in such an innocent and harmless fluid as milk, prodnced the disease, while an inoculation with blood-serum from diseased lungs-a highly infectious fluid, if not deprived of its bacilli and bacillns-germs-remained without the slightest effect after it had been freed from its bacilli and bacillus. germs. I know rery well that the result obtained can hardly be considered as conclusive, and that some more experiments of the same kind are needed to confirm the conclusions arrived at.

\section{THE CONTAGION, THE CAUSES, AND THE NATURE OF TIIE MORBID PROCESS.}

That swiue-plague is an infectious disease, which can be communicated to heathy animals, has been demonstrated by my experiments. It has further been proven that an exceedingly sniall quantity of an infections or contagious substance (blood-sermm or exulation, for iustanec) if inoculated, or directly absorbed by the vasenlar system, is sufficient to produce the disease. It has also been proven that morbid tissnes and morbid products, if consumed by healthy pigs, will cause them to become affected with the plague. Consequently, two mays of infection hare been ascertained with certainty. Inther, if the resnlts of the post-mortem examinations are inquired into more closely, it will be found that the principal morbid changes have occirred in the digestire canal, but especially in the crecum and colon, in all those cases in which the disease had been communicated by ray of the digestive apparatus; and that, on the other hand, the principal seat of the morbid process has been in the organs of respiration and circulation, or in the 
organs situated in the thorax if the contagion had been inoculated or been introduced into the system through wounds and absorbed by the reins and lymplatics.

Whether an inhalation of the contagions or infections principle into the respiratory passage or into the $\ln g \mathrm{~s}$ is sufficient to produce the disease is doubtful. One pig (pig No. 1), an animal free from any lesious or trounds ribaterer, has been exposed twice and has not contracted the disease; but while exposed and immediately after its pen was mored once a day, and as the pen was thus kept clean, and as dry earth is a good disinfectant, it must be snpposed that the animal was never obliged to consume the contagions principle clinging to the excrements of the diseased animals, neither with its food nor mith its water for drinking. Its trough was cleaned three times a day, and always before fresh water was poured in. Pig. B, hoterer, was exposed only once, by being liept together with pig No. 6, and contracted the disease in due time. But the conditions were entirely different. Pen No. 3, in which both pigs were kept, contains a wooden floor: pig B was put in soon after pig No. 5 had died, and the pen, otherwise almays cleaned once a day, had been left dirty (uncleaned) on purpose. So it happened that the ears of corn, throm on the floor for food, became soiled, though perhaps only slightly, with the dung and the urine of dead pig No. 5 and diseased pig No. 6 . Further, both pigs (B and No. 6) tramped through the excrements and soiled their feet, and, as pigs will do, went with their dirty feet into the trongh which contained the water for drinking. Soitis but fair to suppose that pig $\mathrm{B}$ contracted the disease, not by inhaling the contagion, but by consuming the same with its food and mater for drinking. Hence I have come to the conclusion that swine-plague is probably not communicated through the lung's by an inhalation of the atmosphere surrounding the diseased animals or by simple contact, but that, in order to effect a communication of the disease, the contagion or infections priuciple must be introduced directly into a wound within the reach of the reins and lym. phatics, or be taken up by the digestive apparatus. This conclusion of mine has been corroborated by sereral facts, some of which I had an opportunity to observe mrself, and some of which have been related to me by reliable persons. To mention a few will suffice: Mr. Henry Yoths, who lires four miles north of Urbana, informed me that his neighbor, Mr. Stickgrath, who lives only one hundred yards south of him, lost every hog but one on his place; that he, Yothy, had nineteen head of swine shut up in a yard, and has not lost a single animal, notwithstanding Sticligrath's diseased animals hare been running at large, have tramped all around Yothy's pens, and come every day close to the fence; but that his, Yothy's, logss have no lesions or wounds whaterer, and haring remained separated from Stickgratl's hogs by a fence, had no opportunity to consume food or water soiled with the excrements or urine of the latter, and to become infected in that way.

Mr. L. Harris, a few miles north of Champaigu, kept his shoats and pigs separate from his older hogs. Among the former, strine plague made its appearance, and proved to be very fatal. They were liept in a rard west of the house, and had access to a pasture to the west and an orchard to the south. The peculiar, offensive smell emanating from that rard was so marked that I pereeired it sereral times rery plainly when jassing by, at a distance of halt a mile or more, so it is to be supposed that considerable contagion must have been floating in the air. 'The rard in which Mr. Harris kept his old hogs (they were intended to be fattened and were not allowed to run out into at pasture) was not over tifty yards south or southeast of the yard occupied by the diseased and dying shoats 


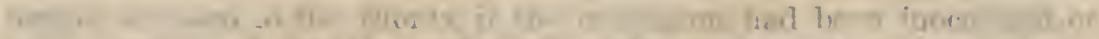

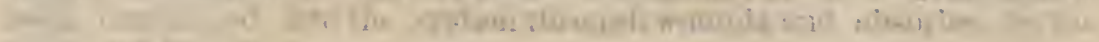

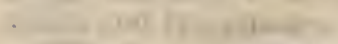

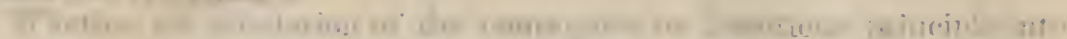

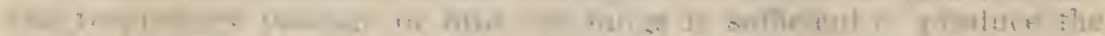

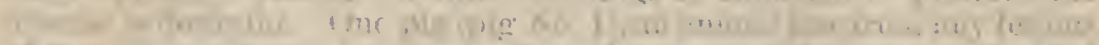

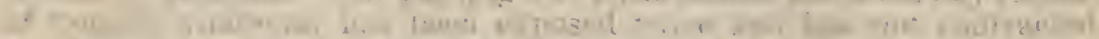

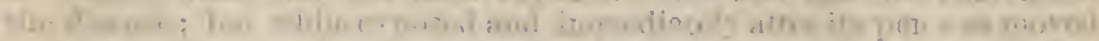

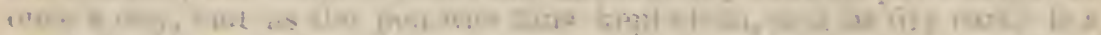

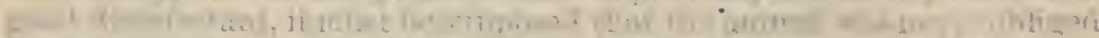

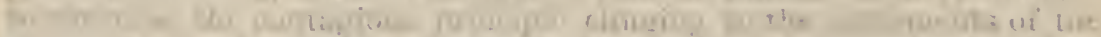

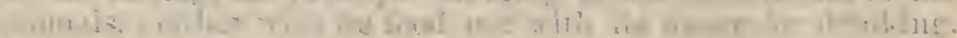

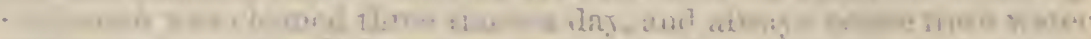

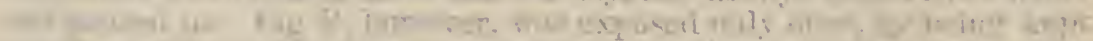

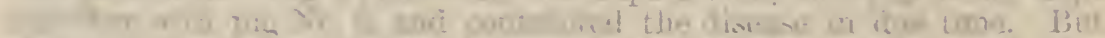

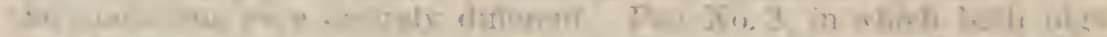

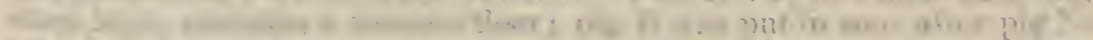

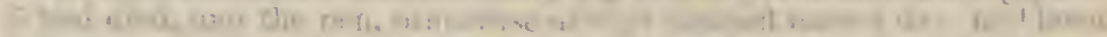

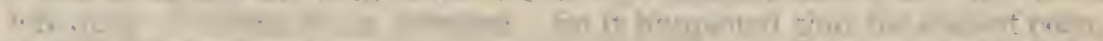

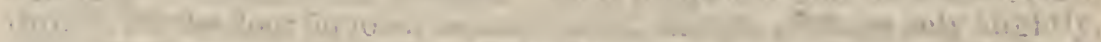

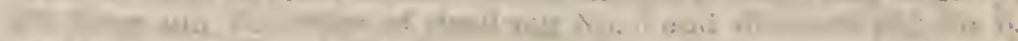

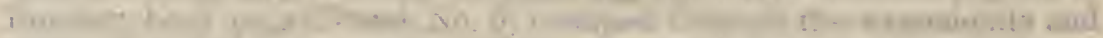

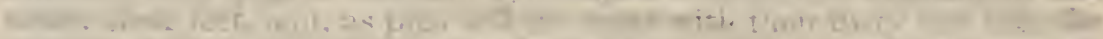

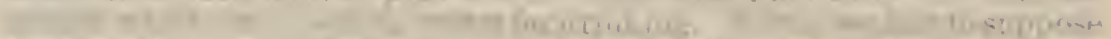

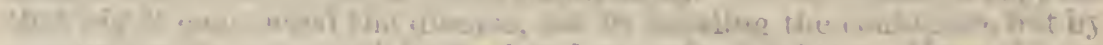
wan

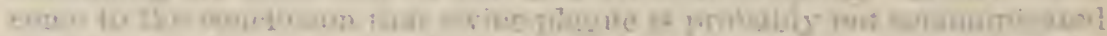

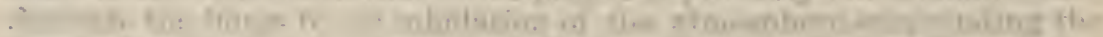

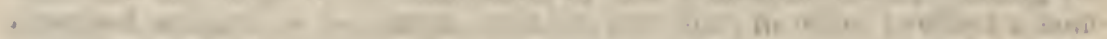

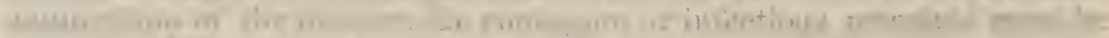

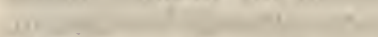

.

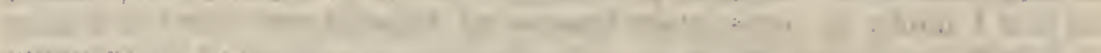

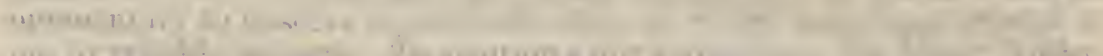
H.

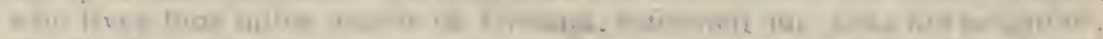

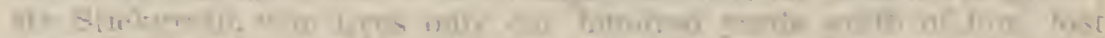

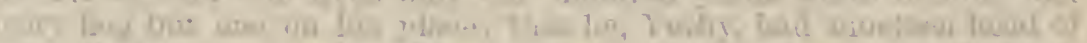

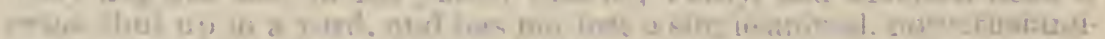

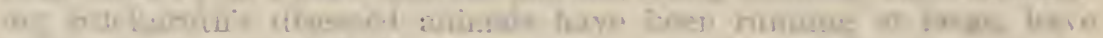

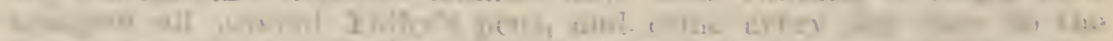

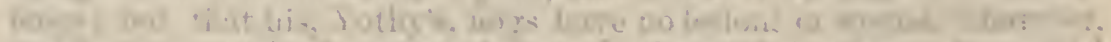

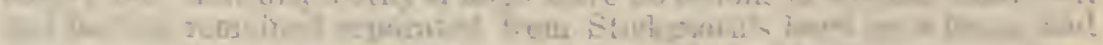

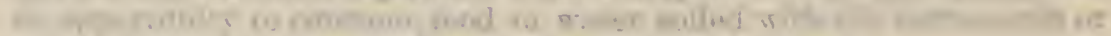

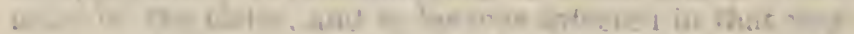

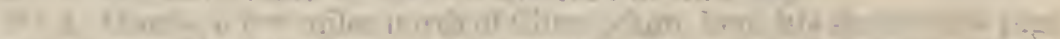

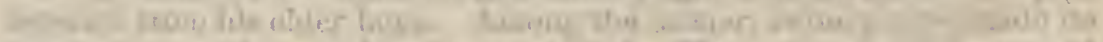

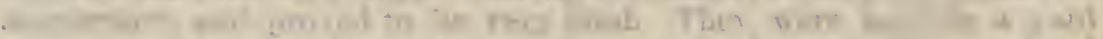

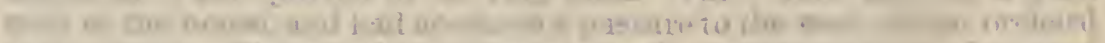

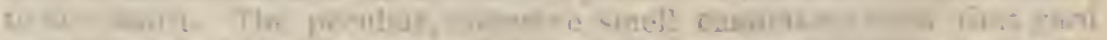

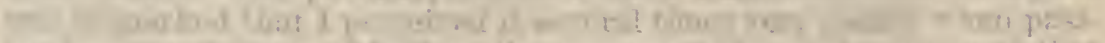

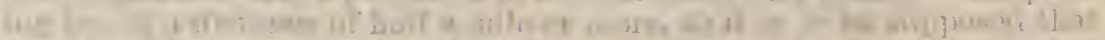

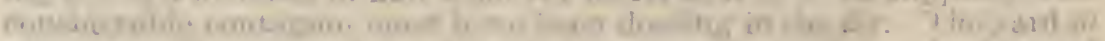

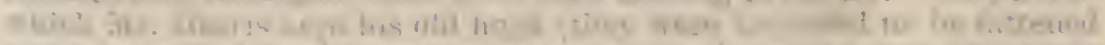

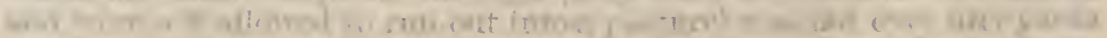

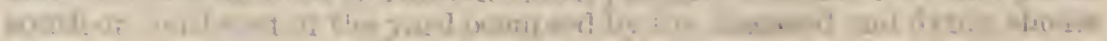




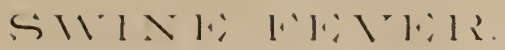

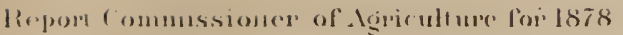

โ’ล18 เาII.

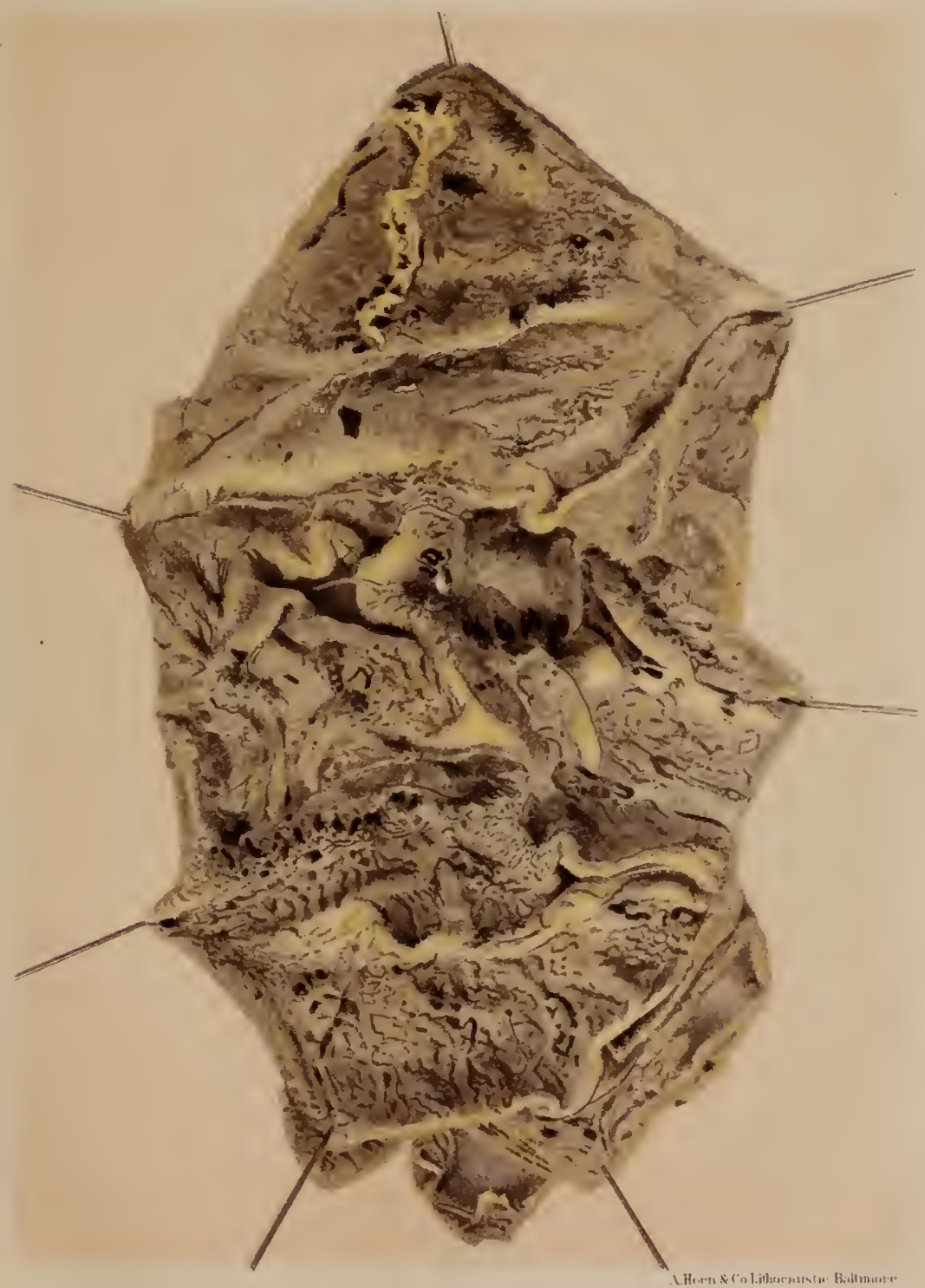

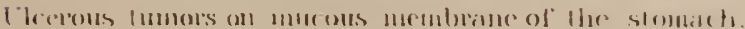



and pigs, consequently the wind, usually in the sonth, carried the effluvia and the foul atmosphere of the former almost constantly into the yard occupied by the old hogs. The latter, notwithstanding, remained exempted. It may yet be stated that the old hogs were fed exclusively with corn, and received nothing but well-water for drinking. On the other hand, I have not been able to learn of any herd remaining exempted after the disease had once made its appearance in the immediate neighborhood, unless the animals constituting the herd were free from any external lesions, were watered from a well, fed with clean food, and shut up during the night and in the moruing till the dew had disappeared from the grass, either in a bare yard not containing any old straw-stacks, or in sties or pens. Animals allowed to run outon a pasture or on grass, clover, or stubble fields at all times of the day, and animals that had external sores or wounds, contracted the disease sooner or later in every instance where the plagne made its appearance in the neighborhood. Further, the plague, at least during the summer or while sonth wind was prevailing, seemed to have a special tendency to spread from south to north. If the history of swine-plague is inquired into it will probably be found that that tendency has been prevailing every year. This year, for instance, the disease made its appearance, as I have been informed, for the first time, in Wisconsin. These facts, of course, conld not fail to be suggestive. So I conceived the idea that the contagious or infectious principle, abundant in the excretious of the diseased animals, might rise in the air in daytime, be carried off a certain distance by winds, and come down again during the uight with the dew. That such might be the case appeared to be possible, because the excrements of hogs, if exposed to the influence of sunlight, heat, rain, and wind, are soon ground to powder (partially at least), which is fine enough to be raised into the air and to be carried off by winds. Moreover, as the bacillus-germs, which, I have no doubt, must be looked upon as the infectious principle, are so exceedingly small, it appears to be possible and even probable that they are carried up into the air by the aqueous vapors arising from evaporating urine and moisture contained in the excrements, and from other evaporating fluids (small pools of water), which may have become pollnted with the excretions of sick hogs. To ascertain the facts, I collected dew from the herbage of a hog-lot occupied by diseased animals, and also from the grass of an adjoining pasture, and on examining the same under the microscope I found the identical bacilli and bacillusgerms invariably found in the blood, other fluids, and morbid tissues of swine affected with the plague. (See drawing VII, fig. 5.) Consequently I have come to the conclusion that the bacillus-germs rise into the air during the day, are carried from one place to another by the wind, aud are introduced into the organism of the animal either by eating herbage (grass, clover, \&c.), or old straw covered with dew, or by entering wounds and being absorbed by the veins and lymphatics. There is, however, still another way by which the contagious or infections principle is conveyed from one place to another. It is by means of rumning water. It has been observed that wherever swine-plague prevailed among hogs that had access to running water (as small creeks, streamlets, \&c.), that all the hogs and pigs which had access to the creek or streamlet below contracted the disease, usually within a short time, while all the animais which had access above remained exempted, unless they became infected by other means. I could cite a large number of instances, but as this observation has been made everywhere, probably nobody who is at all acquainted with swine-plague will ask for any further proof: 
As to the distance which the infections principle can be conreyed through the air, I cannot make any accurate statements, but have reasons to beliere that swine located a distance of one mile from any diseased herd will be safe. To decido this point, which is of rery great importance, requires careful experiments.

The nature of the infectious or contagious principle.-The experiments with pigs $\mathrm{A}$ and $\mathrm{C}$, though not conclusire and needing repetition, indicate very strongly, as has already been mentioned, that the bacilli and their germs found invariably in the blood, in the morbidly changed tissues, and in the excretions of the diseased swine, must constitute the infections or contagious principle of swine-plague. I, for my part, am convinced that șuch is the case. Still I should hesitate to express this opinion if it was supported only by those experiments and not by other facts, such as the peculiarities in the spreading of the disease, the manner in which the infections principle is acting and is communicated to healthy animals, and the workings of the morbid process. (See next chapter.) At any rate, if the bacilli and bacillus-germs constitute the infectious principle, all the strange features of swine-plague find a satisfactory explanation; but if the infections principle consists in an unknown and mysterious ehemical something, the peculiarities of the disease are, to say the least, enreloped in mystery and cannot be explained. What Professor Beale calls bioplasm cond not be discorered under the microscope.

In want of a better name I have called the bacilli "bacilli suis," becanse the same, as far as I hare been able to learn, are peculiar to and characteristic of swine-plagne. The bacillus-germs are small round bodies of-as near as I can figure without the aid of a micrometerabont 0.0007 millimeter diameter, and reflect the light rery strongly. The bacilli suis are small, almost straight, crlindrical bodies of abont 0.003 to 0.005 millimeter in length, and 0.0007 to 0.0005 millimeter in thickness, sometimes moring and sometimes without motion, and in eertain stages of development slightly moniliform, but in others apparently not. (See dramings.)

The causes.- Whether the disease is eaused exchusirely by infectionby the bacilli and their germs being convesed directly or indirectly from diseased animals to healthy ones-or whether those bacilli suis and their germs can be produced independently from, and outside of, the organism of swine; whether, in other words, swine-plagne is a pure contagion, caused exchnsively by means of the infectious or contagions principle, or can derelop spontaneously, is a rery important question, which can be solred only by protracted experiments, and may not be solred at all until the question as to whether a "generatio equiroca" is possible or actually taking place or not has found a definite solution. If the bacilli suis and their germs constitute the sole cause of swine-plagne, as they undoubtediy do, the disease must be considered as a pure contagion, like many other contagious or infections diseases, not capable of a protopathic or spontaneous derelopment, as long as the possibility of a "generatio equivoca" is denied, but if the latter is admitted, or proved to be taking place, a spontaneons derelopment must be considered not only as possible but also as rery probable.

If the conclusions I have arrived at conceming the eause of the clisease are correct, and I liave scarcely any doubt they are, the question as to the eauses has been solved. Still, as a positive linowledge of the true cause or causes is of the greatest importance, and as my experiments are not numerous enough to be absolntely conchisive, further investigations and more experiments of the same, or of similar lind, will 
be rery desirable, and, indeed, necessary, in order to obtain absolute certainty as to the true nature of the cause or causes.

One thing I am sure of, and that is that an exclusice corn diet, as has been asserted by several agrienltural miters, wallowing in dirt and nastiness, starvation, in and in breeding, sc., although by no means calculated to promote health or to invigorate the animal organism, can. not constitute the canse and cannot produce a solitary case of swine. plagne, unless the infectious principles (the bacilli and their germs) are present. If they are, then, of course, dirt and uastiness, consumption of unclean food and of dirty water, facilitate an infection, and warmth and moisture, premnant with organic substances, or organic substances in a state of decay, are undonbtedly well calculated to preserve the bacillus-germs and to derelop the bacilli.

Whether the disease can be communicated to other animals besides swine or not, is a question I am trying at present to decide. Some time ago I had an oceasion to throw away some morbid tissues (parts of diseased lungs) of a diseased hog, which I had used for microscopical examination. I threw them-rers carelessly, I admit-into an empty lot full of rank weeds, across the road. Abont a week after sereral chickens (four or five) died in the neighborhood, of so-called "chicken-cholera." Althongh there was no proof whaterer that these chickens had consumed the morbid tissues, there was a possibility that they had. I bought two healthy chickens, kept them separate, each in a coop, and fed them with the morbidly changed colon of a disensed pig. They consumed the same in my presence, but up to date (Norember 12th) no results have made their appearance. Further, as no case of an infection of any other animals besides swine has come to my knowledge, it rould seem that swine-plague is a disease peculiar to swine like pleuro-pneumonia to cattle.

\section{THE MIORBID PROCESS.}

Concerning the nature of the morbid process, or the manner in which the morbid changes are brought about, the microscope has made some important revelations.

In all those post-mortem examinations (fifty-three in uumber) which I have made since August 3rd, and in all those I had an opportunity of making before that time, I found the lungs more or less affected. The same were partially hepatized, and partially filled ret with fluid exudation or blood-serum. Besides that, where the morbid changes in the lungs were of recent origin, innumerable small red specks, cansed by capillary hyperæmia, or, rather, a stagnation of the blood or embolism in the capillaries, could be observed. In sereral other cases-four or fire in number-where the morbid changes in the lungs were not of a recent origin, or older than, sas, two rreeks, imnumerable small, round, and larger confluent tuberculous-looking centers of beginniug suppuration or decay (incipient abscesses) presented themselves, especially in the lower and anterior portions of the lungs, and usually more pronotnced in the right lobe than in the left one. My friend, Dr. Prentice, who is not only a reterinary surgeon, but also a practicing physician, pronounced the lungs of Mr. Bassett's boar (two years old, and three weeks sick), thus changed, similar or identical in appearance to the consumptive or tuberculons lungs of a human being. Close inrestigation, howerer, soon rerealed the fact that all the morbid changes found in the limgs of different animals-innumerable small red specks, accumulation of bloodserum or exudation, hepatization, red, brown, and gray, and incipient abscesses-are the products or the consequences of extensire capillary em- 
bolism. The other morbid changes, usually found in the thoracic cavitr, such as pleuritis, pericarditis, accumulation of straitr-colored serum, and the morbid changes found sometimes in the heart, but especially in the auricles, in which, in numerons cases, the capillary ressels hare been found to be gorged with block, tend also to show that embolism constitutes the cause, or at least the main cause, of all those changes. The microscope rery fortunately has revealed how this embolism is effected. The capillaries of the lmugs, as is mell known, are narrower than those in other parts of the bodr. The blood of the diseased animals, and especially the blood-serum deposited in the affected pulmonal tissue, contain invariably large numbers of bacillus-germs and bacilli. These bacil. lus-germs, as I have observed with the microscope, and as Hallier, who calls them micrococci, nine years ago found, bud and derelop to bacilli, and show, at a certain period of their derelopment, a great tendency to agglutinate to each other, and to form in that ray larger or smaller, irregular-shaped, and apparently somewhat viscons clusters. (See iratring II, fig. 1; drawing LX, fig. 1a.) These clusters, or some of them, are large enough to close or to obstruct the finer capillaries, and to stop in that war the capillary circulation. As a necessary consequence, the serum of the blood transudes through the walls of the capillary ressels, and is deposited in the tissue of the lungs, in the thoracic carity, and in the pericardium. In some cases, and at some places, the tender walls of the finer capillaries rield to the pressure and rupture, and then extrarasations of blood, snch as hare been obserred in sereral cases, are the consequence. The capillary redness, and the red and purple spots observed in certain comparatively fine portions of the skin, and in the subcutaneous tissues, I have no doubt, are also a product of the same process, and are caused by capillary embolism. If the animals rould ouly live long enough, gangrene or mortification of parts of the slin would be met with quite often, but as other morbid changes cause death, and thus terminate the morbid process usually before the stagnation of the blood in the skin becomes perfect, gangrene or mortification has been found only once in the skin on the lower surface of the body. Certain morbid changes in the abdominal carity, such as abdominal clropsr, and the blood extrarasatious foumd repeatedly in varions organs, such as stomach and intestines, are due to the same cause. The clusters of bacillusgerms also constitute probably the cause of the strelling of the lymphatic glands. Microscopic examinations of the interior of those glands (see drawing IV, fig. 3 ) revealed invariably, besicles some lympl-corpuscles, immense numbers of bacilli and bacillus-germs in different stages of development, some budding; some agghtinated to each other, and some in process of agghtination, \&c. These clusters of bacillus-germs, it seems, not only close the capillary blood-ressels, but probably also the finer lymplaties ramifying in the glands; a sirelling of the latter, therefore, is a natural consequence.

The production of the morbid growths (swine-plagne tumors would be a good name), which are found in nearly every case on the mucons membrane of the crecum and colon, and sometimes, thongh not so often, on the mu 'ous membrane of' other intestines, such as ilimm, jejunwm, cluodenum, stomach, gall-bladder, and uterus, and eren on the conjumctira and the gums, is not so easily explained. It seems that a proliferous process is taking place; new epithelinm-cells and commectire-tissue corpuscles are formed rapidly, but decas before fully dereloped.' These ner morbid and rapidly decaying cells are imbedded in a stroma of a dense connec. tire tissue which, too, is a morbid product, and formed rapidly. In the older aud larger morbid growths or tumors in the cacum and colon this 
connective tissue is usually very abundant, especially in the frequently pedicle-shaped foot or basis. The proliferous morbid growths which occur in the small intestines are almost destitute of it. If these morbid growths or tumors are examined under the microscope, immense numbers of bacilli suis, some of them moving very rapidly and others at rest (sometimes some other bacteria), and comparatively few bacillus-germs will be seen. (See drawing III, fig. 5; trawing VI, fig. 1; drawing V, fig. 2; drawing IV, fig. 2; drawing VII, fig. 2, and drawing $X$, fig. 2.)

It appears to be probable that the excessive proliferous growth of the epithelimm-cells and connective-tissue corpuseles is caused by a constant irritation of tho mucous membrane, or of the membrana intermedia (basement or limitary membrane, Fleming), produced by the bacilli. This is the more probable, as those morbid growtlis occur especially in such parts of the alimentary canal in which the food is known to tarry the longest, in the crecum and in the colon. The morbicl changes (ulcerations) found occasionally in the skin, where they sometimes cause whole portions to become mortified or decayed and to slough off, occur, it seems, only in parts where a wound or lesion has been existing into which the infectious principle, the bacilli or their germs, have been introduced; so, for instance, in the teats of brood-sows wounded by pigs, and in the nose of hogs and pigs that have been ringed. These morbid changes in the skin, it would seem, are produced in a similar way as the morbid growths in the intestines, with only this difference, that instead of an excrescence loss of substance makes its appearance. The skin is constantly exposed to the atmospheric air, and to a much lower and more changeable temperature than the mucous membrane of the intestines, and in consequence the process of decay may become more rapid and may exceed the prob. ably slower process of production.

\section{PERIOD OF INCUBATION.}

The period of incubation-perhaps more correctly "stage of colonization," Klebs-or the time passing between an infection and the first outbreak of the disease, I have found to be firom five to fifteen days, or on an average of about seven days. Still, I have no donbt that in single cases an outbreak may take place a day or two sooner, and in others, though rarely, a day or two later.

\section{MEASURES OF PREVENTION.}

As swine-plague is a contagious or infectious disease, which spreads everywhere by means of direct and indirect infection, and as a spontaneous development is problematic, or has not yet been proven, the principal means of prevention must consist in preventing a dissemination of the contagious or infectious principle, and in an immediate, prompt, and thorough destruction of the same wherever it may be found. To prevent successfully a dissemination of the contagion and to secure a prompt destruction of the same, stringent legislation will be found necessary. As it is, the contagion or the infectious principle is, and has been, disseminated throngh the whole conntry in a wholesale manner, as I shall show immediately. During the first month of ny presence in Champaign I stopped at the Doane House, a hotel belonging to the Illinois Central Raihroad Company, and constituting also the railroad depot. Every night car-loads of cliseased hogs destined for Chicago passed my. window. Only a rery short time ago, on one of the last 
days of October, a farmer, J.T. M., living near Tolono, sold sixty-seven hogs (some, if not all of them, diseased and a fer of them already in a dying condition) for two cents a pound, to be shipped to Chicago. I could cite numerous instances, but I think it is not necessary, because these facts are known to every one where swine-plague is prevailing. Besides, in nearly every little town in the neighborhood of which eases of swine-plague are of frequent occurrenee, is a rendering establishment to which dead hogs are brought. These establishments pay one cent a pound, and the farmers hanl their dead hogs, sometimes ten or fiftecn miles, in open wagons, past farms, barns, and hog-lots, and disseminate thereby the germs of the disease through the whole country. The transportation of dead hogs by, wagon, I admit, might be stopped by State laws, but the latter prove usually to be ineffective where railroaid companies (inter-State and international traffic) are concerned. I inclucle international traffe, because swine-plague is or has been prevailing in Europe. Besides that, there are other contagious diseases which spread exclusively by means of their contagion-I will mention only glanders, foot and month disease or aphthre, and pleuro-pnenmonia of cattle-and can be stamped out and be prevented from spreading only by efficient Congressional legislation. Pleuro-pneumonia particularly deserves special attention. It has already gained a firm foothold in tho East, and would undoubtedly invade the West very soon, or would have done so long ago, if the traffic in cattle were from East to West instead of from West to East. It may, howerer, at any time be carried to the West by shipments of blooded eattle from the East the same as it was imported from Holland to New York, and having once entered any of the Western States or Territories it will soon find ample means to spread toward the East again and to sweep the whole country. If it comes to that it will prove to be much more disastrons to the live-stock interest of the United States than swine-plague or any other contagious disease.

If any transportation of, or traffic in, diseased and dead swine is effectually prohibited by proper laws, a spreading of the swine-plague on a large scale will be impossible, and its ravages will remain limited to localities whero the disease-germs havo not been destroyed, and -been preserved till the same find sufficient food again. In order to prevent such a local spreading, two remedies may be resorted to. The one is a radical one, and consists in destroying erery sick hog or pig immediately, wherever the disease makes its appearance, and in disinfecting the infected premises by such means as are the most effective and the most practicable. If this is done, and if healthy hogs are kept away from such a locality, say for one inonth after the diseased animals have been destroyed, and the sties, pens, \&c., disinfected with chloride of lime or carbolic acid, and the yards plowed, \&c., the disease will bo stamped out. I know that this is a violent way of dealing with the plague, but in the end it may prove to bo by far the cheajest. The other remedy is more of a palliative character, and may be substituted if swine-plague, as is now the case, is prevailiug almost everywhere, or in cases in which the radical measures are considered as too severe and too sweeping. It consists in a perfect isolation of erery diseased herd, not ouly during the actual existence of the plague but for some time, say one month, after the oceurrence of the last case of sickness, and after the sties and pens have been thoronghly cleaned and disinfected with carbolic acid or other disinfectants of equal efficiency, and the yards, de., plowed. Old straw-stacks, \&c., must be burned, or rapidly converted into manure. It is also very essential that diseased animals are not allowed any aceess to running water, streamlets, or creeks accessible to other healthy 
stvine. Those healthy hogs and pigs which are within the possible influence ol the contagious or infections principle, perhaps on the same farm or in the immediate neighborhood of a diseased herd, must be protected by special means. For these, I think, it will be best to mako morable pens, say eight feet square, of common fence-boards (eleven fence-boards will make a pen); put two animals in each pen; place the latter, if possible, on high and chry ground, but by no means in an old hog-lot, on a manure-heap, or near a slongh, and move each pen every noon to a new place, until after all danger has passed. If this is done the animals will not be compelled to eat their food soiled with excrements, and as dry earth is a good disinfectant, an infection, rery likely, will not take place. Besides this, the troughs must always be cleaned before water or food is put in, and the rater for drinking must be fresh and pure, or be drawn from a good well immediately before it is poured into the troughs. Water from ponds, or that which has been exposed in any way or manner to a contamination with the infectious primciple, must not be used. If all this is complied with, and the disease notrith. standing should make its appearance and attack one or another of the animals thus kept, very likely it will remain confined to that one pen.

If the hogs or pigs cannot be treated in that way, it will be advisable to keep every one shut up in its pen, or in a bare yard, from sundown until the dew next morning has disappeared from the grass, and to allow neither sick hogs nor pigs, nor other animals, nor even persons, who have been near or in contact with animals affected with swine-plague, to come near the animals intended to be protected. That good ventilation and general cleanliness constitute valuable auxiliary measures of prerention may not need any mentioning. The worst thing that possibly can be done, if swine-plague is prevailing in the neighborhood, is to shelter the hogs and pigs under or in an old straw or hay stack, because noth. ing is more apt to absorb the contagious or infectious priuciple, and to preserve it longer or more effectively than old straw, hay, or manureheaps composed mostly of hay or stiaw. It is even probable that the contagion of swine-plague, like that of some other contagious diseases, if absorbed by, or clinging to, old straw or hay, \&c., will remain effective and a source of spreading the disease for months, and maybe for a year.

Therapentically but little can be done to prevent an outbreak of swineplague. Where it is sufficient to destroy the infectious principle outside of the animal organism, carbolic acid is effective, and, therefore, a good disinfectant; but where the contagious or infectious principle has already entered the animal organism its ralue is doubtful. Still, wherever there is cause to suspect that the food or the water for drinking may have become contaminated with the contagion of swine-plague, it will be advis. able to give every morning and evening some carbolic acid, say about ten drops for each animal weighing from one humdred and twenty to one humdred and fifty pounds, in the water for drinking; and whererer there is reason to suspect that the infectious principle may be floating in the air, it will be advisable to treat every wound or scratch a hog or pig may happen to have immediately with diluted carbolic acid. During a time, or in a ncighborhood in which swine-plague is prevailing, care should be taken neither to ring. nor to castrate any hog or pig, because every rrouud, no matter how small, is apt to become a port of entry for the infectious principle, and the very smallest amount of the latter is sufficient to produce the disease.

Still, all these minor measures and precautions will avail but little unless a dissemination of the infectious principle, or disease-germs, is made impossible. 1. Any trausportation of dead, sick, or infected swine, 
and ereu of hogs or pigs that hare been the least exposed to the contagion, or may possibly constitute the bearers of the same, must be effectively prohibited. 2. Every one who loses a hog or pig by swineplague must be compelled by law to bury the same immediately, or as soou as it is dead, at least four feet deep, or else to cremate the carcass at once, so that the contagious or infectious prineiple may be thoroughly destroyed, and not be carried by dogs, wolres, rats, crows, \&c., to other places.

Another thing may yet be mentioned, which, if properly exeented, will at least aid rery materially in prerenting the disease; that is, to give all food either in clean troughs, or if corn in the ear is fed, to throw it on a wooden platform which can be swept clean before each feeding.

\section{TREATMENT.}

If the cause and the nature of the morbid process and the character and the importance of the morbid changes are taken into proper consideration, it cannot be expected that a therapeutic treatment will be of much avail in a fully dereloped case of swine-plague. "Specific" remedies, such as are adrertised in column advertisements in certain newspapers, and warranted to be infallible, or to cure every case, can do no good whatever. They are a downright fraud, and serve only to draw the money out of the pockets of the despairing farmer, who is ready to catch at any straw. No cure has ever been found for glanders, anthrax, and cattle-plague, diseases that have been known for more than tro thousand years, and that have been investigated again and again by the most learned reterinarians and the best practitioners of Europe, and yet there is to-day not even a prospect that a treatment will ever bo discovered to which those diseases, once fully developed, will yield. Neither is there any prospect or probability that fully dereloped simeplague will erer yield to treatment. It is tme that the bacilli suis and their germs can be killed or destroyed if outside of the animal organism, or within reach on the surface of the animal's body. Almost any known disinfectant-carbolic acid, thymic acid, chloride of lime, creosote, and a great many others-will destroy them. But the bacilli and their germs are not on the surface of the body, except in such parts of the skin and accessible mucous membranes (conjunctiva and gims) that may happen to have become affeeted by the morbid process. They are inside of the organism, and not only in every part and tissue morbidly affected, in every morbid product, and in every lymphatic gland, but they are also in every drop of blood and in every particle of a drop of blood circulating in the whole organism. Who, I would like to ask, will have the audacity to assert that he is able to destroy those bacilli and their germs withont disturbing the econony of the animal organism to such an extent as to cause the immediate death of the animal? But eren if means should be found by which these bacilli and their germs can be destroyed without serious injury to the animal, a destruction of the same will not be sufficient to effect a cure. Important morbid clianges must be repaired; extensive embolism is existing in some very vital organs; a rapid, proliferous growth of morbid cells has set in; some of the intestines (ceecum and colon) may have become perforated; exulations have been deposited in the lungs, in the thoracic carity, in the perieardium, and in the abdominal cavity; the heart itself may have been morbidly changed, and every lymphatic gland in the whole organism become diseased. How, I would like to know, will those quacks who adrertise their" Sure Cure" and their high-sonnding" "Specitics" to sirindle the farmer out of 
his hard-earned dollar's and cents-how, I ask, will those quacks restore, repair, stop, and reduce all those morbid changes?

Still, I rlo not wish to say that a rational treatment can rlo no good; on the contrary, it may in many cases avert the worst and most fatal morbid changes, and may thereby aid nature considerably in effecting a recorery in all those cases in which the disease presents itself in a mild form, and in which very dangerous or irreparable morbid changes have not yet takeu place. $A$ good dietetical treatment, however, including a strict observation of sanitary prineiples, is of much more importance than the use of medicines. In the first place, the sick animals, if possible, should be kept one by one in separate pens. The latter, if mov. able-movable ones, perhaps six to eight feet square and without it floor, are preferable-ought to be moved once a day, at noon, or after the dew has disappeared from the grass; if the pens are not movable, they must be kept scrupulously clean, because a pig aflected with swineplague has a vitiated appetite, and eats its own excrements and those of others, aud, as those excrements eontain inmumerable bacilli and their germs, will add thereby fuel to the flame; in other words, will increase the extent and the malignancy of the morbid process by introducing into the organism more and more of the infectious principle. The food given ought to be clean, of the very best quality and easy of digestion, and the water for drinking must be clean and fresh, be supplied three times a day in a clean trough, and be clrawn each time, if possible, from a deep well. Water from ponds and water that has been standing in open vessels, and that may possibly have become contaminated with the infectious principle, should not be used. If the diseased animal has any wounds or lesions, they must be washed or dressed from one to three times a day with diluted carbolic acid or other equally effective disinfectants.

Concerning a therapeutic treatment, I have made several experiments, the principal ones of which I will relate, not because they are illustrative of success, as they are not, but because some interesting features of the disease will be brought to light. A therapentic treatment-that is, as far as my experiments are able to show-has not been very successful, but the facts will speak for themselves.

\section{EXPERIMENTS AT MY EXPERIIENTAL STATION, THE VETERINARY HOSPITAL OF THE ILLINOIS INDUSTRIAL UNIVERSITY.}

October S.-At 5.30 o'clock, 1). m., received from Mir. J. A. Hossack eight diseased swine of various size and age for experimental treatment. 'They were put in pen No. 3, which had been thoronghly cleaned, and were fed three times a day with corn in the ear, and provided with elean water for drinking. I had engaged and had comfortable room for only three or four, but Mr. Hossack thought best to bring me every sick animal he had at that time on his place. So it happened that five of the pig's were in an almost dying condition when they arrived. I numbered them I, II, III, IV, V, VI, VII, and VIII. The therapentic treatment consisted in giving three times a day about ten drops of carbolic acid in the water for drinking for each hundred pounds of live weight. In deciding upon that amount, it was taken into consideration that some of the water would remain unconsumed. The troughs were emptied aud cleaned each time before fiesh water was put in.

October 9.-Pig I, a small auimal, dead. Post-mortem examination was made by Dr. Prentice, and revealed the usual morbid changes-hepati- 
zation, pleuritis, serum in pericardin, and morbid gromths in cæecum and colon.

October 10.-Pig II, a large shoat from eight to ten months old, dead. Post-mortem examination by Dr. Prentice. Nearly the same results.

October 11.- Pig III, a small animal, dead. It had probably died on the evening of the 10th; at least it was very much decomposed in the morning, and as pig $B$ had died and had to be examined, no post-mortem examination was made.

October 12.-Pig IV, dead; had died during the night. No. V, an old sow, and Nos. VI, VII, and VIII yet alive. No. VIII is the only one that has any appetite. Pin VI is very low, and will soon die. Post-mortem examination of No. IV. Hxternally: skin on lower surface of the body and betwcen the leg's purple. Internally: lymphatic glands enlarged; bronchial tulues filled with mucus; both lobes of the lungs, but the left one more than the right, hepatized-red, brown, and gray liepatization; two oumces of straw-colored serum in pericardium, and plastic exudations on the surface of the heart. In abdominal eavity abont one pint of serum; spleen eularged; kidneys normal; mesenteric glauds enlarged; intestines free from any morbid growths, and withont any lesions whaterer; interior of stomach slightly corered with bile.

October 13.-OOkl sow No. V, and young sow No. VIII (eight months old) have a little appetite. No. VI is very weak, and No. VH is thull; seems to hare considerable pressure upon the brain. In the erening No. VI is in a dying condition, and lies motionless in a corner. Soms Nos. V and VIII have some appetite; No. VII breathes with a throbbing motion of the flanks; seems to have headache, is very dull, and holds its nose persistently to the floor.

October 14.-Sow VIII considerably improved; sow V some appetite; VII very low; and VI dead. For post-mortem examiuation of No. VI, see account given in the chapter on Morbid Changes.

October 15.-Old sow No. V and sow No. VIII conghing a good deal; VIII has a good appetite; V has not. No. VII, a sow pig about eight months old, dead in the pen. Post-mortcm examination of No. VII at 8.30 o'clock, a. m. Externally: Skin on nose, neck, and lower surface of body pur. ple in spots and patches; carcass not very much emaciated. Interually: some adhesion between posterior part of right lobe of lungs and diaphragm; costal pleura and pericardium affected; surface of the lungs exhibit numerous small red specks; both lobes are partially hepatized, and contain considerable exudation yet in a fluid condition. (See photographs, Plates I and II.) External coat of posterior vena cara morbidly changed, inflamed, and coalesced with pulmonal plemra. In abdomiual eavity: numerous light-colored nodules or tubereles on the surface of the spleen, some of the size of a millet seed, and others as large as a small pea; mesentric glands very much enlarged; numerous small ulcerous tumors or morbid growths on mucous membrane of crecum and colon; the whole interior surface of jejunum, for several feet in length one interrupted layer of a morbid growth and subsequent decay of epithelium cells, easily removed with the back of the scalpel, and learing behind, if thus remover, an uneven villous surface.

October 16.-Old sow No. V and sow No. VIII fair appetite; both cough a great deal. Old sow $\mathrm{V}$ discharged yesterday and to-day large quautities of a glassy mucus exuling from the nose. Discovered two ulcerating sores, one in the left middle teat and one in the right forward teat. Her pigs had been reaned a short time before she contracted the disease. 
October 17.-Sows V and VIII improving, that is, aro less indifferent to surroundings and havo better appetite, but still cough a great deal. Octoler 18.--Sows V and VIII improring; but especially VIII, which has good appetite. In afternoon sow $\mathrm{V}$ had some diarrhea, probably caused by teeding on new corn-old com had been fed before.

October 19.-Old sow V has diarrhea; feces green and semi-fluid. Sow VIII seems to be improving, at least cats a good deal. Sow V is perfectly blind.

October 20.-Sors V and VIII still coughing considerably, but are otherwise improving.

October 21.-Soms V and VIII improving; VIII is already in a littlo better condition.

October 22.-Sows V and VIII improving.

October 23.- Sow $\mathrm{V}$ is still very slow in her morements, but her appetite is much better. Sow VIII still shows difficulty of breathing, but may otherwise be considered as recovered. The diarrhea of sow V has disappeared.

October 24.-Sows V and VIII improving; have good appetite, and are not near so thirsty as formerly; both cough some. Recovery may be considered certain.

October 25.- Sow $V$ rery muel improved; ulcer in forward teat is healing rapidly (the ulcers have been treated with diluted carbolic acid). Sow VIII shows no morbid symptoms, except some coughing aud some difficulty of breathing. She has very good appetite and is very lively.

October 26.-Sow V eats tolerably well, but is still weak. Sow VIII eats and driuks well, and might be looked upon as perfectly healthy if it wero not for the yet existing difficulty of breathing. The excrements have gradually lost their peculiar offensive smell.

October 27.- Sow V fair, and sow VIAI rery good appetite. Tho lat. ter is getting lirely.

October 28.-No perceptible change.

October 29.- Sow V more active, but still partially blind. Sow VIII is gaining in flesh.

October 30.-Both sows have good appetite and are visibly improving.

October 31.-Both improving steadily.

November 1.-Sows $V$ and VII keep on improving. The ulcers of $V$ have healed, and her sight has been partially restored. 'The carbolic. acid treatment has been continued to this day (November 1), but is now discontinued.

November 6.-Both sows have been returned to their owners. Sow VIII is like a perfectly healthy pig, but coughs some and also shows a slight difficulty of breathing. Sow $\mathrm{V}$ has almost entirely recovered her ejesight; is not in as good condition as sow VIII, and coughs some, but breathes perfectly easy.

October 26.-Received of Mr. D. Burwash, at 6 oclock, a. m., a Berkshire pig, about five months old, for experimental purposes; it had been sick two or three days. It proved to be very sererely affected, but was in a good condition as to flesh. Treatment: about eight or wiue drops of carbolic acid in the water for drinking erery morning, and about two drams of bisulphite of soda and one dram of carbonate of soda erery erening. The pig was designated as No. IX, and put in pen No. 2.

October 27.-Pig No. IX worse; has plain symptoms of pnemmonia; died in the aftemoon. Post-mortem examimation three hours after deatl; four ounces of serum in chest, and also a like quantity in pericardium; trachea filled with mucus; both lobes of lungs congested and gorged with exudation; capillary ressels of the auricles of the heart gorged 
with blood; spleen enlarged, and large numbers of tubcrele-like excres. cences on its lower surface; execum and colon full of hardened feces; a few ulcerous tumors in execum, and two large decaying morbid growths in colon; mesenteric glands enlarged; other organs healthy.

Numerous other experiments lhave been made, and quite a variety of medicines have been tested at different places and in different herds. Some of those experiments have been carried out under my personal superintendence, and some by the orners of the diseased animals in accordance with my instructions. But as the results obtained with any one of them are far from satisfactory, it will be sufficient to mention only a few. The prineipal medicines tried were carbolic acid, bisulphite of soda, thymol, salicylie acid, white hellebore or verutrum album, as an emetic, alcohol, and sulphate of iron, and it has been found that neither of them possesses any special curative value. In a few cases in which most of the lesions were external, applications of very much diluted thymol or thymic acid produced apparently good results; the animals recovered, but might have recovered at any rate. Diluted carbolic acid has been used for the same purpose and with the same resnlts. An emetic of white hellebore or veratrum album was given to some shoats (about eight or nine montlis old, and property of Dr. Hall, at Savoy), in the first stage of the disease, and seemed to have arrested the morbid process immediately, at least the shoats recovered. In other more developed cases it did no good whaterer. Bisulphite of soda, salicylic acid, and carbolic acid were used quite extensirely, but no good results plainly due to the influence of those drugs have been observed in any case in which the disease had fully dereloped, neither by myself nor by others. Sulphate of iron has proved to be decidedly injurious. Mr. Bassett used it quite persistently for forty-five nice shoats. Fortythree of them died, one recorered from a slight attack-it had external lesions, which were treated with carbolic acid-and one remained exempted. To bleed sick hogs, in some places a customary practice among farmers against all ailments of swine, has had invariably the very worst consequences, aud accelcrated a fatal termination. A great many farmers in the neighborhood of Champaign have used several kinds of "specifies" and "sure cure" nostrums, but nowe of them are inclined to talk about the results obtained, and so it must be supposed that the latter have remained invisible. One case, which should have been related in the chapter on "Prerentiou," deserves to be mentioned. Mr. Crews had forty-odd hogs, of which he had lost ten or twelre, aud was losing at the rate of two to four a day. I advised him to separate those apparently yet healthy, or but slightly affected, from the very sick ones; to put the former in a separate yard, not accessible to the others; to feed them clean food; to water them three times a day from a well, and to give to each arimal, two or three times a day, about teu drops of carbolic acid in their drinking water. He did so, and saved every one he separated (fourteen in number), while all others, with the exeeption of two animals which died later, died within a short time.

Respectfully submitted.

Chicago, Ill., November 15, 1878.

H. J. DLTMERS, V. $\mathbb{S}$ 


\section{SUPPLEMENTAL REPORT.}

Sir: Since the 15th of November, the day on which I forwarded to ron my full report, I hare devoted my time principally to a solution of some of those questions which had not been fully answered, and have succeeded in ascertaining some additional facts of practical importance. In addition to this the correctness of my conclusions as to the nature of the infectious principle, and the manmer in which swineplague is communicated, has been confirmed by further observations. The vitality of the infectious principle has been tested by experiment; several herds of diseased swine and places whero the disease had been prevailing, and where healthy pigs had been introdnced a few weeks after the occurrence of the last case of swine-plague, have been visited, and a few more post-mortem examinations have been made. In the following, which may be considered as a supplement to inf report of the 15 th of Novem: ber, I have the honor of submitting to you, very respectfully, the results of my investigation.

\section{THE BACILII SUIS.}

These are found invariably, either in one form or another, in all fluids-sucl as blood, urine, mucns, fluid exudations, \&c.-in all morbidly afiected tissues, and in the excrements of the diseased animals, and constitute, be cond a doubt, the infectious principle, or produce the morbid process if transmitted, directly or indirectly, from a diseased animal to a healthy one. These bacilli undergo several changes, and require a certain length of time for further propagation; consequently, if introduced into an animal organism, some time-a period of incubation, or a stage of colonizationmust pass before morbid symptoms can make their appearance. Three stages of development (a germ or micrococcus stage, a bacillus or rod-bacterium stage, aud a germproducing stage) can be discerned.

The micrococci, globular bacteria, or bacillus-germs, as I prefer to call them, are found in immense numbers in the fluids, but especially in the blood aud in the exuda. tions of the diseased animals. If the temperature is not too low, and if sufficient oxygen is present, they soon develop or grow lengthwise, by a kind of budding processa globular bacterium, or bacillus-germ, constantly observed under the microscope, budded, and grew to double its length in exactly two hours in a temperature of $70^{\circ}$ F. (see drawing) - and change gradnally to rod-bacteria, or bacilli. Some of the latter, finally, after a day or two, if circumstances are favorable, commenco to grow again in length, until they appear, magnified 850 diameters, to be from one to six inches long. At the same time, horrever, they become very brittle, and break into two or more pieces. Where a break or separation is to take place, at first a knee or augle is formed, and then a complete break or separation is effected by a swinging motion of both ends, which move to and fro, and alternately open and close, or stretch and bend the knee or angle. After the division has become perfect, which takes only a minute or tro, both ends, thus separated, move apart in different directions. These long bao teria, it seems, are pregnant with new germs; their external envelop disappears or is dissolred, and then the very numerous bacillus-germs become free. In this way a propagation is effected.

Some of the bacilli or rod-bacteria move rery rapidly, while others are apparently motionless. The causes of this motion I have not been able to ascertain with certainty, but have observed repeatedly that no motion takes place if the temperature of the fluid or substance which contains the bacteria is a low one, and that under the mieroscope the motion increases and becomes more lively if the rays of light, thrown upon the slide by the mirror, are sufficiently concentrated to increase the temperature of the object. So it seems that a certain degree of warmth is required; at any rate I never saw any bacilli moving in a fluid or substance immediately after it had been standing in a cold room.

There is, however, also another chango taking place, caused probably by certain conditions which $I$ havo not been able to ascertain. It is as follows: The globular bacteria or bacillus germs commence to bud or grow in length, but on a sudden their derelopment, it seems, ceases, and partially-developed bacilli and simple and budding germs congregate to colonies, agglutinate to each other, and form larger or smaller irregvilarly-shaped and (apparently) viscous clusters. Such clnsters aro found very often in the blood and in other fluids, and invariably in the exudations in the lungs; and in the lymph:tic gland in pulmonal exndation, and in blood serum, this formation can be observed under the microscope if the object remains unchanged for some time, say for an hour or two. In the ulcerous tumors on the intestinal mucous membrane the clusters are comparatively few, but the fully-developed bacilli, many of which more very lively, are always exceedingly numerous. The tumors or morbid growths in the intestines seem to afford the most farorable conditions for the growth and derelopment of the bacilli and their germs. That this must be the case is also suggested by the presence of such immense numbers of bacili and bacillus-germs in the excrements, 
SVI I F: Platif

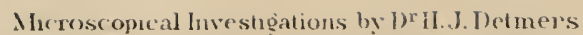

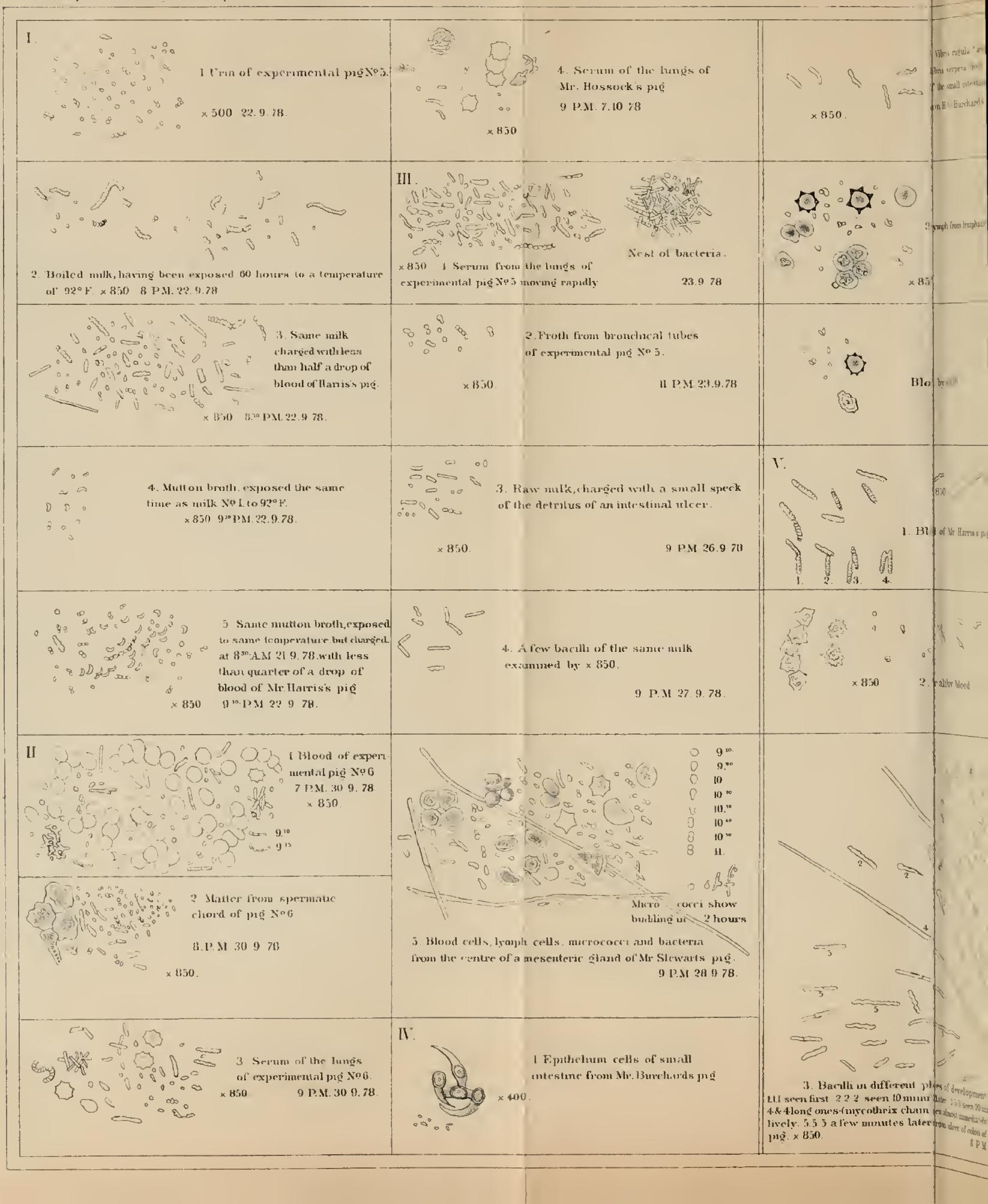


Bacilli and Bacillus-Germs

"ibrus ruğula? and

ms serpens. from an whes"

the small untestumes of

n.lf. C Burchard's pig.

3. inph firom trmpliatic gland

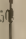

II.

A off $100=0$ Bacill, and bacillus germus m

5. 10 the different ulcerstion on the

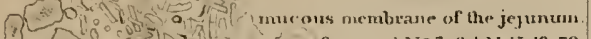

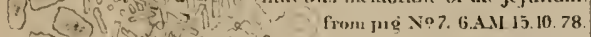

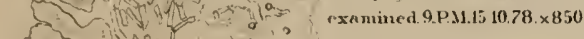

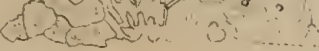

$\therefore=$ lyoken domm epithelunn cells
In very much 2. Sanu duluted

Aretic aceid

$\times 800$. bluod treated

witl, dilyteel acetic ace

etic acid. $\times 850$

Bacill, shoghtly movme

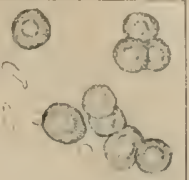

III.

$\times 8 j()$

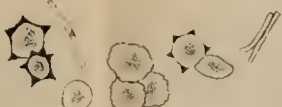

3 Sexum from the lumis of Mr. 13assetts pie ( No11. $\times 850$ examuned two hours after death colon.

$18 \quad 8.78$

\section{IX}

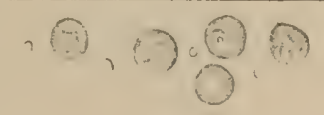

3. The sam object ?0 mumites later.

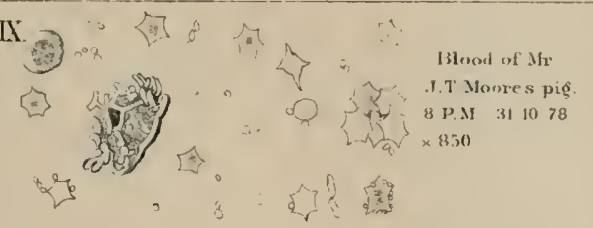

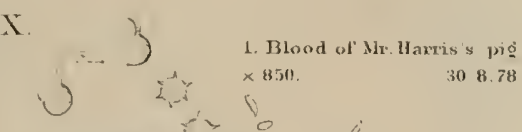

$\sin x 0^{\circ}$

3. Barill of thr mestinal ulcers

of Mfr.Harres's pro $\times 850$ 30. 478

XI.

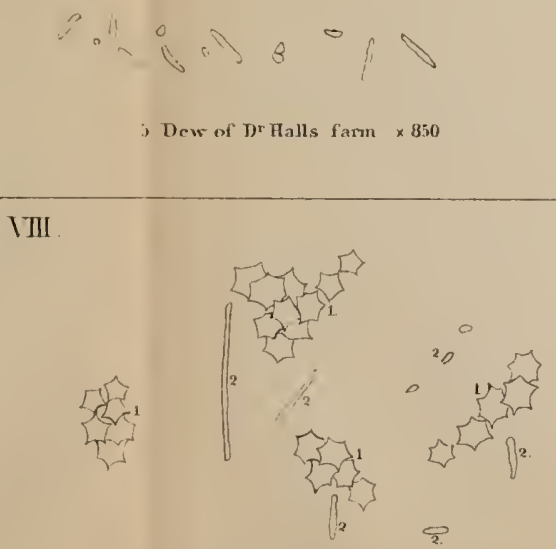

1 Blood of Mr. Bursey's pig. $\times 850 \quad 298.78$ t.blood corjuscules, ? baculi movusg. examuned 3 lious after drath

2 Sixue sprum. after haveng berst exposed for 3 howes to blocodlent.

8.P.M ?"? 1078
I Bacilh and barillus germs loumed in the Giluated exudation of the lunos of M. Ilossocks mo

9. 1:.1.14.1078.

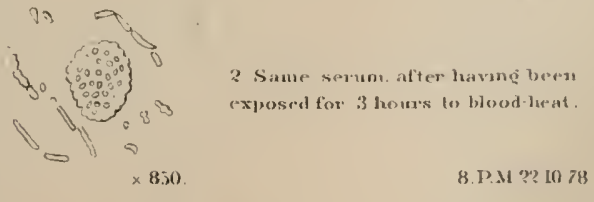

XII Prowessol drision 
that the latter, beyond a doubt, constitute the principal disseminator of the infective principle. Whether tie colonies or viscous clusters of bacillus-gerins and partially develoied bacilli are instrumental in bringing about the cxtensire embolisin in tho lungs and in other tissies, by mereiy closing tho eapillary vessels in a meelianical way, or whether the presence, wowth, devclopment, and propagation of the bacilli and then germs produco peculiax chemical elanges in the composition of tho blood, which alisqualify the latter to pass with facility through the capillaries, or which eause a clotting or retention of tho same in the capillary system, is a question which I am not prepared to decide. According to my own observations, it appears that the colonies or viscons clusters of bacillus-germs and partially developed baeilli get stuck in the canillaries so as to obstruct the passage, and constitute in that way tho principal, if not tho sole, causo of tho embolism. Dr. Orth is of a different opinion. He says: "Tho priucipal effect of the 'Selizomycetes' (bacteria, bacilli, \&c.) is an indirect ono, viz., by producing a proison (virus)." (Archiv. fuev wissenschafiliche und praktische Thierheilliande, 187., page 1.) It is possible that the circulation of tho blood in the capillary system is interfered with by both mechanical obstruction and chemical changes. Still, it seems to me that the observations of Dr. Orth and others apply more to the fully doreloped bacilli in the blood and in the lymph. The vitality of the bacillns-germs, and especially of the bacilli, is not a very great one, except whero the germs are contained in a substance or a fluid not easily subject to decomposition; for instance, in water which contains a slight almixture of organic substances. If such a fuid is kept in a vial with a glass stop, tho germs remain for a long time (orer six weelss) in nearly the same condition, or develop very slowly, according to a mount of oxygen and degree of temperature. In an open ressel tho dovelopment is a more rapid one. If oxygen is oxcluded, or the amount available oxhausted, no further chango seems to be taking place. In the water of streamlets, broolss, ditches, ponds, \&c., the bacillus-germs are not destroyed very soon. How long they retain their vitality I hare not been able to ascertain. In fluids and substances subject to putrefaction, the bacilli and their germs lose their vitality and aro destroyed in a comparatively short timo; at least they disappear as soon as thoso fluids (blood, for instanco) and substances nudergo decomposition. In the blood they disappear as soon as the blood-corpuscles commenco to decompose. That such is the case has been ascertained not only by microscopical observation, but also by clinical experienco. The bacilli and their rerms are also destrosed if brought in contact with, or if acted upon by, alcolsol, carbolic acid, thymol, iodine, \&c.

\section{CLINTCAL ODSERVATIONS.}

The experimental pigs, Nos. 1 and $\Lambda$, put in pen No. 2, on Norember 13 th (together with experimental pig $($ ), in which pen pig No. IX had died of swine-plague on the 28th of Oetober, remained perfeetly healthy, notwithstanding pen No.2, which was thoroughly infected, had received only an ordinary eleaning, but had not been disinfected. Consequently, it must be supposed that the infections principlo (tho bacilli aud their germs) contained in particles of excrement and in the urine elinging to the floor and lodged in tho cracks between the boards must lia fo been destrojed, becauso I observed repeatedly that tho pigs, probably in search of saline substances, licked those parts of tho floor which had become saturated with urino.

Mr. Bassett, who had lost nearly his whole herd of swine-of one lot containing originally forty-five animals only two survived-bonght, about cightecn dass after the oceumence of the last death, two young, healthy pigs, and allowed them to run at largo in his orchard, a pasture, and ono of his swine-yards, the same premises on which the lot of forty-fivo animals just mentioned had been lept. The fer surviving hogs of his old herd are liept in another vard farther north. Seeing that those two pigs remained liealthy, ho thought ho might risk it and luty somo more, and abont two weels later ho bought sixty-nino (not ninety-five, as I behieve I havo stated in my report) healthy Berkshire shoats, from fivo to six months old, at the auction of the Hon. James Scott, president of the Illinois State Boarl of Agriculture, and turned them ont on the samo premises (log-lot, orchard, and pasturo). After theso sixty-nine shoats liad been there two diys they discovered tho burial places of the fort 5 -three dead shoats, logs, and pigs, which, by the ray, had been buried only from two to threo feet deep. 'These they commenced to exhumo immediately, aud soon consumed all the decomnosed carcasses. Alr. Bassett would have prevented this had he discovered them in time. Erery shoat las remained healthy up to date (November :29th), and as the period of incubation (from fivo to fifteen days, or on an arerago soven lays) expired somo time ago, it must be supposed that the infections prineiple, tho bacilli and their germs, had been thoronghly destroyed hy putrefaction. It nust bo mentioned that there are no straw-stacks, Sce., on the swine-raisece, and that the shoats have no access to any streanlet, ditch, or pool of water.

Mr. Locke's herd of swine has been kept perfectly isolated in a pasture near the eity linits of Champaim, and has remained exempt from swine-plache lill lately. The hog-pasture is closo to the Illinois Central Railroad rack. Whether the infec- 
tious principle las been introduced into Sir. Locke's pasture hr the car-loads of diseased swine which pass by overy evening, aud which somotimies remain standing on the tracks, at a distance of not nuch orer forty rods f'ou the her-pasture, for half an hour or longer; whether the vieinity of tho rendering establishnent luas been instruxental in bringing about an infection; or whether the infections principle has been communieated by other means, I have not been able to ascertain.

The herds of Mr. Clelland (or M IeClelland), nine or ten miles northwest of Champaign, and of Mr. Allen, six or seven miles northeast of Urbana, have remained cxempt for a long time, probably because neither of them hes any closo neighbors, but finally the disease, spreading from farm to farm. lias reached tlicir herds.

Mr. Clay West, three and a half miles northwest from Champaign, living also somewhat isolated, expected that his swino (forty-seren head) would remain exempted. Most of thein (forty-two or forty-three) obtained their mater for drinling from a running streamlet which, threc-fourtlus of a mile above, passes through tho hog-pasture of auother farm. On tho latter swine-plagne mado its appearance, and three rreeks later Mr. West's smine commeneed to dic. So it must be supposed that the infection had been broight about by the rater in the streamlet. Mr. West, as soon as he found that his logs commeneed to die, sold trents-seren hend to be shipped to Chicago.

\section{MOREID CIIATGES AFTER DEATII.}

Since Noveuber 15th I hare made somo more post-mortem examinaiious, mostly for tho purpose of obtaining matcrial for microscopical investigation; but have found nothing not found before, or of any special importance, cxecpt in one case, of which, therefore, a full account may not bo superfluous. It was a pig of Mr. Clellan's (or MeClelland's), who had lost four head out of seventecn within a few days, or after brief sickness. Tho pig in question, which was a little orer four months old, had been sick only two or three dajs. 'Tho post-mortcm examination was made on Norember 22d, about sixteen hours after tho animal had dicd.

Extcrially.-Considerable capillary redness of a purple lune in the slin on the lower surface of the body, between the legs, and bchind tho cars. Intcrnally. - Lower and anterior parts of both lobes of the lungs hepatized (reil henatization); tho rest of both lobes gorgerl with blood-scrum or fluici exudation; pericardimm conted with plastic exudation; auricles of the heart congested, the eapillary ressels tinged with darli-colored blood; lymphatic glands, but especially thoso of the mesenterium, very much swelled; lịver, selerotic ; serous membrane of some of the intestines (cxcum and colon) coated with exudation; cechymoses and capillary redness in pyloric portion of tho stomach; and a few worms (Trichoccphalus crenatus) in crecum, but no morbid growths or ulecrons tumors whaterer in any part of the digestive canal. This case is $\pi$ orth mentioning, because no morbid growths or ulecrous tumors wero found in tho caecum and colon, or in other parts of the intestinal canal; it consequently shows once more that embolism and subsequent exudation in the lungs and in other tissues are moro constant and more characteristic of the morbid process of swine-plague than the peculiar morbid growths or ulcerous tumors in the crecum and colon.

Whether those ulcerous tumors on the intestinal mucous membrano occur only in cases in which the infectious principle has been introduced partls or wholly through the digestice canal, and aro absent in those cases in which the bacilli and their germs hare entered exclusirely througly wounds or lesions, or whether, finally, this presence or absence depends upon other influences and conditions, is a question which I am not fully prepared to answer. It has decidedly the appearance that the seat and the character of the morbid ehanges depend, to a certain extent at least, upon the means and parts by and through which tho bacilli and their germs have entered the auimal organism.

Iy opinion, expressed in my report of the 15th ultimo, that an infection is brought abont either throngl the digestive canal or through wounds or lesions, and probably not through the respiratory mucous membrane and through the skin, if no mounds or lesions are existing, has been corroborated by an observation mado at Mr. West's place. I was thero on Norember 20 th. The chisease had made its appearance on Norember 10th. Mr. West had lost five animals, had sold twenty-seren more or less diseased, and still had fourtecn or fiftecn, including four or fire older hogs kept in a separate pen, abont 12 by 16 , which had a wooden floor, and mas separated from the hog-lot or hoy-pasturo only by a board fence. Theso older animals reccive and have received their water for drinking from a well, while all those kept in the hog-lot or hog-pasture, originally fort $F$-two in mumber, had access to the streamlet before mentioned. None of the older animals, although breathing the same atmosplice as the rest, shorred any symptoms of cliscase, and aro still healthy (Norember 20th), as far as I have been able to learn.

In conclusion, I mas sar that swine-plague does not scen to be communicable to anv other domesticated auimals, and must be considered as a clisease sui generis poculiar to swine. 
I intended to make further experiments, by inoculating lealthy animals with bloodserum or pulmonal exndations, frecl from bacilli and bacillus-girms by repeated tiltrations and with cultivated bacilli, but the timo left me (sixtevu dars) was not sufticient to obtain reliablo results. Besicles, it appeared to be desirablo to use tho pigs I hat on hand for the purpose of testing the vitality of the infections principle in snch a way as would give tho test a direct practical value.

I am, very respectfully, jour obedient servant,

Chicago, Ill. December 1, 1878.

H. J. DETMERS, $\nabla . S$.

\section{REPORT OF DR. JAMES LAW.}

Hon. WY. G. LE DUC,

Commissioner of Agrieulture :

SIR: I have the honor to submit the following report of experiments and observations on the prevailing fever in hogs.

As yon are already aware, my attention has been directed mainly to the pathology of the disease, the nature and vitality of the rirus, and its behavior when treated by different disinfeetants. Distant as Ithaea was from all infeeted districts, and seeing it was impossible here to ex. periment on large herds of diseased and exposed swine, it seemed preferable to leave to others all essays of treatment and prevention of the illness by the use of disinfectants and other sanitary measures. This isolated and noninfected locality offered speeial adrantages for conducting that class of observations which I aimed at, as there was no danger of accidental infection from other sources than the experimental pens. At the same time the number of animals subjected to experiment was limited by the necessity for the most perfect isolation of the healthy and diseased, for the employment of separate attendants for each, and for the disinfection of instruments used for scientific observations, and of the persons and clothes of those who conducted these.

The experimental pens were constructed in a high open field, with nothing to impede the free circulation of air; they were large and roomy, with abumdant ventilation from back and front, with perfectly close walls, floors, and roofs, and in cases where two or more existed in the same building the interrening walls were constructed of a donble thickness of matched boards with building pasteboard between, so that no communication could possibly take place excepting through the open air of the field. When it seemed needful disinfeetants were placed at the ventilating orifices. On the pigs showing the first signs of illness, infected pigs were promptly turned over to the care of attendants delegated for these alone, and the food utensils, \&e., for the healthy and cliseased were kept most carefully apart. When passing from one to the other for scientific observations, the healthy were first attended, and afterward the diseased, as far as possible in the order of sererity. Then disinfection was resorted to, and no risit was paid to the healthy pigs until after the lapse of six or eight hours, with free exposure in the interval. In the pens the most scrupulous cleanliness was maintained and deodorizing agents used so as to keep them perfeetly sweet.

I may be allowed to add that I have receired most valuable assistance from tro of my students, Messrs. A. Mr. Farrington and A. G. Boyer, in conducting the claily observations, as well as in making post morten examinations, and in the examination of diseased products. 
INCUBATION OF THE DISEASE.

Our experiments have shown this to vars greatly, though in the great majority of cases it terminated in from three to seven days after inoculation. As shown in the table appended, one sickened on the first day, three on the third, two on the fourth, one on the fifth, two on the sixth, four on the serenth, and one each on the eighth and thirteenth days respectively. A comparison of these results mith those obtained elsewhere seems to show that we have reached the two extremes. Dr. Sutton, observing the result of contact alone in autumn, sets the period at from thirteen to fourteen days; my omn observations in Scotland, in summer, indicated seren to fourteen days; Professor Axe, in London, in summer, concluded on five to eight days; Dr. Budd, in summer, four to fire days; and Professor Osler, in autumn, four to six days.

\section{SYMTTOMS.}

The cases obserred were of all degrees of severity, from a slight access of ferer, with some loss of appetite, irregularity of the bowels, and alternations of heat and cold on the surface, to riolent attacks, terminating fatally after eleren days' illness.

Early symptoms.-In an arerage case, one of the earliest signs of illness was an elevated temperature of the body, amounting to one or two degrees above the former indications furnished by the same animal. This qualification appears requisite, as the temperatures of healthy pigs were found to vary widely under different conditions of life. After active exercise or excitement $104^{\circ} \mathrm{F}$. is not unfrequent, while in a close pen where they are quiet and still, $100^{\circ}$ to $102^{\circ} \mathrm{H}$. is quite as common. On more than one occasion, when a pig got accidentally fixed in a narrow space where he had barely room to stand, the temperature was reduced to $99^{\circ}$ and eren $9 S^{\circ} \mathrm{F}$. The body heat was raised by a hearts meal and lowered by abstinence. Generally a sudden rise of temperature and saturation of the atmosphere with moisture led to an elevation of the body heat, in other cases a reduction of the temperature of the air led to the same phenomenon. (See table of Meteorological Observations and Temperatures.) In connection with the rise of temperature there was generally a diffuse redness of the skin, with increased warmth, alternating with cold, especially in the ears, nose, tail, and limbs. The pulse usually rose perceptibly, sometimes reaching 120 per minute, while the breathing was little if at all affected. The snout was often drawn back, giving a wrinkled or pinched appearance to the face; the movements were less actire, sometimes decidedly stiff and slow; there was perceptible falling off in appetite, and the bowels were usually costive.

Disease at its height. - The temperature rose in most casess to $105^{\circ} \mathrm{F}$., and exceptionally only to $107^{\circ}$ or $108^{\circ} \mathrm{F}$. (Dr. Osler records $110^{\circ} \mathrm{F}$.), to be followed after a variable length of time (three to twenty days) by a a descent to the natural standard, or eren lower. The pulse also róse to 120-130, and the flushes of heat on the skin were much more frequent and extreme. At the same time certain changes appeared in the skin, varying greatly in degree in different cases, but which may be described as follows :

First. A pink or scarlet rash in spots a reraging about one-tenth inch in diameter, but often becoming confluent so as to form an extended blush. Many such spots disappeared momentarily under pressure, showing that the minute blood-ressels were not yet completely blocked, but only dilated. Many, howerer, could not be even temporarily obliterated 
by pressure, shoming already existing embolism if not eren ruptme and the escape of the blood-elements into the tissue.

Second. Ir some, though by no means in all, there appenred black spots on which pressure liad no effect. The cuticle of such spots dried mp and shmmk, and if the prig survired long cnongh was finally de. tached.

Thirl. In nearly all there were slight pointed elevations, mostly around the roots of the bristles, which orer the rhole body had become more erect, rougin, and harsh.

Fourth. Scattered more or less abundantly over the surfuce were black concretions, hardening in most cases into a scab, but in others, and particularly on the inmer side of the thighs, aceumulating as a soft, greasy inunetion. Whero this was not diffiused as a uniform black incrustation, it showed as small black particles nostly at the roots of the bristles, and rras evidently a product of the diseased sebaceons glands.

Fifth. The skin showed at many points, and above all on the pendent margins of the ears, on the hocks and kuees, on the rump and abdomen, an unbroken blue or violet tint, which cauld not be effaced by pressure. In bad cases this was associated with considerable strelling of the ears, and in one with rupture of the integument and loss of blood.

Finally. A great accumulation of scurf took place along the back, and with the tough, rigid state of the skin contributed much to the unthrifty look of the subject.

The arching of the back, the drawing lip of the flank, the advance of the hind toward the fore feet, and the stiff morements of the hind limbs sufficiently attested abdominal suffering, while the contractions of the rectum resisting the introduction of the thermometer testified in most cases to the imitability of the bowels, if not to the thickicning and corrugation of their mucous membrane. The gait was stiff' and uncertain, and the patient icelined to lie in its litter, by preference stretched on its belly. The bowels at this stage were mostly irritable. In the milder eases they were mostly costive, or if the dung was of natural consistency it smelt strongly. In the worst cases, and in sereral of the milder ones, they becane relaxed with a semi-solid fetid discharge, or a yellowish white or slate yellow watery flow, alternating with more confined or costire conditions. Vomiting was noticed once or twice, but was altogether exceptional. One patient ground its teeth, but one only. Sereral had a congh, occurring in paroxysms, but the majority had none, and this is the more remarkable that several of those that appeared to show this immunity harbored numerous lung-roims. In most cases the inguinal glands could be felt to be enlarged.

Stage of sinting.-When patients rere approsching death, the tem. perature, after reaching its lighest point, suddenly descended to below the natmial, the pulse increased to 130 or eren 160 per minute, extreme weakness supervened so that the animal conld barely rise or drag itself aromnd; in some cases the nervous powers were so dulled that the pig lay in a stupor, hardly disturbed when pricked to obtain a drop of blood for examination, and in others there seemed to be actire delirinm, with sudten starting and screaming. Norrous disorder was further shown by general tremors and muscular jerking of the limbs or body. If formerly purging, the anms became relaxed, and the liquid feces escaping involuntarily smeared the thighs and bed. In two this state of things lasted for tro days before death supervened. At this stage moving bacteria were repeatedly detected in the blood.

Sibsidence of ferer.- In cases which seemed to promise recovery, including a majority of the whole, the temperature declined gradually 
toward the matural standard. the bowels became more reomlar, the appetite improred, the skin cleared iip, and all the bad symptoms stealily diminished. As it was not our object to preserve then they were either sacrificed or aginin inoculated, so that the too fregnently tardy and imperfect or uncertain convalescence was not rerified in our pens.

\section{POST-MIORTEMI I.ESIONS.}

In considering the morbid anatonn of the clisense, the lesions of the skin referred to abore under the head of srmptoms need not be again recorder.

The characteristic lesions were fond especially in the digestive organs, the lymphatio glands, and the lungs, though the serons mem. branes and other tisslies were by no means always exempt.

Digestize organs.-In four cases the tongue was the seat of spots of a deep-blue color, ineffaceable by pressure, and in three cases it bore distinct nlcers, similar to those to be described later as existing in the large intestine. Similar ulcers appeared on the soft palate, in two cases, and on the tonsils in one. In four cases the plarynx bore indelible blue spots of extrarasation, but no distinct ulceration. In one in. stance a white concretion in four minute lobes, like pins' heads, was found on the mucous membrane on the back of one arytenoid cartilage, consisting of rounded mucleated cells and granular matter. In one case only did the gullet show patches of congestion. The stomach always contained a fair amount of food, usually smelt intensely acid, the exhalation fuming with ammonia, and presented on the mucous membrane of its great curvature a mottled, dark-lorown discoloration, as is often seen in pigs that have been starved for some time prior to slaughtering. In four cases this membrane bore patehes of thickening from $\frac{1}{4}$ to 1 inch in diameter, of a deep-red color, from blood cxtravasation into and beneath the mucosa. In two cases it bore a dirty yellowish-white pellicle of diphtheritic-looking false membrame, the microscopic characters of which will be noted hereafter. In one case slight erosion of the membrane had ensued, but without the formation of any slough.

The small intestines constantly presented spots of congestion, and sometimes extended tracks of the same, with softening of the mucons membrane and excessive production of mucus. The spots were easily orerlooked mnless when the entire length of the gut was slit open and carefully examined, but when closely examined they presented not only the branching redness resulting from coagulation of bloor in the capillary blood-ressels, but also microscopic extrarasations of the blood ont of thin natural currents. Another point which serred to characterize these limited congestions was a greater or less hæmorrlagic reddening of the mesenteric glands immediatelr adjacent to the congested spots. In three cases only rere distinct erosions fomnd on the small intestines, and in one, ulceration with the dirty-rhite central slough so common in the large intestines. The edge of the ileo-cxcal valre was twice the seat of a sloighing ulcer, and in four subjects the glandular follicles of Peyer's patch were enlarger at this point, a condition which is, however, not uncommon in pigs killed in health.

In the large intestines the lesions were at once more constant and more advanced. The crecum was the seat of dark-red patches from congestion and extravasation in six cases, the colon in six, and the rectum in fire. Ulcers appeared on the caemm in eight cases, on the colon in seren, and on the rectum in three. In two cases the whole leugth of the large intestine was the seat of great thickening of the mucous membrane, 
which was of a deep, dark-red color, and thrown into prominent transverse folds, that considerably diminished its intermal caliber. The large intestine was more entirely free from slight congestion of the mucous membrane, and in two eases only were no ulcers found on this part.

The variety of these ulcers dleserves a passing notice. In a certain number of cases the mucous membrane, though comparatively free from congestion, showed a number of small conical swellings, with yellowish depressed centers, and about the diameter of one-half a line. To the naked eye these appear like enlarged solitary glands, but have been shown by Dr. Klein, of London, to be enlarged and diseased mucons crypts (follicles of Lieberkiihn.) Next, erosions of larger size were not nucommon. In these, the surface layer of the mucons membrane was destroyed, leaving a depressed, red, congested base, and swollen, slightly congested, and reddened edges. Then there are the older nlcers in which, with a more or less reddened base and margin, there is a central dirty. white product, arranged in concentric layers, and usually projecting above the line of the adjacent mncous membrane, and eren overlapping it. This appears like a slough, and though sometimes stained with blood contains no pervious ressels. In one instance this slough, in place of occurring in rounded isolated forms, exteuded transversely to the direction of the intestine, occupying the limits of its morbid transverse folcls for half the circumference of the canal, or even more. These bands were abundant in the cxenm and colon, and at intervals two adjacent ones would merge into each other at their widest parts. Finally, in one case, a great part of the surface of the cremm and colon was covered by a yellowish-white dipthheritic-looking pellicle, in patehes of several inches in length, and projecting above the surface of the mucous membrane at its free border.

In one case only was there a blood-colored liquid effusion into the peritoneum. In another, a transparent exudation between the folds of the mesentery contained a microscopic embryo worm ; but the most careful search could detect no others at this point, nor in the coats of the intestines. In one case, whitish concretions were found on the mesen. tery, projecting from the surface and composed of granular cells like those of the concretion on the larynx.

Liver.-Slight ecchymosis ou the surface of the liver was common, but extensire congestion, and above all softening, were virtually absent. When congestion existed the acini rere most deeply colored in the center, showing the implication of the hepatic veins and intralobular flexus rather than the portal system. In two cases this organ contained slight caseous deposits, in one an acephalocyst, and several times hydatids.

The pancreas appeared to be uniformly healthy.

The splcen appeared unduly black and gorged with blood on two oceasions ouly, and in the worst of these the blood was alive with actively. moving bacteria.

The lymphatic glands of the mesentery and of the abdomen generally may be said to liave been uniformly altered. Those in the vicinity of congested or ulcerated patches of intestines were usually of a dark bloodred, confined to the surface of the gland, or in the worst cases extending through its entire substance. In cases where the disease had passed the crisis, and the subject was advancing towards recovery, there was often simply a grayish discoloration of the surface of the gland, where such hrmorrhagie discoloration would hare been found in the earlier stages. In all cases the glands appeared to be materially enlarged.

These remarks would equally apply to the lymphatic glands in the chest, throat, or other parts where congestion and ecehymosis existed. 


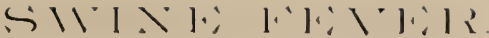

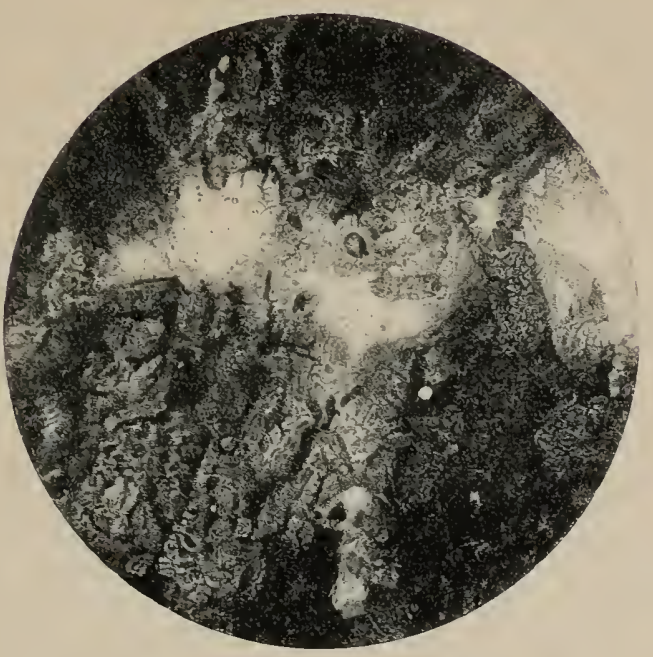

Fig. 1

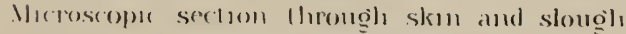

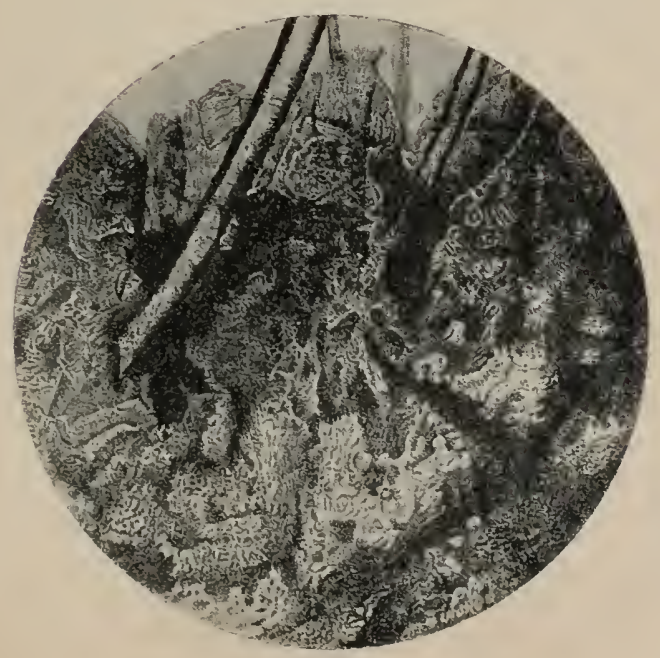

Fis.

Macroscopue section of skan 13 pupple spot 

Respiratory organs.-Congestions and ecchymosis were common on the larynx, windpipe, and pleurx. Though the lungs never entirely escaped, in one case only was an entire lung hepatized. Exudation and consolidation of the lung-tissue were in a few instances confined to the anterior lobes, but as a rule a few of the posterior lobulettes only were affected. In some cases exudation was confined to the interlobular spaces, which accordingly appeared as broad lines circumscribing the lighter-colored lobes, with which they contrasted strongly in color because of their clark blood-stained exudate. Even when the lobules were also the seat of exudation, they were mostly lighter than the interlobular spaces, in this differing from the ordinary inflammation of the lungs, in which the latter appear as yellow lines. The bronchia of the affectecl lobules were invariably filled with a frothy mucus, while in eight subjects they contained uumerous lung-worms (Strongylus elongatus). It is worthy of notice that in nearly all cases in which lung-worms were found, the lobules into which the exudate had taken place wero invariably comnected with the infested bronchia. In one case the windpipe presented along its whole leugth a yellowish-white talse membrane similar to that described as existing on the large intestine. In another instance a blocked bronchium presented a sinall circular slough not unlike the commencing slough of the intestinal mucous membrane. In no case did I meet with the caseous blocking of the bronchia recorded by Klein.

In one case only was there extensive liquid effusion into the pleuræe. This was of a dark blood color, and, besides, the blood-globules contained myriads of actively-moving bacteria. False membranes of recent formation also connected the pulmonic to the phrenic plewrro in this case. The right lung was hepatized throughout. In the same subject the pericardium was the seat of a similar exudate, and fibrinous coagula comnected the cardiac to the mediastinal layer. In three cases the lining membrane of the heart was the seat of spots of ecchymosis, by preference on the papillary muscles. The right heart usually contained a clot of blood which showed a buffy coat in three cases only. In two cases there was a clear translucent exudation around the auricule ventric. ular fiurow, which, under the microscope, showed fat cells and granules, and a network of capillary vessels in which the blood-globules moved freely, and showed no tendency to adhere.

Brain.-In onc case there were fomr hæmorrhagic spots on the duramater, areraging about one line in breadth.

\section{MIICROSCOPIC OBSERVATIONS.}

Skin.-Microscopic sections through the affected portions of skin showed the various grades of congestion; congestion with blocking of the eapillaries, and excess of lymphoid and large granular cells and gramules staining deeply with coloring agents; and congestion, with extravasation and the formation of necrotic spots. (See Plate IX, Fig. 1.) With the earlier congestion there is more or less dropsy of the slin and consequent separation of its intimate textures, while in the later or more severe conditions a fribinous exudation takes place, and this may even exude from the surface and concrete there in dark scabs. In no instance did I meet with the formation of pus in the skin, and notwithstanding. the numerous minute extravasations into the true skin and cuticle, in one case only was there sufficient destruction of a superficial vessel to lead to a temporary hrmorrhage. One feature which I have not seen mentioned by other observers is the implication of the bristle follicles. It has been already stated that the pink papular eruption is mostly ob- 
served around the roots of the bristles, and it may be added that the bristles almays stand ereet and barsh. Morcover, in addition to the general unthriftiness and scurfiness of the skin, it tends early to become coated with greasy exudation, resulting usually in the black coneretion already mentioned and solublo in ether. This is manifestly a product of tho hair follicles and their sebaceous glands, and accordingly a section through ono of these shows the decp congestion of the eapillary plexus. (See Plate IX, Fig. 2.)

Intestine.-Sections throngh those portions of the mucous membrane which are merely congested and reddened, but without ulceration, shows staguation and blocking of the capillary vessels in the mucosa and submucosa, with thickening and softening of the textures, and especially of the epithelial layer. 'This last contains a great excess of granules and aggregations of grauules into cell forms (giint cells of Klein), while the epithelial cells themselves are reduced in size and contain enlarged nuclei. As formerly pointed out by Klein, the degeneration is often greatest aroumd the openings of the erypts of Lieberkiihn, and in their interior, while their cavities are not unfrequently filled with extravasated blood. Besides the above are found lymphoid and wandering blood cells, erystals of himatine and closely aggregated masses of granules staining deep purple blue in hrematoxylon and insoluble in caustic potass -the micrococci of Klein. These last are especially abundant on the surface, but extend into the deeper fibrous layers as well. In severe cases the epithelial layer may be raised from the mucosa by a consider. able dark-red elot, though the escape of blood in large amount is more frequent under tho mucous membrane, so as to separate it from the muscular coat.

The ulcers with a central slongh present at their base the same characters as the congested mucons membrane, as regards cellular and granular proliforation, blocking of ressels, exurlation, and microscopic extrarasation. The slough may be shown to be mate up mainly of small nucleated cells and granules, but it retains under the nicroscope its close laminated appearance, eaused by the gradual extension in depth and breadth by the death of successive layers of the mucous membrane. It contains numerous groups of the granular bacteria already referred to, and extending down to its deepest strata.

Lymphatic glands.-As regards the lymphatic glands, I need only repeat the statement of Klein, that the blocking of ressels and extravasation of blood is most commonly into the outer or cortical portion alone; in the more severe forms in which the medullary part is also implicated, the blood effusion is often confined to the lymph-channels and the connective tissue-partitions, while the glandular eylinder's eseape. It is in eases of longer standing that the cell changes are the most marked. Then there may be found in the lymph-channels the giant cells already mentioned, and the groups of gramular-looling micrococci, similar to those found in the intestinal ulcers, as well as lymph-cells of an abnormally dark gramular aspect.

Organs of respiration. - The characteristic lesion of the lungs is lobular pneumonia, the exudation taling place most abundantly into the connective tissue between the lobules, and there assuming a dark color by reason of the abundant escape of blood-globules. On malking a microscopic section across the smaller air tubes and air sacks, we find in the connective tissues generally, and in the walls of the alreoli and around the bronchia an exudation containing an excess of small round lymphoid cells and granules, and in the air cells themselves accumulations 
of similar rounded cells (Klein's giant cells), grauular matter, and elumps of granular bacteria.

In one instance the wind-pipe from larynx to lung had its superior wall eovered by a yellowish-white diptheritic-looking lajer similar to that which I found on another occasion thronghout nearly the whole large intestine. A section of this under the microscope showed mainly small rounded granular cells, Klein's large granular unioeular cells, and clusters of the granular masses of bacteria, staining deeply with hrmatoxylon. The lirer sometimes showed congestion and blocking of its intralobular capillaries and an escape of small rounded gramular cells (lymph) into the interlobular spaces, the latter affording a marked contrast to the redness in the center of the acini.

Kitheys.-These were, with one exception, pale in their cortical portion, and a eloudy swelling existed in the walls of the tubules. Spots of blood-staining were common on the papilla, and at those points the capillaries were blocked by coagula to a greater or less extent.

Blood.-In most cases no alteration of the blood was detected. In one pig, horrever, on the second day before death, the blood swarmed with bacteria, showing very active morements. In the subjoined drawing's (Plate XIII, Fig. 3) may be seen the various forms presented by one bacterium in a few minntes only. The blood of another pig, which had been inoculated from this one showed the same living germs in equal quantity. They were further foumd in the blood of a rabbit and sheep inoculated from the first-mentioned pig. In an abscess of a juppy which had also been inoculated the germs were abundant. The blood was not examined. In the blood of healthy pigs no such organisms were found. It may be added that the greatest precantions were taken to aroid the introduction of extraneours germs. The caustic potass employed was first fused, then placed with reboiled distilled water in a stoppered bottle that had been heated to a red heat. The glass slides aud eover glasses were cleaned and burned, the skin of the animal cleaned and incised with a knife that had just been heated in the flame of a lamp, the caustic solution and the distilled water for the immersion lens were rebuiled on each occasion before using, and finally the glass rods employed to lift the latter were superheated before being dipped in them. On difierent occasions when the animal was being killed I even received the blood from the flowing vessels beneath the skin into a capillary tube which had just been purified by burning in the flame of a lamp. With these precautions it might have been possible for one or two bacteria to get in from the atmosphere, but not for the swarms I found as soon as the blood was placed under the microscope.

\section{PARASITIC WORIS.}

In view of the fact that the swine-ferer has been repeatedly ascribed to the ravages of worms, it may be rell to notice specially those that were found in the pigs subjected to experiment.

Strongylus clongatus (Dry.), Paradoxus (Mehlis), Lung-ucorm.-The first eight pigs were purehased of a butcher, and had been fed on offal from his slaughter-house. The lungs of all these contained these rorms in numbers varying from ten to forty full-grown specimens, and one pig died, apparently from this canse, on the seventh day. The worms were mostly found in the termmal part of the main bronchinm in the posterior lobe of one or both lungs. Others of the air-tubes were, however, occasioually infested. The infested tubes were filled with a glairy mucus, rendering them totally impervious to air, and containing the 
white thicad-like worms and myriads of microscopic eggs. In every ease the lobules to which such obstructed air-tubes led were red, congested, and solid, or, as in one or two instances, dropsical, and of a slightly translucent, grayish color. Sections of the diseased portion showed the air-cells partially filled with an exudate in which small rounded cell-forms predominated. The walls of the air-cells were the seat of cougested and blocked capillaries and granular cells, while in most cases there were superadded the more specific characters of the fever-the presence of the worms and their irritation having evidently determined the lesions of the specific fever to the infested lobules.

The worms may be thus shortly described: Head slightly conical; mouth terminal, small, circular, with three papillae; body like a stout thread, white or browuish, skin nonstriated; œesophagus short, $0.63 \mathrm{mil}$ limeter's, enlarged posteriorly, club-shaped (Plate XIII, Fig. 4); intestine slightly simuous, and longer than the body; anus opening on a papilla a little in front of the tail. MIale, 8 to 9 lines in length; tail curved, furuished with a bilobed membranous pouch supported by five rays, two of them double, and two long delicate spicula with transverse markings (see Plate XIII, Fig. 5). Female, 1 to 11 inches long; tail turned to one side, narrowing suddenly to be prolonged as a short, curved, conical point; genital orifice in the anterior half of the borly, yet close to tho middle; oviduets very much convoluted. The ova are slightly ovoid $\frac{1}{500}$ inch in diameter, and appear as if they filled the entire body of the adult female (see Plate XIV, Figs. 6, 7, and 8).

Habits.-Like other strongyli, these worms attain sexual maturity in the body of their host, and they lay their eggs in the bronchia, to be carried out in all probability and hatched in pools of water and moist earth. It is wortlyy of note that though I found in the bronchia and air cells eggs in all stages of segmentation, and those containing fully-formed embryos, I did not find a single free embryo worm. The presumption is that, like other closely related worms, they are only hatched out of the body, and that the microscopic embryos live for a variable length of time in water or noist earth, and on vegetables, to bo taken in with these in feeding and drinking.

That these worms are injurious there can be no doubt. Pigs infested by them thrive badly, and many die, as did the poorest of my filst experimental lot. Like all parasites, they multiply rapidly wherever their propagation is favored by the presence of large herds of swine, and especially if these are kept on the same range and water season after season. In such cireumstances they will produce a veritable plague, proving especially destructive to the younger pigs. There is littlo doubt that many outbreaks of alleged hog-cholera, in which the lungs alone are affected, are but instances of the ravages of these lung-worms, but that they are the cause of the specific ferer which we are investigating is negatived by the complete absence of these worms in all of my seeoud experimental lot.

I'ricoceplatus Dispai (Creplin) Whip-Worm of Secinc.-This I found in large numbers in the excum and colon of the experimental pigs, and especially of the first lot-those that had been fed on raw offal. This worm is characterized by a long, delicate, filiform anterior part of the body, and a short, thick, posterior portion. The narrow portion is 0.02 millimeters broad and exceedingly retractile; the posterior portion may be almost 1 millimeter thick. The tegument is very finely striated across, and has a longitudinal papillated band. The ossophagus is very wideand slightly tortuous. 'The male is about $1 \frac{1}{2}$ inches long but the thick portion does not inucle exceed $\frac{1}{2}$ inch, and is curved in a spiral. The 


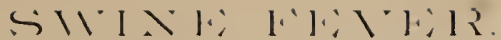

Repom rommossomer of . Igiciculture lom 1878

I'lale IIII.

fonms assumed m rapid sucression by bacternum; also head and tall of lomg wom.

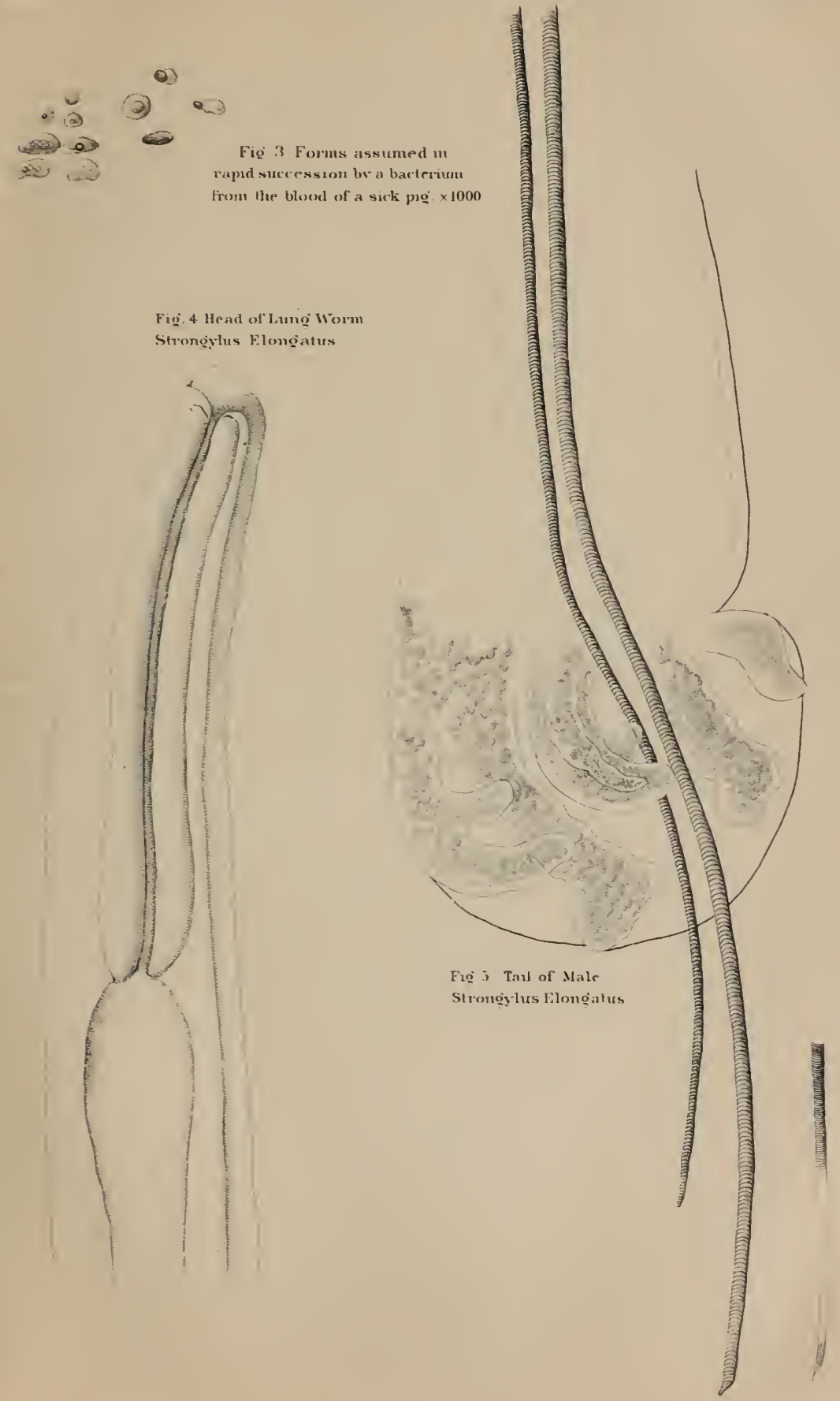



spiculum measures abont 1 line, and is furnished with a funmel-shaped membranous sheath. The fomale is $1 \frac{1}{2}$ to 2 inches in length, the thick portion rarying from $\frac{1}{2}$ to $\frac{3}{4}$ of an inch. The posterior portion is brownish, filled with eggs, and ends in a blunt point. The ova are $0.052 \mathrm{mil}$ limeters in cliameter, with a transparent button-like prolongation at each pole.

Like as with other round worms, the ova are laid in the body of the host, but passing out are hatched in water, \&c., the young spending their early life in pools, streams, $\& c$, and gain access to the body in food and drink. The worm we are at present considering is especially injurious because of its infesting the human being as well as the pig. Liring in the large intestine, it bores its hearl and much of its anterior filiform borly deeply ( $\frac{1}{4}$ inch) into the mucous membrane and sucks the bloorl. Whien present in large numbers it determines active inflammation of the large intestines, with costiveness or diarrhea, and a rapidlyadrancing bloodlessuess. Inasmuch as the seat of its ravages, the cacum and colon, is specially obnoxious to the lesions of the true hogferer, epizootics cansed by the undue prevaleuce of these worms are very liable to be confounded with the latter disease. The worms are so sinall that they are easily overlooked among the solid contents of the riscera, muless special care is exercised in the search.

Sclerostomum dentatum (Diesing).- This is another small worm of the crecum and colon of pigs, found on one occasion only in my experimental animals. It varies from $\frac{1}{3}$ to $\frac{1}{2}$ inch in length and is about $\frac{1}{5}$ line in thickness, hence perhaps more easily overlooked than is the whip-worm, but no less injurious. The body is of a dark gray, brown, or black, according to its contents; the tegument covered with very fine transverse strix: head broad, month teiminal, round, and furnished with six very sharp horny teeth, with which to penetrate the mucous membrane. The gullet is broad and club-shaped, and furnished with two salivary glands, opening by delicate canals into the mouth. Intestine wide and simmous. Male, $\frac{1}{3}$ inch long, $\frac{1}{60}$ inch in thickmess; tail furmished with a bell-slaped membranous expansion, supported by three rays, but open on one side. Testiclo single and extended in a sinnous manner from near the gullet to the tail. Two delicate spiculæ. Female, 4 to 5 lines in length, tail slowly narrowed and terminated abrup's with a sharp projecting point. Ovaries very tortuous, extend from near the gullet to the tail, where they cnd in a globular enlargement, beneath which, and elose to the point of the tail, is the vulva. The ovoid eggs are laid in the intestines, and carried out with the dung, in which they will hatch, and give exit to the embryo worms on the third day. Lilie all this family of roundmouthed worms, this fixes itself to the mucous membrane by its mouth, penetrates the tissues with its sharp teeth, and lives mpon the blood. If present in large numbers it may establish such a drain that the host becomes pale and bloodless, rapidly loses condition, and perishes from anæmia. It will also, like the whip-worm, irritate the bowels and bring on fatal inflammation, with constipation or diarrhea. In both cases alike the lesions are in the cxcum and colon, the common seat of ulceration, \&e., in the specific fever; hence the epizootic is liable to be set down as hog-cholera. It should be added that some member's of the fimily of Sclerostomata, and notably the Sclerostomim equimum (Selerostomum of the horse), pass a portion of their early life encysted in the mucous membrane and even in other internal organs, and there is some reason to suppose that the Sclerostomum of the pig has similar habits, which add materially to the irritation cansed by its presence in largo numbers. The pigs in Virginia reputed as dying from hog-cholera, caused 
by mieroscopic worms in the ralls of the botrels, were, in all probability, the victims of an eprizootic of siclerostomate.

That the genume ben-ferer is not eatused by either of these viurms is best illustrated by the finct that in my second lot I found rese tem whip)worms and uo sclerostomatu, thongh both were diligentlr songlit for.

Cysticerats 'Zemicollis. - This hydatid I found in cousiderable number's in the abdominal eavity (in the omentum, paitonetum, liver, lidners, \&e.), in the peltis, perimenn, and pleure of my first lot of pigs. It consists of an oroid bag of liquid to to 1 inch in length, with an opening at one end, through which the head is dramn back into the sack. The head is supported on a very attenuated thread-like neck, whence the nume. The membrime of the sack is marked by fime tramsverse strie. and if placed in tepid water will often undergo active contractions, during which the lead can be seen to rise and fall in the interior. The head and neck contain an abundance of dark calcareons particles, soluble mith efferrescence in a strong acid.

Seventeen of these hydatids were fed to a Newfomdland puppy, fresh from its mother, ten haring been kept for some time in a solution of common sait, while seren were fresh from a newly-lilled pig. After twentr-five days the puppy was saerificed, and seven tapeworms (T'conic Iraminata) were fomd attached by their hooked snonts to the inucous membrane of the jejumum. Exposure to a strong solntion of common salt for less than a reek in some cases laad been sutticient to lestroy the first ten, while all the seren cysticerei, grown fresh, rlereloped into tapenorms. These lial the globular head with four sucking disks and retractile proboscis, surromded by a double row of 36 hoolilets, having the characteristic long posterior process as show in the accompanying lithograph (Plate NTV, Figs. 9 and 10); also the calcareons marliugs in the lead and neck already referred to.

It is well known that mhen sereral ripe segments of this tapeworm are griver: to a sheep) or goat, the myriads of resulting embryo worms that bore their way into the lirer and other organs will give rise to snch destruetire changes in them that death may eusue in teu days. But here a gain we have the comter evidence in the entire absence of these parasites in my later lot of pigs, showing that they were in no mity responsi. ble for the specitic hog-ferer.

Other paresitio noms of sane. - It is needle'ss to open mp the question of the cumsation of this disease ly the other worms of swiue. Minny rears ago I)r. Tiletcher called attention to the chestructive eliects of thie iand rorn-Stephanums Dentatus-(misnamed selerostoma I'inguiculu) on the liver and other internal or gans, and wen attributed tho hogcholera to its ravages. Doubtless lie was clealing with an epizootic of this worm, but in many instances since, as in my own recent eases, this worm has been sought for in rain.

So with the Trickine Spriralis, the Hook-hated Worm (LChinerhynchus Giges), the common measle hydatid (Cysticeicus C'cllulosa), and the liver Hilies (Fasciola Hi'patica, and Distomum Lanciolatum); howerer alestruetive ther may be to ping in infested localities, the entire absence in my expcrimental jigs sutticiently cxulucles them from the causation of the specific hog-ferer.

ExPRIMLATS OX TIIE PROPARATIOY OF TIS DISEASE J3Y IAOCLLATION ANI OTMTRWISL.

Virutenec of ciried rimes. - In experimenting on the hogs it was sought, first, to ascertain the tenacity of lite of the ilried virns. This was inti- 


\section{SWINH:FHVIR.}

lReport Commissiones of Agriculture for 1878.

Pate An:

Ova, hooks, and head and tail of lung worms
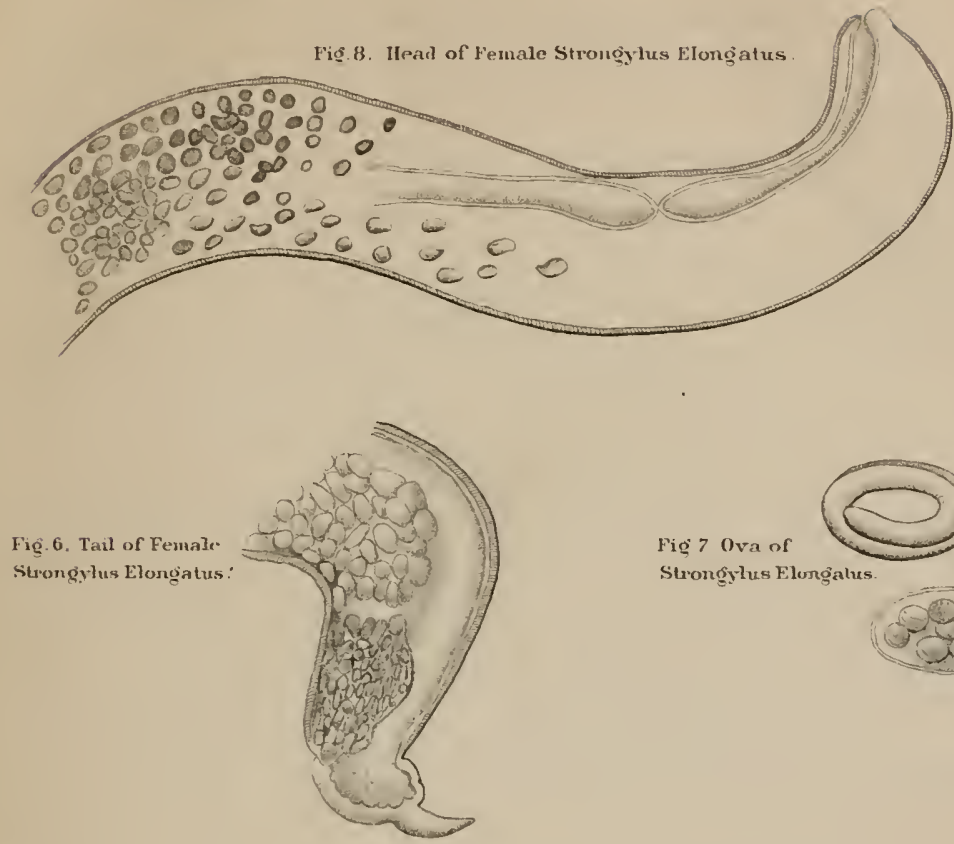

Fig 7 Ova of

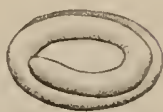

Strongylus Elongalus.

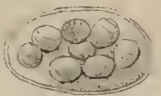

\section{Fig.10. Lone and Shorl hooks of}

Taenia maromata $\times ? 40$

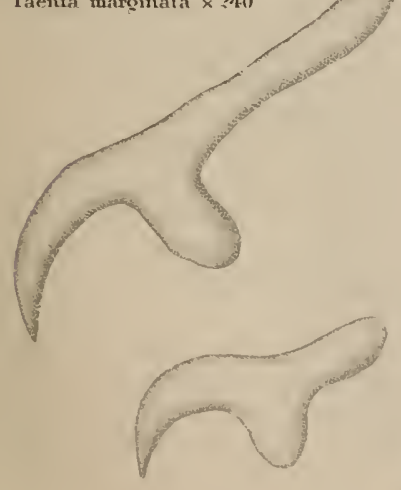

Fig () Head of Thenia marginata $\times 50$.

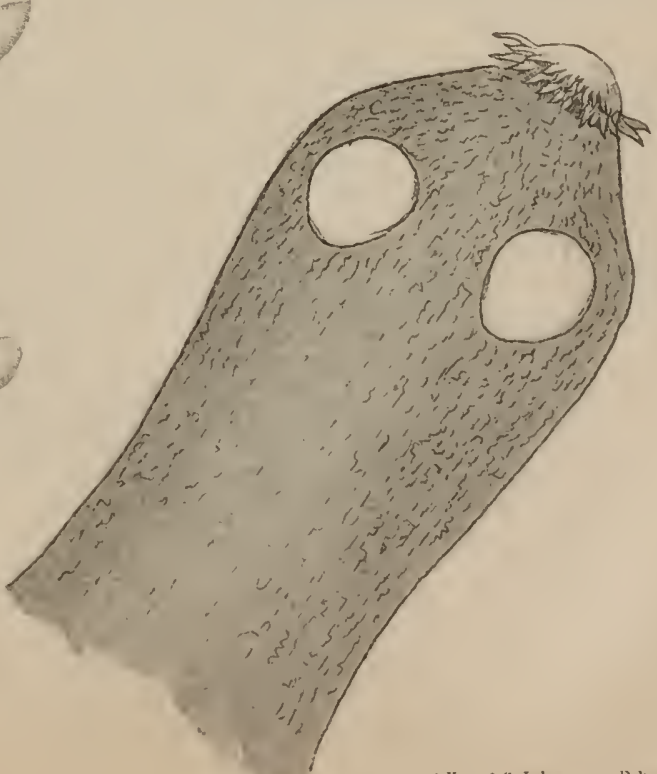



cated thee jeal's ago ly I'rofessol dxe, who succestully inoculated a pig with virus that had remitued dried upon ivory points for twentysix days. It seemed important to test this by further experiment, as upon this question depends the weighty one of arresting or putting an ent to the piagne by the extinction of its poison.

Three pros ware inoculated with virulent produets that had been dried on quills for ONL DAF, one with virus died on the quill for FOUR

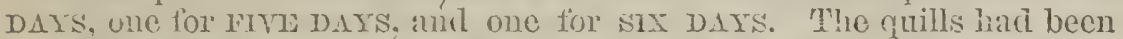
sent from Lew Jersey and North Carolina, walpled in a simple paper corering, and therefore not in any way specially protected against the action of the air. Of the six inoculations, form took effect, and in the two exceptional cases the quills had been treated with disinfectants before inoculation, so that the failure ras to be expected.

Tirulence of the dried intestine.-Iu the case of the quils, the vius Was dried quickly on account of the tenuity of the layer, and no timo was allowed for decomposition. With the diseased intestine the drying in the free air and sum mas necessarily slower, and more time was allowed for septic chamges. Three pins were inoculated with diseased intestiue $\pi$ hich liud been died for THREE and FOUR DAYS respectirely. In one case the diseased product was from North Carolina. In all three cases the inoculation proved successful. The morbid product, therefore, eren in comparatively thick larers, may dry spontaneously, so as to be the means of transmitting tle clisease to the most distant states.

Tirulence of the moist mortid product if secluded from the air.-A pig Was inoculated with a portion of cliseased intestine sent from Illinois in a closely corked bottle. The inoculating material had been THREE DAYS from the pig and smelt slightly putrid. Tho disease dereloped on the sixth day.

A second pig was inoculated with blood from a diseased pig that had been lept for eleven days at 1000 Faluenheit in an isolation apparatus, the outlets of which wele plugged with cotton wool. Illness supervened in twenty-four hours.

The exclusion of air, or moro probably the prevention or retardation of putrefaction, therefore, probably farors the longer preservation of the poison.

Probable non-vimulence of morbid products that have undergone putrefaction.-Two pigs mere inoculated in one day with the elements of an ulicer from a portion of intestine sent from New. Jersey in a box. The product was TwO DAYs from the pig and distinctly putric. Nieither seemed to suffer at any time.

A third pig was placed in a pen with a portion of the same diseased intestine, and sume maume sent with it. 'The intestine disappeared after tha second day, and was probably eaten, but the pig showed no evil effects.

It should be stated that each of these pig's had been formerly inoculated, aud tro appeared to pass through a mild form of the disease, while the third had showed an elerated temperature on three alteruato diays ouly. It may therefore be ruestioned wliether they lad not attained to a certain dencee of insuscentibility which iusured the nenative results. In other cases, liowerer, I have found a second inoculatiou to talie thongh the first had been successfinl, and Dr. Osler records eases of the same kind. The results obtained in the three abore-nentioned pigs would demand further investigation in this direction, as they suggest a probable cxplanation of any vaying vilulence of the disease in wet and dry seasons, in sheals and in the ficlds.

If we can accept Dr. Incin's theory of the baccillar origin of the disease, 
the harmless nature of thoroughly putrid products may be explained on the known pinciple that in preserved or cultivated products the propagation of the septic bacteria leads to the disappearance of the infecting ones.

Tirulence of the blood. - A solitary experiment of Dr. Klein's having appeared to sipport the iclea that the blood was non-virulent, I tested the matter by inoculating two pigs with the blood of one that had been sick for nime days. They sickened on the seventh and eighth days respectirely, and from one of these the disease was still fiuther propatgated by inoculating the blood on three other animalis as recorded below. It may, howerer, still be questioned whether the blood is virulent at all stages, as in the animals infected in the above experiments it ras found to contain numerous actively moving bacteria, which had not been found in certain of the milder eases. This subject demands further inquiury.

Infection through the air.-Only one experiment was instituted on this subject. A healthy pig placed in a pen between two infected ones, and with the rentilating orifices within a foot of each other front and back, had an elevated temperature on the ninth, tenth, and eleventh days, with lameness in the right shoulder, evidently rheumatic. On the twenty-fourth day the temperature r'ose $2 \circ$, and remained $1040 \mathrm{r}$. and upward for six days, when it slowly declined to the natural standard.

Infection of sheep, vabbit, and dog. $-\mathrm{A}$ merino wether, a tame rabbit, and a Newfoundland puppy wero inoculated with blood and pleural fluid, containing numerous actively moving bacteria, talien from tho right rentricle and pleura of a pig that had died the same morning. Next day the temperature of all three was elevated. In the puppy it became normal on the third day, but on the eiglith day a large abscess formed in the seat of inoculation and burst. rithe rabloit land elevatcd temperature for eight days, lost appetite, became weak, and purged, and its blood contained myriads of the characteristic moving bacteria. The wether had his temperature raised for an equal leug'th of time, and had bacteria in his blood, though not so abundantly. IIe did not seem to suffer materially in appetite or general health. The sheep and rab. bit had been each unsuccessfully inoculated on two former oceasions, with tho blood of sick pigs, in which no moving bacteria had been iletected. It remains to be seen whether the virns ean be conreyed back to the pig and with what efiect. Should further experinent show that other domestic animals than swine are subject to a mild form of the disease, and capable of thus conreying it and transmitting it with fital effect to pigs at a distance, it will be a matter for the gravest consideration in all attempts to limit the spread of the malady or to secure its extinction. (Since the above was written, I lave noticed that Dr. Klein has suceeded in transmitting the disease to rabbits, gumea-pigs, and mice.)

Results of disinfection and inoculation of discased products.-Under this head eight experiments were condneted with as many different disinfectants, the morbid products being in erery case such as had prored snecessful by direct inocnlation on other swine. The object being to test first the most arailable and least expensive of the disinfectants, the virulent matters mere treated with $\frac{1}{5}$ per cent. solution of each of the following agents: Bisulphite of soda, carbolic acid, sulphate of iron, chloride of zine, and chloride of lime. The materials to be inoculated were in the thinnest layers, in four cases upon quills and in two in thin sections to be inserted under the slin. They were kept in contact with the disinfectants for five minutes, so that the virulent material was 
thoroughly moistened, softened, and partially dissolved in the fire cases in which a solution was user. In the sixth ease the thin slice was only kept in the fumes of the burning sulphur for fire minutes. In all cases a portion of the disinfectant was necessarily introduced into the round along with the virulent agent. In four ont of the six pigs the disease dereloped and ran its course as shown in the table, the disinfectants thus proving ineffectual being carbolic acid, sulphate of iron; sulphurous acid, and chloride of lime.

The pig inoculated with virus, treated with bisulphite of soda, died on the serenth day, evidently from lung-worms, and without any distinct symptoms of the plague. "There remains the possibility that had it lived longer these would hare appeared.

One agent only out of the six can be set down as having proved an efficient disinfectant as used, namely, the chloride of zinc. The virus, treated with this agent, produced no appreciable illness; and though the pig's temperature was raised on the fourth, sixth, and ninth days, this was probably accidental, as it showed no tendency to become permanent. Finally, two pigs were subjected to a hypodermic injection of a few drops of the blood of a diseased subject, mixed in a dram of a solution of permanganate of potassa for the one, and of bromide of ammonium for the other. Both inoculations took effect, and one of the pigs thus infected furnished the blood which conveyed disease to the sheep, rabbit, and dog, as recorded above.

\section{NATTURE OF THE HOG FEVER.}

Though long confounded with typhoid fever, anthrax (malignant pustule), erysipelas, measles, scarlatina, \&e., this malady is distinet from all of them. In my report for 1875 I pointed out my reasons for declining to recognize in it either of the above maladies, and claiming it to be "a disease sui generis"; and this position has been fully indorsed by the recent researches of Klein, Usler, and others, as well as by my own experiments. This affection may be defined as a specific, contagious fever of swine, characterized by a ligh but variable temperature, by congestion, exudation, ecchymosis, and ulceration of the intestinal mucous membrane, especially that of the crecum and colon, and, to a less extent, of the stomach; by congestions and exudations in the lungs in the form of lobular pneumonia; by general heat and redness of the skin, the latter effaceable by pressure; by darker red and black spots unaffected by pressure; by a papular eruption and abundant dark sebaceous exudation; by ecchymosis on the inucous and serous membranes generally; by swelling and ecchymosis of the lymphatic glands; by irregularity of the bowels, costiveness alternating with a fetid diarrhea; and perhaps most important of all, by the presence of colonies of minute globular micrococei in the rarious seats of morbid change.

An experiment of Dr. Klein, in 1877, in which he cultivated the mierococcus for seven snccessive generations in the aqueous humor taken from the eyes of rabbits, using only a speck on the point of a needle to inoculate erery new portion of the humor, and finally inoculated the product of the fifth and seventh generations successfully on two pigs, seems to establish that these microphytes are the ultimate cause of the clisease. My own experiment, in which the disease was conveyed by blook that lad been kept for eleven days in an incubator at the temperature of the body, goes to support the same conclusion; but I hope still to subject this question to a more crucial test. If we accept this hypothesis of the pathogenic action of the bacteria, it would almost of necessity follow 
that the blood, the elanmel through mhich these must be earried to the rarious organs in which they are fonnd. must prove virulent. One of Dr. Flein's experiments appears to negative this conclnsion, whereas three of mine an to smpport it. From what we hnom of the guncention of mieroplytes, it seens not inprobable that at certaiu suges of its derelopment this specinen mar fail to be injurivas, or nowe prebabiy the germs max be filtered from the biood, being anested in the capiliaries, where they determine the morbid changes, and this niaur specimens of blood inas be obtained which are destitute of the mon lid slement, mutil that is agian produced in abundance br proliferation in the tissues. Br. reference to my experiments, it will be seen that the blond with which the suceessful inoculations were macte mas taken from pigs iu the last stage of the disnase, or just after death. That the bleorl is virulent at certain stages is mquestionable, and in the natme of things this can scarcely fail to lie the ease, eren if $\pi$ e Tere 1 . Fet asicle expeliments and reach our decision fiom the lesions alone.

\section{CATSES.}

It has been no part of mr purpose to investigate the causes of this disease apart from the one specific eause of contagiou. It mas indeed impossible to purstie such a line of inquiry at a clistance from any district where logs are largely raised. mhere the disease prevails extensirels, and there, presumbily. net generations of the poison are taling place. One instance, homerer, of probable generation de noro las been bronght under mis notice, and the attenciant circmustanecs rere snch that I think it important to pubis the principal facts. In the cul of April. 1S 11, Colonel Uotimann, of Horseheads, purchased a large herd of strine to consume the buttermille of his creamery. The strine mero supplied mith sheds, the open range of an orchard, with plenty of shate under the trees, on a gravells soil, rising abraptly 10 to 15 fiect abore the general level of the raller, and were fed fresh huttermilk and corn meal. All ment well until late in June or earls in July, when the hogs began to sicken and elied in large mumbers, with the general srmptoms of the hog ferer. I have mentioned this mainly to negitive the midlespread belief that the sonree of the trouble is in the exchsire feeding mpon conn. Here tre had a laxatire and otherrise mold diet. supplemented onis to a sligint extent by corn. It mar be rell to state that in other rears. Then he has purehased Tresterin hogs, the disease has almass appeared within ten days or a fortinght after their arrival. When Nert Iork State hogs onlr hare been bought the pestilenee lass not brolen out.

In view of the strund assertions that pigs will noi contract the disease when fid in part on green food or on streculent recuables-minips, beets, potatoes. apples. \&e.-I Ind some subjects of experiment freely supplied with potatoes and aplules, but mhenever the poison mas introduced by inoculation I conle detect un nifterence in the perivel of incerbation or the severity of the attack.

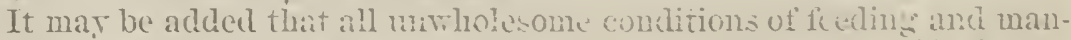
agement will faror the dereionnent of this ns of other specine ferers, by derauging the nutrition, disturbing the balance of waste and repair, loading the blool and tissues with exilte and abmomal products, raisiug the bodr temperature, and on the rilowe bringing about a state of the ststcm extrexicl farorable to the mropagation ani gromth of disease germs. Int while the importauce of all theee mar be recog- 
nized as aceessories, we must not allow then to willelrat our attention from the one condition essential to the revelogunent and propargation of tho malaty-the presence ol the specife poison. I'o puote from my repoit of $18 \% 5$, "The important point is this: We linow this is a con1nupros afiection, to the propagation of which all possible jusalubrions conclitions contribute. So soon as Te concentrate om attention on this point we lave the liey to its prerention, if "1not to its entire extinction."

\section{IS TUT TRTATASNT OF HOG FETFT GOOD POLTCY?}

In talimg what I Juow to he an mpopulax position on this subject, I am led by the strongest convictions of duty. I well lnow how popular wonkl be an investigation into the curative jow ('is of dificrent systems, and eren nostrums, in this disease, and low many hreetlers and dealens in smine mill realil speut more than the value of the sick loog in the purchase of boasted specifies, to say nothing of the cost of attencharece, and low they will rejoice over the wretcleel unthrifty animal whose life is at times preserred. It is not that recorery is impossible. $\Lambda$ certaini proportion, 20, 50, or eren SO per eent., will often surfire. In my cxperimental cases only 21 per cent. lied and orex 29 per cent. recorered from the first attack, so that ther were usecl for further experinent, and this mithout any attempt at melication or trentment furlier than whole. some food, cleandiness, and disinfection of the pens. I an ronvincul that a still better showing conld be mate in the majorit. of cases is the sick animals were sulmitted to careful and intellinent medical treatment.

Were the question of the preservation of the in feeted pig the only one or the main one to be consiclered, I wonld strongly arivo ate menicinal treatment. Int the guestion is rather one of comparison between this one sick lrog or herr and all the healthy swine in the same toma, comnty, State, or nation. This is not a question of morality, lunt a problem in political ecomomy, and when realt with by a goremment must be cle. cided on the gromul of what is best for the whole nation. If, then, the prescrvation and treatment of a single sick log means the incessant and incalculable increase in its boly aud secretions of a poison wluch is in the last degree deacl]y to other logs; if this poison ean be dried and preserved for a lengtli cf time, and carried meanwhile to a ristance of a thousand miles, and if not liogs alone but sheep, guinea-pigs, and even wild animals like rabbits and mice, can contract the disease and convey the poison to any distance in their bodies, then the best interests of the nation demand that the sick animal shall not be preserved, but promptly sacrificed to the good of the community.

'This point is so important that I may be pormitted to direll on it a little further. Some of my experimentul pigs were snecessfully inocizlated with qnills tilat liad been diplech in the morloid exudations of sick pigs in Yow Jersey and North Carolina, and harl been dried and preservel for from one to six days in this eondition. Ifere re had the thinnest possible film, such as might have adlered to the clotling of unan, the hair of an alimal, the feet or bill of a birk, the less or prehensile orrans of an inscet, to a dried leaf, or eren to a floating thistledomm, and might have becu thus carrici in a creat many different ways to infect distant herds. What ras actually convesed scme hundred miles on a dried ruill, and preserved its vinulence for sir days in this condition, can be as certainly preserved on any other dry object, and if bronerlit by 
accident in contact with a raw surface, will produce disease as surely as rid the quills in my inoculations. My own obserrations in this respect hare been more than corroborated by one of Professor Axe, of the Roral Teterinary College, Londion. He produced the disease by inoculating from irory points on which the entaneons exulation had been dried up for the long period of trenty-six days.

That the poison can be preserved eren in the liquid state mhen the germs of putrefaction are excluded, may be inferred from my suecessful inoculations with blood that had been liept in an isolation apparatus, at the ordinary body temperature, for the period of eleren days. As directly to the point is the cultiration of the poison in aqueous humor for seren days, by Klein, and its subsequent successful inoculation. This experiment of Klein is, hotrever, possessed of rastly greater importance, inasmuch as by it it ras first shomn that the poison can be eultirated and indefinitely increaserl out of the animal body as mell as in it. On seren successive days he inoculated seren successive portions of aqneous humor with as much of the inoculated liquid of the previous day as would arlhere to the point of a needle, the first having been similarly inoculated from the sick pig. From the cultirations of the fifth and serenth days, respectively, a drop was taken and two pigs were successfully inoculated therewith. In the cultivation of each day were found myriads of bacillus, but no other organization, and thus Klein was the first to show that the bacillus is the probable cause of the disease. Had there been no repro. duction and increase of the poison, it must hare been rendered inconceirably dilute, an approximate ratio of the poison added to the first day's cultiration, and that added to the last, being about as 1 is to $1,000,000,000,000,000,000$. That such a dilution conld be operatire seems utterly incredible, and as modern research shows that virulence resides not in simple liquids, but in the solid particles contained in them, and as the only definite organisms in the cultiration liquids were the bacilli, it seems ineritable that these are the actire cause of the cliscase. But if so, they cannot only be preserved; but increased in suitable fluids outside the animal body. It is true they disappear when the activo organisms of ordinary putrefaction (bacterium termo) become numerous, but they are not necessarily destroyed. From what we linow of the life of these mycrophrtes it is to be feared that so far as the bacillus lias ad. ranced to the production of spores, it will be preserved in a dormant state, like so many dried seeds, until conditions farorable to its gromth shall transpire. On the other hand it may be recollected that my attempts to propagate the disease from a putrefying bowrel failed, so that further observation is wanted before we can say that the bacillus or its spores are preserved in a septic liquid. Howerer that may be, the possibility of its increase in a non-septic normal fluid is an additional ar'gument for the total destruction of all diseased pigs and morbid prodnets.

In the ease of high-priced pigs, where expense is no object, and whero the patients ean be kept in thoronghly disinfected pens, under the most rigid seclusion, treatment may sometimes be commendable; but in tho case of common herds, and as rierred from the standpoint of the greatest good to the greatest number, there can be no question at all that the treatment of the sick is the most ruinous police, while the most stringent measures for the extinction of the poison is the only economical one. The unirersal experience of veterinarians supports this conclusion, and nearly erery European govermment has now reached the same conviction, 'and absolntely prevent the preserration and treatment of the victims of thoso fatal contagions diseases which most threaten their flocks and herds. 
MELSURES TO ARREST $\Lambda$ ND EXTIRPATE THE DISEASE.

I'o put a stop to the ravages of the fever concerted measures are, essential. One farmer may casily cradicate it from his own herds; but so long as his neighbors contimue to harbor it his stock is daily subjected to the danger of renewed infection. His personal sacrifice is all in vain, so long as he is liable to have his herds infected by a cluance visitor, a wandering animal or bird, or even a favorable wind. What is true of the indivichul farmer is equally true of the township, county, and State. One may crush out the clisease at a cost of immense effort and outlay only to find it reappearing the next day, as the result of carelessness on the part of an adjoining or even distant State or district. In our Easteru States this plaguo is almost invariably the result of importation, and though from the lack of pigs it never gains a wide prevalence, it sufficiently illustrates how the disease is propagated in the West, where its more extended ravages are liable to blind the eyes to the fact. To securo a complete or even partial immunity active measures must be taken over the entire land, and while this cannot be done by States, districts, counties, or eren towns, separately, it will be rendered the more effectual in the precise ratio that it is inaugurated as a uniform system over the entire country, and under one central controlling authority.

Without entering at this time into all the details of the necessary restrictive measures, the following may be especially mentioned: 1st. The appointment of a local authority and inspector to carry out the measures for the suppression of the disease. 2d. The injunction on all having the ownership or care of hogs, and upon all who may be called upon to advise concerming the same, or to treat them, to make known to such local authority all cases of real or suspected hog fever, under a penalty for erery neglect of such injunction. $3 \mathrm{~d}$. The obligation of the local authority, under advice of a competent veterinary inspector, to see to the destruction of all pigs suffering from the plague, their deep burial in a secluded place, and the thorough disinfection of the premises, utensils, and persons. 4th. The thorough seclusion of all domestic animals that have been in contact with the sick pigs, and in the case of sheep aud rabbits the destruction of the sick when this shall appear necessary. 5th. Unless, where all the pigs in the infected herd have been destroyed, the remainder should bo placed on a register and examined daily by the inspector, so that the sick may be taken ont and slaughtered on the appearance of the first signs of illness. 6th. Sheep and rabbits that have been in contact with the sick herd should also be registered, and any removal of such should be prohibited until one month after the last sick animal shall have been disposed of. 7th. All animals and birds, wild and tame, and all persons except those employed in the work, should bo most carefully excluded from infected premises until these have been disinfected and can be considered safe. Sth. The losses sustained by the necessary slaughter of hogs should be made good to the owner to the extent of not more than two-thirds of the real value as assessed by competent and disinterested parties. 9th. Such reimburse. ment should be forfeited when an owner fails to notify the proper authorities of the existence of the disease, or to assist in carrying out the meastures necessary for its supprossion. 10th. A register should be lrawn up of all pigs present on tarms within a given area around the infecterl herd-say, one mile-and no romoral of such animals should be allorred until the disease has becn definitcly suppressed, unless such removal is made by special license granted by the local authority after they hare assured themselves by the examination of an expert that the 
amimals to be moverl are somed and ont of a lealthy herd. 11th. Tail-

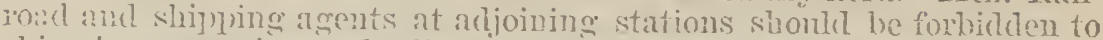
ship pigs, excepting muter license of the local anthority, unt il the plagno

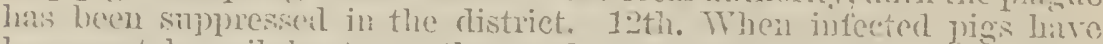
been went by rail, bont, or other mode of conrerane, measures shonid be taken to insure 1he thoungh disinfection of such ears ol coureyances, as well as the banks, clockin, yarels, and other places in or on which the diseased animals may have been turued.

Other measures monld be essential in particruar localities. Thus in the many places wliere the hogs are turned ont as street seavengers anel meet fiom all clifexent localities, such liberty should be pint a stop to whenerer the chisense appears in the distriet, and all hogs foumd at lare should he rendered liable to sumary scizmes and destruction.

The great difficult: of pntting in mactice the means necessary to the extirpation of the disease will be found to consist in the lack of reterinary experts. No one but the accomplished reteriuarian can be relied on to distinguish between the different communicainle and destructire diseases of swiue, and to adopt the measures necessary to their suppression in the different cases. In illnstration Ineed only recall the mumerous reports in which what is supposed to be hog cliolera has been fomd to devend on lung woms, on any one of the four elifferent line?s of intestinal ron!nd

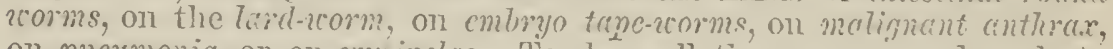
on pnermonia, or on crysipclas. To class all these as one and applis to all the same suppressire measures romid be a sinplle waste of the pmblic moner, but to distinguish them and apply the proper antilote to cach orer a micle extent of territors vould demand a umber of experts whom it wontel be ro casy matter to find. This state of thim $\mathrm{ms}$ is the natural result of a persistent neglect of reterinary sanitary sciences amd medicine as a factor in the national rell-being, aurl must for a time prove a henry ineubus oun all concerteù efforts to restrict and stamy ont our animal plagues. It will retard suceess mnder the best deriser sjstem, and will sometimes lead to losses that might have been saverl, yet if an eameat and prolongeri efiort is made the olstacle slionld not be au insuperable one, and the United States shoukl he purged not of this plagne onlr. but of all those animal pestilenees whicl at present threaten our fiture well-being.

Respectfully submitted.

ITIIACA, N. Y., Jamary 2, $18 \% 9$. 



\section{SWINHFHER?}

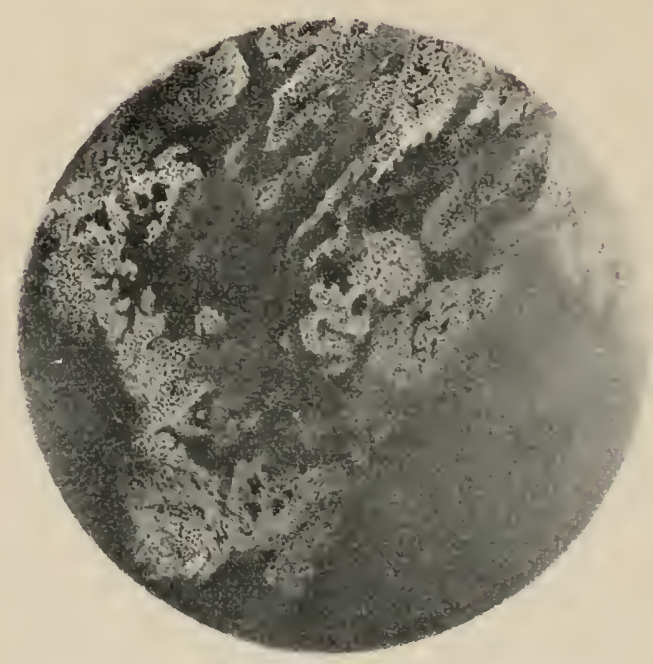

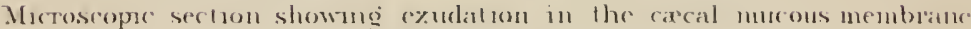
bereath all wher

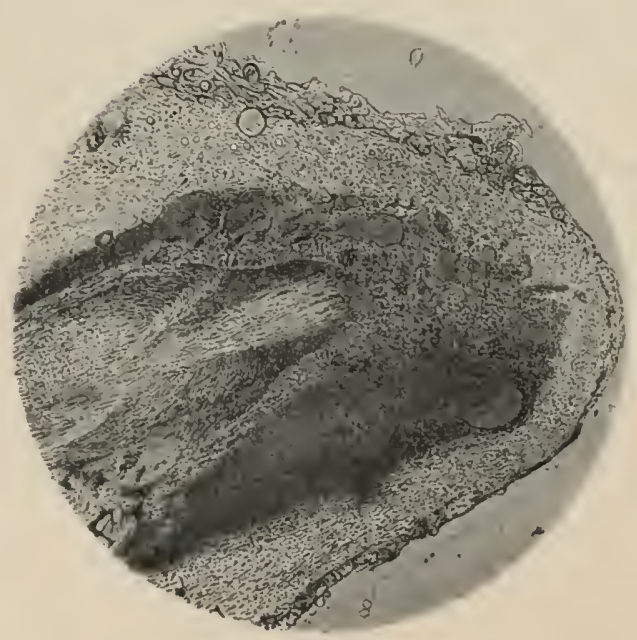

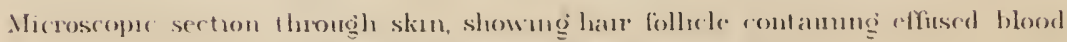

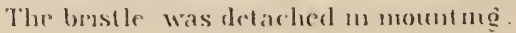


, 


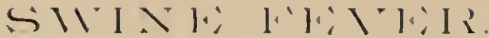

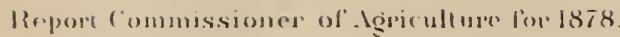

I'al, XI.

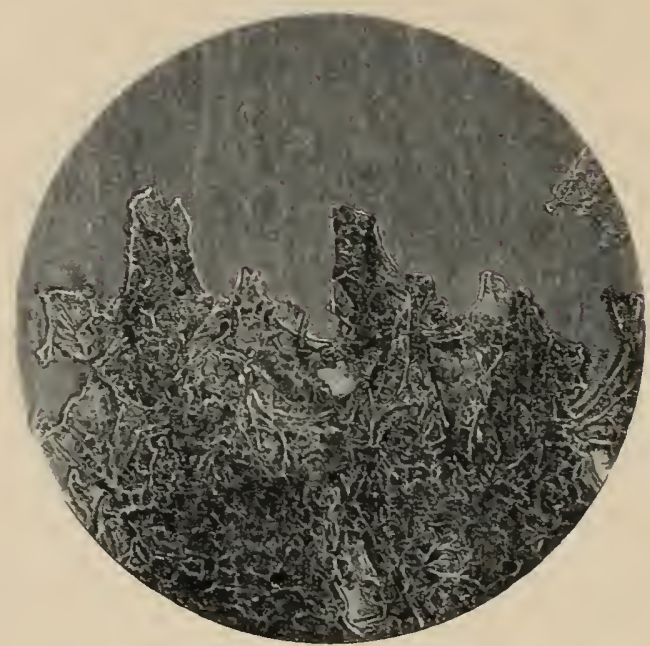

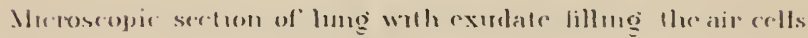
and thirlicmug the alvoblan walls

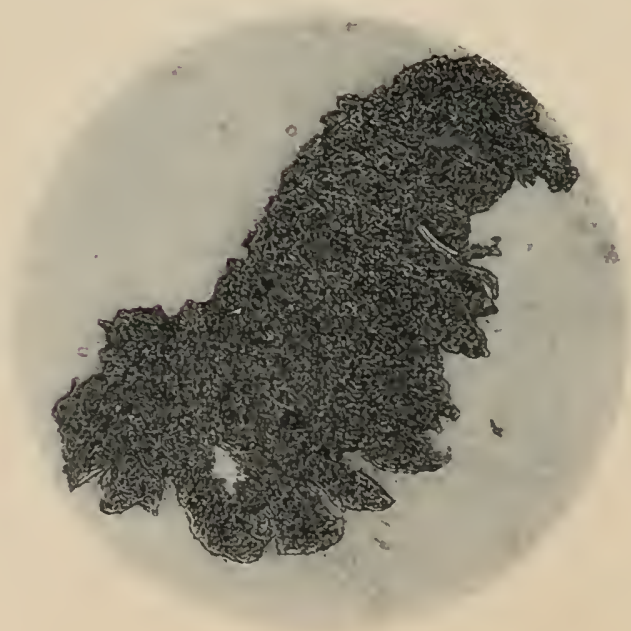

Meruscopue sectıon of congested gut, showing villi with exiess of gmamlarmafter, slamed in hamatoxylon Delached romd cells. 



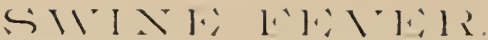

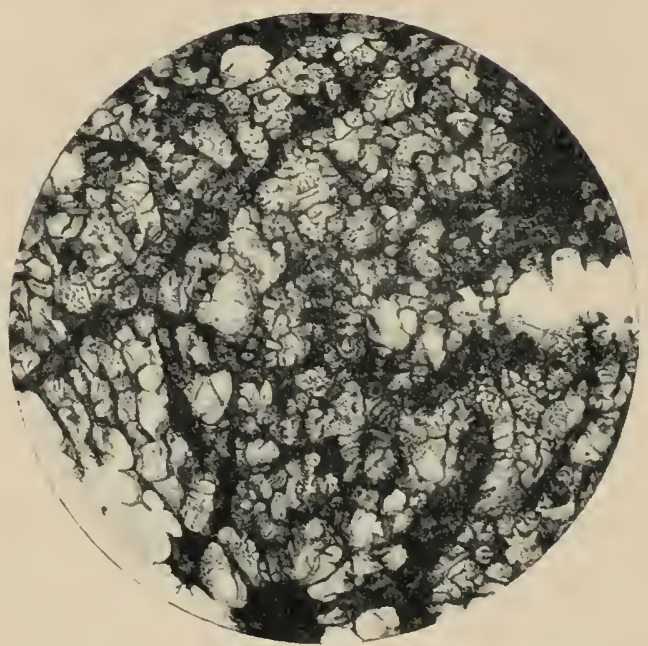

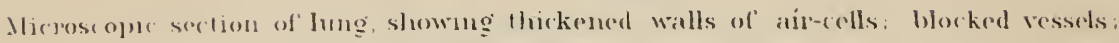
exudale into cell-walls. and a few of the rells

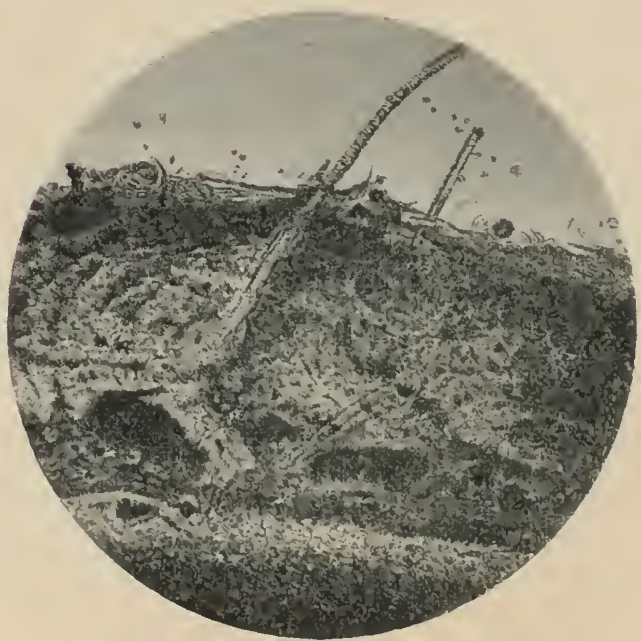

Vicroseofue section from car, showng rattilage and skm with brokem surface, and renst-entangling bristles. 


\section{APPENDIX.}

RECORn of Dr. Law's Experimexts.-.io. 1.

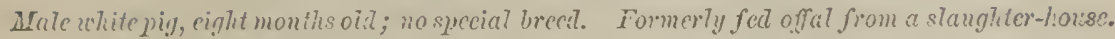

\begin{tabular}{|c|c|c|c|}
\hline - Date. & Hour. & $\begin{array}{l}\text { Temperatire } \\
\text { of botly. }\end{array}$ & IRemartis. \\
\hline $\begin{array}{lr}\text { Sept. } & 30 \\
\text { Oct. } & 1 \\
& 1 \\
& 2 \\
& 3 \\
& 5 \\
& \\
& 6 \\
7 \\
8 \\
9 \\
10 \\
11 \\
12\end{array}$ & 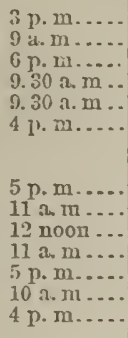 & $\begin{array}{l}104.75 \\
103.25 \\
103.5 \\
102.5 \\
103 \\
102.75 \\
\\
103.25 \\
100 \\
101.5 \\
103.5 \\
101.25 \\
102 \\
99\end{array}$ & 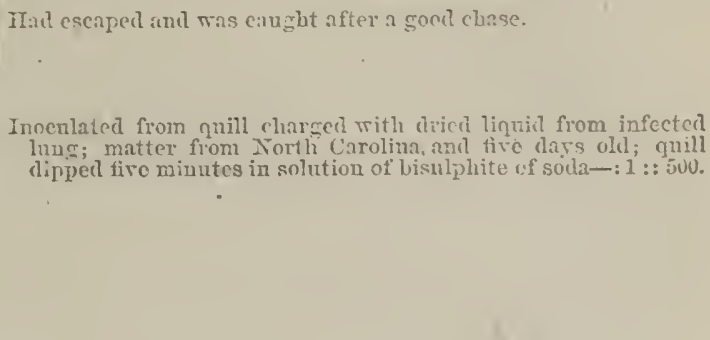 \\
\hline
\end{tabular}

Was fornd spramling npon its belly mable to stant ; lreathing slor, deen, panting, and labored; snout hot, dry, and of a leaden color: ears and feet rarm, bluish, but mithout any rash, cruption, blotches, or extrayasations. Blood appears at tho arms. An hour later this pig died.

Post-mortem cxamination thirty-six hours after death.-Torly in excellent preserration; condition low; skin scnrfy along the back; snout livid blne, but withont petechix.

Digestive organs: Tongue has papillo, at its base redelened; a similar blush appears on the fauces and plarynx.

Stomach and borcls normal.

Liver firm and sonnd. Kïneys and bladder sonnd.

Crethra (intrapelvic) decply congested, almost black, bnt without anj obstruction.

Parasites in abdomen: A few tricocephali (whip-rorms) in the large intestines; a hydatid in the pelvio fascia.

Chest: Pleura normal ; pricardium healthr, with a small quantity of serum.

Right heart: Amricle and reutriclo filled with dark clotted blood.

Left heart : Anricle contains a small clot of black blood ; rentricle empty.

Lungs: $A$ great part of these is in a condition of carnification or infarction. This is confined to definite lobules or mroups of lobules, the collapsed, red, fleshy aspect of which is in marked contrast with tho full form and pale pinkish-ritito color of the remainder.

The air passages (bronchi and bronchia) contain small portions of tho contents of the. stomach whicli havo been vomited mp and dramn into tho lungs in the last riolent efforts to breathe. Tho air-passages leading to the collapsed lobules contain largo quantitics of a watery mucus and pellets of worms (strongylus clongatus) which completely block them. "The obstructed terminal bronchia aro dilnted, and have their mucous membrane variously redelened and congested. Around theso bronchia tho connective tissue is strongly congested and filled with cxtrarasated lrmplu, br which the vessels passing to and from the lobuletts are compressed and obstructed. In view of this statc of things, the explanation of the process of infarction in tho louvles is eass ; the irritation and congestion causec br tho worms in tho infested air-tubes extended to the sumounding connective tissue and the sheaths of tho accompanying blood-ressels; the exudation of lymply compressed and obstructed tho ressels inducing stagnation, congestion, and cxudation in the whole substance of the lobnle of lobuletts to which these led. Hence the inrariable connection of the infareted lobnle, and the blocked, cougested, and morm-infested tulue that led to it. 
Expentument No. 2.

White male pig, ciglit ucclis old, smallest of litter. Formerly fed offal at a slaughter-house.

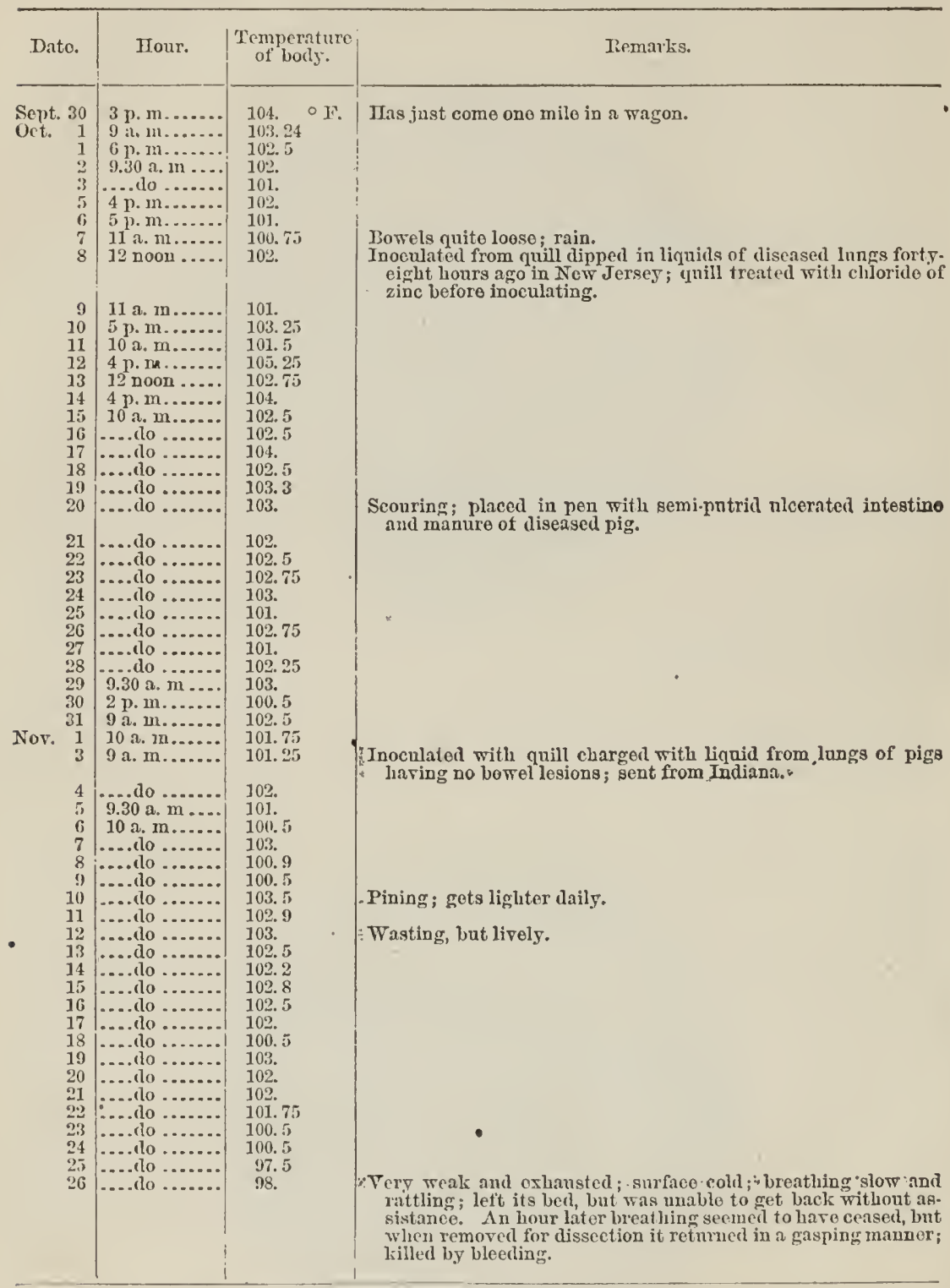

Post-mortem excmination.-Shin: Pale, bloodless, withered, and inclastic,. covererl almost universally with black concretions or mhealthy-looking and thick, dirty, white scurf. Snont beneath the nostrils blne, lut not ecchrmosed.

Digestire organs: 'l'ongme healthy; beneath the right tonsil is a consiclerable collection of dirty, grayisli-yellow, cheesy matter, consisting of pns-cells and much gramular matter.

stomach: Moderately full, contents futid and slightly acid, fimly adherent to the mucons membr:me, and bringing oft" part of the epitholinn when detaclied. The mn- 
cous memirane on tho great curvaturo is congested, and bears several patehes of deep, blood-red extravasation.

Small intestines: Red and congested throughout. The contents are small in quantity and dry, being collected in diry masses at considerable intervals, and partly frothy. The duolewum and first half of the jejunum contains twenty-two ascaricles (A. Suille), one cxtending to 11 iuches in length. At different points tho bowel is eompletely blocked by the rolls of theso worms.

Large intestine: Ilio-cxeal valve normal. Cacum and colon, liko the small intestine, congested throughont nearly its whole extent, with patches of extravasation and crosion at intervals, but none of tho characteristic sloughs nor ulcers, with thick indurated hase. 'The ceeum and mpper portion of the colon eontains thirteen whip-rwolms (trieocephatus crenatus), their heads tirmly imbedded in the mucous membrane, and requiring considerable force to withdraw them.

Licc: : Small and of healthy aspect. Gall-bladder full of a dark-green, tenacions bilc. Spleen small, black, and somewhat softt. Pancreas normal. Mesenterie slands apparently littlo altered. Some rrere slightly congested.

hidneys: Normal. In tho prepuse is a slight, fetid, concretion-liko falso membrane.

On the omentum are two hyltatids.

Iiespiratory oryans: The wholo interior of the larynx is of a dull brownish-red, cxcepting where covered by an extensive false membrane. Along the upper wall of tho windpipe, where the cuts of the cartilages orerlap, is a falso membrano about a third of an inch in breadth, and extending from the larynx as far as the lungs. This has a firm consistency, and a dirty yellowish-white color, tinged with green, and stands ont promixently from the adjacent mucous membrane by an abrupt margin on each side. Under the inicroscopo it is seen to consist of large quantities of granular matter, granulo cells, epithelial and pus eorpuscles, blood globules, and numerous crystals. It also contains egrs of the lung-worm beneath this morbid product.

Lungs: Whole anterior lobe of the right lung carnified, of a deep-red color, and sinks in water. The special bronchus for this lobe, and its divisions, are filled with a tenacious mucus, bnt contain no worms. Several lobulettes in the anterior lobo of the left Iung are in a similar condition. On the posterior border of each lung several lobulettes aro consolidated, being of a dirty-gray color and semi-transparent. They present, in short, the appearance of pulmonary odema. The bronchia leading to these lobulettes are completely filled with a thick mucus and numerous worms (strongylus elongatus) and their eggs.

The bronchial lymphatic glands appear normal.

Blood: The blood is very black, coagulates slowly but firmly, and withont buffy coat, and has its globules full-sized and rounded. Tho right side of the heart beat, when touched, for nearly five hours after the death of the animal, and of its remoral frow the body.

\section{ExperiMLexT No. 3.}

White pig, eight wecks old; no special breed. Has been fcd on raw offal at a slaughter-house.

\begin{tabular}{|c|c|c|c|}
\hline Date. & Hour. & $\left|\begin{array}{c}\text { Temperature } \\
\text { of body. }\end{array}\right|$ & Remarks. \\
\hline $\begin{array}{r}6 \\
7 \\
8 \\
9 \\
10 \\
11 \\
12 \\
13 \\
14 \\
15 \\
16 \\
17 \\
18 \\
12 \\
20 \\
\\
21 \\
22 \\
23\end{array}$ & 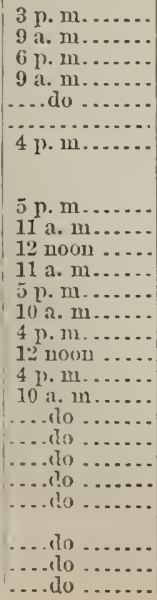 & \begin{tabular}{|l}
$103.50 \mathrm{~T}$. \\
103 \\
102.5 \\
101.5 \\
101 \\
$\ldots \ldots 2.3$ \\
102.3 \\
\\
103 \\
100.75 \\
102.5 \\
102.5 \\
103 \\
103 \\
101 \\
103 \\
104.25 \\
102.25 \\
101.5 \\
103.25 \\
103 \\
102.75 \\
103 \\
100 \\
101.5 \\
102.25
\end{tabular} & $\begin{array}{l}\text { No observations. } \\
\text { Blood taken from saphena rein for cultiration experiment; then } \\
\text { jnoculated with guill-point charged with liquid from diseased } \\
\text { lung, five days old, from Nortl Carolina. } \\
\text { Slightly costire. } \\
\text { Bowels natural. }\end{array}$ \\
\hline
\end{tabular}


Expermext 2io. 3-Continued.

\begin{tabular}{|c|c|c|c|}
\hline Dale. & Hour. & $\begin{array}{c}\text { To mperature } \\
\text { of boty. }\end{array}$ & liemarks. \\
\hline 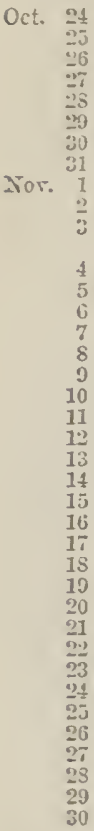 & 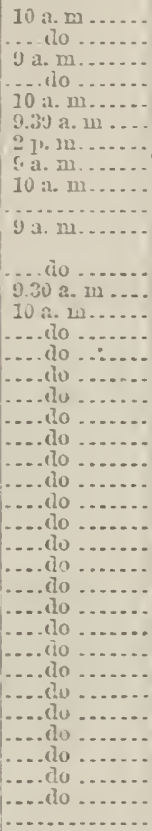 & 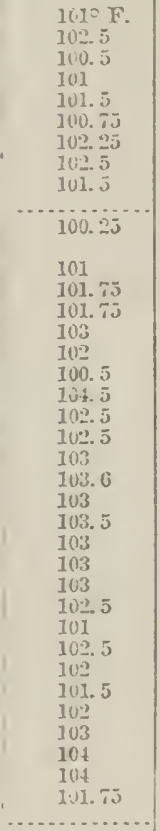 & 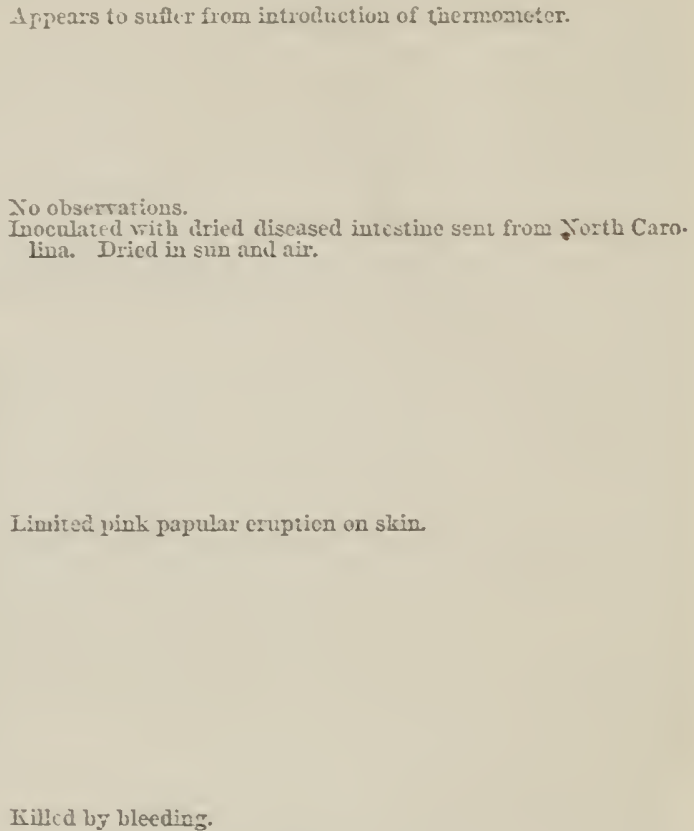 \\
\hline
\end{tabular}

Post-moricm cominalion,-Slin: The seat of some papular cruption aul black incrustatious, but without any patches or purple.

Digestive oryans: Mourll and throat soume.

Stomach: Is mottled, of a dark brown along the great curratire, but without any extrarasations or crosions.

Small intestins: Has sereral limiterl patehes of slight congestion, but no erosions.

It consains tweaty eiscarides.

Large intetincs: Shows some slinht cougestions. but no slongh, erosion, or ulecr. A dozen whip-rorw: are present in the cecum and colon.

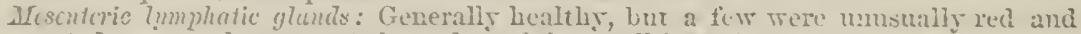
congesterl near to the congested patches of the small intestines.

Iydatils: The alulonicin contains eirht of these.

Lirer : Firm and of wearly a naturil appearance.

splecer and pancreas: Sivuud.

Iidncys: Have corricil substance blanched, bnt are frm and amparentls sounc.

Lungx: Have some lobnleties soliclified red, impervious to air, and sinling in water-

In the main terminal bronehia towards the posterior part of tho lungs are ummerous worm: (strongylles clengetms), though not always in the air-tubes leacing to the consoliclated lowilettes.

Heart: Somud.

Irain: Souml. 
Experment Niu. 1.

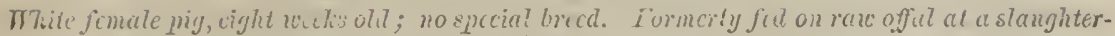
hoilse.

\begin{tabular}{|c|c|c|c|}
\hline Date. & Hour. & $\begin{array}{c}\text { Temperature } \\
\text { of huty. }\end{array}$ & Iicmanks. \\
\hline $\begin{array}{lr}\text { Sept. } 30 \\
\text { Uct. } & 1 \\
1 \\
2 \\
3 \\
5 \\
6 \\
7 \\
8 \\
9 \\
9 \\
10 \\
11 \\
12 \\
13 \\
14 \\
15 \\
16 \\
17 \\
10 \\
19 \\
20 \\
21 \\
22 \\
23 \\
21 \\
21 \\
21 \\
25\end{array}$ & 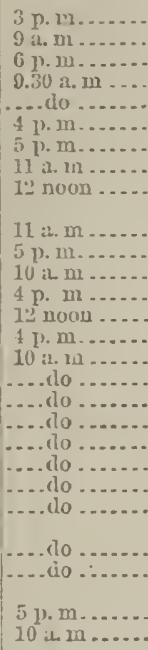 & $\begin{array}{l}103.75 \circ 5 . \\
102.75 \\
104 \\
102 . \\
100.5 \\
102.5 \\
101 \\
103 \\
101.5 \\
102.5 \\
104 \\
102.75 \\
104.5 \\
103 \\
105.75 \\
105 \\
104.5 \\
107 \\
106 \\
104.25 \\
10.5 \\
105.25 \\
164 \\
105.25 \\
105.75 \\
105 \\
106\end{array}$ & $\begin{array}{l}\text { Scoaring. Cold north gale, rain and frost. } \\
\text { Do. } \\
\text { St:in corercel witle purplo and biacls spots with red arcola Tho } \\
\text { criticlo or black spots is dead and ensily srparated. } \\
\text { Extensive purplo blotclies on ear's, fanlss, and abdomen, and a } \\
\text { pink rash ono to two lines in diameter; appetito poor. } \\
\text { Killed to-day by blęcling. }\end{array}$ \\
\hline
\end{tabular}

Post-mortem exumination. - Has becn purging; feces fetid and bright jellow.

Skin : Nearly covered with black spots of from one to two lines in diamcter, and eridently formerl by slonglis or small uccrotic patclies of enticle, infiltrated with blood and dricd $u_{\perp}$. The median line of tho belly between the rows of teats is almost devoid of theso sin: 4 .

A purplo rash in spots areraging ono line across exists in dirterent purts of the body, but is most abmudant on suour, cars, buttocks, root of 1 ail, and limbs, especially on the lower parts and imer sides. At certain points, as on the pendaut half of the cars, on the hocks, in tho region of tho arms, and ou jart of tho snout, there is a uniform

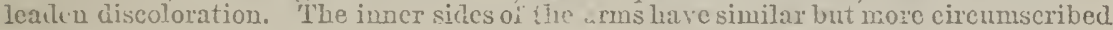
patelies.

Digestire organs: A deep pnrplo blush extcimi along the line of papillo on the right bortler of the tongue. Sinilar spots exist in tlu pesterior nares. Salivary glands aro pale and nomal. The gittural lrapiplatio glanils have spots of congrestion on their surfice, but not exteuding into their interior.

dodomen: No effision. Thec liydulids are fond attached respectively to the posterior surfare of the stomach. to the back of the liver, amel to the mesocoloa.

Stomacin: Full of undigested food, yellow at pylorus. No marked congestion nor softening. No parasites.

Small intestine: Duodenmm withont extra vascularity: its cpithelium gras, pigmented, and easily detached. Jejumm and ilinu had ciremuscribed spots of congestiou ouc-half incli in cliameter on au avurage, and in one case slightiy eroded.

Large intestine: Cocura presents three nlecers, cach one-fonth inch incliameter, having a circular elevated inass of dirtr-white deposit, apparently non-vascular, and a very slightly reddened hase. The matter ou tho siufice of the vilcer consisted of cells, rouml, angular, and of othe: forms, mnel granular matter and inyritds of romed and linear moving vacteria. Nume ot these ulecrs a plyear to be sitnited on the solitary glauks. The sane remark apjplirs to the congestious and erosions of the sunall intestiues. ('olon minciectum liatural.

I'arasitcs: The small intestiues contain tlyee aservides (1. Suilla). 'The colon contains a ronum whip-worm (irimerpholus crenctu!s). The coats of the intestines at tho points of congestion and clit where were earefully exandined for larnsites, but withent

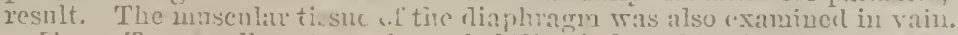

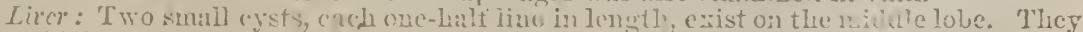
hat thick iibrous walls and liquit coutents in whel the microscope eletecteil cell forms. 
Tho general substance of tho liver is tirm and natural, a few acini only isolated aud in grouns, being congested. The color preclominates in the center of tho acinns. The liver cells aro granular.

Gall-bladder: Is finl, but not to excess, with bright jellow bile. Tho bilc-rlucts in tho liver aro also full.

face.

Pancreas : Normal, pink. Pancreatie lymphatic gland blotehed; deep red on the sur-

Litineys : Normal, unless it be in extra pallor of the cortical substance.

Chest: Heart, right auricio and rentriclo contain clots showing a buffy coat. Leit auricle and rentricle empty. A few petechia exist on tho septum rentriculorum.

Lungs: Petechia exist on tho pleura. A number of lobnlettes aro soliclified or infarcted, and of a deep red flesh color. The bronchia leading to such lobulettes aro blocked by numerous worms (strongylus elongatus) and their eggs, embedided in an abunclant tenacions transparent mucus. In somo cases the bronchia appear clilaterl, the mucous membrano conjested, and the epithelium degenerating, round aud ovid granular cells predominating in its structure. There is no visible stasis (coagulation) of blood in the capillaries of the bronchia. The worms aro confined to tho smaller bronehia, and aro only exceptionally found in the otherwise sound portions of the lungs.

Blood: That from the gluteal rein contains no bacteria nor free hematine so far as can bo detected. Red globules are crenated and shrunken.

EXPERIMENT No. 5.

Female white pig, cight weeks old, no special breed. Formerly kept on raw offal at a slanghterhouse.

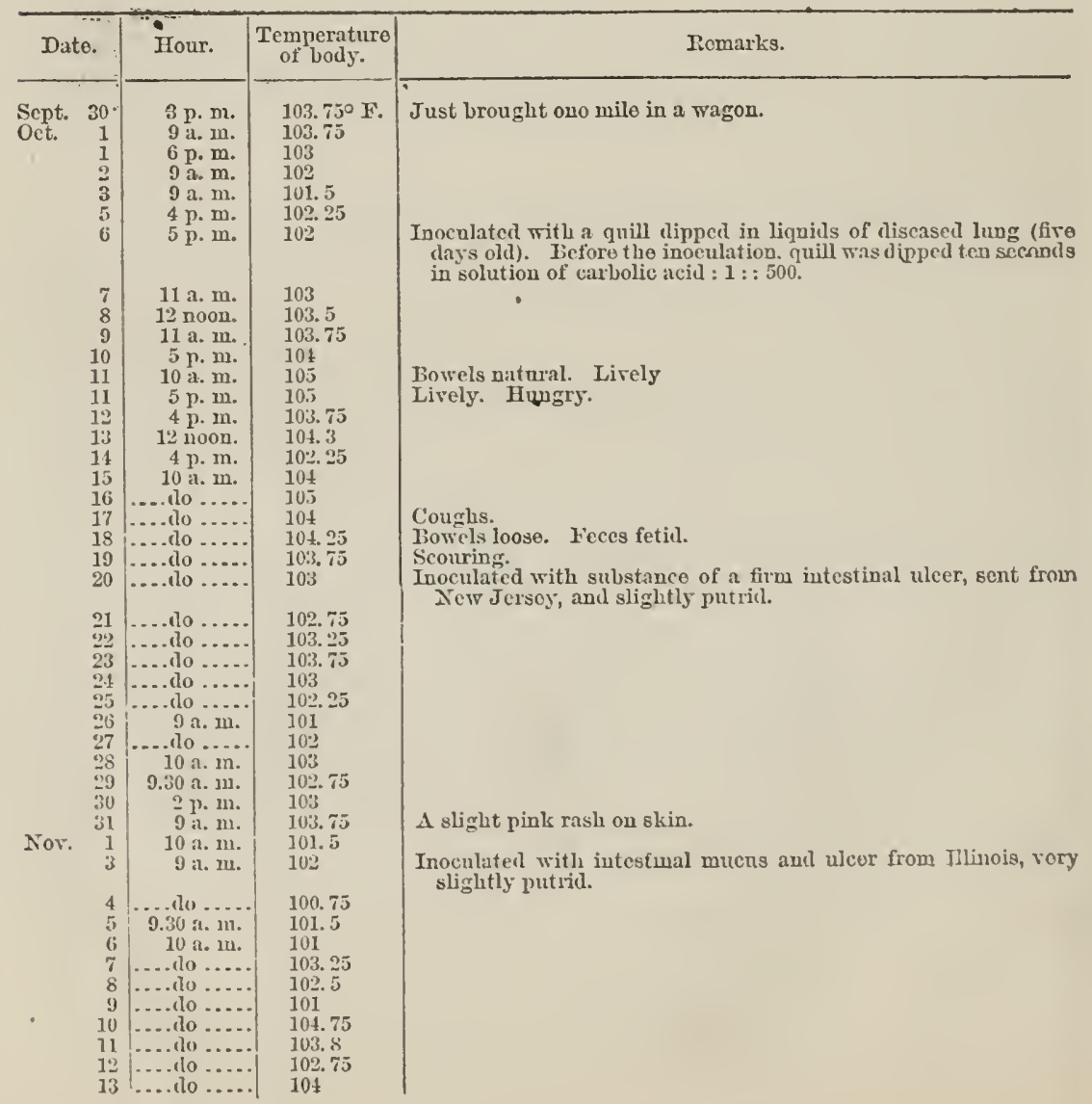


Exinnmext No. 5-Continued.

\begin{tabular}{|c|c|c|c|c|}
\hline \multicolumn{2}{|c|}{ Date. } & Hour. & $\begin{array}{c}\text { Temperature } \\
\text { of boily. }\end{array}$ & Ticmarks. \\
\hline Nov. & $\begin{array}{l}14 \\
15 \\
16 \\
17 \\
18 \\
19 \\
20 \\
21 \\
22 \\
23 \\
24 \\
25 \\
25 \\
26 \\
27 \\
28 \\
29 \\
29 \\
30 \\
1 \\
2 \\
3 \\
3 \\
:\end{array}$ & 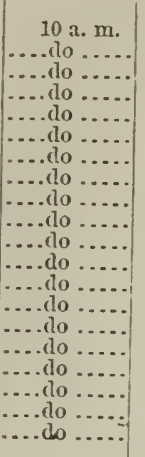 & \begin{tabular}{|l|}
$101 \quad c F . ~$ \\
103.75 \\
103.8 \\
104 \\
104 \\
104 \\
103.75 \\
103.2 \\
103 \\
102.75 \\
103.2 \\
103.8 \\
104 \\
103.5 \\
104 \\
102 \\
103.2 \\
102 \\
103.2 \\
102.5
\end{tabular} & $\begin{array}{l}\text { Shedding black scales, learing red conical papules. } \\
\text { A bundant pink papular eruption. efcessiro between the thighs. }\end{array}$ \\
\hline
\end{tabular}

Post-mortem examination. - Slin : Presents many papules or slightly pink conical elovations, just raised enough to be felt by tho finger; also black concrotions like pinheads and up to twice or thrice that size. It is, howerer, much cleaner than it was a Digestive organs: Nouth normal, likemise the pharyux, larynx, and adjacent lym-
phatic glands.

Stomack: Has its mucons mombrane dark brown along the great currature, but rith out any extravasation, ulcer, or recent lesion.

Small intestines: Have a few spots of congestion, but these are very circumscribed. They contain trelve ascarides.

Large intestine: With fow and slight patches of congestion. No enlargement of Pejer's patehes, nor solitary glands; no erosions. The cæcum contains six whip-
worms.

Lymphatic glands of the mesentery are mostly gray on the ontside from pigmentary deposit, but normal in their interior. The pigmentation is evidently the result of a former blood extravasation, as is so constantly seen in the carlier stages of the disease. The blood coloring matter is being transformed into black pigment, as a concomitant

Licer: Presents sereral hard fellow concretions as large as peas, also spots and patches of purple. Similar rounded jellow concretions are foumd in the mesocolon. They are covered by a reticulated membrane, and are probably the remnant of some Splcen and pancreas: Normal.

Iidncis: One contains two hydatids; excepting marked pallor of the cortical snb-
stance they are otherwise normal. stance they are otherwise normal.

Hydatids: Nine of these are found in different parts of the peritoneum.

Heart: Right side normal; contains a small clot.

Left ventricle: Has numerous patches of extravasation, of a deep claret color, situated mostly on the carnce columne and musculi papilarics. These havo their seat in

margin of the bicuspid valve is slightly thickened.

Lungs: Have a very few red consolidated lobulettes; of the remainder many are only
partially dilated, though they have nearly their normal color.

forty worms (Strongylus elongatus). Thenchium of the right lung contains from thirty to slightly collapsed, but not consolidated nor congested.

Bymphatic glands of chest almost unchanged.

A microscopic scetion from a petechia on tho heart showed, in addition to the blocked capillaries and blood extrarasations, a fino example of the curious oroid parasites
long known as Raincy's cysts. 
Expeinuext No. 6.

Male while pig, cight weeks old; no special breed; has bech hitherio fed rat offul at a slaughterhouse.

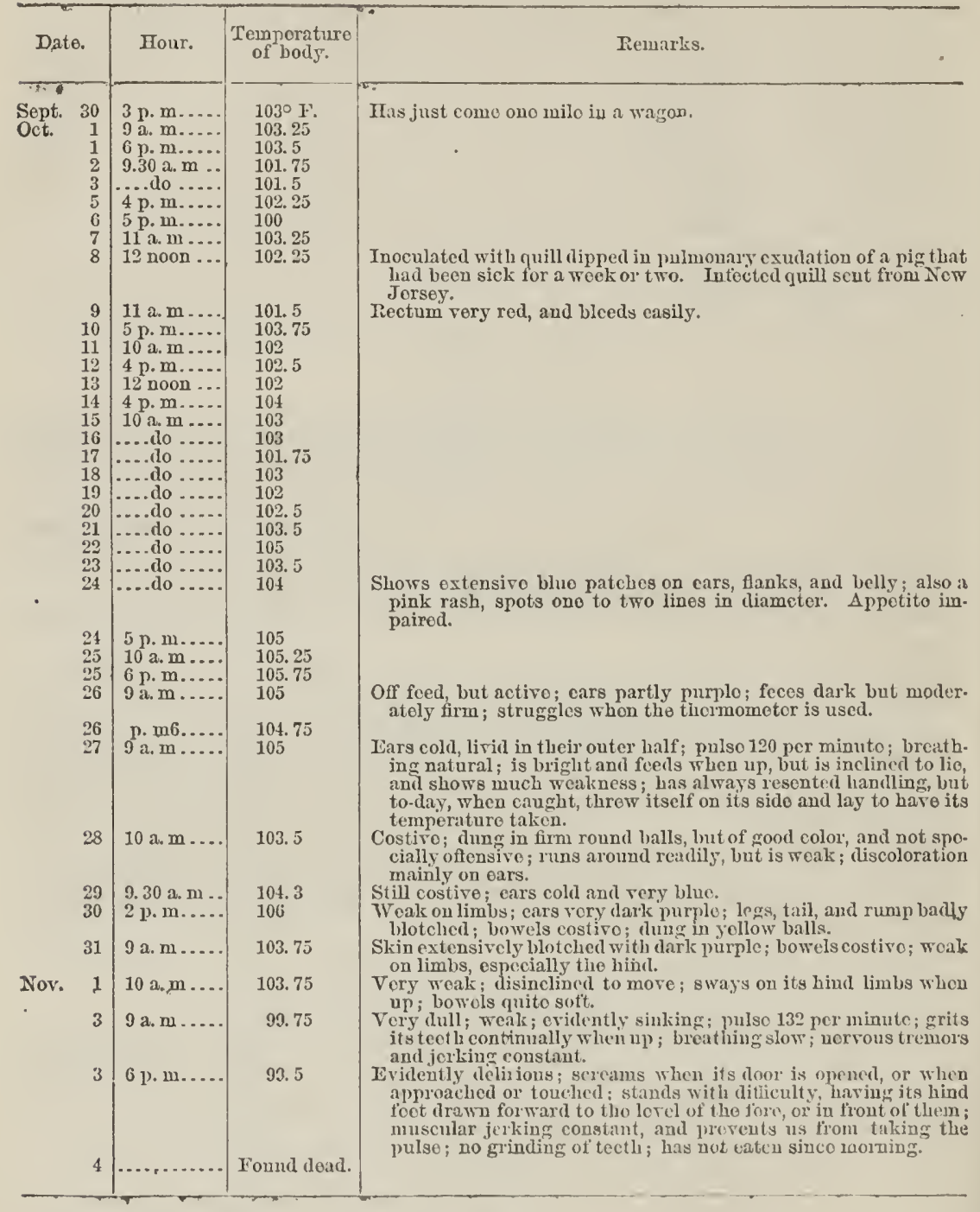

Post-mortcm excmeination, November 4.-Shin: Almost universally searlet, passing to tark purplo on ears, belly, and hocks. Inuer sides of the fore-arms and thiglis have the skin whito, but blotehed with indeliblo purplo spots one-half to one line in breadth. Many of theso spots have a dark red or purplo areola, with a firm black central seab or slough, ovidently resulting from oxtravasation into the cuticlo and superficial lasers of tho true skin. A section mado perpendicularly to the surfaco slows much rednese from blocked brancling blood-vesscls, especially aromnd tho hair follicles, and numer. ous uninuto spots of blood extravasations.

The snout is of uniform dark red, but with deeper piurple spots inefiaceablo by pressure.

Mrargin of the arms deep purple, almost black. 
Digcstive organs: Tongue, left border has an exteusivo slough near the til). Right border has a number of firm elerated points, with purple areola and yellow centers.

Sofl palcite: Lower or buecal surfaco has its follicies deeply stained with blood and surrounded with purplo areola; some follicles aro filled with a sellowish material.

Right tousil: Is swollen and has its ducts distended with a thick, tenacious, transpareut mucus, containiug great numbers of rounded granular colls.

Throat: Epiglottis bears spots of congestion ineffaccable by pressure.

Gullet: Healtly.

Stomach: Moderately full; acid. The mucous membrano on the great curvaturo presents patches of extravasation and erosion, the lutter varying from one to three lines in diameter. Contains a worm (ascaris Suillı).

Small intestine: Contains twelvo ascarides, one as much as ten and onc-eighth inches in length. The mucous membrane prescuts along its wholo course patches of recitezis, congestion, and softening, which are especially mumerous and extensire towards its lower portion.

Mio-cacal ralve: Bears a slougluing ulcer completcly encircling it.

Cacum: Contains a number of nlcurs with white sloughs, many of them confluent, aud forming bands or belts tending to encircle tho gnt, being situated on the summits of the transverse folds.

Colon: Tho anterior portion is much nleerated, somo of the ulcers being confluent and tending to form transferso bands as in the excum, while others aro mere circular masses, two or three lines in diameter, with white uccrotic center, and very little rascularity around the margin.

Rectum: Has patches of congestion and extravasation one line and upwards in breadth; in the case of one, adranced to the formation of a firm white slough and ulcer as in the crcum. Close to the anus tho entire uncous membrane is rery deeply congested and thickened by exudation and extravasation.

Parasite: Tho crecum contained one whipworm (Tricoccphalus crenatus).

Parasites in the peritoncum: In the cavity of the abiomen wero found twelve hydatids in connection with the liver, stomach, omentum, mesentery, meso-colon, and pelvic fascia. Three others were lodged in the perineum near the urethra.

Kidneys: Softened slightly and of an unusual pallor in their cortical portion.

Bladder sound. Iutrapelvic urethra deep red, almost black, from petechial extrarasation.

Crine about two ounces, turbid, strongly acid, albuminous; density, 1020; urea, 2 per cent.

Chcst: Heart has a gelatimoid material filling the auricula-ventricular grooro similar to that scen in No. -

Right hcart has a considerable bufiy clot in both auricle and rentricle. Left auricle contains a small clot, almost the entire substance of which is pale or butiy. It further contains some rery dark fluid blood.

Lungs: A few lobulettes only are infarcted or consolidated. In all cases the bronchia lcading to the consulidated lobulettes aro blocked by worms ( $S$. elongatus). The other bronchia are clear of worms excepting in the inmediate vicinity of the infarcted lobulettes. The great bulk of the lung is healtiny, and of a soft white color, slightly tinged with pink.

I'arasites: Attached to the pleura were two hydatids.

Experiulixt No. $\%$.

Fentale pig, cight weelis old, no special brecd. Formerly fod raw offal at a slaughtcr-house.

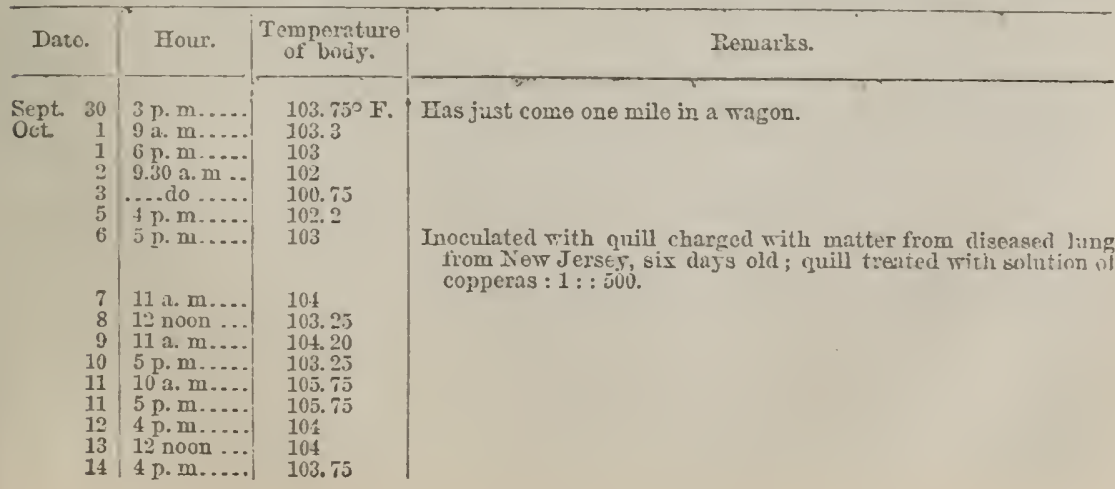


Expermixt No. 7-Continuel.

\begin{tabular}{|c|c|c|c|c|}
\hline \multicolumn{2}{|c|}{ Date. } & 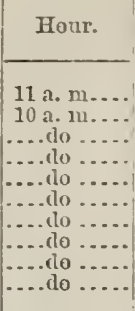 & $\begin{array}{l}\text { Temperature } \\
\text { of boly. } \\
\begin{array}{l}1070 \mathrm{~F} \\
10.5 .75\end{array}\end{array}$ & Remarks. \\
\hline Oct. & $\begin{array}{l}15 \\
16 \\
17 \\
15 \\
19 \\
20 \\
21 \\
22 \\
23 \\
24 \\
24 \\
24 \\
25 \\
25 \\
25 \\
26 \\
27\end{array}$ & 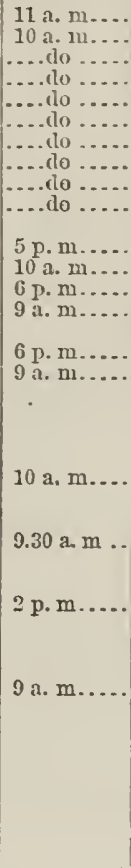 & \begin{tabular}{|l|}
$1070 \mathrm{~F}$ \\
105.75 \\
102.25 \\
104.25 \\
103.55 \\
113.75 \\
104.75 \\
104.25 \\
105.50 \\
105 \\
105.5 \\
106.5 \\
104.75 \\
103 \\
105.5 \\
107
\end{tabular} & 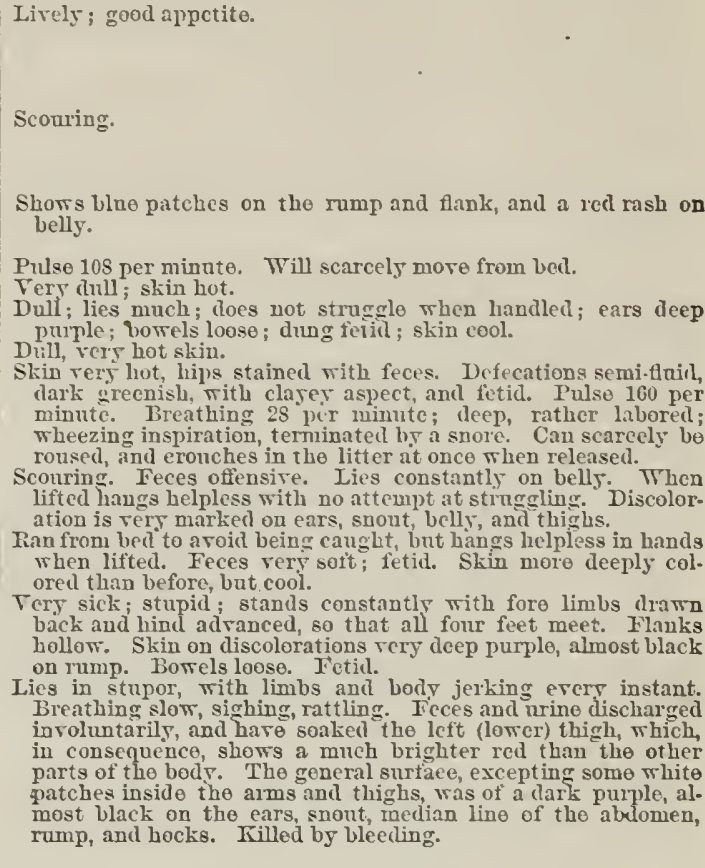 \\
\hline
\end{tabular}

Post-mortem examination.-Blood: Scanty; that from axillary roin is neutral or slightly alkaline. Red ghobules deeply crenated and shrnnken very disproportionatcly to the white globules, which aro large and rounded, but appear deficient in unmbers : $1:: 80$.

Skin: Section of the blue skin of the car shors cutis, cuticle, and bristle follicles deeply congested, most of the capillaries being blocked by coagulated blood, and microscopic extrarasations appearing at short intervals. Tho red globnles in this part are finl, roumded, and of the usual size.

Digestice organs: Tongne has a series of whito slouglus aloug its tip and right margin, rescmbling those of the intestines, being ycllowish-white, laminated, non-valscular, and with very slight congestion aud redness around them. Microscopically these sloughs are comprosed of epithelial cells with much gramular matter. In one a central red spot presents stagnation and congula in the capillaries aud microscopic extravasations. It is manifest these form in the same mamer with the slonghs in the intestines. Cireumscribed spots of the mncons membrane becone the seat of eongestion, resulting in coagulation of tho blood in tho capillaries and exudation and extravasiation alike into the epithelial and sub-cpithelial layers, leading to thickening and induration of the cleeper strata, aud cleath of the more superficial ones.

Soft palate: The buccal or lower surfice bears a similar slongh, while many. of its follicles are red, swollen, aud filled with a yellowisli-white (eheess!) matter.

Throat: The laryngeal surface of the epiglottis is congested, the recluess being inefiaceablo by pressure. The mucons membrane on the back of the right arytenoid cartilage bears a four-lobed warty looking excrescence like a small pin's head, which, under the microscope, discloses only romed gramular cells and free granules.

Abdomen, Stomach: This contains a few ounces of half-digested food. This, together with the lower portion of the gullet, is of a decp yellow hue, apparently from reckurgitated bilc. No marked cougestion of tho mucons membraue.

Small intestine: Shows circumscribed spots aud patches of congestion aud small petechia, but no erosions. 
Larye intestine: Ono slonghing nicer on the ilio-creal valve, three on the cecum, and a considerable number in the colon. The colon and rectnm also bore numerons patehes of extravasation one to two lines in diameter. The last inch of the rectum is of an mifornuly deep dark rerl. The mucosa and sub-1uucosa are aliko gorged with blood, and at one point a bleerling pile projects into the passatre.

Liver, pancrcas, and spleen are firm and seemingly healthy.

Titheys: Firm and apparently sound; cortical part rather pale.

I3latder: Son!nd; moderately tinll.

Lrine: Strongly acid; ilensity, 1026; albuminons; nrea, $3 \frac{21}{110}$ per eent.

I'urasites in abdomen: Attached to the peritonemm of stomacl, liver, and spleen aro seven Thydatids.

Chest: Right heart contains clots; left heart empty. Anriculo-ventricular furrow filled with a gelatinoid material, which, meder the microscope, appears as a loose fibrons stromia, its open meshes filled with a ienrly liomogencons matcrial, togetler with a few fat cells, granule cells, and abundant capillary net-work filled with uncoagulated blood. Tho white corpuscles aro more abmuclant in these than in the axillary vein. No parasites nor ora conld be found in this gelatinoid material.

Lungs: Mostly healthy. Isolater lobnles and at certain points a few adjacent ones are infarcted and solid, and all snch liave their bronchia filled with worms (Strongylus elongatis) and a thick mucous. The plngged bronchia aro mostly dilated, and on the mucous membrane of ono such is a white patch about a line in diameter, resembling the slonghs on the intestines, but not so thick.

ExPERMIENT No. 8.

Thide pig, cight weeks old; common brced. Formerly fed raw offal.

\begin{tabular}{|c|c|c|c|c|}
\hline Date & & Hour. & $\begin{array}{c}\text { Temperature } \\
\text { of body. }\end{array}$ & Temarks. \\
\hline Nox. & $\begin{array}{r}30 \\
1 \\
1 \\
2 \\
3 \\
4 \\
5 \\
\\
6 \\
7 \\
8 \\
9 \\
10 \\
11 \\
13 \\
13 \\
1.4 \\
15 \\
16 \\
17 \\
18 \\
19 \\
20 \\
21 \\
22 \\
23 \\
24 \\
25 \\
26 \\
27 \\
28 \\
29 \\
30 \\
31 \\
1 \\
3 \\
3 \\
4 \\
5 \\
6 \\
7 \\
8\end{array}$ & 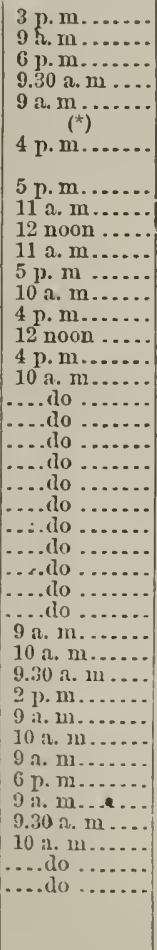 & $\begin{array}{l}104^{\circ} \mathrm{F} . \\
103 \\
103 \\
101.5 \\
101 \\
{ }^{\left({ }^{*}\right)} \\
98.75 \\
\\
99 \\
99 \\
101 \\
104.5 \\
102.75 \\
102.5 \\
103.25 \\
103 \\
104 \\
105 \\
104.25 \\
103.5 \\
101.5 \\
102.5 \\
103.75 \\
104.25 \\
103.5 \\
103.75 \\
103 \\
103 \\
103 \\
103 \\
103 \\
105.3 \\
104 \\
104.2 \\
105.75 \\
104.8 \\
104 \\
103 \\
101 \\
103.5 \\
102.75 \\
102.6\end{array}$ & $\begin{array}{l}\text { Pigs in next two pens inoculated. Was fond between doot } \\
\text { aud bars, where it could not move. } \\
\text { A gain between door and bars. } \\
\text { Costive. } \\
\text { Still rexy costive. } \\
\text { Bowels natural. } \\
\text { Feces fetid. } \\
\text { Lame in right fore limb. } \\
\text { Scours. Feces fetid. } \\
\text { Pigs in adjacent pens reinoculated. }\end{array}$ \\
\hline
\end{tabular}

\footnotetext{
* No observation.
}

Post-mortem examination.-Shin: Nearly covered with black spots from onc-third to one line in diameter, consisting of minute slonghs of epidemis, infiltrated and discolored with blood. In a number of theso the suljacent layers of true slin are congested, 
and eren the seat of microscopic extrarisations of blood, while in some eases the black necrotic cuticle is corered hy a dried crust of exuded lymph of a dark brown colvr.

The right uar is of a deep parple color, and purple patclues of rarious sizes are found inside forearms and thighs, on the hocks, and beneath the chest. In theso parple patches $f^{7}$. traic slin is the swa of extersive congestion with stagnation and coagulation of 4) blood in many of the capillaries, and numerons microscopic clots of extrarasated bi rud, while all the tissues are stainud with hrematine.

Blooi?: That from the jugular is vers dark and formo slowly a soft diffuent clot; red globules ronud and large. That fiom the carotid is crimson, and clots quickls and firmls; red globules crenate, small and shrnnken. Blood from both ressels is slightly alkaline.

Tongue: On the posterior third of the right uorder is a purpie spot one-half line in diameter, mhich cannot be effaced br pressnre. Under the microscope this shows the same congestion and microscopic extrarasations mith the spots on the skiu. The cunical papilio on the upper surface of the organ near its base have their tips of a rert deep purplish re...

Larymx: There is purple punctiform riscoloration on the posterior surface of the epiglottis, which cannot be remored br pressure.

Lymplatic glands: Those around the throat are deeply strined with blood, some only superficialls aud some thronghont. This is true also of the glands of the chest, groin, and abdomen, hut especially of the mesentery. In sereral cases the glands appear to be enlarged. Ticrosccpicali $r$, they present congested capillaries filled with coagulated blood, minute extrarasations, and a profusiou of granules and gramular cells.

Abdomen-parasites in peritoneum: Two hydatids were foumd respectirely in the omentumi and mesentery.

Stomach: Well lilied; great curratnro of a deep dark red; contents strongly acid.

Small intestine: Congested in some parts, bit with no observed extrarasation nor deep discoloration; contents not abnudant, but at interrals stained of a deep biliary yellow, and with excess of mucns thronghont.

1lio-cecal ralve: With Peyer's follicles dilated, and contents in some slightly rellomish.

Cccum: Close to the ilio-creal ralve a considerable erosion, with raised center and margin, but no excess of rascularity.

Colon: Six inclies from the cecum is a sloughing vlcer, one and one-half lines in diameter, raised abore the adjacent membrane, the superficial lasers being of a dirty whito color in the center, and non-rascular, while aronnd the margin of the nicer is no marked redness.

Liver, colon, and rectum: Severai extrarasation patches areraging one line in diameter, bright red, and evidentls quite recent.

No intestinal parasites.

Lircr: Firm; solid; considerable portions are of a deep purple hue, the deep coloration being mostly confined to the center of the acini.

Gidneys: Cortical portion soft and of a very light brown, almost parboiled, appenrance. Papillie and medullary parts of a vers deep red.

Iruscles: Contained no parasites.

Brain: Normal.

[EXPETRIMENT No. 9.

Femalc nig, eight weeñs old; bresd, Chester Thite.

\begin{tabular}{|c|c|c|c|c|}
\hline Date & & Four. & $\begin{array}{l}\text { Temperature } \\
\text { of body. }\end{array}$ & Tiemarks. \\
\hline Nior. & $\begin{array}{r}8 \\
9 \\
10 \\
11 \\
12 \\
13 \\
14 \\
15 \\
16 \\
17 \\
18 \\
19 \\
20 \\
21\end{array}$ & 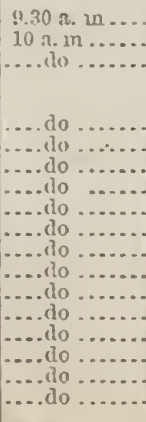 & $\begin{array}{l}103.750 \text {. } \\
103.75 \\
103.75 \\
100.75 \\
101 \\
105 \\
105 \\
105 \\
104 \\
103.8 \\
104.6 \\
104.75 \\
104 \\
105 \\
105 \\
105 \\
100\end{array}$ & 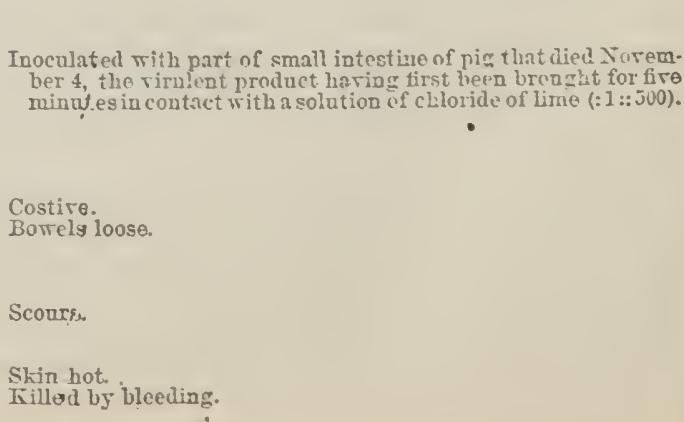 \\
\hline
\end{tabular}


Post-mortem examination, November 21, 11 a. m.-Bory in noon condition.

Shin: Almost deroid of eruption. The ears alone wresent increased rascularity, with a mederate blush and excess of scurf.

Digestice organs: Natural above the stomach. Guttural lymphatic slancts in part congested aurl tho seat of microseopic blood extravasations. Stomacl mottled of a decp brown for a span of two and one-half incbes by three inches along the ruucous membrane, covering its grenter curvature. Contents abubdant, intensely acid, and fumes with ammonia.

Duodenum: Benrs a small erosion near the pylorus.

Jejunum and ilium: Hare patches of cougestion and microscopic extravasation at intervals.

Ilio-cacal valce: IIas its edges thickened and of a dark bluish gray. Many follicles in Peyer's patch coreriug the ralre are distended with a sellowish-white product, but there is no extra rascularity nor erosion.

Ccreum, colon, and rectum: Beal at intervals patches of cougestion and microscopic extravasation in the mucous and subnucous layers, over which the cpithelial layer is softened and easily dletacherl. No ulcers are found.

Liver: Discolored in parts by blue punctiform spots involwing individnal acini or several adjacent ones. Toward the lower margin of the gland the deep redness is mostly contined to the center of the acini.

Splcen: Seems large, but not nnduly gorged with blood nor softened.

Pancreas: Healthy.

Fidneys: Pale in their eortical part, present punctiform petechix on the mednllary portion and papillæe.

Bladder: Empty and normal. Oraries and romb sound.

The mesenteric, sublumbar, and inguinal lymphatic glands appeared enlarged and more or less stained, of a deep blood-red color.

Parasites in the abdomen: Two ascarides in the small intestine; one tricocephatus in the crecum.

Lungs: Present numcrous congested lobules varying in color from brownish pink to a dark purple (almost black). The bronchia learling to these lobules are perrious and withont parasites. The congested lobules seem less solid than when worms have been present.

Heart and pericardium: Normal.

Brain: Sound. Dura mater bears four patches of extrarasation on the right sido near the vertex. The average breadth of these is cne line.

Spinal cord: Sound; subarachnoid fluid, abont two drachms.

Experiment No. 10.

Thite male pig, cight weeks old; breed, Chester. Thite; condition, finc.

\begin{tabular}{|c|c|c|c|}
\hline Date. & Hour. & $\begin{array}{c}\text { Temperatnre } \\
\text { of body. }\end{array}$ & Remarks. \\
\hline Nov. $\begin{array}{r}4 \\
5 \\
6 \\
7 \\
8 \\
9 \\
10 \\
11 \\
12 \\
13 \\
14 \\
15 \\
15\end{array}$ & 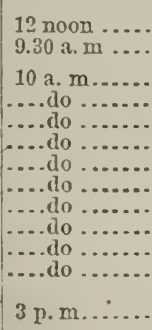 & $\begin{array}{l}104.750 \mathrm{~F} \\
103.75 \\
103.8 \\
103.75 \\
102.5 \\
104.5 \\
103.5 \\
104 \\
104.5 \\
105 \\
105.1 \\
103.5\end{array}$ & $\begin{array}{l}\text { Ears rod. } \\
\text { Losing condit.un. The alkin shows tho customary biack necrotlo } \\
\text { spots of epirlermis. Ears blne at edges. } \\
\text { Respiration } 36 \text {. Killed by blecding. }\end{array}$ \\
\hline
\end{tabular}

Post-mortem cxamination.-Shin: Slight eruption on the ears and blineness on the margins.

Digestive organs: No lesions in the montle or pharyax.

Pharyngeal lymphatic glands: Stained of a deep blood-red color.

Stomach: Well filled with food. Contents strongly acid. On tle grent currature a space of two and one-half inches square has a bromnish mottled cliscoloration, and numerous decper brownish markings, as if fiom altered hematiue.

Small intestine: Epithelinm is thick, soft, and easily detached. Contents liquid, with a great excess of mucus. The bowel is roddened and congested around its entire 
periphery, and for a considerable distance at intervals, the congested portious being mostly empty and contracted.

Ilio-ccecal ralie: Pejer's patch, which passes orer the valve, has many of its follicles filled up with a yellowish-white matter. The whole patch is swollen, but not rery vascular to the naked eje.

Cacum and colon bear petechiro: Many solitary glands in the colon are unusually large; some excessively dilated, filled with yellowish matter, and apparently commeneing to form ulcers. Spots of congestion scattered over the mucous membrane show minute extravasations when placed under the microscope.

Micsenteric glands: Some unchanged; some stained of a deep blood eolor. Inguinal glands large.

Kidneys: Normal.

Liver: Is firm and solicl. Bears numerous punctiform petechio on the posterior surface of its right lobe, and a large dark-purple pateh on the posterior aspect of its middle lobe.

Gall bladder: Moderately filled with a straw-colored, glutinous bile. Membranes of tho bladder unchanged.

Pancreas and spleen: Normal.

Chest-heart: Left rentricle contains petechir. Right auricle just above the auriculo-ventricular valve presents a brownish-red spot which, under the microscope, is seen to contain much granular matter in the sub-serous connective tissue.

Lungs: The right has two dark, blood-colored spots on its posterior part. The left shows similar colorations, mostly in lines along the inter-lobular spaces. The bronchia leading to such points contained no parasites nor exudation.

Bronchial lymphatic glands: Normal.

Brain: Normal.

EXPERIMENT No. 11.

White male pig, eight weeks old; breed, Chester White.

\begin{tabular}{|c|c|c|c|}
\hline Date & Hoar. & $\begin{array}{l}\text { Temperature } \\
\text { of body. }\end{array}$ & Remarks. \\
\hline Nor. & 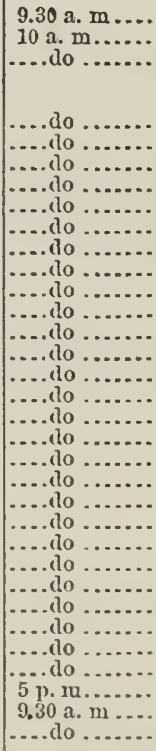 & $\begin{array}{l}102.750 \mathrm{~F} . \\
103 \\
102 \\
100.5 \\
100.75 \\
101.75 \\
104.5 \\
102.5 \\
103.5 \\
103.5 \\
103.25 \\
104.75 \\
102.75 \\
104.5 \\
104.5 \\
105 \\
105 \\
103 \\
103.75 \\
103.3 \\
104 \\
104.25 \\
103 \\
104 \\
103.5 \\
103 \\
102.5 \\
103.2 \\
102.25 \\
100.75 \\
102 \\
102.25 \\
102.5\end{array}$ & $\begin{array}{l}\text { Scouring. } \\
\text { Fotid scouring. } \\
\text { Feces still soft; unusually fetid; skin hot }\end{array}$ \\
\hline
\end{tabular}

Post-mortem examination.-Skin: In great part corered bo the usual black coneretion. Has patches of purplo ou cars and legs.

Digestive organs: Some deposit exists on the lower surface of the tongue, to the left of the frenum, composed of gr:unlar matter and cells having more than one nucleus; cvidently the remmant of a small abscess. On the fauces, to the right side, is a purple patch not remored by pressure, extending to an inch in length and a quarter of an inch in breadth.

Pharynx and larynx: Normal. 
Stomach: Full; contents moderatoly acid. Shows tho usual browuish discoloration of tho mucous menurane covering the great eurvature.

Small intestines: Show only a fow patehes of congestion. Tho follicles of Peyer's patch just above the ilio-cxeal valve are considerably enlarged.

Large intestines: Show a great many enlarged solitary glands, yet but littlo congestion. The rectum is much congested and presents two nlcers: one with raised edges and raw, depressed center; the other, with a firm, dirty-whito slough in the center.

Mesenteric lymphatic glands: Enlarged and thickly streaked with gray. Thoso near tho ilio-cxeal valve, and those above the rectum, aro congested and deeply reddened. Inguinal glands: Are also greatly enlarged and streaked dark-gray with pigment.

Liver: Of normal consistency and color, excepting some fow patches of deep purple.

Gall-bladder moderately filled with a yellowish-green, viscid bile.

Pancreas: Healthy.

Spleen: A portion very dark colored (nearly black) extending its wholo length and about half its breadth; is evidently gorged with blood; but is not raised above the level of the remaining part.

Kidneys: One contains an acephalocyst in its pelvis. The cortical substance of both is pallid, but no other change is noticeable.

The lungs, heart, and brain appeared healthy.

\section{Experinfent No. 12.}

Male pig, eight wecks old; breed, Chester White.

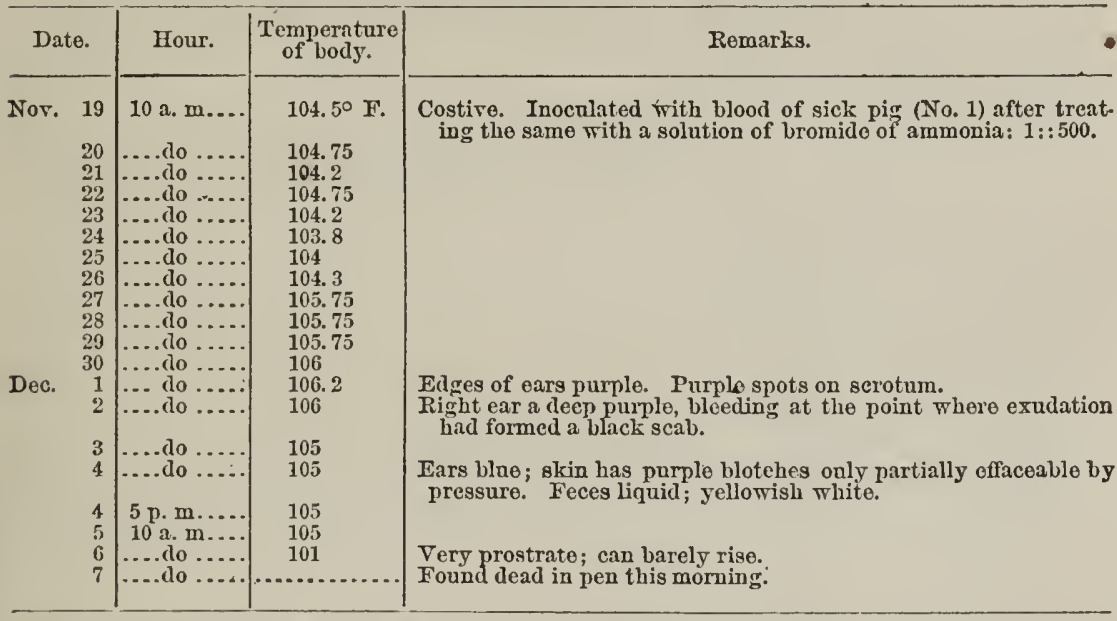

Post-mortem examination.-Skin: Of ears, throat, breast, belly, and legs, of a uniform dark purple; white patches remain inside the forearm and thigh, and along the back, which is covered by a very thick scurf. The discoloration which is due to congestion of capillary vessels, the coagulation of blood within them, and numerous minute extravasations, is confined to the integument. The skin is also abundantly covered with the ursual black coneretions.

Digestive organs: Tongiue blue, but with no abrasions.

Tonsils, fauces, and pharync: The seat of general congestion and discoloration. Esophagrus has some spots of slight congestion.

Stomach: Distended with solid food; not so strongly acid as in many other cases. Its great eurvature has the mucons membrane covered with patches of blood extravasation, such patches standing out in grcater part as dark-red elots.

Small intestine: Exceedingly contracted, almost empty, and congested throughont in varying degree, from a simple branching redness, with softening of the mneons membiane and excessivo production of mueus, to distinct circumscribed extrarasations with decided thickening; in several instances tho redness and tho thickening is most marked on Peyer's patches. The dnodenum contains threo ascarides. Several small ulcers exist just above tho ilfo-cxeal valvo.

Large intestine: Cacum remarkably small and contracted. Neither csecum nor colon contains muel iugesta. The mucons membrane along the wholo large intestine is inflamed, greatly thickened by exudation, and tbrown into prominent circular folds. Its general color is of a dark brownish red, in many points verging upon black. At ditfercnt pounts it shows the charactełistic ulcers with a firm, firty, white slongh in the center of each, but these lave in no ease attained a large size, nor any marked thickening nor induration of their base, and without special caro in the examination 
might be easily orerlooked. The reetum contains numcrous blood extrarasations and some considerable ulcers with the central whitish necrosed portions.

Mesenterie glands: Almost unirersally enlarged and of a deep red, from cougestion and extrarasation.

Liver: Of a rers deep pumpiish brown, gorged with blood, but not materialls softened nor moderately friable. It is especially dark near the margin of the lobes.

Giali-bladder: Moderately full, bile clark green and riscid.

Panereas: Somurl.

Spleen : Enlarged, gorged mith blood, and almost black.

Hiflncys: Nearly nomal as examined cxternally. Corticle substance of a darker red than in most of the diseased pigs, and the papillo bear black extrarasations, punctiform and up to half a line in breadth. The right kidney contains a small cyst in its pelris.

Left supra-renal rapsule is enlarged to about one-third the size of the kidnes, and has a eloi of blood and a collection of eheesy matter superposed in its anterior end.

Lungs: Nearly normal; some congestion in the posterior lowes is eridently quite recent, and the eut surface treely cxudes a frothr liquid.

Hcart: Right reatricle slightly discolored by punctiform petcchia beneath the endocardium. The great aorta contains a rery firm elot, partly bufied.

Blood under is No.10 Hartnack immersion shows no moving bacteria, but a great excess of gramular matter.

EXPERIMENT No. 13.

Thite female pig, eight wceks old ; brced, Chester Whitc.

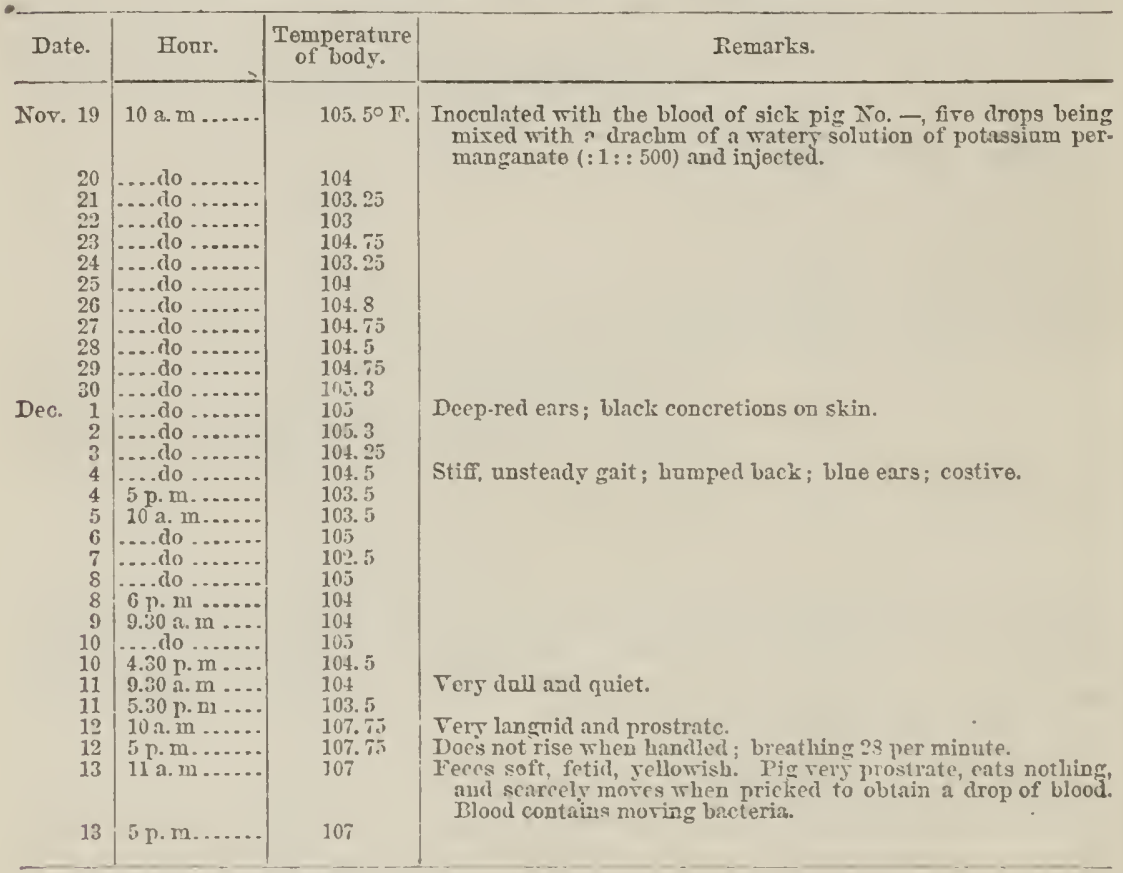

Pig found dead on the morning of December 14.

Post-mortom eramination.-Shin: Blue spots ou the belly. legs, rump. perinemu, and ears. Freo portions of the ears of a dark purple. I'ink piapillary ermption, and black coneretions on the cars.

Digestire nrgans: Tongue has an nlcer, with slough a little to the left of the tipsize one and a half lines in diameter.

Tonsils and soft palate: The seat of a uniform bluish eongestion. Submaxillary Iymphatic glanis in part redilened and congested.

Gullct: Contains clots of at strings, fibrinons material.

Slomach: Near the left cul de sac is a dirts, sellowish-white false mentorane of abont one incli square. The great currature is of a dark-bromnish red, with some brighter red spots of more recent blool extravasation.

Small intestines: Neariy empty, though at intervals were round, hard pellets of in- 
gesta. Tho coats of this bowel were more or less congested, with softening of the membrane at diflerent points.

A large nlcer is forming on the edge of the ilio-erecal ralve, in which the ontline of tlo follicles can still be seen of a yellowish color.

Large intestincs: Crecum and colon congested thronghout, but mreh more at some points than at others. In the mpler part of the colon are extensire cleposits of lialse membrano of a dirty pellowish-vithe color, in places in spots of small size, and in others in extended patches of sereral inches in length. "The erecnm lias smaller spots of the same kind. The reetum is rery much thickened and of a deep red thronghont, the thickening existing mainls in the mucous membrane. It present3, further, nine small ulcers, with the charaetcristic dirty slonghs in the centers.

Parasites: Tho cxecum contains ono whip-rrorm.

licer: In the main firm, but contains bluish patehes.

Panereas: Apparently unchanged.

splcen: Black, full of blood, but not apparently enlarged.

MIcsontcric and sublumbar lymphatic glands: Are almost nniversally of a dark red, alimost black color.

The left kidney: Has a eyst one-half inch in diameter in the anterior part of its pelvis. In common with the right kidnes, it also presents numerous black petechia on the medullary portions and papillie.

Chest and respiratory organs: Laryux shows considerable congestion, especially on the epiglottis and on the arytenoid eartilages.

Pleurce: Contained an aloundant blood-colored liquid exudation, especially in the right sac, where the lung had contracted exteusive adhesions by newly-former false membranes. The liquid effusion contained numerous white and red blood lobules and actively-moving baeteria, which assnmed the most varied forms in rapid snccession.

A loose coagulum forms in the exposed fluid.

Bronchia: Filled with froth having a perceptibly pink tint.

Left lung: Anterior lobes congested and cousolidated by recent exudation. Posterior larer lobe sound.

Right loje: Consolidated throughont; sinks in water; bnt has not jet become firm, gramular, nor friable. The color of this lnng raries from a light bricli-red to a deep red, approaching black, the darker shades mostly occupying the spaces of connective tissue betreen the lobules, these spaces being often stretcherd by the exurlation to the breadth of a line or more. On making a section of the lung a considerable pulnonary rein was found to contain a friable gramnlar grayish clot which laad eridently existed for some time before death.

Pericardium: Contains a large amount of blood-colored effusion, in which bloodglobules and moving bacteria abonnd. The parietal and visceral lajers were connected by loose false membranes. Loose rlark elots and some fluid blood existed in the right side of the heart, and spots of extravasation on the walls of the left ventricle.

Lymphatic glands: In the region of the throat are of a very leep red. The same remark applies to the bronchial and subdorsal glands.

Table shoring the duration of incubation in diffornt cascs.

\begin{tabular}{|c|c|c|c|c|c|}
\hline No. & 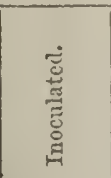 & 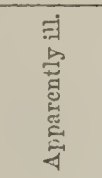 & 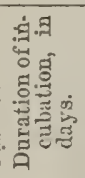 & 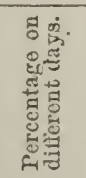 & Remarlss. \\
\hline $\begin{array}{r}1 \\
2 \\
3 \\
4 \\
5 \\
6 \\
7 \\
8 \\
9 \\
10 \\
11 \\
12 \\
13 \\
14 \\
15\end{array}$ & 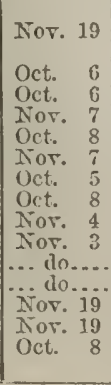 & $\begin{array}{l}\text { Nov. } 20 \\
\text { Oct. } 9 \\
\text { Oct. } 9 \\
\text { Nor. } 10 \\
\text { Oct. } 12 \\
\text { Nor. } 11 \\
\text { Oct. } 10 \\
\text { Oct. } 14 \\
\text { Nor. } 10 \\
\text {.. do... } \\
\text {.. do... } \\
\text { Odo. } \\
\text { Nor. } 26 \\
\text { Nor. } 27 \\
\text { Oct. } 21 \\
\end{array}$ & $\begin{array}{r}1 \\
\\
3 \\
3 \\
3 \\
4 \\
4 \\
5 \\
6 \\
6 \\
7 \\
7 \\
7 \\
7 \\
8 \\
13\end{array}$ & $\begin{array}{c}6.0^{\prime \prime} \\
\ldots \ldots \\
20 \\
\ldots \ldots . . \\
13.3 \\
6.6 \\
13.3 \\
20.6 \\
\\
6.6 \\
6.6\end{array}$ & $\begin{array}{l}\text { Inoculated with old blood that had been kept cleren dase } \\
\text { in an inculbator. } \\
\text { Temperature raisel for three days onls. }\end{array}$ \\
\hline
\end{tabular}




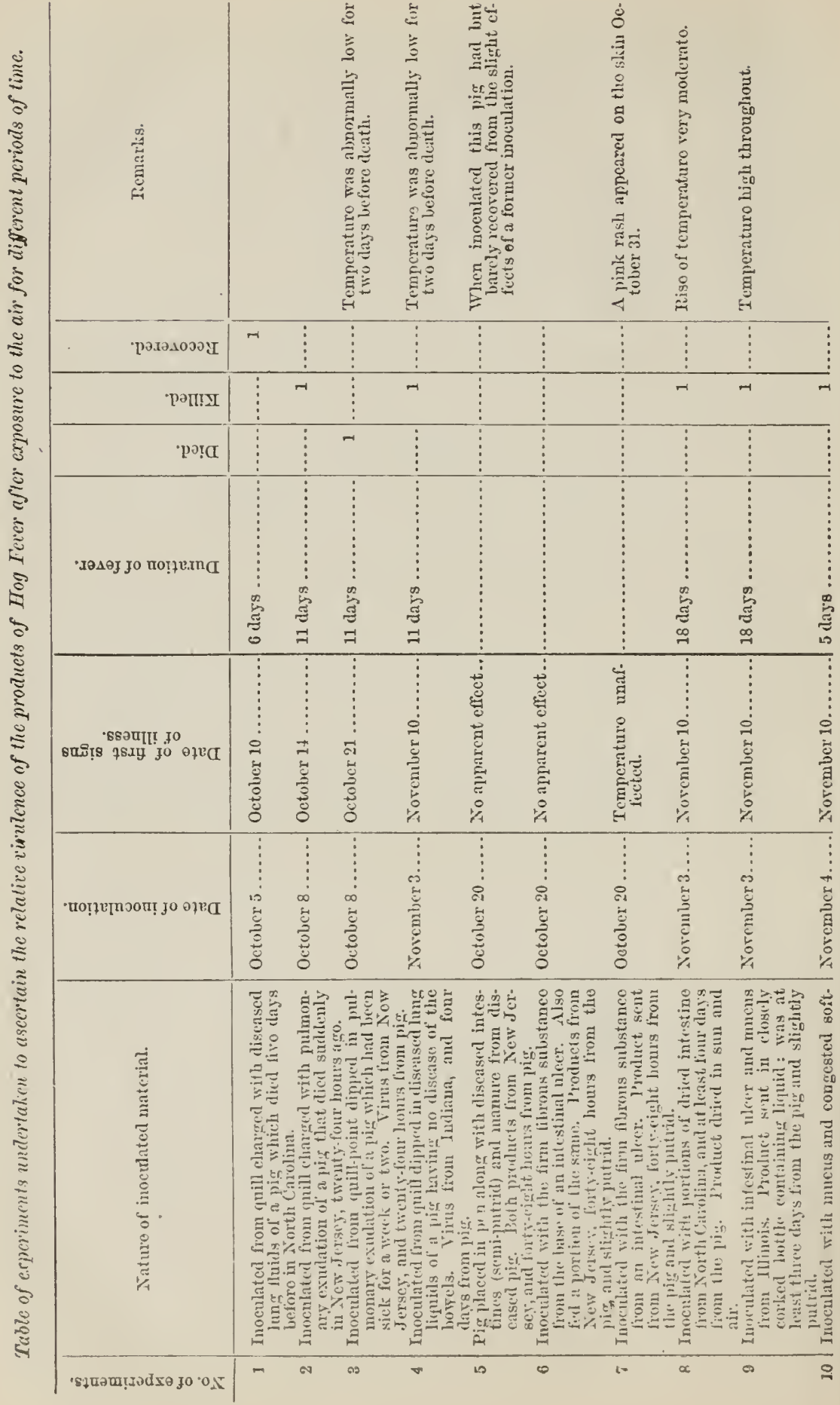


DISFASES OF SWINE AND OTHER ANIMALS.

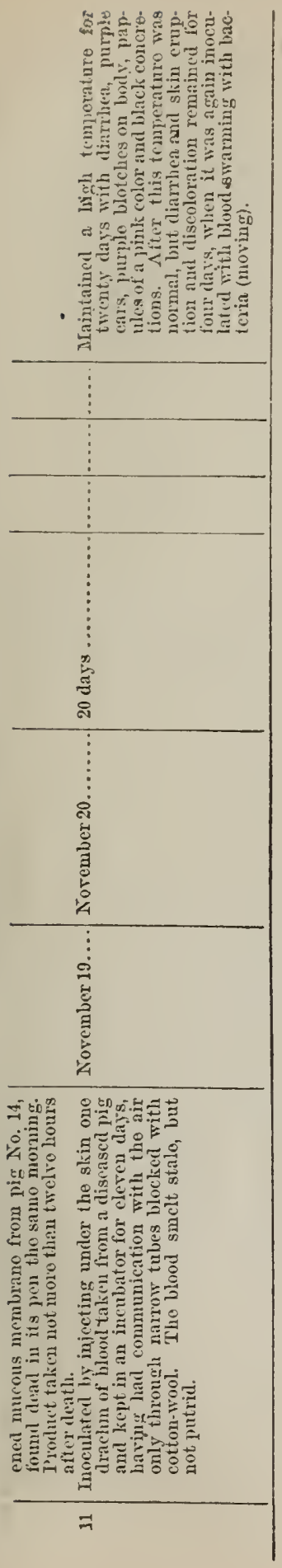




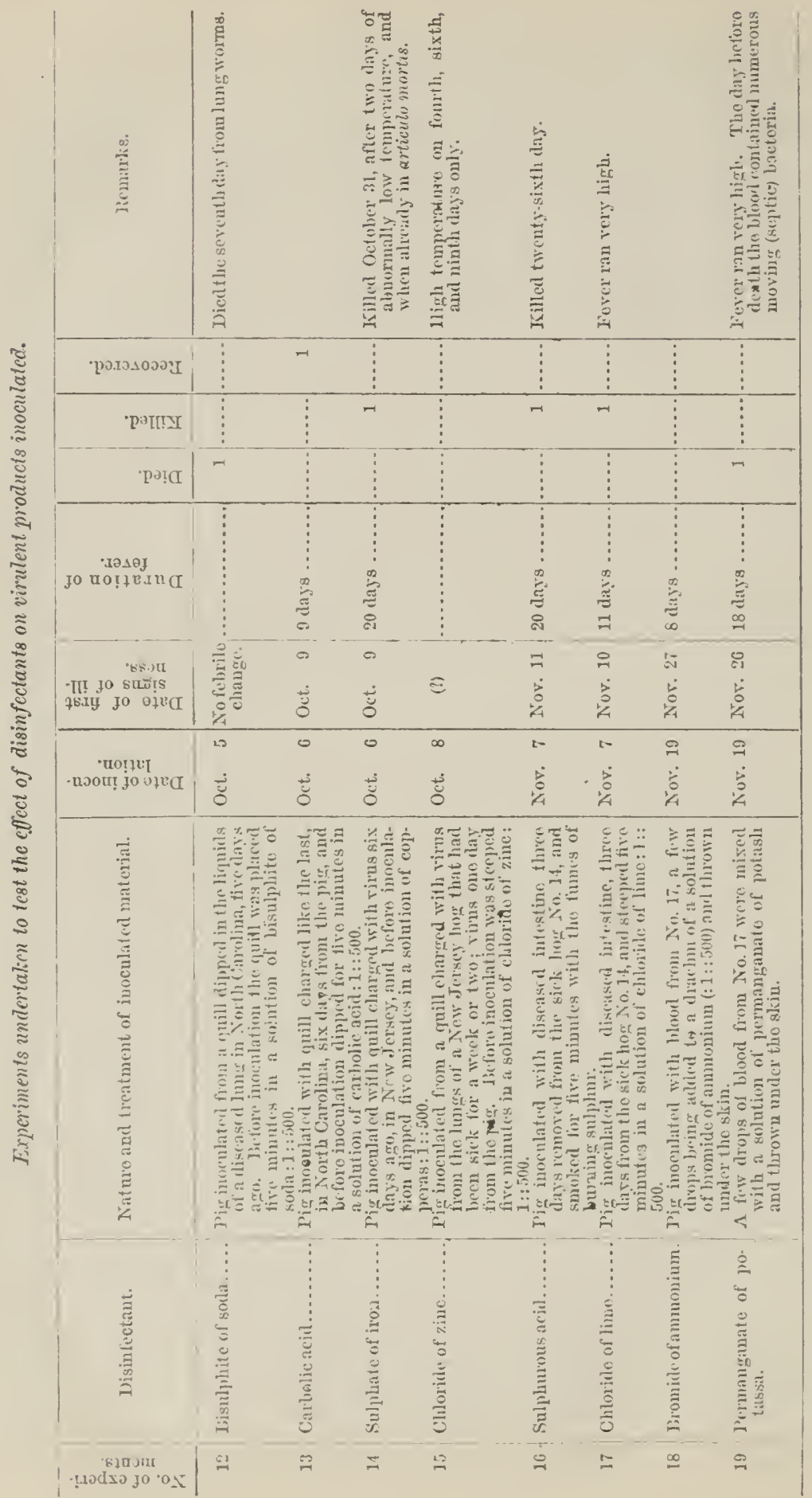


Experimext No. 20.

Fxperiment undertaken as a test of the propagation of the discase-poison through the air.

October 5. - A pig was placed in a pen between two infected ones, and separated from * each only by an impervious doublo wall of matched boards, with building-paper between. The only means of communication was throngh tho open air by means of ventilators at the front and back of each pen, and the openings of which in adjacent pens were less than a foot apart. On tho ninth, tenth, and eleventh days tho pig had an clerated temperature and was lame in the right shoulder, the illness being eridently rheumatie.

On Oetober 29 th, the twenty-fourth dar, the iemperature rose $2 \circ$ and remained at $104^{\circ}$ F. and upward tor six days (till Norenibir 3rrt). It then showed a daily diminution, and by November 8th, having attained the natrial standard, the pig was destroyed.

Experiments on sheep, rabbit, and dog. Inoculation with fresh virulent pig's b?ood, containing moving bacteria.

\begin{tabular}{|c|c|c|c|c|c|}
\hline Subject. & 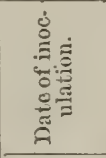 & 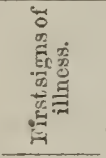 & 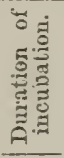 & 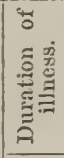 & Remarks. \\
\hline $\begin{array}{l}\text { Merino wether............... } \\
\text { Adult female rabbit.......... } \\
\text { Newfoundland puppy, seren } \\
\text { weels old. } \\
\text { Female pig, twelro weeks old. }\end{array}$ & $\begin{array}{l}\text { Dee. } 14 \\
\text { Dee. } 14 \\
\text { Dec. } 14 \\
\text { Dee. } 14\end{array}$ & $\begin{array}{ll}\text { Dec. } 15 \\
\text { Dec. } 15 \\
\text { Dee. } 15\end{array}$ & $\begin{array}{l}1 \\
1 \\
1\end{array}$ & 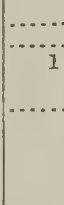 & $\begin{array}{l}\text { Temperature rose } 2.25^{\circ} \text {, but was nor- } \\
\text { mal on the second das. } \\
\text { Purged aetirely for three dars. When } \\
\text { inoenlated the pig was in advanced } \\
\text { non-febrise stage of the ferer, and } \\
\text { the temperature did not rise above } \\
\text { the normal. }\end{array}$ \\
\hline
\end{tabular}

Iroculation with fresh virulent blood in which no moving bacteria had bcen obscrved.

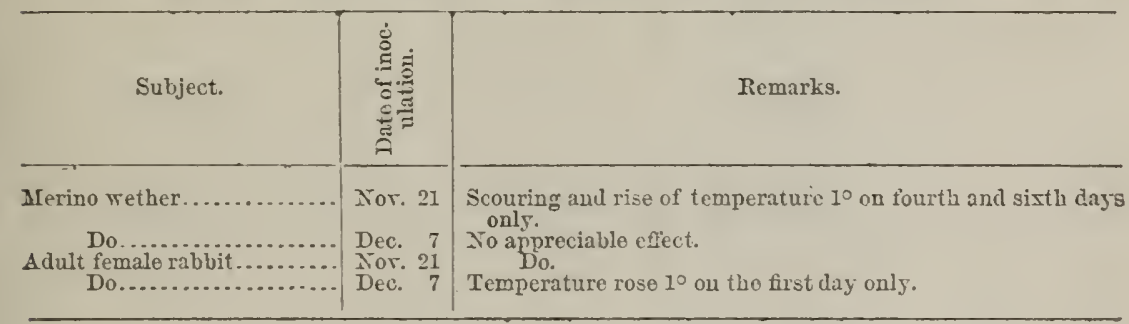









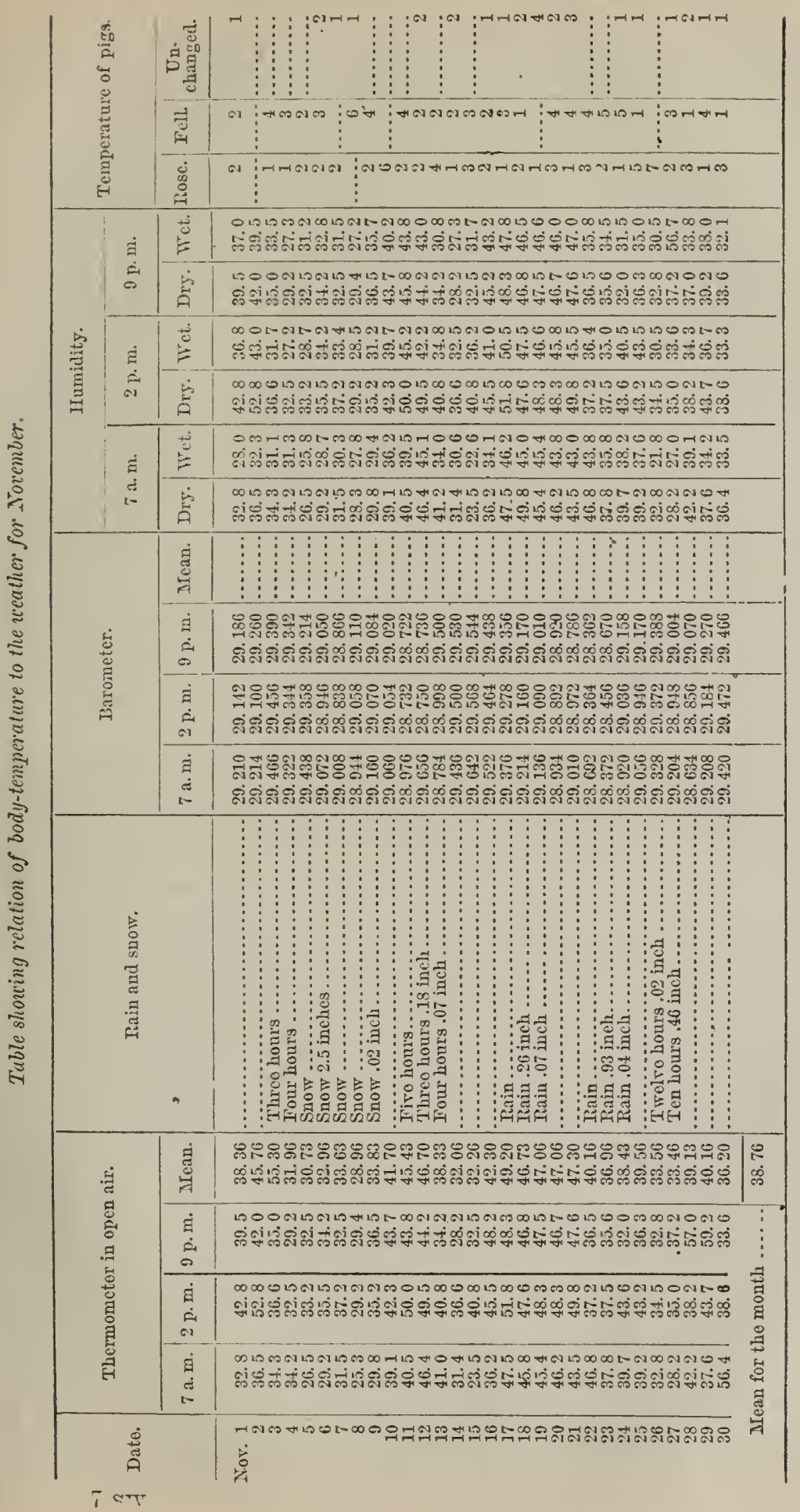




\section{DR. LAW'S SUPPLEMENTAL REPORT.}

As an addendum to wy former report, I would respectfully submit tho following further olsservations on the fever of swine, commouly linown as hog eholera:

\section{EAPLIMLATS LY FEEDLTG TIE VHULENT MATTER.}

A healthy pig was fed the snbstance of an intestinal uleer and a little mamure from the same bowel, but slowed no evil results for tourteen days, when it was put to other uses. It should be audled that the uleer fed to this pigr was partially putrid, and was inoculated on two other swine withont snceess.

$A$ second pig was fed a portion of dried intestine and its contents, both of which had remaincel packed in wheat-bran for a month. Notwithstanding this, the animal retained good health for seventeen dass, when it, ton, wats put to other nses. 'Tho material ficl to thes pig aeted with fatal efiect on two other pigs on which it was inoculated.

'Theso experiments can only bo taken as showing that a small quantity of poison may pass timough tho intestinal canal with impuuity, but they would not wamat the conclusion that similar materials would be equally harmless when talien in larerex quantities and with erery meal, as invariably happens when swino aro fed in the ordinary manuer and plumere their filthy teet and noses fiesh from the pestiferoals mamire into the feeding-trongh. Dr. Osler has succeeded in dercloping the disease hy feeding tho cliseased intestime, but as the feeding was accomplished by foree there is just 1 lio possibility of abrasion and direct inocnlation. Abrasions are indeed so coumon in the mouth from injuries by the teeth and by lard objects masticated and derangements of the epithelial covering of the mucous membrane of the stomach and intestines, aro so fireguent in commection with slight gastro-intestinal disorders, that it is needless to caleulate on an immunity which can ouly bo secured by the entire absence of such lesions. If to securo iumunity in feeding me must provicle that not eren a worm shall bito the mucous membraue of the stomach or intestine, any guarintee rests on an exceedingly slencler basis and had best be rejected at once.

\section{SLCCYSSFUX IXOCULATION WITH FIOZEX PRODCCTS OF TIE DISEASE.}

In tro cases I have successfully inoculated virulent products which had been frozen hard for one and two days respectively. In both instances the resulting discase was of a very violent type, and would assuredls liave proved fatal if left to rum its course. The freeziug had certainls failed to impair the vinulenee; it had rather sealed it uj to bo opened and given free conrso on the oceurrenco of a than; for, onco it is frozen, it is manifest that no finrther change conlel tako placo until it was again thaned ont, and if it was preservecl for one night muchanged in its potener, it wond bo equally muafiected after the lapse of many months, provided its lipuids had remained in tho samo crystalline condition throughout. In this way undoubtelly the rims is often preserved throngh the winter in pens and yarks, as well as in car's and other conveyances, to break forth anew with retuming spring. This is precisely what wo tind to be the caso with the other fatal animal plaches, the virus of rinderjest, lung fever, anthrax, and aphthons fever, being often bound np throngh the winter with frozen manure to reappear with undiminished power on tho aceess of warmer weather. This is a matter of no small moment inasmuch as the long-continued frosts of omr Northern States prevent any such destruction of the poison as talies place so readily in stimmer in comnection with the altemate wetting and drying aud the resulting put retaction.

I havo had instances brought under ny notico in which, after tho prevalence of tho fever in al herd in early summer, new swine were introduced into tho open yard a montl or two after all trace of tho disease had disappeared and had continned to preserve the most perfect health. This is quite in keeping, too, with my failuro in tho attempts to convey the discase bs feeding and inoculating with a semi-puntrid intestine. It serves, moreover, to explain my failure, as the exposwro and wet at a moderately ligh temperature would lead in both cases alike to decomposition and clestruction.

The bearing of this upon the prevention of the diseaso is self-evident. Infeeterl yards aud oflere open and uncorered places may bo cousidered safe after two months' racation in summer, provided that sufficient rain has fallen in the interval fo insure the soaking and putricl decomposition of all organic matter near the surface, and that there aro no great accmulations of manuro, straw, hay, or otler material in which the virus may be preserved dry and infecting. In winter, on the of her hand, the yark or other open infeeted placo may prove non-infecting for weeks and monthis, and yet retain the virus in readiness for a new and deadly career as soon as a thaw suts in. Satety in such eireunstances is contingent on a disuso of the premises su Ione as tho first coutinues aud for at least ono month thereafter. Even cluring tho contimanco of frost such yliaces are laugerons, as tho heat of the animals' boclies or of the rays of 
the smin at millilay may suffice to set the virus free. A gain, while they are especially dancerentit on the accession of warmer weather, yet, when onee the tempciatmo has

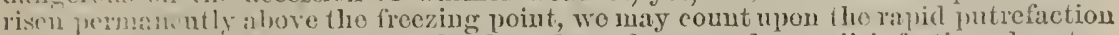
that chistes in alf organic boulies that have been frozen aud on a disinfeetion alunost as spechl, and it may be at times even moro speedy than in the extrene heat of summer. l'? during winter as still infected nntil one or two montlis after the frost lias gono out of the gromel in spring.

This, of condse, hats litfe bearing mon the rnostion of eovered pens, barns, cars, \&c., in which the prison maty bo preserved dry, active, and atecssiblo in winter and summer alike. On this ratestion of infection hlurongh pens in winter I instituted tho following experiment :

CONTAGION FION AX INEECTEI I'EN.

A healthy pio was placed in a peri from whith a sick owo hat been removod thirteen days before. Tho pen hat teen swept ont, but snbjected to no disinfection other than the free circulation of air' and as tho pign was placed in tho pen on December 19, all moist olyects lial been frozen dning tho time tho apatment had stood empty. Tho pig died on the tifleent he elay without having shown any rise of temperatnre, but with post morlem lesions that showed tho operation of the poison. This easo was an oxam. ple of tho rapidly fatal action of tho clisease, the poison laving fallen with prostrating effert on vital organs - tho lungs and brain-and cut life short before thero was time for the full development of all the other lesions. It sufficiently demonstrates the press crvation of tho poison in covered buildiugs at a temperature below tho freezing'point.

SUCCXSSIUL INOCULATION ON PIGS WITI VIRUS THAT ILD LEEN IEPT KOR A MONTA IN DIY WHEAT-BRAY.

Appended will bo found the daily record of two pigs infected by inocnlation with bowel ingesta anl mucous membrano that had been preserved for a month in.dry wheat-bran. In both eases the cliseaso followed tho inoculations promptly and ran a severo conlse, ono easo proving fatal, while in the other death was auticipated by killing tho animal. It the antopsies the usual characteristic lesions wero found.

Here, as in tho caso of the virus preserved on quill-tips, wo find the poison proserved without the slightest impaiment of its poteney. 'Thus two series of inocular tions with (Lied virus show how eareful and thorough unst be the disinfeetion in dry seasons, and indoors in all scasons, aud the importanco of the destruction by fire, or in other certain manuer, of all dry fodder and litter in which the poison may havo becu scereted.

\section{COIIABITATION WITL SICK PIGS IT DIFFERENT STAGES OF THE DISEASIE.}

$\Lambda$ healthy pig was inclused in a pen with a sick one which had bocn inoculated with virnlent blood on tro occasions; the first thirty clays aud tho last fivo days before. After tho first inounlation the pig had suffered fiom a slight tever and the characteristie phenomena of the discase. Beforo the socond inounlition the temperature liad been normal for eiglit days, and it was not materially" affecterl by tho ojeration. In short, the diseaso had manifestly spent itself in the systen of the pig, thongh it han left it a most shumken, einaciated, and wretched spectacle.

The tro pigs oecupied the sume pen, lay on the sime bed, and fed from the samo trongh for sixteen clays, churing which no unequivocal sign of discase was manifested in the healthy pig. It secmed indeed to have successfully resisted the contagion.

It was now removed to another pen and placed in eompany with a pig' in which the diseaso hagl just reached its height. On the twolfh day thercafter its temperaturo permanently rose, and it passed throngh a sharp attack fiom which it is now wecorering.

This seems to show that the poison is muck less virulent niter the fobrile stage of tho malady has passed, and that tho danger from tho recupniting animal clecreisies

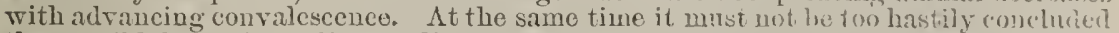
that $a$ inild form of the disease did not exist in this pig during the ocenpluney of $i$ ho first pen. It appears nnepuestionablo that tho poisnn may he pressut in the system,

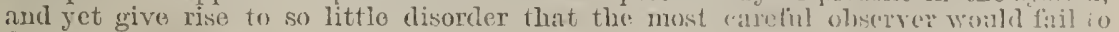
detect anything amiss.

OCCULT FOLAL OF TIL: DISE INi:.

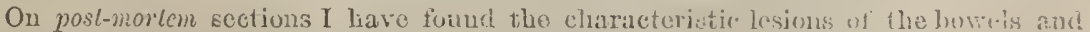

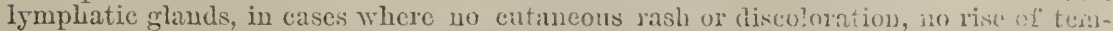
perature, no loathing of food, nor constitutional disoreler had betrayed its prosence during lifo. The occurrence of such slight and occult formis of the discasc must present 
a sorions olstacle to all attempts to stanp it out. In most of the plagues of auimals, and notably in lung ferer, in aphthous fever, and in rinderpest out of its natiro lome, the rise of the body temperature precedes all outward manifestations of the diseaso. In these affections the indications of the thermometer alone enable ws to separate the sick and healthy before the discase has attained to a stage of material danger to their fellows. Bnt in the pig forer the earliest symptoms will vary according to tho vagaries of the poison and its primary seat of elcetion. Perhaps the most common initial symptom is the enlargement of the inguinal glands, bnt it may be some derangement of the digestive organs, or it may be the oleration of the borly temperature, or it may be the appearance of red spots or blotches on the skin, or finally the poison may bo operating in the system in the absence of all exterual manifestations. It is noticeablo that since the access of extremely cold weather tho eutancous cliscoloration has becn much less extensive than during the rarmer season. Even when the temperaturo has becn abnormally raised it will rise and fall in such an irregular manner that no single observation will bo always successful in detecting the discase. To detect such cases tho investigation must be conducted from day to das, and in rict of all possible unauifestations of the disease, to be successful. Then again tho temperature, even in health, raries widely in different swine and under different conditions of lite, so that a knowledge of the body heat of the individual in the existing environment is essential to the drawing of sound deductions from thermometric indications.

\section{INFECTION OF OTIER ANLIATS THAY SWINT.}

I consider the most important part of my researches to bo that which demonstrates the susceptibility of other animals than swine to the fever wo are investigating. Dr. Kline of London, England, claimed, nearly a year ago, that he had conreyed tho discase "with difficulty" to rabbits, Guinea-pigs, and mice, but ho gives no lint as to whether he had subjected the question to the erucial test of reinoculation from theso animals back upon the pig. This test it seemed rery important to apply, so that the identity or otherwise of the two diseases might be determined. I havo accordingly instituted experiments on a rabbit, two sheop, a rat, and a puppy, tho three former of which have turned out successfully.

\section{LNFECTION OF A RABBIT FROM A SICK PIG.}

After trro inoculatious with questionable results, made with the blood of sick pigs, in which microzymes had been observed, a rabbit was once more inoculated, this timo with the pleural effusion of a pig that had died dnring the previous night, and in which were numerous actively moving bacteria. Next day the rablit was very foverish and ill, and continued so for twenty-two dars, when it was killed and showed lesions in many respects resembling those of the sick pigs. The blood of the sick rab. bit contained active microzymes like those of the pig.

\section{SUCCESSFUL LYOCULATIONS FROM THE SICK RABBIT.}

On the fourth day of sickness the blood of the rabbit containing bacteria was inoculated on a healthy pig, but for fifteen days tho pig showed no signs of illness. It was then reinoculated, but this time with the dischargo of an open sore which had formed over an engorgement in the groin of a rabbit. Illness set in on the third day and eontinued for ten days, when the pig was destroyed and found to present the lesious of the fever in a moderate degree.

A second pig, inoculated with the frozen matter which had been taken from the open sore in the rabbit's groin, sickened on tho thirteenth day and remained ill for six days, when an imminent death was anticipated by destroying tho animal. During life and after death it presented tho phenomena of the plague in a very violent form.

It can no longer be doubted, therefore, that the rabbit is itself a victim of this disease, and that the poison can be reproduced and multiplied in the body of this rodent and conreyed back with undiminished virulence to the pig. Wo may follow Dr. Kline in accordiug a similar sad capacity to the other rodents, mico and Guinea-jigs. Tho rabbit, and still more tho mouse, is a frequent risitant of tho hog-pens and rards, where it eats from the samo feeding-troughs with the pig, hides under the same litter, and runs constant risk of infection. Onco infected they may carry the discaso as widely as their wild wanderings may lead them, and communicate it to other herds at a consilerable distance. Their weakness and inability to escape, in severe attaclis of the discase, will make them an easy prey to the ommivorous log, and thus sick and dead alike will bo deroured by tho doomed swine.

\section{PROBABLE SUSCEPTIEILITY OF OTHER RODENTS.}

The infection of these rodents creates the strongest presumption that other geucra of the same family may also contract the disease, and by virtue of an eren closer rela- 
tion to the pigs may succeed in eonveying the malady to thistant herds. The rat is at onco suggested to the mind as bcing almost ubiquitous in piggeries, as feeding in common with the swine, as liablo to bo deroured by the hog when sick or dead, as given to wandering from place to place, and as possessed of a vicious labit of gnawing the fect and other parts of his porcine companion, and thus unconsciously inocnlating him.

I liare up to the present time had the oplortunity of inoculating but one rat with the log-poison. Unfortunately my subject died on the second day thereafter, the body showing somo suspicious lesions, namely, congesterl lungs with considerable interlobular exulation, congested small intestines, dried-up contents ot the large intestines, aud sanguinous discoloration of the tail from the seat of inoculation to the tip.

\section{INOCULATIONS FROM THE RAT.}

With the fresh congested small intestine of the rat I inocnlated one pig, and with the frozen intestine one clay later I inoculated a seconcl. The first had wo appreciable rise of temperature, loss of appetite, nor digestive clisorcler, but on the sixtl day pink and violet emptions, the size of a pin's head and upward, appeared on teats and belly, and on the tenth day there was a manifest enlargement of the inguinal glands. From what I hare secn of the occult forms of the disease I was led to the opinion that this was one of them. Unfortunatels, I had at the time no healthy pig available tor the erucial test of reinoeulation.

In the second pig, inoculated with the frozen intestine, the symptoms were too obscure to be of any real ralue. As soon as I obtain a supply of rats I propose to subject this question to a further inrestigation.

\section{SUCCESSEUL INOCULATION OF SHEEP.}

Less significant than the infection of rats, yet of immense practical importance, is the susceptibility of sheep to the hog-fever. I have experimented on two sheep of different ages, an adult merino rether and a cross-breed lamb, and in both cases havo snceeded in transmitting the clisease.

\section{INFECTION OF THE MERIYO.}

This sheep was inoculated by hypodermic injections of ono and a half drachms of blood from a pig just killed. On the fourth day he had elevated temperature, and on the sixth scouring and snuffling breathing, but the symptoms rapidly subsided. On the fourteenth day he had an injection of two drachms more of blood from a sick pig, and on the trienty-first lay of one drachm of blood and pleural fluid containing multitudes of bacteria. Next day the temperature was raised and the sunfling breathing reappeared, both synaptoms continuing for somo time. On the sixth day his blood was tound to contain moving bacteria similar to those present in the injected blood. On the twenty-third day from the last inoculation ho was reinoculated, this tirno with the scurf from the ear of a sick pig. This was followed by no rise of temperature, but there existed much irritation of the bowels witl redness and strelling of the anus, occasional diamhea, and the passage of an excess of mueus, sometimes stained with blood. Seventeen days after the last inoculation he had another hypodermic injection of one drachm of blood and pleural fluid from a pig just killed. As before, this led to an extensire rise of temperaturo while tho intestinal catarrh continued.

\section{INTECTION OF THE IAMB.}

The lamb was first injected with a saline solution of the scurf and cutaneous cxudation from the ear of a sick pig. There followed a slight rise of temperature, a seurfy eruption on the cars and oozing of blood from different points on their surface, so as to torm dark red scales.

On the sixth day tollowing it was remoculated by the hypodermic injection of one drachm of plenral fluid from a pig just killed, the fluid containing an abunclance of moving bacteria. Next day there was extreme rise of temperature, some dullness and swelling in the right axilla, but appetite and rumination were not altogether lost nor suspended. On the fifth day there $\mathrm{ras}$ tendermess and unusual contraction of the rectum with the passage of bloody inucus, and on the eighth day profuso diarrhea with the passage of much mucus. 
tom of illness. Eleren days later it was reinoculated with scal from the car of the laml, and again three days later with anal mucus from the slicep. The das before this last inoculation it was noted that the inguinal glands were much enlarged, and six days after the temperature was elevated, and puriple spots appeared on the bells. This ferer temperature has lasted but a fer dars up to the present time, but, taken along with the violent rash and the enlarged lympluatic glands, it furnishes satisfactory evidence of the disease. We can therefore atirm of the sheep as of the rabbit that not ouly is it subject to this disease, bnt that it can multiply the poison in its sys. tem and transmit it back to the pig.

Two other pigs have been inoculated from the lamb, but during the few dars that liare clapsed they have shown no ontward symptoms.

\section{UXSCCCESSFLL INOCLLATIOY OT \& PCPPY.}

A draclum of blood and pleural fluid containing bacteria, from a pig just dead, was injected lyppodermically on the side of a Newfoundlaud pupps. Next dar slic was very dull and eareless of food, while her temperature was abnorwall high. 'Tho third day the heat of the body was uatural, and a fair amount of lireliness had returned. A few dars later a largo abscess appeared on the scat of inoculation, discharged and healed, and from this time the health seemed to be re-cstablished.

\section{SIGNIFICANCE OF THE INFECTION OF RODENTS AND SHEEP.}

Many will, no doubt, be startled at the abore developments, and inquire, half incredulously, How is it that the susceptibility of these animals to this aflection has nerer been noticed before? It may eren be snspected that we hare been mistaken as to the identity of the disense, and that wo may be dealing with the malignant anthrax (bloody murain) rather than the specific ferer of swine. But a slight attention to the phenomena and post-mortem lesions of onr cases will speedily dispel the doubt. Mralignant anthrax is more fatal to sheep and rabbits than to the other domestic animals, whereas in $\mathrm{my}$ sheep the disease was so mild that its very cxistenco wonld almost certainls haro been orerlooked in the ordinary management of a flock, and it was only detected in these cases by the careful thermometric and other observations made day by day on the inoculated animals. In the rabbit the disease was more serere, and mould mndonbtedls have proved fatal if left to itself, ret eren in this animal there was no inclication of the rapil course and speedy destruction which characterize the malignant anthrax. Again, although in both cliseases alike, the lymphatic glands are the seat of morbid enlargement, ret the increase and engortrement of the splecn rhich are so constant and so characteristic in malimant anthrax were altogether absent in me pigs infecter from the rabluit. Mnrcorer the diseaso in the pigs ran tho nsual comparativels slow course of the pir-ferer, rather than the spectils fatal one of the anthircx affection. In the inocnlated pigs, too, the combined lesions of the skin, lungs, bowels, and lypphatic glands are nnquestionably those of the swine-plague, and not those of malignunt anthax.

It is not snuprising that the disease should have been hitherto unrecognized in the slecp and rablit. Tho ruost obvious symptoms in jigs-tho pink, purple, violet, or blaclispots and patches of the skin-were never observed in these aninals, mnless $\pi \mathrm{c}$ can consider the ermption on the ears of the lamb as of this nature. In the sheep, to whicl: alone much attention would he paid, the constitutional disturlanco was so slight as to be easily orerlooked, the appetite even, and ruminat ion searecly snffering for a lay,

Again, the failnre to recomnize tho identity of a clisease in tro different genera of animals is fitmiliar to all mho haro wade a stully of comparative nathologr. Cow-poz and horse-pox have existed in all historic ages, but it remained for the inmortal Jenner to recognize and show their identity in the last ecntury. Iraliguant anthrax has prevailed fiom the timo of Moses, Fet in all the older veterinary morks wo find its diflerent forms described as independent diseases-blain, quarter rit. pritrid sore throat, \&e. Even to the present day many cases of this (lisease orenrma in the human sub)ject (maliguant pustule) are mistalien tor erysipelas (black ('rrsijelas). Glander's in lorses secus to have been linown to Aristotle, and was familiar to the ancient Greels Zooiatres and Roman Veterimarii, but its identity witlo the same disenso in man was

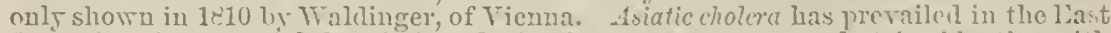
from timo immemorial. but it is only in tho present centure that its iclent ity with cholera in animals has been shomn by Indian and Luropean observers.

It is no wonder, therefore, that the mildness of the hog-fever in the sheep slionld hare masked its tme nature, and that the miversal disregrard of the disease of tho small rodents should have ind us to ignore it in these as well. Now, losicrer, that tho truth is forced upon us, we must recognize it in all further attements to arvest the conrse of the disease or to exterminate it. 'The destruerion aud burial of infecterl pigs, and the disinfection of the premises where they have been, can no longer be eonsidered a sufficient safeguard. Tho extermination of rabluits, wild and tame, of Guinea-rigs, of mice, asd probably also of rats, within the infecterl area, will he equall essential. Sheep must be rigidly exclnded from the hog inclosures, and it 
thes haro gained admittance thes must either be destroyed with the pigs, if fer and ralueless, or thoy must be shnt up in a seehded plaee, or sent to a sife distance firm all hogs mutil they ean be eertified as healthy, when they may be disinferted and released. No danger of a fatal oxtension among sheep is to be apprehenderl; the risease appears to be as harmless to tho sheep as tho fatal glanders is to the clog, yet tho infected sheep is ovidently dangerous to tho hog, and must be carefully sechided in all measures tor the suppression of tho plague.

\section{Record of D1. Law's IEPERLMENTs-No. 1.}

- Pig of common race, eight weeks old.

\begin{tabular}{|c|c|c|c|}
\hline Date. & Hour. & $\begin{array}{l}\text { Bolly temper- } \\
\text { ature. }\end{array}$ & Remarlss. \\
\hline Nor. 19 & $\begin{array}{l}10 \text { a. } 14 . . \\
\text {... . do .... }\end{array}$ & $\begin{array}{l}1010 \mathrm{~F} \text {. } \\
101.5\end{array}$ & $\begin{array}{l}\text { Costive. Inoculated with blood of pig lilled November } 8 \text {, and } \\
\text { kept in inoculator in isolation apparatus, communicating } \\
\text { with the air only throngh plugs of cotton-wool. The blood } \\
\text { smells stale, not putril; its celis hare disappeared. }\end{array}$ \\
\hline
\end{tabular}

101.5

105.2

104.75

104

104

104.75

104.5

105

101.75

104. 75

103.5

104.75

104.25

102.5

104

104

105

103.5

103.5

104

103

103.5

104

103

103

102.25

102.75

102.75

$5 \mathrm{p} . \mathrm{m}$

$139.30 \mathrm{a} . \mathrm{m} . .$.

102.5

100.5

102.75

102.75

102.25

102.5

102

103. 25

101 .

Quito dull. Parple spots and black concretions on tho shin.

lied and black spots on the slin.

Scours. Fars blne and cold.

Do.
Do.
Da.

Bowels continue loose.

Feces fluid and of a bright jellow color.

Quiet; ears deep red; extensive papular cruption and greasy exudation on the skin; scouring.

Hypodermic injection of one dram of blood and pleural fluid fiom pig just dead. Inoculation liquid contains numerous activel moving bacteria.

Dull; has not eaten supper of last night.

Sconrs.

10 a.m......

5 1). $10 . . . .$.

4 p). in ........

10 a. $m$.......

103. 2

103.5

102.5

103.25

103

102.5

102

103

103. 25

103.7

104

102.5

103

101

102

102.7 .5

102.5

103

10.3

$102 . \mathrm{j}$

101.5

103

102.75

Slightly costive.

Sebaceons secretion excossive on the inner sicks of thighs and forearms, \&e. IIas a blackish-brown color; and disagrecablo but not pntrid odor.

Improving; regaining appetite and liveliness. 
Post-mortem examination at once.-Shin: Covered almost nniversally by a blackish exudation in great part dried into ernsts. On tho ears are some remuants of the former exudations and extravasations; half an inch of the tip of one car is necrotic.

Digestive organs: Mouth healthy. Guttural lymphatic glauds greatly enlarged and gray from pigmentation.

Stomach: Full; contents dry and acid; has reddish discoloration as from blood extrarasations and broad lines along its great curvature. 'The mucous membrane at this point is peeling ofr.

Small intestine: Contents abundant and liquid. Spots of congestion of about ono

line in diameter; no uleers nor erosions; six ascarides.

Large intcstine: Presents little abuormal. One or two depressed spots like cicatrices.

IIcsenteric glands: Greatly enlarged and mostly grayish from pigmentary deposit.

Inguinal glands also much enlarged and gray.

Thoracic duct: Is filled with a milky fluid.

Liver: Firm patches of purple. The lower margin very pale; almost transparent.

Splcen: Small, rigid, twisted as if from binding organizing lympl. Its surface is

musually white and fibrous-looking, but there is a deep black line along its anterior border.

Panereas: Sound.

Heart: Right ventricle marked with bluish discoloration, evidently from former ecchymosis. One flap of the tricuspid valve has a round, blackish nodule beneath the endocardium. Left ventricle with similar bluish surface, and bicuspid valre with a translucent thickening.

Respiratory organs: Larynx and right bronchns have each a dark red ecchymosis.

Lungs have black spots of ecchymosis and slight reddening of certain lobules.

Bronchial glands: Enlarged and pigmented.

Subdorsal glands: Enlarged and of a very deep red.

Brain: Generally unchanged.

Experment No. 2.

Poland-China pig, nine weeks old.

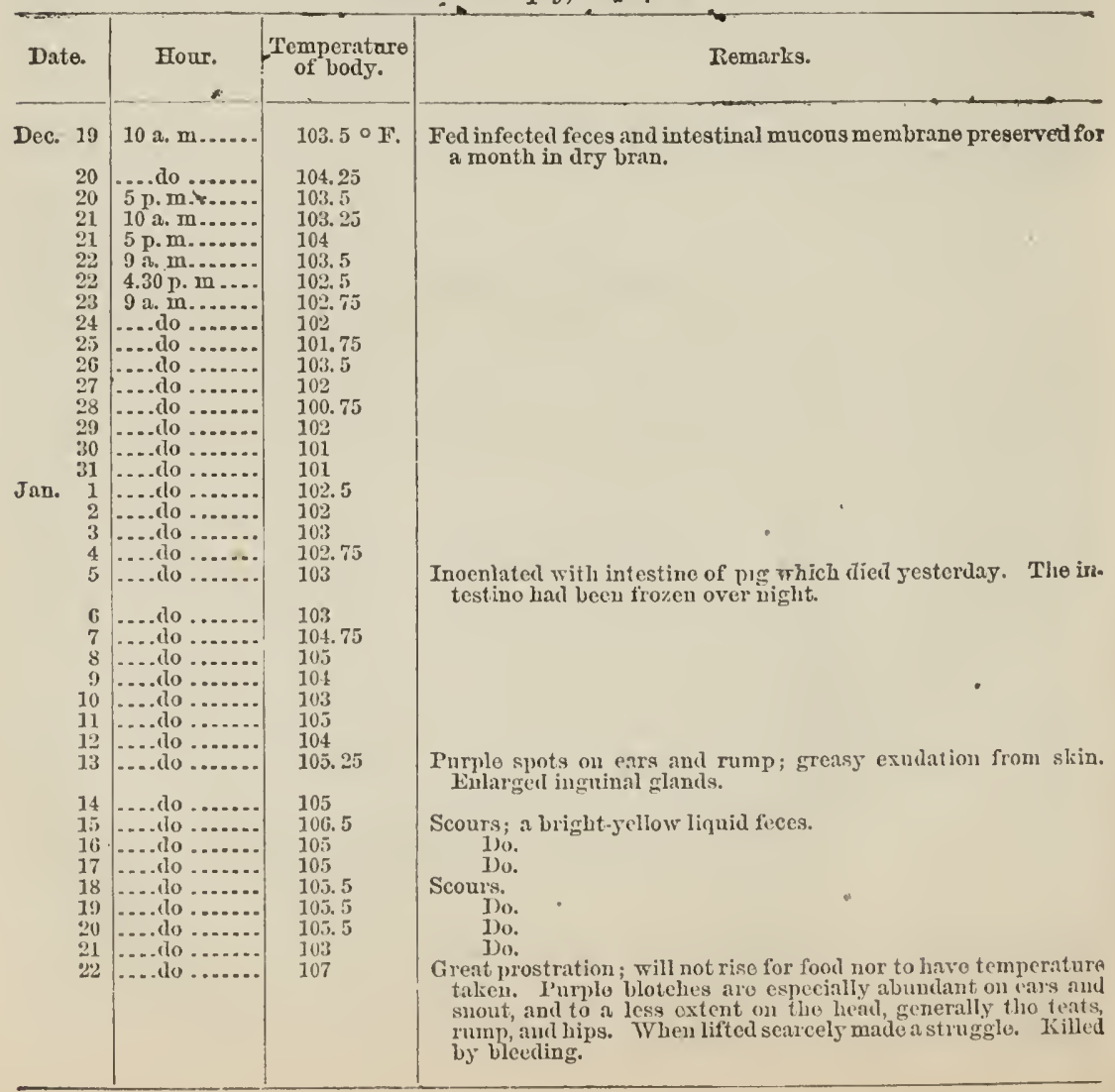


Post-mortem cxamination.-Blood: Dark colored; contained moring bacteria.

Digestivc organs: Tongue sound. Tonsils unusually ied in their openings.

Submaxillary and guttural lymphatic glands: Of a rlark red, merging to a dirty yellow.

Peritoneum: With considerable redilish-brown eftusion and bands of recently formed false membrane. 'The liquid coagnlates on exposure. Under the microscope (No. 10 Hartnack) it is seen to eoutain numerous moving bacteria, also others less active, and two or four segmented chain-like.

Stomach: Full; sour. Great eurvature mottled red and brown.

Sniall intcstincs: Has considerable traeks of deep congestion. It contains much mucus, and ten asearides. One ascaris extended into the gall-duct and as far as the center of the right lobe of the liver; a seeond extended into the middle hepatic lobe. The pressure of these had led to a considerable dilatation of the bile-duet just abore its junction with the cystie duet.

Mio-cocal ralve: Very black, with its follieles enlarged and filled with a jellowish product. The whole length of the large intestine is black from deep pigmentation of its mucons membrane, which is, besides, greatly thickened and puekered. Both conditions imply former active inflammation.

The rectun: Of a dark grayish red; had several caseous deposits under its mucous membrane.

The mescntery: Contains a rellowish caseous deposit as large as a pea.

All the lymphatic glands of the abdomen aro greatly enlarged, pigmented, and in many cases reddened from recent blood-staining. The inguinal lymphatic glands and thoso of the flank are in a similar condition.

Liver: Has patches of deeper purple diseoloration, especially deep in the center of the acini. Pancrcas sound.

Spleen: Shrunken with puckered edges, and whitish thickening of its proper capsule. Kidneys: Vaseular, congested and softened; corticle part dull brownish yellow. Medullary, more or less purple, with deeper shades in lines radiating from the papillx.

Respiratory organs : Margin of epiglottis bears a blue pateh, surrounded by ramified redness. Bronchi and bronchia sound.

Lungs: Of varying shades of light pink in the lobules, cxcepting one or two, which are of a dark red. 'The interlobular spaces are of a deep blood-red eolor, giving a dark marbling over the entire surface. Right pleura contains a little effusion with thread-like false membranes, and the samo bacteria named as existing in the peritoneum.

The axillary prepectoral, internal pectoral, bronchial, and sub-dorsal lymphatic glands were enlarged, pigmented, and in some cases blood-stained.

The har't bore some purple discolored spots on the interual lining.

Experinient No. 3.

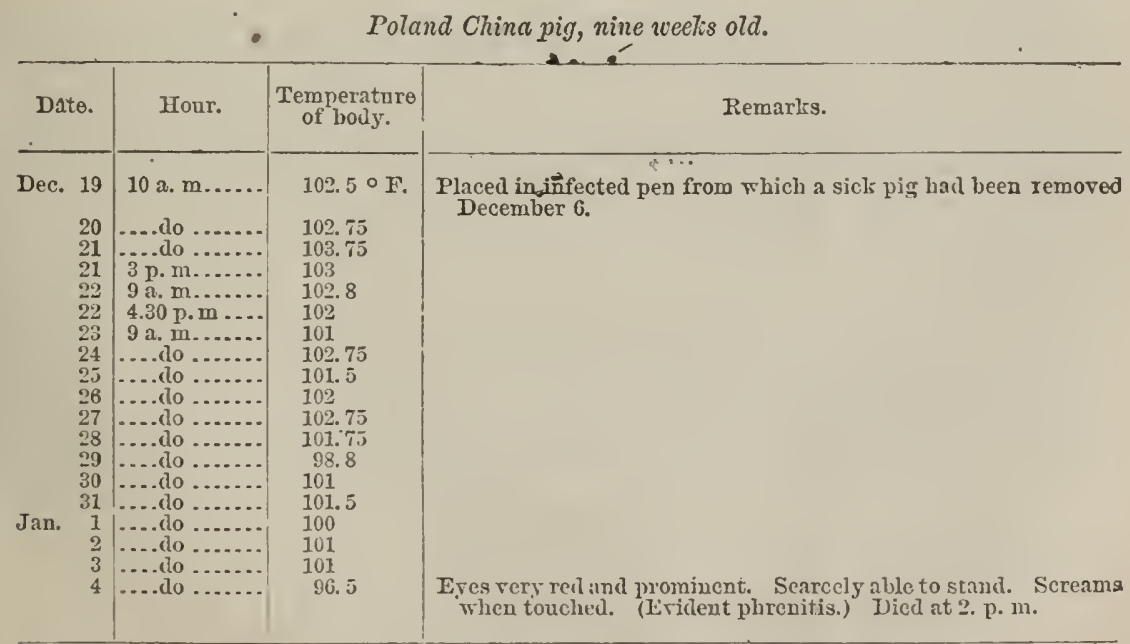

Post-mortom examination the same afternoon. - Skin: Presented little change.

Digestive organs: Month sound, fauces and pharyux of a deep blue color, irremorable by pressure.

Stomach: A portion of about an inch square of a deep red, ankl with an albundant gelatiniform exudation under the mucous membrane. 
Small intestincs : Empty, much eongested, and containing ten asearides.

Laryc intestincs: ILas its mucous membranes congested, reddened, and thirkened. At intervals are circumescribed spots of bloody extrarasation, covered by a elot of blood on the firce surface. These vary from one to two lines in diameter." In a great portion of the colon the contents are very dry and blood-stained. Between tho layers of the mesentery, among the conrolutions of the large intestines, are transincent gelatimoid exudations.

Lirer : Gorged with blood, softened, and somewhat friable.

splecn and pancreas: Normal.

MTesentcric glands: Small, but in some instances partially discolorerl by blool.

Lungs: Congested throughont, of a brick-red, with circunscribed black spots of extravasation.

Bionchia: Filled with frothy liquid, but without worms.

Heart: 'The right cavities were gorged with an intensely black clot. The left carities containcd a smaller clot. No ecchymosis was observed.

\section{Exptriment No. 4.}

Poland China pig, ninewecks old.

\begin{tabular}{|c|c|c|c|}
\hline Date. & & $\begin{array}{c}\text { Temperatare } \\
\text { of body. }\end{array}$ & Rematks. \\
\hline $\begin{array}{r}\text { Dec. } \\
2 \\
2 \\
2 \\
2 \\
2 \\
2 \\
2 \\
2 \\
2 \\
2 \\
2 \\
\text { Jan. } \\
3 \\
3\end{array}$ & 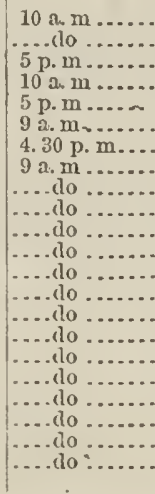 & $\begin{array}{l}103.75^{\circ} \mathrm{F} . \\
104.2 \\
104.5 \\
104 \\
105 \\
104 \\
104.75 \\
103.5 \\
104 \\
102.25 \\
101.75 \\
103.75 \\
102.75 \\
102 \\
101 \\
105 \\
106 \\
103 \\
102 \\
101 \\
101 \\
98.75\end{array}$ & Tery low; can scarcely stand. Died dnrint the following night. \\
\hline
\end{tabular}

Post-mortem examination Jamuary 7.-Shin: Extensively covered with purple maculie and patches. Snout deeply blood-stained, some of the spots extending over the lips into tho mouth. 'Tho greater part of the skin being black, congestions and extravasations into it are only clearly nado ont when it is cut into.

Digcstire organs : 'Pongrio somnd. Plarynx lias pellets of fwoll aecumnlatel in front of the epiglottis. Submaxillary and guttural lymphatic glands evilarged and staincd of a blood recl.

Stomach: Not onc-tlind filled; odor faint, mamkish, not sour. Bears rerl putelies of congestion and ecchynosis on its great curvature.

simall intestincs: Congested almost thronghout. Peycr's patch just above the iliocareal ral ye has some black ecchynosis. On the lower surface of the valve the follic les are cmlargea and filled with a yellowish deposit.

Cacum and, to a still greater extent the colon and reetum, are leeply ennested, aud of a dark resl; tho mucons menbrano is much thickenes and throwin into prominent folkls and wrinliles.

Tiro ascarites were found in the small intestine.

Lircr : Extensirely discolored of a purplo hue, the staining being deepest in the center of the acini.

Splcen: Large, gorgol with blood. Panerens unchanged.

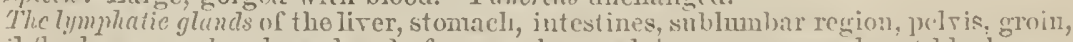
anil flank are much enlarged and of a very deep red, in mans cases almost black.

Fintcys: Cortical substance pale; medullary deep red, with spots of "celysmosis. The anterior part of the left lidney contained a cyst as large as a bean. Thie right eontained tro cysts, ono in tho pelris, tho other in the anterior part.

Respirafory organs:'The epiglottis bore on its posterior surface some congestion and redness, partly ramified and partly cliffuse and incliaceablo by pressure. 
The lungs lave a few black spots of ecchymosis and blood-colored extravasation in tho connertive tissife between tho lobules. The lobnles themselves are only very slightly congested. The left main bronchus present a spot of eccliymosis.

Heart: linjts, presents slight sanguineons discoloration through the lining menbrane.

Experiment No. 5.

l'olend China pig, nine wectis old.

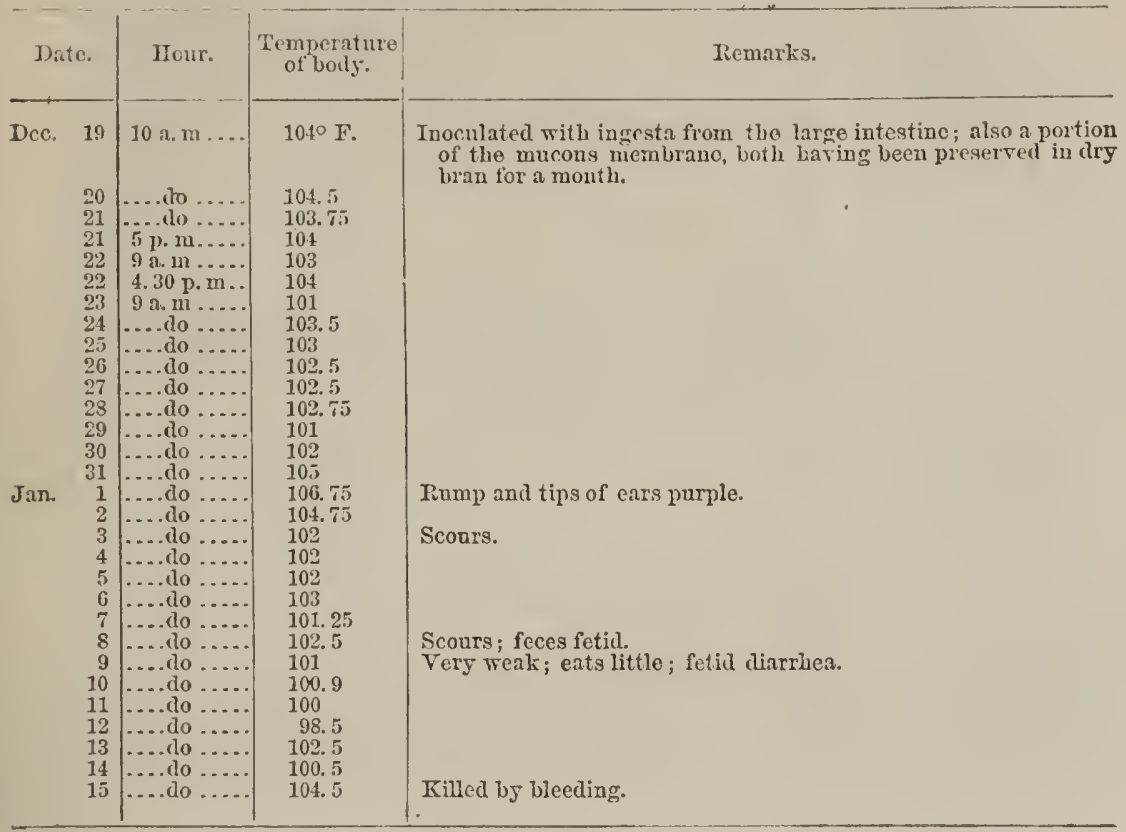

Post-mortem examination at once.-Shin: Ears of a deep purplo and thickly corered with concretions. Remainder of the skin has similar coneretions, bnt no ecclymmosis is oluservable. The snont presents scarcely a spot of discoloration.

Digestive organs: Extensive induration and ulecr on the left sile of its median part and extending over its border. $\Lambda$ similar but smaller uleer exists on the right margin directly opposite. Sinall nlcers exist on the dorsum near the lip ; also a diphtheriticlooking deposit extending over the margin on to the lower surface. Tonsils, patate, and pliarsnx somud. Submaxillary and gutteral $15 \mathrm{mphatic}$ glands are cnlarged and congesterl.

Stomach: Has its nucous membrane thick, rugose, and as if watcr-soaked along its great curvature.

Small intestine: With mucons membrane thickened and puckered thronghont; the ünodenum deeply congested.

Nio-cacal valve: Thickened; its follicles enlarged and filled with a rellow ish deposit. Mincous membrano of cacum and colon deeply pigmented and of a dark gray aspect. Somo parts of the colon are still red in patches. Rectum pigmented, presents soveral small ulcers and a caseous deposit bencath tho mucous membrane.

tiver: Bears blue patches of various sizes; gall-bladder contains a little bile of a bright jellow color, with greenish flakes.

Spleen: Small aud puckered, so that its borders turn inward.

l'anereas sound.

Abdominal lymphatic glands: Hepatic, gastric, splenic, pancreatic, mesenteric, sublumwar, ard pelric, as woll as the iliac, are enlarged, pirmented, and partially congested. isidneys: Corticlo substances pale rellowish, slightly snitened; in the caso of ono, reddened to the depth of one-third line. Medullary portion deeply colorerl.

Tiespiratory organs: Larynx and trachea sound; right lung with alpanst the normal pale pink hito externally, but secms to wo congested internally when cnt into; left lung noarly norwal; heart and pericardium normal. 
Experment No. 6.

Poland China pig, eight weelis old.

\begin{tabular}{|c|c|c|c|}
\hline \multicolumn{2}{|c|}{ Date. } & Hour. & $\begin{array}{l}\text { Body temper- } \\
\text { ature. }\end{array}$ \\
\hline Jan. & $\begin{array}{r}19 \\
20 \\
21 \\
21 \\
22 \\
22 \\
23 \\
21 \\
25 \\
26 \\
27 \\
28 \\
29 \\
30 \\
31 \\
1 \\
2 \\
3 \\
4 \\
5 \\
6 \\
7 \\
8 \\
9 \\
10 \\
11 \\
12 \\
13 \\
14 \\
15 \\
16 \\
17 \\
18 \\
19 \\
20 \\
21 \\
22 \\
23 \\
21 \\
25 \\
26 \\
27 \\
28 \\
29 \\
30 \\
31 \\
\\
\\
\\
\\
\\
\\
\\
\end{array}$ & 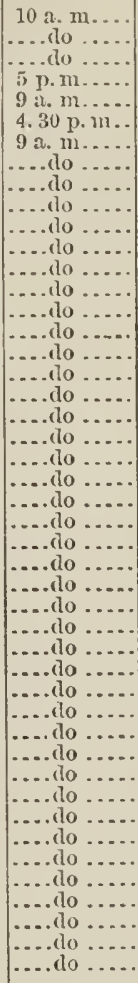 & $\begin{array}{l}10407 . \\
103 \\
103.75 \\
104.5 \\
103.75 \\
104 \\
104.25 \\
103.75 \\
103.75 \\
105 \\
103 \\
104 \\
104 \\
103 \\
102.5 \\
102 \\
103 \\
103.25 \\
103 \\
103 \\
101 \\
102.75 \\
102.5 \\
103 \\
103 \\
103.25 \\
104 \\
101.25 \\
103.5 \\
106 \\
105 \\
105.5 \\
104.8 \\
104.5 \\
104.25 \\
105 \\
103 \\
103 \\
103 \\
101 \\
10.1 .75 \\
104 \\
103 \\
102 \\
102 \\
103\end{array}$ \\
\hline
\end{tabular}

Placed in pen with anothor pig in height of the disense.

Feces conted with film of blood.

Bloody feces.

Do.

Do.

Do.

Do.

Bloorly feces. Inguinal lymphatic glauds enlargod.

Appetite improring.

EXPERMENT No. 7.

I'cmale rabbit.

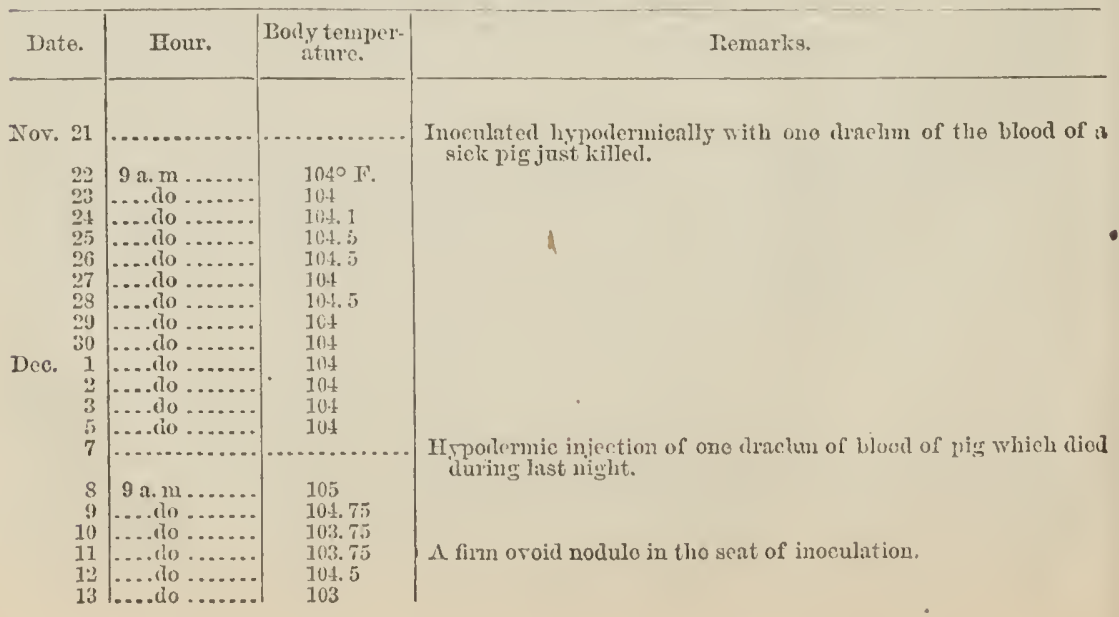


Experiment No. 7-Continued.

\begin{tabular}{|c|c|c|c|}
\hline Dato. & Irour. & $\begin{array}{l}\text { Borly temper- } \\
\text { iture. }\end{array}$ & Tenarks. \\
\hline $\begin{aligned} \text { Dec. } 14 \\
\\
15 \\
15 \\
16 \\
16 \\
17 \\
17 \\
18 \\
18 \\
19 \\
\\
20 \\
21 \\
21 \\
22 \\
22 \\
23 \\
24 \\
2.5 \\
26 \\
27 \\
28 \\
\\
29 \\
30 \\
31 \\
1 \\
2 \\
3 \\
4 \\
5 \\
6 \\
7\end{aligned}$ & 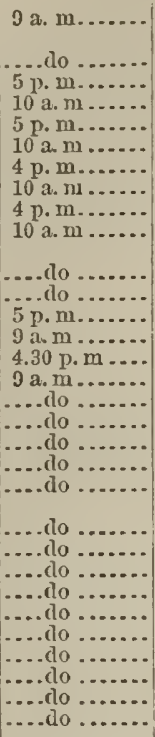 & $\begin{array}{l}103.50 \mathrm{IF} . \\
105.5 \\
105.5 \\
106.25 \\
106.75 \\
105.5 \\
103 \\
105.75 \\
105.5 \\
104 \\
104.75 \\
103.5 \\
104.5 \\
103.5 \\
104.25 \\
103.5 \\
104 \\
104 \\
104.75 \\
104.75 \\
105 \\
104 \\
105 \\
105 \\
104 \\
104 \\
103 \\
103 \\
.103 \\
102.5 \\
102\end{array}$ & $\begin{array}{l}\text { Hypodermie injection of ene drachm of blood of pir found dcad } \\
\text { this morning. Iblood swaruing with activcly-moring bacteria. } \\
\text { Mas not eaten supper. } \\
\text { Eats nothing. }\end{array}$ \\
\hline
\end{tabular}

Post-morten examination at once.-Connected with the raw soxo in the groin was an immense mass of whitish, fibrous material, infiltrated with pus, and extending from tho lumbar vertebra above to the median line below. The mesenteric glands were enlarged and blood-stained. 'I'wo had been transformed with yellow, eheesy-looking masses. The stomach and borrels appeared healthy; also the liver and spleen, heart and lungs.

EXPERMENT No. 8.

Poland China pig, cight wecks old.

\begin{tabular}{|c|c|c|c|}
\hline Dato. & Howr. & $\begin{array}{c}\text { Body tomper- } \\
\text { aturo. }\end{array}$ & Remarks. \\
\hline Dcc. 18 & 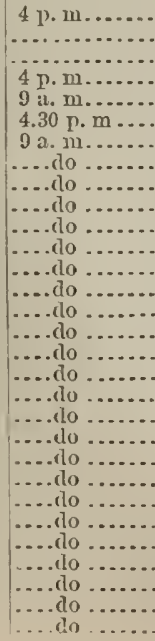 & \begin{tabular}{|l|}
$103.750 \mathrm{~F}$. \\
$\ldots \ldots \ldots \ldots \ldots$ \\
\hdashline 103.5 \\
101.5 \\
103.75 \\
100.75 \\
101 \\
101 \\
101.5 \\
101 \\
101 \\
100 \\
100 \\
102 \\
102.75 \\
102 \\
101.5 \\
102 \\
103.5 \\
104.5 \\
104.75 \\
104.5 \\
104.25 \\
103 \\
103 \\
102.5 \\
103 \\
104.75 \\
105
\end{tabular} & $\begin{array}{l}\text { Inoculated with matter from open sore of siek rabbit. } \\
\text { Feces fotid. } \\
\text { Fetid diarrhœa. }\end{array}$ \\
\hline
\end{tabular}


Post-mortca examination.-Shin: Naturally black; no purple nor congested spots seen.

Digestice orgers: Mlontle and thrnat healthy.

Gullued lymphatic silands: Enlarged amb sonewhit congested.

Stomnch: Moderately fill ; of a deep brownish red along its great curvature.

Small inteșne: Slightly congested in jatehes; contains twelve ascarilles.

Lourge intestine: Nearly normal.

Mcsculeric lymphutic glands: Enlarged and slightly concested. 'Their surfice presents elear, glistening, ronnded masse's liko pins' heads. Fngunal glends liavo the same character.

Lung: Isolated folonletters are dark red and solit; at some points tho interlobular connective tissue is distenclod by a dark-red infiltration.

In the bronchia of the left lnng were twelve strongyli.

Experment No. 9.

Common white pig, ten walis val.

\begin{tabular}{|c|c|c|c|}
\hline Date. & Hour. & $\begin{array}{c}\text { Lody tomper- } \\
\text { iture. }\end{array}$ & Remarks. \\
\hline 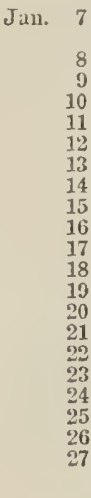 & 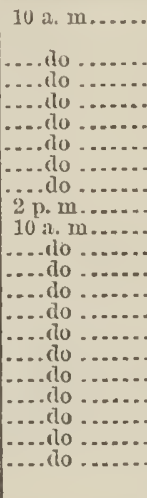 & $\begin{array}{l}1010 \mathrm{I} . \\
102.5 \\
103 \\
103 \\
101.75 \\
102 \\
103 \\
103 \\
101 \\
102.25 \\
103.25 \\
103.8 \\
103 \\
105.25 \\
105.3 \\
104.5 \\
105 \\
102.5 \\
105 \\
98.75 \\
97\end{array}$ & 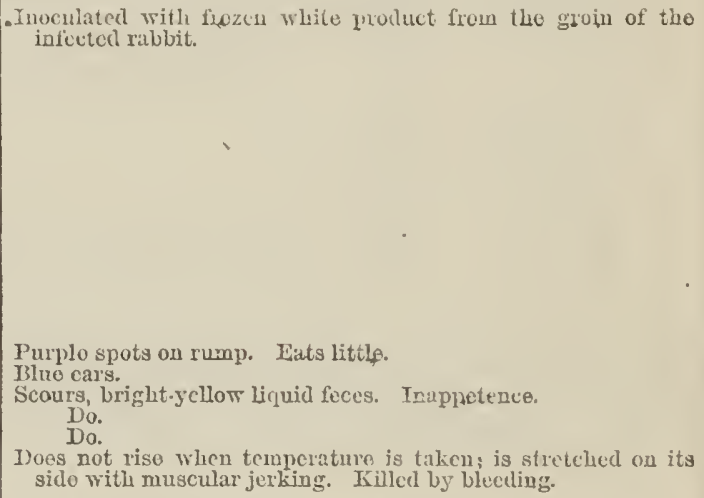 \\
\hline
\end{tabular}

Post-mortem examinction.-Shin: Margin of snont for onc-hatf line tleep of a dark brown, and apparently withont rascularity or life. Bencath this is a red congested line.

Ears : Deeply blotehed with dark red and purplo macular, cach about one-laalf inch in diameter, but to a great extent confluent, so as to form extended lines ami patches. Stump of tail maeulated. Perincum and adjacent parts of hip of a cleep purple.

Digestive organs: Tonguo with a whitish fur. On tho eenter of its dor'sal surface is a dark spot about tro lines in diameter, which is foum to cover a consilderable extravasation and clot on tho muscular substanco. Glandular follicles on tho lower snrfaco of the soft palato filled with a soft yellowish puriform mass.

Submaxilliary lymplntic glands: Greatly eularged and of a deep purple. Crultural glands also bloorl-stained and moderately enlarged.

Stomach: Full, vory fetid, not soms. Great curraturo has its mucons membrano much eougested with numerons black spots of extravasation projecting beyoud the general surface. In tho left cul de suc the ingesta next the mucous mombrane is of a clark baked appearance and firmly atherent to the mucons nembrane, the epithelial layer of which eomes ofî̀ with it. It has evidently been adlerent for some time.

Small intestines: Have large tracts of congestion, and in the dnotemm and commeneement of tho jejunum are ten ascaricles. Seven asearides have mado their way into the gall dnet and the different lobes of the liver, but none in the cystic duet hor gallbladker. The biliary duct is greatly distended and coaterl with a lay we" of yellowishgreen liliary coloring matter.

The ilio-cecal value: Has its margin of a deep grayish-black amb its follicles enlarged.

The large intestines: Aro throughont black from pigmentary deposit, fle hlackness being especially marked on the agminated gland, extending fiom tho ilin-careal ralve on the colon. Many round blackish elovations are seattered orer tho length of the colon, appearing like enlarged solitary glands. On somo parts of the colon the dark 
color is molified by the decp red of a recent congestion. Thronch the whole leugth of the largo intestine the mucons membrano is considerably thickened and prekered. Near the anns are some cascons deposits beneath the mucous membrane, but commmicatiug with the surfiace by opeu oritiees.

The liver: IIas great patehes of a deep purple, decpest in the center of the aseini.

The gall bladdo: Is lull of dark dreen, thick, very viscid bile.

The inguinal, sublumbar, nesenteric, mesocolic, gastric, and hepatic 7ymphatic glands : Aro greatly enlarged and deeply blood-stained.

The kidneys: Somewhat softened, are of a dull yellowish brown in the eortical portiou and of a puple hne, with clarker radiating lines in the medullary.

liceputory organs : Larynx sound. Lungs sound, excepting some sliwht congestion in particnlar lobes, and the filling of the brouchiat and air-cells with blood evidently drann in in dying. No pleural elïusion.

Heart and pericardium: Soumel.

Expeninext No. 10.

ITcrino shcep.

\begin{tabular}{|c|c|c|c|}
\hline Date & Hour. & $\begin{array}{l}\text { Bocly-temper- } \\
\text { ature. }\end{array}$ & Remarlis. \\
\hline Nor. & 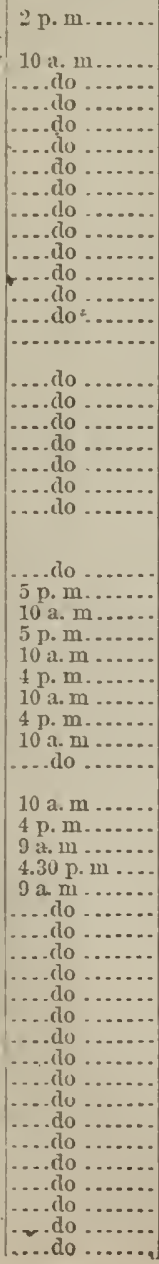 & 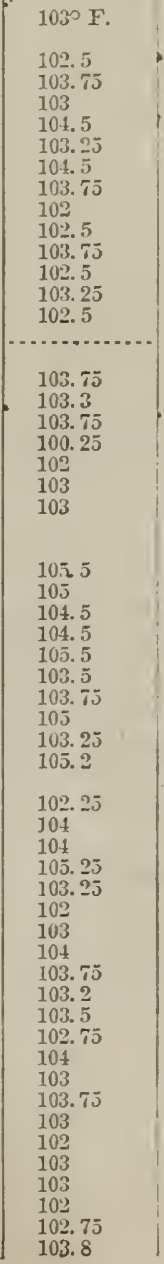 & $\begin{array}{l}\text { Hyporteruic injection of ono and a hilf draclums. Blood from } \\
\text { sick pig just killed. } \\
\text { Scouriug and snufting } \\
\text { Hypodermic injection of tro drachus blood from pig which } \\
\text { died during the night previous. }\end{array}$ \\
\hline
\end{tabular}


Experiment No. 10-Contiuued.

Merino sheep-Continued.

\begin{tabular}{|c|c|c|c|}
\hline Date. & Hour. & $\begin{array}{c}\text { Borty-temper- } \\
\text { ature. }\end{array}$ & Remarks, \\
\hline $\begin{array}{l}11 \\
13 \\
13 \\
14 \\
15 \\
16 \\
17 \\
18 \\
19 \\
90 \\
21 \\
22 \\
23\end{array}$ & 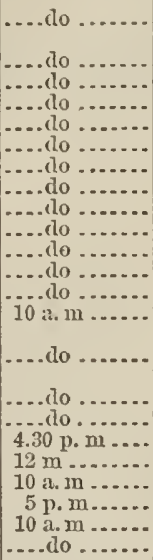 & $\begin{array}{l}10301 . \\
103 \\
103 \\
102.5 \\
103.5 \\
103 \\
103.5 \\
103.5 \\
103 \\
104 \\
102.75 \\
103 \\
103.5 \\
102 \\
101 \\
101.5 \\
104 \\
105 \\
105 \\
103 \\
104 \\
105 \\
104\end{array}$ & $\begin{array}{l}\text { Scours. Anus red and sore. Stiongly objects to the thermom. } \\
\text { eter. Has passed bloody mucus. } \\
\text { Anus still red and pufy, with abundant mucns. } \\
\text { Scours. } \\
\text { Do. } \\
\text { Anus still red and swollen. } \\
\text { Samo afternoon injectod ono rlachm of blood and pleural anid } \\
\text { fiom pig just killed. Fluids contained activo bacteria. } \\
\text { Slight subcutaneous swelling in the light axilla. 'Tendernoso } \\
\text { of the slin of the abdomen. }\end{array}$ \\
\hline
\end{tabular}

Experinent No. 11.

Long wooled (cross-breed) lamb.

\begin{tabular}{|c|c|c|c|}
\hline Date. & Hour. & $\begin{array}{l}\text { Body-tempor } \\
\text { ature. }\end{array}$ & liemarks. \\
\hline $\begin{array}{r}\text { Jan. } 17 \\
18 \\
19 \\
19 \\
20 \\
21 \\
22 \\
22 \\
23 \\
\\
21 \\
25 \\
26 \\
26 \\
27 \\
28 \\
\\
28 \\
29 \\
30\end{array}$ & 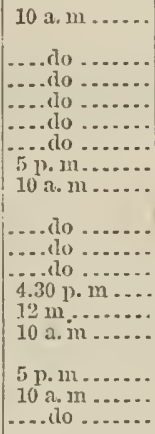 & $\begin{array}{l}104.250 \mathrm{~F} . \\
104.25 \\
103.8 \\
105.25 \\
103.5 \\
106.5 \\
104.75 \\
10.6 .5 \\
108 \\
107 \\
104 \\
108 \\
108 \\
105.25 \\
106 \\
106 \\
104\end{array}$ & 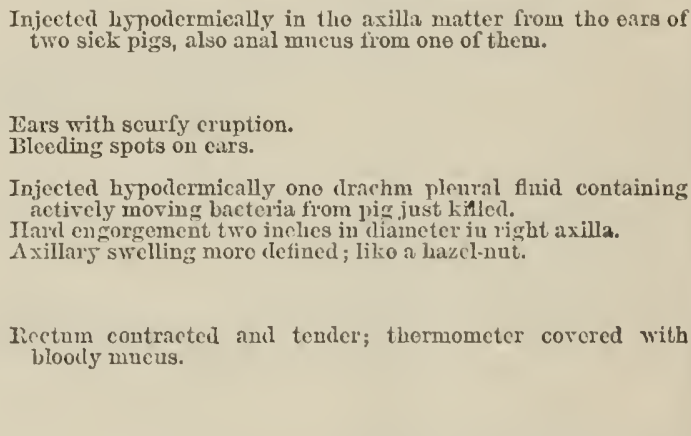 \\
\hline
\end{tabular}

ImracA, N. I., February 5, 1879.

JAMES LAT.

\section{REPORT OF DR. D. W. TOYLES.}

\section{Hon. WMr. G. LE DUC,} Commissioner of Agriculture:

STr: In conducting an examination of the diseases of swine, as prevailing throughont the State of Indiana during the present season, the following plan was pursued, viz:

A tonr of observation and inspection was made through the counties of Floyd, Inarxison, Wishington, Greene, Mrorgan, Monroe, Oren, Put- 
nam, and Bartholomer. Some of the most intelligent and leading stock men of each county were sought, and all the information obtained which they had upon the subject of the disease, both in regard to its present manifestation and past history. Speculators in live hog's and large feelers were closely interrogated upon every feature of the disease as coming within the range of their experience and observation. Diseased herds were visited, and in each case the farm minutely inspected in all its bearing's upon the health of animals; the methorls of breeding, feeding, and general management of swine diligently inquired into; dead animals, where not too far adranced in decomposition, dissected, and living ones, having the disease, were slaughterel for examination, and the pathological indications carefully noted. The month of September was entirely deroted to this branch of the inrestigation.

The object of this method of inquiry was to ascertain whether the disease, as prevailing throughout these several districts, was uniform in its character, differing only in such modification in type as may be due to local influences; or whether these were to be found separate and distinct diseases in different localities, due to entirely different causes for their production; and if uniformity was found to exist in tho character of the disease as now prevailing, to learn from practical aud intelligent observers in each district whether, in any essential particular, it differs from the disease that has prevailed in other years.

\section{PREVALENCE OF THE DISEASE.}

The several districts visited were all more or less affected by the disease, but to a much less extent than during former years, except, perhaps, in the county of Putnam, where it was prevailing for the first time as a general and wide-spread epidemic, the loss being estimated at from fifty to sixty thousand dollars. In this county the surface is sufficiently undulating to produce good drainage; the soil is red clay on limestone. Springs of pure limestone water are abundant, and woodlamns beautifully swarded with blue grass are seen upon almost every farm. Feeding swine has been an extensive and profitable branch of farm industry in this county, and the herds are, therefore, quite large for a mass-growing section. During the summer montlus hogs in this county run upon blue grass and clover, and are fed some corn. We found the corn so fed often unfit for use, because of a rery reprehensible practice of hauling to the field for convenience in feeding and throwing it in an open rail pen, where, by exposiure to heat and moisture, it soon becomes moldy. The mean temperature in this county during the summer was slightly abore, and the rain-fall considerably below, the average seasons.

The comnties of Floyd, Harrison, and Washington possess much the same kind of soil, and are abundantly supplied with rumning sprin $\mathrm{ss}$ of limestone water; but blue grass and clover are not so extensively or generally grown. In these three caunties hog-raising is not a branch of farm industry sufficiently remuneratire to induce the farmers to generally engage in it, and the herds are, therefore, usually small and the animals rery imperfectly cared for.

The observations made in the counties of Greene, Oren, Monroe, Morgan, and Bartholomew were on a line with the White River Valley. This and the Wabash Valley constitute pre-eminently the hog-growing sections of Indiana. It is in this part of the State that the clisease has prevailed to the greatest extent. Hog-raising being the leading business industry, the herds are ordinarily quite large.

No observations were made in the Wabasl country. In the White S SW 
Kiver Valley the disease has prevailed during the present season to inuch less extent than for sereral years past. This is clue in part to the fict that there are not so wany hogis here as formerly-great loss having greatly disconraged hog-raising, a branch of agricnitural inclustry lieretofore paramount to every ofher interest.

The less prevalence of the disease is also due in part to the increased facilities for sclling to siummer packers; the approach of the complaint in and giren locality being the signal for the selling of every marketable animal.

In these hog-growing districts, the surface of the country is yuite flat, affording very imperfect natural drainage, and as a consequence much stignant water prevails. The soil is a mixture of clay and sand. The food is mainly corn, with some clorer during the summer months, the anizals often subsisting upon corm alone from the time of birth to that of slanghter.

In tho comty of Bartholomew there are several "grease factories," where they renier ciead animalis, and it is estimated that durims the year 1876 there were rendered at theso several factories no less than one hundred thousand animals that died of tho disease in that and adjacent counties.

It is the coneurrent testimony of the leading and most intelligent observers, whose experience and observation have been most extensive, that while the disorder prevails more or less at all seasons of the year, it prevails to the greatest extent and with most fatal effect during the dry months of the fall season, and again during the last wiuter and first months of spring-February and March.

\section{SYIIPTONS OF THE DISEASE.}

A greater degree of uniformity was found te exist in the symptoms and character of the disease than was antieipated at the beginning of the investigation. The first synptoms that usually attract the attention of the farmer, indicating approaching disease, is a wheezing congh, coupleci with a disposition to mope. During this period the animal stands about as if in a "browu study," with its ears dropped and its eyes inciined to water or matter.

Following in the usual suecession of symptoms comes a failure in the appetite, with occasional vomiting and diarrhea, although the two lastnamed symptoms constitute an exception, to which constipation is the rule.

A completo failure in the appetite, intenso thirst, with increased temperature of the body, indicates the supervention of the febrile and inflammatory stage of the disease. During this stage the temperature not infrequently rises as high as $107^{\circ} \mathrm{F}$, as indicated by the introdnetion of the thermometer into the rectum of the animal. The congh increases; the breathing becomes more acceleraterl and laborious; the respiratory morements are scarcely observable in the walls of the chest, but become conspicuous at the flank, and range from 30 to 60 inspirations to the minute; the arterial circnlation is increaser in frenuency and diminished in volume. Petechial ermption is often observed on the skin and is most distinctly observable on white amimals. This is che to extravasated blood from the capillaries into the tissues, which, on undergoing decomposition, produces ulceration of the slin in the future course of the disease, particularly if the animal becomes convalesecnt.

In the last stage the animal becomes very weak; staggers in gait, if alle to rise at all; refuses both food and drink; falls in temperature, 
sometimes as low as $60^{\circ} \mathrm{F}$; seelis the sumshine or a ecrering of litter, and speedily dies. Emaciation is a rapidly progressive sympton thronghont the cutire course of the disease.

\section{DUTATION OF THE DISEASE.}

The disorder is by $n 0$ means uniforms in its duration, rarying from a few hours to many days and oven weoks. When death oceurs only a few hours after the attack a complieation of heart discase is usually the cause of the rapid termination of the case. Early fatality may occur also from rapiol congestion of the lungs, producing hepatization of a large portion of that organ. 'The arerage diuation of the discase can be, therefore, scare? y aproximated. Perhaps five days would inchnde the length of time consumed in most fitul 'ases, whereas a much greater length of time is required in cases that recover. In its most violent epidemic form a much less time than five rlays woukl include the comrse of the disease in all fatal cases.

\section{PATIOLOGY OF THE DISEASE.}

As before stated, all dead animals not too far advanced in decomposition rere examined, and one or more sick animals were selected from each diseased herd, and after a careful study of their srinptoms, as compared with the other sick stock or the herd, were slanghtered for examination.

Memoranda froin thirty dissections made from fifteen separate and distinct herds fairly representing the disease as observed under ill the varied cireumstances as to food, soil, water, and general management, show the following results:

In every case, without exception, disease of the lumgs was present, varying in degree from slight congestion to complete softening from suppuration and inflammation. In two cases the $l \mathrm{mng}$ disease was tuberculous in character. In eight cases adhesion occurred between the costal pletura and lumg. In six cases circumseribed spots of inflammation were found on the walls of the heart and its invesiment, with an effusion in the perierrdial sack. In six eases were small patches of ulceration of mucous lining of large intestine. In six eases were congestion of mucous lining of the stomach. In all cases the lirer presented a darker hue than uatural, in four cases slightly, and in one greatly enlarged; but in all other eases in size and general appearance rrould compare favorably with that organ as usually obserred in animals re. garded sound and healthy. The spleen was in all cases discolored, as in case of the liver. In fow eases there was slight congestion of the kidneys. In one case there was evidence of fatty degeneration, aud in all others the organ indicated a healthy condition. The blood was always dark-colored, the muscles pale and relaxed.

The disease of the lungs was in all cases the leading pathologieal condition, to which all other diseased appearances were secondiny in importance, constituting complicatious only.

A section of the lung of an animal slanglitered during the active inflammatory state of the disease shows, under the microseope, a complete solidification of lung-tissue, the air-eells being filled with eyithetial exudation, no extravasated blood appearing. I seetion of the liver of the same animal shows a thickening of the selote acini by a proliteration of epithetial cells, tending to or constituting futty degeneration; other acini in the sane section exhibit a perfectly healthy condition. A sec- 
tion of intestine from same animal shows a healthy condition. These three sections are transmitted with this report for rerification. (See microscopic sections, Plate XV, Figs. 1, 2, and 3.)

The contents of the stomach and intestines were liquid in six cases, and dry, hard, and very dark colored in all other's.

The gall-bladder usually contained a small quantity of thin, greenish fluid.

The trachea and bronchial tubes contained a large quantity of matter apparently consisting of mucus and broken-down epithelium.

\section{DIAGNOSIS OF THE DISEASE.}

Judging from the risible causes that appear most active in its development-the symptoms and pathology of the disease-we feel warranted in pronouncing it, in its milder manifestations, bronchial catarrh, and, iu its most active and fatal form, catarrhal pneumonia.

There is no symptom uniformly present in the disease, as we lacro observed it, that bears any analogy to the symptoms of cholera as affecting the human subject, and the term "hog-eholera" is therefore a misnomer; and although there is, ordinarily, little or nothing in a name, in this instance the misnaming of the disease has been a source of incalculable loss, by suggesting a line of treatment irrationally administered and caleulated to aggravate rather than cure it.

\section{ITS CAUSE.}

It is when seeking the cause of this wide-spread epidemic disease that the field of investigation takes widest range. As already stated, it prevails more or less at all seasons of the year, and under almost every conceivable condition and combination of conditions as to soil, food, water, locality, and general management; but the difference in its prevalence under certain circumstances is so marked and uniform that from these facts we may derire some definite information as to the canses most active in derelopment.

The past history of the disease would indicate that it originated in this country at a time when the condition of swine was visibly altered from a comparative state of nature to one of more perfect ilomestication. When the country was new, affording almost unlimited range, the hogs bred, grew up, and roamed in the forest until maturity. Being allowed the free use of their noses, and being omnirorous in nature, they fed ou worms, roots, mast, and such other food as was provided and given them by their owners; they exereised as their inclination or necessities inclined them; had free access to ummerous springs and streams of rumning water; slept in storm-sheltered thickets on beds of clean leaves, and enjoyed under these circumstances a vigor of constitution and an immunity from disease unknown to the modern swine-breeders of the country. As the country became more densely populated, rendering it necessary to clear up and inclose the land for agricultural purposes, the lank, active, long-nosed animal of the pioneer age began to disappear in order to give place to a new and more adranced civilization in the history of his race. A close business calculation demonstrated that a hog fed to profit on food produced by manual labor must have an inbred teudency to take on flesh, and that tendency encouraged by close confinement and high feeding.

The hog of to-dlay is the result of persistent in-breeding for an obeso habit, encouraged by want of exereise and over-feeding. An animal, 


\section{1 $11: 1 \times 1 \% 1 \%$}

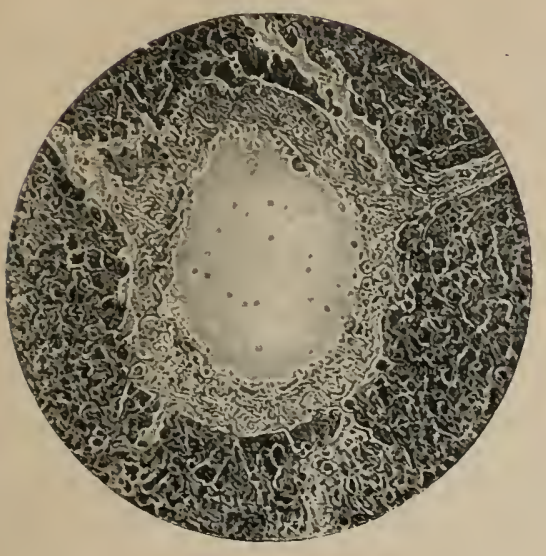

lidi. 1 .

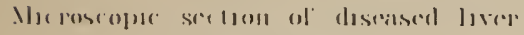
in "Hog ('holes'a "

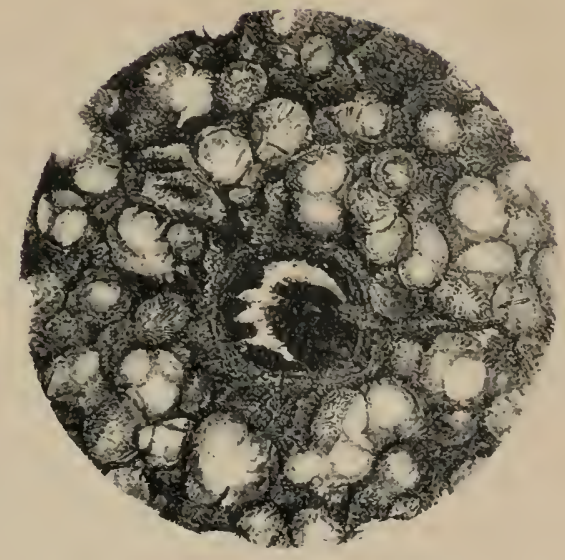

l'ig. ㄹ.

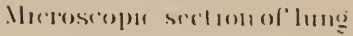
[11 calantha] purmontaia

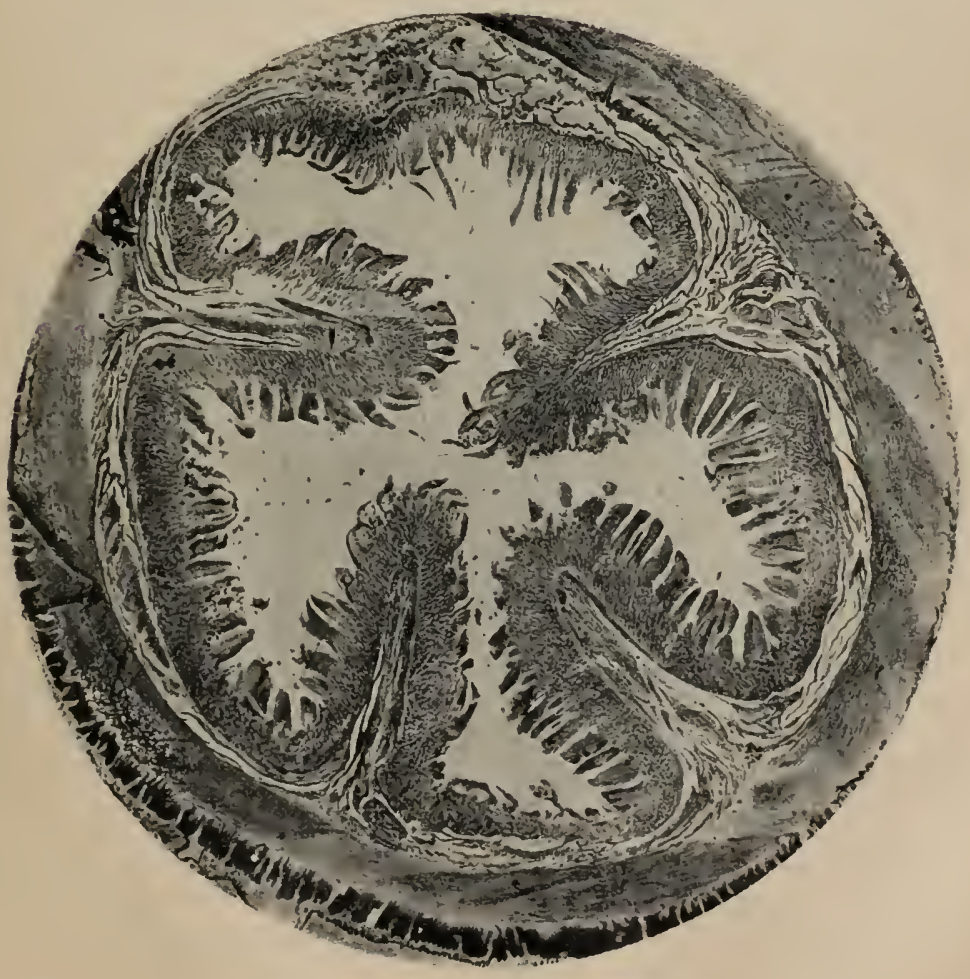

Viog.?

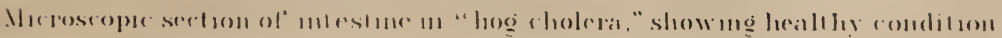



quite comely in shape, early in maturity, of strongly-dereloped fattening tendencies, and of enfeebled constitution, is the intelligent and natural result. An animal thus depriced in part of the constitutional vigor of its ancestors, forced to gire in part the instinctire habits of its race in obedience to the regulations of modern farming, must necessarily have acquired a diseased tendenc5. If, under these circumstances in the era of modern swine-breeding, the animal is more exposed to causes producing disease, a general prevalence of disease must be the result. Do such causes generally prevail, which, operating upon well-known principles in animal physiology, are calculated to produce the diseadse as we have observed it? If not, we are forced, in the absence of visible and rational causes, to indulge in hypothesis, and seek some hidden poison which, operating to produce the disease, mas, therefore, propagate it by contagion.

We have assumed that the animal of the present period is one of impaired constitution, and that its habits, as imposed by the will of the farmer, as to food, water, cleanliness, exercise, aud rest, do not approach so nearly a strict observance of the laws of health as do the instinctive habits of the animal in an unrestrained state of nature. The habits in the latter state hare been briefly alluded to already. What are the altered conditions that conflict with the laws of health as imposed by the former state?

\section{FOOD.}

In considering this branch of the inquiry we will examine briefly the subject of food. The hog is an omnivorous animal; he eats both animal and regetable food; his instinct demands and his health requires it. In his native state he obtains the animal food required by the industrious use of his nose in digging for worms and insects; but the most improved methods of modern swine-breeding have proclaimed the nose of the hog a useless appendage, and bred it to the smallest possible size-a thing of beauty to adorm a ring. The animal, thus deprived of the natural means of obtaining a supply of animal food, is forced to subsist almost exclusively upon vegetable diet, consisting almost wholly of corn. That this style of feeding long pursued is not conducive to the highest state of health would seem self-erident. In the hog-growing districts, corn alone is often the only food fed to swine from birth to slaughtering, and it is in these districts that the disease is most prevalent and fatal. On the contrary, hogs fed the offal from milk and cheese factories, or from city and hotel garbage, are always most free from disease. In the city of New Albany, Indiana, there are more swine to the square mile than elsewhere in the State; their rights are somewhat sacred; they rmu in every street, sleep in every alley, and break into almost every yard; as scarengers they constitute a sort of independent body of health police, anxiliary to the board of health; the arerage councilman regards them in some sense as his constituency, and the people, therefore, have vainly prayed for hog-ordinances and hog-cholera, and still the animal feeds upon our bounty, multiplies liis race, and almost defies disease.

\section{WATER.}

During the dry months of the fall season it seldom happens that hogs have a proper supply of good pure water, even in well-watered districts of country. In all the herds examined where the disease prevailed, in but one instance was a proper supply of pure mater observed; in a large number of cases there was positively no water, only thin mud at the 
watering place. At the farm of Mr. Quinn, near Hartsville, Indiana, where the clisease was prevailing, twelve head of sick animals were running in an inclosure, and when the proprietor was asked about the supply of water, he said, "There was plenty-a good spring." On personal examination the spring was found to issuc from a bill-side, with but little incline; from the piace where it issued to the point where it disappeared from exhainstion-a distance of some 40 feet-there was a long bed of thin mud, and no visible appearance of running water at any

point. He was asked on our return when he last inspected the watering place, and answered, "This morning." He was then asked if he thouglit the supply of water at that spring wonld supply a few horses or cattle with water, if thie logs were taken out, and he replied promptly in the negative, and when asked by what process of reasoning he came to the conclusion that water of acknowledged unfitness for anything else was quite good enongh for loggs, and sick ones at that, he replied, in substance, that hogs would not use water until they rendered it unfit for any other kind of stock!

We mention this case in detail because it fairly represents the views of the average farmer upon the subject of water for swine-n "any water is good enough for a log."

\section{CLEANLINESS.}

The domesticated animal does not approximate the habits of his pioneer ancestor in point of cleanliness. It is the instiuctive habit of the animal to bathe in water and wallow in mud to connteract heat and as a protection against flies; but in a state of nature, when the mud has served its purpose, the animal cleanses himself by friction with the nearest tree; the filthy bed which the domestic animal becomes satisfied to occupy in a state of confinement is never occupied by animals running in the forest, and given opportunity to make and change their sleeping places at will-in short, when allowed to provicle for his own existence, he exercises a more intelligent regard for his wants than is ordinarily exercised for him by his owner, who attempts to supersede instinct by reason.

The frequent allusions made to the native hog may provoke the inquiry, Are we to return to the ill-shapen and ungainly animal of forty years ago? Certainly not. In this age of high-priced corn, such an animal is unworthy of an existence. The only thing to be admired of him is his health and constitution; the only usen̂l lesson to be derived fiom allusion to his history is the means by which these were acquired and maintained. Food, faulty in character and wanting in variety; water, deficient in quantity and purity; quarters, too limited in space and filthy in condition, are the three leading factors in the production of disease of swine.

Special attention was giren to the examination of the surface land occupied by diseased animals, and while there were exceptional eases, in quite a large majority of instances they were running in fields jroducing quite a luxmiant growth of weeds which, during that season, were shedding their seed, bloom, and leaves. The carth was exceedingly dry and dusty. In traveling through the fields the animals created a dust from the earth and from the weedss also, which, together, were taken into the air-passages and lungs with the air breathed, constituting an active sourec of irritation. While pursuing this branch of the inquiry we were informed by some intelligent observers that they bad noticed that animals rumning in such fields, particularly wheat and rye stubble, over- 
growu with weeds, were the most unhealthy; and under these circumstances the greatest amount of disease was obserred. It is at this partienlar season of the year that hogs are most neglected. Haring been turned out during the summer months to take care of themselves, while the grass is green and filled with nutritious qualities, they thrire and do well; but; at the approach of the dry season, green grass gives place to that which is mature and dry, in which state it is indigestible and constipating. The water at this particular season fails. It is also at this season that swine keep their skin clothed with mud as a protection against flies, seriously interfering with its healthy functions as auxiliary to the lungs and other depurating organs of the body. This is the season when the cold nights precipitate heary dews, and while runming through the grass and weeds, during the nights and early morning hours, the animals become rret and cold, to be dried off and seorched in heat aud dust at the returning noonday. During the nights they are ehilled, sending the blood from the surface to the internal organs of the body, and breathe a damp, cold atmosphere; during the day they are overcome with enerrating heat, and breathe a dry atmosphere, loaded with dust and dry particles of decaring regetation. Is not this an array of existing circumstances well calculated to excite catarrhal affections, and are not these conditions as universally present over a large area of country as the disease itself? It may be objected that the disease sometimes prevails where the conditions mentioned are wanting. That it does prevail in some instances where there is no visible cause for its production is true, but the instances are of rare occurrence. As before stated, it prevails again in an active and fatal form during the months of February and Mareh. This is the season when bronchial and lung diseases prevail among the human family, due to the atmospherical changes, and exposure to the damp earth then in a state of alternate freezing and thawing. Smine are similarly affected during that period of the year from the same cause; and being more generally exposed to these causes than the human family, are more liable to such diseases in their epidemic form. The principal objection to this rational theory of the cause of the disease is that it is found to exist at other seasous of the year than those mentioned, and under circumstances where almost all the conditions named are wanting. In a few instances we obserred it where there was no visible waut of first-class care in the management of the swine as to food, water, cleanliness, and shelter, and when they were running on clean blue-grass pastures well shaded and watered; but the prevalence of the disease under such circumstances was exceedingly vare. It is the general opinion amoug farmers that the disease is due to some specific poison, and is contagious in character. This opinion was generally entertained by the farmers of Putnam county, where the disease prevailed this season for the first time as a general and widespread epidemic. Many claimed that the disease was communicated by a lot of diseased swine driven through that cornty from the county of Boone; but many cases occurred on farms entirely off the route traveled by the diseased animals, and entirely isolated from public highwass, and upon which no new or strange animals had been introduced by purchase or otherwise. A toll-gate keeper living near the village of Bainbridge, in that county, had a few smine rumning at large, and coming in close contact with all the animals driren orer the roarl, and still they had escaped the disease; rhile those occupying inclosiures by the roadside generally had it. Numerous instances were reported by reliable and iutelligent men, where the disease prevailed upon one farm with but a partition fence separating the sick animals 
from those of a neighbor, in an adjoining field, and the latter not be affected by it. No case of this kind was reported, where a stream of water led from the diseased herd to the opposite lot of animals, in which the latter escaped; which circumstance would indicate.that while the disease may not be strictly contagious it becomes infections, and can be transmitted by contact with diseased matter. Experimental operations conducted with a riew to ascertain this fact were wanting, because of the lack of absolute knowledge that the animals operated upon would not have had disease withont the introdnction of diseased matter by inoculation; barring this donbt, the introduction of diseased matter into the system of a well animal produces the disease in four out of fire cases. It is a safe practice to separate the sick from the well animals at the very first indication of approaching disease. The eating of the flesh of the dead animals, dying of the disease, by those surviving, is a very reprehensible practice, and should under no circumstance be allowed. The dead should be speedily remored and buried or cremated. Some farmers, however, claim that where they allowed the sick to eat the dead the animals seemed to recover faster by the practice-an obserration, if correctly made, only demonstrating that the herd was suffering from want of animal food to such an extent that that furnished them in a diseased condition did them more good than harm. Those holding to the theory of contagion generally agree in the period of incubation as ranging from ten to twelre days.

Mr. William B. Taylor, of Martinsville, Ind., a gentleman of long experience as a feeder and packer, and an intelligent observer of the disease, states that rrhen a herd of diseased animals were turned in a field with others not previously exposed, that the disease would almost invariably run through the entire diseased herd before attacking the others; and MIr. Joseph Goss, of Gosport, Ind., a feeder and packer of forty years' experience, and a most careful and intelligent observer, corroborates the statement of Mrr. Taylor.

\section{THE·DISEASE AS AFFECTIYG DLFFERENT BREEDS.}

This branch of the inquiry was forced upon our attention by certain parties who claimed in behalf of certain breeds of swine a partial or complete immunity from the disease. Unfortunately our field for observation in this regard was not good, since all the animals obserred were grades in which the Poland.China and Berkshire blood largely predominated. The best information gained upon the subject was to the effect that the breeds for which such immunity was claimed were those not in general use, and that the absence of loss from such breeds is due to the small number of such animals existing in the diseased districts. Such claims were made in behalf of the Chester Whites and Jersey Reds. We saw none of either of these breeds in our trarels, either sick or well. The latter breed may hare a partial immunity from these considerations. It is an Eastern bred animal, developed in a section where in-breeding, close confinement, and orer-feeding and monotonous diet are not so generally practiced as in the West, and that breed has, therefore, possibly a better constitution with which to resist diseased tendenc5.

\section{RECURRENCE OF THE DISEASE.}

All experienced feeders agree in the opinion that animals haring the disease and recorering from it seldom hare a second attack, and state that in purchasing animals to feed preference is always giren to those 
that have gone through with the disease. We are inclined to accept this opinion as of little cousequence, for the reason that such as are fed for pork do not afford a sufficient lapse of time to clearly demonstrate this point; and, on the contrary, among breeding animals that are allowed to live older, in which timely opportunity is given, our information is that a second attack is not an unusual occurrence.

\section{HEREDITARY EFFECT OF THE DISEASE.}

Females having the disease when breeding almost invariably cast their young. If they escape that accident, the offspring usually die very soon after birth. Subsequent litters from the animal, after completely recovering from the disorder, do not appear to be wanting in vigor, and do not exhibit a greater aptitude for the disease than other animals.

\section{PREVENTION OF THE DISEASE.}

The widespread prevalence of the disease, its rapid course and dreadful fatality, warrant the opinion that measures of prevention, if discovered and applied, will be much more beneficial in result than the discovery of a successful line of treatment for the disease, unless that treatment shall consist of some specific remedy, a practical use of which can be made by the farmers in all stages of the complaint. That such a remedy will be discovered, we are of opinion, is not within the range of probability. The measures necessary to prevent disease in domestic animals embrace within their range a careful study of their natural habits and wants, and a strict observance of the laws of health that govern all animal life, the principles of which are the same in their application to the inferior animals as to man. Those errors alluded to when considering the cause of the disease, as, in our opinion, largely contributing to, if not wholly the cause of, its development, must be corrected. The idea that swine are exempt from the ordinary laws governing health, and will thrive under any and all circumstances, must be abandoned. Forced to keep pace in his superior development with the civilization of the age in which he lives, he requires additional care in his management in order to ward off the numerous ills to which he is liable, many of which were unknown to his race in its unimproved state of nature. The food of the animal should, at all times, consist of the greatest possible variety; the water drank should be strictly pure; too many animals should not be herded together; the young animals should be kept to themselves; frequent change of locality, by shifting from one field to another; the frequent plowing up or burning orer of the lots usually denoted as hog-lots in order to disinfect them; frequent change of sleeping-places, and the removal and destruction of old, filthy beddingmaterial. During the dry fall months, when the swine are running at large, they should be daily inspected, and at the approach of that period when the succulent grass is giving place to the mature and dry, laxative food, such as bran-mash or oil-cake; or aperient medicine, as linseed-oil or Glauber salts, given to counteract the constipating effect of the dry grass; the watering-places daily inspected; if running in open fields with high weeds and grass, they should be taken out at night and kept from the cold, wet grass, and turned into woods, if there is such a place available; they should be kept from weedy and stubble fields during the dry dusty period of the fall season, both day and night. When contined in close pens, these pens shonld be cleaned daily, and disinfected when there is stench, by the use of copperas, chlorinated lime, or with dry, 
fresh dirt. The opinion that corn, almost alone, is sufficient food for swine, and contains all that is recessary for the growth and derelopment of the animal, will not be abandoned by the arerage farmer until after many costly lessons from experience, while attempting to freight their com crops to market through this uncertain medium of transportation. A judicious and intelligent system of in-bieeding cannot be abandoned without a rapicl reversion to the ill-shapen aninal of forty years ago, and we do not insist that in-breeding, when judiciously and intelligently practiced, is materially deteriorating in its influence upon the liealth ancl constitution of swine; it is onl 5 by coupling animals near related, that have a constitutional defect or a diseased tendency, and where these defects and tendencies are duplicated, that such a course becomes positively injurious. In the natural state of swine, when running at large and growing up without man's intervention, in-breeding frequently occurs; and the bad tendencies are warded off by the more vigorous males figiting of or destroying the feeble ones and becoming the sires of the race. Thus nature provides for a "survival of the fittest." In artificial breeding, the selections made for breeding purposes are too often made with special reference to shape and beanty, and too little consideration is given to rigor and constitution. There is no practical test made in the prize-ring between the most comely. male and bis less handsome brother, as to which is by nature best entitled to become the sire; but the breeder makes the choice from other considerations than "might makes right." Good feeding is the counterpart of good breeding; but there is a marked difference betweeu good feeding and overfeeding or stuffing. Good feeding consists in giving an amount of good healthy food in sufficient rariety to provide for the waste of the body, and in quantity only sufficient to develop the future growth of the animal. Orerfeeding or stuffing consists in pushing the amount of food to the full assimilative capacity of the animal, with a view to the greatest possible amount of excessire flesh. The first is essential to good breeding; the otiser is deteriorating to the constitutional vigor of the animal.

\section{TREATMENT OF THE DISEASE.}

This branch of the subject we might sum up in these fer words: No remedy was discovered having any marked beueficial effect upon the disease when once fully established; no farmer was found who erer in his own experience tried any remedy or remedies that seemed to exert any well marked curative effect upon the disease. Many isolated cases were reported; one animal recovered by having the tip end of its tail cut off; two, by being saturated with coal-oil, and a few others of like absurdity.

The annonncement of the names of the individual members of the commission appointed to conduct this examination brought to our notice by letter a large number of so-called log "cholera cures," which their several proprietors asked us to test, or allow them to test in our presence. As the requests were coupled with the expressed or understood condition that in ease sairl remedies proved efficient cures their proprietor should have the benefit, for his private use and gain, of an ofticial indorsement of the remedy, we did not think the investigation of such remedies for such purpose came within the range of duties properly devolving upon a commission appointed to make an investigation at the public expense for the public good, and therefore declined to answer all communications relating to such subjects. What valuable discoreries left in temporary obscurity by our course in the matter time alone must 
disclose. Wo must say that in this matter Fe were pot influenced by a strict regard to the observance of a high-toned professional code of medical ethics, but eutirely from a sense of the proper dischaìge of a public duty. The sick herd of Mr. Quinn, preriously alluded to, was taken as one offering a fair opportunity for treatment. The sick animals were all in the formative stage of the disease, and surrounding circumstances seemed farorable to their cure. They were confined to proper limits, in a pen well situated as to lealth and comfort, and were given a dose of purgatire medicine as a starting point, consisting of Glauber salts. It was observed by all with whom we conversed that a larger per cent. of recoreries occurred from among thoso animals that at the commencement of the disease had romiting and diarrhea than from others. The dry and hard condition of the fecal matter found in the animals dissected leads to the belief that purgatires at the commencement of disease would always be a judicious course. Bromide of ammonia was then given in solntion in doses of 30 grains every six hours. This remedy we tested at the suggestion of the Agricultural Department, at the instance of a gentleman who insisted that inasmuch as it exerted a salutary effect in the disease of cholera as affecting the human subject, it might prove equally beneficial in such disease in swine. So it might, but we did not find that an analogous disease, and therefore the remedy having no properties calculated to meet the character of the disease that we did find, proved of no practical benefit in its treatment, the animals dying in abont the same proportion as when not subjected to auy plan of treatment, but left entirely to themselves. Mr. Staddla's herd, in the same county, was subjected to the same plan of treatment with the same results. The herd of Mr. Thomas, in Harrison county, was treated under our direction by giving a mild purgatire at the commencement of the disease, and during the acute inflammatory state of the complaint administered antimonials as a sedative to the circulation, and in the second stage tonics and nutritions food of milk, mill-feed, and regetables, but the per cent. of deaths remained much the same as when not treated. Other isolated cases occurred under circumstances where extra care and effort was made in trying to effect a cure by sereral different lines of treatment, but candor compels the admission that as far as relates to the discorery of any plan of treatment proving sufficiently efficient to entitle it to respectable consideration, our efforts were without good results. And, lest our speculations and theories as to the proper line of treatment may be wrong, and present further obstacles in the way of the discorery of a successful remedy, we will refrain from giving them, preferring to present such points only as we fully beliere will be of practical value.

I remain, very respectfully, your obedient servant,

New Albant, Ind., November 23, 187 S. D. W. VOYLES, M. D.

\section{REPORT OF D. F. SALMION, V. S.}

Hon. WiLliair G. Le DUC,

Commissioner of Agriculture:

SIR: In my investigations of the contagions log-ferer as it exists in North Carolina, it has been my endearor to decile those points which it was indispensable for me to know before adopting preventive measures, rather than others which might be equally interesting from a scientific standpoint. What is the percentage of loss from swine disease in 
this State? Is it one and the same disease from which the hogs are dying in the different parts of it? If lont one, what are its symptoms, post-mortem appearances, nature, and eanse? And what are the means by which such losses may be diminished or entirely prevented? These are the questions which it seemed most important to answer; they are those to which my time has been entirely devoted.

It was found very difficult to obtain information of localities in which the disease existed ; for although requests were made through our newspapers for such information, and althongh, as I have since learned, swine were dying largely in every section of the State, I received during the whole time but three letters naming such localities. If to this we add that a large part of this State is withont railroads; that the farms are large, and, consequently, the country is thinly settled; that usually but few hogs are kept on,each place, it is scen that a great part of the time must have been spent in unproductive work in searching out infected localities, and, when these were found, in traveling from farm to farm to find herds suitable for experiment, or dead animals for examination. These facts must explain the small number of experiments which I was able to carry ont.

To give a connected view of the subject, and one convenient for reference, the report is presented under the following headings:

I.

\section{THE:LOSSES"OF:SWINE.}

a. Extent of disease, number and percentage of deaths.

b. Are the great bulk of these losses caused by one disease, or are they more equally distributed among all those to which these animals are subject?

II.

THE CONTAGIOUS HOG-FEVER.

a. Symptoms.

7. Post-mortem appearances.

c. Nature.

1. Cause.

III.

MEANS OF PREVENTION.

a. Hygienic and medical treatment.

7. Sanitary regulations.

EXTENT OF DISEAST, NUMBER AND PERCENTAGE OF DEATHS.

North Carolina is a State with a great diversity of soil and climato. In the restern or mountainous part the summers are not excessively hot nor the winters extremely cold, and, with the exception of river bottoms which are of comparatively small extent, the soil is rolling and naturally well drained; the water is good; there is no malaria, and the country is rightfully considered a very healthy one. Istending from the mountains for two hundred miles eastward is a strip of country much of which is not sufficiently rolling for good drainage through the compact subsoil, and in a large part of which intermittent fever prevails to 
a considerable extent among people. Still farther east is a strip of sandy and swampy country, extremely malarious, and very subject to intermittent fever and other diseases of malarial origin.

Now, if our hogs were dying of unhealthy surroundings; if their disease or diseases originate to any extent from malarious emanations, it is certainly in this eastern belt that we should expect to find by far the largest percentage of losses. We should not be disappointed in finding in few in the central belt, but in the healthy, elevated west, where the hogs roam in vast mountain forests, we should certainly expect an unusual freedom from disease, especially in summer. Viewing the matter from this standpoint, I visited the western and central sections, and would have gone to the seaboard if my own health had not failed me at this point.

Fortunately statistics have been collected of the number of deaths among swine in the different parts of the State for the year ending April $1,18 i s$, and these, as far as can be obtained (twenty-three counties only out of ninety-four), are as follows:

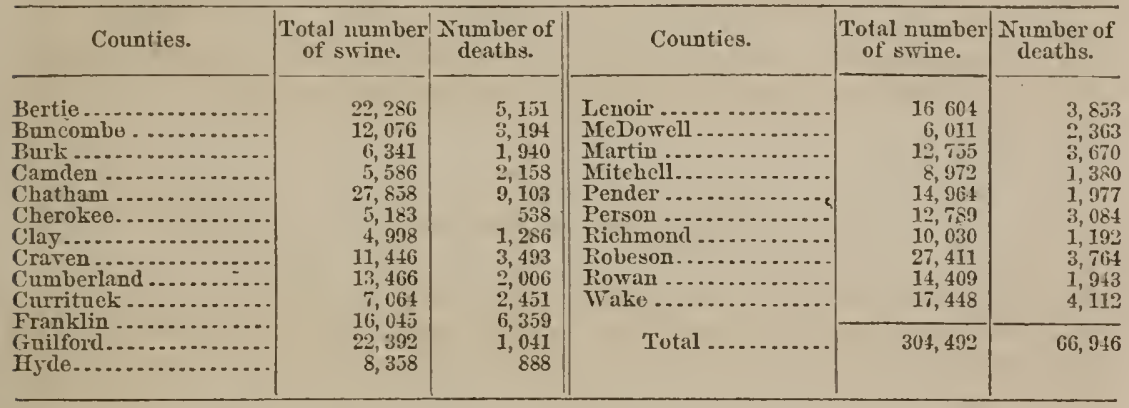

That is to say, hogs have died to an alarming extent from Cherokee, Nitchell, and Buncombe counties in the mountains, to Camden, Currituck, and Craven on the seaboard. Nor was the year above reported an exceptional one, as these losses are now being repeated in Haywood and Yancy in the west, and from thence in localities eastward to the sea. Speaking in round numbers we have reports here from one-fourth of the counties in the State, and these comnties in 1870 contained abont onefourth of the hogs in the State, and contain now very nearly the same number as then. We may, therefore, estimate the losses in the entire State at four times the number in these counties, say 260,000. Taking the counties mentioned, the loss amounts to $21 \frac{1}{2}$ per cent of the whole stock, and ranges from $38 \frac{1}{2}$ per cent. in Camden to only $4 \frac{1}{2}$ per cent. in Guilford.

\section{ARE THESE LOSSES 'IHE RESUL'I' OF A SINGLE DISEASE?}

This question has been raised again and again, whenerer any measure has been proposed for diminishing the death-rate of these amimals, and notwithstanding investigators in widely differentlocalities have observed similar symptoms and similar post-mortem appearances, the great objection to sanitary laws has alwajs been the uncertainty in regard to the affection or affections from which death occurred. It, therefore, seemed advisable to risit a large part of the State in order to decide this question of primary importance. The disease was seen by the writer in Haytrood, Buncombe, and MeDorrell counties, in the mountain district, 
in Rowan, MLevilenburg, Lincoln, Gaston, aud Alamance, in the central belt, and partienlar inquiries were made of those who had observed it in the counties bondering on the coast. Several counties not enumerated above wero visitel, but I was not successful in finding infected localities. Mif greatest regret is that I was not able to mako personal observations in every part of the State.

In each of the comties mentioned a considerable number of herds were risited and examined, and withont exception the living animals presented sinilar symptoms, and the deal ones showed similar "lianges in the difierent organs of the body. Slight variatious were of conrse obserred, as is always the cire in any disease, but these were as great between different individials of the same herd, sick at the same tine, as between different herds, even in different counties. And, what is of great importance, I dia not find a single case in which it conld possibly be supposed that death resulted from a local disease; but in every case a variety of organs, belonging to difierent apparatus, were found diseased; the blood often showed marked changes; there were extravasations in rarious parts of the bods, and always inflammation of the lungs and large intestines, generally, also, of the heart, and often of the eyes; the slin, too, was often plainly affected, and the temperature was found to be inereased before any other symptoms of disease were in the least apparent.

Considering all these facts, there can be no donbt that these animals all died of a general disease - a tisease not caused by changes in any single organ; but, on the contrary, a disease which caused the rarious organie changes observed. Agaiu, from the similarity of symptoms in all these cases which $I$ saw, and in those reported to me from other parts of the State, and from the correspondence in post-mortem appearances, there can searcely remain a shadow of loubt that the great mass of the hogs dying' in North Carolina are affected by one and the same disease.

\section{SYMP'TOMS.}

An increase of temperature precedes for an undetermined and probably rariable length of time the appearance of all other symptoms. In one lot of seven ten-months-old pigs, only one of which showed symp)toms of disease, the six remaining had a temperature varying from $103.6^{\circ} \mathrm{F}$. to $106^{\circ} \mathrm{F}$., and this temperature was preserved unaltered for six days, with no other changes in the condition of the animals than increased dullness of the eyes, a general unthrifty condition and a disinclination to seareh for food, although the appetite was still good. The pig first affected died about this time, and a post-mortem examination left no doubt of the disease.

In another lot of ten three-months-old pigs, but one of which was plainly sick, six had a temperature rauging fiom $104 \frac{10}{2} \mathrm{~F}$. to $107^{\circ} \mathrm{F}$; with one this was $10310 \mathrm{~F}$, with two $101^{\circ} \mathrm{F}$. and 1030 respectively, while with the sick one it reached $107.40 \mathrm{~F}$.

In a herd of twelve, from which one had just died, and one was plainly sick, four others showed a temperature from $1032^{10} \mathrm{~F}$. to $107^{\circ} \mathrm{F}$.

In a lot of fourteen animals, one had died, one was plainly sick, and three others had a temperature from $103^{\circ} \mathrm{F}$. to $10 t^{\circ} \mathrm{F}$.

Of five pigs, one had just died, three had a temperature or $105^{\circ} \mathrm{F}$. to $106^{\circ} \mathrm{F}$, and the remaining one $103^{\circ} \mathrm{F}$.

Of eleven hogs, two had clied, one was plainly sick, and five lad a teruperature rauging from $103^{\circ} \mathrm{F}$. to $106^{\circ} \mathrm{F}$.

From theso and similar cases it has seemed probable that a high tem- 
perature may exist sereral weeks before other symptoms are manifested, or eren that the disease may in some cases be coufined to, and run its course in, the blood, without a localization in any organ or organs. Such a view is also sustained by tho often-observed fact that when the cholera exists in a herd, animals, which show no positive signs of sickness, are forthd in an unhealthy condition, and cannot be made to thrive and fatten. This point, howerer, remains to be cleared up by future investigations. An objection may be brought to tho lower temperature here recorded, that according to other observers it is common to find a temperature of $103^{\circ} \mathrm{F}$. to $104^{\circ} \mathrm{F}$. in healthy animals. This, horrever, does not agree with the observations which I have been able to make. In one herd of ten, the last of a much larger number which had been reciticed by this disease, all of which appeared healthy and thriving, not one showed a temperature by wy thermometer as inigh as $1030 \mathrm{r}$. In sereral other herds of healthy animals which I examined, but notes of which were not preserved, the teimicrature was found to range from $96^{\circ} \mathrm{I}$. to $10210 \mathrm{~F}$. In nearly all these cases the animals were called up from fields where they were ruming at liberty, and were immediately examined. So that, although there may be differences in thermometers, I think thero can be little doubt from these observations that an increase of tempcrature precedes other syniptoms by a number of days.

The first symptoms apparent externally are a dulluess of the ejes, the lids of which are lept nearer elosed than in health, with an accumula. tion of secretion in the corners; there is hanging of the head with lopped ears, an inclination to hide in the litter, to lie on the belly, and keep quiet; as the disease adrances there is considerable thinst, more or less cough, a pink blush, rose-colored spots, and papular exuption on the skin, particularly along the belly, inside of thighs and fore-legs, and about the ears. There is accelerated respiration aud circulation, increased action of the flanks in breathing, tucked-up abdomen, arched back, strelling of the rulva in the female, as if in heat; somctimes, also, of the sheath in the male; loss of appetite, and tenderness of the abdomen; occasionally there was persistent diarrhea, but generally obstinate constipation. In some cases large abraded spots are observed at the projecting parts of the body, caused by separation and loss of the epidermis; in these cases a slight blow or friction on the skin is sufficient to produce such abrasions. In many cases the eruption, blush, and spots are entirely absent; petechir were formed in about one-third of the cases; in one outbreak, chiefly confined to pigs in which the eruption was remarkably plain, there was considerable inflammation of and discharge from the eyes. Some animals have a very disagreeable odor even before death. In nearly all cases there is weakness or partial paralysis of the posterior extremities, and occasionally this paralysis is so complete in the first stages of the disease as to prevent walking or standing.

The percentage of amimals affected and the violence of the synptoms vary greatly, according to the time the disease has existed in a locality. In the early part of an outbreak from 70 to 90 per cent. die, and most of these in the first stages of the disease, from deterioration of the blood or apoplexy. In one case there was a loss of 102 out of 107 head; in other cases whole herds of 30 or 40 succumbed; later, many of the animals linger for weeks, and finally die from persistent lesions of the lungs or bowels. In some instauces a considerable number of those affected-20 to 25 per cent.-recover; many of these lose all their hair, and often the epidermis as well. Of those recovering, a very few fatten rapidly and do well, but by far the greater part canuot be fattened, and are alwass unthrifty and profitless animals, 


\section{POST-MORTEM APPEARANCES.}

In about one-third of the cases petechiæ and larger blood extravasations are seen on the thinner parts of the skin; in a somewhat larger proportion of cases the abraded spots, already mentioned, are present; making a section through these, the skin appears thickened and of a very high color, but the sub-entaneous tissue is not appreciably altered. In one or two cases there was no effusion in the abdomen, but in all the rest this cavity contained a variable quantity of liquid-sometimes of a briglit yellow color and clear, sometimes of a straw color, and very often tuibid and mixed with the coloring matter of the blood. In every case the colon and cacum wero plainly affected, reddened externally, and internally showed changes varying from simply a deep coloration to inflammation and great thickening; in some cases they were studderl with petechix, in other's there were none; ulecrs of various sizes were frequently found, and also thickened fibrous, concentric patehes, oceupying sometimes nearly the entire walls of these organs. In one case there were large blood extravasations in the walls of both colon and cacum, distending them to a thickness of half to three-fourths of an inch; on section, these spots had the appearance of a clot of black blood; they were firm and tough and did not yield to scraping with a knife. Round, fimn nodules, one-half inch in diameter, were frequently found in the walls of these bowels, which, on seetion, were of a grayish-white color, and appeared to be composed of compact fibrous tissue, with the exceptiou of ono case in which they were less firm, and presented the appearances of the extravasated-blood patehes already deseribed. With the exception of petechix the small intestine was nearly always normal; in one case there were two or three patches of inflammation one to two inches in diameter. The rectum was congested or inflamed in spots only; there were occasionally the nodular masses mentioned above, but in a majority of cases this part of the intestine showed little or no change.

The stomach in one-third of the cases was unchanged; in tho remainder there were patches of inflammation from the size of the palm of the liand to the involving of half of the surface of this organ. Sometimes this was confined to the mucons coat, but often implicated the whole thickness of the walls.

The cavity of the thorax in every case contained a considerable qualltity of a turbid, bloody liquid, in some cases nearly black in color; the pleura were generally thickened and covered with false membranes; the lungs were constantly found inflamed, occasionally in a few small spots only, bnt generally the greater part of the lung tissuo was involved. Often these organs were greatly congested throughout, and would break down under the slightest pressure. The bromchial tubes were also found congested or inflamed, and contained considerable frothy mucus, which in some cases entirely filled them. The pericardium was in nearly every case distended with a turbid, blood-colored liquid, but, no false membranes were discovered, and ouly in one case a piece of coagulated lymph the size of a hell's egg was found floating in this liquid. The heart seemed to be congested throughout in most of the cases, aud had patehes of a deeper hue than the rest on its external surface. These patches were very suggestive of inflammation, but in the absence of coagulated lymph this may be considered doubtful. This organ at times contained clots of blood of different consistency, and always of dark color, and at other times all the cavities would be found empty. In all cases the blood was very dark, and generally formed an imperfect elot, and the lymphatic glands were enlarged and greatly con- 
gested. The larymx and pharyux rere found normal in all the postmortem examinations, but in some of the living cases there was consid. erable swelling about the larynx and ulcers on the posterior part of the tougue. The liver was generally as in health, though in some cases it was congested, spotted, and softened, and once was found smaller and more dense than natural. The bile was at times rery thick and lark, and again rely thin and of a bright yellow color. The spleen was normal in two-thirds of the cases; in the remainder it was slightly enlarged and softened. In two cases the interior was almost of a fluicl consistency, while in one the organ was smaller and firmer than in health. The bladder was generally normal, but in two or three cases was inflamed and covered with blood extravasations abont the neck, and contained in these cases bloody or rely turbid urine. The kidneys were seldom more than slightly hypel:aemic, but in a few cases there was considerable extravasated blood in the tissues about the hilum, and on section the substance about the pelvis was found infiltrated with perfectly black blood.

We have here a considerable variety of pathological changes, the only constant ones being congestion and inflammation of the lungs, colon, and cecum, and congestion of the lympliatic glands. To mention any single peculiarities of these lesions as characteristic of this disease would not be possible from this investigation. Neitlier the thickened tibrous patches, the ulcerations, gray elevations of the intestines, the enticular eruption, nor petechice were constant.

\section{NATURE OF THE DISEASE.}

In studying the nature of an unclassified disease the first question that occurs to us is: Is the affection a general or a local one? In other words, does the disease originate from functional or organic disorder of any particular organ or apparatus, or are the anatomical lesions developed secondarily as the consequence of a general affection? And this question, as regards the disease under consideration, can now be answered in a definite and satisfactory manner. Indeed, when we consider that the first sympton, and one preceding all others by several days at least, is an increase of temperature; that when localized a great variety of orgaus belonging to different systems and apparatus are involved, as, for instauce, the nervous system, as shown by occasional paralysis and apoplexy, the lungs, pleura, bronchial tubes, heart, liver, stomach, intestines, spleen, kidneys, bladder, and skin ; that there are considerable changes in the blood, as shown by imperfect coagulation, solution of the coloring matter, and blood extravasations, there can scarcely remain a shadow of doubt that the tromble is not a local but a general one.

The next question in logical succession relates to the contagiousness of the disease. Is its extension due to a principle which is multiplied in the bodies of sick animals, and which is of itself sufficient to eause tho lisease in healthy ones? In auswering this question I will merely men. tion the experiments of Professors Axe, Klein, and Osler, which prove that the disease may be inoculated without detailing their facts; and I will only allude in like manner to the instances already recorded by $\mathrm{Dr}$. Sutton, Professor Axe, and others, which seem to prove its highly contagious character. Most of these facts have been published in recent reports of the Department of Agriculture, and there is no need of repeating them. In my own investigations I have met with facts which entirely confirm the opinion of these observers in regard to this latter point. Thus I have found the disease to start at some point and spread slowly in different directions-not rapidly, as though depending on atmospheric conditions-and the rapidity of this extension depends to a rely great degree on whether these aniands are allowed entire liberty 
or whether they are kept on the premises of the owner. In Mecklemburg county no stock is allowed to rum at large, and the disease existed dmring the present year, in some localities, from early in the summer, and up to October first by fiar the greater part of the country was free firom it; while in Alamance county, where no restraint is put on the animals, the discase spread from one extremity of the county to the opposite in an few weeks. In each of these outbreaks, and, indeed, in erery oue I have observed, it is no difficult matter to find one locality where the hogs have nearly ạll died and the disease has finished its work some weeks or even months before, while in almost erery clirection, at a distance of fire, ten, or fifteen miles, these amimals are just taling the affection; that is, the disease has extended and is extending, and it has required this length of time to trarel this short distance. Can it be possible that an atmospheric or climatic change monld travel no faster than this? Again, if dependent on snch conditions, why do we find one township derastated by it and another not many miles distant entirely free from it? Snch instances are rery apparent in Harwood, Mecklenburg, Lincoln, and Gaston counties at this witing, and were not less so in Buncombe comnty in 1877. If it is claimed that this depends on the condition of the soil, it is only neccessary to reply that in the outbreak just mentioned, in Buncombe county, there are no facts to justify such a theory. In Swamnanoa township, which is high, rolling land, with rery few bottoms, no swamps or malaria, and which cannot be surpassed for healthfulness, the loss was 60 per cent. of the whole stock; while in Upper Howniny, which lias no advantage orer Swannanoa in healthful location, but which is more remote from thoroughfares traveled by western (lroves, the loss was only z per cent. It was probably entirely freo from this disease.

A large number of iustances could be produced of outbreaks in this State, particularly in the western part of it, clearly traceable to infected droves, and this is, above all, the case with the first introduction of the disease. It is difficult to establish exact dates, but all accurato testimony points to 1859 as the first appearance of this trouble. Some thiuk the earliest ontbreaks might hare been a few years before that date, but of this I have been able to get $n 0$ evidence. IIr. Moris, of Polk county, remember's that a drove stopped at his place in 1559 ; that some of the hog's died there of the discase, and that soon atterward this malady spread among most of the hogs in that locality. This was the first appearance of the tromble in that county. Mrs. Davidson, of Buncombe county, remembers that during the life of her father, who was a large hog-raiser, and who lived on the route followed by the droves, no hogs were lost by this discase, but that about the time of his cleath (15j5) (hores eame through with sick animals, and that this was the first ap)pearance of the disease in that locality. Many other people who cannot remember dates are positire in the opinion that the disease was introduced by droves from Temessee and Kentucliy. One man remembers that he was employed by the drovers to lill the amimals that were sick and eure the meat. He also remembers that these animals had diseased lumgs, and such a bad odor that they could searcely be dressed. This was his first experience with the liscase linomn ats "hog-cholera." Colonel Polk, our present commissioner of agrienltme, informs me that the first appearance of this disease in Inson county was in 1859 ; that it was undoubtedly brought there by western droves, and that these animals clied to such an extent that the drovers took them secretly to the wooks and buried them under brush and rails to conceal them. A drover who sold his hogs in Georgia at that time informed me that the disease was first introduced in that State in 1859, and that he had no doubt it 
was carried there by the drores. Indeed, I hare found but one opinion among those best informed on this matter, and that is, that the disease was never known in this section till introslnced by animals driven from Western States; and in some sections of this State, a part of Alamance county for instance, the disease never existed till the present year.

Judging from all these facts, therefore, we cannot escape the conclu. sions that this disease is a contagious ferer.

In this connection there is one more question that is generally raised by those discussing the nature of this ferer, and that is, cloes the clisease always originate from pre-existing contagious germs, ob is it often or generally developed de novo as a result of improper hygienie surroundings". In the consicleration of this question I shall confine nyself to the facts brought ont by the investigation in this State, simply premising that most of these facts are as true of the Miridle States and probably of most of the Southern States as of North Carolina. The first point that attracts attention is the fact that this State ras free from the disease till about 1859, certainly till it was introduced by droves from other States, whatever the dlate may be; hogs had been kept in this State from the time of its first settlement undoubtedly under similar hygienic conditions, and yet the disease had not appeared up to that time, when it was brouglit by imported animals, just as England was free from contagious pleuro-pneumonia up to 1842 , when it was imported with animals from the Continent. It is clained that in the west the disease is produced by overcrowding and filth, but I doubt if these animals are crowded any more now than forty years ago; incleed, I was surprised at the results of my investigations on this point, for, in all the time I hare been risiting infected localities, I have not found a case of orercrowding; and not more than two or three where there was anything like filthy surroundings. In the western part of the State most of the log are kept in the large mountain forests, or are at least allowed the run of the highrays and commons; in the east they either rum in the highways and old fields or hare ample pastures. If it originates from restricted range and unheathful climatic conditions, it is certainily in the east that we should expect to hear of its originating and proving most disastrons; but it was lnown in the mountains as early as in the other parts of the State. And if we examine the list of comnties which I have given above, we shall find it as fatal in the elevated and heathful west, with its immense mountain ranges, as in the malaricus east. I append some conspicuous examples of this:

Loss in eastern counties.

Loss in western counties.

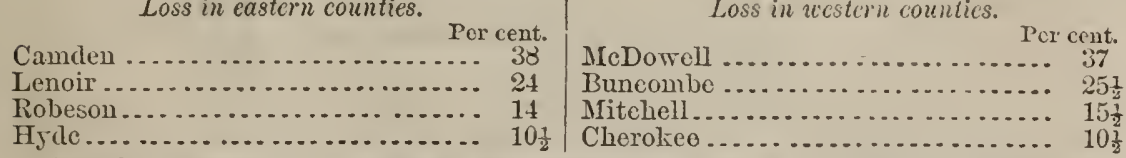

We find here, then, just as large losses in the rrest as in the east, and just as small ones in the east as in the rest; in other words, the disease rages irrespectire of these climatic and hygienic extremes; and this becomes still plainer when we add that in Swanuanoa township) of Buncombe county the loss reached 60 per cent.

Of course, at the present time, as with all contagious diseases wiuch have existed for several years in a country, there are some outbreaks which it is impossible to trace to their sonce; and it seens probable that the eontagion may be preserved over winter in manure, straw, litter, or in the remains of unburied animals which died the preceding year. There are some outbreaks that cannot well be explained otherwisc, aud, indeed, there is no reason to doubt that this may be the case; contugious 
germs may also undoubtedly be earried a considerable distance by other animals or birds, and it is for this reason that many farmers bave conchuded that pasturing hogs on wheat-fields prodnces the disease; but hogs were pastured on wheat-fields as well thirty years ago as now; why dicl not the same result follow then?

I have concluded, therefore, after a careful study of these facts, that this eontagious disease does not originate de novo in North Carolina; and that if the contagious germs now in the State ean be destroyed and their importation irevented, we shall be as free from it in the future as we were before its first importation, about the year 1859 .

\section{HYGIENIC AND IEDICAL TREATMENT $\triangle$ S PREVENTIVES.}

It was one object of this investigation to determine if the best hygienic conditions, clover pasture, large range, and variety of food have any preservative influenee against this contagion; and while a large number of eases where these conditions seemed perfect conld not be collected, the few that were observed prove that these alone are absolntely powerless to keep off the disease. Thus, Mrr. Wadsworth, of Charlotte, lost 117 animals, nearly lis whole stock, which had the rum of a clover pasture and large wood lot, which had in addition slops from the city hotels, and grain. In this case disinfectants were freely used. Mr. Davidson, of Hopewell, lost 50 per cent. of his herd under similar conditions. A herd liept at a slaughter-house, in Charlotte, which had other food as well as the refuse, was the first to take the disease, and suffered to the same exteut as others. Indeed I met with hundreds of cases where animals had large pastures and other food in addition daily, wlfere such popular prerentives as salt and ashes, sulphur, tar, oil of tumentine, chareoal, and copperas were freely and regularly given, where the majority of the animals were neither too fat to be vigorous nor so poor as to be wanting in this respect, and yet from 50 to 90 per cent. succumbed to this affection. In one case where I had the tincture of chloride of iron given regularly is a preventive, commencing before any of the animals showed even an elevation of temperature, and where they were in a large pasture at a considerable distance from any others, the disease lias appeared; two have died and other's will probably follow.

Some experiments were made with bisulphite of sodal, salyeilic acicl, bichromate of potassa, and bromide of ammonia to determine if these have any power to arrest the disease when given before any symptom but increased temperature had appeared; the results of these were as follows:

\begin{tabular}{|c|c|c|c|c|c|}
\hline Agents. & 竞 & $\begin{array}{l}\text { Begimuing of tem- } \\
\text { perature. }\end{array}$ & Dose per day. & 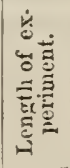 & $\begin{array}{c}\text { Final temperar } \\
\text { ture. }\end{array}$ \\
\hline 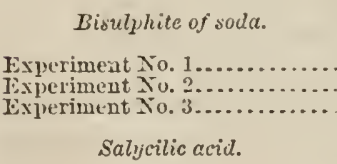 & $\begin{array}{l}6 \\
4 \\
3\end{array}$ & $\begin{array}{l}103.6^{\circ} \text { to } 106^{\circ} \mathrm{r} \ldots \\
1032^{\circ} \text { to } 107^{\circ} \mathrm{F} \\
103^{\circ} \text { to } 104^{\circ} \mathrm{F}\end{array}$ & $\begin{array}{l}4 \text { drachus. } \\
1 \text { ousice.... } \\
1 \text { to } \$ \text { ounce }\end{array}$ & $\begin{array}{c}\text { Dayss. } \\
7 \\
4 \\
7\end{array}$ & $\begin{array}{l}96^{\circ} \text { to } 99^{\circ} \mathrm{F} \\
10^{2} 23^{\circ} \text { to } 1055^{\circ} \mathrm{F} \\
103^{\circ} \text { to } 106^{\circ} \mathrm{F}\end{array}$ \\
\hline 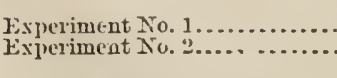 & $\begin{array}{l}4 \\
8\end{array}$ & $\begin{array}{ll}10410 & \text { to } 107^{\circ} \mathrm{F} . . \\
103^{\circ} & \text { to } 106^{\circ} \mathrm{F} . \mathrm{.}\end{array}$ & $\begin{array}{l}30 \text { grains.......... } \\
45 \text { grains......... }\end{array}$ & $\begin{array}{l}7 \\
6\end{array}$ & $\begin{array}{l}100^{\circ} \text { to } 101^{\circ} \mathrm{l} \\
103^{\circ} \text { to } 105^{\circ} \mathrm{l}\end{array}$ \\
\hline 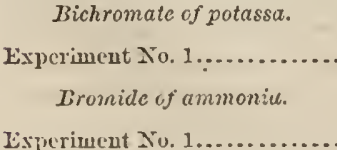 & 3 & $\begin{array}{l}1032^{\circ} \text { to } 107^{\circ} \mathrm{F} . . . \\
103^{\circ} \text { to } 10 \mathrm{G}^{\circ} \mathrm{F} . .\end{array}$ & is grain....... & 7 & $\begin{array}{l}103^{\circ} \text { to } 105^{\circ} \mathrm{F} \\
103^{\circ} \text { to } 106^{\circ} \mathrm{F} \text {. }\end{array}$ \\
\hline
\end{tabular}


These experiments show that none of these agents can be depended nn to stop the changes going on in the blood as a consequence of this disease. Althongh both bisulphite of sorla and salycilic acid in one experiment each appeared to accomplish this, they failed in other eases where given in larger doses for an equal length of time; and when we consider that in no contagions fever has a remedy been discovered capable of arresting the course of the unalady, the donbt in regard to the efficacy of these agents in this clisease must increase.

\section{SANITARY REGULATIONS.}

We are finally brought to the irresistible conclusion that sanitary regulations properly framed and enforced are the only means at our commant for checking the ravages of this disease and relieving our farmers from the enormous losses at present occasioned by it. We cannot expect, howerer, that this desirable object will be accomplished without considerable expense, especially in the tirst years of the attempt. We must expect ontbreaks in all parts of the country where the disease has previously existed, caused by contagious germs which have been preserred in some of the ways already mentioned; but we should be enconraged by the fact that in most parts of the comtry, at least, these germs, unless especially preserved in straw, manure, remains of dead animals, \&c., are entirely destroyed dming winter. Thus, in Swannanoa township, where 60 per cent. of the hogs died in 1877, there has been no outbreak up to October 30,1878 . Above all must we realize the necessity of thoroughly destroying every particle of contagion wherever it appears. Although this would undoubtedly be very expensive, it would certainly be a great saving, even at the start, on the great losses which we are now annually experiencing; and if the work is thoroughly done we may expect that this expense will be reduced to a comparatively small item in the course of a few years. At the worst such ex. pense would be much less than the use of a specific by individual farmers, even if such a remedy were discovered. In regard to such regulations I wonld suggest the following points as necessary according to what is now known of the disease:

1. The regulations should go into effect in winter or early spring when fewest animals are affected, or when, as my experience indicates, the disease is entirely extinct.

2. People living in localities where the disease has prevailed within two years should lieep their hogs in an inclosure free from accumulations of manure, straw, litter of any kind, or remains of dead animals in which the contagion might possibly be preserved, and in which there were no sick hogs the preceding year.

3. That in snch localities, $i$. e., where the disease has existed within two years, it should be madle obligatory for persons owning hogs to report each and every death occmring in their herds promptly (within forty-eight hours if but one, or twenty-four hours if more than one, or if others are sick), to a rlesignated person to be located in erery township or county, unless such deaths were plainly caused by mechanical injuries, drowning, maternity, \&c. And that there should be districts established of convenient size, in each of which a competent veterinarian (or physician in case the veterinarian could not be obtained), should be appointed, to whom the above township or county officer should report whenever two or more such deaths have occurred in the same herd within a fortnight; whenever an unusial number of deaths have occurred in any locality, or whenever there is any reason to suspect the presence of this disease. 
4. On receipt of such report the reterinarian should risit the locality and make a careful investigation into the nature of the discase, using the cliuical thermometer and making post-mortem examinations.

5. If the contagions ferer is indicated the whole herd should be slanghitered, the animals deeply buried, the place thoroughly disinfected. and $n 0$ more hogs allowed there till after a sncceding winter.

6. When the disease exists to any considerable extent in a locality, those omping hog's in adjoining townships or eren comuties, according to the extent of the ontbreak, shonld be required to keep them in small inclosures or jens, at a distance from roads or streams of water coming from infected localities. This is necessary to lessen the danger of infection and to allow more thorongh disinfection in case the disease appears.

7. A certain compensation should be allowed for slanghtered auimals-sar 2.5 per cent. on a fair valuation for those plainly sick, 50 per cent. for those which simply show a rise of temperature abore $103 \frac{10}{2} \mathrm{~F}$., and full value for the healtiry ones.

S. In case a hog-omner fails to comply with abore regulations a penaltr might be fixed, or at least such a person shonld receive no compensation for slaughtered animals.

These are the regulations that seem to me most necessary, but there may undoubtedIy be circumstanees in which these may be adrantageonsly mocified. Thus in case of a herd of several hundred animals, in which but few are affected and the remainder show a healthy temperature, it migint be advisable to simply kill and bury the afiected ones, to thoronghly disinfect the premises and to kill others as soon as a high temperature becomes apparent. Or in ease all were killed the meat of the healthy ones might be preserred aud marketed. It is also possible that, through negligence in making reports or an improper diagnosis of the disease, such a large territory may become infected as to malie it adrisable to establish a sanitary cordon, isolating the locality as unuch as possible; and leave the discase to run its natural conrse. In snch cases no live bogs should be allowed to leave the infected section till after a succeeding winter, nor any carcasses of hogs till after freczing weather; people living within this district should be prohibited from going near swine ontsikle of it, nor should drovers or others from ontsile be allowed to risit the infected swine. All dead animals shonld be promptly and deeply buried, and disinfectants freely used. All hogs in such district, and for twenty miles distance from it in all directions, shonld be kept in small inclosures at a distance from roads, in order to lessen the chances of extension and to allow thorough disinfection.

If such reoulations are thoronghly carried ont there can be no doubt that the ravages of the discase will be greatly diminished at once, and in a few ycars many States which now sufici terribly from it will be completely exempt; while in those where it now proves most disastrons there is reason to beliere it ronld never cause serious losses. Sanitary regulations similar to these are the only means that have ever been snccessfin in combating the contagions discases of animals, and while we wonld not be understood as disconraging the seareh for specific remedies we cammot disgruse our opinion that it is extremely irrational and absurd to delay action in tlis discase till such specific shall have been discovered; in other words to neglect those measures which hare alone succeeded and cling to those which have alwars failed.

Respectfully submitted.

Swarmanos, N. C., November 15, 187 .

D. E. SALMON, T.S. 


\section{REPORT OF DR. ALBERT DUNLAP.}

Hon. Wri. G. Le Duc,

Commissioner of Agriculture:

SIn: On the last day of July, 1S7S, I received from you a "commission to act for the Department of Agriculture in the examination of cliseased animals," accompanied with printed instructions directing me to particularly examine into causes of the disease known as "hog cholera." I interpreted my instructions as follows: Find out what disease or diseases are destroying the swine and the symptoms of the same; the causes, both predisposing and exciting; the stage of incubation, morbid anatomy, \&c., and to discover how far attention to hygienic care will prevent the spread of the disease in infected herds and its inception in healthy droves; and in addition to test the value of various medicinal remedies for curing the sick and preventing the spread of the disease. Recognizing the primal fact that the hog is an animal of short life, low vitality, and of comparatively little pecuniary value, singly, as compared with other domestic animals, and that they are kept in large droves by most Western farmers, I considered it of little profit to attempt to meet each special symptom with its appropriate remedy; but rather, after having fully diagnosed the clisease or diseases, their nature, causes and lesions, and the predisposing causes which had assisted in the spread of the same, to try and devise a system of treatment, both hy gienic and medicinal, which could be used in the treatment of large droves already infected, and reduce the liability of healthy droves contracting the disease. I do not claim for this report any degree of perfection. The limited time allowed only permitterl the examination of the disease under certain climatic influences, and not through the various seasons of the year. I am, therefore, only able to report on the cliseases which came directly under my omn observation in this State (Iowa) during the two months of investigation, briefly referring to cases of diphtheria which I carefully observed last winter, and of which I have seen no cases during this investigation.

The medical literature upon the subject of the cliseases of swine was very limited, and I could find no strictly scientific work treating upon the topic. I was, therefore, forced to fall back upon iny knowledge of the diseases of man as a foundation, and after having fully examined the symptoms and morbid lesions in a series of cases selected ont of an infected drove, I compared those symptoms and lesions with like symptoms and lesions found in man, and thus arrived, I think, at correct conclusions as to the proper name of the diseases under consideration. I was thus materially assisted in tracing out both the predisposing and exciting causes of these ailments. To the casual observer it may seem absurd to form conclusions in regard to diseases of swine from a previous knowledge of the diseases of man, but when we consider that the hog resembles his two-footed brother in many respects, has a similar alimentary canal, like viscera, the same system of bloorl-vessels and nervous structure, is also omnivorous, and that the diseases under consideration are caused by specific blood poisous, which act in like manner on man and brute through the process of inflammation, we can but conclude that if we find a set of certain classified symptoms in a hog with a distinetly marked uniform set of pathological lesions, and a similar set of symptoms in man with like morbid lesions, that these two are one aud the samo disease, and should bear the same title, especially when we can trace the cause in both cases to the same exciting agent. I have been forced 
to depend entirely mpon my own observations for the material of this essay, and I will say in defense of the position or theories I advance, that they are iny conchsions after inspecting over three hundred herds of diseased swine in rarious counties of this State, and after a eareful dissection of nearly one humclred diseased animals. In justice to the farmers of Iowa, it is my duty to state that I received much valnable assistance from their hands. During the progress of my investigations prominent symptoms were pointed out by farmers who liad made the disease a study, aud I am only sorry that I cannot give each one credit for his particnlar contribution. I made my "headquarters in the field," and strived to obtain a thorongh knowledge of the subject in all its details. I was foreed to abandon the use of the mieroscope after a few days' trial.

\section{HOG-CHOLERA.}

Definition.-Any contagious or infectious disease attacking swine with usually fatal results. This definition will inchule all fatal diseases that are contracted by one hog from another, either by direet contact or by contact with the discharges or exhalation of any diseased animal, or the gases arising from any contaminated matter. 'Under this head can be properly included the three diseases I have discovered dming my investigation, viz., diphtheria, typhus, and typhoid fever. The definition will exclude worms, lung-fever, pnenmonia, plemisy, or any special inflammation of interual viseera which are the results of climatic influences, vicissitudes of weather, or improper food. I am led thus aceurately to define the disease and draw the line of distinetion, because I have repeatedly found droves of swine suffering with so-ealled hog-cholera, when, in reality, there was no contagious disease whatever prevailing, but they were sick and dying because the rules of common sense had not been observed in their care. Because a mumber of hogs in a drove are taken siek at one time and with like symptons, it does not follow that they are suffering from any contagious disease, and the sooner the fact is impressed mpon the farmers the better it will be for their poekets. Often it is mot medicine that is needed but a change of food. I will give a few eases which will best illustrate the ideas I wish to convey. Mr. B. kept his swine in a lot of one acre, more or less, where they had but little exercise, regular food, and sheltered bed. After gathering his corn he turned his entire drove into the field to glean. They also had the range of a forty-aere wood lot. 'Two days after he found a number of lis shoats sick, five of which soon diecl. The disease was pmemmonia or Jumg-ferer. Mortid anatomy in each case showed at least one lum liepatized and inflammation of plenta.

Canse.-The hogs were previously confinerl withont exereise and had regular food and sheltered hed. They were then turued ont in large range, exereised fully (espeeially the sloats), slept on bare ground at a time when the weather changed suldenly colder, and the result was lung-fever and deatl. No medication was needed to prevent the healthy shoats contracting the rlisease, and a little care and simple medication would have probably eured the sick.

Mr. M. kept his logs on a clover and giass range. They had stagnant water for drinkiug, and sour, fermented swill was fed freely twice a day. The land was flat river bottom, with black soil; ringers were used to prevent rooting; no roots, vegetables, or corn were given. The natural result of such errors in diet was sickness, emaciation, and rleath. First, the young pigs pined away; sudanina appeared upon the eyelirls, nose, and ears, and one animal after another was attackerl with convulsions and died. The lorood sows and stock logss soon followed in 
the same was, aud when I visited the farm fifty ont of eighty head had been eut off in this useless and mmprofitable wiy. Three sick hogs were killed and dissected. The lungs were white, but showed no sigus of organic disease. 'The kidneys were light colored and showed some irritation in tubules; all internal viscera without organic disease. There was a lack of red corpuscles in muscular tissue, which appeared almost white. The disease, in this case, was simply starration. As ret no contagious disease has appeared in the herd, but the hogs were in such a condition that if exposed to the slightest miasma they would inevitably contract any contagions disease, and, with the debilitated blood to begin with, would rapidly suecumb to it. Now, I assert that although the drove was supplied with abundance of food in kind, yet it was not the nourishment demanded. There was an excess of certain constituents and absence of others necessary to health. Erery article of food furnished this drove contained acill. This was the case with the clover, grass, and slops given them. The water was poisonous also, and they were rleprived of the alkaline salts necessary to life. The small quantity they might have obtained from the ground was made inaecessible by the rings in their noses.

In this drove the tongues of the hogs were large, white, and flabby, indicating plainly the need of change of diet. There are many other errors in diet which will be alluded to when we come to speak of the predisposing eauses-errors which do not cause death, but which render the hog peculiarly liable to contract contagions diseases, and also increase the expense of feeding.

I will now gire an illustration of a case where too much care, misdirected, caused disease and death: Mr. C. builds a so-called model pigpen. It is low and tight; the sum and air are excluded; the floor is of boards, and is raised above the ground. To prevent dampness, straw is furnished liberally to keep the hogs warm. 'The feed-lot is exposed to the north and west winds. The hogs, sleeping in this damp place, with cold boards under them, pack closely together in the clamp straw, for, no matter how dry the straw may be when put in, in the course of a few hours it will be wet and loaded with ammonia. Mark the results. At reveille they come from their sheltered house wet and heated, pass into the feed-lot exposed to the bleak north wind or cold rain from the west, and the natural consequence is conghs, colds, bronchitis, pleurisy, lungfever, inflammation or irritation of some internal viscera from the suclden check given to perspiration, or sudden change of temperature by the inhaled atmosphere. If the exposme is not sufficient to canse a fatal inflammation, it will cause a bronchial irritation, as shown by congh. The system is vitiated, and any contagious clisease prevailing in the ricinity is liable to attack the drove. The owner reports the cough as existing for one or two months as the first symptoms. In this ease the cough was cansed by errors in care, and was but a symptom telling the farmer that his swine had contracted a cold, and that this disorder of the system would debilitate and render them more liable to contract any contagions discase to which they were exposed.

We will now take up in their order the three diseases which come properly moler the title of "hog-cholern," that is the diseases which answer to the definition we have given of hog-cholera. We do not claim that these are the only contagions diseases which are known to cause death. There may have been others in past years, or even in this year, but they did not come under my observation, and having accurate reports from many prominent and intelligent stockinen in all the Trestern States, detailing the symptoms in their infected hogs, I can but con- 
clude that these three diseases are the oniy contagions diseases which hare attacked hogs in the last two rears. After describing each disease, its smontoms. conrse, stage of incubation, pathologieal lesions, causes of death, and exciting catses, we shall take up the sulject of predisposing causes tomard the contraction of these diseases. Then we shall point out the best plan of treatment, both hrgienic and medieal, for curing the sick and preventing the spread of any contagions disease anong healthy animals.

\section{TIPIUS FETER.}

Definition._- I specific contimed ferer, attended with increased tem. perature, usualls abore $105^{\circ} \mathrm{F}$; stupor; congestion of brain; strelling of forehead; stiffiness of joints: excessire soreness of all tissues; a profuse eruption on the belly and insicle of thighs, mith costire bowels during the first few days. and usually terminating in death within forrteen dars.

Symptoms.-IYeadache, as shomn br wrinkled forehead; partially shut eres; nose held near the gromud; loss of appetite; stupor; indisposition to move; excessire soreness of all tissues, the slightest pressure cansing excessire pain; strelling of forehead between the eves; tongne generally large, rhite, and flabby, especially if the disease is complicated with malarial poisoning. There is also great restlessness, shortness of breath, aud congh. The sick hogs are frequently lame in one limb, and cannot erer put it to the ground. The heat of the bodr is excessive, the temperature rarels ranging below $105^{\circ} \mathrm{F}$.. and generally reaching as high as $108^{\circ}$ to $109^{\circ} \mathrm{F}$.; and if the hog is not carried off from the fifth to the serenth dar a copions eruption appears on the borrels and on the inside of the thighs and other soft parts. The bowels are almost almars costire duing the first reek and the discharges hard and dark colored. Thirst is excessire, and the hog will often drink until it falls orer dead. Duxing the second week we hare increase in the sererity of srmptoms. Sordes collect in mouth; small watery pimples appear on nose, erelids, and ears ; there is great prostration of strength, with stagxering gait when forced to malk. Costireness mas now gire place to diarrhea : urine is passed while lying down. and convulsions or fatal stupor interrenes; enlargement of glandular structure, especiallr in the neck. is a common srmptom, but in no case have $I$ found abscess with healthy pus, bat rather thin sanious fluid. A common srmptom during the second meek is thmps, and I have nerer knomn a ease to recorer when this srmptom was present. The thumps appear to be nothing more than a spasmodic action of the nerres. like hiceough in man, aud ilenotes great prostration and approaching death. In adranced stages of the ferer these are the main symptoms. and this alone is a common course of the clisease, as I have observel it. But there are many exceptional cases. Many hogs. especially those debilitated by errors in food or from the effect of malaria, will succumb to the influence of accumulated poison acting on the brain and nervous system, and die mithin twentr-four hours. This is of frequent occurrence, especially in roung pigs and shoats. Others mill die from obstinate constipation, the impacted feces cansing ulceration and rupture of descending colon and rectum. In some herds conrulsions, from eongestion of the brain, oceur during the first day, and mless reliered the case terminates in death in a few hours. Tubercular deposit in the lungs and in the mesenteric glands is very common. In this disease, as also in trybloid ferer, the smouldering spark of scrofula is fanued into a thame by the ferer, and the tuberenlar matter is deposited in the lungs and glands, and the patient 
that might hare recorered from the ferer is carried off with consump. tion. The odors of the exhalations are peculiar, and will at once diagnose the disease from any other. To describe this peculiar smell would be impossible in words.

Duration.-The duration of the disease is rariable. Many animals die within a ferr hours, but if the borrels are emptied by saline cathartics or injections, the animal generally lingers into the second or third reek before the crisis will oceur. The prognosis is rery unfavorable, especially in large droves, where little can be done to relieve symptoms. Our adrice is, in all large herds where this disease obtains access, to destroy at once the sick animals, burn or bury the earcasses of the dead, and labor to check tise progress of the disease by prompt hygienic measures. In small drores, or where the stock is of peculiar value, an effort may be made br the nse of medicinal agents and care to reliere the srmptoms and guide the case to health. But in large herds this effort mill be found unprofitable. When we remember that in man, with all the advantages of a thorough linomledge of the disease, mith skilled physicians and competent nurses to care for the sick, many of those attacked in cromded armies succumb to the influence of the disease, $\pi$ e certainly cannot advise farmer's having large herds to attempt remedial measures. Another argument against attempting to cure those haring well-marked symptoms of the disease is that, if there is the slightest taint of the scrofulons diathesis in the blood, the spark will almost certainly be fanned into a flame, and the patient, reacting from the specific ferer, will be carried off br deposit of tubercular matter in the lungs or mesenteric glands. Now, we know that the hog is an animal of low vitality, and, in a majority of cases, of scrofulous habits, hence we need not be surprised to fiud consumption a rery frequent sequence in this disease.

Pathological lesions.-During the first three dars after the appearance of the ontward symptoms of the disease dissection will show but little, if any, change in the viscera. The bowels mill be found loader with hard fecal matter, and careful examination will disclose some thickness of the inner coat of creum and ascending colon. A hog which has been sick a week or ten days will still disclose no disorganization of internal organs sufficient to account for the serere ontward symptoms. The blood is blacker and less coagulable than in lealth; a general irritated condition of all mucous membranes mill be noticed. The luugs mill show no organic change, unless tubercular matter has already been deposited. In a majority of cases dissected, I lave found the liver, kidneys, and spleen lealthr-at least shoming no signs of disorganization. I have never, in this disease, found abseess of any intemal riscera, but have frequently found a low form of inflammation in the glands of the neck, which discharged a thin, sanious matter, but not true pus. In all cases examined I hare found certain uniform morbid lesions, invariable thickening, and deposit in certain portions of alimentary canal, particularly at opening of small borrels into large borrel. This increase of tissue may take place in stomach or in any portion of alimentary caual, but will always be found in the creum around the ilio-crecal ralre. In a large number of cases I have found at this point that "peculiar bearded appearance" spolien of br Flint. But these black specks were only found during the first fer days of the disease. At a later stage there mas inrariably great increase of tissue, thickening, and hard deposit. During the investigation I dissected orer fifty hogs, all presenting the peculiar srmptoms of typhus ferer, and in erery case I found thickening or deposit around the ilio-creal ralve; in seremal cases where the disease was recent $I$ found the minnte black specks, and my omn opinion 
is that the hearded appearance or black specks are the commeneing lesions of the disease, and that this is followed by thickening or deposit. Anomalous lesions were found in many eases. In one the entire mass of bowels were found agolutinated. In several others were found enormous thickening or deposit in coat of stomach; but in all cases, as before mentioned, there was one lesion always present, a deposit or thickening around the ilio-caeal valve where the solitary glands of execum are situated.

The canse.-The exciting cause of this disease is a specific poison in the bloor, an infectious, miasmatic poison, and the disease cammot be generater by any excess of filth, by want of care, or any errors in foocl. The specific poison must be there. The hog, to contract the disease, must be exposed to the specific miasma arising from another animal suffering from the disease. This disease is very contagions, and if it once obtains access to a drove of swine, prompt measures only can prevent its spread to the entire lot. The rapidity of its spread depends mpon the condition of the drove and the ventilation. When the logs are allowed an extensive range, and aue not crowded together, it will spread slowly; but where they are cooped up in a contracted pen it will spread very rapidly. Although, as I liave before said, this is the most conta. gious and fatal of any disease that has attacked swine, yet it has one redeeming feature, it is more easy to prevent its access to a drove, as the miasm camnot be carried as long distances by wind and other metl. ods of conveyance as ean the poisons. of diphtheria and typhoid ferer.

It may be well for me to explain the statement that filth cannot generate the disease. No amount of filth, no confinement in close quarters, no errors in food ean prodnce the disease, but filth, want of ventilation, and improper food can deprave the system, disorder the stomach and render the animal more liable to the inception of the malarly. Hence the disease often obtains access to a drore by means of one or two animals whose systems are disordererl, and having once obtained a foothold spreads to the healthy ones, the contagious influence being now nearel and stronger.

Ineubation. - From the few eases where the stage of incubation conld be accurately determinerl, that is, the period of time elapsing fin the time of exposure until the ontward manifestations of the disease, I would place the period of incubation at fourteen dars. I liave but two instances to report where the time of exposure could be exactly determined. To verify this statement, in each of these cases the exact time of exposure (by arrival of strange hogs suffering fiom the rlisease, and the first ontward symptoms of the disease were noted, and in each case it was fourteen days from time of exposure until the symptoms of rlisease appeared. [See notes on Homestead (Amana Society) Colony.] We shall speal of the predisposing causes when we come to consider the three diseases collectively, as the same causes will promote the spread of either one of them, but in difterent ratio.

Typhoirl fever-Definition.- I specific continned fever, atteuded.with great prostration of strengtl, stupor, tympanites, diarrhea, showing specific anatomical lesions, namely, nlceration of the solitury glands of crecum and colon. The disease, when meomplicated, l'm.s its conse in nine days. During the first month of my investigation I made no separate classification of those two diseases - typhus and typhoid terer. IIr course was as follows: From each infected dlove inspected, I selected from two to five diseased hogs of various ages and at different stages of the disease. After carefinly noting the age, history, and morbid symp)toms in each ease, the animal was lilled, and exact notes taken of the 
condition of the blood, and also of each of the internal organs. From the start I noticed that the symptoms varied greatly in different droves, particularly in condition of bowrels, the amount of eruption on skin and the duration of the disease aud its fatality. I also noticed the morbid lesions varied greatly in different droves. On my return to my office, after three weeks' inspection, I made a careful review of my notes taken in the field, and found I could separate the symptoms into two distiuct classes, only resembling each other in the one peculiarity of being low or typlioid in their character. I also found that the pathological lesions conld be separated into two distinct classes, and that each of the two classes of symptoms were accompanied with one of the two classes of lesions. I was also impressed with the results obtained from treatment by those whose swine presented the peculiar symptoms and lesions which I now call typhoid fever, who reported that the disease had been promptly checked in their droves and a large part of the sick hogs cured by following my instructions in regard to hygienic care and medical treatment. Those whose hogs presented the typlius symptoms and lesions almost invariably reported that all the sick had died, and in most cases the disease was still continuing its ravages. I had also noticed that the peculiar odor poken of was present in some droves aud absent in other's, and on examining my notes found that this odor was confined to the typhus eases. There was, of course, more or less smell wherever there was any clisease among the swine, but the odor in the typhus form had a certain difference that could be noticed by any one. Thus finding I had two distinct diseases to deal with, the one resembling very nearly typhoid in man, the other presenting symptoms and lesions with which I was not particularly familiar, I turned to my medical library for information, and found a disease deseribed as occurring in man with symptoms and lesions exactly resembling those I had classified in swine. I, therefore, called this second disease typhus fever. I placed typhus first in my list, because I found it the most firequent and most fatal of the three, and the one which has caused the greatest pecuniary loss to the farmers.

Typhoid fever symptoms.-Loss of appetite; headache; aroidance of light; standing with its head in a fence corner, or lying in such a position as to keep the light from its face; will only move when urged, and then but a short distance to resume its former attitude; a hot, dry slini ; high fever; thermometer of ten showing $105^{\circ}$ to $109^{\circ} \mathrm{F}$.; increased urine; diarrhea ; tympanitis ; cough ; shortuess of breath, or quick breathing; stiffuess of hind quarters. The hog moves his back fiom side to side as he moves his lind legs. Bleeding at the nose is a common symptom. These symptoms contiune with remarkable uniformity duing the nine rlays. There is an entire loathing of food, and as the disease progresses rreat weakness is manifest. The hog camnot be forced up, but lies for hours in a semi-stupid condition, but still restless and showing signs of nervous excitement. If the case is of a severe type the symptoms will be aggravated. The bowels will be enormously distended; urine scanty and high colored; feeal matter will be passed while lying down, and the urine will pass every time the hog is moved ; more or less petecchic will be found on the abdomen, but in limited numbers. The first sign of improvement is inclination for food and disposition to move around, and in this disease this is the most critical period. Improper or overabundance of food is liable to cause rupture of bowels and deatl, and it is at this time that many swine which have passed through the disease to the crisis are killed by incantions feeding. The nose bleediug is seldom severe, but hardly ever absent. The cough is of no importance as 
a symptom, as it is present in all inflammatory diseases dependiug upon a specific blocd poison. Many farmers point to a congh lasting from one to three months as a preceding symptom of the disease, but this is a mistake, as the cough is due to the climatic changes or sudden ex. posiure as set forth in another part of my report, and has no connection with the specifie ferer. This preceding congh should have told the fimmer that there was some emor in his management, rhich, muless corrected, would reuder his drore more liable to contract any infections (lisease if exposed to its influence. The tympanitis is a prominent symp). tom in this disease, and if the hog is lying down a gentle tapl on its distended flanks will show the presence of wind. Thumps or hiceough occurring during the secoud week is a fatal symptom. During conralesence small abscesses or boils often appear, and also sloughing of ears; in many cases the entire ears rot off. 'This conclition is due to depraved blood, and demands tonics. Tuberenlar disease in lum gs often makes its appearance during convalesence, and the hog is carrich off by what is known as galloping consumption. Malarial complications often render the dangers of the disease more difficult, and have a material influence upon the rate of mortality. In most cases the malarial debility or ferer is the primary disease, and the typhoid fever the secondary. The canses which lead to this ferer we shall speak of under the head of predisposing causes of the specific forer. Eulargement of the glands of the neck does not often ocem in typhoid fever. The duration of the disease may be set down at from nime to fomteen days when mneomplicated. I lare no data from which I can gire any information on the period of incubation.

Morbid anatomy.-I can best illustrate the lesions by quotiug a few cases from my field-notes: Visited the farm of G. WT. Davis, near Frank Pierce post-office, Johuson comty, Iowa; breed of hogs, Poland-China; range, rolling prairic with clay subsoil; about ten acles in lot; lot covered with giass and brush; hog's also had a rum of rye stubble; water ruming through lot; feed, raw sound corn and sour slop regularly. There was no disease in vicinity, and could trace cause to no contagious influence; discasc had appeared two weelis previously, and nine head had died, three large animals and six shoats. There were twelre animals sick, five large brood-sows and seven shoats. This man complained, like many others, of losing his pigs. Symptoms, loss of appetite, high fever, diarhea, emaciation, general stupor.

Dissection, $\Lambda_{0}$. 1. - Shoat three months old, sick one day; lungs white and showing noorganie discase; some inflammation of stomach; liver and bowels appeared healthy. Thermometer showed $106^{\circ} \mathrm{T}$.

No. 2.-Shoat two months old, sick one week; heat $10 \mathrm{r}^{\circ} \mathrm{F}$; hepati. zation of one lung; liver, spleen, and lidneys appeared normal; some intlammation of imuer coat of stomach. On opening the crecun there rere found deep ulcers scattered around the ilio-crecal valve. These ulcers had only the peritoneal coat for a floor, and were in position of solitary glands.

No. 3.-Age two months, sick twelve days; thermometer showed 1020 F.; lungs, liver, spleen, and kidneys showed no organic disease; lungs lighter colored than normal; considerablo enlargement and inflanmation of mesenteric rlauds; ulceration of solitary glands, but ulcers small and evidently healing.

Here we have an illustration of the discase in three different stages. In the first case ulceration had not yet commenced in the bowels. In the secoud it had eaten through all the coats of the bowels except the peritoneal. In the third case the ulcers were healing, and in a few days 
the pig would have been well again. In some cases I hare found small abscesses of solitary glands, each oue discharging matter on pressure, and I thimk this will usually be found the primary stage of the nlcer. Whatever otler morbid lesions may be found, the farmer should carcfully inspect the inner coat of the borels and determine the nature of the lesions of the ilio execal valve in order that he may acemately diagnose the discase. I would impress this particularly, becanse in several instances I opeued swine and found $n 10$ morbid appearances whatever to account for the severe symptoms until the bowels were examined and the inner coat exposed. In one case a farmer in Hamilton connty, who hacl made a specialty of doctoring hog eluolera, after making what he called a thorough examination, declared that a diseased hog was healthy, but I opened the bowels and showed the signs of specifie disease on the inner coat. Although we find the lesions in both typlum and typhoid fever at this point, we can only look upon it as an effect of a certain poison in the blood, but why it uniformly derelops morbid lesions at this one point has not yet been determined, even in man.

Diphtheria.-A specific septic blood-poison, contagions in its character, with inflammation of mucous nembrane of pharyux (throat), and exudation of lymple; inflammation and abscess of kidneys; constipation and fever. Symptoms: Loss of appetite; fever; swelliug of glands of neck; discharge of blood and matter from nose and month; wealiness; the bowels are casually constipated ; the urine is at first increased in quantity, but afterwards decreases in mount. The hog may try to eat, but there seems to be a difficulty in swallowing the fook. As the disease adrances all the symptoms are aggrarated. The hog becomes stupid, and ouly moves when forced to do so. The glands of the neck are enormously enlarged, the urine diminished, aud is at last entirely suppressed. The animal strains to evacuate its bowels every time it gets up, but passes only a few hard lumps, ancl, muless relieved, it dies within from two to five days from suffocation, caused by swelling of the throat or aecumulated poison in the bloorl acting on the brain. The primary disease may be either constitutional or local, but in either case both general and local effects are soon manifest. This disease is a contagious bloodpoison received into the blood, and passing throngh the stage of inembation, manifests its presence first when the system strives to rid itself of the poison through the four great waste-gates of the body-the lungs, kidneys, bowels, and skin. The expired air, loaded with the poisonous excretion, passes from the lungs, and as it obtains exit from the windpipc, is thrown with force against the posterior fauces. There the poison is deposited, and diphtheritic inflammation and cxudation is the result. The kidueys, also, strire to ejeet the foreign matter and are at first stimulated to increased work; hence the increased flow of uxine; but as the labor increases the kidneys become irritated from orerwork, then inflaned, and the septic poison, instead of being eliminated, is cleposited in the kidneys, aud abscess in the same is the result. It the free egress of air from the lungs is prevented, either by swelling of glands externally, or srrelling and exudation internally, either in fauces or wind-pipe, the poison camnot be thrown off as frecly as it passes into the imngs, and abscess of the lung's is the result. In fuct, wherever this poison is deposited an abscess at once forms. The shin is hot and dry, and there is often an eruption or rash apparent on the surface. Abseess of the liver is also a common sequence of this discase if it has continued tor any length of time. The bowels are invariably costive, and, unless relieved by injection or brisk eathartics, the hog will cie, either in convulsions or coma, from the united depressing influence of the septic and nuxmic poisons 
acting on the brain, as the costive bowels causes increased labor for the kidneys and hastens inflammation of those organs, resulting in abscess. The duration of this disease is from one to six days. Death is caused either by suffocation or from accumulated poison acting on the brain. I saw no case of this disease while making my investigation for the clepartment, and my account of it is taken from my record of the disease as it appeared during the winter of $1877-75$. At that time it spread rapidly, and I had no means of testing the period of incubation. Dissection showed the following morbid lesions: In the first stage, inflammation of throat with diphtheritic exudations on fauces, and intlammation of all intermal viscera. In the second stage, all pathological appearances were more positive. The glands of the neck were enlarged, and often contained pus ; throat often a mass of ulceration, with diphtheritic membrane extending to windpipe; lungs inflamed aud kidneys containing extravasated blood, and showing signs of commencing abscesses. In every case where the symptoms were severe and had continued for several days, abseesses of lumgs, kidneys, liver, and spleen were observed, and putrefaction set in very rapidly, rendering examinations very dangerous. The specific cause of the clisease, as stated in definition, is a septie poison, specitic in type, and rery contagious. It spreads more lapidly than either of the other fevers, and usually within two weeks after it obtains access to a drove it spreads to the entire herd, unless prompt and thorough means are adopted to check its progress. Although, probably, the most contagious of the specific ferers, it yields more rapidly to treatment and care, but if neglected it is more rapidly fatal, few that are attacked escaping with life.

Having treated of the three diseases I have found in swine, I will now glamee at the symptoms and lesions which assist us in a diagnosis of the disease. In typhoid we have diamhea, tympanitis (wind in bowels), very little eruption, and entire loathing of food. 'There is seldom much swelling about the neck, but there is ulceration of the bowels and loss of substance. In typhus we find costive bowels and lank flanks, exeept when filled out with solid feces; protuse eruption; except in fow eases, considerable swelling of glands of neck, but not containing true pus. Dissectiou shows increase of tissue and deposit, frequently in coats of stomach and invariably around the ilio-exeal valve; also accumulation of feees in bowels if they have not been relieved by purgatives before death. In either disease there is seldom much disorganization of intemal viscera, unless in adraneed stages, when tubercular deposits may be found in the lungs. In diphtheria we found constipation. There may be eruption, but this is not a uniform symptom; discharge of matter and blood from the nose and mouth, swelling of glands of neck, appetite not entirely absent, but, although the hog tries to eat, soon turns away firom food. Dissection shows ulceration of throat, exudation and intlammation of lungs and kidneys, and in advanced cases intlanmmation, disorarmization of lidueys, luugs, liver, and spleen. In diphtheria also the lisease spreads more rapidly and is of shorter duration, except in eases of constipation in typhus, where death often occurs in a few lours. In all three diseases we have cough, rapidity of breathing, and ferer.

Predisposing causes.-Inchuded under this head are any canses which, have a tendency to reduee the vital strength of the log; disorder the stomach, or deprave the blood, in any way. These causes are foul air, food improper in quantity or quality, bad water, filth, malaria, atmospheric inthences, scrofulous diathesis, umsual exercise and over-suckling. All of these causes combined camnot genelate the disease, but any ono of them, by reducing the vitality or disordering the system in some way, 
may be the cause of the disease obtaining access to the drove. We will consider each cause and how it can be avoided. One of the common causes of disease among swine is confinement in a pen where the air does not circulate freely enough to carry off the carbonic acid expelled by the hog. 'The result is that from dark to daylight the hogs are forced to breathe an impure atmosphere. Many farmers build luxurious pens, tight and warm, and with an abundant ventilation only above, and abundance of straw below, forgetting that in such a house there is no ventilation, that, in fact, the breath, loaded with exhalation from the hog, is heavier than the air and sinlis to the bottom of the pen. Even if, by reason of increased heat, the expired air attempts to rise, the cold air from above congeals the moisture and it falls as minute rain or snow. Other farmers build tight pens without any thought of ventilation and let the hogs pack in as they choose. In this case the air becomes very foul before morning with noxious gases, and if the owner would but put his hand within he would hardly find the air with sufficient power to sustain life. Now, it follows that we must have the pens so constructed that the swine can have pure air, at the same time the intense cold of our northern winters must be avoided, and either artificial heat must be provided or the heat of the hog utilized to increase the temperature where the surrounding atmosphere is below zero. We must remember that the natural haunts of the species in a wild state are in the torrid zone, and that swine are never found in a northern climate in a wild state except where they have escaped from domestication and become wild-that they are not provided with fur to protect them from extreme cold. Now, common sense teaches that when attempting to domesticate any wild animal his natural habits-food, climate, and mode of life-should be carefully studied. Again, effort has been made by careful breeding and feed to change the natural form and development of the hog-to raise a breed of swine with small bone, little muscle, and capacity for taking on fat while young, and these changes have been made at the expense of natural strength and endurance. It is a common remark among farmers that wild hogs do not have cholera, and acting upon this idea many farmers keep their hogs in large timber lots without shelter, and are disappointed to find disease appear and carry off a large proportion of the drove. In these cașes, where the hog is not confined and forced to breathe foul air, but is exposed to the vicissitudes of weather, with loss of vital forco by so-called improvement of breed, he becomes weakened and succumbs. I have noticed this particularly in regard to diphtheria; several large uroves were almost swept away in a few days, although they had large range, pure water, and good food. This is true of diphtheria poison, but I have nerer known the other fevers to attack any isolated drove having pure air, clay soil in range, and good food, unless hogs having the disease were allowed in the same lot. The confinement of swine in close pens has another danger. The animal, heated by the confined atmosphere and damp straw bed, goes out at feed-call on a cold or rainy morning with its skin and hair damp from the accumulation of the gases which have congealed during the night. The cold, frosty air is a sudden change from the heated atmosphere of the pen, and bronchial lung irritation is the result. It is also wet, and this moisture, if it is a rery cold day, is congealed, and the skin is chilled; and thus, from this error in care, the animal is exposed to a double danger. To avoid these dangers the pen should be so constructed that free rentilation can take place at the top, as it is absolutely necessary in a cold climate to utilizo the natural heat of the hog to lieep the pen at a moderate temperature. It will not do in winter to have any openings below. to admit cold air, 
hence we must use some absorbent for the poisonous gases constantly being exhaled by the hos, and the best and cheapest yet known to man is dry clay, which will take up a large amount of was in proportion to its bulk. The dry clay will also assist in keeping the log dry and clean, and with reasonable ventilation above the air will remain quite pure. The plan for a pig-pen annexed I have furnished to many prominent stock men, and all have united in stating that it is the most perfect plan they hare seen. (See drawing of pig-pen.)

The lot should, if possible, hare a clay soil surface, and the feeding floor should have a slope of two incles to earry off the rain that falls upon it. By having the floor open to sun, rain, and wind it is hept clean and pure; by having the lot sloping away from the pen, the rain will assist in keeping it clean by removing refuse matter from the surface. In this way nature assists the farmer in keeping his pens clean and healthy. No straw or other litter shorld be allowed in sleeping rooms, as it will aceumulate moisture and give forth noxious air at all times. Straw should not be allowed in the lot, as it will absorb any poisonous vapors passing orer, and birds coming from herds infected with septic disease will bring the matter on their feet, and it will retain its life in the straw. But on dry ground, even if it finds lodgment, it will soon be disinfected. The hogs should be furnished with pure fresh water in abundance, not only because it is necessary to health, but because water assists materially in producing fat. On the subject of food supply there has been much difference of opinion, and I can only give my own views and the scientific reasons for them. The prime object in feeding swine is to accumulate fat as rapidly as possible on those intended for market, to keep stock hogs in healthy growing condition, and to have brood-sows in the best condition for bearing and suckling young. Of course, to accomplish these objects the stomach must be kept in healthy condition and not overloaded; the food must be of due variety and in suitable quantities, and its character and quality must be considered. For stock hogs, of conrse, green food is absolutely necessary. The hog cannot thrive upon an exclusive rliet of dry corn and water; but the green food must not be the exclusive diet any more than dry corn. If the hogs are kept on a clover lot, sour fermented slop should not be fed at the same time, but rather roots and vegetables, as potatoes, turnips, rutabagas, and beets, which eontain large quantities of the soda salts, which the clorer lacks. Hogs fed or corm may have sour slop to advantage, as this will assist digestion, and in this case prevent an undue acid condition of the stomach and blood. The hog's natural instinet will lead him to seek just what his system demauds, aud he will root in the ground not for the mere pleasure of destroying the clover-field, but to find certain salts necessary to health that cannot be obtained except from the ground. Then if you deprive him of the means nature has fimisher for obtaining these necessaries of life, you must furnish him with them in some other way.

Observing farmers have learned by experience that sickness in swine shows crror in feed, aud at once change to the opposite extreme. If feeding clover they change to rly corm, and if dry corn to elover. This rule has sared many droves fron bcing swept off by infectious diseases. But I will give a rule which I have arloptes in my investigations which is simple, but which at once tells the famer what general comrse to pursue. If the herd is not doing well, if they do not eat well and appear less active than usual, at once exanine the tongues of a few and notice the eolor; if the tongues are red and contracted give sour slop or turu them on clover pasture or on green food, and they will at onee improve. If their tongnes are large, pale, and flabby, give corn, corn-meal, cooked 


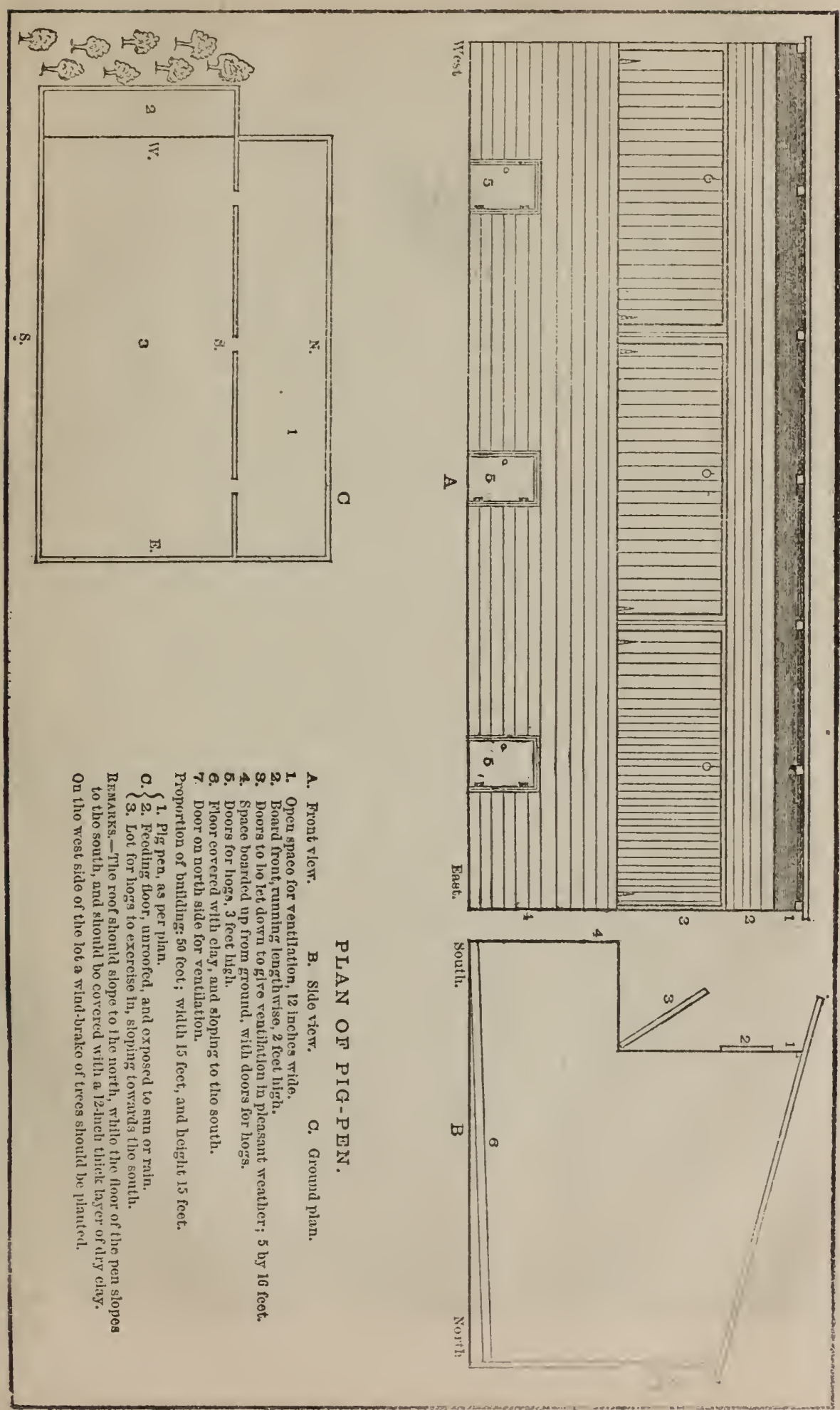


root regetables, and add soda to the feed, or sorla and milk, but give no sour slop. The large, white, pale tongue shows that the stomach and blood are in acid condition and need alkalies; the contracted red tongue shows a subacid condition, and that acids or sour remedies are needed. For years the farmer's' journals have lauded clover-fields and advised keeping swine mpon a clorer range during the entire summer, on the score of economy of feed and health. As far as it goes this is good advice, and yet following this advice has been the chief cause of the spread of the contagious diseases among swine. When the clover range is on clay soil, or the hogs have access to clay banks, and the use of rings is aroided, all will go well, but if rings are used in the nose, or the soil is exclusirely black loam and no other food is furnished but the grass and water, or, perhaps what is worse, sour slop in addition, an acid condition of the blood is engendered. The hog becomes debilitated and peculiarly liable to any contagions diseaso which may appear in the vicinity. Of course farmers must keep their swine on grass and elover, and, as a matter of economy, must use rings to prevent the clover from being rooted up when the range is limited, but they must at the same time study the natural habits and food of the species and supply that food or its constituent elements in some form. The natural food of this class is not a regetable diet, but they rere designed by the Almighty so that they could obtain those roots from the ground. When, therefore, they camnot obtain them, they should be furnished in kind. As a rule, the constituents of all grasses and annual plants are acid-have an acid reaction. Especially is this the caso with clorer. Root regetables hare an alkaline reaction, and are composed largely of phosphates and soda salts. In clay soils the hogs can probably supply themselves from the ground with phosphates, but when confined to a black, loamy soil they can obtain but little of these necessary salts from the earth. A noticeable fact is, that no matter how wide the range the swine will select the bare points to root in rather than the soft loam. Where root regetables cannot be obtained and hogs are kept on clover range, soda and lime or sulphate of iron should be given regularly. Dry corn as an exclusire diet is not a natural food for hogs, and some additions should be made to the bill of fare. Turnips, potatoes, or some other cheap vegetable must be added to insure good health. I lnow there is a bitter feeling among many farmers against cooling or grinding corn for food, on the score of extra expense and trouble, but I have never set known a farmer abandon the practice when once thoroughly tried. It will pay any farmer to grind and cook the corn fed to his logs, even if that staple is worth but 13 cents per bushel. Practical farmers, who have made the profitable feering of hogs a studs, report that one pound of cooked corn-meal is equal to one and one-half pounds of raw meal, and to three of whole corn, in fat-producing power. One arlrantage in feeding cooked feed is that root vegetables can be combined with cornmeal and cooked at the same time. Where raw corn is used as a steady diet sour slop will assist in its digestion, and should be given regularly to prevent as far as possible the evil results of error in diet. ihe use of coal, charcoal, ashes, and rotten logs in the pen assists in keeping tho hogs in health by supplying certain chemicals needed by the animals. I have been thus particular in spealing of errors in diet because 1 believe that this cause more than any other has helped to spread the fatal diseases among swine. A single hog with diseased stomach may be the cause of imparting the malady to a herd, and having thms obtained a foothold it may, umless prompt measures are taken, spread to the well 
hogs, which would, if it had not been for the one or two unhealthy ones, have escaped infection.

The water should be clean, pure, running water, and should be within reach of the hogs at all times. Stagnant water, covered with green scum and loaded with organic impurities, is unfit for hogs to drink, yet many farmers furnish only such to their swine. Foul air, by vitiating the blood, is one of the common predisposing causes of disease. I have already spoken of the influence of heated air on the health of swine, and the evil effects of sudden changes, but I did not mention the depressing influence of the foul air itself upon the animals. Swine breathing air loaded with carbonic acid and ammoniacal gas for half of each day cannot remain healthy any more than man can, and the same natural results will follow-impure blood, disease of lungs, and other viscera. A pen erected on the plan set forth in diagram will remove this cause of disease. The dry clay is the best and cheapest disinfectant yet discovered, and will absorb the poisonous gases and render the air pure. Even thongh a large number of hogs are confined in a limited space, by opening the large doors on the south side on a clear day the sun's rays will dry the clay and renew its absorbing powers.

Scrofula is another common predisposing cause, and one of the principal causes of the large mortality in diseases of swine. The two chief causes of the scrofulous diathesis are breeding young sows and in-breeding. In order to avoid these causes sows should not be allowed to become pregnant until one year old. By that time she has matured and is fitted to bear young. Before that time she is growing and is immature. Not only the mother may be injured by early breeding, but the progeny will inherit disease. In-breeding has been largely practiced in the Western States, and whenerer practiced it is easy to pick out the young resulting from this management. They were the first of the pigs attacked, and the post-mortem examinations disclosed tubercular disease in every case. Before the close of the investigation I became so thoroughly convinced on this subject, that, whenever I detected tubercular disease in lungs or mesentery, I sought out parentage of the pig. In several droves where a portion of the diseased swine were the offspring of in-bred sows and part cross-breed, the tubercular disease was found in the former and not in the latter. In-breeding is often practiced through the effort to obtain a perfectly pure breed of any particular species. With but few exceptions, and those among the imported stock, the pedigree does not extend back more than one or two generations, and often unwittingly the same blood is infused into a drove of sows, although the male may have come from a distance. 'To avoid this grave error, I would advise crossing breeds, selecting carefully the male from some special breed, as PolandChina, and crossing with an opposite breed in shape and habits, as the Essex. The finest drove I saw this year was the result of such a cross. Mr. Pendroy, of Monroe, Jasper county, bred two years to Essex boar and two to Poland-China, making a special effort to obtain as different blood as possible from that in his own herd. The herd of nearly three hundred head were in fine health, except some brood-sows which had been suckled down and were poor. These sows contracted the disease, but it was promptly checked by proper measures, and did not spread to any extent in his drove.

And this illustrates another very frequent cause of the contagious diseases obtaining a foothold in a herd of animals. The brood-sows become worn down with oversuckling and want of suitable food during pig-bearing and nursing, and with systems thus disordered are very liaable to contract any disease in the vicinity. See that brood-sows have 
root-regetables and milk, aud that soda is furnished them liberally with gireen food, and they rill not become so emaciated and debilitated.

Malarial infuences can affect swine as well as man, and is one of the most troublesome and fatal of complications in infections ferens in their first stiges. The low sloughs, covered with green mold and surrounded with rank regetation, are not the most healthy resting places for swine or auy animal, biped or quadruped, especially between the hours of sunset and sturise. The plants are giving off carbonic acid gas duxing the night, and the ret ground, loaded with organic natter, is giving off malaria. If the hogs are allowed to breathe this poisnnous air their blood becomes vitiated and health is impaired, as in man. Typhus and typhoid ferer find a farorable location for incubation here. To aroid these two causes combined, impure water and malaria, let the drove be gathered in at sundomu into a large pen on high ground with sloping surface prepared, and hept there antil the morning sun has dispelled the perceptible wists. If the day is inclement the drove may be allowed to range two hours after the hour for sumrise. They should be furuished pure water to driuk before leaving, if ther are to be contiued in a range with stagrant water. Many rrill say that all this trouble will entail increased expense; but it has not been found more expensire where tried. Swine, like auy other domesticated animal, ean be trained to regular habits, and a drove can be trained to return to its sleeping place, if a smiall quantity of food is furnished them each night until the habit is formed.

Unusual exercise, which debilitates the hog and reakens his rital force, is another canse of the inception of contagions diseases. In several cases which have come under my observation, choice hogs for breeding purposes were purchased from apparently healthy herds, taken on cars and wagons a considerable distance, and after their arriral showed signs of disease and eventually died. In a few days others in the herd to which they had been taken were affected, and thus the disease was spread from a new focus to a large number of droves. I, of course, could not state where these hogs contracted the disease. When they started from their first home they were probably in perfect health, but confined in a close box and jolted around in a wagon, or confined in cars with irregular or unnsual feed, and nervous excitement as adclitional causes, brought on a gastric irritation, and during these travels they were exposed to a contagious illness more or less intense, and their system being in a condition to recrive and take up the poison, it found a lodgment, and after a stage of incubation showed itself by ontward symptoms. Hogs bronght from strange drores should invariably be kept in strict quaratine for at least fourteen days, no matter how perfect the bill of health they bring from their fomer owners. Neglect of this precaution has been the cause of the spread of the disease from new points, and many counties could trace the disease which had carried aff thousands of hogs to a single imported amimal. In one county visited in Western Iowa, which had previously had no smine disease, an estimated loss of over $\$ 100,000$ rorth of hogs was claimed to have been sustained during the past year, and this disease started firm a central point-a single imported log. (I use the term imported as ineaning fiom a distaut county, or another State.) The disease spread to tho drore in which it was placed, and from that drore to adjoining herds. Several expensive lawsuits for damages and much ill-feeling betreen stock-men might have been avoided by attentiou to this point.

We will now take up the subject of treatment, which naturally divides itself under two heads-Preventive and Curative. Each of these can be 
dirided into tro classes, hrs gienic and medicinal. The whole secret of success in prerenting the inception of contagions diseases by hygienic care, as has been already pointed out, can be included under two rules, riz., keep the system of the animal in a healthy state, and avoid exposing it to poisonous, contagious intuences. We have already shomn how the first rule can be followed with success-by fresh, uncontaminated air, suitable food, fresh watex, seasonable exercise, and aroidance of low, damp places for sleeping quarter's; also aroidance of those canses in breeding which are known to engender the scrofulous diathesis. The second requires that all dearl organic matter, such as straw, hay, litter, and other matter, which is liable to catch the poisonous fimgi floating in the air or carried aloug by the wiud, should be kept away from the animal. All strange hogs must be kept in quarantine for fourteen days before being allowed to run with healthy herds. If there is any disease in the ricinity, especial care must be taken that no man, vehicle, or animal from infected localities be allowed to pass orer meadows where healthy hogs are allowed to range; and if any stream passes through your range from an infected district, the stock must be liept from the water, as water will hold the poison and keep it alive for a considerable time. The yards and pens where the swine stay at night must be kept clean of cobs or other organic matter, so that the rains can wash the surface clean. All swine, either brood-sows, shoats, or pigs, not in general health, or showing eridences of debility, should be kept away from the drove and carefully treated, the causes of sickness remored and effects remedied. No medical treatment can be positively recommended as a preventive for contagious diseases. Remedies may be used to correct any derangements of system, as has alrealy been recommended-soda, if the tongue is broad, flabby, and pale; acids, if the tongue is narrow, red, and contracted. In sows worn domin with mursing, nothing can have a better effect and improve their condition more rapidly than soda and sweet mille or buttermilk. If the bowels are constipated, Glauber salts may be given in doses of one-half to one ounce to each hog, or one pound to erery thirty hogs, once a day, uutil the bowels are acted upon. Salt should be furnished to all swine, in small quantities, erery day. If any contagious disease is in the near rieinity, hyposulphite of soda in milk or fresh slop, given every morning on an empty stomach, offers the most reasonable hope as a prerentire, and if the disease is diphtheria or typhoid, belladonna should be added. There is much difference of opinion in regard to the power of belladonna to prevent the spread of the septic diseases, diphtheria and scarlet ferer. From my own obserration I base the belief that it is a positive preventive or prophylactic, and on that account I extend its use to swine, and have recommended its regular use in small doses whenever diphtheria or trphoid was prevailing. As a prerentive, the following would be a good formula for general use: Saturated solution of hyposulphite of soda, one gallon; tincture of belladomna, one tluid ounce. Of this mixture, gire one gill to erery twenty hogs in slop every morning on an empty stomach. Believing that all the contagious cliseases are receired into the system through the mucous mem. brane, and that any agent having power to destroy these minute fungi before their absorption will prevent the disease, I bare for years recommended the use of chlorate of potash or sulphate of soda as preventires when persons are exposed to any contagious diseases. As typhoid has but a limited power of contagion, I camnot say positively that the remedy has prevented the spread of that disease; but I have nerer had a second case occur in a family where the remedies I recommended were used regularly. I would therefore recommend this formula to be used once 
a day where contagious diseases are in the near vicinity to diminish the ehances to the lotrest point. If the tongue is pale and broad, bicarbonate of soda must be added to nentralize the acid in the stomach, also sulphate of iron in doses of five grains will be found useful.

The curatire treatment like the preventive must be both hygienic and medical. If disease has appeared in a herd prompt measures must be at once taken to prevent its spread. The sick must be immediately separated from the well. All organic matter, such as hay, straw, and litter, to which the hogs have access, must be bumed, the lots cleaned up, and erery possible efiort made to destroy contagion. The well hogs, if possible, should be at once placed upon fresh ground; that is, on ground over which the sick hogs have not passed since a heary rain cleansed the surface. Any disorder of stomach or general system should be at once corrected, and at least once a day the remedy before mentioned should be given in slop. Each day all hogs in well herds showing symptoms of disease should be at once separated from the others. Where the season will permit, especially in cases of typhoid fever, keep the entire drove on plowed ground, and have the ground harrowed every day to insure thorough mixture of fecal matter with the soil. Keep the sick hogs on a dry clay floor, with free ventilation, and protected from cold wind and rain ; feed nothing but cooked slop and milk, and these only in limited quantities, adding the medicines recommended with the slop. In typhus and diphtheria the important point is to reliere the borrels as speedily as possible, and for this purpose castor-oil or saline cathartics must be freely giren until the object is accomplished. In typhoid, diarrhea is a prominent symptom, and cathartics should be aroided. When the animal is a valuable one and will repay the trouble, injections of warm soft water into the bowels will be found the best plan for mov. ing the same. The injections should be repeated until the bowels are well acted upon. In diphtheria the important point is to neutralize the poison as rapidly as possible, and eliminate it from the system. This can be effected with the sulphite and belladonna. The following will be found a useful formula, viz: Saturated solntion of sulphite or hyposulphite of soda, one quart; fluid extract belladonna, three drachms; fluid extract aconite, two drachms. Of this mixture give one gill to every sixteen hogs five times a das, in a limited amount of milk or cooked slop. If the glands of neck are swollen to such an extent as to threaten danger from suffocation, oil of turpentine and sweet-oil may be freely applied externally. By following these directions in treatment fer, if any, of the hogs suffering from diphtheria will die, and recorers will be rapid and permanent. When a good article of the powdered herbs can be obtained, the following will be found preferable to the tinctures and fluid extracts: Sulphite or hyposnlphite of soda, five pounds; sulphur, two pounds; powdered belladonna leares, four ounces; powdered aconite root, two ounces; powdered elecampane, a half-pound; powdered ginger, two ounces, and mix thoroughly. On one pound of the powder pour three quarts of water (boiling); add a quart of molasses, stir and cover. Of this mixture give one gill to erery fifteen hogs, or one tablespoonful to every hog, in a little millk, four or tire times a day. The medicine should be kept in a stone crock or wooden bucket-not in a tin ressel. In typhoid fever the condition of tongue is our principal guide to deternine treatment. The sick will, as a rule, utterly refinse food, and rery little medicine will be needed. Carbolic acid in mill, in doses of two to five drops in one pint of milk, as often as the hog will drink, or three times a day if given by force, will accomplish a good purpose if added to medicine, aud oil of turpentine may be added as a useful adjunct. If 
the tongue is red, muriatic acid, diluter in doses of ten drops in a little slop, can be given as often as the hog will drink, or the water may be acidulated with the acid. Where there is a large number of hogs sick it will be impossible to attend cach one. I would therefore advise the use of these remedies to all the sick, not attempting to treat special symptoms in each case. If the disease is promptly treated as above, the first symptoms of typhoid may be destroyed, and the hog will improve at once, but if treatment is delayed the case must run at least a nine days' course. Great care must be exercised in returning to solid food, as this error may render a hog worthless that might have entirely recovered from the effects of the disease.

Under the above course of treatment I have succeeded in checking the spread of the disease, and a large majority of the sick hogs have recovered.

Treatment of typhus fever.-I must confess I have not had any very flattering success in the treatment of this disease, and can only give my views and recommendations and the reasons therefor, hoping that some of my colleagues may have been more successful. As mentioned before, the bowels must be relieved either by saline purgatives or by injections. This is an important point, as impacted fecal matter is a frequent cause of death. Another important point is to keep the hogs on a large range, scattered as much as possible, as crowding together only increases the intensity of the poisou. Internally give as follows: Bromide of potassium, $\frac{1}{2}$ ounce; bromide of ammonia, $\frac{1}{2}$ ounce; gelseminum (fluid ex.), 2 ounces; aconite (fluid ex.), 2 ounces; capsicum (tr.), $\frac{1}{2}$ ounce; water sufficient to make 4 ounces. Of this mixture give one teaspoonful to each hog three to six times a day, in milk or slops. After the bowels have been freely moved the amount of podophyllin (may-apple) must be reduced. The same remedies can be obtained in powdered form and given in infusions: Bromide of potassium and ammonia, of each onehalf ounce; powdered gelsemini and powdered aconite root each onehalf ounce; powdered capsicum (cayenne), two drachms; powdered elecampane, one-half ounce; powdered podophyllin, two to four drachms. Upon this powder pour one quart of boiling water, stir and cover, and give a tablespoonful to each hog twice a day, or oftener, in a little slop. The same medicine may be given to the well animals as soon as they are separated from the sick. It should be given on an empty stomach every morning. The great difficulty in obtaining powdered drugs is that most of tho powdered vegetable drug's have been kept so long in stock that the medicinal properties are lost, and are perfectly inert. I would, therefore, advise the use of fluid extracts in preference to powdered medicines, unless a reliable article can be procured.

The following may be considered the best general treatment for a drove of hogs attacked with contagious disease: Separate the sick from the well animals ; keep the sick on bare and fresl ground, not having been passed over by diseased hogs since a heavy rain. If constipated, see that the bowels are moved either by using salts, oil, or injections. Protect them from inclement weather, and give internally, if the tongues are large, white, and flabby, soda, hyposulphite and bicarbonate, each one-half drachm, sulphite iron five grains, belladonna leaves two quarts, powdered aconite root two grains, elecampane (powdered), twenty graius, once a day to well and three times a day to sick hogs, in millk or fresh, rich slop. If tongues are red and contracted, give water and slop acidulated with muriatic acid to all, and to sick hogs givo bromide, gelseminum, and mandrake, in regular and free doses. I would particularly caution the farmer not to rely upon medical treatment to the exclusion 
of hygienic care, but rather to follow carefully the directions set forth for the case of swine, and make the medical treatment an auxiliary.

$\Lambda$ few words may be proper in regard to worms in alimentary canal. I have found no species of worms which could be strietly included under the head of contagious diseases, or conld in any way be called a cause of the disease to which swine are subject. I have seldom eximnined a hog in auy stage of the disease without funding worms in some form. The long, round worm in the stomach, and frequently the small threadworm in the cacum, have been found. These worms are natural to the swine and to all domestic auimals. They may increase in numbers and cause trouble, but they are not the disease or the canse of the disease, but rather an effect of the condition of weakened mucons membrane which has increased the parasite. Oil of turpentine, in milk or slop, given once a day (preferably on an empty stomach), will expel those worms when so unmerous as to affect health. I have received many letters from farmers and proprietors claiming that the worms were the specific cause, in fact the disease itself, and approving remedies to meet their single indications. I will therefore state emphatically that, in the dissections I have mate, numbering orer one hundred, I have found no form of worms which are not frequent in health, and have found no foreign parasites of any kind that conld be detected with the naked eye that could possibly be a cause of the disease of swine. A careful examination of the liver, lungs, spleen, and kidneys with a powerful microscope may disclose some minute animalcula or parasite (as I said before, I found I could make no practical use of the microscope in field); but even these minute objects are but an effect, and the poison germ lies behind as the canse of the depraved system which has permitted the parasite to find a home. There is one disease known as kidney-worm, of which I have heard almost every farmer speak, but I hare not seeu a specimen of the parasites, although I have dissected a number of hogs which farmers clained were suffering with this affection. I invariably found inflammation of kidneys, but no worm risible to the naked eye.

There secms to be a general belief anong farmers that rings are a strong predisposing cause of disease, and, instead of meeting the opposition to this theory which I expected, I find that careful observers are willing to admit the truth of the statement, and either abandon the rings or furnish the food which is ent off by their use. In Jasper county, which has a rolling, clay soil, and the hogs generally have extensive ranges, I particularly noticed the fact that, in a ride of fifteen miles through a thickly-settled country, the droves in which rings were used were invariably sick, and iu those in which they were not used there were no sick animals. In one drove only the brood-sows were rung, and these alone were attacked at the time of my visit. Although this is but one isolated county, yet it furnishes food for reflection. I do not claim that clover does not contain potash and soda (sodium) in a neutral form. The claim I set forth is that this food has an acid reaction in a green state; that it contains an excess of regetable acid; and that confinement to this diet will induce flatnlency and dyspepsia in any omnivorous animal. It is the natural food of horses, cattle, sheep, deer, and buffaloes, but not of swine; and the anatomy of the hog proves the statement. Mr claim is that no omnivorous animal can remain in health on an exclusive diet of green clover. I appeud the following notes from my daily journal: Joln Nimick, near Washiugton, Iowa, had a breed of Cliester Whites, mixed with Berkshire. Pens, filthy ; range, timber, with clay soil and grass; food, soaked oats after they had been taken sick; good water. Had ninety-four head; sixty-seren died and seren 
recovered; seren now sick. Symptoms: diarrhea, prostration of strength, tympanitis. Dissection of one hog one rear old showed great emaciation, tympanitis, little change in lirer, lungs, spleen, and kidneys. Bowels were expanded with gas, and there were a number of ulcers situated at seit of solitary glands. The disease was typloid ferer. No treatinent was attempted, as the man refused to follow instructions; but the slowness of progress under the rather unfarorable circumstances showed the slight coutagion there is in typhoid, as merely trumiug the drove out on a different pasture had alone checked the rapid progress of the disease, although sick and well remained together.

Johu V. Andersou, Whashingtou, Iowa. Polaud-China herd; on grass and away from straw or manure when attacked. Soil, black loam; water, opeu ditch; inteuse heat, $990 \mathrm{~F}$, at time of attack in July; diseaso in near viciuity, and had been in this herd three weeks. The owner had lost sereuteen hogs, fifty-eight shoats and pigs, and had remaining thirty-eight hogs and three pigs. The disease had spread gradually, and was killiug two or three per day. The symptoms were the same as in last diove-lale, large, aud thbby tougue; diarrhea; tympanitis. All sick. I orclered mills and lime-water, and ground cooked feed made into slop, and linited quautities of soda bicalbonate and hyposulphite (each five rounds), sulphite iron (one pound), given at the rate of one pound to drore of thirty-eight hogs twice a day. Mr. Anderson reported that all the sick auimals recovered except three pigs, two of which were sacrificed in the cause of science. This man did not allow in-breeding; no scrofulous taint was detected in dissection; he did, however, use rings, which I cousider were the predisposing cause of the disease in this herd.

W. J. Hamilton, Washington, Iowa. Breed, Poland-China; feed, growing rye and dry whole corn, with slough water for drinking. Pens clean, large range, but soil black loam, and rings used in nose. The disease had continued ten days, during which time ten had died and thirty-fire had been attacked. Dissection of a few of the sick showed tubercular disease, and the gentleman stated that he had been in-breeding for some time. The same treatment was adopted as in the last case, but report showed no beneficial results when used with sick hogs, or in preventing the spread of disease.

Amana Colony, Homestead, Iowa county, Iowa. Breed, PolandChina; pens in poor order; feed, corn and slop. No disease had been known in the colony for twelve years. In July the agent purchased in Iowa City five boar pigs, and they were lianled to depot and formarded on cars to Homestead when it was intensely warm. On arrival one of the pigs refused to eat, and was put in a small pen in breeding-house, where it died a few days afterward. On the fourteenth day the hogs in pens on each side of the one occapied by infected hog were taken sick and died, and the disease gradually extended until over two humdred had died. Two of the five boars were sent to the North Amana Colony, and in fire days refused food, sickened, and died; and in nimeteen days from their arrival the pigs in pens on each side of the one containing sick boars were taken sick and over five liundred died in a few months. In each of these cases the disease appeared first only in the pens immediately adjoining the infected pen, and afterwards spread to the other pens. The other boars were carriad to the other colonies of the society, remained $\pi$ ell, and no disease appiared in any of the seren settlements except the two mentioned. I visited the man from whom the boars were purchased, but could elicit but very little information. He stated that his " hogs had congh, as all hogs har, and that he load lost about thirtyfive head by the intense heat, they being rery fat, but that no disease 
had appeared in his drove; and, further, that he lost no hogs for some weeks after selling those to the colony." It may have been that these hogs had the poison germ in their system before starting from home, and might have sncceeded in throwing off the poison if they had been retained at home; but worry, fatigne, and confinement during excessively hot weather, in a close box in a tight car, was enough of itself to reduce the animal vitality to a low ebb, and give the most farorable enconragement for the disease.

Respectfully submitter.

Iowa City, Iowa, December 3, 1878.

ALBERT DUNLAP, M. D.

REPORT OF REUBEN F. DYER, MI. D.

Hon. WiLliais G. Le Dud,

Commissioner of Agriculture:

SIR: Having been appointed by you to inrestigate the diseases of swine in this locality, I entered upon that duty August 1st, which duty was to extend over a period of two months. Having performed that duty to the best of my ability, I now proceed to make a detailed report of my investigations.

Having earefully noted the origin and spread of the epidemic among swine in this county, which first made its appearance on the farm of Mr. William O'Mera in May, 1877, the report I am now to make will commence at the time when, from that starting point, the disease has become quite universal in this locality.

In order to thoroughly understand the cause of the disease, I will commence at Mr. O'Mera's farm. He is situated on the bottom-lands of the Illinois River, close to the bluff, which rises some 60 or 70 feet. His hog-yard, which comprises about one acre, is close to the Chicago, Rock Island and Pacific Railroad, so that his herd was exposed to any contagion that might be transmitted by moring stock-trains. An instance of this kind oceurred in the case of Mr. A. Holderman's herd, which was attacked about one month ago. There was no diseased herd within several miles of his place, but the same railroad passes through his farm.

The same condition is seen again in this town near the stock-yards of this railroad. Pigs confined in pens near the stock-yards have been infected in the same manner. Also on the Chicago, Burlington and Quincy Railroad, where the railroad crosses the Mlinois and Michigan Canal, a MIr. Londergrau had some pigs confined in a pen close to the railroad. The trains stopped directly opposite lis pen to take in water, and his pigs became rliseased. As it is a well-known fact that these roads have been shipping diseased hogs, it appears quite erident that these points became infected by disease transmitted by the railroads, and also by wagons transporting hogs to market.

Owners of homs, as soon as the disease attack their herds, and sometimes before, sell all fat animals, havling them to market in wagons. All along the road thus traveled herds will take the disease, and it is probable that the herd so attacked is infected by hogs thus transported. This is evidenced in the manner in which it is distributed, as one herd will take it, and then it may pass two or three farms before another one is infected, and this peculiarity of attack is only observed on roads orer which diseased as well as dead hogs are hanled. When not carried in 
this or some similar manner, but left to its own natural course, as a rule it mores steadily along, taking in each farm in turn. There are but few exceptions to this rule.

In the northern part of this county it is particularly observed on roads over which dead hogs have been transported that hundreds of animals are suftering all along the line of these roads with the same peculiarity of attack as is mitnessed by the live diseased hogs passing. In view of these facts, it is fair to presume that Mr. O'Mera's herd contracted the disease from the stock-trains on the Chicago, Rock Island and Pacific Railroad. From this herd it began to spread to the adjoining farms, going up the biuft's to herds on farms situated along the bluff.

In Jume, 1877, it struck Mr. A. Strawn's herd, and he lost very heavily. West of Mr. Strawn's it attacked Mrs. Hardr's herd, and she lost nearly all. The next farm west, which was only separated by a common board fence, on each side of which hogs were confined, it did not attack, and the owner attributed his immunity to adding sulphur to the swill fed his hogs; but it went east, taking sereral farms, and was only arrested for want of material to prey upon.

From Mr. O'Mera's it crossed the Illinois and Michigan Canal, and extended east and west up and down the Illinois River.

Mr. J. Delbridge had a herd of young hogs, which he sold late in the fall at an auction sale. At the time of sale it was not supposed that his herd was affected, but the heard adjoining his had been dying for some time. The sale was made, and different parties purchased the pigs, took them home, and placed them with their own hogs. In a few days after it was noticed that these pigs were diseased, and every herd in which they were placed, without a single exception, was attacked by the disease in question. In the herds thus contaminated the disease lingered until the spring, but it did not spread much until warm weather, and since the growth of regetation became rank it has spread all over the southeru part of the county, destroying not less than $\$ 50,000$ to $\$ 70,000$ worth of hogs up to this time, and it is still raging. One great source of spreading the disease is observed by the small pigs wandering to the herds of adjoining farms, and thus importing the malady. Farmers usually confine their hogs in lots only sufficiently fenced to keep in the large ones, hence the small pigs readily escape and gain access to other herds. Many farmers tell me that when their herds are sick they do not know what becomes of the small pigs, as they all disappear and seldom return. When asked if they know how their herd contracted the disease, they rery frequently answer, "Well, one morning I noticed a strange pig in my herd which was sick, and in about ten days or two weeks mine began to die." Another instance proving that the disease is transmitted by those infected occurred only a fer days ago. Mr. Dunlary, who lives north of the Illinois River, in Ottawa tornship, purchased five pigs from a Mr. Poundstone, who lives in the infected district south of the river. Soon after Mr. Dunlary placed those pigs in his herd he noticed they were sick. Tro of them soon died, and this morning he telis me he has lost serenty of the remainder of his herd and all his small pigs; also lost eleren of his fat hogs. He had one hundred and ten head, all told. Mrr. Poundstone tells me he has lost his own since selling those to Mr. Dunlavy.

The same rule holds true by placing well pigs in a diseased herd. In March last three well pigs were placed in a diseased herd, and in a short time ther were taken sick. This shows that the disease retained sufiicient vitality through the winter to inpart itself in the spring. I carefully cxannined three of these cases, and found the disease a typical case, 
Only one of them had then died. I might go on and ilinstrate by a good many examples to prove the contagiousness of the so-called hog-cholera.

The mycetic theors, which is now so popular among scientific men, and which ascribes the disease to parasites of the lowest form and smallest size, would seemingly offer the only explanation for this disease. It cannot be a toxic poison, as no one has erer been able to demonstrate an organized poison as a cause of any contagious disease. The lowest forms of organisms live in the air and in water as well as when attached to solid bodies. A specific germ, a farorable medium of derelopment, and contact with the animal to be infected are fundamental conditions for the derelopment of the disease and its diffusion; and erery purturbation, every solution of continuity in the chain of these factors of derelopment may prevent or lessen its lestructive action.

From numerous observations $I$ am convinced that the moring of dead animals does not import the disease as readily as do the live ones. I am led to believe that putrefaction diminishes the capacity for infection, and that the bacteria of decomposition is destructive to the germs of the disease. It is a well-known fact that one low form of organism is destruc. tive to another low form. Climatic influences hare but little control. I think that warm weather acts more favorably to the formation of the infecting germ. Along belts of timber it readily spreads; it also extends out on the prairie where the growth of regetation is luxuriant. Contact of diseased with well animals imports it under all circumstances, climate having no influence to prevent its spread. As to diet and care, it matters not how well or how poorly fed, or how cleanly kept, if such well-fed hogs come in contact with the disease, they are as sure to contract it as those that hare no care. Where not caused by other means, the prevailing wind gives the direction or march of the disease. The greatest distance that it has been earried by the wind, in any well-authenticated case that has come under my observation, is two miles. As a rule, a greater or less number of animals in erery herd will escape the disease, or have it so lightly as not to interfere with their doing well.

It appears that quantity as well as quality of the germ, and aptitude of the animal to receire it, are the conditions which influence contagion. Some animals possess an absolute porrer of resistance. 'Troussean says that "there are individuals who pass unharmed through every kind of an epidemic, be it intluenza or cliolera, searlet fever or measles, smallpox or typhoid ferer. There are individuals whom it is impossible to affect with the raccine virus; inoculate them twents times, and you will obtain no result. If I may use the expression, 'the soil is barren,' and in it the seed cannot germinate. There are others again in whom the porrer of resistance is only temporary. It is in general diffeult to find out the condition upon which this power of resistance depends. It is linown that the ability to resist contagion varies with the age of the individual. 'There is less power of resistance in the youth than in the old man. One attack of a contagious disease generally conters complete immuuity from any subsequent contamination. Occasionally it may be repeated, but these exceptional cases do not at all invalidate the general rule."

The same writer still further says: "It rould appear that virus or morbific inatter, upon its entering the economy for the first time, puts in motion all therein that is fermentable, and so thoroughly destro5s it that the leaven-the contagion-when introduced again, finds nothing whereupon to exert its action."

Wilson says: "That in every epidemic there is always a great rariety in the gravity of the clisease, some cases being rery serious, others rery 
slight, without any apparent cause for such difference. Sometimes an epidemic begins with moderation and closes with sererity, and vice versa."

Trousseau holds: "That erery contagcous disease must have a spontaneous development, as contagion necessarily implies the presence of two individuals, one the giver, the other the receiver, of the morbific germ." This remark he follows by another which modifies it: "While there is every reason to believe," he says, "that at present there are some diseases, such as syphilis, small-pox, and measles, that are always reproduced by contagion, there are other maladies which wo see arise spontaneously."

I beliere it is now generally conceded that all diseases that pass through a regular period of incubation are contagious or infectious, and that they depend upon a morbific germ for their development. In sev. eral of the contagious diseases the morbific germ has been discovered by the microscope, and in all probability the morbific germ in all contagious diseases will yet be discorered, as has already been the case in the measles, small-pox, whooping-cough, scarlatina, typhus and typhoid fevers.

Lubermeister, in his introductory remarks on acute infectious diseases, says " that a peculiarity of infectious diseases, which they have in common with the poisons proper, or intoxications, but by which they also differ in the most marked manner from all other diseases in their specificness, which shows itself in the fact that always and under all circumstances a given kind of disease is solely due to a given kind of morbid agent or cause. There is no such constancy between cause and manifestations in other diseases. Exposure to different degrees of cold will produce different affections. *** $*$ On the other hand, vaccination with the virus of variola only produces variola, if any disease at all is produced by it; vaccination with the raccine matter only produces vaccinia; the infection from a patient with measles only produces measles, and never anything else, and vice versa. Whoever, therefore, is affected with small-pox, measles, syphilis, \&c., is certain that he has taken the disease by becoming infected with small-pox, measles, syphilis, \&c., and of no other disease. In infections diseases the predisposing cause, which in most other diseases plays a more important part than the exciting cause, is to be considered only in so far as it may determine the sererity of the disease. The kind of disease is entirely independent of it. Various physiological conditions may induce other pre-existing affections, and are influential in so far as they may increase or diminish the susceptibility, but the kind of disease will not be determined by it.

"Through the longest series of generations diseases preserve their specific character with the utmost persistency, and if at times some of these characteristics are not brought into complete maturity, owing to an unfavorable field for their development, they assume them again as soon as they are planted in favorable soil. The weather, the period of the Jear, the climate, the conditions of the soil, \&c., conduce to, or prevent the spread of, an infectious disease, but they never change the nature of the disease. The kind of diet and all other physio-chemical influences act indifferently with regard to the nature of the affection, and one in. fectious disease is never changed into another. The doctrine of specificness wonld arise, as a necessary consequence, from the hypothesis of a contagion vivum, eren if it were not already proved by the facts. From the specificness of infections diseases we naturally conclude that they nerer arise spoutaneously, but are dependent upon a transmission or contiuned propagation of the diseased person." 
When a hog is attacked by the disease in question, the first thing that is usually noticed by the owner will be that it has refised its food; it walks slowly along with its nose to the ground. The attack may or may not be preceded by a congh, but a cough is usually noticed in starting the animal from its resting place. It is inclimed to hide itself in its bedding. Sometimes a distinct chill will be noticed, the animal shirering or shaking like one with aguc. There may be bleeding at the nose, also bloody urime. The bowrels mar be loose or costive. Usually in small pigs a diarrhea will be observed, sometimes quite serere and producing pains. Vomiting is often present, and many eases, especially among old hogs, where this is the case, they recorer, while others in the same herd that do not romit or have diarrhea die. In many herds quite a percentage of all that have an active diarrhea recover, while in other herds that are not thus affected, nearly all die. A swelling of the face, ears, watering of the eyes, increased saliva, and also increased discharge from the nose, are all symptoms of the disease. The genitals in sows will be frequently swollen; an eruption orer the entire body; in some cases quite red, in others dark discolored spots appear. Some limp off as if lame in all the feet; others oniy in one foot. Some are attacked by convulsions. The fever rums high for four or fire days, if the animal is not sooner destroyed. In fact, all the tissues of the animal suffer more or less as though the poison affects all. The mouth and throat often have a diphtheritic appearance, and bronchitis and inflammation of the luugs supervene with pleurisy. On post-mortem examination during the period of incubation you will notice the capillaries of the lungs already inflamed and bursting. Later, a cireumscribed interlobular inflammation ; still later, gangrene of the lungs. The liver may be inflamed, also the mucous membrane of the stomach and intestines. The kidneys sometimes present traces of inflammation; in some the peritoneum with slight effision into the abdominal cavity. The temperature during the ferer often runs very high, from $107^{\circ}$ to $105^{\circ} \mathrm{F}$., but some time before death it decreases. The same or nearly the same temperature will be observed morning and evening. There are exceptional cases that have come under my observation.

Among the affections of the nerrous system is an inflammation of the meninges with rigidity of limbs, spinal meningitis, muscular paralysis, and convulsions with eclampsia.

Among intammations may be mentioned that of the pericardium, gangrene of the lungs, interlobular inflammation of lungs, abscess of lumgs, peritonitis and inflammation of mucous membrane of the stomach and intestines, liver, and spleen. The inflammation of the stomach and intestines is of a catarrhal charaeter, sometimes moderate and sometimes serere; diarthea with intense pain; bleeding from the kidneys; abortions by sows with pig; also abscesses in subcutaneous tissue. A hemorrhagic condition manifests itself by bleeding about the ears ; inflammation of pleura with adhesions of a fibrinous character, but no effusion into the plemial earity.

Aggregating a large number of cases in the same herd, you will find all the tissues diseased, but more partieularly the lung tissues and the mucous membrane of the intestines.

I saw one case that had survired the acute attack that in two months terminated by tuberculosis and ascite; gangrene of tissues in hams and about the face; inflammation of fetlock or ankle joints, involving ligament and bone. In observing a diseased herd of several hundred head, rou are impressed with the fact that the intectious poison invades all the tissues to al greater or less extent. In one hog it will be noticed 
that the brain or spinal cord is the point most severely attacked ; in another, the muscular and ligamentous tissues suffer; another, the bowels receive the attack, but all ending alike, with a destruction of lung tissue. The whole course of the attack very much resembles the effeet produced by an epidemie of measles, and quite similar to typhus fever in man.

The first herd that I visited after receiving my appointment was Mr. J. Follet's, of Deer Park. Mr. Follet had a herd of six hundred head, largo and small. They had been dying for three weeks. He had been giving kerosene and lime in their drinking-water. The herd was a mixed breed of Berkshires, Poland-Chinas, and Chester Whites. Two years ago he lost nearly his whole herd. His pasture was woodland prairie, traversed by ravines, so that every rain washed the ground, especially his feeding-ground. The water to drink was from a spring, pumped into a trough by a windmill, and the trough was so constructed that they could not get their feet into the water. This herd was well sheltered from storms and sun, and their sleeping places were seattering out-buildings, so that there was no erowding together.

I advised him to continue lime in wat:r, and to disinfect thoroughly with carbolic acid and chloride of lime, and to give sulphur, soda, bicarbonate, and salt, which he did; also tupentine in swill. The animals soon ceased to die, and he saved nearly all of his older hogs which he had wintered over and a few of this year's pigs. One hog, whenever it found a dead pig, would at once eat into its entrails and devour the whole internal viscera. This hog thrived finely.

Joseph Watts, who had a large herd, lost a great many hogs. They had been dying for about the same length of time. I advised the same course as with Mr. Follet's, but I cannot say that any rery satisfactory results followed. His herd nearly all died, and out of one humdred and fifty head he sared only thirty.

Mr. Henry Green's leerd had, since May, been running on a timothy and clover pasture, through which ran a creek. They had no corn. His year-old hogs began to die first, then the breeding sows, and lastly the pigs. He disinfected rery thoroughly with carbolic acid, chloride of lime, and lime. As he had a very choice lot of Poland-China hogs, he was rery anxions to save them. He sold what pigs would do to go to market, but with all his care by changing lots, turning into his cornfields, ce., he saved only four or five head.

In this herd I separated a few siek ones and placed them by themselves and gave fluid extract aconite to control the fever; but the results were unfavorable, as those thus treated finally died. A few others I gave a physic of mandrake with like results, losing all or nearly all the small pigs. I will here remark that but few of the farmers that have large herds know anywhere near low many small pigs they have, as they only comnt the larger hogs. Mr. Watts thinks he has lost a hundred small pigs.

Mr. Roekrood's herd is confined on an adjoining farm to Mir. Green. He also had a very choice herd of Poland China hogs, numbering one humdred and sixty-five, ninety large ones, seventy-five spring pigs. He sold twenty-two large ones after his herd was taken sick, lost thirty large animals, and has only five or six small pigs and thirty-eight large ones left. He used soda, turpentine, sulphur, and kerosene after the herd was taken sick. Fumigated once with sulphur, and regrets he did not repeat this process, as, he says, "after doing that they appeared so much more lively:" I made several post-mortem examinations in all these herds with like results.

Talman and Ed. Libby's herds were in a woodiand pasture, with 
plenty of good water. Previons to turning ont to pasture this spring he fed salt, sulphur, and rood-ashes combined. As scon as he discovered the herd was sick he took them from the wootland pasture and diviled up the herd, placing some in a yard and some in an orchard, and other's in an open ficld with straw stacks in it, and npon my advice gare salt, sulphur, sodia, and turpentine, disinfecting with earbolic acid.

On the 6th of Oetober I visited his herd and found he had enly lost a few of his loogs, and these were mostly small pigs. He said he "never had hogs do aus better than they are now doing." He continates the sulphur treatment.

Miehael Ryan's herd consisted of only sir shoats, which he had wintered. They were ruming in a pasture or timothy and clover; grass tall; elear stream of water; hedge fence for shelter. When I visited the lot I found them lying in tall grass, and all sick. His farm adjoins that of Mr. Rockwood. One half clied. No treatment.

Mrs. David Stramn lhas a large herd, which she fed sulphur, copperas, and salt up to three months ago. She has commeneed this treatment agaiu. This herd lost hearily. The surroundings in the way of sleeping places were rather bad, being old straw stacks and dirty sheds; but they hat a good pasture with plenty of spring-water for drinkins. IIr's. Strawn's hogs being in very fair condition, she shipped all that were not sick. She lost most of her small pigs. Just in this neighborhoor the disease appcared to be more fatal than in any other locality in this section.

Jolm Craig Morr:s herd consisted of thirty large and twenty small animals, and were confined in woodland pasture. He lost three large and six small hogs. He gave sulphur, copperas, and wood-ashes.

Isaac Recd's herd was confined in an orchard and open-lot pasture. He had five old hogs and screnteen young pigs. Once a reek he gave fine soft coal, wood-ashes, and salt, with occasionally a little sulpliur. He lost hoth liuge and small animals; has only two left.

John Goss laal a herd of serenteen and lost twelve; the remainder had the divease, but got well. He bought seren more and put them in the pen two months after, and they did not talie the disease.

Joseph Blacli"s herd is situated just across the roach sonth of Mr. Henry Green's. Mr. B. put sulphur and asafetida in his swill-barrel, and disinfected with chloride of lime, and saved a large number of his pigs and nearly all the older hogs, while Mr. Green lost severely, and the ouly difference in care and situation consisted in Mrr. Blacli commencing treatment before his herd was taken sick. I saw no reason why MIr. Black should not have lost as many as Green or Rocknooul moler the same conditions.

Mr. Blaclis herd was in a timber and prairie pasture, cut up by ravines. He had seventy-five head, and lost five old and halt his young pigs. He walle lime, sulphur, and wood-ashes.

Richard Snith, living on the south bluff of Jllinois River. hath seventeen hogs, a year old, and thirty young pigs. An old animal and in roung pig were the first to die. The pig weighed from tis to 100 pound: 'The old animal was at sow with sucking pigs. All the pigs cliect, ant in ten days more other pigs began to die. After he had lost four he gave one sow uitrate potash in water and she recovered. I advised anafetidat, sulphur, and soda, with turpentine, iu strill. After lie commenced this treatment he lost no more hogs. Mr. Snith sars, "Lrery time I give turpentine I can see that that eough gets better."

MIr. Gent?cmen's herd was treated with a secret remedy by a IIr. Sutton. Mr. Sutton claimed specific treatment. He also treated some of 
Jr. Watts's and L. C. Lewis's herd, but they rejort no particular success. Mrr. Dunlary also employed a patent-medicine man to treat some of his lrogs, but he says "His medicine does not amomnt to at row" of pins, if the govermment "lid give him a patent."

Mir. Neve'l's herel, at Deer l'ark, was troated with bi-sulphite soda, but withont snesess. Ilo then changed to sulphur in swill, and there was marked improrenent. On Oetober 11 th Mr. Newell reported that this lawt trentment suceceded woll. In all casess where carbolic acid has been used for disinfectirn purposes, parties so using it have added some to the swill in trough. One litter of pigs which I treated entirely with carbolic ateid lassed tho acnto attack, but finally ${ }^{-}$wasted away and died. On post mortem cxamination. I could not discern any inmecliate canse of death.

Connelins Sullivan, living in the outshirts of the eity of Ottawa, had three laxge and six small pigis taken with the cliscase. At the time I saw the lot he Inad lost tro large and one small one. I gave him bromidle ammorimu, but bare not yet heard low it aeted after the second day of administration. Ife sairl then that he conld see no difference. I gave the same remedy to Mrr. 'Thomas T'oombs and at Mr. John Hickey, but have not ret received any report fiom them.

Mr. Hunt tried a renedy administered by Dr. Dunlap, of Iowa. At last accomnts they were still dying, but he sayis he thinks it helped them some.

Many lave used tar as a preventive quite freely with more or less apparent acivantage. While nothing gives entire immunity, yet herds in which this disinfectant has been used do not sufier so sererely as others not so treated.

Abuer Strann Ihad is very fine herd of Berkshires. He is largely engaged in raising fine stock, and is fitted "u with erery convenience for feeding and sheltering it. Still he lost very heavily. The widlow Hardy directly west of him lost all but one or two of her logs, but in the next herd west of widow Mandy's, owned by Mr. Dufiy, which was only separated by a common board fence, not one died. He ferl sulphur mixed in swill. 'This was in the summer of $187 \pi$. This year the disease is not in that locility, and what few animals Mir. Straw's had left have done well, and he has xaised some very tine pig's from a sow and boar that had the disease last year. A Mrr. Degan has also raised a fine litter. of pigs from a sow and bour that cume rery uear dying last year. I have seen screral instances where those that had passed through the disease and were used for breeding purposes hare clone well. I met. with one case, that of ML. Goss, who says that he dirl not succeed in raising pigs fion parents that had been affected, but the canse may have been in the boar, as he made no further test.

Peter Donlary, situated north of the Iilinois Rirer, imported five sows aud introduced them into his leerl the latter part of Angust. He purchased of a Mr. Ponndstone, whose hed it has since been proven was infected at the time, as they subseruently dien. Is Mr. Donlary was situated in a neighborhood where there was no disoisc peuding, I desired to make an effort to quarantine the clisease and confine it to his herd. Now, at the present writing (Ostober sth) it has not spread to any adjoining finms. His nearest ncighbor is eighty rods away. Mr. D. has disinfected thoroughly and continnonsly with a solution of crude car-

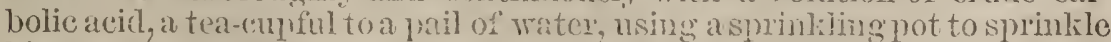
his logs and vards, sleepins and fieching places.

If it ean be established that 1 be lisease can be riarantined, then I think we hare made a nore in the only direction wirle which I havoany 
knowledge by which we can prevent its spread, unless the government will to as Eugland did with the cattle plague, kill every infeeted log and pay the owners a part of the loss, and thus stamp it out. Certain it is that some stringent measure should be used to prevent transporting diseased animals. As long as railroads are allowed to ship, or owners to sell, diseased animals, just so long will we hare the disease spreading over the country. The loss, starting from one contaminated spot in this country by trausportation by rail of diseased hogs, has cost this county this year already not less than seventy-five to one hundred thousand dollars. Some place the figures much higher. The loss is not only to the owners immediately, but in the future. When it shall become universally known that diseased animals are being continually slaughtered and packed for shipment, when Europe shall learn that we are sending them cholera hog-meat to eat, then one of the greatest sources of revenue to this country will be seriously damaged. It is a notorious fact that the stock-yards in Chicago are full of diseased animals. Commission men say that they are selling that class of hogs for slaughtering and packing, and think nothing of it. I know that in the yards in this town hogs die from this disease, aud as rrell hogs are put into the yards preparatory for shipment, they will, of necessity, contract the malady. They are sent to market, and about the time they should be slaughtered are taken sick. I know this is not a rery pleasant picture for those that like a steak of ham with eggs, but it is a true one, and when Congress can only appropriate the paltry sum of ten thousaud dollars to aid in trying to stop this anuual loss of twenty or thirty millions of dollars' worth of property, I want every Congressman to just reflect that almost everything he eats has a little lard in it, and that every time he calls for ham he may be eating a piece of cholera hog. I do not feel competent to present this subject in the light it ought and deserves to be presented. If we wish to preserve this industry the matter must be grappled with vigorously and with no stinted hand, and prosecuted until the last restige of this disease is swept from this country.

I have used by way of experiment nearly all the articles recommended in your circular, bnt the time of observation is so limited I eannot yet report results that would be of any practical information to the govern. ment. Owners of hog's were willing to pay the expense of medicines themselves, and I have to thank those gentlemen who have kindly and earnestly seconded my efforts to arrest the clisease, and at the same time try to obtain information in regard to this terrible scourge. In summing up I do not deem it necessary to give a history of each individual herd that I have seen, as those mentioned are types of them all.

As to treatment, I am led to the conclusion that the use of disinfectants offers the best field for success. The use of turpentine for the cough acts better than anything. I have tried, and when given early, I think, very much mitigates the severity of the disease. A mild laxative like sulphur also acts well; besides, it has the additional adrantage of being destructive to low forms of organisms. Alkalies during the attack are certainly beneficial. Frequent changing of the location of the herd and stamping out every sick pig will, in the end, sare money to the owners.

I hope, now a beginning has been made, that Congressmen will see the importance and real necessity of following up this small beginning until it is thoroughly ascertained what must be done. It it proves, like most contagious diseases, largely uncontrollable after the animal has once been attacked, and must have its own run, then we must turn our attention to eradicating the plague by more expensive and radical means.

Such legislation in regard to transporting diseased animals, or the 
sale of them by owners, or the killing of all animals that have been exposed to the disease, must be enacted as will effectually put a stop to the spread of it over this country.

I am, very respectfully, your obedient servant,

OtTaWa, ILL., October 1, 187 S.

REUBEN F. DYER, M. D.

REPORT OF DR. AIBAN S. PAYNE.

Hon. War. G. Le DUC,

Commissioner of Agriculture :

Sir: My description of this disease (so-called hog-cholera) will be confined to its history as it invaded that beautiful section of country lying between the Blue Ridge and the Catoctin chain of mountains, in Virginia, during the summers of 1869-77-'7S.

\section{GENERAL CONSIDERATIONS ON CONTAGION.}

Before speaking of the endemic and epidemic disease under consideration, generally known as hog-cholera, although a palpable misnomer, I will offer a few remarks upon the subject of contagion. This is always a question of paramount importance, not only to the investigator of diseases, but to the people at large. One great difficulty in arriving at a definite conclusion as to the contagion or non-contagion of a disease, I am persuaded, arises from the too great latitude given to the definition of the word contagion by the older and more systematic writers. In the sense in which this term is used at the present time it strikes my mind as being too vague and indefinite. The same objection may be urged against the term infection. For if you mean to signify by the term contagion a discase that transmits disease from one subject to another by direct contact, without the assistance of any susceptibility or predisposing cause on the part of the patient, I should then contend that very few epidemic or endemic diseases were so, strictly speaking. But if you mean by contagion to signify a disease from which exhalations or emanations may arise during its progress, capable of exciting a similar clisease in those exposed to the influence of the noxious exhalations, or rather deoxygenizing emanations, then I will say that most of these epidemic and endemic diseases to which man and the domesticated animals are equally liable are more or less contagious. For here you have an exciting cause furnished by a foul deoxygenized atmosphere and a predisposing cause furnished by a weakened, impoverished system from improper food, bad water, or from the want of proper protection from inclement weather, or from sudden climatic alternations, causes sufficient of themselves, uuder certain circumstances (which we call epidemic influences), to produce disease in man or domestic animals. Infection is as unfortunate and indefinite a term; nor are the terms "specific" contagion and "contingent" contagion, as defined at the present day, by any means explicit. In my humble opinion fevers are a unit, varied in their character by surrounding circumstances; that is, in a temperate climate a remittent bilious ferer becomes Jellow ferer in a hot climate when the temperature of the atmosphere is at its acrne of power. The theories of ozone, "disease germs," micrococci, sic., are rery plausible in theory, but they have yet to be proven. 
Contagions diseases are produced either by a virus capalyle of eansing them by inoculation, as in small-pox, of by miasma procecting from the sick, as in the plingue, meastes, and scarlet fercr. Lo two plysicians agree as to which diseases are contanions and which are not. The conta gia of the plagne and typlnus, especially the latter, is denied by many. It seems probable that a discase ma be contagions moler ecrtain circumstances and not so under othere. 'That is, a ease of ephemeral ferer, ferer of acclimation, the millest forn of ferer linown to the medical profession, arising from cold sulperindinced by sudden and decided climatic alternations, mar, if tho patient is kept in a close, foul condition, be converted into a disease capable of producing emanations which will reprodnce a similar discase in those exposed to them, and with great virulence. Iphemeral or camp ferer is almost sure to manifest itself in eases where large bodies of healtin men are brought into camp from different sections of the comtry. ILis is equally apt to be the case when you bring together healthy roung animals from different parts of a country, even it from diflerent parts of the same county. We know this much; but how much this materia morbi weichls, what its color is, how it smells, are to us secrets ret hidden from our riow. We know that if a man has fever and it internits he becomes cold and shakes; we say he has "intermittent ferer," "chills and ferer," "ague and ferer," and we know if he lias a long continuance of this kind of ferer, one of the organs of lis system (the spleen) is apt to become enlarged, and this is about ail we really do lnow as ret, because no one has seen, weighed, or smelled the nectrliar miasma which causes intermittent ferer.

I noticed two facts which them important light mpon this subject of hog-cholera in this Piedmont comtry, viz, that recently the larger portion of the sick hogs were under tredre months of age (shoats), and the larger portion of them were taken sick while eating the corn after cattle which were being fattened for marliet. The popular name given this disease is, as I hare before said, a palpable misnomer. If 1 am correct in mr diagnosis-and I think I am-it is Rotheln, or Butch measles, and shonld be classed with the exanthemata, along with erythema, crysipelas, rubeola (measies), roscola, searlatina, nettle-rash, and the artificial exanthemata. The young hogs being mostly the ones affected, strengthens the hypothesis of its being an eruptire ferer. $\Lambda \mathrm{s}$ far back as 1852 I recorded the faet that I considered epiclemic tonsilitis (Rotheln) as the most frequent epidemic cliscase to rhich Pichmont, Vin, was liable, and that this arose from the meist and variable character of the climate. I have sinee seen notiong to make me clinnge this opinion, but mnch to strengthen and confirm me in this theory. Horses, hogs, cattle, and sheep) are as susceptible to disease from (exposure to cold, rainy weather, and to sudien climstic alternations, as the human family; probably more so. 'ithey suffer from cxposure to cold as ensily, and aro as much giren to catarih or cold as the hmman inere

$\Lambda$ disease peculiarly liakle to be felt by the young of hoth the human and animal race, yet ino nge, sex, or color aflords any certain protection from this epidemic discase. called Rotheln, or (icrman measles. In my opinion, then, this so-ealled cholera is no cholera at all-has not a singlo choleroid symptom, as the bowels are invariably constipated mutil moved by medicines, or give way under the last throes of speedy dissolution; but that it is ratlier a ferer jrevailing in an endenic and cjustenie form, subject to all the natural laws gorerning fercrs, from its inception to its termination, in restorntion or in denth, and more closely resembling scarlatina and scarlet ferer than any other of the rarieties of the auginose 
exanthemata, and is now known to some of the medical profession as Rotheln, or German measles.

I will now proceed to give yon a short history of the so-called hogcholera as it appeared in that section of comntry linown as Piedmont, Virgiuia, luring the fall of 1877 and during the spling of $18 \% 8$. In the fall of 1877 log-cholern, so called, made its apppearance in that section of country lying south and cast of the Bull liun Nountains, and the losses by death reached ail a geregate of $S J$ per cent., mostly young animals, as I learned from Messrs. John and Luntwell Hutchison, intelligent farmers living near the old Bratdock road, four miles below the village of Aldie. The people were much divided in opinion, some believing the improved stock of hogs most liable to the disease, other's that they prored to be more exempt from its fearful ravages. The care wlich a farmer took with his hogs, I presume, had more to do with lessening the bill of mortality than the difierence in breeds. Hogs feeding after cattle, and young hogs, were generally the first to show symptoms of the disease. No remedy so far as they knew seemed to be of any benefit. Dr. Ewell recommended calomel, and some persons thought it of service. So far as I could learn no case cccurred north or west of Catoctin Nountains until October of $187 \%$. 'The section of country where it ocenrred as carly as Febrmary, 1877, is at an arerage altitude of 400 feet above tide-mater. On the 13th day of October, 1S77, J. Milton MeVeigh first noticed that one of his hogs, feeding after his fat eattle, appeared stupid, dull, droopy, mopy. He rery soon noticed others appearing to be affected in the same way. This farm is located just above the little village of Aldie (the William Berkley farm), at an arerage altitude of 550 feet above tidewater. He had on his farm at this time fifteen home-raised hogs, but having some large cattle that he thought would justify him in corn-feeding he determined to purchase some hogs to follow after the cattle and eat up the raste com. Accordingly he bought, about the 1st of Angust, 1875, of MIr. Cox twenty-two fine, healthy shoats, of Mr. C. B. Rogers twenty healthy shoats, and of Jack Simpson ten more. These fift, $y$-two animals were turned into a field to run after his cattle. The field was high and dry, rolling, and at an altitude of 600 feet abore tide-water. The hogs had good, comfortable, drs, warm shelter to go to, and in the field there was an abundance of fresh ruming water from a large, fine mountain-spring. A bout the midlle of November the disease cominenced in earmest, first with shoats purchased of IIr. Cox, then with those bought of MIr. Pogers, and lastly with those procured from Mr. Simpson. He lost fiftcen head betreen the midlle of Norember and the Ist of December. One or two rould be talien at a time anrl die, and abont the time he rould flatter himself that the disease had subsicled, one or two more wonld be taken. This continned until the 1st of February, 1878, and ciming this time he lost thirty-nine ont of the fifty-tro shoats. After this, no other cases occurved. None of his home-raiser hogs took the risease until he had sold his cattle and disposed of the remaining shoats, mhen, supposing the disease killed out by frosts and the cold weatlin, he tmrned a fine large sow andeleren pichs into this field where the sick shoats had run. The sow escaped the disease, but the pigss soon berame sick, and he lost seren ont of eleren of them. Abont the ist of Iamuary following, the remainder of these shoats having become fat, and being aj) 2 rently healthr, he lilled fire, and after clressing them he found the shin purplisi, red to pale black; little pustules or pimples covered the shoulders, and hy pressure pus would spin out. The throat gare ummistaliable evidence of disease, and the lumgs were in a condition of decay. The lower bowels were fill of black, hard, dry balls (scybalæe) the color 
of tar, and very dry and hard. These animals had never been in the barn-yard, and there were no marshy places in the field in which they ranged. 'This history, as it occurred on Mr. MeVeigh's place, militates strongly towards the theory of ephemeral fever (fever of acclimation) as the exciting canse. 'The weather was rainy, warm, alternating with damp, raw, chilly weather. The hogs of his neighbors, John Carl, William Tiffany, and Samuel Simpson, living in a sontheasterly direction, were dying at the same time. 'They gave signs of great thirst, would eat mud and soft soap avaricionsly. As a general thing they had a congh, and occasionally vomiting; appearance of eye not noticed. T. C. Brown's hogs, of Middleburg, began to show signs of disease; wonld mope about and look dull and stupid. About the 20th of Jume, 187S, all his hogs had a congh; bowels very much constipated; discharges from calomel sticky and tarry, black as tar itself; great thirst; would eat mud, soft soap, and their own excrements. All had more or less eruption upon the skin; slin had scarlet bhush. Hogs had plenty of good feed, grass, grain, slop. He tried every remedy, almost everything; thought caloinel the only thing of service that was tried; lost about 50 per cent. of his homs. Shoats proved to be most liable to the disease. The hogs of Mr. A. B. Toore, proprietor of Aldie Mills, commenced to show symptoms of disease about the middle of Jnne, 1878. The disease was not as fatal with his hogs as it generally was with those of his neighbors. Attributed this fact to good clean shelters, good food, mill-feed, apples, and slop). Gave no medicines. Altitude of his place 400 feet above tidle-water. About this time, advancing from the nortlieast and traveling sonth (in direction of prevailing winds and fog), it began to be felt at all the farm-houses along the road leading from Micldleburg, in Loudoun county, to Salem, in Faunnier county, playing sad havoe with the young hogs of A. B. Rector, Mr. Hathoway, John Middleton, Howell Brothers, Maj. 'T. B. Hntchison, \&c. Mr. A. B. Rector thonght the plant known in some neighborhoods as barrowroot, in others as burvine, in strong infusion, was beneficial. This region of country is mostly 600 feet above tide-water. Here also the hogs rumning after cattle were those most affected. Abont this time the disease passed up the pike leading fiom Aldie to Upperville and Paris, never halting until it reached near to the summit of the Blne Rirlge, above the village of Paris, in Fanquier comnty, at an altitude of 1,100 feet above tide-water. From Salem it passed up the unain road, leading from Salem to Markham, Mr. 'T. A Rector's hogs being among the first affected. His nearest neighbor, Mr. Wilforl Utterback, living between Mr. Rector and Salem, was umusually fortunate with his hog's. He did not lose many; thimls they need good attention; knows of no remedy. Altitude of Mr. Rector"s and Mr. Utterback's furms, 5ĩ0 feet above tide-water. F. W. Maddlox, proprietor of Oak Hill farm, lost abont one hundred logs. Mi. Charles Brown lost all he had, except five shoats. The disease was very fatal at MIaj. S. B. Barley's farm, near Delaplane Station. At $\Lambda$. J. Chumn's, Joln R. Strother's and others, on the west side of the Little Cobbler MIountain, the disease was very fatal. These farms all lie at an average altitucle of 600 feet above tide-water. No remedy seemed of any avail in stopping its ravages on any of these farms. Above Markham, at MIr. George Strother's, Mr. Conner's, and Mr. Charles Trussel's, the disease was quite fatal. At $M$ rs. Palmer's, above Petersburg, at an altitude of 1,150 feet, it prevailed with violence. The altitnde at Mr. Strother's. Mr. Trussel's, and Mr. A. Commer's is about 550 feet above tide-water. Mr. Trussel's hogs were fed upon inill-stuff, corn, and slop. He lost sixteen ont of twenty. MIr. A. Conner lost eighteen head out of twenty. Young logs were the ones that suffered most. Mr. Charles 'Trussel 
thought his hogs had some kind of a ferer. He tried wo remedies. I think I can safely set down the loss by disease this season in hogs in this rich jrodnctire comntry at 75 per cent. In my travels through this section of the State I saw many hogs, partially recovered, but still in a low state of health, that had lost their hair and their hoofs. The tegumentary tissue (skin) looked as if it came off in fine bran patches, instead of coming off in large flakes. This I considered unmistakable evidence of tegumentary excitement. The internal mucons membrane being a continuation of the external tegumentary tissue (skin), we may reasonably expect to find the internal mucous membrane likewise in a state of phlegmhymenitis. Add to this symptom the significant fact of such great thirst, and we raise a strong presumption that the disease is a fever, and one of the eruptive fevers, beyond peradrenture. The instinct of the hog tells him what is cooling to him, therefore you find him eating mud, soft soap, his omn excrements, rotten mood, ashes, and the like. I met no intelligent man who did not believe that either the hog's lungs or his throat were affected.

Mrs. Simpson's hogs, rumning in the common just below the village of Aldie, within fifty Jards of Ish's tan-yard, were among the first to take the disease. Ish's hogs ran regularly in the common, yet none of them took the disease, while almost erery one of Mirs. Simpson's hogs died. Ish gare his hogs chamber-lye in their slop. Mrrs. Simpson did not use this remedy with her hogs. J. Milton MeVeigh tried the same remedy, but without apparent effect. B. F. Carter, sr., gare his hogs coal-oil, and lost none. B. F. Carter, jr., gave his hogs the oil in same quantity and lost all. D. Mrount and Daniel Lee used asafetida one year, with supposed good effect; another year it had no effect at all. Thomas A. Rector gave his hogs soap-suds and soda in their slop one year, according to advice of the writer, with marked success; persuaded by others to gire turpentine and sulphur in the present epidemic, his loss was large. I found many persons who had come to the conclusion that during some period of the disease the hog's throat was sore, and that the disease was the putrid sore throat, which was so fatal to swine some forty years ago in this Piedmont region of Virginia. I find most of them agree that there is swelling about the face and eyes, eruption on the skin, great thirst, often cough, occasional romiting, constipated bowels, a thumping in the side or sides, lower bowrels full of hard, dry balls of fecal matter, with a rapid loss of flesh. Other farmers seem to notice sequelie of the disease more, and speak of swelling of the forelegs; that they shed their hair and hoofs; skin peels off; and new skin becomes scurfy.

I gare for publication a short history of the so-called hog-cholera as it prevailed in this section of Virginia in 1868 or 1869 . I have no notes left, and I am not morally certain in which year the disease prevailed. I remember, however, to have remarked that the first indication of sickness in the hog noticed by me ras closing the eye in the bright sunshine of morning. Now, this symptom may have been from swelling of the face, but I then attributed it to contraction of the pupil of the eye and from intolerance of light. The next one had a ticking in the side, and then a rapid loss of flesh, so much so that a large fat log would become so thin in a few days that you could almost read a nerrspaper through him. I will remark that the only symptom at all like cholera is this rapid loss of flesh. But then there is no purging, no loss of fluid by urination, but it seems rather that the heat in the internal organs of the hog is so intense that all the fluids in his system are dried up. To satisfy myself on this point I placed them in pens, with clean, dry plank for flooring, overnight, and in the morning the large hogs wonld be 
almost living skeletons; but you nerer conld discern ans urinary or other discharges on the clean dry floor of their pens. I made some post-mortem examinations, and generally found inflammation in rarious stages in the posterior portion of the lungs, and the glands and throat in a gangrenons condition-blood thick and black as tar and disinclined to florr; indeed, in some cases it was black, hard, and as (lry as a chip). Any one who carefully reads the reports of the Department of A griculture for 18.7 will pereeive that some of the writers describe the disease as attended br a fever; others, again, speal of the peculiar eruption attending it. Now, I submit that if there is a ferer accompanying hogcholera, and an eruption also, it is mima-facie eriance that it is a disease which rightfully belongs to that class of maladies knomn as exuptive fevers, and it only remains for us to establish to which species of the exanthemata it belongs for us to place its treatment on solic? and wellestablished grounds.

The description $I$ gare in 1872 and the account giren by Dr. Gillespie in 1877 , goes rery far to identify rotheln with the hog disease that prevailed in Piedmont region of Virginia in 1877-'78. Fortunatels the remedy I shall recommend as a prerentire, as well as a curatire, agent during its prevalence is equally beneficial in scarlet ferer, diphtlicria, and erysipelas in some forms. It is a trite saring but a trie one that an onnee of prevention is worth a pound of cure. If this is true in regard to cliseases in the human family, it becomes eminently more so in the diseases incident to domestic animals.

Etiology.-The canses of disease are, unfortunately, frequently obscure, althongh they are sometimes evident enongh. The canses of disease resolre into sereral varieties. As writers diride them differently, a short explanation may not be out of place. As a general thing the predisposing and oceasional eauses are the only ones on which much stress is laid by medical writers. Causes accessory are those which have only a secondary infuence in the production of disease, as the want of proper shelter for domestic animals in inclement weather may be indirectly the means of prodncing disease among them. Accidental eanses are those which act only on certain given couditions and which do not alwars produce the same disease. Cold may be an accidental canse of acrite paeumonia, inflammatory rhenmatism, \&e. Proximate canse is the disease itself; superabundance of blood is the cause of plethorn, \&c.; cxternal causes are such as act externalls to the patient, as coll, \&c.; these canses are such as deternine the form of the disease; interial canses are those which arise within the body; mechanieal canses are those which act mechanieally upon the windpipe in producing sufinention; negative canses comprise all those tinings the mivation of which mar derange the functions, as want of food, water, \&e. They are opposed to positive eanses which of themselves directly induce ilisease, as the use of crude, rotten, indigestible food, \&e; oceasional or exciting causes (actual canses) are those which immediately modue the discase. Ocenlt, hidden, or obsenre eanses, any eauses with mhich tre aur nuequainted; also certain inappreciable conditions of the atmosphereif I may use such a word, "distemperature"-mlich wre helieve mives rise to endemic and epidemic diseases. Physiolngienl canses are those which act only on living matter, as narcotics; preclisposing ne "cmote canses are those which render the body liable to disease, as prerions low, depressed condition of srstem, ball health, \&e. ; mineipal canses are those which exert the ehief influence in the prodnetion of disense as distinguished from the accessory canses; specific or asserted canses are those whici almars prodnce a determinate disease, contaggia, for ex ample. 
The deaths, in many instances, in this hor-tisease arose from a mechanical canse. Throwing him down on his back to "drench him" with some remedy produced sufiocation, the wind-pipe or the swollen tonsils were tilted back by pressure upon the epiglottis, and the glottis being thus inechanically closed lio air conld penetrate the lungs, and the result was death. Wherr drencling is resorter to, the animal should be made to stand up on its hind feet, and sudden deaths will not so often occur from the administration of snch remedies. Whe treatment of rothetn and epidemic diseases gencrally resolves itself into prophylactic (preventive) and curative. A mong the most valuable remedial agents to prevent epidemic diseases anong domestic animals, especially the hog, may be enumerated a good, clean, dry bed of leares or stratr often renewed, protected bJ a good sbelter and with a plank floor; a good supply of pure rumuing water to drink; plenty of good, strong, generous food, made up of corn, buckwheat, or oats, regetables, fruits, and slop. Give them regularly a little dry salt, all the "soapsnds" you can, and let them have a bank of hickory ashes to run to. By this means the hog would be better able to withstand the sudden climatie alternations of from heat to colki, for these elimatic alternations are, in my opinion, the most prolific source of all epidemic diseases to which the human race as well as domestic animalis are liable. It is an admitted fact, I beliere, that domestic animals, in fact all animals, breathe more through the pores of the skin than the hman family do. By this the intemal organs are relieved of a considerable burden. Hence arises the importance of keeping the pores of the skin open and in a healthy working condition. To effectnally do this you must provide your hogs with frequent new beds; burn up the old ones, which, when worn down to dust, become inoistened and the whole tegumentary tissue of the hog is agglutinated, as it were, by a paste-like substance, and is rendered totally unfit to perform the functions necessary in the animal economy. WVe can see why this should strongly predispose to clisease. To further prevent this undesirable condition of the hog's skin, I rould recommend mashing with strong soapsuds and then scrubbing them dry with a clean corn-cob until their skin presented a red, healthy glow. Sce that the pores in the fore legs are open (the little saftety-ralres); give them plents of chlorate of.potash of the strength of two drams to a pint of water, and the chances of disease will be greatly lessener. Timothy, orchard, and other grasses incline them to constipation, which cannot be reliered except by the strongest remedial agents. Green plantain and purslane are good for hogs.

For a long time a great many German physicians, and a number of the profession in our own comntry to-day, believe that the extract of belladonua (deadly nightshade) given beforehand will prevent children from catching scarlet ferer. Now, as rotheln is a kindred eruptive ferer, might not some herb be found that woukd prove a preventive in this discase? I am more inclined to reconmend Veratrum viride (Ámerican hellebore) as a prophylactic in this clisease, becanse I am satisfied that renesection (bleeding) in the early stages of the malady is demanded. I remember that all hogs not castrated, and those castrated early in the rlisease of 1865 or 1869 , recorered, and unt only recorered, but mad good recoreries. So did all the hogs I sam in those years early enougb. to get blood from them. After the first and second stage of the disease in those years the blood was rery dark, black, thick, and conli not be made to How. From this condition of the blood, and from the low tenperature I found in many hogs, I suspected congestive chills, or more probably dumb chills, of a rery severe character. I am still disposed to cling to this opinion. In all those cases where the log is mopy and 
chilly looking, I would, after the first stage of lowering the pulse has passed, recommend a teacupful of a strong infusion of the leaves of dogrrood or the same quantity of a strong cold infusion of boneset. In either case add a teaspoonfinl of powdered ginger or thirty drops of the oil of black pepper, to be given morning, noon, and night regularly. Chlorate of potash, two drams to a pint of water, for drink at will.

I think the hog is peculiarly susceptible to the influence of malaria, therefore they hat better be liept in the woods, or in a pen, or on high and dry places where there is not much grass, and fed on corn, oats, and buckwheat, with a proportionate admixture of fruits, regetables, and slops. Soapsnds, all the preparations of potash, hickory ashes, soda, saleratus, \&e., are anti-febrile, and will be found very beneficial when given in slops. In my opinion the throat and the adjacent parts, the upper and the posterior portions of the lungs, are the only really vulnerable portions in the animal economy of the hog. Protect these and you thereby protect the whole hog. I have no doubt that in one epidemic in this hog disease you may have it so dressed in the livery of pneumonia that the most aceurate observer might diagnose the disease to be primarily pneumonia. In another case you may have an exudation of membrane, thereby simulating very closely diphtheria. Again, you may have rotheln, but the disease spreading to the parenchymatus portion of the lung and on to the pleura, producing rotheln complicated with pleuro-pnemmonia, and so on. To show that the stomach of the hog is not very susceptible to the action of poison, I will state a fact known to almost every one in this region of country, that the hog can feed sumptuonsly on the rattlesnake, moccasin, and the poisonons copperhead with perfect impunity. Again, unless the snake bites the log about the throat, and on the jugnlar vein and carotid artery, there is no harm done, but if over either of these blood-ressels the bite is speedily fatal. The internal remedy upon which I most rely, both as a preventive and curative agent, is that invalnable remedial agent, chlorate of potash. Dr. L. P. Dodge, in Georgia Medical Companion, December number, 1872, page 717 , says:

The therapentical effects of this agent are obtained by direct application and by absorption. When taken into the stomach it imparts a cooling sensation to the mouth and throat; the circulation is somewhat depressed. Hence it has been classed by authors as refrigerant, and from increased action of kidneys diuretic. By some it has been supposed to exert hepatic action. Without doubt it does, but to what extent we are not prepared to state. When applied locally to ulcerated surfaces of the mucous membrane, as in ulcerated stromatitis and many other diseases of the mucous membrano, and also to ulcers of the integuments, it has a stimulating action, as shown by increased sensation of the parts and excited vascular action, which becomes alteralive, and, therefore, salutary. Its most decided effects are obtained when taken into the system. Chlorate of potash, we think, has a specific action on the mucous membrane-the glandular and cutaneous s5stems. In scarlatina it is nniversally recognized as the best remedy. In diseases of the mouth and throat, whether ulcerative or inflammatory, chlorate of potash has a salutary effect. In diphtheria it is one of the most reliable remedies for lesions of the throat. In no disease is its alterative action better shown. Given to an adult in tablespoonful doses of the saturated solution every hour for trrenty-four hours, and there will be a marked change in the general appearance of the diseased parts. The exudation will bo diminished, the ferer remored, the surface paler, the swelling diminished, the vascular action less, the sensation ameliorated ; the skin becomes cool, the pulse less frequent; in fact, a large per cent. of the incipient form of diphtheria requires no other remedy.

You can, then, safely give the hog one good dose of calomel in this disease, and then rely with an abiding confidence on the chlorate of potash.

Respectfully submitted.

Markinir, VA., November 25, 1878.

ALBAN S. PAINE, M. D. 


\section{REPORT OF DR. J. N. MCNUTT.}

Hon. War. G. Le DUC,

\section{Commissioner of Agriculture:}

SIR: I have the honor to report that, in obedience to instructions from your department, I have devoted the past two months to the investigation of diseases of swine. Though my labor has been confined to one county (Jefferson), I had abundance of material, and have examined several humdred diseased hogs, and made thirty post mortem examinations.

While the results of my experiments and examinations may not be as satisfactory as could be wislied, I am convinced, first, of the nature of the disease, and, secondly, that if it caunot be cured in all cases, it can by proper hygienie measures be with much certainty prevented.

I have aimed to have the results of my examinations as practical as possible, and will endeavor to present them devoid of any scientific theories.

The disease has, in this connty, as in other portions of the State, prevailed in different localities for a number of years. It nsually begins in early spring, and increases in extent and severity until the late summer and fall months, disappearing toward the approach of winter, only to appear in another locality with the return of spring. Although in different seasons and localities it presents different symptoms, it is evidently the same fatal enemy to the pig raiser, only in another garb. Unfortunately, as the name of a disease should convey some idea of its nature, this dreaded scourge is called "hog-cholera," why we know not, unless from its rapid and almost certain fatality.

While the pathological conditions found in my examinations were many and varied, yet the main lesions pointed to the intestinal mucous membrane and luugs, with sufficient uniformity to clearly indicate the nature of the disease; and as it is clearly shown that the disease, while contagious, is not communicable to other animals nor to man, it is evidently a specific contagious disease sui generis-typhoid ferer of swine. The disease occasionally begins suddenly with symptoms of a chill, the pig stauding drawn up and shivering on the sunny side of a barn or fence. But the disease generally begins more insidionsly, aud the first thing noticed is, in a previously healthy pig, a dull appearance with a wrinkled, drawn look about the lead and neck. It stands with back humped, head and shoulders drooping, eyes listless and watery; loss of appetite, or perhaps eats for a few moments and then stands over its food with an appearance of loathing; sometimes it show a disposition to nausea, great and constant thirst, increased temperature, first abont breast and belly, ancl atter one or two days extending over body and limbs. Fever at first of a remittent character; temperature in rectum $102 \circ-104^{\circ} \mathrm{F}$., in morning; in the evening rises to $106^{\circ}-109 \circ \mathrm{F}$. Has hacking cough, which is increased on exertion; sometimes attended with frotly (white or yellowish) and in last stage offensive discharge from the nose. Breathing rapid and labored, with drawing in of the flanks; panting. Bowels usually, at first, constipated; in some continue so; in others become lax after a few days, to be frequently followed, especially in protracted cases, by very dark fetid diarrhea. Kidneys usually act well, though urine is generally scanty and high colored. In very malignant cases it is suppressed. As the disease progresses the patient shows a disposition to get away from the herd; lies on its belly under straw, brush, or any place for a shade; is stirred up with diffieulty; walks with 
a staggering. painful gait. Some, if ther attempt to run, go siderise, and carry their head to one side. In thite hogs, rose-colored spots appear on belly and inside of arms and breast, effaceable by pressure, but retum immediately. On dark hogs, the spots are of a petechia or hemorrhagic character, with clevation of the cuticle, especially behind the shoulders and on the neckand back of the ears. In one case, sick three weeks, I found sloughs one inch or more in diameter, thickly scattered over belị, neck, and snont. Large abscesses are occasionally secu in parotid glands (belind the cars), and in a few maigmant case's the leg's swell mutil the skin bursts, discharging a thick, Jellow serum. In some cases the hoof's till oft. If the case does not end fatally, as it often does in a few dars, the symptoms increase in severity. The animals rapidly lose flesh, get lousy, refuse to eat or take note of their surroundings; if possible to arouse them, they immediately relapse into at stup:or. Some pass off in this way ; in others, convulsions close the seene. When one oecasionally gets well, it is after a rery protracted convalescence. Abscesses, ulcer's, \&c., form on clifterent parts of the body. The hair all falls oft; and it seldom makes much hog anyway.

My subjects for post mortem examinations were taken, some of them a few hours after leuth, and others were killed during various stages of the disease, from the first clay to the third, and in the fourth week, by bleeding. The subjects that liad died were usually very much emaciated, lousy, offensive; suout and ears a dark purple; eyes shrunken, sometimes ulcerated, and body covered with dark spots of extravisated blooci.

The principal lesions found were in the alimentary mucous membrane and in the organs of the chest. The tongue I seldom found eoated, thongh usually rect and often ulcerated, especially towards tho base, extending into throat and down the osophagus. The stomach was usually found distended with undigested acid, and sometimes offensive ingesta and flatus. The ilemm (small bowel) and colon (large howel) filled with hard dry feces or with clark liquid, fetid discharges, and distended with gas. The mucons membrane of stomach and intestines, diftering with the stage of the disease at which death hald oecured, presented the varions stages of inflammation aud its sequela, from a faint pink blusls to a dark red thickened condition. 'This was the ease with the whole surface of the stomach and of the ileum or colon, or more or less extensive portions of each. In some cisses the dark thickened membrane could be easily stripped from the sub-mucous coat. Ulcers in the glands of the smail intestine and excum were frequent. Perer's glands in two or three cases wero very much enlarged and thickened, and covered with hard, dark seabs. In sereral eases the ileum was so contracted in several places that they looked as if they had been seorched.

The peritonem was generally more or less inflamed, and in two cases I found in one two and in the other four quarts of stralw-colored serum in the abdominal cavity; a portion of which, in the largest, was coagulated, apparently by the great heat of the bowels. (The temperature was $109^{\circ}$ F.)

The lungs I found, with two exceptions, in different degrees of inflammation, varying with the period of the disease, which constitnte pnenmonia. This was the case either in the first stage (that of congestion), the second stage, (no hepatization), or third stage (glay hepatizatiou); though, as is msual in diseases of a low and teeble character, these stages were not always well marled, but often presented more the condition called splenization, caused by the blood not rielding sufficient plastic matter to form the firm, resisting character of hepatization. 
The amount of lumg involred, of course, varies in each case; in some one lobe, wsully the mpuer if the left lung, and lomer if the right; in others, again, all of one lmong, and in one case I found the whole of both lungs involved, the left in the thirel and right in the second stage. In young pirs I found what is linown as lobular pneumonia, that is, diseased lobules, of which each lobe is composed, were mixed indiscriminately with healthy lobules, giving this lung a mottled appearance. In one case I found the discase in the upper lobe of the right lung. The inflammation was conlined to the air vesicles, and eonstituted "vesicular pnemuoniu." In this case I found tubercles seattered through the diseased lung", and in one the uly)er lobe of the left lung was one mass of tubercles. All of the cases were eomplicated, to a greater or less extent, either with intammation of the pleura (the corering of the lmnes), or of the bronchi (air-plasirges). In some cases the bronehial tubes were inflaned and filled with a frothy and oceasionally a bloody mueus, in others uleciated and scereting a yellow, oflensive pus; the ulceration often extending into the luyux, and eveu into the nasal passages. In six ou eight cases tho plenra, especially the light, presented more or less extensive patelies of inflammation, with alhesions between the pulmonary and the costal portions, that is, between the portion of the plenra and that lining the chest.

'I'he heart was, in protracted cases, pale and solt, and in one case in. flammation of the pericardium (covering of the heart) with effusion into the pericardial sack was observed.

The liver was, in most eases, more or less congested, and in one case very much cnlarged and filled with patches of inflammation. The gallbladker was usually filled, sometimes disteuded, with dark-green, thick bile.

The pleura was in all eases enlarged, and in one ease very dark, almost black, and so friable that it would not sustain its own weight. The kidneys were usually pale and sometimes soft, and in the two cases where there was so much cellema of the lungs and smppression of the mine; the malpighian bodies were of a dark-red color, and the lining of the pelvis (iuside of kidney) was very much inflamed and covered with extravasated blood.

With a few exceptions the mesenteric, inguinal, and other lymphatic glands, especially bronchial and cervical, were in various stages of inflammation and enlargement, and in some cases of a peculiar dark-1ed color.

The brain proper and the spinal cord I found usually in a normal condition. In one case there was effusion into the ventricles. The meninges of the brain and spine were, in protracted cases, congested or intlaned, and in two cases the dura mater (lining of the skill) was thickenesl and easily separated from the skull.

'The cause of the disease has been variously ascribed to feeding, crowding, orerduving, filthy pens, ringing, \&c. From information obtained from hog-raisers, from om own observation, and reasoning from analosy, I am satisfied that the real cause of the disease is the present manuer of breecling, raising, and feeding the pigs, and as a result of my observation and treatment I found the same remedies as used in remittents in the luman subject as the most effectual. I am satisfied that the disease is at least dereloped by malaria, and reliered, if at all, by the same treatment as malarial diseases in man. Instead of raising pigs from a sow eight or ten months old, and cramming then with slops and ily corน in order to make three-hundred-pound porkers of then in twelre uonths, select good healthy sows fiom eighteen to twenty-four unouths 
old; allow them to have but one litter each year; let the pigs grow up naturally; feed them but little, and give them no dry corn; let them have plenty of water and clay to drink and bathe in, and give them a chance to root for a living, and to that end furnish them good pasturage on soft, moist, and, if possible, shady soil, where varions roots are plenty; in fact, let them "root, hog, or clie," and wallow to their hearts' content. The roots they may get are their natural food, and by frequent bathing in muddy pools they keep the skin in a lively, healthy condition, free from dandruff and vermin. A hog looks filthy enough when he first comes out of his cool bath in a mud-hole; but see him after lie has dried the clay in the sun and rubbed it off on some eonrenient stump or fence-corner, and he is a nice, clean, and rery presentable animal. After he has attained his natural growth in this manner, say from eighteen months to two years, he can be fattened on corn, if you will, withont fear of disease. That the disease once started is easily communieated by contagion and infection I have easily found by tracing its ravages in regions of my inquiries. Starting from a diseased hog brought into the neighborhood, it next showed itself in the herd of the only neighbor who let his hogs run at large, and whose logs visited an infected farm. Thence it was conveyed by the hogs of the second party dying alongside of a large pasture filled with well-fed, well-watered hogs. Then other neighbors' log's broke into this pasture and mingled with the sick logs, and soon went lome to die of the disease and infect others. Others, again, separated by a large creek, crossed to the infected neighborhood and were soon numbered with the dead. During a dry, south wind, lasting several days, hogs one mile to the north, separated by the same creek, developed the disease. Thence it was traced in the same manner, carried either by straying hogs or dry winds, and in the case of wincls always in the direction of the wind, and then often jumping two or three farms for farorable material.

Treatment.-Under this head I will necessarily be very brief, for unless the case is taken early in the clisease, $i$. e., unless the pig-raiser understands the early symptoms of the disease and adopts what might be called the heroic treatment at onee, little, if anything, can be clone by medication.

After fully satisfying myself as to the nature of the disease, I found by taking the ease in its ineipiency and giving a good cathartic (calomel 5 to 20 grains, and podophyllin $\frac{1}{2}$ to 2 grains, according to age) in boiled potatoes at night, to be followed each morning for two or three days by sulphate cinchoneidia 10 to 40 grains, according to a ge, in slops, and after and during this treatment give spirits turpentine ( 5 to 20 drops), or carbolic acid in slops (1 to 3 drops) every four hours, resulted in a cure in 80 to 90 per cent. of eases treated. In addition I would follow suggestious recommended in prevention of the rlisease, viz., isolate the sick; lieep them in pastures with free access to water and clay. Clay is one of our best antisepties, and the hog knows it, and will when thirsty, if he can, mix it with the water before he drinks. Give them but little, if auything, to eat, aucl, if any, such regetables as turnips, parsnips, artichokes, and other food of this class. By no means feed corn, especially dry corn. I really think that if the suggestions as to the manner of breeding, feeding, and caring for the pig liere offered wero followed out there would be but little, if any, need for treatment.

Before closing I wish to acknowledge my indebtedness to Maj. James S. Mellen, of Saint Louis, for many and valuable suggestions. I am yours, very respectfully, \&c.,

Previt, ir in.. Oetnler 14. 18TR. 
REPORT OF DR. C. M. HINES.

Hon. Wir. G. LeDUC,

Commissioner of Agriculture :

SIR: Having been honored with an appointment as an inspector of diseases of domesticated animals, under the direction of the Department of Agriculture, I accepted the same on the first day of August, and at once took the necessary steps to find a field for an investigation, which had reference more particularly to the diseases of swine.

After diligent inquiry I found the disease was not sufficiently extensive in the State of Kansas for any extended inquiry into the cause and remedy for "hog-cho.era," or the infectious fever of hogs. Under instructions from the department I therefore proceeded to Cass county, Nebraska, where it was said to prevail as an epidemic in the neighbor. hood of Eight-Mile Grove.

Upon my arrival at Plattsmouth, the cointy seat of Cass county, I was informed that no "hog-cholera" had prevailed in that region for nearly three months prior to my arrival.

After a detention of several days in the vain effort of finding a proper conveyance into the country, I at last succeeded, being aided by Mr. James Hall, of Eight-Mile Grove. I was assured that I would find but little of the disease, as I was too early in the season, it being more prevalent in cold weather.

As the time for investigation was limited, I determined to make as much of it as possible. Passing through Cass county I found several small herds under treatment by a veterinary surgeon, and in nearly every case I found they were being "doctored" by the owner, or some one professing to cure the disease. Also, other owners, rejecting all interference, were apathetic, and seemed to consider it something beyond human ken, and as one expressed it, left them to "worry through." Indeed, one farmer said that he intended as soon as he was sure the disease was in the herd, to "ship all those larg'e enough for the market"-an example followed by many others, making widespread havoc. From Cass county I proceeded through Otoe, to the borders of Johnson county, passing over a large portion of both counties, returning again to Plattsmouth when the time for the investigation had nearly expired.

In arriving at the conclusions to be found in this article, $I$ must be permitted the privilege of argument, in order to show my reasons for the same, and, first, I would observe that the disease known as "hog cholera," or "infectious fever of hogs," is not, as I think, so difficult of solution, nor has it a protean character. I consider it one disease from two causes having two effects.

The hog is said to be improved by "crossing," and persons ignorant scientifically of its effects, and how far it may be carried with propriety, write and speak learnedly of the matter. They attempt to improve upon nature, and it lias been carried to such an extent as to almost obliterate all traces of original breeds. They attempt also to make a distinct, separate, and, as they suppose, permanent stock that will reproduce itself. Although all logs may belong to the one great family, there is a law in nature that, where a great divergence has taken place from any parent stock, a teudency to revert must prevail, or the creature must suffer from the lex talionis natura. "So true is it that nature has caprices which art cannot imitate."

Persons, otherwise good farmers, who have improved their stock, as $12 \mathrm{SW}$ 
they suppose, by crossing or continual breeding in the same stock, do so until they are really ignorant of how close they are breeding, aud of its evil effects, for (as in the human being) the penalty for this violation of the law of nature is loss of vitality, less porer of resistimg diseases, and scrofulous degeneracy.

I have seen pigs not a month old which were totally blind, with large sores on the jaws, and hogs of eight or ten months with great sloughing sores on the body, and I hare been told by reliable gentlemen that some lose the flesh from the jatrs, leaving the bone exposerl. In the older hog this affection mas, perhaps, be bronght about by feeding exclusively upon old corn that had been exposed to the elements, but time did not allow for proof of this.

Cholera in Kansas and Nebraska seems to attack preferably the Berkshire, and the Berlishire crossed by the Poland-China, which appear to be the kinds preferred in those States. The "common stock," and those not bred so close, are not so liable to the disease as where they have been contimually crossed and called "fine-blooded." I lave been told by gentlemen who are largely engaged in hog-raising that the commou stock and those of pure breed are less liable to the disease-that they have been in adjoining ranges to those diseased, and hare escaped the infection. I have no doubt of this fact.

TREATHENT OF THE HOG, HIS FOOD, QUARTERS, ETC.

Of food.-As Dr. Detmers, of Missouri, in a report upon this same subject says, "Becanse he is a hog, must he be treated hoggishly?" Poor hog! Man seems to think he "has no stomach that he need respect." With what do ther not dose him (in lien of what he would find for himself, were he at liberty?) Stone coal, charcoal, ashes, concentrated lye! Give him sour food, and afterward an alkali to correct acidity of stomach! All very good when intelligently administered, no doubt. But, does not the hog need an acid sometimes as well?

The almost unirersal food for swine in these States is corn, nothing but corn. If, perchance, they get any green food it is green corn cut and thrown to them.

Corn is raised in such abundance and the price is so low, in order that there may be a return for the labor of the farmer it must be converted into either beef or pork; and as, according to general belief and practice, a hog requires less care than other domestic animals, and can stand anything, he is the favorite instrument through which to realize gain, and every farmer has his herd of hogs, large or small.

Of quarters. - The laws of the States of Kansas and Nebraska prohibit the running at large of domestic animals, and, as a consequence, the hog is confined in quarters of rarious kinds aud dimensions, dependent upon the ability, inclination, or industry of the farmer. Thus we find that in a prairie country where fencing is expensive they are not apt to hare too much range.

In that part of the State of Nebraska to which my obserratious extended nearly all tho farms were located on water-courses of rariable size, and for convenience the hog-pens were on the bauks of the streams, in many cases at an inclination of from $15^{\circ}$ to $25^{\circ}$. The inclostures were full of manure of perhaps years' standing, mixed with earth of the lind known as the loess deposits, into which the hogs rooted, wallowed, and when sick they would eat, in a vain effort to relieve their sufferings. (In many cases scarcely anything else was found in the alimentary canal.) 
They had at pleasure the privilege of indulging in a bath of or drinking the semi-fluirl matter in the strearus passing tlırough their inclosures, composed of old aud recent manure, with an admixture of the black soil and material of a like character conveyed to them from sties fifty or a hundrer miles above. They might also at their pleasure, after such recreation, bask themselves in the sunshine (with the mereury in the nimeties) on the hill-side the livelong day.

Fed with corn that had been exposed to tho snows and rains of one and sometimes two year's; heated by the sun in smmmer, cooled by the snows of winter, wished by the rains of spring, and fanned at pleasure by rude Loreas, is it to be wondered at that animals so treated, and from which so much is expected, suonld beenme diseased and die, and that, following the example of the farmer who said that he woudd "ship his hogs as soon as he was satisfied disease was in his herd," the "hogcholera" should continne, being spread by rail over a great extent of country, dropjuing some here and some there? True, all are not so treated, and where they are treated in a rational manuer few are lost.

If the same atteution was given the hog that is bestowed on other domestic animals there would be less canse for complaint, and it is useless to attempt to remedy the matter except by a radical change in the treatment of the animal.

Many fariners keep their corn in cribs without covering, and one who was losing hogs every day told me that he had been feeding them on corn that had been exposerl to the elements for two years. I have found that in proportion to the care taken so was the ratio of health and dis. ease, all other things being equal.

The canses, then, in my opinion, which derelop the disease known as "hor-cholera" are of two kinds. First, continual close breeding, which has a tendency to lessen ritality, produce a scrofulous condition of body, with less power of resisting disease; second, want of proper treatment, which includes food, quarters, and general management.

\section{SYAPTOMS OF DISEASE AND MODES OF ATTACK.}

First mode of attack.-Generally the hog is sick a considerable time before it is noticed, and he is not cut off as suddenly as many suppose.

The log's external depurating apparatus is said to be fixed in the posterior portion of the fore leg and the nose. When the disease sets in the discharge from these parts ceases, and often (especially in young pigs) a swelling of the fore leg may be noticerl, extending to the shoulder. The nose becomes dry, and the hog now has the fever. His bowels become constipated, and when moved by the administration of a cathartic his discharges are of scybala, coated with mucous or epithelium. His appetite fails, and he eats what is unusual for him in a state of health, such as dirt and herbage, that, when well, he would pass by. He lies down, or leans against the side of the inclosure, and when started up moves wearily. Two moist streaks may bo seen, one from each eye; holds his hearl down, and his ears fall; when lying down rises up and falls down; stumbles along as though he had rheumatism; is weak in the fore legrs ; becomes lousy, and if he does not die by the disease which fixes itself upon the brain and spinal cord, he may recorer, but is often left entirely blind. If recovery or death does not take place in this first mode of attack, he passes into the condition of those under the second mole of attack, and the force of the disease is exerted upon the 
mucous membranes of the alimentary canal. In this first mode of attack the disease is seated in the serous membranes.

Second mode of attack.-Begins with fever, as in the first mode, but, although the brain is affected, the force of the disease is exerted more directly upon the stomach, bowels, and lungs (upon the mucous membranes). The hog loses his appetite, grows rapidly thin, and instead of the discharge from the eyes it is from the bowels. He lurches from side to side as he moves along, is weak in the loins, has diarrhea, often vom. its, and worms are sometimes discharged from both stomach and bowels. The discharge from the bowels is of a yellow color, seemingly unixed with pus. In this mode of attack all the parasites that infest the hog, of whatever character, seem roused to unusual activity, and the hog, unable to partake of a sufficient amount of nourishment, these parasites, fixing themselves in many parts of the body, prey upon its vitals until it suceumbs.

Cough is a prominent symptom, sometimes from the first; is of a spasmodic character, and apparently due to some extent to nervous irritation. In some cases, at every fit of coughing there would be a discharge from the bowels.

Character of the disease.-As before stated, it attacks first the serous, secondly the mucous membranes, or it may be confined to either.

In the first mode of attack the fever is of a sthenic character, and presents many of the characteristics of mcastes in the human being. There is fever, discharges from the eyes, sometimes a discharge from the nostrils, and discoloration of the skin. Cough, which is an attendant upon measles in man, is generally absent in the hog in the beginning of this disease. I prefer to consider it a ferer dereloped in the same manner as typhus or typhoid fever is in man; that there is "blood poisoning," and that the disease germs are intangible; that it has no symptom in common with cholera in man, save the diarrhea. The action of the infection upon the blood is quite the opposite to that of cholera, for in the disease in question there is a lack of fibrin and of hrmatin; it is pale, deficient in red corpuscles, and does not "cup." I do not believe that it is dependent upon any particular condition of the atmosphere, except that portion immediately surrounding the diseased animals. I think there can be no doubt that it may be communicated to other hogs, and more readily to those of a like breed, and living under like conditions. Being(as I think) not primarily of a typhoid character, I cannot see any reason why this term should be applied to the disease. The truth is, I believe, that the hog is sick some time before it is generally noticed, and that a little attention given him at the commencement will stop it. Is this, then, of a typhoid character? In confirmation of this I will state a little circumstance related to me by a gentleman in this neighborhood. A colored barber called upon him at his farm one day, and while looking at a fine hog, which the omner said would eat but little, and appeared to be sick, the barber said: "Your hog has the cholera. I will cure him"; and immediately, to the great amusement of the gentleman, caught the hog, opened his mouth, made two incisions in the papillie at the root of the tongue, and then began rubbing the fore-legs of the animal with a corn cob. Telling the gentlemen to give the hog a dose of some purgative medicine, he went his way. In a few hours the hog began to eat and recovered in a short time.

of infection.-Hogs of the same class, and placed under like circumstances, are more liable to convey the infection to each other than to those differently situated. I met with a farmer in Nebraska who was 
purchasing diseased hogs at a low figure, and taking them ou his farm for treatment, without fear of communicating the disease to his own herd. He had some knowledge of the disease, and had treated his orn herd.

Professor Law says, as quoted by the commissioner of agriculture of the State of Virginia, "contagion is the main cause of the disease." We are satisfied that we understand the circumstances under which one may contract the chills or intermittent fever, but I presume no medical man will say that he can touch the "disease germs," as they are termed. Contagion cannot cause it, but may aid in spreading it.

Prevention of the disease.-In my opinion the surest means of preven. tion are those of a hygienic character. Do not breed close, give the animal a variety of food, keep his range clean, and protect him from extremes of heat and cold. In a prairie country, where clomesticated animals are not allowed to run at large, I would recommend that ranges for the hog should be inclosed by portable fences in sections. Posts should be placed at the proper distances (they might be of iron and driven) and the sections wired together or fastenings might be attached to each section so as to unite at once. Constructed in this manner the range may be changed to another location in a few hours. This should be done once or twice a year at least, and preferably in the spring and the beginning of winter. Raise vegetables especially for them. If possible sow oats, and let them have the range of the field. Give them fresh water to drink, which may be raised by a windmill and conveyed through pipes to the range. Instead of having hogs to "follow" the cattle, as a matter of economy, I would feed them separately, and have the corn for the cattle ground in a horse-power mill.

Eradication of the disease. - This might be effected partly through State laws prohibiting the transportation through the States of hogs showing evidence of disease, attention to hygienic laws, and a greater admixture of the breeds known as "common stock," gradually brought about.

Treatment of the disease.-This is very simple if attended to in time, and very few need be lost. Simply a transfer to a new range and a change of food at the beginning of the disease will save a great many. Give the hog a purgative of soft soap, raw linseed-oil, or any simple purgative; afterward warm mashes and comfortable dry quarters. Very often this is all that is necessary to arrest the disease. As soon as his nose becomes moist and the secretion is restored in his fore-legs, you may count upon his recovery. A farmer told me that his herd had the "cholera," and that he fed the living with the carcasses of those that died, and his hogs recovered. Another that, having more fresh beef than he wanted, fed the surplus to his herd, and they recovered. This food, being unusual, acted upon their bowels, hence their recovery.

In investigating this disease I had many obstacles to contend with. There were no herds to be found within a reasonable distance (nor beyond that I was aware of) which had not been dosed with something, and none so isolated as to be entirely free from contact in some way with other herds. As a consequence I made no use of the clinical thermometer, which would have given no perfect data to discourse upon.

The first herd of hogs treated numbered forty-five head, situated on high and dry land; but the range was dirty from the accumulations of old manure, thes having been fed on corn from crib exposed to the elements for a considerable period. Were drinking water from a well. All sick. No other hog had been near the range except a boar, and he was said to be well; neither had. any been away from the herd. The breed 
was Berkshire, crossed with Poland China. Owing to the inland sitnation and want of necessary articles at the place the troughs were not made with circular holes, but were constructed in the following manner:

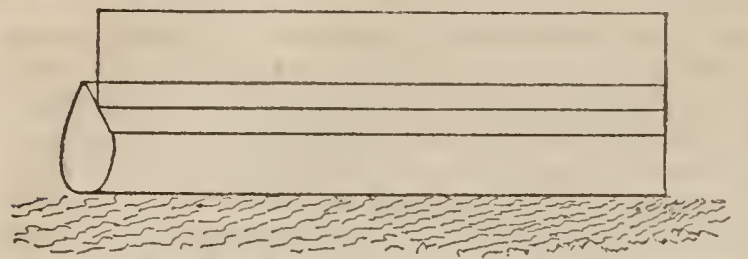

The trougl was dirided longitudinally by a board on edge so that the hogs could feed on either side without permitting the admission of the feet, thus: They were graded $1,2,3,4$, according to age and condition. The herd was suffering from both modes of attack, as heretofore described. They were mored from their range and placed on new ground. As a general thing the younger hogs suffered the most.

Pen No. 1 contained the oldest hogs, fifteen in number, from one to three years old.

Pen No. 2 contained fourteen head, from eight months to one year old.

Pen No. 3 contained eleren head, from fire to eight months old.

Pen No. 4 contained fire head, from fire to twelre months old, and was the dead pen.

No food was allowed for the space of twelre hours. Nos. 1 and 2 were giren 'salt and water, which they were compelled to drink, being without food or water. This had the effect of causing romiting and purging. In sereral cases worms were discharged from the stomach and botrels; principally from those suffering from the second mode of attack. Some had to be pressed forward and urged to drink. After the action of the salt the tincture chloride of iron was administered in water in doses of twenty drops every four hours, for the older, and fifteen for the younger hogs. A mash of bran was made (which wasal ways f'ed while fresh and sweet), and they were allowed to partake moderately of the iron half an hour after the first dose. They were fed at interrals between the doses of iron, and no other food was giren until convalescence began, when they were allowed some corn in connection with the mash. In those suffering from the disease in the first mode, there was constipation of the bowels, dry noses, and watery discharges from the eyes. When the bowels were moved (and in some instances ther were very torpid), the passages would be stercoraceous, and covered with a whito substance (apparently epithelitim), were very hard, and upon examination appeared to be composed almost entirely of earth. These began to improre on the third, and were so much improved on the sixtl das that they were allowed a more liberal supply of fooc. They were not considered out of danger until the eighth or tenth day. It was not necessary to gire any other purgative, and gradually the discharges from the botrels became of a proper consisteney.

No. 3. Host of these had diarrhea. Some had a congh, and whenerer a fit of conghing came on there wonld be a profuse discharge from the bowels, thin and ot a yellow color. Occasionally there would be romiting also, showing the great irritability of the pneumo-gastric nerves. Worms would also, at times, be ejecterl from the stomach or botrels. To these were admiuistered from one and a balf to two thid onnces of raw linseedoil, accorrling to the age of the anizaal. After the action of the oil the discharges were not so frequent, and the anmals seemed more lively. Twenty drous of carbolic acicl were then administered to the older, and fifteen to the younger hogs every four hours. 
The action of this remedy not meeting my expectations, I had recourse on the third day to the tincture chloride of iron, as in the cases of Nos. 1 and 2. Fifteen drops were given to the older and twelve drops to the younger erery four liours with marked improrement. The food given was the same in all eases. Convalescence in this class was slower than in Nos. 1 and 2, it beginning a day or two later, and the recovery was more protracted, with the prospect, in some cases, that a month or longer must elapse before they wonld be of any value.

No. 4.-The dead-pen.-In this pen were five hogs of different ages, ranging from five months to a year old. They were selected for this pen, as there was but little hope of saving them. Two were sick after the first mode of attack, and three after the second morle. Linseed-oil was administered in corn-meal and water. They had to be urged and brought up to drink. One utterly refused, and was too far gone to undergo treatment. He died in a few hours in convulsions, as in the first mode. The morning after two more were found dead, and the next day another died. These latter were after the second mode. One after the first mode recorered. The tincture chloride of iron was administered to these also. As they began to improve, which was in from six to ten clays from beginning of treatment, they were fed more liberally according to their condition. The pens were kept clean, the manure being removed at once. Chloride of lime was used as a disinfectant.

The Ioss was four out of forty-five hogs. Together with the foregoing treatment, the following was administered every four hours, between the doses of iron: Powdered alum, ऊiss; sulphur sub., ziij; portdered saltpeter, 亏iss; flaxseed-meal, zix. These were mixed, and two pounds of the mixture was added to every barrel of mash in which it was given.

The second berd treated numbered originally 123 head; several had died, reducing it to 114. The breed was Berkshire crossed with PolandChina. They had been bred very close. This mas a bad lot to treat, as they had been dosed with "condition porrders" "concentrated lye," and several other articles. They had beeu fed on corn exclusirely. Their range was located on a hill-side, and a stream of water passed through it. It was corered to a considerable depth with old and recent manure, exposed to the sun, and withont shelter for the hogs. The stream was thick with innd and manure, where the hogs could wallow at pleasure and bask in the sun all day. There were other ranges above and below; the number I have no idea of, but presume that erery farm located near this stream had its rauge on it, as it was common so to do for convenience. No other logs had been bronght there, and none taken away and returned.

The herd was mored to new ground in the shade, and graded according to size and condition. They were divided into fire classes.

First class.-This consisted of eighteen hogs, the ages ranging from one to three years. They were suffering with symptoms belonging to the first mode of attack; had no cough. The bowels of some had been moved by remedies, others not. Could partake of some food, but not heartily. They were treated together.

Sccond class. - This consisted of twenty-one hogs, ranging from one to two years, and were sufiering from an attack after the second mode. They had cough and diarrhea.

Third class.-This consisted of thirty-nine hogs, ranging from fire months to one year old, suffering from an attack after the first mode.

Fourth class. - This consisted of twenty-six hogs, ranging from five months to one year old, suffering from an attack after the second mode. Fifth class;-dead-pen.-This consisted of ten hogs of different ages. 
Three were after the first mode and seven after the second mode of attack.

Believing that the theory of blood-poisoning was correct, I did not see any reason for a change of treatment from that followed in the case of the first herl. Those suffering from the disease by the first mode of attack were first given salt and water and afterward the iron, as in the case of the first heril. Those suffering from an attack in the second mode received a dose of linseed-oil, and afterward the iron and powder as detailed in the case of the first herd. Many had to be urged and forced to drink. Some refused altogether to partake of anything. I sum up the deaths by class :

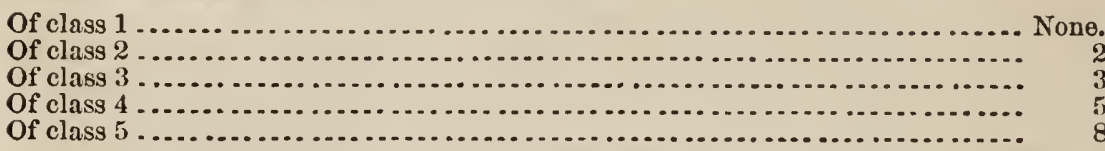

Total number of deaths. 18

Nine had died before treatment, making twenty-seren in all.

Post-mortem examinations.-In making post-mortem examinations, I was afforded opportunities in Nebraska (besides those under my own observation), by Mr. A. J. Rainey, a veterinary surgeon, who had a large number of animals under treatment. Also, by a Mr. Dudly, an enterprising farmer residing in the neighborhood of Syracuse, who gave me permission to examine his herd, in any manner I saw flt, in furtherance of my object.

In my description of appearances after death, I shall confine myself to one or two dying under each mode of attack.

Hog six months old.-The blood.-This had the appearance of water colored yellow. Fibrin broken up, and a want of hematin. Excess of serum and salt. Poured upon the ground it was absorbed, leaving scarcely a perceptible stain.

The brain.-Effusion of serum in cavity of skull, and softening of the brain. Effusion in the membrane of the eye.

The lungs.-Effusion of serum in pleural eavity. Base of lungs some. what congested, apparently of a passive character.

The heart.-Normal condition, but pale.

The stomach.-Normal condition, the spleen enlarged.

The liver.-There was but little bile in the gall-bladder; the organ was darker in color, with petechial spots. Kidneys pale. No ulceration of intestines. This hog died from the first mode of attack.

Hog six months old.-This hog had recovered from an attack in the first mode. Was left blind, and had an ulcer on one of his feet. He was killed. Was apparently free of disease; the blood. was of the proper consistency and color, and coagulated. Blindness was the effect of the disease.

Examination of those dying from sccond mode of attack.-Hog six months old.-This hog was very thin, nearly all the fat having been absorbed, Could detect no disease of the brain. In this case there was the usual diaxrhea, congh, \&c., belonging to this class. Heart normal in structure, but pale. No effusion in pleural cavity.

Lungs.-These presented the appearance mentioned by writers on this disease as gray hepatization.

Stomach.-This presented evidences of disease. Two ulcerated patches were found, nearly healed, circular in form, and eight or ten inches in diameter. The dead mucous membrane was still adherent, but was easily removed. 
The liver was discolored; dark patches were diffused over its surface. One iarge worm (Ascaris lumbricoides) was found in the duodenum. There was a large nlcer, about an inch in diameter, in the ascending colon, plainly seen on the external surface of the intestine. Its edges were very hard, and the inflammation extended some distance beyond. There were other ulcerations in different parts of the intestines, but less extensive.

The spleen was of natural size, but darker in color.

The kidneys presented a grayish appearance, very pale, and having an appearance as though there had been a deposit of black pigment in their substance. They were easily broken up, the internal portiou or belly showing evidences of suppuration.

The bladder.-This organ was intensely inflamed, so much so as to diminish its capacity to one fluid ounce. All the organs in the course of the alimentary canal had more or less petechial spots on them.

Hog five months old.-Killed him. He was very much emaciated. Was apparently recovering from the disease, but very slow and doubtful. Found three large worms in the stomach and one in the duodenum. The one in the duodenum had his head inserted in the gall duct up to the gall bladder. There was some chronic inflammation at the upper portion of the duodenum where the worm had fixed himself. The stomach of the hog was full of grass. It seemed that this hog would have to die of inanition, the presence of the parasite interfering with the flow of bile into the alimentary canal.

Geology of the district of country where these examinations were made: The soil is of what is termed the "Loess deposits," and by analysis by Samuel Aughey, Ph. D., contains-

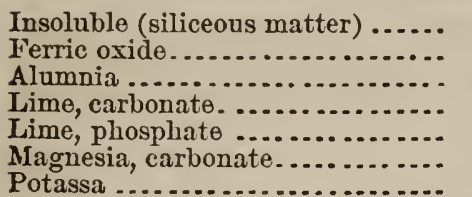

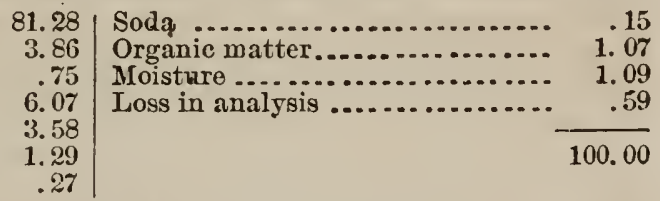

Parasites.-Of the entozoa that infest the hog I hare seen but three kinds. Two of those are familiar to most persons, and are found in man. The third is a smaller parasite, and is often found in the stomach of the hog, and which is said at times to destroy the pyloric orifice of the stomach. I have seen but one of this species; it was white, and from eight lines to an inch in length.

I append a statement by some farmers in Kansas, who are successful hog-raisers, as to their treatment of hogs. Mr. Jacob Allen, of Neosho county, says: "Last year my hogs had the fever, or 'hog-cholera.' They would eat dirt; dirt was found in lumps in their stomachs; but few worms, and those in intestines and kidneys. No trichina under microscope. Were constipated. I lost some; cured the others by the use of senna and jalap."

Rev. John Schoemakers, of Osage Mission: "Has been a resident here for thirty years, and states that he is of opinion that the disease comes of want of proper management, forcing them with corn, and want of a variety of food." He states that they have a large number of hogs on the Mission farm, but that they lose none by cholera. They are let run in a large field that las been under cultivation. Does not confine them to pens.

Mr. David Bloomer, of Neosho connty, feeds his older hogs corn in the winter and spring. Sows oats for them in two separate fields, and at different times. When the oats are four. inches high he turns them 
into the field first sowed, and afterwards into the second field, so as to keep them until com is "ont of the milk," when he cuts and feeds them corn. Feeds his pigs on oats and shorts during the winter. Lets the sows wean the pigs. Breets his sows twice a year; first litter to come abont the 20th of February, next litter the 20th September. After the green oats are gone he tums them into a pasture of 120 acres. They have access o clcar rumning water and to shade in summer. Has corer for pigs in winter, but none for old hogs. Does not "slunck" his corn, and keeps it always under corer. Breed, pure Berkshire, not bred close. Loses no hogs by cholera.

In conclusion I have to state that of other diseases affecting animals in the States of Kansas and Nebraska, there were an unusually small number, and only of those familiar to nearly erery one.

In giving a name to the discase known as "hog-cholera," I hare no hesitation in saying that the disease in the latter stages has all the characteristics of gastro-enteric ferer in man.

Very respectfully, your obedient serrant,

Osage Mission, Kans., October 29, 1878.

C. M. HINES, $M$. $D$.

\section{PREVALENCE OF DISEASES AMONG DONESTICATED ANI- MALS.}

By a perusal of the subjoined correspondence of the department, it will be seen that there has been no abatement of diseases among domesticated animals during the current year. Those incident to swine seem to hare been quite as prevalent and almost as fatal and destructire to the animals attacked as they were during the year 1877 . The per cent. of deaths for the last-named year was giren at 58.9t, while this year it is given at 52.75. Now that the disease which has been so destructive to this class of farm animals has been shomn by recent inrestigations to be highly infectious and contagious, proper care and rigilance on the part of farmers and stock-grower's will lessen the spread of the plagne, and confine it to stch limits as to greatly reduce the heary annual losses of the past fer years.

Many diseases of a malignant and contagious character have prerailed among other classes of farm animals the past year, which will receire the attention of the department during the coming season.

\section{ATABAMA.}

Bibb County.-The losses from eholera among hogs aro aunually very leavy. At least 40 per eent. of all the hogs in the eounty suffer from this disease, and 75 per cent. of those attaeked die. Cholera is also prevalent among fowls, and large numbers of then itic.

Clarlic.-A few horses annually dio in this eounty of farcs, a fatal contagions disease, ancl in few fiom want of eare and proper altention, the latter mostly owned by negroes. There seems to be no diseaso among stock-eattle. Both hogs wid clickens die of eliolera.

Cullman.-There is some murrain among eattle, and eonsiderable cholera among the hogs and clickens in this countr. There is but little stock ruised in the eounty.

Escambia. - The only elass of farm stock affected by contagious discases iu this eounty is that of swine. These discases liave been a great duamback to locr-raising.

Tef(e): son.-Iforses suffer severely from distemper. Cattle are occasionally affected with black tongue and numrain, but at this tine are mumally luealtly. "Hogs are serionsIy atreeted with cholera, quiusy, and other unkmown diseases. Thu losses have been rery heavy this season. Cholera aud roupe prevail anoug fowls. 
Lauderdale. - We hare had no infectious or contagious diseases among horses or cattle in this county. They suffer terribls, however, cluring the rinter for lack of food and proper attention. At least five liwiulred horses and inules, and a greater number of cattie, aro ammally lost from this cause. Hog-cholera prevails here every year, and the lisses are sometimes enormous. I estimate that between 7,000 and 8,000 head hare been lost during the past year. 'The courlition of farm stock generally is lowworse than at any time since the war.

MFadison.-No infections or contagions diseases prevail among farm animals in this county. Hogs freqnently die of so-called clsolera. Fowls are afilicted with the same malady. The general condition of farm animals as compared with previous years is good.

Monroe. - A few hogs only have been lost by disease in this connty this jear.

Saint Clair. - Stock in this connty is in very good health and condition. I hear of no infectious or contagions diseases.

Walker.-Horses are serionsly affected and frequently die of epizootic distemper. A good many cattle are lost by murrain and black tongue, and many hogs die of cholera. Nowls die of cholera and a disease which affects their throats. Tliere are but fow sheep raised in this county; but this industry is on the increase.

\section{ARKANSAS.}

Baxter Cormty. - The graded calves of this county have this year suffered severly by a disease called black-leg. The first symptom is a lameness, and they usually die within from twenty-four to thirty-six hours. No remedy has been found. About one-fifth of the calres have been attacked, and nine-tenths of those attacked havo died.

Boone.-The only diseases of any moment that have prevailed among farm animals the past year are those incident to swine. The losses have not been very heavy.

Bradley.-Horses, cattle, and sheep are free from disease. About 10 per cent. of all the hogs in the county have died during the past year from eating cotton-seeds and lying in the dust. Cotton is the only product that is raised here for the market.

Fulton.-Hogs in a few localities of this cornty have been fatally affected with cholera.

Grant.-Chicken-cholera is prevailing here to an alarming extent. The hog-cholera has somewhat abated. There are no diseases existing among horses, sheep, or cattle, of a serious nature.

Marion.-Horses and sheep are very healthy, and cattle moderately so. Many of the latter have died this season of black-leg. Many fowls are annually lost by a disease commonly known as cholera. A great many hogs have been lost this season in this county by an unknown disease. It is not cholera, but more resembles yellow ferer in man.

Monroe.-Cholera among hogs and fowls prevails here every year, and usually proves very fatal. All other kinds of farm stock are healthy this year.

Montgomery. - Horses, cattle, and sheep are proverbially healthy, at least the exception is so small that it, is not worthy of note. Until this summer hogs have been healthy, but cholera is prevailing extensively among them at this time.

Perry.-The health and condition of farm animals is generally good. Diseases among hogs continue to prevail at irregular intervals.

Pope.-Occasionaly a liorse dies here from bots and blind staggers, and sometimes from bad treatment. Fino cattle brought here from other States frequently die of murrain. Hogs suffer terribly from what is called cholera. In some localities it kills almost every animal. Fowls also suffer from eholera. Sheep die of rot and bad management.

Serier.-All classes of farm stock are healthy save that of swine, and a good many of these animals are dying in the northern part of tho county of cholera.

Saint Francis.-A new disease has appeared in this neighborhood among cattle; it first appeared among sucking ealves, but has lately carried off several grown cattle. The symptoms are a trembling appearance and gradual prostration, which ends in death in from three to seven days.

Stone.-All classes of farm animals have been unusnally healthy during the past Jear in this county.

White.-At least one-third of the hogs in this county have been afflicted with disease during the past year, and of this number eighty-fire per cent. have died.

\section{CALIFORNIA.}

Calareras Connty. - We hare never bad any infectious or contagious diseases among any class of farm animals. Erery year we loso a greater or less number of animals by starration. Last wiuter probably ten per cent. of all the cattle and sheep in this county clicd from this cause alone. In 1862 fully three-fourths of all the cattle died for the want of feed. 
Contra Costa.-Hogs here are snbject to cholera and pnenmonia. These diseases are brought on hy lack of proper care and attention.

Lassen.-There are no infectious or contagious diseases prevalent among domesticated animals in this county.

San Bernardino. - This portion of California has always been remarkably healthy for all classes of farm animals. No contagions disease has erer prevailed here except scab among sheep, and this disease never destroys the animals.

San Diego.-The only disease existing amoug cattle is murrain; this clisease is very fatal, especially in dry seasons. Hog-cholera is not known here. A good many sheep are killed by eating poison-weed after our spring grasses are clried up. We lose a good many fowls from a disease known as swelled head.

Shasta.-Horses in this district aro annually afflicted with an epizootic distemper; if properly cares for but few of them die. Cattle and hogs are healthy. Sheep are affected with scab, but when washed and properly treated but few are lost. Our State is turning some attention to the Angora goat. I think the raising of these animals will erentually make the best business of the State. California contains a vast extent of comntry adapted to the roving of this animal which is fit for nothing else. It subsists entirely on brush, and seldom, if ever, grazes.

Tuolumne.-Farm animals of all kinds are iu a healthy condition. The weather is mild, and feed is starting.

Fuba.-A kind of epizootic disease is serionsly affecting horses in this county. Diseases among cattle are generally caused by waut of proper care in winter. Cholera prevails among hogs and fowls. Sheep become diseased for want of proper care, and keeping too many together.

\section{COLORADO.}

Bent County.-Neither horses nor cattle are affected with infectious or contagious diseases here. Cattle-raisers estimate their annual losses at about 5 per cent. A few sheep are lost by a disease known as scab. Stock is in extraordinary good condition at this writing.

Gunnison.- This is a new county, and there are not over one thousand horses in it. About half of these hare suffered this rear with epizootic distemper, but none have died. There are no hogs or sheep in this county. There are a few fowls, but they are entirely free from disease.

San Juan.-There are no domestic animals raised in this county, and none are wintered here. During the early summer there are quite a number of animals poisoned by eating a weed which the Mexicans call "Loco." The botanic name of this weed is unknown to the writer.

\section{DAKOTA TERRITORY.}

Brule County.-There is but little stock in this county. No disease of a serious character prevails.

Lake.-A few horses have died of distemper this year, and a few calves and cattle have been lost by the disease known as black-leg. Fowls are affected with rough, scabby legs, and perhaps 10 per cent. of them die from this disease very suddenly and while in good condition.

Pembina.-This is a very new county, and contains but a fow farmers and little stock. What little we hare is healthy, and free from all infectious or contagious diseases.

Traill.-A contagious but not very fatal distemper exists among horses in this county. The symptoms are a discharge from the nostrils, and swelling of the throat to such an extent as to prevent even the swallowing of water for three or four days at a time. Pants when driven severely, and his tongue hangs out of his month.

\section{DELAWARE.}

New Castle County.-Chicken cholera prerails this season. The best preventire is a tea made of smartweed, and placed easy of access to the fowls. Condition of farm animals, "good and improving." We believe the best stock and the best care will insure most satisfactory and profitable results.

\section{FLORIDA.}

Calhoun County.-Cattle are generally affected with black tongue, hollow horn, and murrain. Horses suffer to a considerable extent with staggers and scurry; and many hogs are annually lost by cholera and staggers.

Columbia.-Native horses are generally much more healthy than those bronght in from Northern States. Cattle have been generally healthy, cxcept iu a few localities, and in these the losses have been quite heavy. About one-third of the hogs in the county have died from cholera, and the thumps; the greatest fatality ever known has occurred among fowls this year. 
Duval.-There is no disease of any kind existing among farm animals here, except a disease known as salt sickness, which affects cattle only. Diseases affecting fowls are attributable to lice, and are contagious because they are infected by contact. They receive wo care. The breed is wild; they are rarely fed, and the only wonder is that they do not all die.

Lafayette.-There are but few horses in this county, perhaps not ower fifty head, and but little attention is paid to raising or caring for them. There are aluout 3,000 cattle in the county. They depend entirely on wood range for subsistence, aud are generally in bad condition. Hogs subsist on mast, and do very well. No sheep are raised here. During the summer fowls are afflicted with cholera.

Levy. - Staggers among horses is very fatal, especially among young animals. Epizootic distemper is the most fatal infectious disease among this class of animals. Cattle are affected with what is known as "salts" ; called this, perhaps, for want of a better name. Hogs are subject to cholera, sheep to black tongue, and fowls to "sore-head."

Mradison.-Distemper and glanders are the only contagious diseases prevailing among borses in this county. Cholera has been very destructive among hogs. A few cases of thumps have been reported among the same class of animals. Miny fowls have died of cholera and sore-head.

Polk. - The losses of cattle in this county, from various causes, amount to about 5 per cent. of the whole number. But few horses are raised here, and sheep are just being introduced. Fowls do not do well; the climate seems to be too warm for them.

Saint John's. - No sort of attention is paid to the raising of hogs or sheep in this county. I have not learned of a single person having an improved breed of pigs. All depend on the "razor-back" or "land pike." But little disease prevails among any class of stock.

Santa Rosa.-Very few cattle die from disease here, but a great many die from want of proper care in the winter, and food in the spring. Some few sheep die of rot or grub. Hogs are sometimes afflicted with fatal diseases.

Sumter.-Pink root or foot disease is quite common among white hogs, but does not affect black ones. Salt-sick is a disease common among cattle. We have no remedy, but some recover.

Suwannee.-Out of 60 head of horses recently brought here from Texas, 36 died, with no apparent well marked symptoms of disease. No other horses were so affected. Hogs are afflicted with so-called cholera, and chickens with what is here known as sore-head. The head of the forvl becomes very sore, and so much swollen that the tongue hangs out of the mouth, the eyes swell shut, and they soon die.

Volusia.-Horses and mules are seldom attacked by any disease except blind stag. gers and sand disease. About 60 per cent. of the first and 20 per cent. of the latter, attacked by these diseases, die. Cattle are affected with salt-sick and hollow-horn. The greater loss is from the former. Hogs and chickens are sometimes affected with cholera and other diseases.

Wahulla.-Horses, colts, and mules die of staggers, grubs, and colic; cattle of hollow-horn and hollow-tail, and hogs of thumps and cholera. Chickens also die of cholera.

\section{GEORGLA.}

Charlton County.-During the past twelve months hogs have died in greater numbers than was ever known before. Wo have no improved breeds, our hogs all being "land pikes." We have no romedy for the discases which carry them off in such numbers.

Coffce.-Horses in this county are seldom attacked by contagious diseases. A fow are affected with epizootic distemper, and a good many die of staggers. Occasionally one dies with colic or sand disease. Cattle are only affected with diseases brought on by poverty in the winter season. Cholera among hogs is the most dreadful and fatal discase we have to contend with. Shcep aro sometimes affected with staggers and sore-head, but rarely die except from old age or poverty.

De Kalb. - The value of horses lost by disease in this county during the past rear will reach $\$ 5,000$, and that of hogs $\$ 8,000$ or more. Immense numbers of chickeus have also died of cholera.

Fannin.-Stock of all kinds have been remarkably freo from infectious and contagious diseases in this county. Stock here is raised only for domestic purposes.

Forsyth.-Horses are affected with bots and staggers, and a good many cattle die of distemper and murrain, and hogs of cholera.

Hart.-The losses in this county from diseases among farm stock are generally very light.

Jones.-The only disease among cattle here is hollow-horn, and that, as a general rule, is produced by neglect in bad weather. Hogs and fowls have suffered severely with cholera the past two seasons.

Laurcns. - Wo lave no infectious or contagious disease among horses, cattle, or sheep. Disease prevails molo or less among hogs every year. The gencral condition of farm stock is good. 
Lincoln.-Farm animals this year have generally been exempt from infections and contagious diseases. In a low localities chicken cholera prevails with more or less futality.

Marion.-A few horses have died during the past sear of epizootic and lung fever. Cattle and sheep are healthy. Cholera is quite prevalent and rery fatal amoug both hogs and chickers.

Ifurray.-About 5 per cent. of the hogs and sheep of this county are annually lost by disease. Perhaps \& per cent. of tho cattle are lost by murrain.

Pulashi.-We have no contagious discases among horses except distemper, and that xarely kills. Cattle are healthy, hut logs are moro or less subject to cholera every year. The only disease afiecting sheep is rot. Fowls have more or less cholera every year, which is generally rery fatal.

Randolph.-The most fatal disease among horses which has prevailed here during the past year is staggers. Cattle are suljeet to a good many naladies, some of which are quite fatal. Cholera and big-shoulder sweep off a great many hogs annually. In some localities alnost all the fowls have been destroyed by cholera.

Rockdale.-No diseases of a very destructive chararter have visited our farm stock during the past sear.

Schley. - There are no diseases of any character prevaiiing amoug farm stock in this county. This section is most prosperous to the farmer, as there is a full crop of all products and good health througliout to both man and lieast.

Screven.-The most provalent disease here, and the most distressing one to the farmers, is colic in mules. It is very fatal, and generally kills within from five to ten hours. At least fire out of every seren of those attacked die. It seems to be caused by an accumulation of wiud in the body, and not in the intestines. The body swells to the greatest dimensions, and the most excrutiating pains follow and continue until death.

Spalding.-The losses among farm stock in this county from the varions diseases inciclent to the same will probably reach as high as $\$ 16,000$ for the current year.

Tattnall.-Staggers is the most fatal disfase among horses in this county, aud blacktongue ameng cattle, although more of each class die of porerty than from the effects of disease. Cholera is rery fatal among hogs aud forls.

Towne.-There aro ne diseases prevailing among farm animals in this county except bots and distemper among horses and milk-sick among cattle; also, cholera among hogs.

Union.-We have no contagions disease among any class of farm stock, bnt a good many animals are lost every year from common and well-known diseases.

Washington.-Murrain among cattle and cholera among hogs and chickens are diseases that are proving very fittal here. Nearly all the animals and fowls attacked by these diseases die, as wo have no remedies. Young animals and those being fattened seem the most liable to attack. Farm animals in this countr are now in a better condition than ever before at this season of the year. One reason for this is that a large number of planters do their cotton-ginning by steam and water-power instead of with animals.

Wilcox.-A greater or smaller number of hogs die orery year of a disease called cholera. All other classes of farm stock are measurably healthy.

Trilles.-Hors die annually in some localities in this county of a disease called cholera. Some jears this disease is much more destructive than in others.

\section{IDAHO TERRITORY.}

Bcar Lake County.-Horses are occasionally subject to a distemper which is regarded as contagious. The symptoms are heary discharges from the nostrils.

Idaho.-Tlis climate is very favorable to farmi stock. All classes subsist on the abundant bunch-grass of the range during the winter, and discase is rarely known among them.

\section{ILLIXOIS.}

Adams County. - A good many horses have died during tho past jear of distemper. As usual, tho so-called hog-cholera has prevailed cxtensirely, and has carried off stock to the value of $\$ 25,000$ or $\$ 30,000$.

Carroll. - All farm animals have been remarkably free from contagious diseases except hogs. Never before has there been so great a mortality among swine in this county. With pigs and shoats the disease has been most fatal. No remedies seem to bo of any benefit, and no sanitury condition is a sa feguard against attack. They aro aflected in a great variety of ways aud apparently by difierent diseases.

Clark. A mild form of epizootic distemper prevails among horses in the southeastern part of the county, and there have been somo deaths. Hog-cholera prevails in a rery fatal form in the castern part of the county, and many hogs are dying. Chickencholera is also very prevalent and fatal. 
Clinton.-A good many horses are every year attacked by an epizootic distemper, and about 5 per cent. of those attacked die.

Crauford.-Hogs frequently die of a disease commonly known is elolera. 1 great many chickeus are anuually lost ly a disease of like character.

De Kalb. - Diseases among swine have prevailed to a most fearful and destructire extent among the hogs in this county during the past season. The losses are estimated at $\$ 50,000$ and upwards.

Ford.-Hog-cholera is abont the only disease of consequence that provails in this locality. It is snuetimes very fatal aud destructive.

Grundy.-At present hog-cholera is prevailing in one or two townships of this countr, and many hogs are dying. A Mr. Ely has lost 160 out of a herd of 260 head, and the disease is still raging.

Hancock.-The value of hogs lost in this county during the past year will amount to orer $\$ 35,000$.

Hardin.-Horses in this ennty are more free fiom disease at this time than they have been for three sears past. Distemper in a rather bad form is the worst disease now affecting this animal. Cattle are also unusually healthy. Hogs are less affected with eholera than for many jears past. Poke-root slop is the best preventire we have yet found, in addition to the burning of the dead carcasses. A law should be passed for the fine and imprisonment of any person who negleets this latter precantion.

Henderson.- The mortality among hogs for this Tear is greater than for any previous year. The losses up to this time will exceed $\$ 80,000$. I feel conficlent that injuclicious feeding, in commection with insufficient shelter, are the predisposing causes of disease among swine.

Iroquois.-D Dring the past few months the number of hogs lost in this county by disease has been immense. Several breeders of fine Berkshires have lost their entiro herds.

Jackson.-Hog-cholera is the only disease that has seriously affected any class of farm animals in this county.

Johnson.-Hog-cholera has prevailed to a limited extent this season, therefore the losses have not been very heavy.

kankakee.-A large number of hogs have clied of disease during the present year. Perhaps the aggregate of these losses would amount to $\$ 15,000$ in this county. Alout 1 per cent. of all the fowls die every year from diseases incident to them.

Kendall.-Hogs have been seriously afiected with cholera. Other classes of farm stock have had the usual affections.

Knox. - With the exception of swine all other classes of farm animals havo remained in good health during the past season. The mortality among hogs has been very great.

Lee.-Domesticated animals in this county have been remarkably healthy for the last sear with the exception of hogs, which have died in great numbers. My own opinion is that the predisposing cause has been too close in-breeding, and a consequent weakening of the constitution and loss of vitality.

Livingston.-No infections or contagious disease prevails amoug horses, cattle, or shcep. Diseases incident to swino and poultry are quite prevalent and fatal. I presume the diseases affecting swine are similar to those existing elsewhere.

McDovough. - The loss among hogs in this county during the past year has been very heary-perhaps $\$ 100,000$ would not corer it. Other classes of farm stock have remained in their usual health.

McHenry.-Hogs in this county are seriously afflicted with infectious or contagious diseases. Some 2,500 have died from the plague. About nino-tentlis of those attacked die, and the agrregato losses thus far will reach $\$ 15,000$. Other classes of farm stock are healthy, and their general condition above an arerage.

Lacoupin.- Hogs aud forls are annually affected with cholera, and great numbers of each die of this disease.

Madison.-No infectious or contagious diseases have recently prevailed among horses and cattlo in this county. Among hogs the cholera is quite prevalent aud rery fatal, reducing the number at a rapid rate. A great many fowls die from the so-called chicken-cholera and from gapes.

Monroe. - We have had a great deal of hog-cliolera in this comity. I think the disease is mostly eaused by malaria, the result of filthy keeping and careless feeding. We also have elicken-cholera, for which we have no remerly.

ogle.-Hog-cholera, or disease among swine, still prevails to a limited extent in some localities in this county, but is not so serere or so fatal as last year.

Piatt.-There is no infectious or contagions cliseaso prerailing among any class of farm animals except among swine, Recently a malarial fercr broke out among some imported stallions in our county, onned by Jr. Harrey E. Benson, and thoy all died. There wero eight or ten of them in number.

Pike.-Hogs aro gencrally seriously affected here mith cholera at two periods of their existence, viz., in July, before they are old enough to wean, or between milk and 
grass, and again just before ther are old enough or large enough to fatten. Some die at all stages and every season of the year from the offects of this baneful and destructive disease.

Pope.-The only disease of any moment prevalent among farm stock in this county is cholera among hogs and chickens. The annual losses among both classes are very heary.

Pulaski.-But few farm animals are raised in this county, and the losses from disease have been light during the past year.

Randolph. - What is known here as hog-cholera has prevailed in several parts of the county, but has generally been most destructive where large numbers were herded together. Cases are reported of several droves, numbering one hundred or more, where but ten or fifteen head, in all, recovered.

Sangamon.-Horses, cattle, and sheep have been healthy during the past year. There has been the usual loss among hogs and fowls, but the aggregate cannot be given in the absence of reliable data.

Sehuyler.- Hogs are the ouly farm animals that have been affected with infectious or contagious diseases in this connty during the past season. Great numbers of turkeys and chickens have also died of cholera, but I can give no idea as to numbers that have been lost.

Shelby.-During the past year hogs have died in great numbers in this county of cholera and lung diseases. The aggregate loss will amount to over $\$ 60,000$. A fow horses havo died of distemper, and a good many cattle of dry murrain.

Stark.-The hog-cholera has been very severe on some farms this fall, a good many farmers having lost nearly all their stock hogs and some of their fattening stock.

Stephenson.-The losses of swine in this county have been fearful. The class now dying are mostly shoats-last spring's pigs-and they are dying so rapidly in some localities that it is impossible for the farmers to hunt them up and bury or burn them, consequently the air is tainted with their carcasses.

Tazewell.- Immense numbers of hogs have died in this county during the past year of the various diseases which afflict them. No cure has been discovered for these maladies.

Wabash.-Cholera among swine seems to be the only disease affecting any class of our farm animals. About one-half of all the hogs in the county amnually die of this disease.

Washington.-The usual diseases have prevailed among farm animals in this county during the past jear, and the losses among all classes will reach $\$ 3,000$ or $\$ 10,000$ in value.

\section{INDIANA.}

Adams County. - The only class of farm animals affected by disease in our county is the bog. The disease seems to be epidemic and contagious, and has occasioned heavy losses among hog-raisers.

Brown.-The only disease of any consequence that has prevailed among farm animals in this county during the past year is cholera among swine.

Carroll.-Cholera has been very destructive among swine duriug the present year. The losses in this county will a mount to $\$ 38,000$ or $\$ 40,000$. The symptoms are various and seem to defy anything like successful treatment.

Clay.- I doubt if this county at any time during the past eighteen years has been clear of the hog-eholera. In most herds it has been very fatal.

Clinton.-The losses in this county during the present year from diseases among swine will amount to over $\$ 20,000$.

Crawford. - The general condition of farm animals in this county at this time will compare favorably with previous years, and is fully np to an average, if not above.

Dearborn.-There has been but very little hog-eholera in this county during the present year.

Decatur. - All classes of farm animals in this connty are healthy except that of hogs. These animals are aftected with the usual maladies, and the losses have been very heary during the last year.

Greene. - With tho exception of hogs and fowls all classes of farm stock have been measurably healthy during the past season. Perhaps fivo thousand hogs have been lost during the jear by the usual diseases.

Hancock.-The value of the hogs lost in this county during this past year from the various diseases affecting them will a mount to over $\$ 60,000$.

Hendrichs.-Our horses, cattle, and sheep are comparatively exempt from disease, but hogs and poultry are seriously affected. The losses among hogs particularly are very heavy.

Jay.-The ouly farm animals affected with disease in this county are hogs, and they die by the thonsands. The disease affecting them is known as hog-cholera. About one-lialf of those attacked dio. I think tho disease is contagions.

Kosoiusko.-Nearly 50 per cent. of the hogs in this comty have died this season. 
Some farmers have lost as high as 80 per cent. Some die of a disease resembling lung fever, some of cholera, while others are literally eaten np with worms. The flesh of the hogs fairly swarms with these worms.

Marion.-Hog-cholera is the only disease of any consequence prevailing in this county. Tho losses hare been heary.

Miami.-The losses to the farmers of this county from diseases among swine will amount to over $\$ 20,000$ for the present year. Cholera has been very destructive among fowls.

Ohio.--But few losses have been sustained during the past year from diseases amoug horses and eattle. Cholera prevails among hogs, and is frequeutly very fatal. Those fed on soap-suds and kept out of the dust seem to be exempt from disease. Plenty of lime, sand, and pure water will prevent eholera among fowls.

Shelby.-Horses, cattle, and sheep in this county are measurably clear of disease. Hogs and fowls, however, are reported as largoly aftlieted with cholera, from which inany of them die. No remedy seems to prove effectual.

Stark.-The disease among hogs in this county is commonly lnown as cholera, although the symptoms are varied. The disease has not been very destructive this season.

Suitzerland.-Some distemper exists among horses, but the losses have been comparatively small. Cattlo are healthy and free from all contagious diseases. Hog cholera is prevalent, but not sufficiently general to discourage hog-raising. Tho losses from this disease will perbaps amount to one per cent. There is some chicken-cholera prevalent, but not sufficient to impede the business.

Tippccanoc.-For this and for several years past it would bo safo to say that 50 per cent. of all the swine pigged in this county have died of what is usually termed hogcholera. This year nearly all the farmers in this region have been afraid to feed their hogs, and have shipped them as soon as shippers eould handle them at the summer paeking-houses. The fine heavy hogs that the Wabash Valley used to produce are things of the past. All other kinds of farm stoek are healthy.

Tipton.-Hog-cholera has prevailed to an alarming extent during the past year and has been very destruetive. The disease is of varied symptoms. Some die very suddenly, while others linger for a fow days or weeks.

\section{INDIAN TERRITORY.}

Cherokce Nation. - It will be several years, under the most farorable circumstances, before our peoplo can hope to be as abundantly supplied with farm stock as they were before the late war; but it is encouraging to know that our people, by their vigilance and iudustry, have inereased the number of their eattle, horses, hogs, \&c., and now have not only suffieient for home supply but a small surplus to ship each year to distant markets. Among cattle the most serious and fatal disease we have to contend with is murrain. Hogs are afflicted with various diseases which are classed under the general name of cholera. Tho principal diseaso among horses is distempor, though they are occasionally afflicted with blindness and big-head.

IOWA.

Adair County.-Diseases are prevailing among horses and swine in this county. The losses in logs have been heary.

Buchanan. - The only epidemie that has provailed among any class of farm animals during the past jear has prevailed among hogs. The mortality among this class of animals has been very heavy.

Crawford.- Hogs in this county have been largely affected by cholera, and bnt few attacked by the disease recover. The greatest destruction has occurred among pigs.
The losses aro estimated at $\$ 40,000$ for the year.

Des Moincs. - A fow horses and sheep and a great many hogs have been lost in this connty during the past season by disease.

Emmett. - A few colts liare died here with a disease known as distemper. No disease among other classes of farm animals.

Fayctte--Perhaps $\$ 3,000$ would cover all the losses of farm animals in this county for the past year from purely contagious diseases, but the losses from all other causes would no doubt swell the aggregate loss to twice or three times this amount.

Franklin.- Hogs have remained healthy until within a few weeks past. Recently a number of fat hogs and shoats hase been lost in this locality.

Guthric.-Distemper is the most common disease among horses, and black-leg among cattle. The latter is more prevalent and fatal among calres than among grown eattle. Cholera and quinsy prevail among hogs, and these diseases are quite destruetive. Chickens have eholera, and I never knew one attacked by the disease to get well. sheep are healthy. 
Harrison.-Hogs are annually attacked with a disease known hero as choleral, and a great many of them dio. The past year has proven as disastrous as former sensous.

Humboldt. - This county has becn remarkably fieo from all infectious and coatagious diseases among farm amimals. Thero has been some eloolera and roup among chickeus. Tho largest loss of hogs that I have heard of was firo out of a herd of over ono hundred head.

Ida.-Hogs are iying in this locality this ycar of iuflammation of the lungs. Abont one-half the herds affected die. 'The animals dio in abont one week after the first srmptoms are noticed. Those that recover from the disease do not amount to much. This is the first year that hogs have died of any disease in this county.

Iowa. - Imong horses the only contagious disease prevailing seems to bo a very serious distemper. It affects youm loorses to a greater extent than old animals. Quinsy and clolera have prevailer anong loogs this year, but to a less extent than usual. The losses will amount to $\$ 18,000$ or $\$ 20,000$.

Jackson.-Cattle have becu remarkably healthy, and so liave hogs until within three or four months past. From information recently receiverl I am inclined to believe that the losses will bo heary-heavier, perhaps, than ever before.

Jefferson.-Horses and cattle are healthy in this locality. IIog-cholera provails in somo sections of the countr, but not in as malignant a form as usual. Still the losses have been quite heary. Fatal diseases prevail among fowls, for which wo havo no remedy. The general condition of firm stock is above the average.

Johnson. - No dismase has prevailed this year among either horses, cattle, or sheep in this county. Tho losses, therefore, are merely nominal. 'The loss of hous is not so great as last year. The largest number of those that have died were young hogs, and therefore were of less market value. The disease, in all cases, was supposed to bo cholera.

Lyon.-Until the past summer all classes of domestic animals liave been extremely healthy in this connty. During the past summer some herds on the Littlo Rock were affected with a diseaso claimed to be black-leg, which I doubt, but of which quito a number dicd. I notice that all animals well cared for thongh last winter havo escaped. Wo have never had a case of hog-cholera in the connty. I hear of no cliseases among fowls.

Marion.-Hogs and sheep are less affected by diseaso than usual at this season of tho jear. To infectious or contagions disease exists among horses and cattlo. Some seasons a great many fowls die of cliscase.

Marshall.-Hogs have suffered to a greater extent from diseaso tho past season than erer before. Tho losses have been heaviest amoug pigs and shoats. The losses are estimated at from $\$ 85,000$ to $\$ 90,000$.

Monona.-Lung fever has caused some heavy.losses among lorses in this comnty during the past year. There have been some losses anong cattle from black-leg and other cliseases. "Hog-cholera prevails, and the losses, as usual, havo becn very heary. Almost all those attacked dic. The tew that reeover are worthless.

O'Brien.-Cholera or influenza kill a good many logs in this eounty overy year, althongh the diseaso has nover appeared as an cpidenie.

Palo dlto.-The only contagious disease known among horses hero is glamilers or nasal glect. Our young cattle are sometimes attacked with black-leg. I have never known farm animals to be in a more thritty and healthy condition than they are this year.

Poreshick.-Horses are afflicted witl an epizootic distemper, which has caused many deaths. Tho mortality among hogs, from a disease supposed to be some kiml of ferer, has been terrible. 'Tho losses the present year, in swine alone, will aggregate from $\$ 36,000$ to $\$ 40,000$.

Sionx.-This is a new county, and but few farm animals aro raised. The fer we havo are in good health and condition.

Story.-Hog-cholera has prevailed extensively, aud has beon most virulent aud dostructive during the past season. About one-half the hogs in the comuty have been attaclied. and (99 per cent. of those attacked havo died. 'The losses will amount to orer $\$ 30,000$.

Woodbury.-The ansessors' returns showed 9,982 hogs in this counts this year. Teu per cent. of these were attackerl by a disease known as cholera, and about all thoso afficeted dieil. I bolicvo the disease to bo an affection of tho lumgs. Horses are tronbled to some extent with lnug diseases, but other classes of farm stock aro liealthy and in good condition.

Whashington.-No diseases of eonsecinenee have recent ly prevailed among farm animals in this comnty, asirle from those incident to swine. Diseases among theso animals seem to bo most destructive whero corm is the only diet. 'The losses during the year will reach $\$ 10,000$.

Tright.-Durine the last two years wo havo been gresitly troullecl with hog-cholera in this comnty. It is about the only cliscase of couseguence anong our firm animals 
that we have to contend against. It has been verr destructive to swine. Wo lose a few young eattle every year with a disease called black-leg.

\section{KANSAS.}

Allen Connty.-Cholera and congestion of the lungs earry off a good many hogs in this county every Jear. Scab in sheep and cholera among fowls also prevail to somo extent.

Broun.-Hog-cholera is the only disease that has mevailed to any considerable extent in this county during the present year. The losses have been quito heavy.

Chautauqua. $-A$ fow horses, perhaps 200 head, have been lost in this county by an mnkuown fever. Grown cattle are affected with murrain and young ones with blackleg. Cholera and pnenmonic fever are prevailing among hogs, and these diseases are proving quite fatal. $\Lambda$ good many fowls are dying of a disease called cholera.

Clay.-Our stock is anmally visited by one kind of disease and another, and sometimes our losses are very heavy. This year our losses among all classes of animals will agrgregate from $\$ 12,000$ to $\$ 15,000$.

Cloml.-Tho only disease of an infectious or contagious character is that prevailing among swipe, and generally known as hog-cholera. It is not so prevalent this year as formerly. The condition of all kinds of farm animals is from 25 to 50 per cent. better than in any previous years.

Crauford. - The prinçipal disease among horses is lung ferer, brought on for want of shelter and proper attention. Cholera prevails very extensively among fowls.

Davis. - Cattle are occasionally fatally affected with black-leg, and cholera prevails to a limited extent among hogs where many are kept together.

Elk.-Horses and cattle suffer from varions diseases, and tho losses will this jear perhaps amount to $\$ 7,000$ or $\$ 8,000$. No epidemic has previtiled among hogs during the year, but a great many fowls have bcen lost by the usual disease.

Ford.-A disease called Texas fever prevails here among cattle. It hardly ever proves fatal to cattle brought from Texas, but when it attacks native cattle it is very severe, aud generally fatal. A discase like cholera affects chickens, and seems to be contagious.

Franlitin.-There are no diseases of any kind provailing among farm stock in this county. Stock-raising of every kind is greatly on tho increase hero.

Jactison.--The prevailing disease among cattle is black-leg, and that is confined priucipally to calves and yearlings. Hogs are afflicted with cliolera, but the disease is not so prevalent this season as usual. Chicken-cholera amnually destroys a great many fowls. The condition of farm animais is fully an average.

Kingman.-Cattle are afflicted with wolf-tail and hollow-horn. Four ont of every ten horses that are brought hero from the East dio before they become acclimated. Hogs and sheep are liealthy.

Labette. - Spanish fever lias prevailed among some cattle infected by stock brought in from Texas and the Indian Nation. Cholera has also prevailed to a limited extent amollg hogs.

Leaicuiorth.-Horses aro rarely sick, but when they are attacked by disease they usually die. Hogs are afflicted with various diseases, and they nearly all dic that aro taken sick, as nobody tries to doctor them. Fowls also die rapidly.

Lincoln. - All classes of farm animals in this county lave been oxceedingly healthy during the past year. Stock is in very good condition.

Miami. The only disease reported among farm animals is that existing among swine. This disease was very destructive last year.

Ifitchell.- Murrain, black-leg, and lung-ferer have prevailed to some extent amoug cattlo during the past season, and elolera, quins, thumps, and fever among swine. $\Lambda$ lamentable ignorance seems to prevail in regard to the nature and cause of disease among swine.

Temalia.- To disease of consequence has prerailed among our stock this season. There has been some hog disense, and a greater loss thim usual from diseases among fowls. In sono instances parties have lost all they had.

Reno.-A number of horses in this locality have been sick with blind-staggers and glanders, and some haro had a mild form of the epizootic. The first troo diseases prove quite fatal, one of my neighbors haviug lost five animals, another three, and so on. Cattle are usually healthy. A few cases of black-leg, or something like it, have occurred. $\Lambda$ clisease is prevalent among hogs, which causes them to lose the nse of their hind parts, and from which they die in about six weeks. Sheep are very healthy. Fowls are frequently scriously affeeted in the fall with cholera.

\section{KENTUCKY.}

Brcathitt County.-A good many hogs have been lost this sear by cholera, and many sheep with foot-rot. Horses aro suffering with distemper, and cattle aro frequently 
Bullitt.-Cholera prevails to a considerable extent among hogs in this county. It seems to be more fatal among pigs and shoats than among older hogs.

Calloway.-Distemper prevails among horses, cholera among hogs and fowls, and rot among sheep. Cattle aro healthy.

Carroll.-The disease known as hog-cholera is not so prevalent this year as nsual. Many of oux swine, howerer, havo a delicate and unhealthy look, and do not improve fast even with the best treatment. This we regard as an evidence that the discase is hereditary.

Clay.-The so-called cholera among hogs has proved very disastrous to the farmers of this county during the past year.

Cumberland. - A few horses have died of distemper. in this county. Thero are no infectious or contagious diseases prevalent among cattle. Hogs are aflicted with cholera, and a great many have died.

Estill.-The only diseases of consequence prevailing among cattlo are hollow-horn and murrain. Horses are afflicted with distemper, and occasionally die of some kind of lung-fever. Hogs are badly afilicted with cholera. I should say from 80 to 90 per cent. of those attacked with the diseaso dic. $\Lambda$ good many hogs also suffer from thumps, and abont two-thirds of them die. Cholera also prevails among forrls.

Fleming.-Horses are afflicted with distemper and lung diseases, from which about one in twenty dic. The most destructive disease we have to contend with is cholera among hogs. At least one-fifth of all the hogs in this county annually die from this disease. Tro years ago I lost one huudred and seven head, and this fall I hare already lost sixty head more.

Hart.-Hogs, in some portions of the county, are more or less affected every year with cholera, but the loss this season is small compared with other years. Horses and cattle are freo from all contagious diseases. Chickens suffer from various diseases.

Kenton.-There is but little stock raised in this county, and the only discase that has caused material loss to farmers is that among hogs.

Knox.-Hogs in this county have been seriously attlicted with cholera and blindstaggers. Mlurrain has also prevailed extensively among cattle, and distemper among horses.

Lewis.-This is one of the largest poultry-raising districts in the State. The loss by disease runs into the thousands. The shipments from this post are about one thousand chickens per week.

Martin. - The most prevalent and destructive disease among any class of farm animals is that of cholera among hogs. This disease is very fatal, and makes its appearance semi-annually. We have no remedy. Fowls also suffer with a disease generally known as cholera.

Ohio.-Hogs, as well as fowls, are still afflicted with cholera. Tho mortality among the former has been very large.

Oldham.-Distemper is the only disease afflicting cattle in this loeality. Hog cholera prevails more or less all the time. Sheep are affected with various diseases, among others those of rot and scsl. Fowls aro suffering from cholera and roup. We have been unusually free from discases of all kinds this year.

Pendleton.- Hog-cholera las not been so destructive this season as in previous jears. The losses this year will, perhaps, not amount to over $\$ 16,000$ or $\$ 18,000$.

Rovan.-Hog's die in great numbers from cholera. There is no other infectious or contagious disease prevaleut among the farm animals in this county. Fowls also die in great numbers from a disease generally called cholera.

Russell. -The disease commonly called hog-cholera has prevailed to a fearful extent in some portions of this county. The losses have been at least 75 per cent. of those attacked. Out of a herd of 75 liead I lost 55. I hardly think the disease is contagious. So fearful has been the ravages of the disease that there will not be enough pork raised in the county to supply the home demand. Other classes of farm stock are in good health.

Shelby. - But few horses are raised in the county. The assessors report 9,588 head of cattle in the county. Owing to the rarages of hog-cholera there has been a falling off in the number of swine. Sheep husbandry is largely on the increase, and aggregates nearly double that of any previous year. At least 45,000 head havo been placed on the farms of the county this fall for breeding purposes. No diseases of consequence, except hog-cholera, are prevalent.

Farren.--The losses have been quite heary from diseases among hogs. Other classes of farm stock are healthy.

Whitley.-Distemper is quite provalent among horses, and occasionally wo have a caso of murrain among cattle. Hog-cholera frequently prevails, and is often very fatal.

\section{LOUISIANA.}

Bienville County.-Horses here are subject to bots, colic, distemper, and blind-staggers. Perhaps 50 per cent. of the losses are occasioned by bots. The most common 
disease among cattle is known as screw-worm or "wolf" (in the back), hollow-hom, and, occasionally, murrain. Hogs aro subject to cholera and mange. The former is mueh tho more fatal.

Claiboins.-Cholera among hogs is the most destrnctive diseaso now prevailing in this county. Domestic fowls are also dying rapidly from the effects of the samo discase. Wo havo recently lost some fine cattle, hogs, and mules by hydrophobia. They were bitten by mad dogs.

De Soto.-The only destructive disease among farm animals that we have to contend with here is a diseaso amoug swine, which kills about one-half of those attacked.

Jackson.-Horse 3 frequently die here of blind-staggers and bots, and cattle of hollowlorn or head disease. A good many hogs are annually lost by cholera and thumps, and sheep with scab.

West Feliciana.-Charbon, which has prevailed in a mild form amoug horses and mules, and distemper among sheep, are the only affections among any class of farm animals. A few deaths have occurred among horses and mules, and many sheep have died of distemper.

\section{MAINE.}

Piscataquis County. - No infectious or contagious diseases prevail among farm stock in this county. About 10 per cent. of the fowls are annually carried off by disease.

Waldo. - The only contagious disease we have to contend with here is an epizootic distemper among horses, and this is fatal in but few eases.

Fork. -The usual number of diseases have prevailed among farm animals in this county during the past year, and the losses will amount to from $\$ 10,000$ to $\$ 12,000$.

\section{MARTLAND.}

Alleghany County.-Hogs hare what we call cholera, and but few of those attacked recover. Fowls also havo what we term cholera, and nearly all that are affected die.

Baltimore.-Lung fever has prevailed amoug cattle in the vicinity of Baltimore for the past twelve or fifteen years, and the losses have been considerable. Hog-cholera prevails in a few localities in the county, and a number of animals have died. The losses in fowls seem to be less than in former years.

Dorchester.-Hog-cholera prevails to a limited extent in this county.

Howard. - Some seasons the losses from hog-cholera are very heary, and perhaps amount to as high as $\$ 5,000$. The anunal losses from chicken-cholera will amount to that sum.

\section{MIICHIGAY.}

Alpena County.-As this is a lumbering county a large number of horses and cattle (oxen) are nsed, but very few of them are raised here. A few milch eows and a fow stock bulls, however, have been raised in the county. No disease has prevailed since the epizootic in horses.

Cass. -Distemper has prevailed among horses, milch fever among cattle, and so-callod cholera among swine and fowls.

Chippewa.-This is a new county and we have but little stock as yet, and it is entirely healthy. Grass is grand for dairy eattle. It is always green and nutritious. All animals that run at large in the summer are rolling fat in the fall.

Clinton.-Farm animals in this locality are free from all infectious or contagions diseases.

Delta.-This is comparatively a new county, and what little stock it contains is in a healthy and thriving condition.

Emmett.-A fow horses have been affected with colds and a discharge from the nose, but none have died.

Houghton.-Diseases among hogs have prevailed here for three years. Some hare died suddenly when in apparent health and in good condition. A number of cattle are afteeted with cancer or worm in the tail.

Huron.-Distemper prevails among horses, but the disease seldom proves fatal. All other farm animals aro free from intections and contagious diseases.

Kalamaz0o.-No disease has prevailed this year among farm animals except cholera among swine. This disease has prevailed to a limited extent this fall.

kent. -There have been no infectious or contagious diseases prevalent among farm animals during the past year.

Manistce. - The general condition of farm animals in this county is good, and rather above the average.

Muskegon.-The proportion of farm animals that are attacked and die with infectious and contagious diseases in this county is rery small. Of horses perhaps 1 per cent. are lost; of sheep, one-half of 1 per cent. I hear of no losses among cattle and hogs. Of fowls perhaps 5 per cent. die anuually of disease.

Oakland.-One year ago the disease lnown as hog-cholera created a good deal of un- 
easiness, but the low price of pork has cansed the "thinning ont" to such an extcut that we now hear bnt little complaint. 'The losses this year' will perhaps amonnt to $\$ 9,000$ or $\$ 10,000$.

Otsego. - Several hogs have been lost by the farmers in this county during the past year from somo discaso thought to be contagions. All other classes of stock are healthy.

Presque Islc.-Horses, hogs, and forls in this locality are measurably healthy, but calves seem to bo aficeted witl a contagions clisease.

Saginar.-Abont 1 per cent. of the cattle and hoos raised in this county annually dio of disease. As a rnle all our stock is housed in tho winter and comtortably cared for.

Saint Clair.-Several horses have died in this county during the present sear of contagious diseases. Cholera prevails among swine in one locality, but has not appeared in a very malignant form.

\section{MINNESOTA.}

Betrami County.-The only disease prevalent among any elass of farm animals is distemper among horses. 'This is an Indian agenes, and there are but fer animals in the county.

Faribanit.-A few cattle die anmally in this comnty of a disease known as blackleg, and a few sheep with the seab. Other classes of farm stock are bealthy.

Houston.- The only discase among our stock that we hare had to contend with the past season has been the so-called cholera among hogs.

Isanti._Cattle in this comnty are freqnently attacked with black murrain, and a disease that canses a rising and rmming sore on the head. There is no remedy known for the latter disease, ancl when an animal is attacked by it, it is generally killed. Hogs are snbject to cholera and a disease called staggers, both of which are very fatal. Lac-qui-parle.-Black-leg is quite preralent among eattle, bnt is principally confined to young animals. All dio that are attacked with the discase. The gencral condition of firm animals is abore the arerage.

Martin. - A few horses dic annually in this county from epizootic, and perhaps 5 per cent. of the cattle from black-leg. Stock generally is in good health and condition.

Nicollet.-Glanders prevails among hor'ses in this comnts, and is the only contagions disease with which theso animals are afflicted. Qnito a number of eattle died of black-leg during the past spring, and abont one hundred more from the eftects of eating smutted coriu.

Olmsted. - No cliseases prerail among any classes of farm animals in this connty that I am aware of. In some localities clrolera exists among chickens.

Pope--Epizootic has prevailed among horses, of late, with some fatal cases. Cattle have been suffering more or less with black-leg, which is fatal, with but few exceptions. Hogs and sheep have becu healthy, so far as I can learn.

lifec.-All classes of domesticated animals in this connty are in good health. I have not hearl of the prevalence of any infectious or contagious diseases dnring the year.

Rock.-There has nerer been a marked case of any infectious or contagions diseaso among farm stock in this connty. There yet lingers somo traees of epizootic distemper in horses, but few, if any, deaths hare ocenred from that canso this year.

Saint Louis. - Our farm animals are remarkably free from all infectious or contagions diseases. The discases peculiar to fowls are roup, se., muel of which is due to inbreeding.

Scolt.-Recently there has appeared among horses here an epictemic or endemic disease somewlat alkin to the cpizontic of some years ago. The first symptom is a muens elischarge from the nose, enlminating in ten or twelve days in an afteetion of the liciners. Atrew having reached this stage the disease generally proves fatal. It taken in fime the patient can be enred.

Suift.-The only disease of a serions character that has visited any of the farm animals in this comnty, during the past sear, is black-leg among cattle.

Yellow Meclicine. $-\Lambda$ few hor'ses in this connty have been afilicted with distemper, but none hare died. No otler contagious clisease is prevalent, and all classes of tarm stock are healthy.

\section{MIISSISSIPRI.}

Calhoun County. - In this comty, loorses and cattle are rarely if ever aficeted with intections and contagious discases. Hogs are trequently aflieted witl cholern, and the estimate giren $(\$ \bar{r}, 500)$ is hardly lighl enongh during a sear of its general prevalence. Sheep are hardly erer atlieted with any ilisease save rot. Fowls of every breed occasionally have cholera, and when it attacks a llock it generally kills them all.

Choctaw.-Cattlo suffer with charbon, horn-ail, and murrain, and logs frequently die of cholera or swine-pox. Sometimes a farmer loses nearly all his hogrs by these maladies. 
Corington.-Owing to the extremely hot weather during the summer wo lost at least $20 \mathrm{per}$ cent. of our farm horses by staggers. All ages were afiected alike. $\Lambda$ t this time all elasses of farm animals are in fuo eondition.

Fonklin.-The number of logs affected with diseases during the past summer was greater than nsual, and at least 50 per ecnt. of thoso affected died. Other animals have remained healthr.

Holmes. $-\Lambda$ good mainy colts dio in this comnty every year from distenuper. Hogs dio in great numbers of cholera, lung ferer, and quinsy. Fowls are subject to cholera ancl romp, and frequent!y one-lialf of them are lost by these rliscases.

Leake.-From the most reliablo information I am able to obtain, I am led to believe that about 8,000 hogs were lost in this county during the past season, a large majority of which died of cholera.

Lee. - A very destructive disease prevails among fowls in this locality. It made its appearance liere four or five years ago, and has continued with more or less virulence ever since. It frequently swecps off whole flocks. I myself have this year lost 300 game fowls. It is not cholera, but a clisease moro resembling paralrsis. They are taken very suddenly, lose the use of their limbs, fall down and fintfer until they die, which is generally within from twelve to forty-eight hours. If they linger beyond that length of timo they aro apt to recover. 'The disease is singularly sudden and fatal, and causes a heary loss to the people of this locality.

Loundes. - Since the prevalence of the epizootic some jears ago no contagious discase has prevailed among horses in this loeality. Murrain is the most fatal discase we hare among cattle, and it ammully proves very destructive. Tho losses among hogs from a disease called cholera are very heavy. Fowls also dic oftener of cholera than of any other disease.

Mrarshall.-The usual disenses prevail among all classes of farm animals, and the aggregate losses this Jear will perhaps amount to from $\$ 8,000$ to $\$ 10,000$.

Noxubee. - All classes of fim aninals, with the exception of hogs, have been freo from disease this year. The losses among swine have been very heary, and will perhaps aggregate $\$ 10,000$. Pastures were quite good throughout the summer, but very little cattle feed has been housed, and a spring report will no doubt tell a tale of starvation, \&c.

Prentiss. - A fow cases of hog-eholera have been reported in the county, but the disease has not been rery destructive.

Rankin.-Charbon and blind-staggers occasionally prerail among horses, and rarious fatal diseases among logs.

Scolt. - The only diseases of any consequence that have occurred among farm animals in this county during the past jear have been among swine. Between one and two thousand head have died.

Tippah. - Last year a number of hogs died here from a swelling of the head. The head would swell until the skin would break, and the hog would blect to death in a few hours. I cured a cow recently of murrain by giving her kerosene oil, lard oil, and epsom salts, in doses a few hours apart.

Tishomingo.-Diseases of a mild typo have prevailed among all classes of farm animals during the past year. The losses havo been light.

Tillinson.-Hogrs in this county frequently sufier and dio of pnermonia and congested liver, as do also forls.

Yazoo. - 1 great many horses dic annually in this county from a disease called bighead or big-jaw - an enlargement and softening of tho bones. It is cansed by feediug corn exclusively. Hog's annually suffer severely with cholera.

\section{MISSOURI.}

Andrew Couizly. - This ycar lias been remarkably favorable to all linds of firm stock.

I have heard of no infections or contagious discases among any class except loogs.

Barton.-The losses among horses, cattle, and hogs from disease will probably amount to $\$ 10,000$ or $\$ 12,000$ for the present rear. Diseases have not been so prevalent among farm animals during tho past season as usual.

Benton.-All classes of farm animals, with the exception of hogs, have remained healthy during the past jear.

Buchanan.-Horses, cattle, nuid sheen are free from scrions discases, but eholera exists among both hogs and fowls. With my own hogs I noticed that all those that had diarrliea recovered. The most of those aflicted were costive and had high fever. Cattle are frequently attackesl with hoven, eansed by eating white elorer.

Clay.-Heary lesses have been sustained by the farmers of this county during tho past year in the loss of hogs, shecp, and fow ls by various contagious and malignant diseases. Horses and cattle have remained healthy.

Franklin.-Tho so-called hogr-cholera has not been so prevalent and wide-spread in this connty the past scason as during previons years.

Henry.-No epidemic lias prevailed among horses hero for sereral years past. Texas 
fever among cattle has prevailed to a limited extent, but onl $y$ when parties here violated quarantine laws regarding it. Hog-cholera has provailed extensively, and the estimated loss is put at lowest figures $\$ 20,000$ annually.

Hickory.-Hog-cholera has prevailed to some extent in this county during the past year, but the losses have not been as heary as usual.

Jasper.-Hogs and fowls are aftleted with cholera, and eattle with a disease generally known as murrain.

Lawrence.-Black-leg prevails to a considerable extent, and is very fatal among calves and yearlings. There is also some murrain among olcler eattle. Cholera (so called) is quite provalent among hogs, but the greatest fatality seems to be among pigs and sloats. I do not think one hog out of a thousand, however, clies of cholera. The disease is more like lung fever or congestion of the lungs, and has been very destruetire the past year, especially among young stock.

Lewis. - I have heard of 110 infections or contagious diseases among domesticated animals in this county, except among hogs. The cliseases which affect hogs are manifested by rarions symptoms. Tho annnal losses aro very heary. We havo no remedy, but generally separate the sick from the well hogs immediately on discovering that they aro sick.

Marion.-The disease prevailing among swine and poultry in this locality is commonly called cholera, and that among horses and sheep is designated as distemper.

Miller.- Hogs and fowls in this connty are dying at a rapid rate of a disease commonly known as cholera. All other kinds of farm stock aro healthy.

Mississippi. - $\mathrm{A}$ few eases of hlind-staggers among horses and murrain among eattle have occurred. Cholera prevails among swine, but it is impossible to gire the amount of annual losses.

New Madrid.-The diseases most prevalent here among farm stock are cholera among hogs and fowls, distemper among horses and mules, murrain and hollow-horn among cattle, and rot among sheep.

Nodaway. - A contagious distemper prevails among horses, but it is not of a very fatal character. Black-log and Texas fever havo been very destructive to cattle. Hog-cholera also prevails and seems to be much more fatal to pigs than to older animals. Sheep are to a limited extent aftlicted with scab and grub in the head.

Pettis.-Cholera and lung diseases have prevailed among hogs during the past year, and have been very fatal. Fowls have also suffered cousiderably with what we term cholera.

Phclps.-A few horses have died of distemper, and some cattle of Texas fever and murrain. A heary loss has been sustained by the farmers of the county from diseases among swine.

Pike.-Hog-cholera is the only disease that has prevailed among any class of farm animals in this county during tho past year. Tho losses will amount to from $\$ 12,000$ to $\$ 15,000$.

Platte.-There is bnt little demand for horses here, henco stock-raisers have turned their attention to raising cattle. They find them nore profitable and less liable to disease, and ready for market at a much earlier age. When cattle are well cared for we lose but few by disease. The most skillful farmer, with the assistance of our best physicians, have completely failed to find a remedy for diseases of hogs. All die that are attacked, and the same can bo said of fowls that aro attacked by disease. But fow sheep are raised in this county.

Polk:-Cattle are affected to a limited extent with 'Texas ferer and black-leg. Other classes of farm stock are healthy, with the exception of logs, and a good many of these have been lost by the rarions diseases ineident to them.

I'utnam.-The class of animals mostly affected with disease in this county is hogs, a great many of which die of a diseaso generally known as cholera. The remedies used, as a rule, I do not think amount to much. The general condition of firm animals is better than last year.

Shelby.-Horses, cattle, and sheep are rery healthy, but our hogs die at a fearful rate with a disease commonly called cholera. It prevails at almost all seasons of tho vear, but with more virulence during some months than in others. Sometimes it will kill nine-tenths of all the hogs in a herd, at others perhaps one-half, and at still others but a few will die. Wo do not know what causes the disease, nor have wo a remedy for it. Chicken-cholera also prevails to a fearful extent, and sometimes carries off as high as nine-tenths of the crop. The general condition of farm stock, aside from bogs, is good.

Stoddard.-Our prineipal losses aro from cholera among swine and fowls. Horses, cattle, and sheep aro moderately free from diseases.

Stonc.-The so-ealled hog-cholera is more fatal this season than nsual. The losses up to this time are estimated at from $\$ 40,000$ to $\$ 50,000$.

Torth. - All farm animals except hogs are free from disease. Theso animals aro afflieted witl cholera. Chickens also occasionally suffer from cholera.

Irright. - No disease of any moment exists amoug farm stock in this county. Last year about one-tliird the hogs in this county diecl of cholera. 
MONTANA TERRITORY.

Lewis and Clarke County. - Stock of all kinds in this county are comparatively healthy. $\Delta$ few shecp introduced from Oregon show the scab to some cxtent.

\section{NEBRASIKA,}

Cass County.-The ouly discases among farm animals in this county are confined to swine. The losses are not very heavy.

Cedar.- Many eattle die in this connty during the month of Norember from a disease contracted by feeding on corn-stalks, but the disease does not seem to bo infectious or contagious.

Clay.-Deaths frequently occur among horses from colic, forers, and inflammatory affections. Cattle are affected with murrain and black-leg. There is no cholera at present among hogs, but there has been a loss of about 600 head of shcep in the county during the past year from diseases incident to this class of stock. Many fowls, especially young chicks, die of roupe and gapes.

Cuming. - There are a fow cases of epizootic and distemper among horses, but the diseases are of a mild type, and but few animals have becn lost. Black-leg is about the only malady among eattle. Hog-cholera prevails to a greater or less extent every year.

Dakota.-From ten to fifty head of horses annually die in this county, supposed to be from the effects of alkali. About one hundred yearling calves die annually of a disease called black-leg. We occasionally lose hogs by cholera, but the disease is not prevalent this rear. Fowls also frequently die of cholera.

Furnas. - We have a new disease among eattle here that has killed a great many in the past two weeks. They are attacked by a twitching and jerking of the nerres of the whole body, bloat a little, are in great pain and agony, and die within from six to fifteen hours. I examined four animals to-day, and found two with the galls bursted, another very large, and a fourth blood-shotten. The cattle thus attacked have been rmning in corn-tields after the corn had been harvested. The disease is new to us, and we do not understand it.

Greeley.-A good many horses die annually in this county, but in alpoost every case the loss can bo traced to exposure and ill treatment.

Knox.-Black-leg prevails extensively among calves and is very fatal. There are no diseases prevalent among other classes of farm animals.

Mrerrich.-But little disease prevails among domesticated animals in this county. Perhaps $\$ 3,000$ or $\$ 4,000$ will cover the ammual losses for all classes.

Nucholls. - A rery bad distemper prevails among horses in this conntr. There is also prevalent a mild form of epizootic which few horses escape. Cholcra also prevails among hogs.

Paunee.-Cholera has prevailed to a fearful extent among hogs in this county during the past season, and the losses, in vahne, will exceed $\$ 10,000$.

Platte.-Young cattlo frequently dio within a few hours after being attacked with a disease supposed to be caused by eating smut found on the stalks of com. A good many hogs have died from that pest of the farmer, the cholera, but at present the diseaso seems to be confined to one locality in tho county.

Red Willow. - While this is a remarkably healthy climate for farm stock, a good many cattle and sheep annually die from diseases incident to these animals.

Richardson.-The disease commonly known as cholera has carricd off' a great many hogs in this locality during the past season.

Saline.-This is a new county, and what few farm animals we have are in a very healthy condition.

Sarpy.-Black-leg is quite prevalent and destructive among calves. There scems to be more cases this fall than usual. Hogs are aftected with a lung disease, which made its appearance here last year. The disease is chiefly confined to pigs from three to six months old. At least 10 per cent. of those attacked die.

Saunders.-The only diseases prevalent among horses are glanders and distemper, or quinsy. Some six head of horses have died of these diseases. The increase in the production of hogs is 7,543. Of this number 33 per cent. were affected with eholera, and one-third of them died. The only disease among sheep is foot-rot.

Valley.-This is a new comnty, and what little stock we bave is healthy, and free from all infectious aud eontagious discases.

Trayne. - No discase of any consequenco has prevailed among farm animals in this county since the epizootic some years ago.

Trebster. - The farm animals in this combty are entirely free from all diseases of an infectious and miasmatic character.

Fork.-Some hog-cholera prevails in this county, also cholera among chickens. Horses and cattle are healthy. 


\section{NEVADA.}

Nye County-All kinds of stock range our mountains and plaius, and are only gathered in once a fear to comal. No diseases of an infections or contagious character prevail among them at present. All losses ocenr from starration and exposure in winter.

\section{NEW JERSEY.}

Burlington County.-The prevailing clisease among cattle in this conuty is pleuropneumonia. It is very fatil, and the losses in this class of animals havo been rery heavs. Hog-cholera is prevailing extensively and in a very fatal form. The samo might be said of diseases among fowls. The losses among all classes of farma animals will annually amount to orer $\$ 100,000$.

Camden.-Thero are no diseases provalent among Iorses, except thoso peculiar to colts and young horses. These are generally of a mild character. Hog-cholera prevails to some extent; so cloes eliolera among fowls.

Cape May.-During the past year horses liavo suffered sererely from a discase called blind staggers. A gool many animals have been lost. Hog-cholera prevails to a limiterl extent.

Midalesex. - A contarious lung ferer prevails among cattle in this county, but it has not as fet appearch in a very malignaut form.

\section{NET MEXICO TERRITORY.}

Colfax County.-Scarcely any disease is prevalent among domesticated animals in this county save seab among sheep. The losses among this class of stoek perliaps amount to 1 per cent. of the wholo number raised. There is scarcely any infeetious or contagious diseaso among our larger farm animals.

Dona Ana.-A few flocks of sheep, of improved variety, havo scab in a mild form. Hogs and fowls aro free from cholera. Oceasionally a cow is lost by hoven, brought on by eating green alfalfa; and I lost two merino rams the past summer from the samo cause. I also lost two Angora bneks from an unknown disease.

San Miguel.-There are about 100,000 slreep amually raised in this count5, and about 1 per cent. of them dio of an affection of the milt.

Ta08.-Horses are generally aflected with epizootic distemper and cattle with Texas fever. A great many lio in the spring of tho rear from tho effects of eating poisonweed. Hogs, sheep, and fowls are generally healthy.

\section{NEW YORK.}

Allegany County.-Our horses aro frequently attacked with straugles or distemper, a disease which is believed to be contagious. A fer cows are annually lost from milk fever, and a limited number of calves lio of murrain. Sheep are affected with foot-rot, and many forls tie of cholera.

Chenango.- I have heard of a few calres dying of worm in tho lungs, which seems to be a new discase in this eountr. A farmer who lost threo examined tho lungs and found large quantities of worms about an inch loug aud the size of an ordinary thread. I lost a few calres by the disease known as black-leg, and on opening the lungs fonnd a few worms.

Fulton.-Owing to abmuclant feed, stock of all linds is in fine condition this fall.

Genesec.-The vilue of farm stock lost by various diseases during the past 5 ear in this combty will amount to from $\$ 20,000$ to $\$ 25,000$. The heaviest losses have oceured among horses and swine.

Montgomery. - $\mathrm{A}$ great many cows sufier anuually frem abortion; and the loss by accident and the rarions inflammatory and congestive diseases will averago ono cow for every dairy of thixty-firo cows. No contagious discase prevails in any of our flocks or herds.

Niagara.-Light «lisenses. with but few fatal lesults, hare prevailed among swino dumng the past season. Other classes of stock liave remained healthr.

Sencea. - Ill classes of farm animals in this county have been umusually healthy during the past rear.

\section{NOSTII CAROLLNA.}

Alleghany Count:- Wo havo no diseases among either horses, cattle, or hogs. Sheep oecasionally die fiom clistemper and a kiseaso called rot. Young cliclis frequently dio of gapes.

fivenswick:-On consultation with the best informed persons in the county I do not find that any discases hare prevailed among farm animals during tho past year. 
Large numbers of fowls liave died, but it is impossible to estimate the number or giro any 11 ane to the clisease.

Cheroliec. - There are no diseases of a contagious character prevalent anoug the farm animals of this county. There liave been some losses of joung elickens and turlicys by gapes, but I do not think this clisease is contagions.

Cimberland. - The loss of hogs from the various diseases to which they are incident, but all of which are called cholera, has been rery great. $\Lambda$ great many fowls have also died from a disease generally known as cholera.

Curritzek:-The only disease of any consequence that we have had to contend with among the farm stock in this county has been that commonly lnown as cholera among swine. The loss so fur has been quite heavy.

Halifax.-All classes of farm stock have been more freo from disease this year than any year during the pisst ten.

Hayroou.-Hog-cholera prevails to a greater or less extent every year and kills a great many aninals of all sizes, but is more fatal among pigs. Chicken-cholera is also quite prevalent and fatal. Stocle gencrally is in better condition.

Henderson. - A large number of both cattle and hogs have been lost during the past sear; perliaps the aggregate for these two classes alone will amount to $\$ 18,000$ or $\$ 20,000$.

Hertford.-Horses aud mules are affected with but one contagious disease-that of glauders or farcy. All that aro attacked die. Thousands of hogs die annually of disease, but whether it is contagious or not we havo not determincd. Cholera is generally prevalent and very destructive amoug fowls.

Jaclison.-Infeetious and contagious diseases among horses, cattle, and sheep aro almost unknown in this comnty. Last year nearly all the hogs in the county died of disease, but during the previons fire years but few were attacked.

Madison.-The ouly class of animals afiected by disease during the past rear has been that of swine. Cholera has been quite prevalent and fatal among fowls in some localities.

Yitchell.-Large numbers of hogs and fowls are annually lost in this county by a discase commonly called cholera.

Orange.-Some four or five thousand hogs have becn lost by disease in this county during the current year. A few horses and cattle have also died from diseases peculiar to these classes of farm animals.

Pamlico.-Tho most prevalent and fatal disease we have to contend with is that of cholera among hogs and fowls. The disease annmally carries off numbers of both hogs and clomestic fowls. 'The coudition and quality of furm animals is better than for years past aud is gradually and surcly improving.

Perquimons.-Hogs aro much diseased in this comty and aro rery cheap. Young pigs attaclied with cholcra seldom recover.

Person.-The prevailing disease among farm animals here is that of cholera among hogs, which is very destructive. Trichina destroy many of the pigs and shoats. Sheep are healthy, but a great many fowls dic of cholera. The goose aud peafowl are the only species of clomestic fowls that do not suffer with it.

I.obeson. - Hogs in this county are more affected by disease than any other class of animals. Cholera is the prevailing discase among them, and for which we have no remedy. Tho general condition of farm animals is 50 per cent. better than for previous years.

Sampson.-No epidemic has visited horses, mules, cattle, or sheep so far as I havo been able to learn. At least one-third of tho hogs of the county die erery year from a discaso known as cholera. If any recover they are of no value, as the clisease either leaves them deaf, blind, or afflicted in some other way. Fowls die in about the same proportion from a clisease of like character.

Transylectia. - We havo no contagious diseases amoug cattle. Our losses are occasioned by exposure and want of feed during winter. No unusual discase is provalent anoug any class of farm animals.

Wale.-Horses, cattle, and shecp are free from infections and contagious diseases. Hog's suffer a good deal from cholera nud lung discases. When theso diseases appear in a herd thero seenis to be no cessation matil the last animal is destroyed. Forrls are sulject to all sorts of discases, aud frequently the mortality anong them is very great.

Iilkes. - We have some distemper among eattle, but are at a loss to know what canses it. It secms to prevail mostly where the people have the trplooid forer. Cholera is the provailing diseaso among logs and chickens. It has been verg destructivo during the past sumner.

Iadkin.-Hog and chicken cholera has prevailed hero for several years past. When the disease gets among a class of fowls it lills nearly all of them.

Yancey.-Distemper prevails among horses aud sheep, and murrain and hollow-lorn among cattle. Hogs have been seriously affected with cholera and some lind of fever; a good many fowls are also lost by cholera. The condition of all kinds of farm stock is better than usual at this season of the sear. 
OHIO.

Ashland County.- Te hare no infectious or contagious diseases among domesticated animals in this county. There are a few sporadic cases of disease and death, but the aggregate loss is rery small. About one tarmer out of every twenty-fivo loses his chickens every vear br cholera.

Athens. - The so-called cholera prevails among hogs aud fowls in this countr. I belicre the greatest number of deaths among cattle have occurred among cows, which have died of milk fever. The disease shows itself from tho first to the third das after calving, and generally attacks the animal after the fourth calving. Select breeds and good milkers, and those in good condition, are generally the ones that suffer. The srmptoms are loss of appetite, staggering gait, wild look, and cessation of rumination; thes fall down and cannot rise; the brain seems to be afiected; the animal will dast about, striking her head and horns against the ground, when she soon dies. Wo have no remedy.

Auglaize.-Hogs seem to be the only farm animals seriously affected with disease. They suffer with the disease generally known as cholera. The losses so far this rear will anount in value to from $\$ 25,000$ to $\$ 30,000$.

Broun.-A fer colts are lost in this county by distemper, and a good raany hogs and forls annually die of a disease commonly called cholera. Sheep die of grub in the head and of neglect while young.

Erie.-There is no special disease prevailing amoug the farm animals in this county.

Fairfield. - With the exception of swine the live stock of this county has been comparativel free from disease during the past year. Swine have suffered with cholera, though not so extensively as in former years.

Frankin.-Large numbers of hogs and fowls have died in this connty during the past rear of the rarious diseases common to them.

Gallia.-Hog-cholera prevails to some extent in this county, but in a rather mild form this season. Chicken-cholera is quite preralent and malignant, and the losses are hears.

Geauga.-No disease of consequence exists among anj class of farm animals in this county. The general condition of farm stock is good.

Guemsey. - The prevalent diseases anong horses are those affecting the lungs, principally lung-ferers. Hogs are affected with cholera and cattle with murrain.

Hardin.-Hog-cholera has prevailed to a limited extent in the northern part of the county, but in this locality we have not suffered from the disease this rear.

Jefferson. - No diseases of a malignant character have prevailed among farm animals in this county during the past year. Owing to abundant pasturage farm stock is in very high condition.

Knox.-There is no disease among farm animals here. Chicken-cholera prevails every year and carries off a great many fowls.

Ieigs.-Thero have been few, if any, leaths among farm animals in this county during the present rear, except from natural causes. During the past eight or ten rears chicken-cholera has prevailcd from time to time, and is prevalent in some localities at this writing.

Mercer.-The so-called cholera still prevails among hogs in some localities in this county. Cholera among fowls is also prevalent, but the disease is not so fatal as formerly.

Miami.-But little disease exists among farm animals in this county asido from the so-called cholera among hogs. The loss among this class of animals is, in some rears, sers heary.

Honroe. - Yo infectious or contagious disease has prevailed among farm animals in in this county during the past rear.

Montgomery-Chicken cholera has provailed as an epidemic during the past soason, and many fowls hare been lost. Cholera among hogs has also been very destructive.

Ottaxa.-The only disease prerailing among any class of farm animals is a clisease among hogs, and this is confined to two townships of the connty. The animals have a diarrhea, romit, and wheeze as one afthicted with asthma. Ther dio very suddenly.

Paulding.-The mortality among horses has been umusally large in this county during the past year. The same can be said of cattle. During the two sears hog-cholera has been very extensive and fatal. Forls are also subject to cholera.

Iichlavid. - It is estimated that the product of chickens in this county will aggregate 150,000 per ammun, and that 25 per cent. of these clie of cholera. Sereral diseases anuually prevail among farm auimals, and frequently the losses are very heary.

Summit.-Soveral fatal diseases are prevalent anong horses, among others inflammation of the lungs and bowels, aud distemper or epizootic. Cattle are aftlicted with hollow-horn and murrain. The prevalent cliseases among hogs are cholera and blind staggers. But fer of these animals recover. Consumption carries off a good many sheep, and cholera is very destructive among forls.

Trumbull.-The production of farm animals in this coanty has decreased in the past 
four or five years, but stoek of all kinds has improved in quality. No infectious or contagions diseases are prevailing.

Tuscarawas. - No epidemic disease has recently prevailed among farm animals in this county, but a good many domesticated animals have been lost during tho year by the various maladies incident to this class of property.

Wood.- Horses and cattle have been free from infectious and contagious diseases during the past year. Hogs and chickens have suffered serercly from a disease commonly known as hogand chieken cholera. The losses among hogs have heavy been very, as some farmers have lost entire lıerds. Sheep have healthy.

Tyandot.-Cholera has prevailed among logs to a limited extent in this county the past season. Cholera has scriously affected tho fowls, in some cases streeping off whole flocks.

\section{OREGON.}

Clackamas County. - No discase among horses. A good many eattlo dio annually for want of proper attention. A few hogs die every year from liver-disease.

Linn.-Horses here are suffering to a limited extent with contagious distemper ; cattle are healthy, but sheep aro subjeet to scab and other diseases.

Polk:-Cattle, hogs, shecp, and fowls are afticted with tho usual diseases, though the losses are never very heavy.

Tillamook.-There aro no diseases of a contagions nature prevailing among the farm animals in this county.

PENRISIVANIA.

Armistrong County.-Cholera prevails to somo extent among hogs in the eastern part of the county. One man recently lost twenty head by this disease. Clicken-cholera also prevails, and is fatal in most cases. A good many sheep anmually dio of foot-rot and grub in the head.

Blair.-Distemper and lung-fever prevail among horses, and cholera among hogs and chiekens. Foot-rot also seriously affects sheep where not properly treated and cared for.

Erie.-No speeial diseases have prevailed among farm animals in this locality for some years, and henco the losses have been comparatively light.

Lycoming.-Thero havo been no infectious or contagious diseases among farm animals in this county tho past year.

If Kean.-The condition of farm animals is good compared with previous years. Horses are overworked in tho oil regions, and many die from abuse and laek of proper attention.

Northampton.- Thero has been no contagious diseases among farm animals in this county so far as I have been able to ascertain.

Perry.-Losses among horses and cattle from rarious diseases will perhaps reach $\$ 3,000$ annually in this county. Losses among hogs, when no epidemic diseaso prevails, will probably amount to $\$ 800$ or $\$ 1,000$ per aunum. Some years cholera is very estruetive among chickens, so much so as to kill about all in some loealities.

Wayne.-But few horses are lost here by contagious diseases. A good many young pigs and chicliens die of cholera.

\section{SOUTII CAROLINA.}

Barmwell County. - The only disease known among horses in this eounty is staggers or blind staggers. Wo know nothing abont the pathology of the clisease and have no remedy. Ninety-nine animals out of a hundred that are afflicted with the disease die. Occasionally our hogs are afflieted with cholera. Sometimes one farmer will lose twothirds of his entire stock of hogs while his next-door neighbor will lose none. Fowls die by the hundreds when closely confined in coops that have remained on the same ground for a number of years.

Colleton.-Many hogs are annually lost in this county by a disease generally known as hog-cholera. Great numbers of fowls also dio of a disease called cholera.

Lexington.- Hogs haro suffered less this than last year from cholera. Tho losses last sear wero frightful. Fowls have this year suffered beyond all precedent from so-called chelera. I had a fine lot of 100 Bramals, from which I had 150 dozen eggs during the early spring. As warm weather came on they were attaeked and nearly all diedonly one of those attacked survived. Unless something can be done to prevent the annual recurrence of this fatal epidemic, we will have to stop trying to raise fowls.

Oconce.-Wo have no infectious or contagious diseases among either horses, eattle, or shecp. In a few loealities of the eounty hogs have suffered from cholera. Thero are a few localities along the Blue Ridge range of mountains where the eattle greatly sutfer from milk sickness. An appropriation by Congress for the discovery of the cause of this disease would be emimently proper. 
Orangebrgh.-Hog-eholera has prevailed this year in some localities in this county. Pickicns.-The diseases common to cattlo are distemper, murrain, and milk-sick. Distemper is regarded as contagious, and a similar diseaso provails among horses. The prevailing diseases among liogs is commonly ealled cholera, and it nearly always proves fatal.

\section{TLNNESSEE.}

Bclford County.-Thero is no disease here among cattlo oxcept murrain, which was brought in from other States and seems to be contagious. The most fatal disease amoug hogs is cholera, for which wo havo no remedy.

Bcnton.-Horses, cattle, sheep, and fowls are affected with the usual discases. Wo have hat no hog-cholera this year. This discaso usnally kills nearly all tho hogs in this section alsout onco in every three or fonr years.

Bradley.-All kinds of domestie animals are exceclingly healthy in this cointy.

Blount.-Horses and mules snfier from distemper, epizootic, and glanders; cattlo from murrain and sore tongue; hogs from cholera and quinsy; sheep from rot; and fowls from cholera. These diseases prove fatal in many eases.

Dycr.-Horses, cattle, and sheep in this comty suffer very littlo from disease of any kind. Hogs and chickens frequently snffer terribly from the ravages of elolera. The diseaso seems to bo infections or contagions with both classes, and is very fatal, as but fer of either class recorer. 'The nlalady is not at all understood, and no remedy that amounts to much has as jet been discovered.

Fcntress. - There aro but few horses in this mountainons county, but cattle aro plentiful. Hogs conld bo raised hero in great abundanee were it not for the ravages of tho diseaso known as cholera. Fowls fiequently dio of gapes.

IIamblen.- Several horses haro died during the past season with blind staggers or brain fever. The condition of farm animals is better than usual.

Hardeman. - Thero were somo losses of horses and cattle last spring from starvation and bad treatment. Wo havo suffered greater losses, however, from diseases among hogs than of any other class of farm animals. The disease is called cholera by some, and by others red mange, and by still others measles. 'The hog at first presents a mangy appearance; afterwards it breaks out in pimples or sores, and soon dies. $\Lambda$ black hog of mine which recovered from the diseaso is now gray.

Hardin.-Milch-cows and oxen have suffered severely during the past season from murrain. Cholcra prevails among swine of all ages.

Henderson.-Blind staggers is abont the only discase that proves destructive among horses. Every diseaso incidont to the hog is called choleri, and diseases are moro prevalent among swine than among any other class of animals. Rot prevails anong sheep, and cholera among towls.

Jacison. - The great bulk of the annual losses of hogs in this county occurs from a disease knowu as cholera. Fowls die of a similar disease.

Macon.-Cholera is the only disease that afrects hogs in this county. Tho discase has been quito prevalent and fatal during the year. Chickens also dio of cholera.

Irarion.- Horses aro subject to distemper and blind staggers, from which many of them dio. Cholera prevails among our hogs, and lias proved very tatal. During somo years almost all the fowls clio oi cholera. All kinds of stock sufter for want of proper attention.

Homoe.-There are from two to three thousand horses annually raised in this county. 'Thero is but little disease among this class of animals-nothing worse than common distemper, and an occasional caso of bots or colic. About five thousand cattle aro aunually raised, and they are soldom afrected with disease. Formerly log.cholera prevailed extensirely, and the fatality was rery great, but of lato years the clisease has been very mild and has not prevailed as an epidemic. But little interest is taken in sheep. Fowls aro raised by almost every fiumily, and have bceome an important matter of trado among the ladies of the comnty in buying little items in stores.

Morgan.-Diseases in various forms have prevailed extensively among our hog's and fowls for years yast. They have not been so preralent during the past year.

Obion.-Horses, cattle, aud shecp aro remarkably healthy. Cholera exists among hogs, and a good many animals liavo becn lost, bnt the disease is not rery extensive this season. Cholera also prevails among fowls in some localities.

Orerlon.-On eattle do not often suffer fiom contagions discases, but many of them dio for want of proper care and attention. Hogs and fowls sufer from cholera, and sheep from rot.

I'cry.-Tho loss of hogs from cholera in this county durng the past year will amount to not less than $\$ 12,000$. Sheep have been afiected with rot, and a good many fowls have died with cholera.

Scquatchic.-Swino are aftected with what secms to be diseases of a local character. Many of theso cliscases are no cloubt brought on by careless treatmont.

Scrier:-But little disease has prerailed among farm animals in this county during 
the past yeai:. A good many hogs have been lost, but the diseases among them have not been so widespread as iu former years.

Iin buren.-The discaso among hogs in this county is generally called cholera, although it manifests varied symptoms. Chickens are also allected by a discase desiguated as eholera.

Wcalky.-Witl the exception of slight affections among hogs and chickens, all classes of farm animals havo been unusually healthy during the past year.

TEXAs.

Akstin Connty. - The losses of horses by infectious and contagious diseases varies greatly, but for tho last two years they have been musually large. Tho losses have been heaviest among stoek horses on the prairic, aud the diseaso affecting them seems to be a distemper or kind ot eronp. A strange disease has been prevailing among eattle in the northern part of the county, and every animal attacked has died. The discases among logs are elolera, lung affections, measles, inflammations of the throat, \&.c. Nost of the animals attacked die. Cholera prevails among chickens, and losses have been very heavy.

Bandera.-All classes of domesticated animals have been unusually free from disease during the past ycar. Fowls are afflicted with rarious diseases, some of which are very fatal.

Bcxar.-A few diseases ammally provail among domesticated animals in this county, and the amnual losses among all classes will probably aggregato from $\$ 8,000$ to $\$ 10,000$.

Camp.-Stock generally is in good condition in this county. I have heard of no diseases provailiug among any class of farm animals.

Comal.-The only disease among Inorses consists in a swelling of the glands of the throat, frequently ending in ulecration. The clisease prevails more extensirely in spring when the weather is cold and wet. Tho majority of the animals that dio aro colts. The afiection secms to bo an epidemic, produced by scanty pasturago and rough weather. Thero are no contagious diseases prevalent among cattlo, hogs, or sheep.

De Tritt.-Horses, cattle, hogs, and sheep are gencrally healthy and iu good condition in this comty. The losses are so small as to attract but little or no attention. fowls frequently dio of a diseaso known as cholera.

Eastland. - A good mauy horses die in this county of blind staggers and big head, cansed priacipally by fecding unsouncl corm. Diseases amoug eattlo are not so fatal this season as they were last ycur. Wo have no special diseases among hogs, but a great many of them havo died this year for lack of feed. Foot-rot and scab prevail among sleep. Fowls die of various maladies.

Harrison. - A fewer number of horses havo died from disease in this eounty during the past twelve months than for several years past. Our hog's dio in considerable mumbers from a wheezing disease caused, no cloubt, by cating cotton-secd, picking them up from about onr gin-houses, or where they have been dropped by cattle. Our chickens and turkeys have died by the thousands with a discase we call the cholera.

Hays.- Our farm animals are in remarkably good health and condition. We hare becn free trom all contagious diseases for three years past.

Hill.-A diseaso heretofore muknown las been quite tromblesome to horses in this neighborhood. Our stockimen generally designate it as "loin distemper." Cholera anoing hogs and fowls is tirequently quite prevalent and fatal.

Hoplins. - Horses in this locality are afiected with g'lander's, and cattle with bloody murrain. Hogs are afrected with cholera, and a discaso which eauses wheezing aud choking, as of it hard lump in the throat. Theso discases generally follow an acorn crop. Sheep dio with scab, and a great mayy fowls are lost by cholera.

Jasper.- Farm animals are in much better condition than for sereral years past. No contagions disease prevails except among hogs, and the losses aro quite small, as
we raise but few hogs in this comty.

Eer.-I hare never known an infectious or contagious clisease to prevail among horses and mules in this connt. T. Fifte-four cattle have died during 1 lie present year of dry murrain. A largo number of goats and slicep hare dien of toot-rot and seab. A great mauy hogs have died of a diseaso termed soro eyes, and many forls have died of cholera. So destructive has ween the latter clisease that many farmers are entirely without ehickens. The condition of all furm animals, howerer, is a littlo better thau the average.

Lacaca.-Ticks lill a good many colts in this connty erery spring. We hare some distemper among horses, bit it has rarely been fatal. Until this year hogs have always been healthr, hut for several months past cholera has prevailed anong them, and in some neighborhoods all hare died. The disease seens to be contagions, and I think was introdneed by the importation of fine breeds.

Llano.-Owing to depredations by Indians, but fow horses are raised in this county. 
Cattle are moderately healthy, and hogs entirely so. Sheep have seab occasionally, but the disease is curcd by dipping. Fowls aro subject to cholera, and I never knew one to recover from an attack of this disease.

Marion. - Wo havo had, and still have, hog and chicken eholera in several localities in this county. It is very destructivo during somo seasons.

Matagorda. - Cattle in this locality havo been healthy this sear with the exception of an epidemic of opthalmia, which seemed to bo atmospheric in its origin; or, in other words, it was cansed by excessive heat and moisture. A good many horses have died from the effects of bites and stings of insects, which were never so bad before. Ticks, screw-worm, and tho largo horse or cow fly havo destroyed many animals. Measles prevail among young pigs and shoats, and a gooch many of those attackod die. This disease is both contagious and infectious.

Maverick:-There aro no hogs raised in this county. Horses and eattle are healthy. There is some scab among sheep, but much less than in former years.

Ifenard.-The disease called scab prevails among shecp, yet I beliero a greater number die from eareless management than from this or any other disease. Other classes of stock are healthy and in good condition.

Montague.-Cholera among hogs prevails to some extent this season, but the disease is not so general as in former ycars. Tho general condition of farm stock is good.

Navarro.-The losses among hogs in this county from cholera and other diseases will aggregate for the past year not less than $\$ 15,000 \mathrm{in}$ ralue. Chickens also die of cholera, and sheep from liver-rot and scab. Horses and eattle are bealthy.

Rusk:-Hogs and chickens are suffering with a disease called cholera, which seems to visit somo portions of the county annually. Various preventives are used, but no specific has as yet been found for it.

San Patricio.-There are no discases affeeting any class of farm animals in this county. I havo resided here twenty-seven years, and this is the first year within that timo that any important diseaso has prorailed among fowls. About nine-tenths of them have died in this town and surrounding localities of cholera, at least tho disease was so pronounced by those who know the symptoms.

Somerville.-Stock of all kinds in this county have been unusually healthy this year.

Titus. - Infectious and contagious diseases affecting horses aro not so fatal as heretofore, though glanders and distemper kill a great nany. A large number, however, aro lost by staggers and bots. Cattlo aro affected with murrain and black tongue, and nearly all die that are attacked by these diseases. Many also die from feeding on acorns. A great many hogs are annually lost by cholera and red mange or measles, thumps, and staggers. Scab, rot, glanders, and black tongue produce fearful ravages among sheep. We have no remedy for these diseases.

Upshur.-A good many cattlo and hogs have clied in this county during the past year of diseases peculiar to these classes of farm animals.

Uvalde.-Horses dio of blind staggers and a kind of lung ferer, and cattle of lung forer and spinal diseases. Tho principal disease among hogs is cholera. Sheep dio of scab and lung ferer, and ehickens of cholera. Wo have no successful remedies for any of these maladies.

Victoria. - This has been a very disastrous year for sheep, owing to the great amount of wet weather. There is no diseaso among native cattle, but about ono-third of those imported die of Spanish fever. Horses, and especially colts, dio of distemper.

Williamson.-The principal diseaso among horses is distemper. The disease prevails to a greater or less extent every fall, and prineipally among colts. Tho losses among cattle aro generally occasioned by the samo disease. Wo oecasionally havo hog and chicken cholera, but tho losses aro not very heavy from this disease. A fer sheop are annually lost by scal, but not so many as in former years.

Young.-All kinds of stoek and poultry havo been unexecptionably free from disease during the past year.

\section{UTAII TERRITORY.}

San Pcte County.-Contagions diseases hare provailed among cattle in this county during the present year. A few cases of bloody murrain have also occurred.

Trasatch. - There is no malignant diseaso prevailing among farm animals in this county. Fowls are subject to croup, of which a good many dic.

\section{VERMON'.}

Addison County.-Horses are afflicted with a distemper which is regarded as contagious. Cattlo haro what is called murrain or black-leg, a disease which seems to bo epidemic and contagious, but is confined mostly to calves. Mfurrain nerer at'acks lean cattle. Many deatlis occur anoug cows in early summer from milk ferer. Cattlo generally are in fine condition.

Calcdonia.-No infectious or contagions diseases of a serious nature havo provailed among farm animals in this county duriug tho past ycar. 'The season has been farorable, and stock gonerally is in good condition. 
Chittendcn.-The number of cows have increased in this county since the last census, nearly one-sixth. Horses and swino remain about tho same. Sheep have fallen of materially, say three-fourths. At present there is a lively interest in fowls, especially of pure bloods. 'Tho number hasinereased at least one-third. Our animals are
all in a healthy condition.

Grand Islc.-Since the prevalence of the epizootic some years sinec, thero has been no infectious or contagious diseases among horses in this county. Cattle, sheep, and hogs are almost entirely free from disease. I ascribe such exemptions to the better caro they receive in good feed, protection from storms and cold weather, and better
caro generally.

Futland.-Foot-rot has presailed extensively and fatally among shcep in this county during the sear, but the disease is now diminishing.

\section{VIRGINIA.}

Accomac County. - The annual losses from disease among all classes of farm animals in this county will amount to from $\$ 12,000$ to $\$ 15,000$.

Alexandria.-Upwards of 100 head of cattle have died in this county during the past year, principally of pleuro-pneumonia. The origin of the disease has been traced to Georgetown. It occurred first among cattle thero about two years ago, and has sinco gradually traveled down the river to a distance of about 25 miles. It has not, as 5 et,

Botelourt.-There has been no infectious diseaso among horses in this county for several years past. The discaso affecting cattle seems to bo confined to those under one year old, and is known as bloody murrain. Those that are best kept are moro liable to the disease than those poorly cared for. Flour of sulphur given with salt once a day for three dass is the best remedy known here. Hog-cholera, the only disease affecting swine, is less malignant than in former years. Cholera in fowls has been successfully treated by placing iron in the water which is given them to drink.

Brunswick:-Cattlo sometimes die in large numbers from a disease called murrain. A good many hog: are also annually lost by cholera, a disease which appears under

Campbell. - Wo have had no infectious or contagious diseases either among our horses, cattle, hogs, or sheep, with the exception of an umknown disease that has prevailed among cattle in the vicinity of Lynchburg. Cholcra among fowls sometimes depopu-

Dinwiddie -

Dinwiddie.-A good many horses, cattle, hogs, and fowls have died this season from hogs in this county. Essex. - I have lie

Essex. - I have heard of no infectious or contagious diseases prevailing among any
class of farm animals, except swine.

Floyd. - The only contagious disease among horses here is a distemper which affects
very seriously the head and throat of the anime cattle is black-leg. Its attacks are more frequent amone Thost fatal rlisease among to two years of age. The only discase affecting strino is young animals of from one other animals are healthy.

Glouccster. - A large number of horses, hogs, and sheep have been lost by disease in this locality during the past season. The disease affecting hogs is the so-called
cholcri.

Greonc. - The infections and contagious diseases prevailing here are distemper among
orses, and cholera among hogs and chickens.

Halifax. - An infectious distemper is prevailing among horses in this county, and mrurain and distemper among eattle. The latter seems to bo a contagious fever, and
kills nearly all attacked. The prevailing diseases among hogs are measles and quinsy.
There are no diseases among sheep. Tho condition of all farm-stock is good better There are no diseases among sheep. Tho condition of all farm-stock is good, better high grade of fever, and gencrally considered ant. The eattlo distemper, which is a havo to contend with. No effectual remedy contagions, is the worst disease farmers proved generally quite a sneessful remedy has been found, but the following has proved generally quite a snceessful preventivo: 1 gallon commou salt; $\frac{1}{4}$ pound flour
of sulphur; 2 ounces saltpeter and 2 ounces copperas. Dissolvo these ingredients in
three gallons of water and mix with red clay to the and put in troughs for the eattle to red clay to the consisteney of plastering mortar, the first of July to the first of November. The tronghs should bo kept supplied from

Henrico.-Hog-cholera has beerember. It rarely fails as a preventive.

the hogs affected have died.

Highland.-The prevailing

and mad stagger or fits. Catteases among horses are lung fever, distemper, diarrhea Domestic fowls also have cholera.

Jamcs City.- Hor have cholera.

of former attacks of epizootic fuently affected with a distemper, the results, no doubt

14 SW 
cholera a change of both pasture and food is recommended. Raw turnips fed on alternate days are thought to bo a preventive.

Page.-Perhaps $\$ 5,000$ or $\$ 6,000$ will cover tho loss among all classes of domestic animals by diseaso in this county during tho past year. Farm stock is in much botter condition than usual.

Patrick.-There havo been some losses of horses in this conntry by distemper and cattle by murrain. Hogs, as usual, have been serionsly aftlicted with cholera.

Pittsylvania.-The principal disense among horses in this county, during the past year, has been pnemnonia or lumg-forer, which is not considered contagious. Cattlo are afflicted with murrain, aud hogs with various diseases.

Rappahannoch.-Tho number of horses and eattlo afiected with contagious diseases in this locality is small. Somo few hogs dio of eholera. Shecp are healthy.

Roanoke. -No diseases havo prevailed among farm animals in this county during the past year. There has been somo cholera among chickons, but tho disease has not prevailed as an epidemie.

Rockbridge.-Black-leg is the only disease that affects cattlo fatally in this county. I do not think it contagious, thongh all the animals attacked by it die. Hogs and fowls are sometimes fatally aflecterl by cholera.

Snyth.-Distemper has prerailed to some extent among the horses in this county, but it has proved fatal in but fow instances.

Spottsylxania.-No diseases of a maliguant character havo prevailed among farm stock in this county during the past year.

Sussex.-Cholera has, and still is prevailing to a considerable extent amoug hogs and forls in this loeality. The losses have been quite heary.

Washington.-Distemper and murrain provail among horses and eattle, aul eholora among hogs. A disease similar to murrain also prevails among sheep. Fowls are annually lost iu great numbers by a disease called cholera.

Wise.-Diseases havo prevailch to a considerable extent among hogs in this county adring the past season. All other classes of farm animals are healthy.

\section{WASHTYGTON TERRITORY.}

King County. - There are no infectious or contagious diseases among horses, cattle, or hogs. Sheep, however, are afllicted with scab, and fowls moro or less troubled with vermin.

San Juan.-No infectious or contagious diseases exist among either horses, eattle, hogs, or sheep in this locality. There are frequently losses among all classes of farm stock from accident or lack of proper attention.

\section{WEST VIRGINIA.}

Boone County. - Epizootic distemper prevails amoug horses, murrain among eattle, and eholera aniong hogs. Fowls are subjeet to both cholera and gapes.

Doddridge.-Distemper is the only entagious disease prevalent among horses and that of foot-rot among sheep. Murrain also exists among eattle. All of these diseases are destructive, but none of them so much so as cholera among hogs. Many persons regard this disease as contagious.

Gilmer:-No diseases of any consequence are prevailing among farm stock in this county. Oceasionally a horse is affected with distemper, but I have never heard of a case of lung-forer. Cattlo are sometimes affected with foot-evil, which is the only disease I ever hear of as affecting this class of animals. I have heard of a few cases of cholera among hogs.

Grant.-I Lave malle diligent inquiry, but can hear of no infectious or contagrious diseases existing among tho farm stock in this county.

Greenbrier. - There aro no infections or contagious diseases prevailing among farm animals in this county. About 13,000 chickens and other domestic fowls are annually lost by the people of this county from clisease.

Harrison. - The only disease wo havo among horses is an infectious disease, which, for the want of a better name, wo call "distemper." Horses that have it, gonerally recover. Among soung cattle we have a diseaso called "black leg," which anmually kills a number of eattle, and generally those in high condition. Our losses aro sometimes very heary from this canse. Wo also have a disease amonrr cattle which affects their icet, and which wo call "foot-evil." This diseaso does not lill eattle, but linders them in their growth and deteriorates them in valne. If :s sinplo and sure remedy could be fonnd for this disease it would save onu people a considcrable amiual loss. We occasioually have a ease of hog-eholera, and those att acked usually die, but, as a general thing, hous are very healthy in this comity. Chickens, in some loealities, have suffered with cholera, and the thocks attacked geuerally all die.

Lewis. - No discases of any consenteuee la re aflected the fimm aninuls of this comnty during the past jear. Pasturage is rery abumdant, and eattlo aro gencrally in good 
condition. Hogs are in good health, which wo attribute to their consumption of bitnminous coal.

Logan.-Horses here are much giren to distemper. Sometimes tho diseaso proves fatal; but tho greatest loss oceurs from colic and bots. Cattle sometimes have a distemper mueh like that of horses, but this seldom occurs. Discascs are preval cnt among hogs, and they often dio quite suddenly. Sheep and fowls are in pretty good condition. Sometimes the former are aflieted with rot.

Morgan.-The number of hogs and chickens that have died in this connty during the past year of eholera has been rery large. Other classes of farm stock have bcen bealthy.

\section{WISCONSLY.}

Door County. - No infectious or contagious diseases prevail among any elass of farm animals in this countr.

Dunn.-Last winter horses in this county wero serionsly affected with distemper; but it disappeared in April and has not sinee made its appearance. Several animals were lost. Cattle and hogs are healthy, and are in rery good eondition.

Grcen.-Tho so-called cholera has prevailed among tho hogs in this county for the first time during the present year. A great many bave died. Cholcra prevails extensively among fowls also, and many thousands have died.

Iowa.-Diseases among swine have been rery prevalent during the past year, and the losses to the farmer's of this county have, consequently, been very heavy, as the maladies have been of a fatal character. Other classes of stock have been healthy.

Jackson. - There are no discases whatever of a destructive nature prevalent among farm animals in this county.

Juncau.-Distemper and inflammation of the lungs, or lung forer, are the only diseases of a serious character prevailing among horses. Other classes of stock are bealthy.

Kewaunee.-Aside from a few horses afflicted with glanders, all classes of farm animals are in good health.

MYonroe. - All classes of farm animals are in good condition and measurably healthy.

Ozaukee. - With the exception of a few cases of hog-cholera, I have heard of no othor disease among farm animals in this county.

Portage.-Domestic animals in this county aro exempt from contagious diseases to a remarkable degree. Indeed, I hear of but fow farm animals dying of any discase, except sheep and hogs-sheep from grub, and hogs from llack romit, or something like it.

\section{WYOMING TERRITORY.}

Laramie County. - There are no diseases whatever among farm animals in this connty. The losses among cattle, cansed by eating the poisonous loco weed, will perhaps not exceed 1 per cent. Abont 300,000 head of eattle come in to the Territory annually from Texas, Oregon, Montana, Idaho, and Nevada.

\section{CORRESPONDENCE RELATING TO THE MORE COMMION DIS- LASES OF DOMESTICATED ANIMALS.}

\section{ALABANIA.}

\section{Mr. Robert Wardland, Tuscumbia, Colbert county, Alabama, says:}

Not having had much experience with farm animals, I will eonfine my remarks to fowls and the ailments to which they are sulject. I yrow them for ms own table, and not for market or fancy purposes. Long years ago I levoted eonsiderable attention to forrls, and soon beeame satisfied that the majority of the diseases incident to them were induced by carelessness and inattention to their sanitary condition. I have fomd that prevention is much better than cure, and $110 \%$, if 1 desire a sick chicheu to experiment, I am compelled to go to some of my neighbors for the subject. In cases of what is known as cholera, the liver of the chicken is found very pale, much enlaryed, and literally rotten. The whole internal viscera is more or less derunged. With sueh cases it is the reriest qnackery to attempt a eure. A careful cxamina ion ot the disease known as gapes has convinced mo that it has its origin in parasites. These, and that other great pest, lice, produce many of the diseases which result so fatally to fowls.

Ny treatment of fowls, which has proved very successful, is rery simple. I givo them a well rentilated jet cheap house, provided with plenty of roosts, nests, \&c. 
Next, I have none but healthy birds to breed from, and am rers particular to keep their quarters perfectly elean. I have my hen-house cleaned once a week during summer, and once in every ten dass 'during the winter season. I remore the contents and have them stored nuder cover for use as a fertilizer for my crops. I use quicklime and wood-ashes as disinfectants, and charcoal as an absorbent. The result is clean houses and healthy fowls.

I pay close attention to their food. Too much corn makes them fat and indolent. Once or twice a day is as often as they should have grain. They should be provided with grass lots for grazing, as the amount of this kind of food they will consume would astonish any ono who has not given tho subject attention. Puro water and plenty of it is indispensable. Sick birds should at once be separated from the well ones, but the best plan is to cut off their heads and bury them.

I am partial to clark-colored fowls, as I am of the opinion that they are more hardy than the light-colored ones. I am eareful not to orerstock my flock, and breed only from those that are peaceable, and as a result have no games or ill-natured fowls.

\section{Mr. V. C. Larmore, Valley Head, De Kalb county, says :}

My observations and experience with farm stock extends to a period of near forty sears. In the care of horses I am particular to gire them good grazing and somud feed. In winter I givo them good shelter and feed both hay and grain. I also givo them salt and ashes, slaked lime, and copperas or saltpeter. During the summer months I keep the nits cleanly scraped off from their limbs and bodies. I practice about the same treatment with cattle, and in addition use sulphur, rosin, and turpentine in the summer and fall to keep off the ticks. I use the same preparation to remove lice from my hogs. When disease is in the neighborhood I give them salt and ashes, and sometimes turpentine. My hogs have been visited but once with cholera, and then they had it rery bad. I tried everything I could hear of, but to no purpose until I separated them into three different lots. I put the well ones into a field by themselves, those that looked feeble into another, and the sick ones $I$ turned into a meadow through which a stream passed. I drore them through this ereek once or twice a day. I burned all the dead carcasses, old beds, and eren tho woods where they had been running in the mast. I had about two hundred head, and many of them died, but they commenced to improve soon after I commenced this treatment, and soon the disease disappeared.

\section{Mr. R. Tucker, Marion, Perry county, says:}

Hog-cholera seems to prevail throughout the United States, and perhaps more hogs dio from the effects of this disease than from all other causes combined. I havo been using preventives for years, and when I attend strictly to this duty I hardly over loso a hog by cholera or any other disease. I use copperas, lime, ashes, charcoal, sulphur, and tar. The most of these articles are good for worms and keep the hog in a lealtliy condition. Cholera makes its appearanco in various forms, and in many cases, I think, what we call cholera is caused principally by worms.

In this latitude wo have a disease called murrain among eattle, which, perhaps, is more destructive than any other to this elass of domestic animals. It usually makes its appearance in the spring of the year. We have what is known as both the dry and bloody murrain. As preventivos wo use salt and sulphur freely, and keep tar in the feeding-troughs. When a serere case makes its appearance it is hard to cure, though soap aud oil have been used in cases of dry murrain with some success.

Blind staggers seem to be the prevailing discaso among horses and mules. A horse properly fed on sound corn and haF, with lime, wood-ashes, tar, and sulpluur constantly in their troughs, will never have the blind staggers. Bots and colie also kill a good many horses. Oil and chloroform will generally effect a speedy cure in such eases.

\section{Dr. George T. MeWhorter, Chickasaw, Colbert county, says:}

In connection with my report of the hog-rlisease, which prevailed so fatally here during the past season, I desire to call your attention to reports from Van Wert and Problo counties, Ohio, Iroquois county, Ohio, and Lauderdale county, Alabama, found in tho Report of the Commissioner' of Agrieulture for 18\%6, page 10s. I am convinced that the "new disease" mentioned by correspondents from these counties is the same that prevailed here, and that it is caused by tho worm, spccimens of which I sent you. You will observe that all call attention to the lung trouble, some stating that tho lungs were tho unly parts affected. By careful examination I founcl, as stated in my report, the lungs, liver, stomaeh, and bowels infested by these worms, but in every case the lung tissue had suffered most, in some eases being entirely broken clown.

I suspect also that much of the pneumonia (page 109, same report) reprorted from Kentueky, Illinois, Ohio, Indiana, and Kansas is lue to the same cause. The troublo is so much more patent in the lungs than elsewhere that it might reasonably be overlooked in other situations. You will remenber that the worms taken fiom the luugs were much larger than those from the bowels. I attribute this to tho iuferred fact 
that the lungs afford better conditions for their development than the other organs. The fact that their presence in the lungs is so mueh more deleterions to the health of the animal, and manifests itself by such decided symptoms, is perhaps the reason that some have supposed that they alone were affected. I am still of the opinion that the alimentars canal is the nidus in whieh the egg is hatehed, and from which the young worm starts, producing violent and noticeable symptoms when the lungs are reached aud perforated.

ARIRANSAS.

\section{Mr. William B. Turman, Waldron, Scott county, says :}

As hogs are the only class of farm animals affected by disease in this locality, I will confine ny remarlis to the malady generally known as hog-eholera. The symptoms are a cough, followed by constrained breathing, producing, in many cases, a movement similar to thumps in horses. The animal refuses food. After a while great thirst prevails, and scarlet red spots, from the size of a pin's head to that of a man's hand, appear on the surface of the body. At this stage of the disease they refuse to leave their beds. In some cases death ensues within a few hours, while in others the animal may linger for several days. Perhaps one hog in ten survives a mild attack. An examination after death reveals the lungs, to all appearances, greatly affeeted, and in many cases much decomposed. In some cases the blood is also found coagulated in and around the kidneys, and the entire flesh in a more or less putrid condition.

I am informed ly Mr. W. M. Johnson that for the last twenty years he has kept his hogs healthy by giving them, with their food, common pine tar, occasionally smearing some on the hair of his hogs. He has not lost a single hog by this very common disease.

Mr. Dearman keeps his hogs healthy by giving them soap, pine tar, and sulphur. MIr. A. J. Gentz keeps his in good condition by mixing boiled garget or poke root with their feed. Mr. A. H. Hooper gives sulphate of iron and salt, which has proven an excellent preventive with him.

\section{Mr. W. W. Hughey, Warren, Bradley county, says :}

There has beer no disease in this immediate vieinity that has seriously affected swine sinee 1873. During that year fully three-fourths of the hogs in the county died of what is commonly known as hog-eholera. The first symptom of the disease was a refusal to eat, followed by a dull, stupid appearance. Frequently eruptions about the size of a pea would appear on the body, and death would then ensue in from five to twelve hours. In a few hours after death the carcass would swell to such an extent as to break the skin in many places, from which a yellowish water would run.

Aluout the 20th of December last, a similar disease made its appearance in the resterm part of the county, which is proving quite fatal to grown and fatted hogs. Not more than one in five of those attaeked recover. We expect it to spread throughout the county by the first of May, as it did on itg former visit. Hogs are not raised here for market, yet most farmers endeavor to raise a sufficient number to provide themselves with their own meat.

\section{Mr. J. N. Deaderick, Wittsburg, Cross county, says :}

The most fatal diseases we have among horses here are staggers, Spanish fever, and charbon. In sleepy staggers a disposition is shown to move around in a circle The gcneral treatment is blistering orer the brain and profuse bleeding from the nose. The disease lasts from one to two days, and the fatality among those attacked is about 90 per eent.

In Spanish fever the symptoms are extreme languor, stupor, and high fever. The duration of this disease is from five to fifteen days, and the per cent. of deaths about the same as in staggers.

Charbon first makes its appearance by a small hard lump, somewhat resembling that eaused by the sting of a wasp. This lump grows and spreads very rapidly, and frequently chokes the animal to death in a few hours. The remedy generally used is to paint with iodine.

Cattle are affected with murrain, Spanish fever, and charbon, and occasionally a disease resembling dropsy in the human system. When attacked with the latter disease they generally drop dead without a struggle, and on tapping them, very often as much as a barrel of water will exude from the ineision. The fatality in murrain is aloont 95 per cent., and in dropsy all die.

Hogs are affected with cholera, quinsy, and mange. The symptoms of cholera are raried. In the most violent cases there are discharges from the bowels, bladder, and lungs. In other cases a loss of appetite is occasioned, and there is a disposition to bed up during the night; and during the hottest weather, if driven from their beds, they will shiver as though suffering with a hard ehill. The loss is about 75 per cent. of ali attacked. A great many remedies are used, but with littlo suecess. I valne soft soap 
more than anything else. Pinetar is a good remedy for quinsy. Mange or seab is very fatal to young pigs. It appears as ulcer's in the mouth, throat, and in the body. Carbolic acill, sulphur, aud turpentine are used with considerable success. The fatality in this clisease is about 50 per eent. of those attacked.

Sheep aro sometimes affected with rot, a disease somewhat resembling Spanish fever or dly raurrain in eattlo. The fatality is about 50 per eent.

Chickens are liable to cholera, and often drop dead from their roosts without warning. Others have copious discharges of filthy, green matter, their combs and gills become very pale, and after lingering a week or two die in a very emaciated condition. It frequently happens that some farmers will lose their entire flocks by this disease, while others living near by will notlose any. There seems to be no remedy, and abont all die that are attaclied by the disease.

\section{FLORIDA.}

\section{Mr. T. K. Collins, Mikesville, Columbia county, says :}

A disease commonly called "thumps" is perhaps the most fatal disease that affects hogs in this part of Horida-more fatal from the fact that no remedy has ever been found for it, at least to my knowledge. I have resided here seventeen years, and during that time have not known a single ease cured, notwithstanding 8 per cent. of our hogs die of it annually. The first symptoms of the disease are a cough, shortness of breath, thumping or bellows-like motion of the sides, with loss of appetite, and ultimately, like in cases of consumption in man, waste away and die a mere skeleton. The duration of the disease is from one to three months. I ean offer no remedy for this disease, or even suggest ils cause. Some old stock-raisers say that this disease is always worse after a heavy pine mast, which my own experience confirms.

Staggers is also a commou disease among hogs hero, but it is seldom fatal. Cutting the ears or scarifying the head generally gives relief, but cold applications or sunstroke treatment, when applicable, is considered better.

Cholera made its appearance among swine here this season, and cut our meat crop short. Most of those attacked died suddenly, many of them even before they were known to be siek. This disease is new to us, and as yet we have found no remedy for it. These are about the only diseases that attack swine in this locality.

\section{Mr. Chester S. Coe, Coe's Mills, Liberty county, says:}

With the exception of cholera among hogs we have but few other diseases among any elass of farm stock. As regards this disease we have never been satisfied as to its origin, as liogs take it at any time and under all eircumstances, those running at large in the range as well as those kejt in inclosed pastures. During many years' experience I have noticed that those which we term yard hogs-i.e., that are fed on dishwater and kitehen slops-soldom or never take the cholera, and that if those that take it in the range are eonfined in pens and fed on kitehen slops, with the arldition of a little copperas and sulphur, they generally get well. As for a preventive, we have never found a positive one, though 1 am of the opinion that if hogs are frequently fed on slops seasoned as above stated they will seldom take the cholera.

In an every-day experience of over sixty years in the use of horses and mules I have never lost but one, and that one I lost by blind staggers. Good care in feeding, watering, and driving, with an occasional haudful of salt mixed with a little lime or strong ashes, has always kept my stock in health and good order.

I have had no disease anong my fowls for thirty years. Wo keep a supply of nux vomica on hand, and twice or thrice a week mix it with their feed, giving from a fourth to a teaspoon level full, according to the number to be fed. This has kept them free from all disease; and more than that, if a hawk ever takes ono he will never come baek for another. There is no pereeptible difference caused in the taste of tho meat. The drug may bo used by bruising two or three buttons and steeping them in hot water. Tyen add a few spoonfuls in mixing up their feed.

\section{INDIANA.}

\section{Mr. D. C. Smith, Vincennes, Knox county, says:}

The diseaso known as hog-eholera is eaused by worms. There are two kinds of worms. One works upon the kidneys, iver, heart, and lungs, and is more dangerous when it is in the region of the heart. It looks like a kidney-worm, but is somewhat smaller. It penetriates to all parts of the body. I have found it between the leaf-lard and the intestines, and hetween the shonlder and the ribs. The other worm works upon the stomach and small intestines, and causes the diarrhea. When they are in the liver they cause a dry, hacking cough; when in the lungs the cough is more severe, and 
the hog mill bleed at the nose, and a bloody foam will run from its mouth. The fymptoms of the disease may be seen in the hair of the hog standing up straight, and the discoloration of the skin behind the ears, which sometimes turns yellow and at others assumes a bluish cast. The hog will walk very slowl 5 , and when it stops will drop its head and look as though it wero standing on its nose. Some will become lame in their fore legs. When the worm is in the stomach the hog will purge and rowit.

I have taken as high as ten worms out of the liver of one hog.

I have a remedy for these diseases, which I hare used with great success for ten years. Since using it I have never lost any hogs by cholera. The remedy is as follows: Mix two tablespoonfinls of spirits of turpentine in a half-barrel of slop, stir well, and feed three times a week overy other week. Give this amount to fifteen or tweinty head. While they are eating pour a tablespoonful of coal-oil across the back and shoulders of each hog. This will penetrate the skin and drive the worms inwardly, when the turpentime will kill and expel them.

The following are extracts from a letter from Mr. Lewis Bollman, of Bloomington, dated August 26, 1878:

I see that jou have appointed a commission to investigate the hog-cholera. I hope that it may result in some greater practical utility than prior commissious have effected. Allow me to add to this communication the little I know about it.

I have almays understood that the disease originated at Aurora, in this State, a town on the Ohio River, in Dearborn eounty. A large clistiliers is there, and rears ago it fed about 4,000 hogs on the distillery siops. This excessire crowding and unnatural feeding generated the disease, and from there it slowly but steadily spread over the West.

While a farmer here years ago, I raised from 50 to 75 hogs annually, and for three jears my neighbors lost many hogs with this disease. One year my adjoining neighbor lost about 70 head ; there being betreen our hogs the common rail-fence only. I never had a hog sick from the cholera, and I attribrite this exemption to my practice of salting ms hogs with a mixture of salt and pulverized brimstone and copperas. Of three parts, two salt; of the remaining part, two parts brimstone and one part copperas. I adopted this salting to destroy intestinal worms and lice. I strictly adhered to this practice twice a reek in summer and about erery ten dass in winter.

A farmer here told me the other clay that he lost hogs one rear only from the disease, but having adopted this feeding with sulphur and copperas he nerer since had anj of his hogs sick with it.

Whether this salting is really a preventive I cannot certainly say. I but state my experience. In its modes of infection the hog-cholera is much like the rinderpest when in Great Britain. If well animals crossed the track of diseased ones they caught the disease, as with cholera. If I remember rightly British anthorities were forced to confine their cattle to the farms of their owners and to prohibit the sales of unfattened cattle at fairs where such are generally purchased by those purposing to fatten.

So far as my observation extends I believe this moving of our hogs, and allowing them to run outside of their owner's inclosure, is the cause of the continued existence of the disease.

A farmer here recently rented an out-field to hog down, located about a mile from his bome. The first thing he knew was that that field emitted a stench from his dead hogs. About $\$ 300$ worth died in a few days, nearly all that he had. So I learn that many have died around this place in consequence of their running at large. The greatest fatality exists on our rirer bottoms where the hogs are collected by purchase and driven on the extensive corn-field to hog down the corn.

I suggest to your consideration a careful examination into the consequences of this mode of moring stock hogs in order to fatten them, and if found to be a common and fruitful source of the spread and continuation of the disease that the exclusion resorted to in Great Britain be enforced here. It is a quarantine regulation such as is now sought to be enforced in our Western cities to stav the spread of the yellow fever.

Beliering that he had made an error in attributing the cause of the disease in this herd to the fact of its remoral to another farm, Mr. Bollman writes as follows under date of September 2, 1878:

A few days ago I wrote jou a letter, chiefly on the topic of hog-cholera, mentioning a recent case of a farmer here who had lost about $\$ 300$ worth of hogs by that disease. I attributed the loss to moving the hogs to another farm. I saw him since writing, and learn that it is probable the hogs were liable to the disease before their removal. He has raised hogs very extensively, and heretofore has lost hearily from the cholera. His recent loss, I am now satisfied, was the result of overerowding his farm with hogsan error so certain to this result that I now again write that the attention of your commission may be directed to it. 
One of the greatest difficulties a farmer has to encounter arises from having a large number of certain kinds of stock, whieh cannot safely be crowded, no matter how complete may be his arrangements to grow them, or any one of them.

Hogs, sheep, fowls, the silk-wnrm, de., cannot be raised in large numbers together without soon exhibiting a liability to epidemical and other diseases. The diseased eondition of the sheep at the close of the war obliged farmers to sell their flocks at the lowest prices. All attempts to raise ehickens in large numbers, or the silk-worm, have failed from lirge losses by epidemieal diseases. And so with the human race. An army generates camp-fever, measles, and other diseases, no matter how strictly every sanitary regulation may be enforced.

As a farmer, I found it was eass to raise twclve or fifteen hogs, but difficult when the number was increased to fifty or eighty. I mentioned my exemption from hogcholera, as I suppose from the regular saltiug with copperas, but I am satisfied that as long as any farmer, from year to jear, grows many hogs together, the hog-cholera cannot bo eradicated. Few farmers understand this tendency to fatal diseases from too great numbers, and I hope the commission may gire it a thorougl examination.

\section{ILLTNOIS.}

\section{Dr. Joseph Sybertz, V.S., Bell rille, Saint Clair comty, Ill., contributes} the following paper on the disease commonly lnown as "hog-cholera":

We must regard this affection of pigs as a disease peculiar to this species of the family suida, having close aftinities with the scarlet ferer of man, ret essentially distinct. Few diseases are designated with a greater number of names than this one. For instance, it is called enteric ferer, tJphus, pig distemper, epizootic influenza of swine, measles, scarlatina, gastro-enteritis, anthrax, \&c. Some authorities adrocate the theory that the affection known as hog-cholera is in reality typhoid fever (abdom. inal typhus). Veterinary authorities agree that it is a form of anthrax or carbuncular ferer. But there is an essential difference between anthrax and typhoid fever.

In the first-mentioned disease, the presence of bacteria in the blood is invariable, these parasites, indeed, being considered the canse of the affection. In typhoid fever, bacteria have never been discorered, either in the blood of the patient or in the characteristic lesions of the disease, the determining symptoms in this affection being ulceration of the glands of Peyer, as shown in post-mortem examinations. Now, in all forms of anthrax this ulceration is never seen, although mycosis (fungus) of the intestines is frequently noticed.

The line of demarkation between these affections is, then, sufficiently broad ; but to which of them does hog-eholera belong?

Hog-cholera is a disease peculiar to pigs of this part of the country; the virus is not communicable to other domestic animals, so far as is ascertained up to this time by the veterinary surgeons of this conntry.

For the sake of brevity, I will, in dealing with the disease, call it by the conrentional or rather common name of hog-cholera.

Hog-cholera is a contagious, febrile, and exanthematous disease, and embraces scarlatina in degrees of virulence in all stages.

Course of the disease. - $a$, stage of incubation; $b$, stage of florescence; $c$, stage of desquamation (scaling off).

The contagion poisons the blood, and produces local inflammation and ulceration in rarious parts of the system, thongh more frequently in some portions than in others. The action of this contagion possesses the peculiarity that it affects chiefly the skin and the throat, and originates in both a diffuse inflammation.

Symptoms in general. - First stage: Fever with a full and frequent pulse; the pharynx presents an exanthematous flush, but there is no effusion; gencral debility; appetite smaller than in health; thirst increased; skin hot and diy; sometimes a profuso diarrhea, and in single subjects delirum or spasm. The urine remains of its natural color.

Second stage: More intense ferer; elevation of the temperature of the rectum to $35^{\circ}$ $40^{\circ}$ Lelsius; trcmulons motions of the cervical muscles; pharynx inflamed; deglutition lifficult; the aunygdal swollen; the mucous membrane presents a virid red appearance. There is occasionally vomiting or diarrhea, usually constipation. A dry, hard congh is one of the symptoms in early stages, and continnes to the last; quick and ribrating pulse, and occasionally epistaxis (the state of bleeding from the nose). Increased Leat and redness of the slin; tho eruption is not so generally clistributed as in the former affection; it disappears often suddenly, and returns after an uncertain period of time. By the effinsion of the red points, the disease passes on to the-

Third stage: The symptoms are of a graver type, even in the first accession. In fiatal cases the patient is, in fact, by an elevation of the temperature to $43^{\circ}$ Lelsius, stricken dead by the poison in a few hours, before auy eruption or local symptoms come on. The eruption does not present scarlet appearance, but is more of a livid 
bue, and frequently interspersed with petechir. In young animals convulsions and coma aro frequent concomitauts ; in grown, delirinm and deafness, sometimes great restlessuess, running round towards one side, until at length the patient breaks down and lies helpless and insensible, or in a muttering delirium, till at length deatl approaches silently, and lifo ends withont a struggle. The temperature is high until death approaches and bloody urine flows, when it very perceptibly diminishes.

The sequela of the disease are: Anasarca (effision of serum in the cellular substance); ophthalmia (inflammation of the membranes or ceats of the eyo or eyeball); otitis (inflammation of the ear); enteritis (inflammation of the intestines); and cynanche parotidia (inflammation of tho salivary glands), cansing diffienlty of breathing and swallowing; in grown hogs, affection of the sub-maxillary (mandibular) and inguinal gland, the last mentioned eansing the staggering gait in young animals.

A secondary stage frequently follows, mostly caused by catching cold or by a disturbed crisis; then metastasis (a sudden and complete remoral of the disease from one part to another) often occurs. This would seem to account for the fact that medical experts found so many different lesions by post-mortcm examinations.

The next cause of the clisease is an atmospherical contagion, which is always transferable. The infection is therefore donblo, atmospherical and individual.

Only constant lesion (and it is questionable whether it can be considered entirely characteristic) is the want of coagulability of the blood and the petechial eruption; all other lesions may be considered incidental; sometimes scarcely one organ of the body is found that is not the seat of some anatomical lesion.

If we consider the hog-cholera as an independent disease, and the malignant throat disease as a partial symptom of it, or the latter disease as an independent typhus disease, an infection of the blood, and the first as a partial symptom of it, has been up to this time, so far as $I$ know, not ascertained, and the process of this epidemic is still a mystery, as in other epidemics.

In single cases and in epidemics it has sometimes the character of a local affection (mailignant throat disease) ; in others, more the character of a general illness (infection); or it may be distinguished by this, that it occurs in all forms intermixed.

I have seen in different hygienic conditions swine affected with the disease, but, by perfect cleanliness, which necessitates the separation of the sound from diseased, and the free use of disinfectants, the poison, even generated or introduced, will be virtually starred out. In neglected hygienic conditions, I saw patients without care and treatment recovering, and on the contrary, the best rules and remedies designated for the prevention and most carcful treatment could not prevent them from dying. These are sporadical cases. If the epidemic has existed for a length of time, the disease will seem to become more mild, and a much larger proportion will recover, while the first cases that occur will be very serere and will nearly all prove fatal.

In my practico as a reterinary surgeon I havo tried neany recommended remedies, but without much success.

I have adopted the following rules: $\Lambda$ s a preventive, disinfection of the atmosphere and the surrounding objects, and disinfectants for the free use of the animal. Protect them from the hot-bed of manure and eloso sleeping-places, whero they are huddled together in great numbers; supply them with sufficient fresh straw for bedding in different places, as far as possible from each other. Supply them with fresh waterand a succulent diet.

When the disease exists the sick shonld be placed by themselves, and the healthy ores taken to a fresh and disinfected place. Very sick hogs, without any hopo of recorering, should be instantaneously taken from the herd, killed, the carcasses interred very deep, and with quick-lime anil sulphate of iron overstrewed, so that no noxious emanation takes placo.

For disinfection of fecal matters of stables, pens, or other places giving rise to noxions emanations, fill up a bucket with a strong milk of lime, add about one-half pornd of sulphate of iron beforo separately dissolved in water, and sprinkle it upon the places which sou intend to disinfect.

For disinfection of surrounding objects, as stable-walls, troughs, pen-rails, \&c., take a strong solution of chlorido of lime ( 1 pound to 12 pounds water), and whitewash the objects. This operation develops much chlorine, which destrojs the contagion and purifies tho surrounding air.

A specific remedy in general never will be found; disinfectant, diaphoretic, sedative, refrigerant, astringent, salino, cathartic, antiseptic, and antizymotic agents, ono or more of them, according to tho demand of each form and stage of the disease, aro bene-
ficial.

Of greater importance, and more useful than the medical treatment, is the provention of it. From the pecnliar construction of the larynx in logs it is sometimes not possible to give medicino in form of a drench without their vomiting a part of it, or dying from suffocation; beside, this is not practicable with a great nuinber of animals, and would hardly compensate for tho trouble and expense necessary to secure the life 
of diseased hogs. For this reason the best may is to select such remedies as the animals are apt to use willingly. The medicine should be given in a form snitable to their small appetite, and in a way that they may get an approximately full dose of it, according to their age.

\section{IOWA.}

\section{Mr. George T. Gibbs, College Springs, Page county, sass :}

As I have been broken up br the so-called hog-cholera, I have come to the conclusion to give you my theory in regard to the disease. I believo the wholo difficulty lies in the manner of breeding which has been practiced for the last fifteen or twenty rears. We hold to the maxim that like produces like, aud pay ligh prices for shorthorns to improve our cattle and large sums for fine bogs to improve our swine, and then give the lie to our theory by our practice. The practice by most loog-raisers, and especially by those that have been supplying the country with fime stock, has been to breed their sows at the age of from six to eight months, then fatten them and breed from the pigs at the same age. I claim that this has been kept up until the constitution of the hog has been rnined, and any little thing will bring on disease, which sometimes becomes epidemic and appears to be contagious. If you breed from animals whose borlies are immatnre and constitntions already- weakened, if like produces like, you are getting an animal weakened from infuncy. The old way of breeding was to allow stock hogs to make a little bone and mnscle as well as fat, to mature their bodies before allowing them to breed, and when yon once got a good breeder to keep her as long as she would bear pigs. In those days we never heard of hog-cholera, and wo could raise eight, ten, and twelve pigs from one sow. $I y$ father kept one sow for sereral years, which raised ten pigs every litter. He sold the pigs all over the county for breeders. They were not hazel-splitters eitber. I have belped to butcher some of this breed that dressed 250 ponnds at six to eight months old, and some that were kept until four years of age weighed 800 pounds. Now hog-raisers get two or three pigs from a sow, sometimes only one. A great many object to fine stock on this account; but we can raise cight or ten pigs at a litter from thoroughlored Poland-China, Berkshire, or Chester Whites, if wo treat them properly.

I expect to be laughed at by the wise and scientific, but $I$ lave watched this mat. ter closel 5 for the last five jears, and I am satisfied I have found the true solution of the difficulty.

\section{SOUTH CAROLNA.}

\section{Dr. C. J. Faust, Graham's, S. C., writes under recent date as follows:}

I see much written in regard to hog-cholera, as it is termed in the Northwest and in our own Southern country. So far as ms omn observation goes I am inclined to think that Dr. J. M. Johnson, of Loclisburg, Ark., is correct in regard to its symptoms, cause, treatment, and pathology. Last winter I lost ten or twelve head myself ont of a herd of twenty-four. Thes were all in fine order.

We also had an epidemic of staggers among horses and mules in onr neighborhood, which proved fatal to a great many animals. Tho disease generally lasts from six to forty-eight hours. An animad attacked with it rarely recorers. I lost seren head of horses myself last minter, which cost mo $\$ 1,200$, and many of my noighbors lost a greater or less number. The disease lnown as staggers, however, was not the cause of the deatl of all of them. The animal, when first attacked, seems to be stiff in his fore legs, is very dull in riding, and when touched with the whip springs off vers suddenly for the inoment; but this is soon orer. The nervons sensation seems to be rery aente, and when allowed to run on an hour or so the animal does not seem to have power to lift his fect high enough to keep him from hitting them against the smallest rise on the surface of the earth or any small object in his was. He soon commences to go around in a circle, sar $\$ 0$ or 100 feet in diameter, and when once broken off from this circlo ho will go over anything in his course, and will even plunge into a dwelling. He becomes dangerons to those around him, and will go on until ho is thrown down by running over some large object, when he soon dies in great agrony. Our treatment has been full blood-letting, eren to fainting, and copious drenching with a free purgative, composed of 300 grains of aloes, 150 grains jalap, and 80 grains of calomel, made into a bolus. This is placed upon a long paddle, two and one-half inches in width, and the paddle put down the hor'se's throat as far as it will go. The bolus rolls off without trouble aud the animal swallows it. It soon acts thoroughis on the howels. If this treatment shonld hare the desired effect the horse shonld not be allowed to eat anything for two days, and then only bran mashes and a little green food. This shonld be contimued for several days, when the horse will begin to slowly and gradually recover. 


\section{VIRGINIA.}

\section{Mr. Charles M. Keyser, Cedar Point, Page county, says:}

Haring had some experience with the disease commonly called hog-eholera, I will try and relate the result of my insestigations made reccntly. The disease was close to we and there rere some cases in my immediate ricinity. Aluont October 10th last I perned my hogs to fatten in their usual health, as I thought. Abont the 1st of December I found that they beran to refuse some of their food, so I butchered them, and, upon examination, I found their luugs and livers in a very bad condition. The Iungs were very much darkened and decared, and the pores or small tubes were filled with worms about the size of a hair; they raried from one to three inches in length, and seemed to completely choke the hor. In color ther resembler that of the kidneyworm, though thes were not so large. I had no microscone and conld not make a close examiuation. The lirer was full of boils, and seemed to be in a perfectly torpid condition. The bowels scemed to be in a healthr condition.

My former experience concerning the disease is that the lungs and liver are the points most affectec. The symptoms of the disease were manifested in a dull and drooping condition of the animal, conghing, and a hearing of the flanks-a beating and working like a bellows. In some iustances the anima!s wonld turn quite a complete somersault and fall over dead. In other cases they would die quite easy.

I do not think there is any cure for the disease after it gets a fair hold on the animal. It seems that hogs that run at large-roain through the woods and fields-are more liable to the disease than those that are kept in clean, comfortable pens and are well cared for. The use of tar in the troughs and wood-ashes (hickory preferable) spread on the ground where they are ferl, in a dry time or in a dry place, is a rery good prerentive, if not a cure, in some cases. They will eat some and inliale a little, which has a good effect on the animal.

\section{PLEURO-PNEUIIONIA OR LUNG FEVER OF CATTLE.}

The folloming letter, addressed by the Commissioner of Agriculture to Hon. A. S. Parddock, chairman of the Senate Committee on Agriculture, on the 14th day of February last, gives all the facts in regard to the prevalence of pleuro-pneumonia among cattle in this country, so far as they were then known to this department:

SrR: I have the honor to acknowledge the receipt of jour letter of recent date, asking for such information as may be in my possession relating to the subject of pleuro-pneumonia among eattle. The subject is one that is attracting great attention in this country at present; hence information is rapidly accumulating in this department, the more important portion of which I hererrith transmit for the information of your committee. I shall first gice a brief statement of the action of the department in the matter, and then submit such letters, telegrams, and other information of an important character bearing upon the subject as hare recently come into my possession.

In August, 187\%, within one month after my accession to the position of Commissioner of Agriculture, I instituted a preliminary examination of diseases of domesticated animals. For years I have been cognizant of the loss of immense numbers of swine and other farm animals by disease, supposed to be of an infectious and contagious character; and, with the rery limited means at my disposal, I opened a correspondence with leading farmers and stock-grotrers in almost every county in the United States for the purpose of eliciting definite information in regard to these maladies, and the probable annual losses occasioned thereby. The result of this correspondence was the accumulation of a rast amount of important information on the subject under consideration, which, by request of the Senate, was communicated to that body on the 27 th day 
of February, 1878, and was afterward published as Senate Ex. Doc. No. 35.

In order that a thorough examination might be made into some of the more destructire diseases affecting farm animals, and such remeciial and sanitary measures instituted as would prevent the spread of such maladies as were well known to be both infections and contagious, an appropriation of $\$ 30,000$ was asked, and the sum of $\$ 10,000$ was granted. In iny letter of transmissal to the Senate in February, 1878, the following language is used:

Our wide extent of country and its great diversity of temperaturo and rariation of climate, the severity of frosts in some sections, and the intensity of heat in other localites, render farm stock liable to the attacks and ravages of almost every disease known in the history of domestic animals. So general and fatal have many of these maladies grown that stock breeding and rearing has, to some extent, become a precarious calling instead of the profitable business of tomer years. This would seem especially true as it relates to swine. Year by rear new diseases, heretofore unknown in our country, make their appearance among this class of farm animals, while older ones become permanently localized and much more fatal in their results. Farmers, as a rule, aro neglectful of their stock, and pay but little attention to sporadic cases of sickness amoug their flocks and herds. It is only when diseases become general, and consequently of an epidemic and contagions character, that active measures are taken for the relief of the attlicted animals. It is then generally too late, as remedies hare ceased to have their usual beneficial effects, and the disease is only stajed when it has no more victims to prey upon.

This interest is too great to be longer neglected by the general gorernment. Not only the health of its citizens, but one of the greatest sources of our wealth, demands that it should furnish the means for a most searching and thorough inrestigation into the causes of all diseases affecting live stock.

At the time this communication was made it was not known that the destructive disease known as eontagious or malignant pleuro-pneumonia among cattle was prevalent to any considerable extent in any section of the country. There may have been, and no doubt were, isolated cases of the disease, but they were not sufficient in number to attract attention or cause alarm. During the past summer and fall my attention was called to the prevalence of the diseaso in several localities widely separated from each other. Among other letters addressed to me on the subject, I cite the following.

\section{J. Elwood Hancock, of Burlington County, New Jersey, writes:}

The prevailing disease among cattle in this county is pleuro-pneumonia. The disease is very fatal, and the losses among this class of animals from this malady have been very heavy.

Mr. J. E. Hancock, of Columbus, Burlington County, New Jerses, states that the disease has been prevalent in that county for some years. He says:

I have had some experienco with pleuro-pneumonia among cattle, baring lost onethird of my herd from its ravages in 1861, when I succeeded in cradicating the disease after a duration of about six months. I had a second visitation of the malady in wy herd in the early part of 1866, when I lost 6 head from a herd of 23 . Of the inimals affected I am satisfied that not more than one-third will recover.

N. W. Pierson, Alexandria, Va., writes as follows, under tate of October 12, 1878:

The principal disease among cattle in this locality is pleuro-pneumonia. The disease started from Georgetown, D. C., two jears ago, and has gradually spread dowu the Potomac for a distance of abont 25 miles, extending back from the river not more than 2 miles.

B. A. Murrill, Campbell County, Virginia, writes, about the same date:

An unknown disease has prevailed this fall among cattle in the immediate ricinity of Lynchburg, but has not spread elsewhere. [This disease was pronounced pleuropneumonia by competent authority.] 
R. L. Ragland, Halifax County, Virginia, writes that the cattle in that county are affected with a contagious distemper which is supposed to be pleuro-pneumonia.

C. Gingrich, Reistertown, Baltimore County, Mraryland, says :

Lung fever (pleuro-pnepumouia) has prerailed among eattle in tho ricinity of Baltimoro for tho past twelve or fifteen sears, and the losses from the same havo been quito heary.

A report from William S. Vansant, reterinary surgeon, contained in the report of the New Jersey State board of a griculture for 1876 , shows that nineteen different herds of cattle suffered from this disease in Burlington Connty of that State during the year above named. It would seem that while the disease has been almost constantly present in New Jersey for many years past, no organized effort on the part of the State has been made for its suppression and extirpation.

With no means at my command for the suppression of the malady, in November last I cansed an examination to be made of some of the aflicted cattle in the vicinity of Alexandria, Va. The inrestigation was conducted by Dr. Alban S. Payne, of Fauquer County, Virginia, who, as will be seen by his report below, pronounced the disease a contagions type of pleuro-pneumonia. The results of his inrestigation are thus given in the following brief extract from his report:

I visited Mr. Roberts's mill, one mile south of the eity of Alexandria, Va., with as littlo delay, under existing cireumstances, as possible. I found DIr. Roberts, in connection with his other business operations, carrying on a dairy. On his farm were sixty-two milch cows, and of these forty have had pleuro-pneumonia. Twenty-two have not as yet taken the disease. I also found almost in the heart of Alexandria City two cows sicls with the disease. One of these cows belonged to Mr. Townsend Baggott and the other to Colonel Suttle. I also examined about the suburbs of Washington City some sick cows. All the cases I saw were, without doubt, eases of pleuropneumonia of the non-malignant variety.

Knowing the insidious and destructire character of this disease, and that it was liable to assume a contagious form and cause the destruction of millions of dollars' worth of property, and interrupt and perhaps destroy one of our greatest commercial interests and sources of income, I called the attention of Congress to the existence of this fatal malady in my preliminary report, bearing date of November last, and asked the immediate interrention of the government by the enactment of measures for its suppression and extirpation. The following is a brief extract from this report:

One of the most dreaded eontagions diseases known among cattle is that of pleuropneumonia, or lung ferer. It was brought to this country as early as the jear 1843, and has since prerailed to a greater or less extent in several of tho Eastern and a few of the Southern States. It made its appearance about a century ago in Central Europe, and has since spread to most European countries. With the exception of rinderpest, it is the most dreaded and destruetivo disease known amoug cattle. Unliko Texas cattle fover, which is controlled in our northern latitudes by the appearance of frost, this disease "knows no limitation by winter or summer, cold or heat, rain or drought, high or low latitudle." It is the most insidious of all plagnes, for tho poison may be retained in the system for a period of ono or two months, and even for a longer period, in a latent form, and the iufected animal in the mean time may be transported from ono end of the continent to the other in apparent good health, yet all the while carrying and scattering the seeds of this dreaded pestilence.

Since the appearanee of this affeetion on our shores it has prevailed at different times in the States of Massachusetts, Couneeticut, New York, New Jerser, Maryland, Delaware, Virginia, aud in the District of Columbia. It has recently shown itself at two points in Virginia (Alexandria and Lynchburgr), where it was recently prevailing in a virulent form.

At present the disease seems to be circumseribed by narrow limits, and could be extirpated with but little cost in comparison witl the sum that would be required should tho plague be communicated to the countless herds west of the Alleghany Mountains, 
This disease is of such a destructive nature as to have called forth for its immediate extirpation the assistance of every European government in which it has appeared, many of them having found it necessary toexpend millions of dollars in its suppression. Tho interests involved in this case are of so vast a character and of such overshadowing importance, both to the farming and commercial interests of the countrs, as to require the active intervention of the Federal Government for their protection, and for this reason the considerato attention of Congress is resjectfully asked to this important matter.

Prof. F. S. Billings, V. S., temporarily residing in Germany, writes under recent date as follows:

\section{BerLLx, January 16, 1879,}

14 Louisen Street.

MYY DEAR SIR: I intended in my last to have mentioned some ideas for your consideration upon the so-called contagious pleuro-pneumonia of cattlo in the United States. I have given the subject a loug-continued consideration, and it seems to mo the viows which now appear conformable to our case will find their approval with you. The disease is one which is rather a new thing to us, and while we find cases coning to pass in many sections, still we cannot say it has acquired any devastating extension. I truly believe that by using what means we have at command, and by fixing two or at the most threo points by which eattle can be imported from Canada, and by furthermore exacting that such cattle be accompanied by attested health certificates of eompetent men, and furthermore that all such cattle, oxcept when destined for immediate slaughter, be compelled to undergo twenty days of quarantino at point of entry when unaccompanied by such ccrtificates, like rules applied to sea-ports-if we can make and enforce such regulations, then in one jear at the most $\pi \theta$ can stamp the disease ont of the United States and keep it out. For us the inoculation should be absolutely forbidden and severely punished. It is only of value in localities where the disease has become almost domesticated, and where of the two evils the lesser must be chosen, and that is, as is being attempted in Saxony, to inoculate every animal, and produce as soon as possible the artificial disease; all newly-introduced animals to be by law at once inoculated.

This renders the losses less severe to such a community, probably not over 25 to 30 per cent., if as mnch: statistics as yet aro mureliablo. But it is self-evident this is also the way by which the disease is reniered a constaney-it becomes domiciled, a thing we do not desire. Hence I recommend to your consileration the absolute killing of every infected and exposed animal, or, perhaps, utter quarantining-isolation of tho latter under rigid inspection. Tho slanglitered animals to be paid for at full market price, real, not fancy, by the respective State governments, or, better, by the general government; for, if we are to have a general law, then the general government must take care of it. I earnestly recommend your bringing this to the attention of Congress, and you yourself must sce the recommendition is logical and true to the country's interest. 'The first cost might be a little startling, but the final results equally fortunate. The rinderpest was at last reports limited and decreasing.

Your obedient servant,

To Hon. Wr. G. LE Dec,

F. S. BILLINGS.

Commissioner of Agricnlture, Washington, D. C.

Professor Gadsden, of Philadelphia, who recently made an examination of infected and diseased cattle on Long Island, writes as follows:

\section{Nortir Texti Street,} Philadelphia, January 29, $18 \% 9$.

Sir: I consider it my duty to report to you that the contagions clisease known as "plenro-pnenmonia" exists to a fright ful cxtent among the cow's near T3rooklm, Long Island. On the return of Professor McEachran, the eattle-inspector of Canaia, from Washington, he asked me to accompany him to New Yurk State, and find out for our selves if the report was truo that a contagions thisease existed. Wo found it too true, as at a flistillery at Williamsburg we foumd a large lyre, or cow-louse, containing about eight hundred cows, with rery many of them in tho last stages of "contagious pleuro-pnemmonia." Others hal this disease in a milder form. The place was very dirty, the cows very much erowded, eciling low, and everything favorable for the rapid spread of this disease.

Tho cows belong to a number of milkmen, who keep them thero very cheap on hot swill (from the distillery) anc hay, nhich increases the milk very mon. This place is a regular pest-house for tho disease. We were informed, on good anthority, that just before the cows die they are killed and dressed, then sent into the New York market as beef, where we are told that they bring a good price becalise they are tender and not too fat. Others are sold, when the milk dries up, to farmers on Long Island. 
This disease is very prevalent within a fer miles of Brooklyn, and has been for some time. Cannot you, sir, try and stamp it out? as I am afraid if it spreads from there the English Government will not receive any cattle from our ports, as they have a law ready to put in force as soon as they are satisfied this or any contagions disense exists in eattle. I have made innuiry from several veterinary surgeons in this state; they all answer there aro no contagious diseases in cattle in their district. I have no reason to beliere there is any in Pennsylvania or in the Western States; so I do hope this disease on Long Island will not interfere with the sending of live cattle from Philadelphia to Eugland, as I lnow they are making great preparations for this spring's trade.

Respectfully, \&c.,

Hon. War. G. Le Duc,

J. W. GADSDEN, V. S.

Commissioner of Agriculture.

On the morning of the 30th of Jannary, 1879, the following telegrams appeared in the metropolitan journals :

Toronto, Ontario, January 30.

Intelligence of the slaughtering of cattle lately shipped to Liverpool on a steamship creates an anxious feeling among dealers here. On or about the 14th instant the steamship Ontario sailed from Portland for Englaud with a cargo of cattle, the shippers being Messrs. T. Crawford \& Co., of this city. The cattle numbered 265 head, and were, according to Mr. Craw ford's statement, in sound condition, having been examined by competent men at both Montreal and Portland. The Ontario reached Liverpool on Sunday last, and on the following day Messrs. Crawford \& Co. received a cable dispatch from their agent there that the cattle had been detained for inspection by order of the British Government. This inspection was evidently attended with unsatisfactory results, for on Tuesday the agent cabled that the cattlo had been condemned on account of disease and were to be slaughtered. The disease was said to be pleuro-pneumonia. The Toronto Exportation Company and Messrs. Crawford \& Co., the two firms that do the largest shipping business in their line in the city, were instructed by their agents to ship, no more. 'The first named have a cargo of $1 \% 0$ head on the steamship State of Alabara, which it is anticipated will arrive at Liverpool on Friday noxt. What will become of these remains to be seen. The general feeling is that it is not at all likely that a trade which was rapidly becoming a necessity for England will be allowed to suffer interruption for any great length of time without a good cause for the embargo being adduced.

OTTAWA, ONTakio, Jamuary 30.

ted the importation of cattle from the United States, the eabinet met last evening to consider the situation. The result of the meeting was the adoption of a resolution that steps would be taken to prerent any injury being done to Canada.

\section{Montreal, Quebec, Jainary 30.}

Considerable anxiety exists in regard to the order from the imperial government prohibiting the importation of Canadian eattle into England. It is said if the order is continued cattle will be slauglitered here and the meat will be taken across in refrigerators.

The following letter from the president of the American Veterinary College will explain itself:

\section{American Veterinary Coleege,} New York, February 1, 1879.

SIR: In returning from Washington, where he had the honor of seeing you, Professor McEachran, of Canada, asked me if pleuro-pnenmonia was to be found in New York State. I took him to Long Islaud, and there had the opportunity to show him a barn where a large number of cows (some 600) are kept, and where we found ourselves in the difficult task, not to detect diseased animals, but to discorer healthy cows. Post mortcms confirmed our diagnosis, so that no doubt cau bo had of its correctness.

The milk and the carcasses of these diseased subjects find their way to our market in New York City. Our boarls of health have no veterinarian to detect the disease and enforce the laws! Our market meat-inspectors are deficient in detecting diseased from healthy meat! Our cattle are exposed to the spreading of that fearful disease! Our exportation is now impeded to such extent that to-day $I$ am told animals exported to France even must hare a clean bill of health, and England is threatening closing her ports to our stock!

May I respectfully be allowed to call your attention to this stato of affairs, and to 
place myself at your orders for whatever professional assistance I may be able to give your department in orercoming this great danger to our European cattle trade and to our own livo stock.

I am, sir, your obedient servant,

Hon. W. G. LE DUC,

A. LIAUTARD.

Commissioner of Agriculture.

On the 4th instant I receired the following telegram from Mr. J. B. Sherman, superintendent of the Chicago Union Stock-Iards:

Uxion Stock-Yands, Chicago, Ill., February 4, 1879.

The Commissioner of Agriculture:

The most important blow struck at the interest of this city, State, and Northwest is the report in circulation in reference to the prevalence of cattle disease in the West, aEd these reports are absolutely false. I hare sent a telegram to the Secretary of State, on whom I wish you would at once call.

This business of the export of liro cattle to England has dereloped immense proportions in the last year, and wo must not, cannot, remain quiet and seo it destrojed. It is worth millions to the country, and affects directly every farmer in the Northwest, while the whole country feels the effect of this large increase in its exports. The action of the British and Canadian Govermments is based on a misconception of the facts, and wo need such final inrestigation as will put tho matter at rest.

\section{To which the annexed reply was at once forwarded:}

J. B. SHERILAN, :Superintendent.

\section{Departunext of Agriculture,}

Trashington, D. C., February 4, 1879.

J. B. SHERMLAN, Superintendent Union Stock-Yards, Chicago, Ill.:

The disease to which your telegram refers appeared in this conntry as early as 1843 , and there is no more reason for the present action of the British Government in this matter than has existed for years past. Pleuro-pnenmonia has never troubled the cattle-breeders of the West, from whence alone cattle for exportation are derived, but the existence of the disease on our eastern coast at all is a constant threat to the cattleraising country beyond the Alleghany Mountains, for the extermination of which I have asked authority of Congress. I hope and expect that action will be taken that will speedily remove all excuse for the objectionable orders of the British Gorernment.

WM. G. LE DUC,

Commissioner of Agrieulture.

On the recommendation of gentlemen largely interested in the licestock trade, I at once made the following appointment of an examiner for the port of New York:

Departanent of Agriculture,

Washington, D. C., February 5, 1879.

SIR: Yon are hereby appointed an exammer, and directed to make as thorough inquiry and examination as the owners and shippers of stock will permit into the condition of the live stock sent, or abont to be sent, from your port, and certify daily to this department the health of each particnlar slipment, so far as possible, examining particularly as to pleuro-pneumonia in cattle, and notiug the presence or absence of this disease in each case. You are authorized to give a copy of jour certiticate for the department to the shippers, if desired.

\section{Dr. Johy J. Craver,}

WM. G. LE DUC,

Commissioner of Agrienlture.

I also formarded a like appointment by telegraph to H. J. Detmers, $V$.S., Chicago, Ill., and receired prompt replies from both accepting the positions tendered.

These examiners were also directed to furnish a certificate of health to such shippers of live stock as might desire it, a copy of which is herewith appended: 
INSPECTION OF CATTLE FROM THE PORT OF - , AUTIORIZED BY THE UNITED STATES GOVERNIENT, AND UNDER TIIE IMIEDIATE DIRECTION OF THE COMMISSIONER OF AGRICULTURE.

This is to certify that I have this day inspected — beef eattle, owned by Messrs. port of Liverpool, England, and found tho animals sound.

Dated February -, 1879.

(Signed)

Inspétor.

These letters were promptly followed by the following, addressed to the Secretary of the Treasury, informing him of the action taken by this department:

\section{Departalex of Agriculture, Washington, February 5, 1879.}

Sin: I have the honor to inclose for your information a copy of a letter this day addressed to Dr. John J. Craven, of Jersey City, N. J. I have also telegraphed to Dr. Detmers, of Chicago, substantially the same instructions as are noted in Dr. Craven's lotter.

So far as the limited funds at the command of the department will permit, the proposed examinations will be continued, with the view of furnishing shippers information relative to the health of the stock, and thus prevent the shipment of auy that are diseased; and tho eertificate of the veterinary surgeon of this department making the examination will be in the nature of a "bill of health," and should go far towards allaying any apprehensions, real or fancied, which may be entertained by persons who receive the stock.

This department is ready to second any efforts made by the Treasury Department to quiet the unnecessary excitement now apparent in Europe and in our own country on this subject.

Respectfully, your obedient servant,

WM. G. LE DUC, Commissioner.

Hon. Johy SHerman, Secretary of the Treasury.

\section{To which the following reply has been received:}

\section{Treasury DepartMent, OFFICE OF THE SECRETARY, Washington, D. C., February 7, 1879.}

SIR: I am in receipt of your letter of the 5th instant, inelosing a copy of one addressed by you to Dr. John J. Craven, of Jersey City, N. J., authorizing him to make inquiries into the condition of live stoek about to be sent from that port to foreign countries, and to certify daily to your department the health of each particular shipment as far as possible.

I inclose herewith for your information twelve copies of a circular issued by this department, under dato of the lst instant, requiring as a condition preecdent to the shipment of live cattle abroad an examination thereof by tho customs-officers with referenee to their freedom from disease, and the issuance of a certiticato by the collector that they aro free from such disease, if the facts shall be found to warrant it.

Doubtless Dr. Craven, and any other person appointed by your department for the purpose named, conld give valuable aid to the colleetors of the ports from which such shipments are made, and this department would be pleased if you would instruet the experts selected by you to afford aid to the customs-officers in this respect as far as possible.

You will see that the cireular requires that the officers of the customs shall also furnish this department from time to time such information upon the snbject as they may be able to procure, and I would be pleased if you will also forward such information as you recoive it.

This department has furnished the State Department with copies of the circulars before mentioned, and the Secretary of State has doubtless furnished them to the proper representative of the British Government.

This department perceives the importance of protecting its export trado in live animals as far as possible, and will do all in its power to attain the desired object.

Very respectfully, 


\section{The following is a copy of the circular inclosed by the Secretary of the Treasury: \\ [Circular.]}

INFORMATION IN REGARD TO CATTLE DISEASE.

Treasury Departuent, Washington, D. C., February 1, $18 \% 9$.

To collectors of eustoms and others:

By department's circular of December 18, 1878, it was directed that live caltie shipped from the rarious ports of the United States might bo examined with reference to tho question whether they were freo from contagious diseases, and that, it' found to be free irom such diseases, a certificate to that effect shonld be giren.

By that circular such inspection was not made compulsory, but the certificate was to bo issued only upon the application of parties interesterl.

As the export trade in live cattle from the United States is of vital importance to large interests, every precaution should be taken to guard against the shipment of diseased animals abroad, and such a guaranteo given as will satisfy foreign countries, especially Great Britain, that no risk will ensno from such shipments of communicating contagions or infectious diseases to the animals in foreigu countrics by shipments from the United States.

Collectors of customs are, therefore, instructed that in no case will live animals be permitted to be shipped from their respectire ports nutil atter an inspection of the animals with reforence to their freclom fiom disease, and the issuance of a certificate showing that they are free from the class of diseases mentioned.

Notice of rejected cattle should be promptly given to this departinent.

In order that this department may be fully iuformed in regard to such discases in any part of the United States, collectors of customs are requested to promptly forward to this department any information which they may be ablo to obtain of the presence of contagious or infectious cliseases prevailing among live animals in their vicinity.

It is probable that if the disease prevails to any considerable extent it will be noticed in the local press, and collectors are requested to send copics of any such notices to this department for its information.

JOHN SHERMAN, Secretary.

The following letter has been receired from Prof. James Law, who, it will bo seen, has been orclered to the port of New York by the governor of that State:

Astor House, New Fork, February 8, 1879.

DEAR SIR: I came down here last night in accordance with instructions from the governor of New York to ascertain and report as to tho existence of the lung fever in cattle. From what I have secn to-day I have no doubt of its existence in Kiugs and Queens Counties, but I hope very soen to be able to report on the post-mortem lesions as well as the ante-mortem symptoms.

I hear that the malady exists in Watertown, Conn., perhaps at Ratonah, Westchester County, New York, and around Newark, N. J. The two first places I expect to visit in the interest of New York, and I shall find out what I can about the vicinity of the shipping yards for the stock exported to Great Britain. Would it be well for me to visit Newark also before returning?

I strongly commend the position you have taken in this matter, as the only just and tenable one. If we should ever sulter from a temporary suspension of the foreign trade in cattle, it will be well expenderl if it shonld lead to a thorongh extinction of the lung plague in the United States.

Yours, very truly,

Hon. WM. G. LE DUC, Cormissioner of Agriculture:

JAMES LAW.

The following late telegrams, showing the action of the British Gov. ernment, are appended:

THE AMERICAN CATTLE TRADE-NO FURTRER INTERFERENCE EXPECTED.

Loxdox, February 8 .

A committee of the Cattle Trade $\Lambda$ sseciation at Liverpool, in order to avoid interruption to the trade, have offered to erect the necessary lairage and abattoirs to coinply with the requirements of the Priry Council. It is believed, howerer, that, in consequenco of the growing importance of the trade to Liverpool, either the authori- 
ties or the corporation or the dock board rill undertake the work. AIl arrivals of eattlo from Anerica sinco the steamer Ontario's cargo have becn folind entirely free from disease. 'The severity of tho weather, therefore, it is beliered eauscd the outbreak in that iustanco. The British Govemment is, mder the circumstances, not inclined to interfere with the importation of cattlo from America, provided there is adequate inspection before shipment and provision of the requirel lairage at Liverpool to put them in position to meet such cases as the Ontario's. It is not beliered that slauglutei on tho quays mill be enforced where no disease exists. Persons in the trade say that under these conditions $\Lambda$ merican shippers need not fear any interference with the business.

Loxiox, February 9.

In regard to the importation of cattle from America, no action of ihe Privy Couneil bas been made known since the notice read in the Liverpool tom council on February 5, that cattlo cannot bo landed at the Liverpool docks after March 1, unless provision is made for slaughter on tho quay.

\section{THE CATTLE EXPORT TIADE-IFFECT OF THE BRITISH ORDER IN COUXCIL.}

Liverpool, Fcbruary 11.

The order of the Privy Conncil adopted yesterday roroling after March 3, 1879, article 13 of the toreigi animals order so far as it relates to the United States was a great surprise to the trade here. All cattle from the United States after March 3 will haro to be slaughtered in abattoirs now being prepared on the dock estates of Birkenhead and Liverpool within ten days after landing.

I also forward you articles on the subject of pleuro-pneumonia, clipped from the National Live Stock Jommal of March, 1875, and Norember, 1878 , from the pen of Dr. James Law. They were inclosed to me and my attention directed to them by Mr. J. H. Sanders, the able editor of that Journal.

[From the National Live Stock Journal of Iarch, 1878.]

THE GREATEST DATGER TO OUR STOCK-THE LUYG FETER-CONTAGIOUS PLEUROPXEUMONLA.

The Jourual has frequently called attention to the great dangers that beset our live stock from importel plagues of foreign origin. During the past year the sndden in. vasion of Western Europe and England by tho rinderpest roused the agricultural community from their drean of safety, and called forth from the Treasury an order remarkable alike for its promptitude aud good intentions, and for the fatal blunders which rendered it worse than a dead letter. Once more there seems a prospect of a renewal of these apprehensions, the Russo-Turkish war having led to an extension of this cattle plaguo into Hungary, from which the Atlantic coast and Great Britain may be any day infected, oming to the activity of the stock trade. Should this unfortunately take place, it will find us no better prepared than wo wero a year ago, and our Treasury order, now in force, will freel invite the discase to enter, provided it makes its adrent respectably-in tlie systems of blooded stoch; and not in poor cross-bred animals, which it would be ruinous to import, eren if sound. A similar welcome is extended, by implication, to all those rmminants which aro leroted nore particularly to luxurr, and hare not been degradel to such rulgar utilitarian objects as the production of meat or wool. Yet all ruminants are sulject to rinderpest, and this malads was carried to France, in 1866, by two gazelles, as other plagues havo often been earried to new countries br tho privilereil blooded stock.

But we started out to $10^{\text {tice }}$ a darger which is no longer separated from us by the broad barrier of the Atlantic, and rroose malign presence is not to bo dismissed by any ono of ten thousand contingencies, as is the caso with the pessible adrent of the rinderpest. This danger stancts in ony miclst, anch is stendily gaining in force as it encroaches further and further, showine low certain it is, if unchecked, to lay tho whole country under contribution, and inflict nost disastrons and permanent losses. The lung fever of cattle, imported into Brookly1s, L. I., for the first time, in 1843, in a. Duteh cow, has never since been at any time cutirely absent from our soil. From this center it has slowly and irregularly extended orer a portion of New York, New Jersey, Pennstrlrania, Maryland, Dclawarc, and Virginia, besichs havine repeatedly invaded Connecticut. The slowness of its extension has bergotten af filse sensc of security, and no real apprehensious of scrior.s consequences remain from an arimal poison which has been for orer a thirl of a century liddlen awas iu the near vicinity of the Atlantic const.

To clisturi this comfortable and restful condition of the public mind is an unpleasant 
task, which nothing but the imperative sense of duty would eompel us to undertake. But this diseaso has a histors, which wo can only ignore at our peril; and as its records can now be drawn from all quarters of the globe, we can havo before ns an unequivocal testimony as to what will inevitably happen under given eonditions of elimate, surroundings, and treatment.

England imported the lung fever of eattle in 1842 , just one year before we did, was soon very generally infeeted, and has continued so to the present time. Up to 1869 , it is estimated that England had lost, almost exelusively from this disease, $5,549,780$ head of cattle, worth $£ 83,616,854$ (say $\$ 400,000,000$ ). For the sueeeeding nino jears, up to 1878, the losses have been, in the main, as extensire, so that wo may set them down as now reaching at least $\$ 500,000,000$ in deaths alone, withont counting all the contimgent expenses, of deteriorated health, loss of markets, progeny, crops, manure, \&c., disinfeetion, quarantine, \&c. With us no attempts have been mado to estimate tho losses, but they cannot exceod an inconsiderablo fraetion of those above named; and thus we have slept on in a pleasant dream of immunity.

It is even alleged that the disease has, in a great measuro, been shorn of its virulent power, by being tramsplanted to tho shores of the Now World, and that wo may comfort ourselves with this, and continue to ignore its presence. If, on the other hand, it can be shown that the difference is in $n 0$ material respect affected by climate, bint altogether determined by the surroundings, it will bo well for us to attend to the facts of the ease, and face the real danger. Tho lung fever, which had really entered England, by a special importation, some time before the free trade act of 1842 , was, by virtue of this act, thrown upon her in constantly aecumulating accessions. The ports at which the continental cattle were landed, and the markets in which they wero sold -London (Smithfield Market), Sonthampton, Dover, Harwich, Hull, Noweastle, Edinburgh, \&c.-insured the mingling of the imported stock, week by reek, with the native store cattle. Then, if they failed to find a profitablo salo, they were sent by cars to other and inland markets, where they were again and again brought into contact with numerons herds of store eattle, by which the germs of tho disease were taken in, and carried all over the eountry.

With us, on the other hand, the disease was long confined to the dairies of Brooklyn and Now York, where the cows were kept until they died, or were fattened for the buteher. A fow doubtless found their way to the country, and by these the disease was carried to different farms, which were thus constituted centers of contagion from which the adjaeent country beeame infected. But any sueh movement from the city dairies was necessarily of the most restrieted kind, and it never took placo to any great distance. It would hare been folly to move a eommon milch cow, worth $\$ 40$ to $\$ 70$, to the West, where she could be bought for ono-half or one-third of that sun. The same deterrent condition existed in the caso of the farms on whieh the discased city cows had been brought. Sales were no doubt occasionally made from iufected herds, to secure the apparent value of au animal which the owner had good reason to believe to be doomed, aud as sueh animals wonld, for obvious reasons, bo scut as far from home as possible, this beeame a prineipal means of the formation of more distant centers of contagion and the wider diffusion of the malady. But with us the diseaso has hitherto had to fight against tho heaviest obstacles- tho current of cattle traffic having been almost without exception from the eheaply-raised herds of the West to the profitable markets of the East. The exeeptions have only been in tho case of thoroughbred stoek, and hitherto our Western stock has escaped contamination by this means.

The wonder is not so much that tho plague has failed to reach the West, but that in the face of such tremendous obstacles it has succeeded in invading all of the six or seven States that are now infeeted. In Great Britain, where some would hare us believe that the disease is more virulent, we can point to a moro satisfactory record. There the great body of the country has been infected for thirty-fivo sears, but tho greater part of tho highlands, exelnsively deroted to the raising of eattlo and shecp, has cnjoyed tho most perfect immunity. Hero, under nearly all possiblo predisposing causes of lung disease-altitude, exposure, cold, chilling rains, and fogs, the piereing blasts of the Atlantie and German Oeeans-this contagious lung disease has never penetrated, though severely ravaging the lowlauds immediately adjacent. The explanation is, that these hills support none but the native black cattle, and other breeds are nover introduced. In spite of the alleged virulence of tho diseaso in England, it has proved powerless to enter this magie circlo from which all but the native stock is oxcluded. The same holds true concerning some parts of Normandy, Brittany, the Chaunel Islands, Spain, Portugal, Norway, Sweden, \&c.

The fact that the disease has maintained a foothold among ns for thirty-four rears, and in spito of all obstaeles has made a slow but constant exteusion, is sufficient ground for tho grarest apprehensions. A disease-poison which shows such an obstinate vitality aad such persistent aggressiveness eamnot bo allowed to exist amoug us without the certainty of futme losses whieh will eelipso those of Great Britain by as mueh as our herds of eattlo exceed those of that nation. A recent outbreak in Clinton, N. J., caused by a cow brought from Ohio, suggests tho possibility of the disease 
having alreadr reached the latter State; an occurrence which was inevitable soonos or later, but the actual existence of which raust enormously increase our dangers. With every such step westward there is the introduction of more diseased and infected cattlo into the natural current of the traffic, and the earlier probability of the general iufection of all parts to tho east of such ultimate centers of disease. 'There is, further, the infection of more cattlo cars, which, carricd West, may be the means of securing a rapid extension of the plague to our most distant States and Territories.

\section{FELATIVE DANGERS OF THE POISONS OF LUNG FEVER AND OTHER PLAGUES.}

The persistent vitality of the lung-fever poison, in comparison with that of any other animal plagues, is noteworthy. It lias held a tenacious grasp on the United States for over a third of a century, though forbidden by circumstances to make a wide extension. Aphthous fever (foot and mouth aiscaso), on the other hand, though twice imported into Canada within the last ten jears, and on one occasion midely spread in New York and New England, was on each occasion easily and early extinguished, and with little or no effort on the part of the States. It might indeed almost he said to have dicd out of itself. Even the dreaded rinderpest has its poison early destroyed by free exposure to the air, in thin layers, at the ordinary summer temperature. Numerous experiments on hides hung up and freely exposed in warm weather have shown that tho infecting power is lost as soon as they aro quite dried. But the poison of lung fever maintains its virulence for months in the dry state in buildings, and we havo known parks, with sheds, that proved regularly infecting year after year to all cattle turned into them. In other eases we have known the virus carried for miles on the clothes of attendants, and thus introduced inte new herds.

A far greater danger lies in the lengthened period during which the poison of lung fever remains dormant in the system. This averages about three weeks or a month, but may extend, in exceptional cases, to not less than two months. An ox or a cow which has been exposed to the contagion may, therefore, be carried from one extremity of the continent to the other, may be exposed in a succession of markets, and may change hands an indefinite number of times, and be all the while in the best apparent health, though infallibly approaching the manifestation of the disease, and for the latter portion of the time spreading the germs of the malady to others. There is here an opportunity for the unscrupulous to sell off exposed and infected animals without the purchaser having tho least suspicion of foul play. There is also the strong probability of animals that have contracted the disease by accident, in cars or otherwise, in passiug to a new home, mingling with the herd of the new owner and infecting them extensively before there is a suspicion that anything is amiss. This long period of incubation after the animal is infected, and the equally long period of latency of the malady in animals he has infected, one or two of which only will be attacked at intervals of a month, lull suspicion as to the presence of contagion, and it is too often only after great damage has been done that the truth dawns on the mind.

In aphthous fever and rinderpest, on the other hand, the disease shows itself in from one to four days after infection, and the surrounding animals are so rapidly attacked after the coming of the infected stranger, that there is no room for hesitancy as to the existence of contagion. Nor can the victims of these diseases be carried far from the point where they have been infected and disposed of as sound animals; so that in the very vigor and promptitude of their action we have an excellent basis for their restriction and control.

\section{DANGER OF INFECTION IN OUR UNFENCED STOCK RANGES.}

It is needful to note the above-named insidious progress and stealthy invasions of the lung fever, and to contrast them with the more prompt and open manifestations of the other animal plagues, in order to show the great peril to which we aro suljjected by the presence in onr midst of a pestilence which literally walketh in darkness. Let us now consider the prospective infection of our great stock ranges. That this is inevitable, though slow, at the present rate of progress of the plague, has been sufficiently shomn. That it might occur any day by an animal infected in an Eastern farm or stock-yard, or in a railroad car in which it was sent for the improvement of the Western herds, must be abundantly evident to every one who has read this article. If we now add the fact that more than one thoroughbred Ayrshire and Jersey herd has been infected with this disease during the past year, we are at once confronted with a strong probability of an early Western infection. Let us remember that thoroughbreds alone are carried West for improvement of native herds, and that a bull of the Ayrshire, Sersey, Holstein, or short-horn breed, taken from a herd now or recently infected, may be carried to any of our Western Territories and mingle for a month with the native herds before his own infection is so much as suspected, and we can conceive how imminent is the danger when the infection has reached our Eastern thoroughbred cattle.

To illustrate the result of the infection of our unfenced stock ranges, I mast quote 
another page from the history of this disease in other countrics. The instance of Anstralia is the most recent as well as the most striking. Tho lung fever was iutroduced into Melboume in 1858, by a short-lıoru English cow, which died soon after landing. IIaving been confined to an inclosed placo, there is every reason to beliove that with her the disease would have ended, had not a teamster turned his yoko of oren into the infected park under cover of the night. Theso oxen working on the strcets infected others, tho disease soon spread to tho open country, and the mortality increased at an alarming rate. Vigorous measures for its suppression were adopted, thonsands of infected aud diseased cattle were slanglitered, but all proved of no avail. Not only were the free, roaming herds infected, but so many places were contaninated that it was soon perceived that help from this sourco was not to be expectel. Destroy a whole infected herd, and ron still left the infection in the station from which, in its unfenced state, other herds eould not bo exclucted, and where they wero ecrtain to take in the germs of the malady. After enormons losses had been sustained by the combiuch operations of the pest and tho polc-ax, it was concluded that the remedy was worse than the disease, and the colonists reluctantly fell back on tho expedient of inoculation. This is based on the fact that the diseaso is rarelr contracted a second time by the eame animal, and it cau be practiced on all calres with losses at the rate of from two to five jer cent. only, so that the mortality is insignifieant as compared with the thirty to fifty per cent. which perish where the afiection is contracted in the ordinary way. The great objection to inoculation is, that it can ouly be practiced at the expense of a universal cliffusion of the poisou, and of its maintenanco in a state of constant activity and growth. With such a universal diffusion of the rirus, the stock owners are virtually debarred from introducing auy now stock for improving the native breels, or infusing new vigor or stamina, inasmuch as such new arrivals would almost certainly fall carly victims to the plague. Australia, therefore, now suffers from the permanent incubus of the lung plague, and can only import high-class cattlo at great risk.

This is an occurrence of resterday, but it is only a repetition of the immemorial experience of the steppes of Russia. There we fud the same conditions of great herds roaming free over immense minclosed tracts, and all the facilities for an easy and wide dithnsion of animal poisons. There, accordingly, wo find the home, in all ages, of tho animal plagnes of tho Old Work. To theso endless steppes Europe and European colonists owe their frequent invasions of lung fever, rinderpest, aphthous fever, and sheep-pox. To these are to be charged the losses, to be estimated only by many thousauds of millions, which hare repeatedly fallen on the other civilized countries of the world. From these steppes the disease has spread orer the continent on the oceasion of erery great European war, dating from the expulsion of the Goths from Hungary by Attila and his Hums, in A. D. 376, down to tho present Turkish war, which has secured the exteusion of the riulerpest to Hungary at least. On theso steppes, too, the Russian veteriuarians believe the rinderpest, at least, to be an imported disease derirer? from Eastem and Ceutral Asia, yet all their efforts to crush ont this or the lung fever, though receiriug the freest support from the Russiau Government, have failed. The same conditions exist, to a large extent, at the Cape of Good Hope; and there, too, the lung fever, imported in 1854, has aequired a permanent residenee.

\section{PREVENTIVE MEASURES DFMANDED.}

Such is the history. Now comes the question pregnant with weal or woo to our future stoek, agricultural, and natioual interests: Shall wo learn from tho disastrous experience of others and extirpate tho lung plagno from the United States whilo it is still possible, or shall wo sit quietly by with folled hauds and await tho inevitable, early or late, infection of onr open Western stock ranges, aud then repeat, for the benefit of other nations, the already twice-told tale of a despernte and extravagant but frnitless attempt to suppress a plaguo which wo have criminally allowed to pass bejond our control? With or without a prodisal but rain efiort to cmsh out the poison, tho results may bo thus summed np: Tho infection of stock-yards, loadingbanks, cars, and markets, and a general diffusion of the plingne over the Eastrm States. This would imply a national loss, by cattlo disease, liko that of Englanel, but mueh more extensive in ratio with onr great numbers of stoek. Thins Englanel, with her $6,000,000$ hearl of cattle, has lost in cleaths alone from limg forer in the course of forty years over $\$ 500,000,000$. Wo, therefore, with our $\$ 8,000,000$, should loso not less thau $\$ 2,000,000,000$ in tho samo length of time, allowing still a wirie margin for the lower average value per liead in America. And this terrible drain is for deathy slone, without counting all the expeuses of deteriornted health in tho snrvivors, of juolnee lost, of loss of progeny, of loss of fodder no longer safe to feed to cattie, of climinished harvests for lack of enltivation and mamure, of quarantiue amd separate attenclants whenever now stock is brought on a fariu, of clennsing and disinfection of sleets and buildings, \&e., which becone absolutely essential in the ciremmstances.

We do not inelude the expense of supervising the trade, examining and quarantiu. 
Ing the stock at the fronticr of every State, and of the disinfection of cars, loadingbailks, stocli-yaris, and markets. If such were resorted to, after an cxtensire infection of our Western herks by lung ferer, the cattle trade wonld be virtnally stopped. Thus a safo nuarantine for store cattle could not be less than threo weclis, and a registration and supervision for five weeks more on the farms to which they are taken, would be absolutely essential. Thins the quarantine yards and sheds would be continual centers of infection, and would require to bo rerr extensive, thoronghly isolated from each other, and constantly and perfectly disiufeeted, the air as well as the solids, to prevent the infectiou of nerly-arrired stock. Such an incubns wion the trade would amount to a virtual prohibition. In rinderpest, sheep-pox, and aphthous ferer, quarantine is a comparativel simple and arailable expedient, as the disease shors itself within a weck; but, in lung terer, with the germs lying unsuspeeted in tho sjstem for one or two months, a piotectivo quarantine is practically impossible wherever an active cattle trade is carried on. Hence in the countries of Central and Western Europe, throngh which the actire traffic from the East is earriel on, a complete control is usually maintained orer rinclerpest and sheep-pox, while the peoples hare resigned themselves to the prevalenco of lung ferer as an unaroidable infliction. The same holds in Great Britain. Twice within eleren years has she crushed out inrasions of rinderpest, and repeatedly has the same thing been aceomplished for sheep-pox; but the lung ferer is accepted as a pecessary evil, between which and her large importations of continental cattle sho must mako a deliberato choice.

Happily, in theso United States we are as yet under no sneh compulsion. The lung ferer on American soil is still confined to the Eastern States and to inclosed farms, from which it is quite possible to eradicate it thoroughly. Of this possibility we have abundant eridence, alike in the old World and the New. In several countries of Western Europe, through which there is no continuous cattle trafic between nations on opposite sides, this disease has been killed out and permanently exclnded by an intelligent reterinary sanitary supervision. Sweden imported the disease in Ayrshire stock in 1847, but at once circumscribed the infected herls and places, slanghtered the diseased, disinfected all with which they bar come in contact, and promptly extinguished the outbreak. Denmark, invaded the same jear from a similar source, and on several subsequent occasions from Holland and England, as often quenched the poison by analogous measures. Oldenburg, Schleswig, and Torway, successively inraded by the importation of infected Ayrshires, in 1858, 1859, and 1860, respectively, enjoyed a similar happy riddance, through the application of the same system of suppression. Switzerland, long slandered as the native home of the lung plagne, has at last a roke to the truth of the statement of the immortal Haller, made more than a century ago, that this discase onl $\mathrm{p}$ occurs "when an animal has been brought from an infected district"; and, by the judicious nse of suppressive measures, has permanently rid the country of the pestilence, and demonstrated that their Alpine air is as clear and wholesomo for beast as for man.

In America, Massachusetts and Connecticut have furnished examples equall 5 striking. 'The former imported the disease in Dutch cattle in May, 1859. In April, 1860, when it had gained nearly a year's headway, an act was passed, and a commission appointed, with full power to oxtirpate it. $\Lambda$ fler tho slanghter of 932 cattle, it was believed that this had been achiered; but new centers of infection were discovered in the two sncceerling jears, and it was not until 1865 that the commonwealth was purged of the poison. Since that year the lnng fover has been nnknown in Massachnsetts. Connecticut has had a similar experience. Her proximity to Now York City and Long Island has brought npon her a series of invasions; bnt, profiting by the expericnee of her neighbor, sho has, on each occasion, grappled successfully with the enems, and dricen him from her midst.

What has been dono by the Scandinavian nations, by Oldenbnrg and Switzerland, by Massachusetts aad Connecticut, can bo clono by all of our Eastern States. On this point the teaching of history is as unequivocal as on the certainty of the irreparable results if our open Western stock ranges were infected. The ono indispensable prerequisite to sucess is tho vigorous and simnltaneons action of the rarions infected States, and its persistent maintenanco nntil the last infected beast has disappeared and tho last contaminated place or thing has been purified. It matters little whether coutrolled by State or national government, if rigor and unifuraity of action can be secured; but, as such combined and untlagging work is necessary, it coild be best controlled by an intelligent central authority. The United Stateg foremment is as mueh called upion to defend her possessions against an enemy like this-so implacable, so relentless, and so certain, if not repelled, to lay us under an incubns which will increaso with the coming centuries, and dwarf tho prosperity to which we are eutitledas against the less insidious one who attacks us openly with fire and sword. Let the national Congress consider this matter well. Let every stock-owner press it upon his Representative as a matter that cannot be safely ignored even for a singlo day. Let boards of agriculture, farmers' clubs and conventions, granges, ard all citizens who value the future well-being of the nation, unite in a strong representation on the sub- 
iect. The danger threatens all classes alike, though the first sufierers will be the stockowners; for every tax upon production necessarily enhances the value of the product; and, as agricultural progress must be seriously retarded, the tax will not fall upon meat alone, but upon every product of the farm. Nothing can excuse a continued neglect of this sulject, the dangers surrounding which increase from day to day, and the final results of which, if once it reaches onr Westem and Southern States and Territolvin. can only be computed by the prospective increase of our population and our herds of cattle. For this is not like an evil preying on our currency, banking, trade, or manufactures, the full extent of which may be, in a great measure, seen from tho beginning, and the repair of which may be at any time inaugurated by legislative enactment. T'le animal plague only increases its devastations as we increase the numbers of our herds, and threatens soon to acquire an extension to which no legislation can oppose a check, and a prevalence in the face of which the most desperate efforts of the nation will prove of no avail. 'Thus our cattle are increasing at the rate of $13,500,000$ erery ten years, so that by the end of this century they may be exactly doubled, with a prospective loss, if our Western and Sonthern ranges are infected, of $\$ 130,000,000$ yearly in deaths alone.

The choice is now in our power. So far as we know, our stock-raising States and Territories are still unaffected. We can still successfully meet and expel tho invader; next year it may be too late.

[From the National Live Stock Journal of November, 1878.]

\section{OUR GOVERNMENT AND THE ENGLISH CONTAGIOUS DISEASES ACT.}

By an Associated Press dispatch from Washington we learn that "The Secretary of State has been officially notified of the passage of an act by the British Parliament entitled 'The Contagious Diseases (Animal) $\Lambda \mathrm{ct}, 1878$ '' under which, except in the case of countries specially exempted by the Privy Council, in whole or in part, from the operations of the act, all animals landed from abroad in any part of the United Kingdom will, after the 1st of January next, bo slaughtered at the port of debarkation. The British Government has also notified Secretary Evarts that, in case the United States desire to be exempted from the operations of the act, the lords will require a statement of the laws which regnlate the importation of animals into this country, and the method adopted to prevent the spreading of any contagious disease when it exists in any part of the United States. Secretary Evarts has sent a copy of the act of the British Parliament to the Secretary of the Treasury, in order that he may furnish the desired information prelimiuary to any action being taken to have the animals shipped from the United States into the Unitod Kingdom exempted."

We think it will puzzle the Secretary of the Treasury to find any methods that have been adopted by our general government "to prevent the spreading of any contagious disease when it exists in any part of the United States"; and if ho will take the trouble to investigate the matter pretty thoroughly, he will find that all the regulations that have from time to timo been ordered by his department to prevent the introduction of contagious and infections diseases into the United States from foroign countries are practically worthless. When this fact comes to be reported to the British Government, it is not unlikely that the exemption which the United States now enjoys from the operation of the act will be revoked, notwithstanding our present comparative freedom from any diseases likely to be transmitted by exportation to England. When this condition of things is brought about, and tho business of exporting fat cattle, sheep, and swine from this country to lingland-which has, within the past few years, grown to such enormous proportions and exercised so powerful an influence upon prices in this country-comes to a sudden halt, we shall expect such a pressure to be brought to bear upon Congiess as will compel the passage of some such act as that introduced into the House Iast May by Hon. J. S. Jones, of Ohio, to which reference was made in these columus in June last.

But is it wise in us to await unfavorable action on the part of the British Government before taking such steps as will preclude all probability of this country being included in the prohibition? Clearly, the interest is too large, and the efrect of adverse action on the part of the Government of Great Britain upon our farming community would be too disastrous, to justify us in taking any chances in the matter. The regulations now provided by law against the importation of plagues and infections diseases from abroad are confessedly worthless; and as for the stamping out of such discases when they do make their appearance, we have absolutely no law that is general in its operation. A few of the States liave attempted it on their own account, but most of them have no laws at all upon the snbject, and nono can be effectual withont the sanction of onr general goverument; for Congress alone las the power to regulate commeree with foroign nations and between the several States.

It is imperative that early and efficient action be taken by our Congress upon this matter, if wo would not have our present luerative trade in fat cattlo and sheep with 
England seriously crippled. Members of Congress are now at home among the people, and such a pressure ought to be brought to bear upon them as will compel them to act npon this question as soon as they reassemble at Washington.

In addition to the foregoing, I inclose you copies of the laws passed by the legislatures of Massachusetts and New York for the suppression and extirpation of the disease during its prevalence in those States, and the rules adopted and enforced by the British Goremment for the extirpation of this and other contagious diseases among farm animals in its Indian possessions. *

All of which is respectfully submitted.

Hon. A. S. PADDOCK, Chairman Senate Committee on Agriculture, Washington, D. C.

Since the publication of the above letter (Senate Mis. Doc. No. 71, Forty-fifth Congress, third session), many additional facts in relation to the prevalence of this disease, and the measures taken to suppress, and, if possible, eradicate it in the various localities in which it has been found to exist, have come into the possession of the department. To the information contained in the following letter from the pen of Dr. James Law, which appeared in the New York Tribune of February 25, is due in part the active measures instituted by the authorities of that State for the suppression of this destructire malady:

\section{A REVIEW OF THE DISEASE.}

To the Editor of THe Tribune:

SIR: The excitement about the cattle disease has had its proverbial course of nine days, and there are already signs of reaction. From every side we begin to hear state. ments that the danger has been exaggerated, that the disease only exists in three or four herds, that it is seen only sporadically-not epidemically; that the English livestock trade must be speedily re-established; and that, in short, the whole thing has been a gigantic mistake. Should this spirit prevail so as to prevent a uniform and concerted action by the different infected States to crush out this baneful exotic, it will rob the country of her best, and perhaps her only chance, of securing and main. taining the European live-stock market.

If the object of this laisser faire argument is to soothe the minds of our European cousins, and persuade them that this disease is less dangerous than that of Europe, they may as well save their labor. Europe has learned by centuries of sad experience the true nature of the contagious pleuro-pneumonia of cattle. Europeans now realize that wherever there is one animal suffering from this disease, there is a standing menace to the whole cattle of the country. They know that where they allow the disease to exist at all it decimates their herds yearly. They know that wherever they have boldly grappled with the enemy, crushed out every remnant of the malady and its virus, and jealously guarded their frontiers against its further importation, they have permanently cleared their folls of a disastrous pestilence. They see that wherever the disease has appeared in Western Europe, or in the western or southern hemispheres, it has only been where a diseased animal or its virulent products have carried the seeds into such a land. 'They know that so long as they allow the free importation of cattle from an infected country, all their efforts to crush it out of their home stock will be absolutely futile.

Turning to England, which has been the main agent in drawing public attention to the matter, she was absolutely ignorant of this disease until forty years ago, and in Youatt's and other veterinary works published prior to this date we find the most unsatisfactory accounts of this and other plagues known only on the continent. But from 1839 , when it was first, in the present century, bronght to the British Isles, and above all since 1842, which brought the free-trade act and the free importation of continental stock, Great Britain has suffered more from this than from all other animal plagues put together. It was estimated that in the first quarter of a century after its introduction this plague cost England $\$ 450,000,000$ in deaths alone. The additional losses from deterioration and lack of livo stock, and from the infection of forage, \&c., which

\footnotetext{
* For these acts and the rules allnded to in this paragraph, see appendix.
} 
could no longer be put to their most profitablo nses, lave never been computed, but must enormonsly swoll thie smin total.

England liad a hard lesson to learn, and she has been forty rears in learning it, but we way depend npon it slie has now learned it most thoroughly, and can no more forget it nor treat it with indifference while tho present generation survives. Many years agro I was engaged, with other veterinarians who had acquainted thomselves with the continental experience and literature, in enforeing on Great 13ritain the truth that to deal with this disease economically they must kill out the poison within their own borders, and exclude all stock from iufected countries. Then, as now, wro found many alleging that the clisease was native to tho soil, and occurred sporadically, not opiclemically. Then, as now, we found men bearing the name of reterinarians, who had fallen so far behind the age as to support these allegations, being either eriminally ignorant, or so morally oblique that they preferred the wrong because the popular side. So long as it can be shown that this diseaso nerer invades a new country, but as imported in the animal body or in some of its products, so long will all claims for its .spontaneous generation, its sporadic appearance, or its development from certain local conditions, like swill-feeding, be put out of court.

TIIE DISEASE PROPAGATED BY CONTAGION.

The history of the malady in all time, and in all countries and lemispheres, east, West, north, and south, testifies with one voice that out of the steppes of Eastern Europe and $A$ sia it is propagated by contagion alone. The unreasoning and misleading talk about "no epidemie" is, therefore, iu the highest degree reprehensible. The affection is not an epidemic in the sense of being due to some gonerally diffused influence, which acts alike upon all the stock of the country, and strikes them down indiscriminately, and without regard to proximity or contact. Were this the caso, our efforts to permanently oxtirpate it were vain. But its sprearl is almays and only proportionate to the facilities for contagion and infection. And the present comparative immunity of America is only dine to the fact that tho plague reached here at that seaport torward which the greater part of the cattle traffic of the conntry tends, and from which fow animals are removed inlaud. Given in the United States tho same free movement of cattle from our infected points to all points inland as was till recently seen iu Great Britain, and there would speedily follow the same general infection of the country. This is sufficiently illustrated in our past American experienco. Nassachusotts imported the disease from Europe, and although it was met by repressivo measures as soon as recognized, it cost the commonwealth two years and 570,000 to extirpate it. It was imported into Brooklyn, and though it had to fight its way amainst the uniform current of cattlo traffic eastward and northward, it has extended to Now Jersey, Pennsylvania, Maryland, Virginia, and the District of Columbia.

My recent observations in this neighborhood are in perfect harnony with the above. The stables at Blissville, holding 800 to 900 cattle, fatting and milling, the property of different owners, who could purchase when they choso in the surounding infocted locality, conld not fail to beoome a prominent hot-bed of the diseaso. IIad such stables, with all their drawbacks of overerowding, filth, and swill-feed, been thoroughly disinfected, filled with healthy Western stock and sedulonsly seclnded from all neighboring cattle and visitors, they would not bavo become infected with contagious plenro-pueumonia. Again, at Fifteenth street, Brooklyn, I found that all, or nearly all, the dairies in the vicinity had recently suffered from the disease, and that this infectod center was within two blocks of Prospect Park, where the herd of Jerseys liad been subjocted to its ravagos in August and Soptember. At Now Lots, Kings County, where I found seven iufectod herds in a very limited area, tho testimony of tho owners was to the effoct that the cliseaso only appeared and spread throngh their herds as thoy bought new cows from jobbers. At Roslyn, Qneeus County, I found tro infected herds; tho first contaminated by two eows bought fiom a Now York jobler, and the second by two cows bought from the first. In Now York City I found ous infected heri, cansed by a cow purchased from the samo jobber whose cows took the rlisease to Roslyn. 'The Comneetiout herd which I examined at Morrisania was infeeted by two cows purelinsed from a Now York jobbor, and the same man, according to his own sworn testimony, was proceeding to resell members of the same infected herd into other dairies when his career was cut short by tho action of the motropolitan board of liealth. Nor wore the results in such cases but the infection of one or two in a herd; where tho diseased cow was introduced a general infection was the usmal consequence. All that I could learn about the progress of the disease in this and former years was to tho samo effect. Tho malady never appeared apart from the introduction of strange animals, and when introduced the general infection of the herd was the consequence.

RAPID SPREAD OF TIIE PLAGUE.

The disease is not widely prevalent, because it extends its ravages only by contagion and infection, and the conditions of the American cattle trade have been strougly op- 
posed to this. But the disease has not only held its own for thirty-six jears, but lias slorly gained against every obstacle until it numbers its victims in six different States. It is not wantiug in virulence, but will, when it has a fair opportunits. sweep with remorseless force orer the entire land. To this it is dail tending. From Brooklyn it has laborionsly crept onward as far as Maryland and Virginia, and unless extirpated it will continue its baleful course nntil, reacluing our open pasturages of the West and South, it will poison the sources of our eattle trade, descend upon our Eastern States with every cattle-train, infect the rolling stock on all our great railroad trunks, and bid defiance to all control. Wherever it has met with similar conditions it has proved thus intractable. In the steppes of Eastern Europe it has held peremial sway despite the best directed efiorts of the Russian Goremment, and on the open pastures of Australia it still prevails, notwitlistanding the most persistent and almost ruinous efforts for its extermiuation. So will it prove should we neglect the present opportnuity and allow it to spread until it reaches our unfenced ranges of Texas, Kansas, Colorado, Wroming, \&e.

We are adrised to employ inoculation. But what is inoculation? If successful, the production of the diseaso artificially, with its prominent lesions, in a less rital organ. In erery stablo where cattle are snecessfully inoculated the poison is produced in unlimited quantity. It is diffused through the air. It lodges in the clrs parts of the building, in the fodder, ete., and is preserved for months and years. Unless these buildings are subsequently disinfected, they are deadly to the first susceptible animal that enters them. Finally, the immunity obtained br inoculation is not permanent, but lasts at the most for about two rears. Inoculation, therefore, is a ruinous recourse, unless a country is already generally infected. It is itself a prolifie means of spreading the poison. It cannot be effectual, unless the whole bovine race of the country are operated on and all the calves as soon as dropped; and so long as it is practiced, the stables must be considered infected, and the stock coming from such infected centers must be Leld to be dangerous to the animals. No conntry in Europo has practiced inoculation to so great an extent as Holland, and no country in Europe is to-day more extensively ravaged by this disease. England has tried inoculation to a very large extent, and England has been reluctantly compelled to abandon it. Australia has fallen back upon it as a dernier resort, and she has found that it only lessens the losses, whilo it has failed to exterminate tho disease.

\section{TIIE INTECTION MUST BE STAMPED OUT.}

The day may come when we, too, may wisely follow Australia in adopting a general inoculation as a palliatice of the disease. But this can only be if we criminally neglect the plague until it reaches our Western stock-ranges and bids defiance to all efforts at its extinetion. To follow such a course at the present time wonld be ruinous, indeed, and those who counsel it eannot understand the problem we have to deal with. As already remarked, Eugland, engaged in extirpating the diseaso from her own herds, will nerer offer us an umrestricted trade in cattle so long as we harbor this insidious enem5. A maintenanee of infection br continued inoculation of our herds assuredly means the indefinite suspension of our foreign live-cattle trade; and nothing will secure the resumption of this trade short of the cutire extermination of the malady.

Certificates of soundness of the cattlo shipped are not worth the paper they are written on. No one wonld knowingly export sick animals to Europe, and no one is capable of detecting the existence of this disease during its lengthened period of incubation. Wo need not shut our ejes to this fact, for assuredly the Euglish, who hare had a far longer and harder experience of the disease, will not. Those who, knowing the character of the inalads, counsel any measures short of its speedy and absolute extinction, are the true enemies of the live-stock interests and of the country. If their words sholld prevail, the future generations of Americans, seeing their country more ravaged than oren the States of Europe, and by plagues exotic to her soil, will look back with regret to the time when it had been possible for their fathers to have arerted sueh a baleful legacy.

It is still possible for ns as a nation to do what has been done by Norrav, Srreden, Denmark, Holstein, Oldenburg, Sritzerland, Massachusetts, and Conuecticut, and what is now being attempted in England, to stamp out this plagne, which as an exotic should nerer have gained a footing on onr shores. If the governors and legislatures of the States now infected and if Congress do their duty, they will follow the lead of Gorernor Robinson, of New York, and spare no effort nor expense until this plague has been banished to tho old World, whence it camo. And if every citizen will do his duty lie will canso such power to be exerted ou theso State and national authorities as will forbid any further neglect of this matter. No one having a full acquaintance with the subject can afford to rcmain silent in face of the existing facts, and this feeling alono has impelled me to pen the above remarks. New York mas act alone, but, if so, she must either establish a long quarantino at her border or sho will soon arain import the disease from New Jersey. New Jersey may act iudependently, 
but she must be left in constant danger of infection from Pennsylrania and Maryland. So with the other States. The onl $r$ path of safety is to wage a war of extermination simultaneously in all the infected States; and should tho Stato legislatures and Congress fail to meet the need, they will prove recreant to their trust, and entail a great evil upon this contineut.

Yours, \&e.,

IтнAсA, N. Y., Fcbruary 21, 1879.

JAJIES LAT.

In pursuance of the provisions of an act passed by the legislature of New York in the year 1878 , entitled "An act in relation to infectious and contagious diseases of animals," on the 12 th day of February last Gorernor Robinson appointed General Marsena R. Patrick his assistant, and directed him to take actire measures for the suppression and extirpation of the disease in Kings and Queens Counties of that State. The follow. ing instructions were issued to General Patrick by the governor:

It has been made known to me that the infectious and contagious disease among neat cattle, called pleuro-pnenmonia, has been brought into and exists in rarious places in the counties of Kings aud Queens of this State. You are therefore directed, as such assistant, to prohibit the morement of cattle within said counties, except on license from yourself after skilled examination under your direetion. You are also directed to compel all omners of cattle, their agents, employes, or serrants, and all reterinary surgeons, to report forthwith to sou all cases of disease by them suspected to be contagious. When such notification is receired, sou aro direeted to have the cases examined, and to cause all such animals as are found to be infected with the said disease destroyed and buried with slashed hides. Yon are directed, further, to quarantine all cattle which have been exposed to the infeetion of said disease, or are loeated in an infected place; bnt you mas, in your diseretion, permit such auimals to be slaughtered on the premises and the carcasses to be disposed of as meat if, upon examination, they shall be found fit for such use. You will forbid and prerent all persons not employed in the care of the cattle there kept from entering any infected premises. You will likewise prevent all animals and fowls from entering such premises. You will prevent all persons so employed in the care of animals from going into stables, or yards, or premises where eattlo are kept, other than those in whieh they are employed. You will cause the clothing of all persous engaged in the care, slaughter, or rendering of diseased or exposed cattle, or iu any employment richich brings them in contact with sneh diseased animals, to be disinfected before they leave the premises where sueh animals are. You will prerent the manure, forage, and litter upon infeeted premises from being removed therefrom; and rou will eause such disposition to be made thereof as will, in your judgment, best prercut the spread of infection. You will cause all buildings, rards, and premises iu which said disease exists, or has existed, to be thoroughly disinfected.

You are further directed, whenever the slaughter of diseased or infeeted animals is found necessary, to certify the ralne of the animal or animals so slanghtered at the time of slaughter, taking accomut of their condition and circumstances, and to cleliver to their owner or owners, when requested, a duplieate of snch certificate. Whenerer any owner of sneh cattle, or his agent or servant, has willfully or linowingly withheld, or allowed to be withheld, notiee of the existence of disease upon his premises or among his cattle, you will not make sueh certificate. You aro further directed to take such measures as you decm neeessary to disinfect all cars, or rehicles, or movable artieles by which contagion is liable to be transmitted. You are also to take such measures as will secure a registry of eattle introduced into any premises in which disease has existed, and to keep such eattle under supervision for the period of three months after the removal of the last diseased animal and the subsequent disinfectiou of such premises. You are further authorized and empowered to ineur sueh expenses in carrying out the provisions of the foregoing order as mas, in rour judgment, be necessary, and to see to it that the bills for snch expenses be trausmitted to this department only throngh yourself, after sou haro examined and approred them, in writing.

By the gorernor.

L. ROBINSON.

General Patrick at once established his headquarters at the Brooklyn board of health, and called to his assistance Professor Law and many other eminent reterinarians. Actire measures were immediately instituted for a suppression of the disease, which will no doubt be continued with the same energy until it is extirpated. 
Further legislation having been found necessary for the speedy and complete eradication of this malady, an additional act was promptly passed by the legislature of New York, on the 15th day of April. (For provisions of this act, see appendix.)

During the latter part of February last, and shortly after the com. mencement of this inrestigation of the condition of the dairy stock in the vicinity of Brooklyn, Dr. Law was summoned before the Senate Committee on Agriculture, which was then engaged in taking testimony in regard to the prevalence of pleuro-pneumonia among cattle in this country. At the request of this committee he submitted the following written statement:

\section{PLEURO-PNEUMONIA IN NEW YORK AND ELSEWHERE.}

\section{Statenent of DR. James Law.}

\section{INFECTION AND INEECTED PLACES AROUND NEW YORK.}

Up to the time of my learing Now York we had found in that neighborhood thirtcen centers of the contagious pleuro-pneumonia, embracing over twenty separate herds, and more than one thousand animals. At one place alone (Blissville), we are now killing the sick at the rate of twenty head and upward per day. We are further doing all we can to encourage the slaughter under our own supervision of the animals that are in such infeeted stables, but which do not jet show signs of illness. These are being disposed of at the rate of from thirty to seventy per diem.

Healthy animals slaughtered in this way are sold as human food and their hides disinfected. All infeeted places are placarded as such, and plaeed in quarantine, within whieh neither man, beast, nor bird is allowed to enter or pass out, save the necessary attendants, who are disinfeeted and forbidden to go near other cattle.

In the infected counties no movement of cattle is allowed save under special permit giren after examination. All aro compelled, under penalty, to report to General Patrick the existence of cases of contagious disease as well as all suspicious cases. Finall5, all sick cattle killed to stay the progress of the malady are paid for by the State, according to appraisement, which shall in no case exceed one-half the origimal value of the animal. This point I consider all essential to encourage the owuers of sick stock to report them, and at the same time to aroid the risk of artificial or careless infection of unmarketable animals for the purpose of selling them to the State.

The minor details of our action I need not record.

\section{CATTLE KEPT AT THE BLISSVILLE SWTLL-STABLES.}

It having been testified before the committee that the cows in the stables of Gaff, Fleischmann \& Co. were there for dlairy purposes only, I think it requisite to correct the statement. The stables were filled not only with cows, but also steers and bulls. The stock bolonged to many different parties, but mostly to dealers and butehers who hired their board. The orners of the stock had on their part, as a rule, no interest in the milk, which went to third parties as payment for the care-taking of the animals. The healthy cattle fattened rapidly and were sold for beef, and as there was a constant change of stock the contagion had an ample field among the newly-come and suseeptible animals, and had a chance of extension to other places and herds with every beast remored, fat or otherwise.

I have had testimony that the fat stock frequently went out of Long Island, but have no personal knowledge of this. Now any such movement is prevented, and the consequent dauger is at au end.

\section{NATURE OF THE CONTAGIOUS PLEURO-PAEUMONIA.}

When speaking of this disease we should strike out of our vocabulary such words as epidemic and sporadic. Out of Eastern Europe or Asia the malady is absolutely unknoren, sare as propagated by contagion or infection.

Whererer, ont of these regions, it has made an inroad, it can almays be traced to the importation of a sick or convalescent animal, or of some produet of such an animal. Many such instances could be drawn from the records of its existence on the contiuent of Europe, but, manifestly, those cases are more satisfactory which refer to the extension of the disease to distant islands and continents. During the Europeau wars at the beginning of the century, this malady, like the rinderpest, prevailed all orer Europe, wherever tho armies marched, and the eastern or steppe eattle were 
drawn for their support. But the British Isles remaincd perfectly exempt until 1839 , when the pleuro-pneumonia reached Ireland by some cattlo scut by tho British consul at the Hague.

It spread from this center, reached England some time in 1841, and since the passage of the free-trade act of 1812 has been kept up by continual arrivals of infected continental stock.

Yet it only reached where the railroads penetrated, and sccmed to respect the Highlands of Scotland, where the native black cattle only are bred, and into which outside stock are never brought.

The United States knew no such contagions disease until the importation of an infected Duteh cow in Brooklyn, in 1843, and this, together with one or two other importations, havo furuished the waterial for its extension over seven different States.

Australia, with her thousands of herds, was respected until 1858, when an English cow convesed the poison which has since ravaged her herds withont intermission.

The Cape of Good Hope remained elear until 1854, when an English cow carried the infection which still prevails iu the eape berds.

The same truth is shown negatively by the faet that erery conntry and State that has vigorously stamped out the first arrivals of disease, and taken measures to prevent further importation, has rid its territory of tho pestilence. Among them may bo named Norway, Sweden, Demmark, Schleswig; Oldenburg, Switzerland, Massachusetts, and Connecticut. Some of the countries have been agaiu infected in comneetion nith tho Danish and Frameo-German wars, which, for the time, destroyed all safeguards, but until such a contingeney arrived their herds were preserved in bealth.

The fact that in our comntry and in Western Europe this disease is propagated only by contagion, is the grand central truth round which all our thoughts of tho malady should revolve, and mpon which we should base erery measure adopted for its extinction. If tho affection could arise spontaneously, from any faulty conditions of hrgiene in our own land, then farewell to all hope of permanently ridding our herds of the plague. But all history testifies to the contrary, and we can foretell with as much contidence as wo can the rising of to-morrow's sum, that if we conld once extinguish. the products of the imported poison, wo need fear no moro contagious pleuro-pnenmonia until it is again imported from an infected land.

There is no such thing as a sporadic case of contagious pleuro-pneumonia, and no epidemic case in the sense that it is due to some condition of life apart from the presence of the virus in the country. Every case in this country, as in Western Europe, the Cape of Good Hope, and Australia, is the result of direct or indirect contagion, and of that alone.

It is true that affectious of the chest will occur in all future time as they occur in other animals, and in man himself, and as they occurred in cattle beforo the importation of the contagious gorm, but such cases hare not been in the past and will not be in the future the cause of the propagation of the clisease from animal to animal, or in otwer words of the developmcnt of a contagium.

Extirpate from the country this exotic contagium and wo can supply unassailable beef to the world.

\section{DANGER TO THE COUNTRY OF THE POSSIBLE INFECTION OF WESTERN IIERDS.}

For ten years I have been publiely warning the country of the danger of allowing this disease to extend to our Westeru States and Territories. (Seo especially National Live Stock Journal, March, 1878, and Transactions of New York Stato Agricultural Society, 18\%7-\%8.) Infection of the Western lierds mcans speedy infection of all the cattlo cars of the railwars, yards, loading-banks, \&c., and the starting of a constant stream of infected animals towards onr Lastern States and markets.

This means a uniform infection of the country and losses of thousands of millions of dollars in a short space of time.

Worso than this, should the malady extend to our unfenced cattle-ranges it will be practicaliy unmanageable. Such has been the expericnco on the open stoppes of Russia and the cattle-ranges of Australia, where the most costly efiorts at the extinction of the disease have proved futile and the poor palliation of inoculation has been established. (Sce National Livo Stock Jouxnal, March, 18.8.)

\section{DATGEI OF INOCULATION.}

The public adrocacy of inoculation demands a word on this subject.

Successful inoculation in firorable conditions leads to tho loss of but two or threo per cent. of auimals operated on. The survirors are protected from contagious pleuro-pneumonia for a varialblo period areraging two years. But every inoculated animal is infeeted, the places where inoculated inimals are lept are infected, all their products aro infected, and there must be tho most thorough system of disinfection for all such places and things before immunity can be gained. Erery new animal intro. 
duced and every calf born must be inoculatod. It becomes evident, therefore, that to tho stock of the country at large inoculation produces all the clangers of an equal extemsion of the diseaso in the ordinary way.

Inoculation, therefore, is ruinous to any attempt at extinguishing the poison. It has been triel in lfolland more extensively than in any country in Europe, and Holland is to-day tho most plague-raraged country on the continent. It has been followed extensively in Great Britain, but she has been reluctantly compelled to abandon it in favor of a system of absolute extinction. It has been practiced widely around New York, jet this district is probably now the most prolific center of the discase in America.

Australia has fallen back upon it as a dernier resort, after a fruitless attempt to expol the malady from the open pastures. We, too, must one day come to this wretched palliation, if wo neglect to stamp ont the disease whilo still confined to our eastern and inclosed farms, and allow it to reach our western open prairies.

\section{DANGER OF MEDICINAL TREATMENT.}

As with inoculation, so with tho maintenance of sick animals alivo for treatment. The production and diffusion of the poison is in exact ratio to tho period during which the :nimal is allowed to survivo after illness has been detected. To treat the sick, therefore, is almost cquivalent to propagating the disease; because on a largo seale and in all sorts of stables it is impossiblo to keop up a constant disinfection of the air and other disensed prodnets.

Wherever extinction of the poison is attempted, treatment of the disease must be forbidden muder heary ponalties.

\section{IMIPORTANCE OF UNITED STATIS ACTION.}

The isolated action by inclividual States is eminently unsatisfactory. In Now York we are working at the extermination of the disease, but after we have accomplished this we can only preserve our immunity by subjecting all New Jersey cattle to a quarantine of one or two months at our frontier. If New Jersey on her part lills it out, she wust quarantine against Penusylvania, Pennsylvania against Mraryland and Virginia, and so on as far as the disease is found to extend. Isolated action will bo incomparably moro expensive, tardy, and uncertain than a uniform movement under one central head, and crerythiug onght to give way to secure such a desirable result. Tho question iprolves tens of millions of dollars of our foreign commerce annually, and the trado has been steadily increasing, so that it is surely a matter in which the central goverument can properly act.

\section{SUGGLSTION OF MEASURES FOR THE EXTLCTION OF TIIE DISEASE.}

1st. Appoint a veterinary sanitary staff to act with the Commissioner of A griculture in stamping out tho contagion.

2d. Mako it incumbent on all stock-owners and their representatives, and on all reterinarians, to report all suspicions cases to the Commissioner under a penalty.

3d. Let the sanitury staff promptly investigate all such cases and take measures accordingly.

4th. Let every infected county be proclaimed and placarded, and let all morements of cattle within such county bo forbidden cxcepting by special licenso.

5th. Let all sick animals in an infected her? bo at once slaughtered, thoir hides slashed, and tho carcasses deeply buried; and in case the owner has not withheld notice of the existence of the disease let him obtain an order on the treasury for a suitable indemuity, which should in no case exceed one-half the value of the animals; failuro to notify should entail loss of tho indermits.

6th. Let all cattlo found in infected plaees be likewiso slaughtered, their hides disinfected, and their beef allowed to pass into consumption as food, if fit for this purpose. For such aninals, iudemunity should bo allowed to the extent of not more than tro-thirds of the valne, after cleducting salvage obtained from meat and hides.

7th. Let all infected stables, all manure, and all movable objects that have como in contact with discased cattle, be subjected to an exhanstive disinfection, and let all cattlo afterward placed in such buildings be sequestered in quarantine under the supervision of the veterinary sanitary anthorities until at least three months after the remoral of the last sick animal and tho disinfection of the premises.

8tli. Let all railroad cars, slipips, boats, wagons, and other movable objects that have become infected be cleansed a ad disinfected under tho direction of the veterinary sanitary stafl before they are again used for the transportation of eattle.

The advice to slaughter the expoech as well as the sick cattle I think very important, as it enables us to stamp out the disease quickly and to disinfect once for all, and 
obviates the necessity for a long-continued and expensire supervision in the case of every infected herd. If such exposed animals are placed in quarantine, as we are still compelled to do by a defeat of the law in New York, we find that erery three weeks or a month a new case develops, necessitating continued visitation, professional examination, and slaughter, and repeated and expensive disinfection, withont taking into account the enormonsly enlanced danger of the extension of the disease to other berds.

Ono other question will not brook an hour's delay. The testimony concerning the two ship-ioads of cattlo slaughtered at Liverpool may be misleading, but unless a gigantic blunder has been committed it implies that the disease has already reached one or more isolated spots in the West. This was inevitable sooner or later if the disease was not crushed out in the East, and I have constantly uttered warnings on the subject. If it has already taken place it should be treated at once, for the evidence im. plies that not only has the malady gained a footing in the West, but that the orrners of the infected stock are acting unfairly by the country, and selling off their infected stock to make what salrage they can. There are, then, not only of infected cars, stockyards, \&c., but of the sale of lean stock to different localities in the West, whence we shall hare new streams of infection, until our unfenced ranges suffer. No delay should occur in ascertaining the facts of the ease. If there has been a mistake it will relieve the country to know it, whereas if there is even one center of infection in the West it should be stamped ont promptly at any cost.

\section{REPORT ON THE STOCK-YARDS AT THE PORT OF NEW YORK.}

In unvestigating the existence and status of lung fever in the cattle of Long Island and Manhattan Island, I met with several outbreaks in which the disease was traced to cows sold into the herds in question by Patrick McCabe, a New York jobber. Three such instances may be named: First, Mr. Wheelock, farmer, at Roslyn, Qneens County, purchased two cows of McCabe in August, which communicated the disease to the whole herd of eighteen head, and to that of a farm about two miles diitant, to which two of his (Wheelock's) cows were taken. Second, Mr. Brazzel, Eighty-first street, New York, got a cow from McCabe the week after Christmas which conreyed the disease to his herd. 'Third, Mrs. Stur, Fifticth street, New York, hadl a cow from MicCabe about ten dass ago on trial. This cow had been sick ever since her arrival, and when I saw her on Saturday was in a condition of adranced pleuro-pneumonia. I had further information, from a man in the tracle who las a high reputation for honor, that the cattlo that had passed through the hands of this McCabe had been for two years the most prolific source of disease in the dairies of Brooklyn and Long Island.

Accordingly on Saturday last, in company with Dr. Lautard, I went to examine his (McCabe's) premises and stock, when wo were much surprised to find that he kept them in the Now York public stock-sards at Sixticth street, and I could not discover that he had any other place. The clerk found in charge of the office at the vards assured us that he constantly kept his cows there, aud only removed them as he found purchasers. He did not think he could have any other placo for keeping cows.

At the time of our visit he had a number of cows in the yards. At these yards the cows of all the dealers are usually placed in the sheep-house for warmth, but this is immediately adjacent to the inclosures for the other stock, and all alike must enter and leave by the same roads and gates or wharves. Further, when the sheep-house is crowded the cows are turned ont into the open cattlo inclosures in the yard. Cows are received in these yards indiscriminately from near as well as remote places, inclnding among the former Westchester, Rockland, and Orange Counties, which, according to the best evidenco I can obtain, are infected. (I have not jet rerified the last fact by personal olservation.) No precaution is taken to prevent the proximity or contact of these cows with the other stock.

There seems, therefore, no alternative; we must consider the New York stock-yards at Sixtieth street as infected, and that stock shipped from theso yards to Enrope will be liable to develop the discase after landing if kept alive long enough to allow of the completion of the period of incubation. That the evil results have been seen mainly in the cows is explained by the fact that they are allowed time after leaving the rards for the completion of the period of incubation (one to two months), whereas the fat cattle eren if sent to Europe aro slanghtered before this time has elapsed.

\section{JERSIR CITY STOCK-YARDS.}

In these as in the New York stock-yards there is the entire absence of any means of separating cow's brought from near and infected neighborhoods and stock brought from the West or other uninfected localities. The corr-stable is at the north side of the yarls and can ouly be reached by cattlo that hare passed through among the inclosures for the other stock. The stable itself is furnished with oqen gates, not doors, facing the 
inclosures for other stock and separated from them only by a narrow wagon road, perhaps tiftecu feet widle.

Mr. Fowler, whom I found in charge of the yard, was violently denunciatory of the mere idea that this diseaso existed anywhere, and of all who would wention such a subject, and conld with difficulty be persuaded to give any information regarding the yards, tho stock, its proximity in tho inclosures, and its disposal. Ho admitted, however, that they got four or five cows per week, and on rare occasions one or two carloads; that they mostly came from Eastern Pennsylvania, and that they remaiued in the yards until they were sold to parties in New York City, Brooklyn, Jersey City, Staten Island, \&c. I may here state that on the occasion of my visit, late on Saturday night, the cow-stable contained eighteen cows and eight calves waiting for salo; so that, according to $\mathrm{Mr}$. Fowler, I must have hit upon tho very exceptional case of an arrival of two car-loads.

I further drew from Mr. Fowler that the fat stock for exportation were taken from any part of the yards, wherever suitable animals could be found, and carried by boats to tho ocean-going steamers. There was no attempt made to keep such animals apart from such as might possibly come from infected districts in New Jersey and adjacent States, nor from the inclosures where such cattle had formerly bcen, as indeed why sliould there be, sccing the whole story of the discasc was a fabrication?

As bearing on the question of the probable infection of these yards, I shall add that the malady is well known to exist in Alexandria, Va. I have had the most circumstantial reports of its existence around Washington. Accorling to Dr. Corliss, it prevails to some extent around Newark, N. J. Last year it made havoc in the town of Clinton, and the year before near Burlington, N. J. Further, in making inquiry among the farmers at New Lots, Kings County, New York, whoso herds aro now infected, I found that they had repeatedly traced the disease to Jersey cows brought into their herds. Thero is, therefore, the strongest eircumstantial evidence that both the Jersey and New York stock-Yards, the two points from which cattle aro shipped to Europe, aro infected places, and that the apparent absence of disease in American cattle whon lauded in England is due to the fact that they have not yet liad time to pass through the long incubation period of the disease.

\section{ABSLTDITY OF A CERTIFICATE OF SOUNDNESS.}

The professional examination at the yards of animals destiued for exportation can never be better thau a farce. The most accomplished veterinarian has no means of letecting the presence of the specific poison until the period of ineubation has passed, and as this lasts for from three weoks to two months, the evideuce of infection contracted in the New York stock-yards cannot possibly be recognized until long after the animals have landed in Englaud. Tho great mass of our Western eattle is sound so far as tho contagious pleuro-pneumonia is coneerned, and if infected, it is presumably only after they have been sent East. The disease, therefore, can only be in the incubation stage so long as they remain on our shores, and in this stage no man can recognize it, though it only wants time for its development. Any examination in such a case inust be the most empty of forms, and must be prejudicial rather than beneficial, inasmuch as it leads to the certifying of the soundness of auimals that may be, and often probably are, infected. It is quite manifest that in the case of cattlo that may have been infected in the New York or Now Jersey stock yards, an examination a fortnight later on their landing in Liverpool wonld be almost as great a farce as the cxamination prior to shipment at New York. Hence the soundness of the English position in ordering the slanghter at the quays of all cattlo from an infected country.

THE COURSE OF SAFETY.

If wo can be assured that there is not yet an infected center in tho great stockraising regions of the West, tho cattlo from there might be safely shipped to England under the following regulations:

1st. Let the Western cattle-trains be made nu of cars that have never been used for the local cattle traftic in the eastern parts of the Atlantic States or of such as have been thoroughly cleansed and disinfected beforo use.

2d. Let all such trains be from the West through, and let these take on board uo live nor dead cattle, nor other ummanufactured products of eattle, cast of given points on the respective lines, such points to bo designated as soon as wo know conclusively how far the pleuro-pnenmonia has extended westward. Let such trains pass to designaterl stock-yards on the quays at least one-fourth of a mile apart from all other stock-yards, or cattle stables, or pastures.

3el. Let such yards bo rigidly closed anainst all visitors, no ono being admitted except the nccessary attendauts, and no ono being employed as such who has recently been in charge of other cattle in the East.

4th. Shonld it bo necessary to sell any such stock for home consuxption, they must 
be driven by their attendants to other sards or pastures at a distance, or to the other stock-yards, where burers may see them. The attendants on the foreigu stock-yaris may drive such animals into the common stock-yards, but must not, on any accont, enter themselves.

5th. The cattle intended for export must be transferred to the ocean-going ships direct, or carricd to them on boats that have never beeu used for conveying other cattle, or that liare been subjected to the most thorough disinfection subsequent to such use.

6th. It should be shown that the ocean-going vessels, in which the export cattle are shipped, have not carried, and do not now carry, any hides or other unmanufactured products of cattle; or, if they havo previously carrich such articles, that they havo been thoroughly disinfected since.

PLETRO-PNETMONIA-THE LUNG PLAGTE-CONTAGIOUS LUAG DISEASE OF CATTLE.

Pleuro-pneumonia is a malignant contagious ferer to which, as far as known, cattle onls are liable, and in them is accompanied by inflammation and other diseased conditions of the lungs and their membranes, together with great prostration of the entire system.

It proceeds from a poisoned condition of the blood. Ilom, when, or where this poison was first generated it is impossible to tell. Nor is it less difficult to determine its specific nature. So far as reliable information has yet reached, it is nerer generated spontaneously, but depends entirely on the introduction of a virus or eontagion into the system of a healthy animal. A siugle animal so infected infects the herd; the herd, subdirided and scattered, infects otlier herds until in time large areas of comntry have been visited and derastated by the fearful scourge.

Beginning; as we have reason to believe, in the far-off East, and at a remote clate, its course has been westward until, crossing the Atlantic in the system of stock imported from European states, it has at length found lodgment here.

The earliest symptoms of the disease are not always easily detected, there being no intensity of inflammation at first, and the period of incubation varying often from eight or nine days to three or four months. The knowledge of the existence of the disease in adjoining States or farms, or eren in remoto sections from which cattle have been introduced, should serve to put every one on gnard and lead to frequent thermometric trials even with cattle apparently in perfect health. While such trials rould not, perhaps, in every case determine infallibly the existence or non-existence of the clisease, yet in a very large majority of cases-possibly in nine out of ten, and particularly if other s5mptoms were present-they would lead to a right conclusion. The trial is mate by inserting the thermometer in the rectum. If a rise of temperature to $103^{\circ}-106^{\circ}$ Fahrenheit is observed we may be reasonably sure that the disease exists, at least in an incipient state.

Its further derelopment is inclicated by fits of shivering, often so slight and transient as to eseape the notice of all sare the practiced eye; by a dull, staring eoat, with (frequently) a rigid skin; by a harsh, dry- congh, the more apparent when the animal is made to more briskly; by irregnlur chewing of the eud; constipated bowels; excrement dry; mine diminished, but with high eolor; and, in the case of cows, by a lalling ofì in the quantity of mill.

At an early stage of plenro-pneumonia there is a harsh sound or roar produeed by the passage of air throigh the wind-pipe and its sublivis. ions, which may sometimes be heard at some distance from the sick animal. Oceasionally the air rushing through the bronchial tube (made rigid by a mass of hardened lung) produces a very decidet whistling noise. I somerhat watery discharge from the nose, inereased in the 
act of coughing, is noticed early in the disease, and driving sick cattle in the earliest stage produces much thir'st, and there is sometimes a ropy saliva discharged from the mouth, while the muzzle is hot and dry.

As the malady progresses the pulse rises to seventy, eighty, and even a luundred beats per minute; the respirations to thirty-five and forty per minnte, and are labored and andible, while each expiration is accompanied in most eases by a short distinetice grunt or groan, the more marked whenever pressure is applied to the ribs over the lungs.

At this stage the cough increases, the gait becomes more languid, the eyes more prominent and fixed; the countenance assumes an uneasy, pained expression, and a disposition is manifested by the sick to separate from the well. When the animal stands the elbows are turned out, the fore limbs extended, the hind feet drawn formard under the body, the head and neck stretched out, and the back arched, while the nostrils are more or less convulsively expanded at each inspiration. Wheu lying, to which there is a tendency, the animal rests, especially in the latter stages of the disease, on its brisket, or on the affected side, leaving the ribs on the healthy side as much freedom of motion as possible.

With a still further advance in the disease, the pulse becomes more frequent (often rising to 120 per minute) and the heart-beats, at first subdued, are now maxised and palpitating; the tongue becomes foul and covered with fur, and the breath has a nauseous smell. Listlessness, grunting, grinding of the teeth, diminished secretions, and weakness rapidly increase; the breathing is more frequent and labored; the animal gasps for breath; the spasmodic action of the nostrils is more marked, the groan more audible; the temperature is irregular, the tendency being to coldness of the horns and cxtremities. These conditions are followed by a mattery or watery discharge from the eyes and nose, rapid loss of flesh, hide bound, and either obstinate constipation or else a violent watery diarrhœa of fotid matter associated often with a considerable discharge of clear-colored urine.

Percussion over the limgs will, in the beginning, often reveal the clisease when not otherwise apparent. With some practice and a little care almost any one can distinguish the sick from healthy cattle by listening to the sides of the chest. In the earlier stages of the diseaso pereussion gives out a clear or resonant somud, followed, as the malady increases, by a dull, heary one, easily distinguished from the somd caused by the lungs in bealth.

Where one lung only is affected, partial, sometimes complete, restoration may result; but acute pleuro-pneumonia, in which both lungs are aflected, we may safely assert is never terminated except by death.

As stated above, the period of incubation of this disease varies from eight or nine days to three or four months ; the usual arerage period being from twenty-fire to forty days. The acute stage of the disorder varies from seven to twenty-one days. Convalescence extends over a period of from one to three months, during the greater part of which time the convalescent animal is often capable of infecting healthy cattle.

As a rule, in mild outbreaks, the mortality attains twenty-fire per cent., and in serere epidemics sixty, seventy, or even one hundred per cent.

In England, the lung disease has more than doubled the ordinary mortality of the country, eutailing a loss of many millions of dollars.

While varions remedies for this insidious disease have firom time to time been recommended and tried, not one of them, nor all of them combined, have proved a specific against its destruetire effects; and as a means to be relied on for the protection of the stock of the country, they 
are worse than useless. As a rule, the malady baffles the slill of the most learned veterinary practitioners, frequently attaining its greatest mortality where most they have combated it.

Nerertheless, as there may be cireumstances under which partial relief might be aftorled by timely remedial agents, it is cleemed expedient to give in this place the treatment which, in general, has been found most efficacious.

The course most obviously to be pursued, when the slightest symptom of the disease is observed, or where the slightest cause for suspicion exists, is to apply the thermometer, to separate at once every suspected animal from the rest, to use disinfeetants, to adopt a low diet, and to watch carefully for further developments. The weight of testimony is against bleeding. If constipation is detected it should be removed by a moderate dose of salts. Slight diamhoea need not be checked; but when violent use a mixture of gallic acid (or its equivalent) and gruel, one-half ounce of the former to one-half pint of the latter; or else, one-half ounce powdered alum to one quart of milk. Sometimes there is considerable swelling or bloating of the stomach, which may be removed by carbonate of ammonia-one ounce in a moderate quantity of gruel, repeated if necessary. To lower the temperature and ease the breathing give acid sulphite of soda, one ounce, twice a dlay. In an advanced stage of the disease administer one or two ounces of whiskey or of oil of turpentine every three or four hours. If no relief is observed employ copious warm-water injections, and give two or three times a day an ounce of carbonate of ammonia in a quart of linseed-tea. Althongh out of place in the aeute stage of the disease, blisters, setons, rowels, and eanterization may be applied in some eases to advantage after the fever has abated. Several preparations of earbolic acid have been tried with moro or less suceess. Perhaps the best is-

Pure carbolie acid, 1 drachm;

$$
\text { Water, } 1 \text { pint; }
$$

given at a dose, three times a day.

Convalescence begun, restoratiou to health will be hastened by giving a teaspoonful of sulphate of iron in the food at each meal. The herd itself from which the sick have been removed should be placed, as a possibly preventive measure, on daily closes of the same preparation, (sulphate of iron,) allowing abont half a drachm to a drachm per capita, mixed with an equal amount of coriander seeds, given in meal or bran, the better to disguise the iron.

A post-mortem examination of the chest generally reveals layers of yellowish, friable, filse membrane (eovering-skin) stretehing across and around the sack containing the heart. With them is found a yellowish, clotted fluid, highly charged with albumen and shreds of solid deposit. Diseasert portions of one or both lungs are found adhering to the mem. brane of the ribs and diaphragm, from which there is more or less difficulty in detaching them. The membrane covering the lung, usually smooth and glistening, is rough and mottled with a number of more or less marked pimples or warts.

The fluid around one or both lumgs varies from a few ounees to sercral gallons. At times it is tolerably clear when warm, and gelatinizes on cooling; at others it is diftienlt to separate it from the shreds of lymph and false membranes in which it is held. Pus-cells often abound in it, and it assumes in some cases the character of pus, from which au intolerable stench sometimes proceeds.

On remoring the lungs the essential appearances of the disease in all 
eases will be found quite uniform, although differing considerably in extent.

In recent and mild eases in which only one lumg is affected, the surface of the lung may be smooth; parts of it collapsed, as in health, with the normal pink color jreserved. The affected part is swollen, hard, and mottled. On cutting into this, the older diseased portions present a rery peculiar marbled appearmee. The substance of the lobnles is solid and of a dark red color, and the tissue between the lobules is of a yellowish-red, more or less spotted with red points, but sometimes of almost pure yellowish-white color. The more recent deposits are distinguished mainly by a lighter red color of the thickened lobtles.

At a more adranced stage of the disease the lung will be found harder and of darker color, its tissues having lost a portion of the marbled appearance, the blood-ressels obstructed, and showing how nourishment had been eut off from the lungs, while the older, darker, and more solid portion of the latter have become detached, so that they remain as foreign bodies imbedded in the eavities of the diseased tissue. The admission of air into these cavities, by dissolution of the lung tissue, produces the cavernous sounds which the ear can detect in the living animal.

On taking a warm diseased lung, severing the still healthy portions, making incisions into the parts soliditied, and suspending them so that they may drain, a large amount of yellowish serum, of a translncent character, and varying greatly in weight, is obtained. The quantity of this serum, and of the solidified deposit in a diseased lung, is so large that, from a normal weight of four or five pounds, a lung attains ten, twenty, forty, or even fifty pounds.

The condition of the air-passages will be found to vary from one of perfect freedlom in the healthy portions of the luings to a state in which the mucous surface is coated with false membrane, or solid exudations of lympll in the diseased parts. These passages are sometimes found nearly filled, thronghont their whole extent, with a deposit similar to that ustally found on the surface of the diseased lung.

The beart's sack is sometimes found to be thickened by deposits around it, and not unfrequently to contain an excess of serum. The lieart itself is contracted and pale, containing a little dark blood.

The organs of digestion at different stages manifest a state of dryness. The third stomach, which is so constantly packed with dry food in febrile diseases, is in the same condition in plenro-pnemonia. In advanced cases there is found a more or less diffuse redness, and even efiusion of blood in the large intestines, with fiuid, fetid, and sometimes slightly blood-stained excrement, such as is discharged in life.

Such briefly, and in language free from technicalities, are the description, cause, symptoms, treatment, and post-mortem appearances of pleuro-pneumonia as gathered from previons publications of this Department and other recognized authorities. 


\section{A P P E N D X.}

\section{MASSACHUSETTS.}

\section{LUNG FEVER OR PLEURO-PNEUIONIA OF CATTLE.}

\section{The following act, for the suppression and extirpation of the disease} called pleuro-pnemonia anong cattle, was passed by the Massachusetts legislature April 4, 1860:

AN ACT to provide for the cxtirpation of the discase called pleuro-pueumonia among cattle.

be it chacted, s.e., as follow's :

SECrion 1. 'The gorernor is hereby anthorized to appoint three commissioners, who shall visit withont lelay the sereral places in this commonwealth where the discase among eattle ealled pleuro-pmeumonia may bo known or suspected to exist, and sluall have fill power to cause all eattle belonging to the herds in which tho diseaso has aj)peared, or nay appear, or which have belonged to such herds since the disease may be knom to have existed therein, to be forthwith killed and huried, and the premises where such eattle have heen kept cleansed and purified; and to make sueh ourler in relation to the furtlier use and ocemation of sucl premises as may seem to then to be necessary to prevent the extension of the disease.

SEC. 2. The commissioners sliall canse all cattle in the aforesaid herts not appearing to be affected hy tho diseaso to be appraised before heing killed at what would bare been their fair market rahe if the disease had not existed; and the value of the cattle thus appraised shall be allowed and paid ont of the treasury of the commonwealth to the owner or omners thereof.

SEc. 3. Any person who shall knowingly disregard any lawful order or direction of said commissioners, or who sliall sell or otherwise dispose of an animal which he knows, or has good reason to suspect, Ins been exposed to the aforesaid disease, shall forfeit a sum not exceding fire lumdred dollars.

SEC. 4. The commissioners shall make a full report to the secretary of the board of agriculture of their proceedings and of the result of their observations and inquiries relative to the nature aud character of the disease.

SEC. 5. The commissioners shall duly certify all allowances made umder the seeond section of this act, and other cxpenses ineuried by them, or nnder their direction, in the excention of their service, to the governor and commeil; and the governor is liereby anthorized to draw his warrant therefor upon the treasur.

SEC. 6. This act shall take cffect from its passagc, and continue in force for the term of one year thereafter, and no Ionger.

[Apjiroved April 4, 1860.]

\section{On the 12th of Jume, 1S60, the following additional acts vere passed:}

\section{AT $\triangle \mathrm{CT}$ conceming contagious disease among cattle.}

SECTION 1. The selectmen of tomns, and the mayor and aldermen of cities, in case of the existenee in this commontrealth of the discase called pleuro-pnemmonia, or any other contagions discaso anuong cattle, shall cause tho cattlo in their resjective tornis and cities which are infected, or which havo been exposed to infection, to bo secmred or collecterl in some suitable place or places within such city or tom, and kept isolated; and, when taken from tho possession of their omers, to bo maintained, onefifth of the expense thereof to be paid by tho tom or eity wherein the animal is kept, and fonr-fifths at the expense of the comimonrealth, sueh isolation to continue so longr at: the "xistence of such diseaso or other circmustances renders tho same necessary.

SEC. 2. Sail selectmen and mayor and aldermen, when any such animal is adjuilged by veterinary surgeon, or plrysician by them selected, to be infected with the liseiso ealled plemro-pnemuonia, or any other contagious disease, nay, in their tiseretion, order sucl diseased animal to be forthwith lifled and buried it the expense of such town or city.

SEC. 3. Such selectmen and mafor and aldermen shall cause all eattle which they shall so order to bo killed to be appraised by theo competent and disinterested mein, under oath, at the value thereof at the time of the appraisal, and the amount of tho appraisal shall be paid as provided in the first sectivu. 
SEc. 4. Said sclectmen and maror and aldermen are herehy anthorized to probibit the departiure of eattle fiom any inclosure or to exclude cattle therefrom.

SEC. 5. Said selcetmen and mayor and aldermen may make regulations in writing to regulate or prolibit the passage from, to, or through their respective cities or towns, or from llace to place witlin the same, of any neat cattle, and may arrest and cletain, at the cost of the owurrs thereof, all eattle found passing in violation of such regula. tions, and may take all other necessary measures for the enforcement of such prohibition, and also for preventing the spread of any such disease among the eattle in their respective towns and cities and the immediate vicinity thereof.

SEC. 6. 'The regulations made by selectmen and mayor aud aldermen in pnrsuanco of the forcooing section shall be recorded upon the records of their towns and eities respectively, and shall be published in such towns and cities in snch manner as may be provided in such regulations.

SEC. 7 . Said sclectmen and mayor and aldermen are authorized to canse all cattle infected with such disease, or which have been exposed thereto, to be forthwith branded upon the rump with the letter $\mathrm{P}$, so as to distinguish the animal from other cattle; and no eattle so branded shall be sold or disposed of except with the knowledge and eonsent of such selectmen and major and aldermen. Any person, without such knowledge and consent, selling and disposing of an auin:al known to be effected with sucli disease, or known to have been exposed thereto within one year from such sale or disposal, shall be punished br fine not exceeding fire hundred dollars, or by imprisonment not exceeding one year.

SEc. 8. Any person disobeying the orders of the sclectmen or mayor and aldermen, made in conformity with the fourth section, or driving or transporting any neat cattle contrary to the regulations made, recorded, and published as aforesaid, shall be pumished by fine not excecding fire hundred dollars, or by imprisonment not exceeding one year.

SEC. 9. Whoerer knows, or has reason to suspect, the existence of any such disease among the cattle in his possession or under his eare, shall forthwith give notice to the selectmen of the town or mayor and aldermen of the eity where such cattlo may be kept, and for failure so to do shall be punished by a fino not exceeding fire hundred dollars, or by imprisonment not exceeding one jear.

SEC. 10. Any town or city whose officers shall neglect or refuse to carry into effect the provisions of section one, two, three, four, fire, six, and seven, shall forfeit a sum not exceeding fire lumndred dollars for each day's neglect.

SEc. 11. All appraisals made under the provisions of this act shall be in trriting, and signed by the appraisers, and the same shall bo certified to the governor and conncil, and to the treasurer of the several towns and eities wherein the cattle appraised belong, by the selectmen and mayors and aldermen respectirely.

SEC. 12. The selectmen of tho towns and mayor and aldermen of the eities are hereby authorized, when in their judgment it shall be necessary to carry into effect the purposes of this act, to take and hold possession, for a term not exceeding one year, within their respective towns and cities, of any lands, withont buildings other than barns thercon, upon which it may be necessary to enclose and isolate any cattle, and they sliall causo the damages sustained by the owners in eonsequence of sucli taking and holding to be appraised by the assessors of the town or eity wherein the lands so taken are situated, and they shall further eause a description of such land, setting forth the boundaries thereof, and tho area as nearly as may be estimated, together with said appraisal by the assessors, to be entered upon the records of the town or city. The amount of said appraisal shall be pairl as provided in the first section, in such sums and at such times as the selectmen or mayor and aldermen respectively may order. If the owner of any land so taken shall be dissatisfied with the appraisal of said assessors, he may, by action of contract, recorer of tho town or eity wherein the lands lie, a fair compensation for the damages sustained by him; but no cost shall be taxed miless the damages recovered in such action, exclusive of interest, exeeed the appraisal of the assessors. And the commonwealth shall reimburse any town or city four-fifths of any sum recorered of such town or city in any such action.

$\triangle \mathrm{N}$ ACT in addition to an act conccrning contagious diseases among cattle.

SECTION 1. In ardition to the commissioners appointed under the provisions of chapter oue hundred and ninety-two of the acts of the sear one thousand eight hundred and sixty, the goreruor, by and with the advice and consent of the council, is hereby anthorized to appoint two additional persons to constitute, with those now in office, a board of commissioner:s non the subject of pleuro-pneumonia, or any other contagious disease now existing among the cattlo of the commonwealth.

SEC. 2. When said commissioners shall make and publish any regnlations concerning the extirpation, cure, or treatment of eattle infected with, or which have been exposed to the disease of pleuro-pncumonia, or other contagious disease, such regnlations shall s:ipersede the regulations made by selectmen of towns and mayors and aldermen of cities, npon the same subject-matter, and the operation of the regulations made by such selectmen and majors and aldermen shall bo suspended during the time those 
made by the commissioned's as aforesaid shall be in force. And said selectmen and mayors and aldermen shall carry out and cuforce all orders and directions of said commissioners, to them clirected, as they shall from time to time issur.

SEc. 3. In adrlition to the power amd anthority conferred on the selectmen of towns and mayors and aldermen of cities, by the act to which this is in addition, and which are herein conferted upon said commissioners, the same commissioners sliall have porrer to provide for the establishment of a hospital or quarantine in some suitable place or places, witl proper accommodations of buildings, land, \&c., wherein may bo detained any cattle by them selected, so that said cattle so infected and exposed may be thero treated by such scientific practitioners of the liealing art as may be there apjointer to treat the same. And for this purposo said commissioners may take any lancls and buildings in the manner provided in the twelfth section of the act to which this is an adlition.

SEC. 4. The governor, hy and with the adrice and consent of the comncil, is hereby authorized to appoint three competent persons to be a board of exaniners to examine into the disease called pleuro-pmeumonia, aud who shall attend at the hospital at quarantiue established by the commissioners uentioned in the foregoing section, and there treat and experiment upon sucl number of cattle, both soumd and infected, as will enable them to study the symptoms and laws of the disease, and ascertaiu, so far as they can, the best mode of treating cattle in view of the prevention and eure of the disease, and who shall leep a fill reconl of tlieir proceedings, and make a report thereon to the govornor and conncil, when their investigation shall have been concluded: Provided, That the expense of said board of examiners shall not exceed ten thousand dollau's.

SEC. 5. The selectmeu of the several towns, and the mayors and aldermen of the scveral cities, shall, within twenty-four lours after they shall have notice that any cattle in their respectivo towns and cities are intected with, or liave becn exposed to, any such disease, give notice in writing to said commissioners of the same.

SEC. 6. The commissioners are authorized to make all necessary regulations for the treatment, cure, and extirpation of said disease, and may lirect the selectmen of towns and mayors and aldermen of cities to enforce and carry into effect all such regulations as may, from time to time, be made for that end: and any such officer refusing or neglecting to enforce and carry ont any regulation of the commissioners, shall be pumished by fine not exccediug five humdred ilollars for every such ofiense.

SEc. 7. The commissioners may, when in their juilgment the public good shall require it, canse to be killed and buried any eattle which are infected with, or which have bren exposed to said disease, and said commissionerg shall cause saicl cattle to be appraised in the same manner provicled in tho act to which this is an addition; and tho appraised value of such cattle shall be paid, one-fifth by the towns in which said cattle are kept, and the remainder by the commonwealth.

SEC. 8. Whocver shall drive or transport any cattle from any portion of the commonwealth east of the Connecticut River to any part west of said river betoro the first day of April next without consent of the commissioners, shall be punished by fine not exceeding five hundred dollars, or by imprisonment in tho county jail not excecding one year.

SEc. 9. Whoever shall drive or transport any cattle from any portion of the commonwealth into any other State before the first day of $A$ pril next, without the consent of the commissioners, shall be punished by fine not exceeding five luundred dollars, or by imprisonment in the county jail not exceding one year.

Skc. 10. If any person tails to comply with any regulations made, or with any order given, by the commissioners, lo shall be punished by fine not exeecling five hundred dollars, or by imprisonment not execeding one year.

SEC. 11. Prosecutions under the two preceding scetions may be prosceuted in any county ill this commonmealth.

SEc. 12. All appraisals made under this act shall be in miting and signed br the appraisers and certified by the commissioners, and shall be by them transmitted to the goverumor and comucil, and to tho treasurers of the several cities and towns wherein the cattle appraised wero lecpt.

SEC. 13. 'The provisions of eliapter one hundred and ninetr-two of the acts of one thousaud eiglit humbled and sixty [except so far as they authorize the appointment of commissioners] are hereby repealed, but this repeal sliall not affect the valiclity of the proceclings lielet ofore law fully had under the provisions of said cliapter.

Skc. 14. Tho commissioners and examiners sliall keep a full record of their doings, and make report of the same to tho next legislature, on or before the 10th day of Jannary next, unless sooner required by the governor; and tho said record, or an abstract of the same, shall be printed in the ammul rolume of Transactions cf the State Board of Agriculture.

SEC. 15. The governor, with the alvice and consent of the comneil, shall have power to terminate the commission and board of examiners whenever, in his judgment, tho public safoty may permit. 


\section{STATE OF NEW YORL.}

$\triangle N$ ACT to prevent tho introluction and spread of the diseaso known as rinderpest, and for the protection of the flocks and herds of sheep and cattle in the Stato of New York from this and other infectious and contagious diseases. I'assed April 20, 1866.

Be it enactel by the senate and assembly of S'cw Fork:

SEctiox 1. It shall be the duty of the health officer of the port of New York, in addition to the duties now imposed on him by existing law, to examine and inquire whether any animals are brought in any ressels arriving at said port in violation of any regulation of law passed by the Congress of the Uuited States prohibiting the importation of such animals.

2. Whenever any animal is brought as a ship's cow, with no intentiou of landing the same or of violating any such law or regulation of Congress as aforesaid, the same shall $b_{B}$ carefully examined aud kept in qnarantine for the space of at least twentyone clays, and if any symptoms of the infection or incubation of the disease commonly known as the rinderpest or any other infectious or contagions diseaso shall present themselves, it shall bo the duty of the said health officer immediately to cause the said animal or animals to be slaughtered, aud their remains boxed with a sufficient quantity of quicklime, sulphate of iron, or other disinfectaut, and with suficient weights placed in said box to prevent the same from floating, aud to bo cast into the waters of the said port. It shall also be his duty to eleanso and disinfect by suitablo ageneies the berth or section of the ship in which said animal or animals were lying or slaughtered, and also to cause the elothing and persons of all taking eare of the samo or cngaged in slaughter and burial to bo cleansed and disinfected.

3. William Kelley, of Dntchess County, Marseua R. Patrick, of Ontario County, and Lewis F. Allen, of Erio County, are hereby appointed as commissioners under this act, and with power's and duties as hereinafter enumerated.

4. In the erent of any such disease as the rinderpest or infectious disease of cattle or sheep breaking out or bcing suspected to exist in any locality in this State, it shall be the duty of all persons owning or having any interest whatever in the said cattle, immediately to notify the said commissioners or any one of them of the existence of sncl disease; wherempon the said commissioners shall establish a sanitary cordon around such locality. And thereupon it shall be the duty of the said commissioners to appoint an assistant commissioner for such district with all powers conferred by this act on the said commissioners or their agents or appointees, which said assistant commissioner shall immediately proceed to the placo or places whero such disease is reported to exist, aud causo tho said animal or auimals to be separated from all connectiou or proximity with or to all other animals of the ruminant order, and take snch other precautionary measures as shall bo deemed nocessary; and if in his opinion the said disease shall be ineurable or threaten to spread to other animals, to cause the same immediately to be slaughtered, their remains to bo deeply buried, and all places in which the said animals haro been confined or kept to be cleansed and disinfected by any of the ageneies above mentioned; and also to eause the same to bo earefully locked or barred so as to prerent all access to tho same by any animals of a like kincl for a period of at least ono month. Any animal thus slaughtered shall be appraised nnder the supervision of said commissioners, and ono-half of the valne of said animal shall be paid by the State to the owner thereof.

5. It shall be the duty of the said assistant commissioner, immediately on his being notified of his appointment, or at any time thereafter of the breaking out of the said clisease in any place contiguous to the same and within the comnty in which he resides, to givo public notices of the same in at least one newspaper printed or published in the said county, and to canse notice to bo posted $\mathrm{mp}$ in at least fivo conspicuous places in said ueighborhood, and it shall bo his duty to enjoin, in said notice and otherwise, all persons concerned in the care or supervision of neat eattle or sheep not to como within one hundred feet of the said locality without the special permission of the said assistant commissioner.

6. It shall he the duty of the commissioners appointed under this act, whenerer they are advised that any such disease has mado its appearance withiu the limits of the State, to publisl in the State paner and in at least one paper published in any county where such disease exists, a statement of the methods approved by the New York Agrienltural Society for the treatment of cattlo affected therewith, for tho isolation of the same, for the ilisinfection of tho premises or building in which said cattlo aro found affected as aforesaid, and for the prevention of the spread of the same through any ageucies of whatever kiud.

7. The comnissioners aforesaid, and all such assistants as they may appoint, whenever in their judgment or discretion it shall appear in any caso that the disease is not likely to sicld to any remedial treatment, or whemerer it shall seem that the cost or worth of any such remedial treatment shall bo greater than tho value of any animal or animals so affected, or whenover in any case such disease shall assnme auch form of malignity as shall threaten its spread to premises, either contagions or infections or 
ofherwise, are herehy empowered to canso the said animals to be slanghtered forthwith and lmied, as above provided, and to do all such things as are mentioned in tho fonth section of this atet.

8. The sail commissioners or their assistants are hereby cupowered to enter upon and take possession of all premises or parts thereof where eattle so atiected as atoresaid are found, and to cause the said cattle to be confined in snitable inclosures or bnitdings for any time requisite in tho judgment of the said commissioners or their assistants, and prior to the slanghter and burial of the said animals and the full and complete disinfecting aud cleansing of such prenises; and all persons, whether owners of or interested in such cattle or otherwise, who shall resist, impecle, or hinder the saich commissioners or their assistants in the excention of their duties under this act shall be deemed guilty, and on conviction of the same, of a misilemeanor, and shall be punisluable with fiue not exceeding one thonsand dollars, or imprisomment not excecling the term of six months, or of both, in the discretion of the court before which they shall be adjudged gnilty as aforesaid.

9. The commissioners shat have power to establish all such quarantiue or ot her regulations as they may deem necessary to prevent the spread of the disease, or its transit in railroad cars, by ressels, or by driving along the public highways; and it shall be proper for the gorerner of the State, by pnblic proclamation as aforesaid, to enjoin all persons concerned or engaged in the traftic or transit of cattle or shcep, not to enter upon any such places, or take therefrom any such animal, or to pass throngh any such locality, and within such distances from the samo as in the said proclamation mas bo prescribed.

10. The snm of one thonsand dollars, or so much thereof as may be necessary, is hereby appropriated to pay to the said commissioners for their services, whilo actually engaged in the duties cnjoined upon them in this act, at the rate of five dollars per day to each, and such further sums asmay canse them aetual expenditures in traroling to and from the places they may bo called upon to inspect or visit, and in tho printing or publishing of all regulations or notices montioned in this act. And the further sum of fifteen thousand dollars, or so much thereof as may bo necessary, is horeby apropriated ont of any monoy in the treasury not othermise appropriated, to pay for animals slaughtered by the provisions of this aet, and the comptroller is hereby directed to pay for the same on the warrant of the said commissioners.

11. The assistant commissioners aro to receire for each and erery day while actually eugaged in dnties provided by this act the sum of threo dollars per day, and all actnal expenses and disbursements paid or incurred in the discharge of their dutics as aforesaid, which.said smms shall be a charge upon the comnty for which the is appointed, and shall, when duly audited by the board of supervisors of the said county, bo paid by the county treasurer.

12. The slaughtering of animals for beef after having been exposed to the contagion, or supposerl to have been so exposed, may be permitted by the commissioners, or probibited by them, as they may judge proper.

13. This act shall tako efiect immediatcly, and shall continne in force for ono sear.

$\Delta X \Lambda C T$ in wation to infections and contagious diseases of aumals. Passed $\Delta$ pril 15,1878 ; threefiltbs being present.

The people of the Statc of New Tork, represented in the senate and assembly, do enact as follores:

SECriox 1. Whenever any infections or contagions disease affectingr domestic animals shall be bronght into or shall break out in this State, it sliall he the duty of the goveruor to take measures to suppress the same promptly, and to prevent the saure firom spreading.

5. For suchi purpose the goveruor shanll havo power-

To issue his proclamation, stating that infectious or contagions disease exists in auy county or counties of the State, and warning all persons to seclude all auimals in their possession that are affected with sucl diseaso or havo been exposed to the infection or contagion thereof, aud ordering all persons to take snch precantions against the spreading of such disease as the nature there of may in his judgment render necessary or expedient.

To order that any premises, farm or farms whero suel clisease exists or has existed be put in quarantine, so that no domestic animal bo removel from or brought to tho prenises or places so quarantined, and to preseribe snch regulations as lic may judgo neccssary or expedient to prevent iufection or contagion being commmieated in any way from the places so quarantined.

To call upon all sherifts and deputy sheriffs to carry ont and cuforce the provisions of such proclamations, orders, and regulations; and it shall be the duty of all sherifis and deputy slierifi's to ober and oluservo all orders and instructions which they may receire from the grovemor in the premises.

To exploy such and so many medical and veteriuary practitioners and such other 
persons as he may fiom time to time decm necessary to assist him in performing his duty as set forth in the first section of this aet, and to fix their compensation.

To order all or any animals coming into the State to be detained at any place or places for the purpose of inspection and examination.

To prescribe regulations for the destruction of avimals affected with infections or coutagious disease, and for the proper disposition of their licies and careasses, aud of all oljects which might convey infection or contagion, provided that 110 animal shall be destroyed umless first examined by a medical or veterinary practitioner in the employ of the governor, as aforesaid.

To prescribe regulations for the disiufeetion of all premises, bnildings, and railway cars, and of all objects from or by which infection or contagion may take place or bo conveyed.

To alter and modify from time to time, as he may deem expedient, the terms of all such proclamations, orders, and regulations, and to cancel or withdraw the same at any time.

o 3. Any person transgressing the terms of any proclamation, order or regulation issued or prescribed by the governor under authority of this act shall be gnilty of a misdemeanor.

0 4. All expenses incurred by the governor in carrving out the provisions of this act and in performing the duty hereby devolved upon him, shall bo andited by the comptroller as extraordinary expenses of the executive department, and shall be paid ont of auy moneys in the treasury not otherwise appropriated.

\section{THE IMPORTATION OF CATTLE PROHIBITED.}

The following is an official copy of the act passed by Congress to prohibit the importation of cattle in 1865 :

AN ACT to prevent the spread of foreign cliseases among the eattle of the United States.

Be it enacted by the Scnate and Housc of Representatives of the United Statcs of America in Congress assembled, That the importation of cattle be, and hereby is, probibited. And it shall be the duty of the Secretary of the Treasury to make such reginlations as will give this law full and immediate eftect, and to send copies of them to the proper officers in this country and to all officers or agents of the United States in foreign countries.

SECTION 2. And be it further enacted, That when the President shall gire thirty days' notice by proclamation that no further danger is to be apprehended from the spread of foreign infectious or contagions diseases among cattle, this law shall be of no force, and cattle may be imported in the same way as before its passage.

Passed the House of Representatives December 11, 1865.

Attest:

EDWARD MCPHERSON, CTerl:

\section{THE BRITISH GOVERNMENT.}

The following is an abstract of the rules and regulations aclopted by the British Government to prevent the spread of the rinderpest and pleuro-pneumonia among cattle, and foot and mouth disease among sheep in its Indian possessions:

1. When eattle or sheep are purchased at a fair, they should always be treated as having been probably exposed to contagion.

2. When cattle or sheep aro being removed from one locality to another, they should not be allowed to mix with other cattle or sheep en route, and should nerer be kept orernight in or near quarters previously ocenpied, as such quarters are often contanimated by haring recently been occupich by diseased animals.

3. When cattle or sheep are purchased in a fair or elsewhere, they slonild, on being bronght to the purchaser's premises, be kept by themselves, and not allowed to mix with the old cattle of the farm, at pasture, or watering time, or any other time. They should be kept by themselves in complete isolation for one month or six weeks, in order to have proof afforded whether they are affected with a contagions disease or not.

1. When cattle are traveling, or are moved from one district to another. they are 
liable to bo exposed to contagion and contract disease; therefore, on their arrival at home, they should be earefnlly inspected, and if they havo passed througli an infected distriet, they shonld be lept by themselves for some time. (See Rules 20 aud 21.)

5. When cliseases of a contagions natme, or supposed to be of a contagions nature, appear among eattle, the dirst important duty is to separate the sick from the healthy animals.

6. Carefully inspect all the animals, and remove to the hospital any showing the slightest symptoms of ilisease.

7. Divide the liealthy cattlo into several lots, making each lot as small in number as space will permit. Picket the eattle in such lots a good distanco apart and to windward of the sick cattle. Frequently inspect each lot, and remore at onco any animal in the least unwell. By steadily adopting this plan, tho disease will bo found in a few days to exist only among one or two lots, and by at once removing to the liospital any becoming sick, tho disease will spcedily bo arrested in spreading through tho herd. Each lot should be kept isolated from other cattle for a period from four to six wecks.

8. The hospital to contain the diseased eattlo should be inclosed by a strong fence and isolated. The attendants and the sick cattle must not bo permitted to leavo the isolated area. Food and water may bo taken to the attcudauts and cattle, but no forage, water, litter, elothing, or anything elso shonld bo taken from tho hospital. Dogs should not be allowed to go to and from the hospital, as they may earry contagium to places where healthy stoek may be.

9. The dry litter, \&c., of the hospital should bo burnt inside tho hospital area, and the moist dung and discharges, \&e., should be frequently removed from tho stalls and buried in pits dug in tho hospital premises. These pits shonld bo six fect or more deep, and should be filled with the wet litter, dung, \&c., of the hospital up to within two feet of tho surrounding ground surface, and then quicklimo and good fresh earth should be used to fill np the remaining two feet.

10. The stalls, walls, \&c., and ground of the lospital should be scrupulously cleaned by frequent sweepings and washings, and after every cleansing disinfectants, lime, ashes, or even dry carth, should bo plentifully scattered over the floors and ground, and the wood-work and walls should be first washed and then whitewashed.

11. The hospital should be well ventilated; sulphur fumigation should be daily carried out for an hour or so in tho hospital building, and at this timo the doors and windows may be closed and the ventilators only kept partly open.

12. The constant burning of sufficient litter, opposito tho doors or the windward side of the building, at seasons when flies are numerous and troublesome to cattle.

13. The sick eattle shoukl bo kept scrupulously clean, and have thin gruel and fresh green grass in its season for diet. The healthy cattlo should also be kept on laxative food, as cattle fed on hard dry food havo tho disease in a more serero form than those fed on laxative foller.

14. When these contagions diseases have prevailed among eattle or sheep, they should not be allowed to pasture, or to bo kept with unaffected herds, until a month or six weoks have oxpired after tho last caso of diseaso occurring among the affected lot.

15. Animals that recover should be well washed with warm water and soap prior to being removed from tho hospital, and, if obtainalle, carbolic acid should bo alded to the warm water in the proportion of one wineglassful of the acid to a gallon of warm water.

16. Carcasses of stock that dio of rinderpest, black-quarter, and other forms of anthrax fever, and pleuro-pnemmonia, should be buried and covered with at least four feet of earth.

17. The hides of cattlo that die of these contagions diseases should be either well scored or slashed with a knife, thus destroying their value, and shonld be then buried with the careasses.

18. The surface of earth floors of stalls and ground on which cattlo affected with contagious diseases havo been kept should bo removed and buried, and the earth below should bo well dug up and turned over, and the floor remade with iresh eartl. Brick and stono floors may be scraped, washed, and disinfected with cynicklimo or earbolic acil.

19. Poles of carts and harness, or saddlery, \&c., used by animals affected with contagious diseases, slionld bo washed and disinfected.

20. Tho periods of incubation of rinderpest, black-quarter, and other forms of anthrax fever all believed to be within twenty-cight days; so a month has been naned as the timo for an animal supposed to havo been exposed to the contagimn of these diseases to be kept isolated.

21. The period of ineubation of pleuro-pneumonia varies from two to six weeks, but has been found, as a rulo, to bo about forty days; so, when cattle liave been exposed to the contagium of this disease, they shonld bo kept isolated for forty-five days. 


\section{A STRANGE CATTLE DISEASE.}

\section{Mr. W. W. Lenoir, of Shull's Mills, Watauga County, North Carolina,} gives the following account of a strange disease which has prevailed among cattle in that State for several years past:

Sin: Your lettcr, directed to my former residence in Haywood county, North Carolina, reached me after long delay, but ought to have been answered sooner. I retained no copy of the letter written by mo in 1872, to which you refer, in relation to the strange disease among cattle which has bcen of late years in tho North west aud North, incorreetly ealled the Texas fever, but which was known throughout a large portion of the South for many years before the independence and annexation of Texas by the -aguc name of the distemper, and is still so named.

It evidently prevailed first near the coast, and a dim outline of its history and progress, and of tho imperfeet knowledge and erromeons theories which prevailed eoncerning it, can be traced in this State, and probably in other Southern States, in the legislation concerning it.

In North Carolina we have a broad belt of land adjoining the coast, stretching entirely across the State from Virginia to South Carolina, which is almost a lerel plain, and whieh extends far enough inland to include many counties and parts of counties. This belt is eomposed of large bodies of exceedingly rich alluvial swamp-lands, which aro rarely dry enough for cultivation without artiticial drainacre, and which lie along the streams, and are separated from each other by bodies of lavel, sandy, Ary land which form the remainder of this level belt.

These swamp-lands aro covered with dense forests of eypress, juniper, oak, and quite a variety of other kinds of trees, many of them of immenso size. The dry sandy lands bctween the swamps are covered almost cxclusively with forests of pino trees.

Above this level belt lies another broad belt, which also sweeps entirely across the State, and is called tho sand hills. Tho alluvial lands along the streams extend through and above the sand hills, and have a similar forest growth, but are narrower, and form sometimes swamps and sometimes rich alluvial bottoms dry enough for culti. vation in grain without ditehing. The uplands of the sand-hill region are composed of innumerable hillocks, and low tlat ridges, and narrow plains of rery sandy land, the forest growth of which is almost exclusively pine.

Abore the sand-hills and extending from them to the Piedmont region, another broad belt runs across the. State, which may bo called the midland belt of Nortl Carolina. This is an undulating region, composed of elas upland, interspersed with fine alluvial bottoms along the streams. This belt is almost destitnte of pine, cxcept in the old ficlds, of which there are far too many-lands which havo been once in eultivation, and hare now growu up in thickets of what are ealled old-field pines. The principal nativo forest growth of this belt of the State is oak, with an abundant mixture, however, of hickory, poplar, walnut, dogwood, sourwood, gum, and a variety of other trees.

Above this midland belt of the State comes the Piedmont region, extending to the foot-hills and lower portions of the southeastern slopes of the Blue Ridge, and including the secondary ranges southeast of the Blue Ridge, called Lauratorrn, Brushy, and South Mountains, \&e.; and the fine Piedmont ralleys of the Dan, Yadkin, Catawba, Broad, and other rivers; which lie between the smaller mountain ranges and the Blue Ridge.

The Piedmont region is marked by a surface bccoming by degrces more and more undulatory, broken, and at length mountainous; by the presence still of alluvial bottoms along the streams; by a greater variety of soil as well as surface of the uplands, portions of whicl are here found to be somemhat sandy; by a greater variety of forest trees, and by the partial reappearance of pines, which are now found scattered over the uplands among the other trees, not in excess, but in ample abundanco.

Finally, wo have the monntain region, including the summit of the Bluo Ridge, which in North Carolina forms the water-shed between the Atlantic and Mississippi waters, and extending from it to the Alleghany range, which forms the Stato line between North Carolina and Tennessee. This highly elevated mountain belt has a cool, moist, temperate, healthful elimate, and a delightfully varied surface of lovely valleys and rich mountain sides. Its agricultural resourees are wonderfully varied and extensive. It is a laud eminently suitable for permanent pastures and meadows; and when its immense forests are subdued and its lines of transportation opened up, it will soon become the finest grazing, stock-raising, and dairving land in the United States.

Please excuse this slight outline of the State, which is interesting in itselt and has some bearing on the subject.

An early statute on the subject of the "distemper," enacted in North Carolina many years ago, prohibited the driving of cattle from the pine lands in the eastern portion 
of the State to the oaklands in tho middle portion of the State. This marked the progress the lisease was making at that dato, and indieated tho belief that its cause existed in and was confined to tho pine lands in tho eastern portion of the State. But the diseaso has slowly erept across the midland belt and into and nearly across the Piedmont belt of this State. A recent North Carolina statuto, passed I think in 1876\%7, prolubits the lriving of cattle from below the Blue Ridge into Watauga county, which is on and west of the I3lue Ridge, in the mountain region of the State.

I regret that I have not the means, in this secluded locality, of giving you exact dates and fuller references. I think that when I wroto tho letter in $187 \%$, to which you refer, tho "distemper" hat just reached Morganton, in Burko county, North "Carolina, within a few miles of the foot-hills of the Blue Ridge. I am glad to be ablo to state that its progress, as it approaches the Blne Ridge and reaches higher eleration, secms to be slower; and strengthens the belief generally helel here, that it will not ret a permanent foot-luold in the cool climate of our mountains west of the Blue Rilge.

Some of the facts comnected with the progress and contagions elaracter of this discase aro so strango as to challenge credulty; and yet so important and so easily rerified, that it is still more strange that they are so littlo known, and have becu subjected to so littlo careful aud systematic investigation.

The progress of tho discase orer the region which it infests may bo compared to that of tho discase callerl ringworm on a surface of the human body. "There is a slowly advancing angry exterual border around the infected region, in which border tho diseaso is violently active, lilling a large proportion of the cattlo where it first makes its appearance, on many of the farms all, or nearly all. This angry border adrances at an irregular rate, and presents an irregular ontline, pausing in places for several years; and then perhaps advancing suddenly and destructively sereral miles in a single season. I think I havo observed in Caldwell and Burke comnties, Nortl Carolina, and it is probably the caso clscwhere, that it sometimes makes more rapil progress along tlio deep valleys than above them. I hare not observed that it adrances along tho leadin thorouglifues of travel and traftic, exeept as they conform with such valleys. lu Wilkes county, Nortl Carolina, it has macle a long panse on the south bauk of tho Yalkin River. But I foar it is about to get a permanent foothold on the north bank. James Gwyn, Elkin, Surry connty, North Carolina, who lives on the north bank of tho Yadkin in Wilkes comty, has lost cattlo twico from it, and can inform you of its progress, in lis neighborhool.

But thougl thus ixegular in its nutliue and progress, this angry border which surrounds the inteeted region has, at all times, a tolerably detinite location, and is clesignated among us as the "distemper" line. "The region within, over which the diseaso has already passed, is said to he within or below the "distemper" line. The region beyoud it to which the distemper has not permanently reached, is saik to bo above or without the "distemper" line.

The disease is most fatal in autumn, disappears after white frost, and does not reappear until warm weather in the late spring or summer.

'The country below the distemper lino, like the surfaco within the borler of the ringworm, seems to be eomparatively free frow the lisease. The eattle lavo becomo acclimated, and thero are only oceasional cases of tho "distemper." But whenerer" cattle from abovo the distemper lino are driven bolow it after wam weather is well adranced, or in winter, and suffered to remain there till then, there is a strong probability that they will take the "distemper" and die of it.

When cattle from below the distemper line are driven above it in winter, they may remain there permanently without any probability that they will sufler from or propagate the discase. And if cattle from below the "disteruper" lime, and acclimated lhere, are driven abore the distemper lino after warm weather has set in, they will thrive and fatten, and show no ontward appearance of the disease. But they iupart the disease in its most destruetivo character, especially when they have been lueated by hard driring or work, to the healthy eattle around them. Cattle only passing over the road which they have traveled, it nay be several days before, if it las not rained in the mean time, will take the cliseaso and clie. As eattlo aro very apt to sucll tlio rung of other eattle in passing over it, it seems probablo that in such cilses the gerus of the disease are inlialed from the dmur.

Still more woudertil than this, when taken in connection with it, is the fact that the cattlo thus taking the clisease from apparently healthy eattle, and dying of it in its acute form, may die surrosuded by healthy cattle of their own neighlyorloood to which they will not impart the disease. However violent such acciclental outbreaks of the discaso may be at tho time, it never gains a permanent foothold when carricel in this way far above tho slowly advancing "distemper" line.

I am not slilled nor well-read in tho diseases of cattle, or in otlici eliseases. In the only book 1 have which treats of tho liscases of eattle, a slip-shou American rehash and abridgment ot a standard English work, tho diseaso called in Englaud red water resembles our so-called "distemper" more than any other cisease described in it. 
The organized aud widely extended inquiries of your department might determine somo very interesting and important questions concerning this clisease. Has it causes which give it a spontaneons origin in eertain loealities in the Southern States? Can those canses be removed? What are tho best methods of preventing the spread of it besond those localities, and of sappressing it whero it has already a permanent footlold beyond them? What is tho best treatment of tho animals attacked ly it, \&c.

A widespread belief exists that it is cansed by ticks. I am suro that this is an error. Bat it is worth investigating for the salse of explocling it. The ticks which often prey in clisgnsting numbers on the cattle at the South, both above and below the "distemper line," and may well aggravate the distemper, or any other disease, are worth investigating on their own account. Cattle may be kept free fiom them by tho regular aldition of brimstone to their food or salt.

Hoping that this very meager and imperfect statement may aid you in direeting a more minute and accurate investigation of this disease, which lias been so fatal to Southern eattlo and has so depressed their value,

I am, very respectfully, yours,

Hon. War. G. Le DUC, Commissioner of Agriculture.

W. IV. LENOIR.

\section{RINDERPEST OR CATTLE PLAGUE.}

The following letter, addressed to the Commissioner of Agriculture, gives the symptoms and post mortem appearances of the destructive disease known as rinderpest or cattle plague:

Sin: At yonr request I will give as fully as possible the symptoms and post nortem appearances of a fatal disease in cattle, known as rinderpest or cattle plague.

The clisease I allude to made only one great invasion in Great Britain during the presert century (in the years 1865 and 1866), and swept away many thousands of caltle, tho money loss from its ravages being between ten and twelve million pounds sterling. At that time (1865 and 1866) I was in practice in a largo agricultural distriet of England (Berkshiro), and as soon as the diseaso visited that county I was appointed by the govermment one of the cattle-plague inspectors, and therefore had ample opportnnities of examining large numbers of animals affected with the clisease, and availed myself of tho chanee of making many post mortems.

The disease is purely contagious, and therefore preventable. It is a specifie, malignant fever, indigenous to the Asiatic steppes of Russia, runs a definite eourse, and generally terminates fatally. It is essentially a clisease of the bovine fanily, but may be communicated to the sheep, goat, deer, \&c. It has a period of iucubation varying from four to ten days; during this period the animal gires no indieation of being affected.

Symptoms.-Primary fever, as indicated by a rise in the temperature; a remarkably dull and dispirited condition of the animal, which will stand with its head hanging down, cars drawn back, and coat staring, refusing all fool or ever water. Rumination is suspended; if made to move it shows great prostration of strength, and frequently staggers as if about to fall. The skin is hot in places, and remarkably so betwcen the finus; an eruption on, and a peculian appearance and condition of, tho mucous memlurane of the mouth is scen; it is red and furred, presenting raw-looking spots, especially on the inmer side of the upper lip and along the roof. The breath is fetid, and the mucous membrane of the vagina alters to a dark-1ed eolor. These signs are rarcly absent. 'Tears carly trickle from the eyes, which aro red and expressive of suffering, and a watery discharge flows from the nostrils. There is a continuous increase of these secretions, which become more or less purulent in the adranced stage of the malady; rigors aud twitching of the stperficial muscles, failing pulse, oppressed breathing, sores on the skin, with discharges from the same. Emphysema of the tissues of the neck and back; the extremities are cold at the commencement of the risease, and in the latter stages the increased heat of the body gives plaee to a romarkable coldness along the eon'se of the spine. Secretion of milk is amesterl vory suddcnly, the animal grinds its teeth, arches the back, moans, and shows signs of great uneasiuess.

$\Lambda t$ first tho bowels are constipated, but soon violent purging eommences, lealing to dysentery, the evacnations being slimy, liquid, and sometimes of a dirty-yellow color, tinged with blood, of a fetil character, with muel straining. The urine is seanty and dark in color. The bnceal membrane becomes covered with a yellowish-white inaterial, which can be casily stripped off, showing an ulcerated surface uuder it. The ani- 
mal now stands with great difficulty, gets quito drowsy and unconscions; the breathing short, quick, and more painful.

The animal will sometimes sink as carly as twelvo honrs from tho commencement of tho attack, bnt in many cases tho diseaso will be protracted to the fifth or sixth, and occasionally to the eighth or ninth day. As icath approaches the inncous membranes acquiro a leaden lune, with dark-colored spots on their surface. Tympauitis sets in, and the discharges from the lowels aro involuntary.

The mortality in Great Britain was very great. The disease is highly contagions, and will not yield to medical treatuent. Vaccination ancl inoculation wero tried, but all secmed only to spread tho postilence.

Post mortem aplicarances will differ according to the part of the organism chiefly affected, and especially according to the timo of duration of tho malady. In many cases, the roof of the mouth will bo fonnd covered with a dirty-yellow exulation upon an ulcerated surface, the lining of tho larynx, pharynx, and all tho mucous membranes of the mouth is of a deop red color, and often covered with a larer partaking of the characters of lymph and pus combined, varying from the finest film to a quarter of an inch in substance. Tho lungs aro often covered with a soft membranous exudation; emphysema of them is also very commonly found, but not always. On opening tho abdominal cavity, the omentum is frequently found to present patches of redness; the intestincs aro altered in color, from the condition of tho mucous membrane being partially seen through their walls. On cutting tho rumen (or pauncli) a quantity of nndigested food is generally found, but nothing more than a tinge of reduess in patclics can be found here. Tho reticulum (honey-comb) does not show any signs of tho disease; tho omasum (manifolds) affords, in the majority of cases, very characteristic indications of the effects of the malady, its folds being inflameal in patches, or vlceratod in patches, ovon showing large perforations from sloughing, with claret-colorerl edgos. The contents of this stomach are dry and eaked.

The fourth, or true digestive stomach, the abomasmm (rennet) is inflamed and shows specitic lesions of the disease. The contents are nearly always thid, and often mixed with blood; tho mucous membrano is not only intensely red, but is studded with superficial erosions; the membrane can be easily removed from the submucons tissuos, in somo cases showing deep sloughs or ulcers. This condition is moro marked near tho pyloric region, being of a claret color.

The intestines show similar morbid changes, partieularly the jejunum and the ileum, also the execum, which shows a peculiar mottled appearance from the accumulations, in the follicles, of a dirty-white or yellowish sceretion. Tho liver is mostly unaffected, but tho gall-bladder is remarkably full. Tho lining membrame of the vagina is of a dark red color and semi-dotached condition.

I have given above all the early symptoms of this disease, together with the post mortem appearances, and I am suro you will agreo with mo that it differs materially from any other diseaso of the cow or sheep.

Sheep will tako the discase from eattlo; in order to test this, experiments were triod at the Royal Veterinary Colloge, London. Sheep took the discase from cattlo and died, showing the same post-mortem appearances. Cattlo also took it from tho shcop and died. Atterward Professor Simonds found a largo number of sheep in England affected, from having bcen in company with or near discased cattlo.

Professor Law, of Cornell University, says: "Treatment of this plagne shonld bo legally prohibited under all circumstances, all the attempts of tho different schools of medicine, and of empiricism have only increased its ravages; whilo nations and districts that have vigorously stamped it out, and excluded it, havo saved their property."

I trust we have no cases of this terrible scourgo in this country, amd that the reports in some of the Philadelphia newspapers of the past week, of its prevalence in the vicinity of Washington, may prove to bo unfounded, as I have cause to believo they are. But if ever introduced into this country, the victims and all other eattlo with which they had beon in contact, should be promptly destroyed and buried decply, and the places and things with which they havo come in contact bo disinfected in the most perfoct mamer.

I have tho hoinor to be, sir, your most obedient scrvant,

JOHN W. GADSDEN,

Philddelpuin, October 26, 1878.

M. I. C. V. S., England. 



\section{G L A N D E R S.}

\section{EXPLANATION OF ILIUSTRATIONS.}

[These illustrations are photographic copies of the plates accompanying Professor Gerlach's treatise on glanders, published in the Jahresbericht der Koeniglichen Thierarzncischule zu Hannover, 1868. The same illustrate the morbid anatomy of glauders.]

Plate I.-Fig. I. Development of glanders-cells of connective-tissuo corpuscles in the mincous membraxe of the septum. Enlargement 300 .

1. Spiudle-shaped cells, with a large oval nuclens.

2. The same, more swelled; mucleus larger; a second nueleus developing.

3. Cells liko No. 2, but with cnds blunted; more grannlated aud approaching decay.

4. Round eells of different size, with a large nucleus; tho largest ones havoa dark, graunlated nucleus; beneath free nuclei and gramulaterl detritus.

FIG. II. Mieroseopic ent from gray-5ellowish glauders; nodules of the mucous mentbrane of the septum, in which (cut) can be seen spindle-shaped cells in different stages of development to round cells with a fibrous intercellular substance. Enlargement 300. At $a$ the spindle-shaped cells and at $b$ the round colls provailing.

FIG. III. Development of glauders-cells of epithelium elements in the pulmonal zodules. Enlargement 300.

1. Normal eylinder-eell with a nuclens.

2. Cylinder-cell with a second nucleus doveloping.

3. Cyliuder-cell with two and threo developed nuclei.

4. Bag-shaped rudiments of cylinder-cells filled with young round eells.

5. Giant-colls with joung round cells.

6. Small and large round cells with a large, lark, and granulated uncleus.

Plate II.-Fig. IV. Lower end of the septum with glanders-nodnles and ulcers. (Natural size.)

1. Various gray glanders-nodules.

2. A group of glanders-nodules with a round hole in the middle. (Incipient glanders-ulcers.)

3. A solitary glanders-ulcer.

4. Coufluent glanders-ulcers with elevated borders and dirty bottom.

Fig. V. Transversal ents through the gray nodnles in the mucous membrano of the septum. (Natural size.)

a. Gray nodule in the midst of the tissue of the mucous membrane; the upper layer of the mucous membramo raised.

b. Gray nodule in the upper layer of the mucous membrane, risible on the surface.

Fig. VI. A picce of the lower border of a lung, cut surface. (Natural size.)

1. Miliary tubereles.

2. Tuberelo of tho sizo of a pea.

3. A large chlamelers-uodule dereloping.

Fig. VII. Also a piece of the lower border of a lung, eut surface. (Natural size.)

I. Miliary nodules sumzonnded by a red crust.

2. Large gray glanders-nodulo (glanders excrescenco) growing yet in one direction. 


\section{GIANIDHIRS.}

Report fommissiones of Agriculture for 1878 .

Plate 1 .

Fig.1.
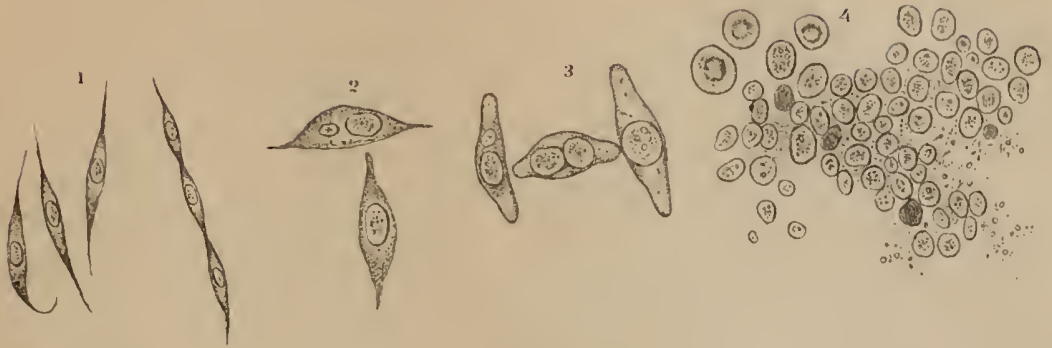

Fig..1.

Development of glanders-cells of comective-tissuc corjurscles in the mucous membrame of the septum

Fig. II.

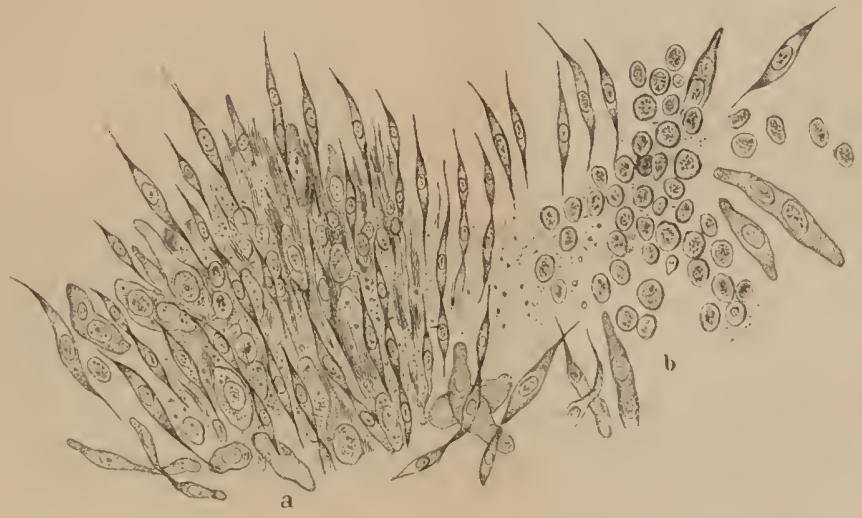

Fig. II

Mirroscopje cul from gara-yellowish glanders.

Fig.III.
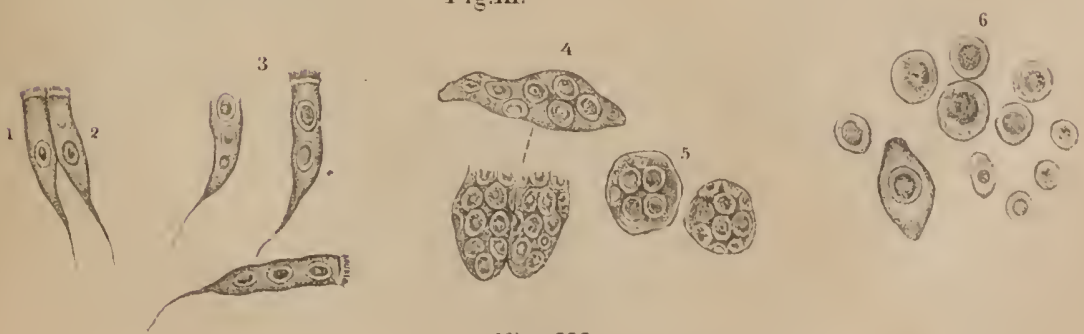

l'ig. III

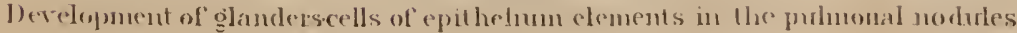





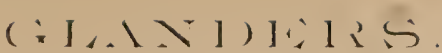

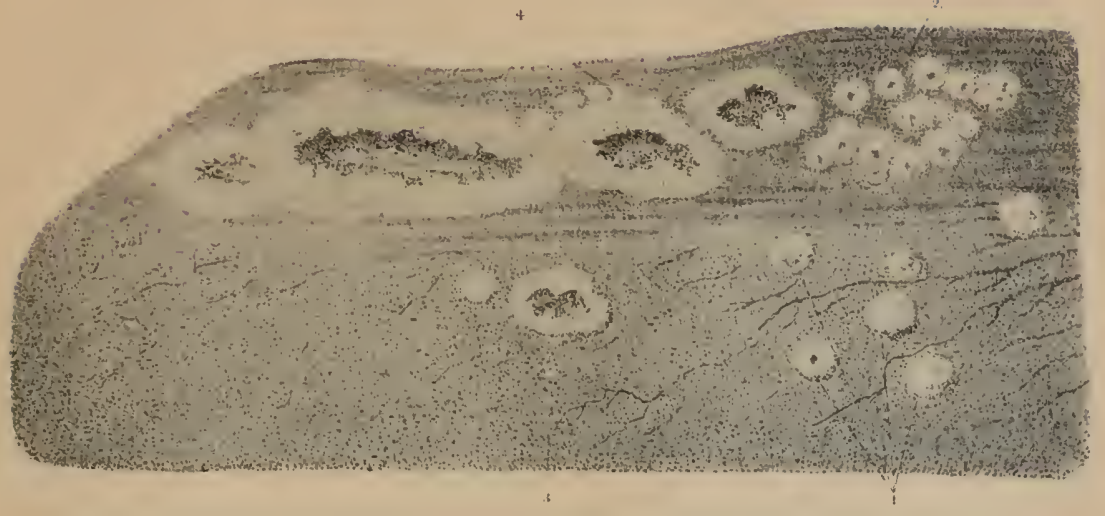

l'iog. II

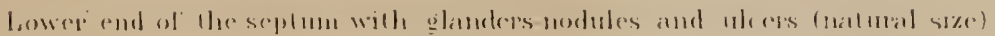

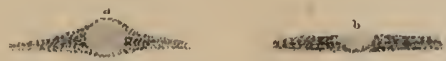

l'ie. 1 :

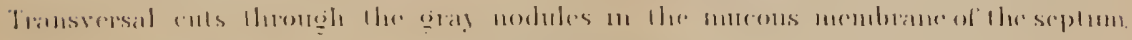
$\mid$ |เil|1;a) si\%(2).

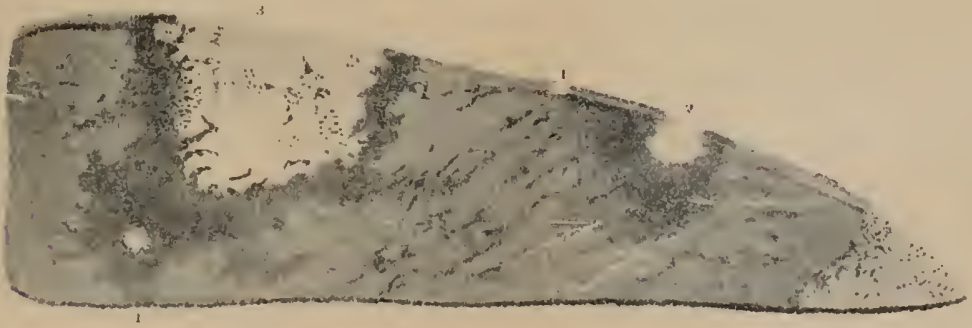

Fid I I

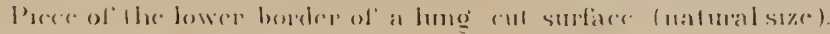

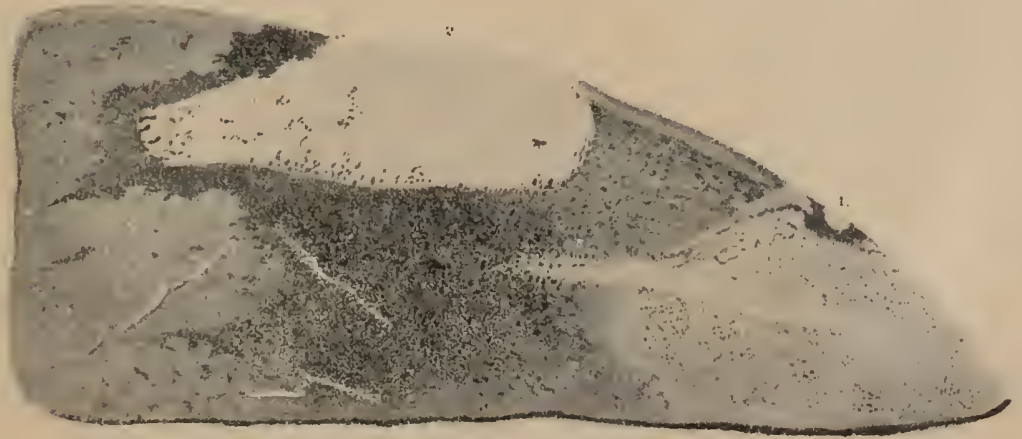

l'iog. I'II

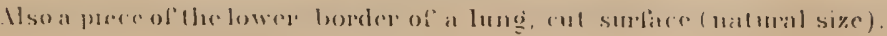





\section{GLANDERS.}

Br Dr. H. J. Demmens, V. S., Chicago, $I I$.

Defnrtron.-Glanders is a contagious diseaso sui generis of animals belonging to the genus cquus. It has usually a chronic course, can be communicated by means of its contagion to sereral other species of animals and to human beings, and must be considered incurable if fully developed. The principal seat of the morbid process is usually in the mucous membrane of the nasal cavities. Three main symptoms, viz., discharges from the nose, swelling of the submaxillary lymphatic glands, and particularly ulcers of a peculiar, chancrous character in the mucous membrane of the septum of the nose, characterize glanders, and are, therefore, of the greatest diagnostic value. Wherever theso three symptoms, or only two of them, are present and fully developed, there the diagnosis is secured. But unfortumately this is not always the case; sometimes two, and even all three, principal symptoms may be wanting, and still the horse may be affected with glanders. In such a case the seat of the morbid process is not in the nasal carities, but further on in the respiratory passages, or even in the lungs. Several such cases have come to my observation, and have also been described by others, especially by Professor Gerlach. In still other eases, in which the disease might be called "external glanders," but is better lnown by the name of "farcy," the morbid process has its principal, or even its exclusire, seat in the subcutaneous connective tissue and in the skin or cutis. The late Professor Gerlach, in his treatise on Glanders, published in the "Jahresbericht der Koeniglichen Thierar:neischule zu Hannover, 1868, discriminates, in consequence of these differences, three distinct forms: Nasal or common glanders, pulmonal glanders, and farcy. As such a division of glanders proper into nasal and pulmonal glanders-farcy is described by erery author under a separate head-facilitates considerably the diagnosis, and explains also at once why just those symptoms which are ustually looked upon as most characteristic remain sometimes imperfectly developed, or entirely unobserved, it will be convenient to adopt Gerlach's classification.

1. NASAL GLANDERS.-This form is that which is most common, best known, and characterized by the three principal symptoms which havo been mentioned.

(a.) The discharge from the nosc, although the most conspicuous of those three symptoms, is really the one which is the least characteristic, or of the least diagnostic value, because several other diseases of the respiratory organs are also attended witl discharges from the nose, which are more or less similar. It is true, the discharge in glanders possesses some properties which, if considered as a total, are characteristic and are not found combined in any other disease; but the difficulty is one or another of these qualities is not always sufficiently developed. Consequently, if the other two principal symptoms, the swelling of the lymphatic glands and the ulcers in the nose, are absent or not obserred, the discharges 
from tie nose are seldom characteristic enough to serre as the sole basis of a reliable diagnosis. rithe same are frequently onc-sided, and, according to most anthors, oftener from the left than from the right nostril. According to my cxperience they are nearly, if not quite, as often from the right as from the left nasal earity, ancl, at any rate, just as often from both nostrils as from one only, but always more abundant from one, either right or left, than from the other. At the beginning the discharges are usually thin, alnost watery, frequently greenish, or somewhat similar in color to grass juice; afterrward the same applear to bo composed of tro different fluids, one sellowish and watery and the other whitish and mucous. Still later the discharges become thicker, more stieky, exhibit frequently a inixtme of different colors, are sometimes greenish, sometimes dirty white or grayish, contain not selclom streaks of blood, and, in adranced stages especially, particles of bone or cartilage. They have a great tendency to alhero to the borklers of the nostrils and to dry there to dirty yellow-brownish crusts. As to quantity, tho nasal discharges in glinders are seldom very copious, at least not as copious as in many other discases-strangles, for instance. The quantity, howerer, varies. Sometimes, especially when the weather is warm and dry, the discharges may be very insignificant or bo absent altogether, and, at other times, particularly if tho weather is rough, wet, and cold, will increaso in quantity and becone comisaratively abundant. Several anthors have attached sipecial importance to one or another of the vaxious properties as something characteristic, by which the nasal discharges in glanders ean be distinguished from those of other disesses, but, in reality, none of those properties are constant enough, or belong exchisively to glanders, to be alone of great diagnostic value. Sollejsel and Kersting considered the stichiness as such a characteristic, but the discharges in straugles are frequently just as sticky. P'inter and Vitét relied upon the specific gravity; they found that the nasal diseharges of glanders, which consist partly of inatter and partly of mucus, sink to a certain extent in water, while the muens discharges of distemjer swim on the surface. This test is of some value, but is not decisire, because matter is sometimes admired also to the nasal discharges of other diseases. Others have laid stress upon the one-sidedness of the discharge, but the latter is just as often from both nostrils as only from one, and a one-sided discharge belongs also to some other discases; is, for instance, observed in a catarthal infiammation of one of the frontal or maxillary sinuses, if earies in one of the three last molars of the upper jaw has efiected a fistulous opening into the maxillary simus, if a polypus lis deroloped in one of the nasal cavities, \&e. Professor Gerlach considers the greenish color as a very importaut characteristic, but that, too, is not reliable, becanse it is not constant, is usually observed only at the beginning, and belongs frequently, also, to the nasal discharges of caturh, stramgles, and influenza, if the patients are kept on green food or in a pasture. The masal lischarge constitutes a characteristic symptom of glanders only, if all its essential properties are present (sufticiently (leveloped), and are cousidered as a whole. If the other principal symptoms (swelling of the Iymphatic glands and uleers in the nasal cavity) are absent or remain umobserved, some minor symptoms, which may happon to be present, and the absence of all such symptoms which are peculiar to other diseases, make fiequently a diagnosis possible.

(b.) A distinetly limited swelling of the submaxillary lymphatie glands constitutes the second essential sympton, which is more elaracteristic of mlanders, and of greater cliagnostic value than the discliarge from the nose. The swelling corresponals to the discharge; that is, if the latter 
is one-sider, for instance, from the left nostril onlr, the glands of the corresponding left side of the Lead are affected, and if the discharge is from both nostrils the glands of both sicles are swelled, but always those of that sire the most on winich the discharge is most copious. The stelling does not exhibit any conspictons sign of infammation, and is usually not nainful, excent at the beginning or after a studden increase of the morbid process. It is almars clistinctly limited, and the swelled gland is always havd and msually of tize slape and size of a peanut; may ocensionails, howerer, be fond as large as a hen's egg. Large inflammatory strellings without distinct limits do not belong to glanders. At first the smelled glands are more or less movable beneath the skin, but afterwards, in an adranced stage of the clisease, the same frequently appear to be attached move or less firmly to the bone and are immovable. The swelling, unless irritated by external causes, never dissolves in suppuration like the inflammatory strelings conmon in distemper, and is absent on ir if the Irmpliatic glands bave been extirpated, if the lymphaties have become obliterated, or if the morbid process in tho micous membrane of the respiratory passages is situated too high to be within the province of those irmphatics which are connceted with the submaxillar: glands, for the strelling is cansed solely by a deposit of deleterious matter which has been absorbed by the lymphatics. Professor Gerlach looks mon every horse as probably affected with glan. flers which shows a distinctly limited, hard, knotty, and painless swelling of the submaxillary lymphatic glands. I will not contradict a man. of his experience and learniug, and admit that such a swelling constitutes a rery suspicions and characteristic indication of glanders, especially if some other symptoms of that disease are also present; but I am obliged to remark that I have seen horses not affected with glanders in which those glands were strelled to the size of a peanut, and rero hard, without pain, and morable.

(c.) Uleers of a peculiar, chancrous character on the mucous membrane of the nose, and especially of the septum or cartilaginous partition between the nasal cavities, constitute by far the most characteristic symptom, and, in fact, the only one which makes the diagnosis a certainty, eren if all other symptoms shonld be absent or imperfeetly dereloped. Still, such is merer the case; if there are ulcers in the nose, then there is also a discharge of matter mixed with mucus from the corresponding nostril. In some cases these ulcers are present, but are situated too high to be seen unless the horse is examined in bright sumlight and the rays of the sum are reflected by a mirror into the cavity of the nose. The seat of the ulcers is nsually on the septum and near the nasal bone. Their size and shape vary (Fig. IV). Some ulcers are small, isolated, almost round; others are large, of an irregular shape, and of meren depth. All produce matter, have elevated, corroded worders, a dirty, steatomatous-looking bottom, and are never covered with a scab. $\Lambda$ t first small gray specks or elerated gray spots (glauders-nodules), varying in size from that of a pin's head to that of a pea, make their appearance (Fig. IV, 1 and 2 , and Fig. $V$, $a$ and $b$ ). These notules soon decay and form nlcers. Gradually the nleers inerease in size and depth (Fig. IV, 3$)$; their borders become more elevated and corroded; the process of decay goes on; and if trro or more small ulcers are close together, they become confluent, unite, aud constitute one large, irregulariy-shaped ulcer (Fig. IV, 4), which continues to increase in size and depth. Deeay and destruction work their way deeper and deeper, eren into the cartilage, and if nleers happen to be existiug in both cavities, or on both sides of the septum, it occurs not seldom that the latter becomes per- 
forated. I obserred sereral such cases, one especially in Lee Centre, Lee county, Illinois, in 1866, in which the hole in the lower or anterior part of the septum was fully as large as a silver half-rlollar. The borders of the same appeared irregular, corroded, mnch swelled or elevated over the surface of the septum, and coated with a dirty-looking, liscolored, and blood-streaked glanders-matter. The disease, in that case, was far adranced, and the animal about ready to die.

Sometimes it happens that a glanders-nlcer shows a tendency to heal; it loses its chancrolis character; granulation makes its appearance; a scurf or scab is formed; a healing takes place, and a fibrous, whitishcolored, somewhat puckered or star-shaped scar is left behind.

Some authors have attached considerable diaguostic importance to a bluish or lead-gray color of the nasal mucous membrane, and to bluish or lead-gray spots, which usually make their appearance before it comes to nlceration. Such a bluish color, howerer, is not a constant symptom-in some cases only small red specks can be seen on an otherwise rather pale mucous membiane, and is not characteristic either, becanse it is observed also in eatarrhal diseases, and in horses driven against the wind in cold weather.

(d.) Ifinor symptoms. - The three principal symptoms just rescribed are usually accompanied by some others of minor diagnostic value, but under certain eireumstances very important, especially if one or another of the principal symptoms should happen to be imperfectly developed. As such minor symptoms, may be mentioned, first, an accumulation of a glassy, whitish-giay mucus in the inner canthus or corner of the eye of the diseased side of the head. It is a symptom which usually makes its appearance at the beginning of the discase; second, a lusterless, dry, and dirty-looking, or so-called "dead" coat of hair; third, more or less difficulty in breathing; fourth, a peculiar short and dry congh, somewhat similar to the well-known congh of a horse affected with heaves. These last three symptoms, of which the congh is the most eharacteristic, make their appearance only after the morbid process has made considerable progress. In some eases the plain ontbreak of tho disease, or the appearance of plain and nmmistakable symptoms, is preceded by a swelling of the inguinal, the axillary, and other lyuphatic glands.

The difficulty of breathing, and the peculiar and somewhat eharacteristic cough, though only minor symptoms in common or nasal glanders, rise to great diagnostic importance if the morbirl process laas its principal seat in the lungs instead of the mucoms membrame of the nasal carities-if, in other words, the animal is affected with that form of the disease which Professor' Gerlach has called "pulmonal glander's."

It happens sometimes that a horse is affected with glanders and communicates the disease to other healthy animals, but does not itselt sliow any of the three principal symptoms characteristic of that disease; has $n$ o discharge from the nose, no swelled glands, and no uleers in the nasal cavities. The late Professor Spinola, in his lectures on reterinary pathology at Berlin, related such a case to his students, which will serve as an illustration. It is substantially as follows: In a village near Berlin glanders broke ont in a stable in which several horses were kept. A veterinary surgeon was ealled, who made an investigation and condemned every horse that showed any symptoms of the disease, and every animal condemned was immediately killed. The horses apparently not alffected were liept for several weeks under police control, and from time to time inspected, but finally released. Among them was one old sorrel horse which had the heares, and which had been brought 
into the stable a short time before the first case of glanders made its appearance. This sorrel horse soon after was sold to a man in another village, and came into a stable containing also quite a number of horses. In that stable, too, glanders broke out. A veterinary surgeon (another one) was called, and every horse showing symptoms of glanders was condemned and immediately destroyed. The old sorrel horse, however, which was known to have "the heaves," was again released after some length of time, together with those which had remained exempted, and was sold once more, this time to a man who kept over 30 horses (I have forgotten the exact number) in his stable a fer miles from the city. In this last stable glanders likewise made its appearance after some lapse of time, but in that case Professor Spinola was called. He, too, after a careful investigation, condemned every horse that showed any symptom of glanders, and insisted upon condemning also the old sorrel horse, whose history was then unknown to him, notwithstanding that no symptoms of disease, except such as are usual attendants of heares, conld be observed. The owner hesitated to consent to the loss of a horse apparently not affected with glanders, but Spinola insisted upon the condemnation. The post mortem examination revealed that the old horse, which had the "heaves," was affected with pulmonal glanders in a very high degree; and Spinola, after learning the history of the old sorrel, was convinced that the latter had caused the outbreak of the disease in all three stables. Professor Gerlach, in his valuable treatise, cites several cases, which to relate would lead too far. Some cases, though not so strking as that related above, have also come under my own observation. In pulmonal glanders the morbid process has its principal seat in the lungs, and may remain limited to the latter for months, and even for one or two years; and during that time, or as long as the morbid process is confined to the lungs, no prominent symptoms may make their appearance except such as are usual attendants upon heaves-some difficulty of breathing, and a peculiar short, weak, and dull cough, which must be heard, but is not easily described. Finally, however, but not before the disease has made considerable progress, the difficulty of breathing increases, more or less discharge from the mose makes its appearance, emaciation sets in, the natural glossiness of the coat of hair disappears and becomes rough, stands on end, and exhibits a so-called dead and dirty-looking appearance. The skin, too, loses some of its natural elasticity, and the animal becomes "hide-bound."

The morbid changes are revealed only at the post mortem examination. Smaller and larger glanders-nodules (usually called tubercles) present themselves in different stages of derelopment and subsequent decay in the tissue of the lung's. Some of them present themselves as formations rich in glanders-cells (see illustrations), and others, especially if the clisease is of long standing, as decayed, cheesy, dried, and shrunk substances and glanders-tumors of a sarcomatous and fibroid character. In some of the oldest ones eren a deposit of lime-salts may have taken place. I remember one case, which occurred in Germany, a few miles from iny residence, about trenty years ago, when I first commenced to practice. I was called to examine a horse suffering from some pulmonal disorder. The symptoms were those of pulmonal glanders in an adranced stage of development; even nasal discharges had made their appearance. I cliagnosticated glanders, but being young and without much experience, declined to take the responsibility of condemning the horse, becanse the laws of Germany are very strict in that respect, and provide that every horse affected with glanders be destroyed immediately. I therefore reported the case, not to the proper executive authorities, but to the 
reterinary surgeon-general, who, at my solicitation, came immediately and examined the animal. He did not pronounce it a clear case of glanders, but doubted, at least hesitated. The owner, howerer, consented voluntarily to have the horse lilled. The post mortem examination rerealed pulmonal glanders in a rery adranced stage. A similar case, of which I shall have to give a brief account in another chapter, I lad an opportunity to observe in 1866, near Dixon, Lee county, Illinois.

As the principal symptoms of pulmonal glanders are essentially, for some length of time at least, only such as are also observed in common cases of heares (one of the most frequ('nt disorders of horses), the dliagnosis must frequently be based, as a lawrer would say, upon eircumstantial evidence.

$\Lambda$ horse must be suspected of being affected with glanders, first, if the peculiar, treak, and dly cough constitutes, compared with the diffienlty of breathing, the predominating symptom; if the animal becomes more and more cmaciated and hide-bound, and if the appearance of the coat of hair is such as to indicate the presence of a cachectic disease. Second, if it is known that the animal in question has been exposed to the contagion. Third, if other horses have become affected with glanders or farcy, after having been together with the animal that shows those symptoms. Fourth, if a horse apparently affected with heaves has previonsly exhibited other symptoms, more or less characteristic or suspicious, of glanders. Fifth, if other symptous, such as are observed in so-called "nasal glect," or incipient nasal glanders, make their appearance.

\section{FARCT, OR EXTERNAL GLANDERS.}

The name "farey" is given to such eases of glanders in which the morbid process has its seat in, and immediately beneath, the skin, and in which nodnles, boils (glanders-buboes), and vilcers of a very infections and chancrous character make their appearance in the subcutaneous tissue, and in the skin itself. Glanders-nodnles and lenticnlar nlcers in the tissue of the skin, boils beneath the skin, smaller and larger open nleers penetrating the same, a strand-shaped swelling of the subcutaneous lymphatics, swelled lymphatic glands, and odemata, the latter especially in the legs and on the head, constitute the most essential symptoms.

Professor Gerlach discriminates two forms: Subcutaneous glanders or common farey, and exanthematous glanders or skin farcy.

(a.) Subeutancous glanders or common farcy. - The morbid process in this rather frecuent disease has its principal seat in the subentaneons commective tissne, and in the lymphatic system of the skin and between the slin and the museles, bnt especially on the inner sille of the hind legs, on the lips, on the neck, between the fore legs, and on all such plaees where the shin is thin and fine. At first distinetly limited swellings of an inflammatory character (incipient boils or glanders-buboes) make their appearance in the subcutaneous tissue. 'These swellings or' boils soon commence to dissolve, or to decay, from within; the nlecration begins in the center, but the matter, being very corrosive, soon works its way into the skin, the boil fullally opens, and presents a farey-rlleer with a steatomatous bottom, and elevated, correiled, and inflanerl borders. At the same time, or even before the formation of the first nlcer has become completed, deleterious matter is absorber by the nearest lymphaties, and deposited in the lymphatic glands. The former, in conseqnence, swell to hard and plainly visible conds or strands, and the latter to painful and distinctly limited tumors. The partial or total 
closing of the limphatic ressels and glands thus effected interferes with, and even prevents, a performance of their functions, or stops the absoiption of lymph, and cedenatous smelings, more or less extensire, are the necessary consequenee. The same make their appearance especially if the seat of the morbid process is on the inside of a leg, and if either the inguinal or axillary glands are swelled and closed by a deposit of deleterious matter. The more extensive and complete the swelling and closing of the lymphatic ressels and glands, or the more lymphaties are affected, the more extensive is also the œdema. Lameness, usually cansed by such an celema, is also a frequent attendant.

The rotindish boils or tumors increase in size from that of a hazel-nut to that of a hen's egg. At first, when such a boil is making its appearance, it is not fastened to the skin ; the latter can jet be mored a little in every direction over the boil, but soon the neoplastic process and the subsequent decar mill extend to the tissue of the skin, and boil and skin will become formly united before the ulcer breaks and discharges its extremely infections and corrosive contents, consisting of decaying glanders-cells or matter, and lyrimph.

(b.) Exanthematous glanders or stin farcy.-In this form of glanders or farcy the principal seat of the morbid process is in the tissue and in the lymphaties of the slin or cutis. It is a rare form in horses, but the only one in which extermal glanders or farey makes its appearance in a human being. Distinctly limited strellings (nodules and tumors) of the size of a pea to that of a lazel-put, either isolated, or mited and resembling a string of beads, malie their appearance in the tissue of the skin. These swellings soon break, and then present round nlcers with elevated and corroded borkers. The discharge consists of a mixture of matter, composed mainly of decayed glanders-cells and lympli. In other, though rather rare cases, the swellings are very snill and numerous, and present themselves as small nodules, some of which are so small as to be scarcely visible, while others are about as large as common peas. These small swellings, too, are soon changed to ulcers, which are mstully flat, lenticular, and constantly suppurating. Ii close together the same become frequently confluent. Onlr one case of skin-farey has ever come under my observation. It was abont five years ago, at Manhattan, Kans. Xinmerons, small ulcers were crowided closely together on the nose and the muzzle of the horse, which was also affected with nasal glanders.

On the lumman skin, not bcing covered with hair, the whole process ean be observed mncli better than on the skin of a horse. Professor Virchow's description of skin-farey in men may, therefore, find a place. Virchow says :

At first these spots are mucl reddenel, but very small, aimost like flea-bites; then papnlar swellings are formed : the surface of those swellings rises gradnully rather in the shape of a round and solid eleration than of a pustnle, and assumes a yellowish color, which gives it a pustulous appearnnce. If the epirlernis is remover from such a tlat or roundish papule or nodnle, which is not depressed in the center, but surromeled by a swelled and reddened cont, a puriform, moderatel consistent fellowish fluid is formed, which coutains but few or nunized coustitnents, and consists mainly of the decared elements of tho formerly solid notule. The flnid, therefore, is not lodged in a pustulons elevation of the epirlermis, but in a small bole in the corium, which penetrates the latter as if it had been made with a punch. After sone time the fluid (matter) becomes colored by hemorrhagic admixtures; still later its color is changeal to bluish red, and finally small brown or blackish crasts or scabs are formed. Sneh eruptions appear sometimes in enormous numbers on the whole boly.-(Gerlach's Treatise.)

Nasal glect.-This is a name which I lave accepted only with great reluctance, because it signifies no definite disease, and is used frequently, 
as I shall hereafter have an opportunity to show, to corer ignoranec, frrud, and crime. It ean be retained only if applied exclusively to such cases of disease (usually occult or incipient glanders) in which the horse has a suspicious-looking discharge from the nose, but shows no other characteristic symptoms snfficiently dereloped to base upon them a sure diagnosis. So, for instance, it may happen that a horse has a chronic discharge of matter and mucus from one or both nostrils, and, perhaps, also a distinctly limited swelling of the submaxillary lymphatic glands, and yet neither the discharge nor the swelling may be sufficiently characteristic to justify the decision that the horse in question is affected with glanders, because the latter is a disease which, for obrious reasons, demands a correct and positive diagnosis. To declare that a horse has glanders is equal to condemning the same to be killed. The term "nasal gleet," therefore, is convenient and admissible, if used exclusirely to signify a disorder of the respiratory organs attended with suspicious discharges from the nose, and other symptoms common in glanders, but not yet fully enough developed or sufficiently characteristic, one way or another, to make the existence or absence of glanders a certainty. Such a disorder, of course, must be considered as incipient or occult glanders till every donbt has been removed.

Chronic and acute glanders.-Glanders, as a rule, is a chronic disease. The morbid changes develop slowly. Of the varions forms in which the disease is able to make its appearance, pulmonal glanders, unless complicated with one of the other forms, or with other inflammatory or fererish diseases, is the most chronic, or takes the longest time to produce conspicuous symptoms and to become fatal. It takes frequently two or three years before the animal succumbs. Nasal glanders is usually not quite so slow in its progress; still it also very often takes half a year or longer before the morbid process makes sufficient headtray to produce plain, unmistakable symptoms, or before the chancrous nlcers, characteristic of glanders, make their appearance in the mucous membrane of the septum of the nose. Farcy, or external glanders, is usually the least chronic (comes the soonest to a termination) of the various (uncombined) forms of glanders. Plain and unmistakable symptoms (veritable farcy-ulcers) make their appearance almost always within three months and frequently within a week or two after the infection has taken place. In mules and asses, however, the various forms of glanders are usually less clironic, make a more rapid progress, are more destructive, and come sooner to a termiuation than in horses. The progress of the morbid process depends also to a great extent upon the constitution and the organization of the animal and the mode and manner in which it is kept. Weather and temperature, too, have considerable inftence; warm and dry weather usually retards, and cold, wet, and stormy or inclement weather usually accelerates and spreads the morbid process. IIost anthors discriminate between acute and a chronic form of glanders. From a practical staudpoint such a distinction is perfectly admissible, but to separate acute and chronic glander's as two different diseases, as has been done by some (French) anthors, must lead, and lias led, to rery dangerous mistakes and to great confusion. Every form of glanders, as I have said before, is naturally-co ipso-more or less chronic in its course, but may become acute, either from the first beginning or at ans stage of its development, and sometimes very sucldenly, wder any of the following conditions:

1. If a complication takes place either with one of the other forms of glanders or with another disease or disorder. Sometimes even a small 
wound is sufficient to inaugurate the acute course or a rapid progress of the morbicl process.

2. If glanders has been communicated by a clirect introduction of glanders-matter into a wound, or a direct contact of the contagion with the blood. The greater the quantity of glanders-matter introduced the more concentrated the contagion inoculated, or the larger the wound the more acute or rapidly progressing and spreading is usually the morbid process of the communicated disease.

3 . If the constitution of the animal has been meakened, or if the vitality of its organism has been serionsly impaired either bj glanders itself or by any other disease, the course of glanders, although naturally slow or chronic from the beginning, is usually changed to an acute one as soon as the morbid changes hare become sufficiently important and extensive to weaken essentially the constitution of the animal, and to cause a profuse infection or spreading of the contagion through the lymplatics in the animal organism. Toward its fatal termination glanders, therefore, always changes its course from chronic to acute. Unlike most other diseases it commences chronic and ends acute.

4. Exposure to wet, cold, and inclement weather, catching cold, hard work, close, dirty, and ill-ventilated stables, unhealthy food, Sc.-in short, ererything that is calculated to produce an injurious influence upon the organism, or is calculated to impair the health of the animal, has a tendency to accelerate the morbid process, to change the chronic course of glanders to an acute one, and to hasten the outbreak after an infection has taken place.

The morbid process of glanders is accelerated and caused to spread more rapidly if the latter becomes complicated with an inflammation, or with any rery fererish or very typhoid disease. The morbid processes of glanders and inflammation increase each other reciprocalls. The inflammatory process adopts, to a great extent, the nature and characteristics of glanders, and the morbid process of the latter disease becomes blended with the former, and assumes the attributes of an inflammation. In either case all the symptoms become rery violent, and the morbid process progresses and spreads rery rapidly, particularly in those tissues which are in a state of inflammation. Ulceration, too, becomes extensire in a short time, and the lymphatics, by absorbing the deleterious matter, seem to spread the contagion and the elements; of glanders rapidly through the whole system. If the original disease is glanders, farcy will also make its appearance mithin a short time; and vice versa, existing farcy will soon be complicated with nasal and pulmonal glanders of an inflammatory character. The exudations produced by an inflammation which has assumed the nature of glander's are always very deleterious and corrosice and destroy like a caustic the tissues with which they come in contact. The morbid changes effected by such an inflammation resemble those of a malignant diphtheria. In extreme cases the morbid process may become so violent as to cause the neoplastic process, characteristic of glanders, to be superseded by immediate destruction and mortification. In such a case profuse, diphtheritic ulceration and destruction of tissue talie the place of the neoplastic production of glanders-cells and their subsequent decas. The glanders-cells are destroyed (decay or perish) before their formation has been completed, consequently are absent.

That a direct and abundant introduction of glanders-matter into a wound, or a direct contact of the contagion with the blood, is well calculated to produce an acute form of glanders, or sufficient to inaugurate a rapid progress of the morbid process, is probably best illustrated by a 
case which occurred about eleren Jears ago, near Dixon, T.ee county, Illinois, where I was then practicing. A farmer, Mr. B., came to my office with a horse which he had recently bought, and which was apparently suflering from seme pulmonal disorder. Tho animal was in a moderately good condition and free from ferer. The morbid symptoms observed consisted in a slightly laborious breathing, a sliort, dull, but somerhat loose (not (rys) congh, some diseharge from one nostril, and a slight swelling of the submaxillary lymphatic glands of the same side of the head. The symptoms, consequently, were the same as are usually obserred in pulmonal glanders; but as none of them were suffieiently developed or presented sufficiently characteristic properties to indicate with certainty the presence of glanders, and as no nlecrs-the most important diagnostic symptom of glanders-conkl be discovered in the nose, I hesitated to make a definite diannosis, but infomed the owner of my suspicion, and advised him to put the horse, if comvenient, to hard work for the purpose of accelerating thereby the morbid process (if glanders), and to return the auinal for further cxanination within a reek or so. A few days afterwarls the same farmer came again to my office with another horse with a badly tom erelid and an inflamed eje for treatment. This latter horse, which I will c:ull hor'se No. 2, hat been bitten in the eyelicl and had the same torn by the horse rith the suspicious symptonis, which I had seen betore, and which I. will call horse No. 1. In examining the wound, which probably had been made dming the night, I found the boulers very much swelled, and the womnd and the conjunctiva of the eye in a eondition which strengthened my suspicions of horse No. 1 being affected with glanders. Still, by means of a few stitehes, I mited the margins of tho wound as well as circmustances permitted. After I had performed the operation I examined the horse as to his general health, but especially as to symptoms of glanders. With the exception of some fererish acceleration of the pulse and the very inflaned condition of the torn eyelid and the conjumetiva, no morbid symptoms could be found. The horse appeared to be in good health and free fiom any respiratory lisorder. The next day I saw both horses, Nos. 2 and 1, on L.'s faim, a few miles from Dixon. Horse No. 2 har ligh fever; the round in the eyelirl presenter cousiderable swelling and had suppuxated; some of the stitches liad been torn ont; and a lump of grayish and glassy miteus had aceumulated in the inner corner or canthus of the eye. These symptoms, though comparatively insignificant muler other circumstances, convineed me still more that the torn erelid rould not heal and that lorse No. 1 was aflected with glanders, and had eommmicated the contagion to liorse No. 2. In the condition of horse No. 1 no essential changes hat taken place, except perhaps a slight increase in the clischarges from the nose. About a week later horse No. 2 juesenter plain and ummistakable symptous of glanders, consisting of lameness, swclling of the inguinal glands, copious rlischarges from the nose, swelling of the submaxillary glands, and diphtheritic uleeration on the septum. The condition of horse No. 1 was almost nuelianged. Both horses wero killed the next day. The post mortem examination of horse No. 1 rerealed, besickes the characteristic morbid changes in the lnngs, indieative of pulnomal glanders of long standing; only a few small ulcers hisl mp on the septum, while horse No. 2 showed all the essential symptons of fully-rleveloped acnte masal glanders and of incipient farer, but searecly any morbir changes in the lungs. Whether the inoculation with glanders-contagion effected by the biting and tearing of the eycliel constituted the fist communication of the contagion to horse No."2 by horse No. 1, or whether a previous in. 
fection Lad taken place (both Irorses had been worked together, and had been kept in the same stable a meek or two before the erelid was torn), I was unable to ciecide, but lold myself convinced that the direct introduction of a comparatively large quantity of the contagion into a fresh wound, and the immediate contact of the same with the blood, constituted the cause of the acute course of the disease, inangurated by the inflammation in tlie wound of the erelid. There can be no clonbt of the disease haring been communicated by horse No. 1 to horse No. 2, because subsennent innuiries elicited the fact that horse No. 1 had become infected with glanders sereral months before he came into the possession of $M \mathrm{r}$. B., by another horse to which the disease had been communicated by a condemned Urited States Army horse affected with glanders and sold by the gorernment to a farmer, in whose possession lie died.

Another case, perhaps not less illustratire, occurred in the same year, also not far from Dixon. I was called upon to examine a mule which showed stispicious srmptoms, indicating the presence of glanders, but as no nleers conld be discorered in the nose a definite diagnosis could not be made. This, hotrever, was the more necessary and desirable, as the mule in question had come fom another State (Indiana), and had been bought onls a fer dass before. To get ont of the diffienlty and to force a decision, I inoculated the mule with lis own nasal discharges monder the sternum behind the fore legs. In a few days a nice farey-uleer had dereloped, tlie symptoms of glanders proper, too, had made considerable progress, and the chronic course of the disease had been changed to an acute one.

Wherever glanders presents itself as an acute disease, either an uncommonly large quantity of the contagion has been introduced at once and brought in direct contact with the blood, or a complication of some sort has been effected.

The nature of glanders. - The hrpothesis in regard to the nature of glanders, and the theories concerning the morbid changes and their relative importance, have differed rery widely, and hare recently undergone great changes. Although modern investigations have prored beyond a reasomable doubt that all the old hypotheses are crroneous, some of tiren seem yet to have their adherents.

At the end of the last and the beginning of this present century most reterinarians looked upon glander's as a blood disease. Bourgelat (1779), Kersting (1784), and Coleman (1839), supposed that slanders proceeds from a morbid, corrupt, or defective composition of the blood and looked ripon that as the immediate canse of the disease.

Later reterinarians advanced different opinions. Druuy (18\$9) called glanders an affection tuberculease, considered it, together with strangles or distemper, grease-lıeal, \&c., as a tuberenlons disease, and denied, like most French reterinarian, the existence of a contagion. Marel (1825) looked upon glanders as the natural consequence of a clroxic ixflammation of the nasal meous membranes. Dance and Cruveilhier commected glanders with an infammation of the lymphatics. Loiset fornd thrombosis in the Iymplatics of the mucons membrane of the nose, and after that a tendency previriled to consider glanders as a pyæmic disease. This new coctrine crilminated in the lypothesis of Tessier, who denied the absorption of matter, substituted a formation of matter (pus) in the blood, and pronourced glauders as one of many diseases in which a tendeney to produce matter is primarily existing in the blood. Finally clinical observatiors mere made in France mhich removed (?) every doubt as to the prænic nature of glanders. Remault (Recucil de mél. vétér.. 183J, p. 396) published observations, according to which glauders 
proceeded from a fistule on the withers, from bruising of the upper cyelid, and from a fistule of the spermatic cord. Dupuy (Butletin de l'Acatémie de méd., 1836, p. 481) observed that glanders proceeded from a seton on the shoulder. Riss (Recueil de méd. vétér., 1837, p. 602) observed several eases of glanders which were caused by serere contusions of the nose. Rey observed that glanders made its appearanee after a fracture of the nasal and maxillary bones. Afterwards Renault and Bouley (Recueil de mét. vétér., 1840, p. 257) endearored to corrobonate or to affirm these observations by direct experiments. They injected matter into the veins of horses, and claimed to have produced glanders-nicers in the nose of a liorse by such an injection of innocent matter. Rey (Recucil de mél. vétér., 1S67, p. 417) looks mon the experiment of Renault and Bonley as a singular case, but Professor Hering in Stutt gart (Repertorium, $1868,1.36)$ does not find it singular at all, and says that he made the same experiments a long time ago, and had sncceeded in producing in some cases glanders, in other cases suppuration (in the lungs), and in others no result whaterer. Such statements are, to say the least, exceedingly queer, particularly if made by such a learned and experienced man and otherwise so reliable an authority as Professor Hering, becanse such observations are, and must be, based upon a mistake either ono way or another. There are three possibilities: Either the matter injected into the veins must have been taken from a horse affected with glanders or farey, the animals experimented on must have been previonsly infected with the disease, or exposed in some way to the contagion, or the clisease produced was no glanders at all. A previous infection must be considered as the most probable solution, because the horses suibjected to such experiments are usually old or condemned animals bought for anatomical purposes at from two to four dollars a liead. A great many experiments with injections of matter (pus) into the reins of horses-probably the most that ever have been undertaken-have been made at about the same time, but independently and at different places, by Professor Guenther in Hanover (Nebel u. Vix Zeitschrift, 2. B.) and Professor Spinola in Berlin (Ueber das Vorkommen der Eiterlinoten in den Lungen, 1839). The same were afterwards repeated at various times by Professor Gerlach, the late director of the Royal Teterinary School in Berlin, who died in 1577. Neither of these three very reliable inrestigators nor anybody else, except Bouley aud Hering, has ever succeeded in producing (?) glander's in a horse by an injection of inmocent matter (pus) into the reins.

All those hypotheses and theories, notwithstanding some of them were only short-lived, contributed a great deal in creating the confusion in regard to the contagiousness or non-eontagionsness of glanders (la morre), which, until recently, has been prevailing amoug the French veterinarians. Bouley separated acute glander's and chronie glanders as two distinct or entirely different diseases, and considered chronie gianders as non-contagious, and acute glanders and farey as contagious and pyæmic diseases. Godine (Elémons dHygiène rétérinaire, suivis de recherehes sur la morve, etc., 1S15), went still further, and denied the contagionsness of glanders altogether. Bouley, howerer, finally admitted that contagious acute glanders might, under certain circumstanees, be dereloped firom nou-contagious ehronic glanders. These fallacious doctrines of the professors of the Alfort veterinary school, not only cansed great confusion in regard to diagnosis (glanders not being considered as a disease sui gencris, was frequently confounded with other diseases), but also great losses, amounting to millions of dollars, to the people of France, by preventing a strict condemuation of glandered horses, and allowing thereby an unlimited spreading of the clisease. 
The reterinarians of Belgium, too, became infected with the French or rather Alfort confusion, otherwise they never would have stated in their official reports (Bulletin du conseil supérieur d'agriculture du royaume de Belgique Arme, 1858, Buxxelles, 1860), that of 810 glandered horses, 136 had been cured. The reterinary school of Lyous, France, has always kept aloof from the errors of the Alfort institution in regard to glanders, and has never denied the contagiousness of that disease.

The German veterinarians, though differing at times considerably in opinion as to the nature of glanders, have never doubted its contagiousness; and German goveruments have always been rery strict in taking the most effectire measures against the spreading of that terrible enemy of the equine race by requiring a prompt destruction of every horse reported by a reterinary surgeon as being affected with the disease. As a consequence, glanders has become a rare disease in Germany, and the anmul losses are very insignificant.

Most of the older Germau veterinarians looked upon glanders as a dyscratic disease. Some believed they had found the immediate cause in a qualitative change of the animal albumen; others, in a morbid increase of fibrin. As to the morbid ehanges, some thonght they had discorered something characteristic in a stagnation of lympls in the lymphatics, others in a formation of tubercles, and still others cousidered glanders as a product of serofulosis. A few went even so far as to hold glanders to be identical with tuberculosis and scrofulosis. The tuberculosis doctrine originated in France, and gained a good many adherents willing to look upon glanders as an equine tuberenlosis. The scrofulosis doctrine was based upon the erroneons supposition that glanders proceeds or develops from strangles or distemper, and that the latter is a scrofulous disease. Erdt (in his Rotzdyscrasic und ihre verwandton Kr.ankiheiten) declared glauders, as recently as 1863 , to be a dyscratic disease, and discriminated a scrofulosis, blennorrhoic, septicamic, carcinomatous, syphylitie, and other forms of glanders, but considered scrofulosis glanders as the generic form. Professor Gerlach, in his valuable treatise from which several of the notes jnst given have been taken, refutes the theories of Erdt by the following statement, for the correctness of which I can vouch from my own knowledge of the facts:

Tho breed of the milk-white (white-born) horses of the royal stables of the lato Kings of Hanover was kept puro by continnous in-and-in breeding. As a conseruenco more than half of the number of colts borm perished every jear of scrofulous diseases. At the post-mortem examinations the mesenterial glands presented every staçe of scrofulosis firom simple swelling to a cheesy degeneration. Still, never a caso of glandcrs occurred, neither among tho colts nor among the grown horses. This riroves that scrofulosis really makes its appearance in colts in exactly the samo torri as in children, and it is therefore not justifiable to attributo an entirely different disease of horses to serofulosis.

For our present better knowledge of the nature and the morbid anatomy of glanders we are indebterl especially to the thorough, uribiased, and seientific researches and investigations of Professors virchow (Handbueh der speciellen Pathologie, Bd. 2, and Die liranlihaften Geschucuelste, Bd. 2); Leisering (Bericht ueber das Teterinairwesen im Koenigreich Sachsen, 1862 und 1867); Ravitsch (Tirchow's Archiv, Bd. 23); Loloft, (Magazin von Gurlt und Hertwig Bd. 30), and Gerlach (Jahresbericht der Koenigl. Thieraraneischule zu Hannover, 1S6S).

THE MORBID PROCESŚ.

Glanders commences as a neoplastic process-new morbid formations (glanders-cells) are produced. The muconis membrane of the respira. 
tory passage, the lungs, the subcutaneous tissue and the cutis, and, oeeasionaily, some of the comnective tissues of other parts of the body, constitute the primary seat of the morbic changes. The lrmphatic ressels and glands become secondarily affected. The neoplastic process, howerer, does not in every case of glanders ocem in all those tissues named; its seat in a certain tissue determines the forin of the disease. In common or nasal glanders the morbid changes have their main seat in the mncous membrane of the nasal cavities, and of the maxiliary sinnses; in pulmonal glanders the same make their apnearance principally in the lungs; and in farey the neoplastic process is taling place either in the subcutaneous comnectire tissue (common farey), or in the cutis itselt (slin-firey). In other tissues, morbid ehanges, as a general rủe, octur only if cyluters has become complicated with another discase-an inflammatory process, for instance. The products of the neoplastie process consist of roumd cells, and of spindle-shaped cells. The latter, usually, undergo further changes; some of them tlerelop to round cells, and others serve as the elements of excessive or morbid growths of ' comnecrive tissue, which, howerer, do not present anything characteristic, and must be considered as suborclinate produets of the neoplastic process. The round cells are in shape and form similar to granulation-cells and nutter-compuseles, but vary in size from that of the latter to two, three, four, tire, and in some cases eren ten times as large. The youngest round-cells, or those latest produccd, present rather delieate ontlines, and are the smallest; the oldest ones, which are distinguisherl by their grantated contents and their dark color, are the largest, and sometimes very large. All have lange nuclei, which grow in the same proportion as the cells, and present in the older ones a dark, granulated appearanee. (Fig. I, No. 4, and Fig. III, No. 6.)

The formation of these cells constitutes the real formation of all the morbid changes in glanclers, and may, therefore, be considered as something characteristic of the clisease, and the cells themselres are approipriately designated as glander-cells. These giander-eelis have two diffurent sonrces; they procech from connective-tissue corpuscles, and also fiom epithelinm-cells.

i. Development of glunders-cells from connective-tissue corpuscles.-The latter become proliterous and swell; the nucleus of each cell or corpus. clo grows larger; a second and a third nucleus are prodnced within the walls of the cell, but not by a division of the first one. The other contents of the cell grachaliy araulate, the appendages or extensions drop off; finaliy the whole body of the cell decays. The melei become free; the mucleus-eurelope or niembrane expands, and becomes clistinet fion the interior, and the metamorphosis of a melens into a nueleated eell is thus completid. Such a new cell present:s at first a rery delicate contour and a large and hright nuclens, but, uncler firvoruble vircumstances, will soon beeoms firmer and grow larger. Under nufarvorable concitions no funther development will take place. (Fin. I, Tos. 1 and t.)

$\because$. Dexclopment of glenders-cells fiom crithclium-cells-il process of proliteration makes its appearanee in the tesselated and eylindrical epithelinm-eells, is planinest, l:owerer, in the larter. At first the oral muclens increases in size: then a second, and finally a thind nucleus are formed at a little distare firom the mper obtuse and of the first, whel is not clivided. The formation and gowth of these melei catise the ("ylindrical cell to inereas in size, or to swell, and to change its original shape till it is transtomed to a nere bag fillerl with nuclei and smali rommel cells. Finally the hag or the old eell-membrane decays and brealis, and the muclei and joung cells are liberated. (Fig. III, Nos. 1 
and 4.) Such a production or development of glanders.cells just described can take place in young or undeveloped and incipient epithelimm-cells, becarse roumel giant-eells filled with nivelei and small round cells are formed frequently in the deeper or youngest stratil of the epithelium. (Fig. III, No. 3.)

Wherever such a neoplastic growth is making its appearance the process is always essentially the same. The original nuclei of the primary epithelium-eells and comnective tissue-cor]uscles increase in size, and new nuclei are formed within the external membiane, or envelope, of the primary cells. rihese nnclei are transformed into small round cells, mhich are liberated by the deeay of the old mother or brood-celis, and constitute what is ealled daugliter-cells, and grow larger. This growth and development constitntes a characteristic peeuliarity of the large round ghlanders-cells, which distinguishes the same from otherwise similar granulation-cells, matter-eor'mscles, and tubercle-cells, becanse the latter, during their whole existenee, remain melınged at their first stages of derelopment. Although young glanders-cells are small, aud large ones old, the ditherence in size does not depend exclusively upon the age of the cells. Other growth-promoting and growth-letarding influences linst be existing, because some cells grow faster than others, and some do not seem to grow at all. Under ecrtain circumstances only small cells can be found, which are not difierent from eommon matter corpuseles, and in other cases a great many large ones, sometimes of an extraordinary size, present themselves. If the morbid process is a violent or a rery rapid one, the glanders-cells are always small; rapid development and a fluid intercellular substance constituto the agencies which deprive the cells of their ability to grow, or eanse them to xemain small, and of a somewliat uniform size. Consequently, in all those cases in which the morbid process of glanders is blended from the beginning with more or less inflammation and exudation, the glanders-cells will be small and numerous; and as the imflammatory exudations destroy and dissolve the intercellular substance, the latter and the exudations themsclves will constitnte a fluid in which the glander's-colls are kept suspended. The glanders-natter thus formed does not present, nuder the microscope, any characteristic difierences from any other matter or pus. A production of glanders-natter and of mmerous small glanders-cells is common if the neoplastic process has its scat in the subcutaneous and intermuscular connective tissues consequent in fiurey. In all those cases, howerer, in which glamders presents itself as a chronic disease, fiee from any complications with infiammatory processes, ce., whatever, in which the formation of the glanders-cells is a gradual and slow one, and in which the interceltular substance is not destroyed and dissolved, tho glanders-cells will grow to a vertain size, aus young cells with delieato contours and large, bright nuclei, older and largex ones, and very large ones with darlk-colored nuelei and gimmlated contents, will present themselves.

'The vitality of the neoplastic produets of glanders is limited, but differs considerably according to circumstances. 'The small, rapidly prodnced, and therefore numerous, cells, sinspended in a dissolved intereellular tissue and exulations, are similar in erery respect to inattereorjuscles; the same not only do not grow, but shrink and decily rery soon. If the intercellular substance dees not decar, but retains its original connective properties, tho glanders-celis not only grow larer, but also a great deal older, than matter-corpuscles or tuber'le-cells. 'This vitality will he the greate $"$ the larner the slatee or tile greater the amount of the connective intercellular substance between the single eclls. Their 
ane, however, probably never exceeds a year or sereral months, notwithstanding that some glanders-nodules, tubereles, and tumors may exist, apparently unchanged, a much longer time, because the constituents of the latter, the glanders-cells, change. Old ones decay, and new ones talie their place even if the whole tubercle or tumor remains essen. tially as it is. It is to be supposed that such a change is taking place, because every old glanders-tubercle or tumor contains always old and new cells in different stages of development.

The retrogressive metamorphosis may be ealled a fatty necrobiosis. At first small granules (fat granules) make their appearance in the nuclei; the latter swell or increase in size, and grow darker; granules appear also within the cells, but outside of the nuclei; finally the euvelopes or external membranes of the cells decay and fall to pieces, and a graumlated detritus is left behind. Therefore, after a regressive metamorphosis has set in, the glanders-nodules or tubereles and tumors are found to contain a granulated detritus, small and large granulated cells, and fiee granulated nuclei, if examined under the microscope. The glanders-cells may thus perish or be destroyed without any simultaneous decay of the intercellular substance. In such a case the further changes which are going on in the tissues, in which the glanders-cells are imberlded, differ according to eireumstances. It the glanders-cells are but few, and rather far apart, the granulated detritus is removed by absorption, and the morbid process comes to a termination by local healing. In other cases new glanderscells are produced, and take the place of the old ones, and the morbid growth (tubercle or tumor) continues to exist. If the decaying glanders-cells are numerous and lodged close together, the retrogressive metamorphosis is usually attended with a morbid of excessive growth or production of intercellular connective tissue; and the absorption of the detritus in such a case is attended with, and makes room for, a somewhat extensive production of new fibrous (scar) tissue; linear and somewhat prominent, white stripes, usually uniting in a common center, corresponding to the center of the former neoplastic process, make their appearance and constitute a star-shaped, whitish scar or cicatrix. In chronic glanders such cicatrices occur very often in the mucous membrane of the septum; the hard, fibroid, and callous swellings, which are sometimes found in the mucous membrane of the nose, and the fibroid tumors which occur in the lungs, and which are easily distinguished from the more pulpy glanders-nodules and tumors, are produced in the same way.

Frequently, however, that is, in all such tubereles and tumors in which the gilanders-cells are numerous and separated only by very little intercellular tissue, the decay or retrogressive metamorphosis of the glanders-cells involves and causes a simultameous decay and destruction of the intercellular substance, and of the tissue in which the morbid products are imbedded. The continuity is destroyed, and an abscess is formed. The decay usually, though not necessarily, begins in the center of the nidus of cells, and it seems that certain extermal influences are able to change or to accelerate the whole process. So, for instance, a general decay, or a formation of ulcers or abscesses, does not usually take place in the mucous membrane of the maxillary cavities, but almost invariabls, or, at any rate, a great deal earlier in such parts of the nasal mucous membrane, which are exposed to the current of air passing through the nose at each breath. The irritation caused by the passage of air probably constitutes the eause of the more frequent oecurrence of glanders-ulcers in the mucous membrane of the septum than in any 
other part of the nasal mucous membrane. If glanders has become complicated with inflammation, the whole process, as has already been mentioned, is entirely different. In farcy, too, in which the morbid changes have their seat in the loose subcutaneous connectire tissue, the abscesses are formed in a somewhat different way.

The infectiousness of the neoplastic products of glanders constitutes a specific and pathognomonic attribute of the same, which excludes identification with any other otherwise similar neoplastic or morbid products. The same specific ageney, or the same virus, which is instrumental in communicating the disease from one animal to another, constitutes also the cause which spreads the morbid process within the organism of the affected animal. The efficiency does not seem to be dependent upon any particular shape or form of the morbid products, but to be inherent in the material, because not only the live glanders-cells, but also the dead or decayed ones, the granulated and cheesy detritus, and the watery transudations are infectious. The immediate changes produced by a local infection within the tissue, or the creeping of the morbid process from cell to cell, can be seen only under the microscope. If the glanders-process is not complicated, that is, if no other disease is existing, the spreading of the moribid process, or the progress of the local infection, is a very slow one, but is accelerated or becomes rapid if a complication sets in. The morbid process, hotrever, spreads not only by means of a direct infection from cell to cell, but also by means of the lymphatics, which absorb infectious elements and deposit the same in the nearest lymphatic glands. That this is the case becomes evident if an animal is inoculated with glanders-virus. The lymphatics proceeding from the inoculation wound soon commence to swell like strands or chords, and undergo not seldom ulcerous decay. The lymphatic glands, too, commence to swell to solid and painful tumors which afterwards become harder and firmer, but less painful. A morbid production of connective tissue causes the firmness of the swelling, and usually renders such a diseased gland impervious to a further passage of the contents (lymph and infectious glanders elements) of the lymphatics, and prevents, therefore, a further spreading of the infection. If, however, a lymphatic gland, thus degenerated, becomes finally itself a seat of the neoplastic glander's process, or of the production of glanders-cells, the 15mphatics which pass from that gland to another one will also absorb infectious material, and cause thereby a further spreading of the infection and of the morbid process. In nasal glanders, a swelling of the submaxillary lymphatic glands (which receive directly through the lrmphatic ressels the lymph from the seat of the morbid process), unattended with any affection whaterer of the lymphatics beyond them, is a very frequent occurrence. Hence the spreading of the morbid process by means of the lymphatics is also usually a slow one in chronic glanders; sereral months may elapse before a new somrce of infection is formed. The spreading, howerer, will be a comparatively rapid one in all cases of glanders in which a complication with another destructire or acute disease, as an inflammatory process, has taken place. The morbid process is also apt to spread more rapidly through the lymphaties in common farcy, in which loose connective tissue constitutes the seat of the disease. The morbid process of glanders, therefore, is infectious; a spreading of the same is not only effected within the tissue by a propagation of the glanders-cells, but also by means of the lymphatics which absorb the rirus and carry the same to the nearest lymphatic glands, where the progress of the morbid process stops, if the latter are degenerated by an excessire production of connective 
tissue, but proceeds further if those glands become the seat of a neoplastic production of glanders-cells, as is usually the ease in farcy, and always if glanders is complieated with intlammation. It is evident that by sueh a spreading of the virus and absorption of deleterious glanders-matter some infectious elements, whatever their nature may be, will finally pass into the blood, and cause in that way a general c!isorder, or a general dyscratic condition usually called "glanders-dyerasy." That virus or infectious elements pass over into the blood, and pervade the whole animal organism, becomes apparent by the fact that the blood and the various animal secretions, the sweat for instance, possess contagions properties alleady at an early stage of the disease, or before the morbid process has spread much beyoud its original seat, and are able to communicate the glander's from one animal to another. It may ap)pear to be somewhat strange that the early infectiousness of the blood and of the varions secretions does not efrect a general outbreak of the glanders-process in every suitable part (mucous membranes and connective tissues) of the animal body, and that, notwithstanding the faeility with which the glanders-contagion communicates the discase from one animal to another, tle morbid process remains usually for a long time confined to certain parts of the organism. It is, however, not any more surprising than a healing; or a cessation of the morbid process, of other equal!y contagious diseases-pleuro-pneumonia of cattle for instancewhile the organism is yet replete with the contagion, which, in very small quantities, is able to communicate the morbid proeess to other animals. The truth is, ow knowledge concerning the true nature of the contagious prineiple of the varions contagious diseases is yet too limited. If the theories of Hallier and other's, based upon the discorery of micrococei, Se., in the bloorl and in the secretions of animals aftected with contagious diseases should prove to be correct; if, in other words, those mierococci-in glanders Malleomyces equestris, H.-do constitute the infectious elements, and the real, immediate eause of the morbic changes, all those strange phenomena may yet find a satisfactory explanation. If, howerer, those microcoeci should not constitute the contagion, and should not be the cause of the morbid proeess, but the product of the same, or if their presence should prove to be a merely aceidental one, it will be difficult to reconcile those facts. Professor Gerlach, who discards those theories as unfounded, liuts at an exhanstion of predisposition as affording a possible explanation.

THE ANATOMICAI, CHANGES,-The morbid products of the glaudersprocess make their aljpearance usually in more or less distinctly limited nests, or in shape of nodules or tubereles and tumors, which vary considerably in size. Some of them are as small as the size of a pin's head, and are called miliary tubercles; others are larger, of the size of a pea; and still others are quite large, and constitute tumors or glauders-excrescences. Practieally, therefore, a diserimination between glander'stubercles or small nests of glauders-cells, and tumors or large oues, is admissible. The former, however, must not be looked mpon as identical with genuine tubercles as occurring in tuberculosis. A glanders-tubercle is a different thing altogether, only the name has become too convenient to be abolished. Glanders-tubercles oceur-1, in the substauce and in the subserous tissue of the lumgs; 2 , in the mucons membrane of the nasal carities and of the maxillary simuses, but especially in the mueons membrane of the septum; 3 , in the swelled and indurated submaxillary glands; and, 4, in the cutis. Some authors liave considered the presence of small wiliary tubercles in the lungs as the criterion of the presence of glanders, but others have 
foumd that glanders may exist and still no tubercles may be found in the lumss. Protessor Roell, in Vicuna, found miliary tubercles in only abont $66^{\circ}$ per cent. of all cases that came under his observation, and Professor Leisering, in I)resten, and Professor Gerlach, in Berlin, searched for then fiequently in vain. Glanders-tubercles malie their appearance in the lungs only if the morbid process, which has its principal seat usually - I would like to siy, normally -in the mucous membraite of the nose, extends to the lungs; or if original nasal glanders has become complicated with pulmoual glanders, which, in the course of time, is a common occureuce. In those cases in which such a complication is existing from the beginning; or in which pulmonal glanders constitutes the plimury disease and nasal glanders the complication, miliary tubercles are found in the lungs fiequently within a short time after an infection has taken place, sometimes within fiom one to three weeks. The same are imbedded in the healthy pulmonal tissue, are surrounded by a court of turgid blood-ressels (Fig. VII, No. 1), have each a small bloodressel of their own, are at first grayish-white and rather soft, consist of more or less uniform and rather small round cells, with unclei, connected with each other by a delicate intercellulary tissue, and become, when older, enveioped by a fine tissue of connective fibers. The court of turgid or congested ressels around the tubercles lisapjears after some time, the blood-ressel which cnters the tubercle becomes obliterated, and the substance of the latter, receiving no more uutriment, undergoes decay. A necrobiotic process commences, the round cells shrink, the intercellulary substance recays, and the interior of the tubercle is changed to a cheesy substance, in which finally lime-salts are deposited. The whole process is the same as that which is taking place in a true tubercle in tuberculosis, therefore every lifference disappears atter the retrogressive process has set in. Mence, glanders-tubereles have froquently been identified with reritable or tubereulosis tubercles, and glanders itself has, at times, been looked npon as a tuberculosis of horses, which assumes peculiar forms, difrerent from tuberculosis of other animals; but as real common tuberculosis occurs in lorses as an independent disease, the same as in other animals, as the cells of a glanders-tubercle are usually somerhat larger than those of a genuine (tuberculosis) tubercle, and as, finally, each glanders-tubercle possesses a full intercellnlary substance, and has a blook-ressel of its own, either of which is wanting in the veritable (tuberculosis) tubercle, there can be no doulut as to glanders and tuberculosis of horses being entirely different diseases. Besides that, in tuberculosis of horses, the single tubercles are usually a great deal lingrer than the miliary tubercles of glauders, and only the smallest ones (those of the size of a jea) present some similarity to the larger glanderstubercles. The retrogressive process does not present anything eharacteristic.

In the mucous membrane of the nose the glanders-tubercles or nodules are always plainest on the septum (Fig. IV, Nos. 1 and 2). They, too, vary in size frem that of a pin's head to that of a pea, and project but little over the suriace of the membrane, and are therefore sometimes scarcely visible. At a post mortem examination, however, the same can be scen and felt more plainly, because then the mucous membrane is less succuleit and swelled. Eitlier singly or in groujes they are imbedded in the mucous membrane, usually in the mper layer, and are rlistinguished from tho reddened membrane by their gray, grayish-mhite, oi grayishycllow color. Somctimes these tubercles, or glanders-nodules, are situated deeper, in the middle or lower layer of the mucosa, and therefore less distinctly circumscribed, and indicated only by a slight elevation 
above the surface of the membrane, but not by any distinet color. On a cut, however, the same ean be seen very plainly (Fig. V, $a$ and $b$ ). The substance of the glanders-nodules in the nose is more or less soft, and consists of round cells, free nuclei, spindle-shaped cells, and a fine connective intercellular substance. The spindle-shaperl cells are lodged mostly side by side; some of them, the younger ones, are rather thin, and others are swelled in the middle, and are ripe and near breaking. The nodules or glanders-tubercles present usually a gray-yellowish color, if composed principally of round cells, and their color is somewhat indistinct if spindle-shaped cells eonstitute the prevailing element. The retrogressive metamorphosis consists in a decaying to a fatty or cheesy substance. A real shrinking and exsiceation and a deposit of lime-salts do not occur. Glanders nodules or tubercles in the cutis are a comparatively rare oceurrence in horses, but are observed very often in human beings affected with glanders. As the skin of horses is coated with hair, only the larger tubercles or nodules will be noticerl; the very small ones usually escapo observation till the regressive process has been completed, and has changed them to small lenticular ulcers. Otherwise the morbid changes are the same as in the mucous membrane.

Miliary tubercles, finally, can also frequently be found imbedded in the morbidly increased connective tissue of the indurated submaxillary and other lymphatic glands. On a cut the same can often be pressed out of the surrounding tissue as small lnnots or nodules. An exsiceation is a frequent occurrence, but a deposit of lime-salts has not yet been observed.

Glanders-tumors, or very large nests of glanders-cells, can be found fully developed only in the lumgs, but are even there not as frequent as the tubercles. They have their seat usually immediately beneath the pulmonal pleura, especially toward the lower sharp border of the lungs. In some cases, however, the same are also found imbedded in the pulmonal tissue, and are then not seldom numerous. The tumors, or glanders growths, are either distinctly limited, and varying in size trom that of a cherry to that of an apple, or the same are more or less diffuse. The large tumors seem to becomposed of two or more smaller ones which have increased in size till they have come in contact with each other and have united. The intermediate pulmonal tissue in such a case has disappeared. Large tumors thus produced are frequently of an irregular shape. The pulmonal tissue surrounding the gray or grayish-yellow tumors is at first hyperæmic, and the ontlines of the latter are more or less indistinct, but afterwards the same become more defined. On a cut these tumors present an appearanee somewhat similar to bacon. In some cases the same are more or less firm and solid, like a fibroid growth, and in others of the consistency of a sarcoma. (Fig. VII, No. 2, presents the grayish-yellow cut-surfice of a glanders-tumor in natural size, for the most part distinetly limited from the hyperamic pulmonal tissue, but at one end yet encroaching upon the latter, and not yet presenting a distinct demarcation. Fig. VI, No. 3, is a swaller glanders-tumor in natural size, presenting yet visible, small, round, primary nodules and some remnants of pulmonal tissue, indieating plainly that the growth takes place, not from one but from several centers, and is not effected by peripheric apposition.) Under the microseope the coustituents are found to be essentially the same as those of the smaller nodules or tubereles. The round cells, however, vary much more in size. Some are very large and distinguished by their dark and granulated nuclei. Numerous epithelial mother-cells, containing nuclei and incipient cells, spindle-shaped cells in different stages of development, some, maybe, 
very much swelled or just breaking, and others decayed and discharging their granulated contents and large nuclei, and a connective intercellular substance which gives the whole tumor its continuity and a certain degree of solidity, constitute the principal components. The softer glauders-tumors, similar in consistency to a sarcoma, are composed mainly of round cells, while the firmer or more solid ones consist principally of spindle-shaped cells, and contain comparatively fer round cells imbedded in the intercellular substance, which latter is here and there fibrous and solid, and thereby the canse of the greater firmness. The presence of botl kinds of cells, spindle-shaped and large, round ones, proves that connective-tissue corpuscles, as well as epithelium e.ements, contribute to the formation of pulmonal glanders-tumors. Tho retrogressive metamorphosis proceeds, according to the observations of Gerlach, in two different ways. Sometimes all components of the glanderstumor, the intercellular substance as well as the glanders-cells, undergo a process of decay which proceeds either from one center-if the tumor is a simple onc-or from several centers simultaneously, if the tumor is a complicated one. In the former case the whole tumor is changed to one cavity with cheesy contents, but in the latter two or more larger or smaller cavities, corresponding to the number of the original tubercles or tumors, are produced. The contents of the same present also a cheesy appearance. Sometimes, however, the whole process is different. The round-cells decay and are absorbed, and an excessive growth or production of connective tissue is taking place. The tumor becomes harder and firmer, and assumes finally the characteristics of a fibroid growth, which contains interspersed in its tissue a few round-cells, and may not undergo any further changes for a long time. Such fibroid tumors correspond to the fibroid cicatrices which occur frequently in the mucous membrane of the septum, and are found not seldom if the morbid process has been a very slow or chronic one. If glanders is acute or complicated with other morbid processes which accelerate its progress, such hard and firm fibroid tumors or cicatrices are never formed. On the contrary, the glanders-tumors decay rapidly, often before the same have had time to assume definite shape and form.

Glanders-ulcers or abscesses are produced if the intercellular substance of the tubercles undergoes dissolution. Dissolved intercellular substance and decayed and decaying glanders-cells constitute the matter. The process is about as follows:

Farcy-ulcers in the subcutaneous connective tissue.-Tho development or the growth of a farcy-tumor is always attended with some local inflammation in the surrounding tissues. A violent proliferation begins in the center of the tumor, and numerous small round-cells which can scarcely be discriminated from matter-corpuscles are produced. The inflammatory process furnishes a sufficient quantity of exudation to loosen and to envelope the round-cells almost immediately after the same have been produced. Some white blood-corpuscles may becomo intermixed, but the same must be regarded as strangers, because a very large majority of the cells suspended in the fluid exudation are the product of the proliferous process. So it may happen that a farcy boil or tumor shows fluctuation, and contains matter within a few days, or is changed to an abscess much sooner than a common boil. The matter of a farcy-ulcer does not exbibit any distinctive difference from other pus except in so far as it possesses infectious qualities. Almost as soon as a farcy-boil has been changed to an abscess, or contains matter, the nearest subcutaneous lymphatics commence to swell to plainly visible chords or strands, and in their course not seldom new boils are formed, 
Which also undergo the same metamorphosis as the first one. Hence it happens rely frequently that farey boils and ulcers malie their appearance in rows somewhat resembling strings of bearls, which constitutes one of the characteristics of the disease. A little later the nearest lymphatic glands, too, commence to swell and to be changed to hard. and more or less painful farcy-buboes. The circulation or the current of lymph in the lymphatics of such a swelled slaud or glands becomes interrupted, and in eonsequence odematons swelling make their appearance in the parts in which snch an interruption has been effected, usnally in a leg. The swelling of the lymphatics and of the lymphatic glands, the lrmphatic abscesses, and the appearance of nedemata hare led to mistakes; an inflammation of the lrmpliaties has been supposer to constitute the primary and the production of farey-ulcers a secondary morbid process. Sometimes, it is true, it is rather difficult to find the primary boils or nlcers from which the morbid process has spread. The comparatively rapid dissemination of the glanders-virus throngh the lymphatics in the loose subcutaneous connective tissue explains why farcy nsually spreads sooner orer the whole body, and becomes fatal in much less time than either pulinonal or nasal glanders.

The products of the glanders-process, howerer, do not always present themselves as distinctly limited growths in form of nodnles, tubercles, tumors, and boils. The morbid products in certain cases, especially in such in which an inflammatory cxudation is taking place in the same parts in which the glanders-process has its seat, becone diftuse, and the glanders-cells almost as soon as produced are carried off by the exudation. Gerlach discriminates two forms of diffuse glanders, viz., glanders-catarrh and diffuse production of glanders-cells in the micons membranes.

1. Glanders-catam 7 .-If the glanders-process makes its appearance in a mucons membrane, the first morbid changes and symptoms are always those of glanders, blended with a catarrhal affection. Consequently the first stage of nasal glanders may appropriately be called a " glanderscatarrh," and may under farorahle circumstances exist almost michanged for a long time without being attended by any other characteristic symptoms except perhaps some swelling of the submaxillary lympbatic glands (so-called Inasal gleet). Afterrard, in a more advanced stage of the disease, more characteristic morbid changes make their appearance, but the catarrhal discharge from the nose remains. In glander's-catarrh the secretions of the nasal mucous membrane differ ouly in so far from those observed in a common catarrh as they present frequently a greenish or green-yellowish color, and contain very soon epithelium-seales and sinall, ronnd glanders-cells similar to matter-eorpuscles. With the appearance of the epithelium débris, howerer, the somewhat characteristic greenish color usually disappears. The glanders-cells have their source in the epithelinm-producing layer of the mucosa, and develop from epithelimmcells, but are carried off or washed amay by the fluiel exudations. Still the discharge itself, althongh containing glanders-cells, offers no claracteristic of great diagnostic value except its infectionsness, which exists from the very beginning. The microscope reveals no essential differences, neither between the nasal discharges in glanders and in eatarrh nor between furey matter and common pus.

2. Diffuse production of glanders-cells in the muenes membrane.-The glandel's-cells are not produced in certain limited spots or nest:3, but in diffusion over large parts of the murous membrane. The latter appears swellerl aud loosened in its tissme, and contains larger or sinaller munbers of round glanders-eells of difterent size. Afterwards au exuberant 
morbid growth of connectire tissne malies its appearance, which eanses the mucons membrane to become more or less thick and eallons. If the glanders-process extenis to the frontal and maxillary carities, the naturally fine mucous membrane, especially of the latter, is usually found coated with a muco-purulent secretion, and presents more or less uneven swelling and degeneration, caused by an exubcrant neoplastic production of connective tissue clements. In the nasal carity, but especially on the septum, the diffise glanders-process penetrates not seldom the whole mueous membrane, and extends to the submucosa. Callons strellings are formed by an exuberant production of neoplastic elements of connective tissue, and within these swellings appear diffuse center-stations, or nests of round cells, which (latter) gradually nndergo decay and are absorbed. Fibrons or scar-tissne, which afterwards shinks or contracts to a scar or eicatrix, takes their place. So it may happen that scars or cicatrices malke their appearance without any ulceration having preceded. These sears or cicatrices usually contain a center, from which several whitish strands of fibrous tissue, prodnced by the sane process, are radiating in different directions. Still not every scar or cicatrix found on the mucous membrane of the septum lias been produced in the same way, without any preceding nlceration. Under favorable circumstances a healing even of a glanders-ulcer will now and then be effected, but iu such a case the sear left behind is usually less prominent or conspicuous, and is destitute of such long radiating strands of fibrous tissue.

Glanders-ulccrs. - The same, if present, constitute the most eharacteristic and ummistakable morbid change of the whole morbid process, and are found nsually in the mucous inembrane of the septum, especially toward the nasal bones, but also in the mueous membrane of the conchre, the nasal dnets, the larynx, and the windpipe, and, in rare cases, in the cutis. Professor Gerlach says he has found uleers in the mucosa of the throat and windpipe only in acnte glanders. I remember one of chronic glanders that oceurred in 1869 in Quiney, Ill, in which, at the post-mortem examination, numerous nlcers presented themselves in the nasal ducts and in the mucous membraue of the larynx and windpipe, but nome on the septum. In that horse the only observable symptom consisted, for a long time, in difficulty of breathing, resembling a kind of roaring when exereised. The post-mortem examination, made by myself, revealed glanders in a very advanced stage of development, notwithstanding that the horse, a fine black roadster, was not suspected of being affeeted with glanders up to within two weeks before he was killed.

Glanders-nlecrs are always preceded by glanders-nodules or tubereles in the mucous membrane or slin, respectirely, and are the product of a decay of the glanders-cells and a dissolution of the intercellular substance of those nodules or tubercles. The process, howerer, by which these uleers are developed is not always the same, but varies somemhat according to the size and sitnation of the tubereles. If the latter are large, of the size of a pea, and extend deep into the mucons membrane, a depression, which soon changes to a small hole, at first not larger than a pin's head, makes its appearance in the middle of the external surface. This hole, howerer, soon grows larger (Fig. IV, No. 2), and constitutes within a few days an nleer corresponding in size to that of the former tubercle (Fig. IV, No. 3). The deeper the latter extends into the mueosa or submucosa, the deeper will also be the uleer.

If the glanders-tubcreles are very small and superfieial, or, as it sometimes happens, visible only as gray specks or dots, the proceeding is a little different. At first the epithelium is cast off; a swall, scarcely 
visible loss of substance takes place, which gives the incipient ulcer the appearance of a small erosion. In other cases the decayed, superficial part of the tubercle presents itself as a yellowish-gray mass, which remains for a short time coated with epithelium. The decaying tubercle, in such a case, has the appearance of a small pustule. In both cases, finally, small, flat, lenticular ulcers are formed, which, if numerous and close together, as frequently happens (glanders-tubercles, if very small, are usually situated close together in groups), become soon contluent, and present then one large, flat ulcer with an uneven bottom. A few days ago I had an opportunity to obserre small lenticular, and one medium-sized conflnent ulcer, on the right side of the septum of the nose of a former circus-horse that had been affected with glanders-had had discharges from the nose-for over eight months.

A glanders-ulcer once formed grows in depth and circumference as follows: At the bottom and on the borders of the ulcer, and also in the immediate neighborhood of the same, appear again gray specks and nodules (nests of round cells), which also undergo decay, become confluent with the ulcer, and increase thereby the size and depth of the latter. The bottom of a glanders-ulcer presents a grayish-yellow (baconlike) appearance, marked with red blotches, and is composed mainly of round glanders-cells, the decay of which adds to the depths of the ulcer. Consequently, as after each decay new round cells make their appearance, a glanders-ulcer is not only able to work its way through the mucous membrane and its connective tissue, but also into and even through the cartilagenons septum and the osseous conchr. This, hor. ever, takes place only in a very advanced stage of the disease, and under the influence of a complication with an inflammatory process. The bottom of a deep ulcer presents usually a dirty appearance, caused by decay or decomposition of tissue and blood (Fig. IV, No.4). Growth of a glanders-ulcer in circumference is a very common occurrence. The process is usually a rapid one, if the ulcer is composed originally of small lentieular ulcers, so-called erosions, with corroded gray or inflamed and red borders. If two or more of such compound ulcers happen to be in close proximity of each other, the same rery often become confluent in a comparatively short time, and present then one large ulcer. ating surface. In the cutis the ulceration process is exactly the same, and is invariably preceded by a formation of glanders-tubercles. The latter have their seat nsually in the skin of the lips and nostrils, seldom in the skin of the legs and of other parts of the body. In the cutis, too, deep ulcers, and flat and lenticular ones, can be discriminated. In some eases the cutis-ulcers hare a special tendency to increase in depth-if the preceding tubercles have been large-while in others a tendency to grow in circumference is prevailing. The latter is the case especially if the tubercles have been small and close together. Both kinds of ulcers, however, like those in the mucous membrane, produce abundant exudation and matter, a peculiarity by which deep glanders-ulcers situated in the skin are easily discriminated from farcy-ulcers or glandersabscesses. Besides that, the latter are always kettle-shaped, have red and elevated borders, and are situated in the subcutaneous commective tissue, while the former have their seat in the skir.

\section{THE CAUSES AND ORIGIN OF GLANIRLiS.}

As to the causes and origin of glanders, opinions, especially in former times, have differed very widely. A great many veterinarians, particu. larly in France, and there until quite recently, either denied its conta. 
giousness altogether (La Fosse, sen. and jun., Fromage Defeugre, and Dupuy barely admitted the possisility of an infection; Coleman (English), Smith (English), and Rodet considered only acute glauders as a contagions disease, as did Hutrel d'Arboval and many others), or expressed doubt as to the existence of a contagion.-Dutz. Consequently a spontaneous de. velopment or the possibility of the same was not questioned except by a few decided contagionists, such as Volpi in Italy, White in Englaud, and, in modern times, Gerlach in Germany. Nearly all German, most of the English, and a great many French reterinarians (it is but just to mention among the latter Solleysel (1669), De Samier (1734), Bourgelat (1765), Garsault (1770), Vitet (1783), Gohier (1813), Delwart, and Leblanc) admitted that most cases of glanders owe their origin to infection, but did not doubt the possibility of a protopathic, and even of a dentropathic development. Even at the present day an auchtochthonous and a deuteropathic derelopment, too, are looked upon as something possible, or even self-evident and of frequent occurrence, not only by non-professional men, but also by a great many veterinarians of high stauding. As causes of auchtochthonous glauders, all possible injurious agencies have been accused, the same as in all other contagious diseases, such as pleuropneumonia of cattle, for instance, which latter, as is now more generally admitted, spreads, and is caused exclusively by infection or by means of the contagion. As principal causes of glanders have been considered spoiled, decayed, and insufficient food, or food of a bad quality or unsuitable composition; dirty, crowded, and ill-ventilated stables ; overwork, hardships, and exposure of any kind or description; in short, nearly everything that is calculated to have an injurious effect upon the animal organism. A great many liorses in every country and in every clime are exposed to some or to all of the injurious influences just entmerated, and there is not the least doubt that these influences are well able to weaken the constitution of an animal, to produce emaciation and debility, and to cause a whole army of more or less dangerous and frequently fatal diseases, but still glanders is not any more frequent among horses thus exposed and suffering than among others, which are well kept and well treated in every respect. In every country and in every clime a larger or smaller number of horses are exposed to all those injuries mentioned, are worked to death, starved to death, suffocated to death in foul stable-air, poisoned to death with spoiled food and with impure, stagnant water, and still there are countries in which glanders is an unknown, or, at least, an exceedingly rare disease, while in other countries in which horses, on an average, are not kept any worse, or, may be, are kept much better, glanders is a very frequent disease, and causes annually great losses. As a general tule, which, howrever, suffers apparent exceptions as I shall show hereafter, glanders is frequent in all those conntries in which a great many horses are imported, and rare in all those countries in which more horses are raised than needed, or from which horses are exported. Besides that, nobody has ever succeeded in producing glanders by merely exposing or subjecting a horse that has never been exposed to the influence of glanders-contagion to any or to all the injurious agencies and influences which have been mentioned as being accused as the causes of protopathic glanders. In the West, where I have lived and practiced during the last thirteen years, glanders, as I have been informed by reliable persons, used to be an almost unknown disease before the civil war, but has been spread by condemned army horses during and immediately after the war, and is now frequent and can be found everywhere.

Among asses and mules glanders is comparatively not as frequent a 
disease as among liorses, notwithstanding that the former have more preclisposition, are easier and sooner infected, and sncenmb qnicker. If a protopathic development were possible, or frequently taking place, one should suppose that it would occur especially in those animals (asses and mules) which possess the greatest predisposition, or, in which, if affected, the morbid process is always the most rapid and the most violent. Besides that, asses and mules particnlarly, are, as a general rule, more exposed to bad treatment and to all those calamitics which liare been looked mon as probable eanses of glanders, than horses. That glanders is not so frequent amoug asses and mules as among lorses, is simply due to the fact that the former are less mmerous and usnatly less exposed to the contagion, because less nsed on the road and for trareling purposes, than horses. An exception, perhaps, may be made with the Anerican army, or with any other army in which mules are extensively employed, and in them, I suppose, cases of glanders are just as frequent, and perhaps more frequent among the mules than among the liorses.

In modern times, most reterinary writers, it seems, have abandoned the possibility of an autochthonous or idiopathic origin of glanders, but the denteropathic development is yet upheld by a mreat many. The diseases snpposed to terminate in glanders are especially strangles or distemper, infuenza, catarihal affections of the respiratory inucous membranes, and nlceration in rarious parts of the animal body. 'To enumerate all the eases recorded in the reterinary literature in which glanders is said or believed to lave developed from other diseases, or been produced by an absorption of matter, wonld lead too far, for the same are very mumerous. As to the different theories that have been adranced, I have to refer to what has been said in the first part of this treatise. To show, hotrerer, how easily mistakes may be made, I may be allowed to relate a case that occurred last summer in Chicago. Sereral horses, constituting the stock of a bankrupt eirens, all animals in a rery fino condition, were put up for keeping by the authorities in charge, in a eertain livery and boarding stable. In the same stable inflnenza prevailed, and nearly every horse, excepting those circus-horses, became affected with influenza in its so-called catarthal rheunatic form. Deaths did not oecur, but sonue liorses became affected sererely. After the cirens-horses lhad been in the livery-stable for sereral weeks they were sold by the United States marshai, and the day after the sale it was found that one of them, a fine black gelding, was affected with plainly dereloped nasal glander's, and had commmnicated the disease alrearly to his stall-mate, which exhibited sufficient symptoms, a slight discharge from the right nostril and a characteristic swelling of the right submaxillary lympluatic glankl, to warrant the diagnostication of glauders. After the discorery had been made, it leaked ont that the black gelding" had been "runniug from the nose" for over eight months. When the sale took place, some of the livery and boarding horses hat not yet fully recorered from their influenza. "Nor, if one or" more of the same should hare become infeeted with glanders, and if the merelr accidental discovery of the existence of that disease in one of the cirens-horses had not been marle, the cry would have been raised immediately that glanders had dereloped from influenza. Further eomments, I think, are unnecessary. It may suffice to suggest that a great mauy apparent developments of glanders firom other diseases may lave taken place in a similar way. There also can be no doubt that a great many cases of occult glanders (so-called nasal gleet) have been looked upon and treated as distemper, catarrh, iutlnenza, \&e., and afterwards, when plain symptoms of glanders made their appearance, it was more convenient all around to suppose that glanders had pro- 
ceerled from the disease first diagnosticated, than to admit a diagnostic mistake. So with farey. It undorbterlly has happened a great mary times that the first srmptoms of farey have been mistalien for an inflammation of the lympluaties, and as farey in its further course becomes fres quently complicated witl glanders, it is east to conchide tlat an inflammation of the lymphatics constitutes a primary disease of glanders. Under certain circumstances $I$ admit it is rather dififenlt to discriminate at once an inflammation of the lymphatics and subsequent ulceration on formation of abscesses from genuine farcy, and so mistakes, undoubtedly, have occurred.

Besides all that, the diseases looked mpon as the possible progenitors of glanders are similar to the latter only in regard to a few external symptoms but entirely different as far as the morbid process is concerned. They lack altogether, during their whole course, from first beginuing to their fixal termination, the specific characteristies of glanders, and a conversion of any one of them into the lattel clisease must be looker unon as just as impossible as it is to change a cow to a horse, or a goat to a hog. Still, this does not exclude the possibility of an animal affected with one of those disorders, or with any other clisease, becoming infected with glanders or farcy. On the contrary, a diseased condition of the respiratory mucons membranes seems to facilitate an infection, if an exposure to glanders contagion is taking place. At any rate, the morbid process of glanders is always much more riolent, and makes a more rapid progress in a diseased organism, than in one that is otherwise perfectly bealthy. To get at the bottom of the facts and to guard against mistakes, it will be necessary never to lose sight of the specific characteristics of the glanders process.

Notwithstanding all those cases of apparent denteropathic development of glanders, which ean be found in tine veterinary literature of nearly every comtry, I am not afraid to say I do not believe that a case of real deuteropathic glanders, one that can stand a thorongh and unbiaserl inrestigation, has ever occurred. Gerlacl, in his treatise, repeated!y mentionerl, says, on page 115 , "A gemuine dlevelopment (pro. topathic and denteropathic) mist be considered as not proved."

Glanders, as well as pleuro-pnemmonia, Russian cattle-plagne, and scab and mange, will cease to exist if a propagation by means of infection is mate impossible. If, for instance, within the limits of the United States all animals affected with glanders were destrojed at once, and at the same time erery place where glanders-contagion may be existing were thoroughly disinfected, and if any importation of glandered horses or of the contagion were successfully prohibited or prevented, glanders would at once become extinct, and would nerer make its appearance again within the limits of the United States, unless imported again from other conntries. It is a disease that can be eradicated.

I said before that glanders is most frequent in those conntries in which ummerous horses are imported from other countries. This is an undeniable fact, except in regarl to those commonwealths in which good reterinary schools provide a sufficient number of thoroughly educated veterinary surgeons, and in which stringent laws enforce the immediate destruction of every animal affected with glanders, prohibit veterinary quackery, and do not allow anyborly to keep or to treat a glandered animal unless he is a qualified veterinary surgeon, and gives sufficient bonds to pay possible damages.

I know very well that I shall be contradicted, but mere denials, or questions asking where glanders originally comes from, if a spontaneons derelopinent does not take place, will not do. Such questions, of 
course, I cannot answer. When Gerlach first pronounced pleuro-pnenmonia of cattle a pure contagion, that is, a clisease propagated exclusively by means of infection, Professor Spinola asked pertly if Gerlach had imported pleuro-pneumonia from the moon, but failed utterly-and everybody else, too- to show a solitary case of an unmistakable and wellanthenticated spontaneous development. If any one can show me a case of spontaneous glanders, not caused by infection, or give satisfactory and unmistakable proof that a protopathic or deuteropathic development of glanders has occurred, I will take back what I have said, but not before.

The contagion.-The contagion must be considered as the exclusire cause of glanders. When I lived in Dixon, Lee county, Illinois, from the fall of 1865 to September, 1868, I had an opportunity of observing numerous cases of glanders. A friend of mine, D. W. McKinney, dealer in horses and proprietor of a livery-stable, knew nearly every horse in the whole county, and taking special interest in those cases of glanders, assisted me in inquiring into the history of every horse affected. As a result, every case, without exception, was traced back to an infection by condemned United States army horses that had been sold to the farmers.

The contagious principle is dereloped during the very first stages of the disease, and even before plain symptoms have made their appearance. It exists most concentrated in the immediate products of the morbid process, but especially in the discharges from the nose, and in the contents of the glanders and farcy ulcers. It is present also in all the secretions and excretions of the affected animals, as has been proved by numerous direct experiments. Professor Gerlach, in order to ascertaiu if the contagion is contained not only in the fluid animal humors and excretions, and in the fluid and solid products of the morbid process, but also in the pulmonal exhalation and in the perspiration, has made several interesting experiments, and has found that an inoculation of a healthy horse with artificially condensed exhalation aud perspiration of a glandered animal produces the disease. He has, however, not succeeded in communicating glanders by injecting defibrinated blood of glandered horses (100 and 200 grains respectively) into the veins of healthy animals. Still, the contagiousness of the blood has been established long ago by Abildgardt and Viborg in Copenhagen.

The experiments of Gerlach and of others, and numerous cinical observations, too, have proved beyond a doubt that the contagion contained in the exhalation and perspiration clings, though only in small quantities, to the aqueous vapors exhaled by the respiratory organs and perspired by the skin. The contagious principle, therefore, is volatile only in a limited degree, and to produce an infection by means of the exhalation and perspiration at a distance of several feet requires usually some length of time. So it happens very often that a horse occupying with a glandered horse the same stable, but not the same stall, remains exempted. The more forcible and aceclerated the breathing, and the more abundant the perspiration of the horse affected with glanders, the greater, it seems, is the danger of an infection of healthy horses that are near, or oceupy the same stable.

Another question not easily answered, and yet an object for investigation, may bo asked; that is, Do organic forms constitute the contagion; is the contagious principle bound on, or inseparable from, organic forms; or is its action merely a chemical one? On this question the opinions of the best authorities differ. Professor Gerlach, in his successful experiments with condensed exhalation and perspiration, found no organic forms whatever in the perfectly limpid drops; further, he 
found no organic forms in the rery infectious caseons substances taken from the mucous membrane of a horse affected with diphtheritic glanders. He, therefore, has come to the conclusion that the glanders-contagion does not consist in, nor is bound on, organic forms, and that the action of the contagious principle must be a chemical one. On the other hand Hallier and others have found organic growth (micrococci) in the humors of glandered horses and in the products of the morbid process of glanders, and are inclined to consider those micrococci as the agency which causes the disease, produces the morbid changes, and effects a communication of the glandered process to other healthy animals. If Hallier and others are right, a great many mysterious phenomena obserred in glanders find an explanation, but if Gerlach's observations are correct, Hallier's theories necessarily fall to the ground. Gerlach says : "Hallier finds everywhere fungi, and Chaurean finds everywhere cells." Still, notwithstanding my high regard for Gerlach and the thoroughness of his investigations, I think the finds of Hallier and of other investigators cannot be discarded; positire evidence is always of more value than negatire proof. Haeckel (History of Creation, vol. 1, Protista.) and Klebs (Archiv fuer experimental-Pathologie, 1873), separate the microscopic organisms found in glanders and in other contagious diseases from the class "fungus," and consider them as a separate class, belonging neither to the animal nor to the regetable kingdom. Whaterer may be the truth as to the real nature of the contagious principle, future investigatious must rereal. I myself have had no opportunity" to make thorough microscopical investigations of the morbid products of glanders, and can, therefore, not adrance any definite opinion of my own. Mere speculations cannot bring any facts to light; thorough and patient observations are necessary.

The glanders-contagion, whatever its nature may be, communicates glanders and farcy not only to the animals belonging to the genus equus, but also to other animals and to man. Numerous cases are reported every year in the periodical reterinary literature. The only domesticated animal that seems to be exempted, or to be destitute of any predisposition is the ox.

Glandered horses, as soon as the disease has been diagnosticated, are usually remored to the cow-stable, or to pens or places where cattle are liept, and still no case, as far as I hare been able to learn, is on record in which an ox or a cow has contracted the disease. Sheep are easily infected. Goats, too, possess sufficient predisposition. Ercolani described a case in "Il medico veterinaria," 1861, and Wirth succeeded in communicating glanders to a male goat by means of inoculation (Avchiv fuer Thierheilliunde, Bd. 6, Heft 1, 18t4). Hogs seem to possess but little predisposition, and cases of dogs becoming infected and dying of glanders have been communicated by Nordstroem (Tidskrift for Veterinairer, etc., 1862) and Langeron (Revue vétérinaire, etc., Toulouse, série I, 1876). Several cases are on record in which wild animals, lions especially, have beeome infected with glanders by being fed with meat of glandered horses. According to the experiments of Viborg and Ringheim, the flesh of a horse affected with glanders can be eaten without danger of infection if properly cooked or fried.

One important phenomenon must be mentioned, and that is, that glanders always becomes a frequent disease after any great war. Such was the case in our own country after the great civil war, as I have mentioned before, and also in Germany and France, hut especially in the latter country, after the war of 1870-'71. Cases of glanders will also be frequent during the next few years in the Turkish Empire, and in those 
Turkish provinces which hare become independent, or separatei from the Ottoman territories. The canse of this frequency is an obvions one. It eonsists in the abmudant opportunity of infection. One horse aftected with (occult) glanders in either of the hostile armies can, for obvious reasons, communicate the discase with the greatest fucility to a largo number of animals. The firet of glander's becoming freyuent after each lurge war has been ised rery frequently as an argument in faror of a protopathie rerclopment, but if it is looked npon in a proper light it proves, if anything, the exclusive spreadiug of the disease by means of the contagion.

Precention and treatment.-As to a medical treatment, there is scarcely a remedy luown in the whole materia nedica that has not been used against glanders, but, so far at least, with rery poor suecess. It is true a great many pretented cures are on record. But if the slow or chronie progress of the morbid process, its frequent rewisslons in warm and dry weather, exacerbations in rongh, cold, and inclement weather aud in a foul atmosphere, and the great confusion that has prevailed in regard to the true nature of glander's are talien into considezation, it is no wonder that mistakes and cleceptions hare occurred. Some of the cases that are said to have been cured have been no glanders at all, and in others the pretended cures have been only temporary-a mere remission. Confirmed glanders must be considered as incurable; and it would, therefore, be for the benefit of every one if our general government (Congress) would enact a law which should make it a (riminal oflense to keep and to use a horse, or any other aninal, known to be aftected with glanders. Any attempt to cure should also be strictly forbidden, because a prompt and immediate destruction of every animai aftected with clanders, a disease which spreads only br means of its contagion, coustitutes the best, surest, and cheapest, and in fact the only prerention.

A case of recent occurrence will serve to illustrate how glanders spreads, and how much cheaper it is to destroy a glandered horse at once than to permit the same to communicate the disease to healthy animals. It will also slow the necessity of a stringent law waking the sale of an animal linomz to be affected with a contagious discase a criminal offense.

Last fall Mrr. George T. . . . . Pottanatomie county, Kausas, bought a horse of a Mr. Cli. .. Manhattan, Riley eonnty, Kausas, and pastured and stabled the same with his other horses, about twenty-four or twenty-five in number. The horse in question, when bought, had some discharge frow the nose, which, of course, was pronounced to be nothing but the product of eatarrh-in common parlance, a cold. In the course of the winter sereral of Mr. T. . . . 's horses commenced to hare clischarges from the nose. Mr. T. . . . became alamed, and brunght the new hor'se, whose nasal discharges had increased, and who showed other symptoms of ciisease, such as a staring coat, enaciation, sce, to me for examination. I found the symptoms to be those of an ationced stage of glanders. Subsequent inquiries rerealed some of the previous history of the animal. J4. Ch. . . had bonght the horse fiom another man, whose name I do not remember, only a fer days before he sold the same to IIr. 'l. . . . , and had kept the animal, while in his possessiou, strictly separated from his ofler horses, because he knew that the same had a chronic discharge from the nose, and had had it for about two years. Is not such a transaction erininal? And still, in the ease mentioned, there is 110 redress to be had. Mr. "1. . . . is a compantively poor man; lis farm is nolt gaged, and all the property he may eall his own consists in his stock, but especially in his horses. As I noved aray from Liansas 
early in the spring, I luave not learned how many of his horses have become aftected, but several had contracterl the disease before I left. Besicles that, his horses had been together quite often with those of his neighbors, on the prairie, betore he knew them to be affected with glanders. It is possible that he has lost, or will lose, nearly erery animal he has. Mr. Ch. . . does not own anything; all his property is in his Wife's name; consequently Mr. T. ....., if he suos for damages, will have to pay lawyer's fees and costs, but cannot recover anything. If there rore a United States law which made it a eriminal ofiense to soll animals affected with contagious diseases, or to own and to keep amimals which exhibit symptoms of contagious discases, and to nenlect to advise the proper authorities of the fact, such eases as the one related would not oceur. If MI: T. . . . were not an honest nan, he would undonbtedly have liept still, and would have sold his glandered horses to other innocent parties, aud contributed in that way in spreading the disease. I could relate numerous similar cases, but think this one will suffice, especially as this article is already too long.

A successful prevention of glanders is possible only if the contagionwhich, even if it should not constitute the sole and only cause of the disease, eauses at least nine hundred and ninety-nime eases of one thousand-is thoroughly destroyed wherever it may exist or whererer it inay be found. Consequently every animal affected with glanders should be killed as soon as the nature of the disease becomes linown, and be buried sufficiently deep or be cremated. But as the contagion adheres frequently also to the stables-manger, Hoor, partition, Sc.-that have been occupied, the stable uteusils-brush, curry-comb, Ee., and the hamess, blankets, halters, bridles, saddles, \&c.-that hare been used or been in contact with glandered horses, it is of great importance to know what will best aud most effectually destroy the contagion. Professor Gerlach has made very interesting and valuable experiments, to relate which, however, would lead too far. I will therefore only state the results arrived at. The discharges from the nose, glanders-matter, \&c., lose their infectionsuess if perfectly dried by being exposed to currents of air or to the rays of the sum; but kept moist, for instance in a daup cellar, wrapped up in a moist rag, or alhering to the cormers of the manger, to a damp wall or tloor, or to the bedding or the manure, \&c., the contagion seems to possess great vitality, and may remain effective for half a year or longer. Putrefaction does not destroy the contagious principle. Chlorine destroys the contagion, and is therefore a very efficient disinfectant, proviled the chlorides used come in actual contact with the contagion. A brief exposure of the infections substances, nasal discharges, glandersmatter, \&c., to the inthence of chlorine in a gaseous state, mixed with the atmosphere, is ineflective. As a remedy to be giren internally, chlorine, in slitpe of chlorine-rater, for obvious reasons camnot be used; chenical combinations will be effected before an absorntion can take place. The best and surest destroyer of the glanders-contagion is carbolic acid. It may be used not only as a disinfectant or for the pulpose of destroying the contagion clinging to the rood-mork of the stable Ec., but also in incipient eases of farcy, anci in cases in wlich an infection with slanders-matter has just taken place in a wound, tor instance, as a local remedy. If applied to the glanders-nlcers on the septum, or to farey-ulcers, a tendeney to heal will make its appeanunce. As a clisinfectant, a solution of carbolic acid in glycerine or alcolıol and water $(1: 1$ or $2: 20)$ is perfectly stroug euough to be effective. Old stratw, haj, and berlding must be burued, aud blankets, \&c., are best disinfected 
by exposing the same for some time to a temperature of $2120 \mathrm{~F}$., or higher, either in an oven or in boiling hot water.

As to a therapentic treatment only a few words will be necessary. Some of the most heroic medicines have been used with very donbtful results. So, for instance, Professor Ercolani, in Turin, claims to hare had good success with arsenate of strychmine, but others who hare made the same experiments have had no success whatever. Lacaze (Rerue Vétér., \&ic., Toulouse, 1876), asserts to have been successful with large doses of alcohol, but he discriminates contagions and noncontagious glanders, and so no comment will be necessary. In former times cantharides mere considered as a remedy, but later investigations lave proved them to be perfectly worthless. That every kind of mercurial combination and a great many sure-eure nostrums have been used and been adrertised as specific remedies, as in every other incurable disease, is too self-evident to need any further mentioning.

The only rational treatment of a horse or other animal, affected with glanclers, consists in a proper and effectire application, in the right place, of either half an ounce of lead or fire inches of steel; and until such treatment is invariably adopted, or made compulsory, there will be no prospect whaterer of freeing this comntry from this loathsome disease, dangerous eren to man, in whom, if once infected, it is just as incurable as in horses. 


\section{INDEX.}

Alabarma, chiseases of farm animals in . ..........

Alabama, diseases of farm animals in ............................ 186,211

Appropriations for investigating diseases of farm auimals................ 5,220

Arkansas, diseases of farm animals in ................................. 187, 213

Autopsies in swine disease........................... $33,49,55,59,103,128,142,174,184$

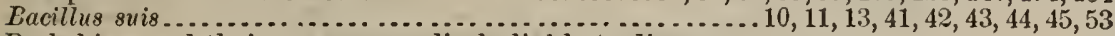

Berkshires aud their crosses peculialy liable to disease ................. 178

British Government rules for treating plenro-pnewmonia and riuderpest ..... $\quad 251$

British orders in council conceruing cattle imports..................... 227

Califoruia, diseases of farm animals in . . . . . . . . . . . . . . . . . . . . . . . . . 187

Cattle export trade, British orders in council ........................... 227

Chieago stock-5ards full of diseased animals ............................. 164

Colorado, diseases of farm animals in ............................... 188

Commissioner's letter to Hon. A. S. Paldock on pleuro-pnenmonia.......... 219

Commissiou to iuvestigate diseases of farm animals in ................ 5

Congressional action necessary to arrest cattle disease .................. 221

Contagion in swine disease ........................................ . 9, 39, 165

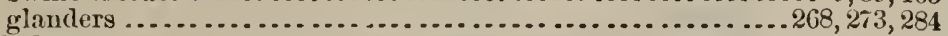

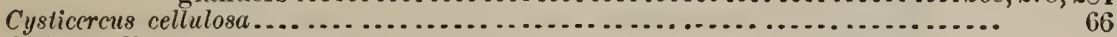

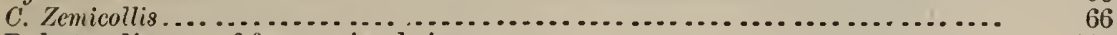

Daknta, disease of firm animals in .............................. 188

Deaths of swine, nnmber and percentage of ........................ 124

Delaware, diseases of farm animals in ............................. 188

Detmers, Dr. J. H., pa per on glanders ............................... 257

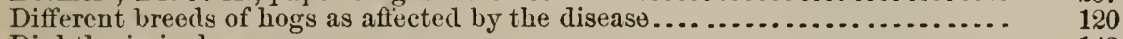

Diphtheria in hogs........................................... 143

predisposing eanses............................... 144

Diseased hogs butchered and packed for market........................ 164

Diseases retarded by extreme cold ................................... 6

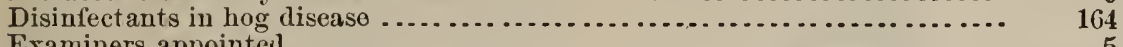

Examiners appointed ............................................ 5

Experiments in hog disease..........................................

Farcy, common (subcutancous glanders) ............................. 262

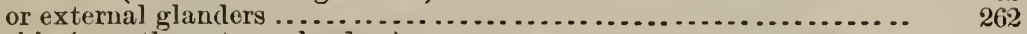

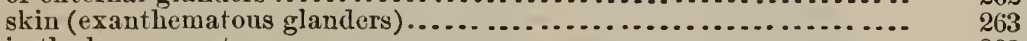

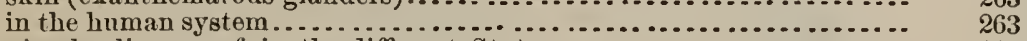

Farm animals, diseases of, in the different States....................... 186

total losses by disease................................ 5

Florida, diseases of farm animals in . . . . . . . . . . . . . . . . . . . . . . . . . . . .

Germs, morbific, in hog diseases.................

Ascaris lumbricoides..................... 185

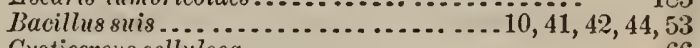

Cysticercus cellulosa ....................... 66

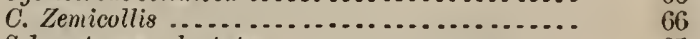

Sclerostomuin dentatum ..................... 65

Stongylus elongatus ......................... 63

Tricocephalus dispai........................... 64

Georgia, diseases of farm animals in ................................ 189

in the wucous membrano ..................... 278

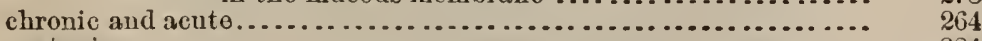

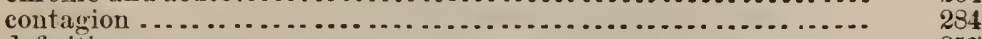

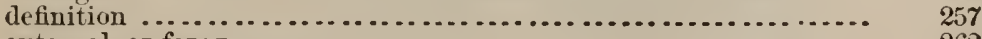

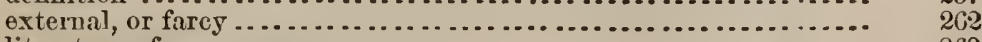

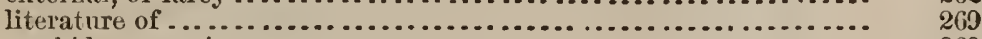

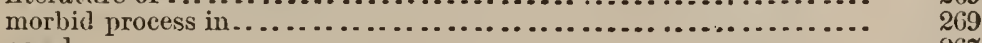

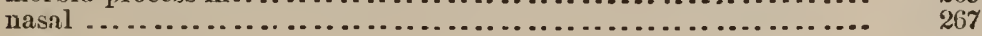

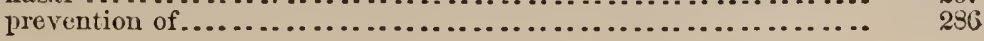


Glanders, spmptons........................................... 260, 264

post-mortem indications.............................. 261

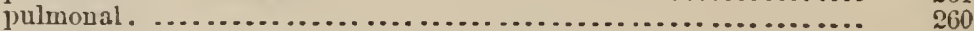

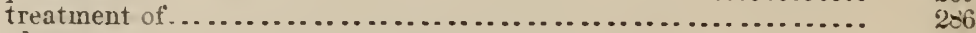

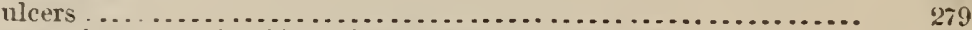

Hog-cholera a misuomer; should he classed with exanthemata............. 165

detinitiou. ........................................... 136

has all the characters of gastro-enteric ferer in man ......... 186

Ilog disease, action of Congress invoked ............................. 164

afiecting difterent breeds of hogs ........................ 120

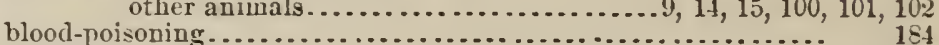

can it be etfectually quarantined $1 . . . \ldots \ldots \ldots \ldots \ldots \ldots \ldots \ldots \ldots . . . \ldots \ldots$

causes ...................................... 42, $70,136,166,175,178$

hogs eating grain left by fattening cattle .............. 17s

too cluse breeding ............................. 178

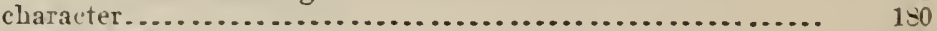

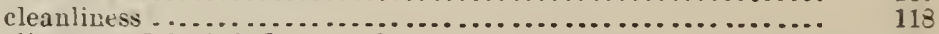

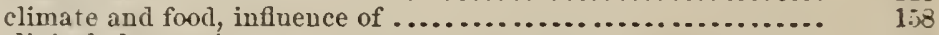

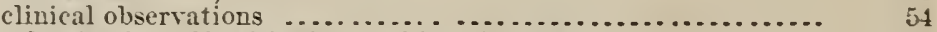

cohabitation of healthe hogs with sick ones................. 99

communicated bs passing car and wagon loads of infected hogs.. 150

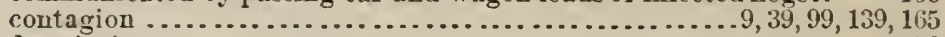

description ........................................ 20

destruction in many cases the only remedy .................. 139

diagnosis ............................................ 116

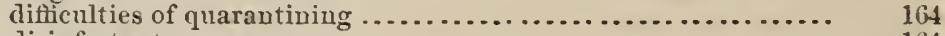

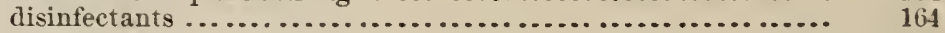

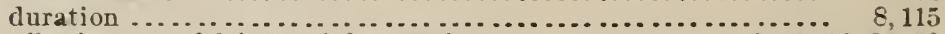

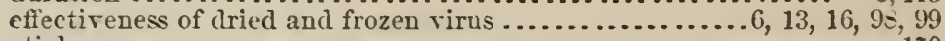

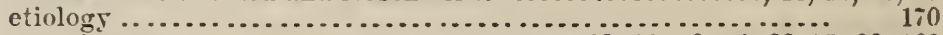

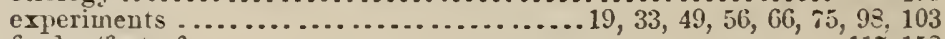

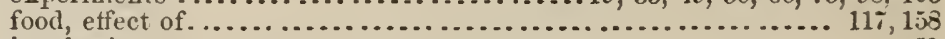

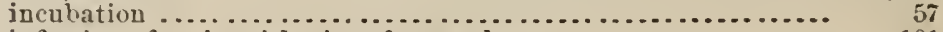

infection of a pig with virus from a sheep.................. 101

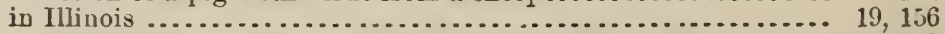

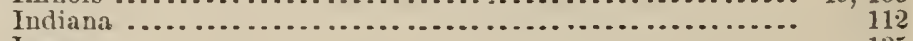

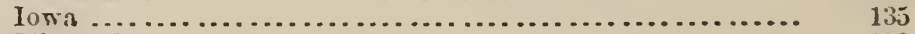

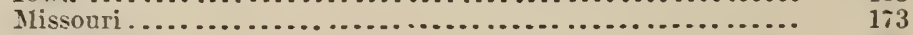

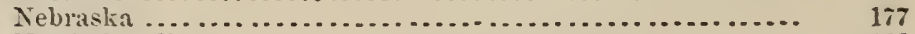

North Carolina....................................... 123

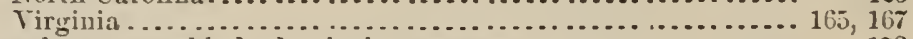

largely preventable by hrgienic mensures.................. 173

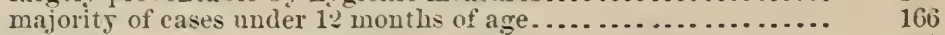

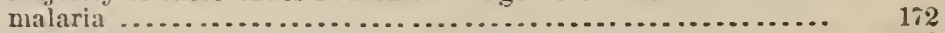

modes of attack, first molle .......................... 179

second 1 wode ........................... $1 \geqslant 0$

morbific germs........................... $41,42,44,53,64,65,66,158$ more fatal in summer and fall ........................ 6 measures of arrest aud ('xtirpation ...................... . . 139,181

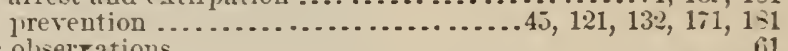

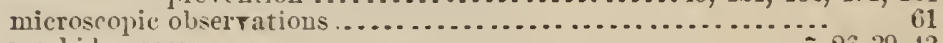
morbid process .......................................... $26,39,43$

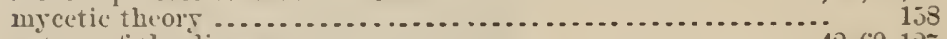

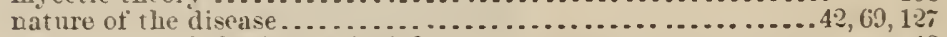

infectious principle........................ 42

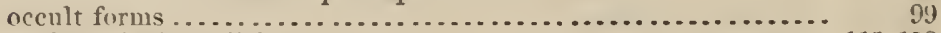

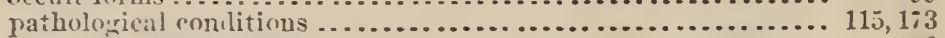

per cemt. of tatal cases . . . . . . . . . . . . . . . . . . . . . . . . . . . . . $1=6$

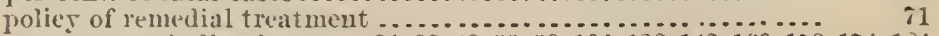

fost-inortem indications. . ... $31,33,49,5 \dot{3}, 59,103,123,142,160,1 ; 0,1 ; 4,184$

jrevalence ........................................ 113

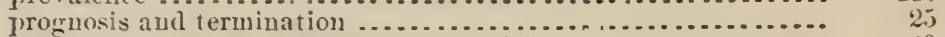

propagation through inhalation doubtful ................... 40

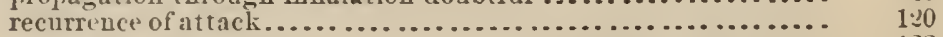

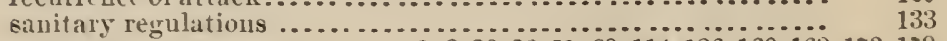

syinptolus $\ldots \ldots \ldots \ldots \ldots \ldots \ldots \ldots .7,8,20,2.57,69,114,120,160,169,173,179$

вупоптия ....................................... 19

treatnient $\ldots \ldots \ldots \ldots \ldots \ldots \ldots \ldots \ldots \ldots \ldots \ldots \ldots \ldots \ldots .43,52,12 ., 169,1 ; 2,1 ; 6,151$ 
Ilog discase, tumors .....................................

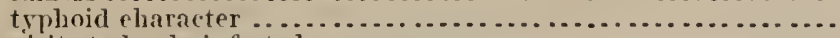

Page.

11,44

visits to herds infected ................................... 161

virns, dried or frozen, effectireness of $\ldots \ldots \ldots \ldots \ldots \ldots \ldots \ldots, 13,16,98,99$

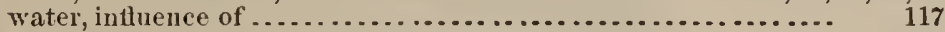

Ilogs in health, treatment, food, and quarters ........................... 178

losses from disease .......................................... 5,124

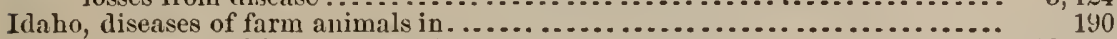

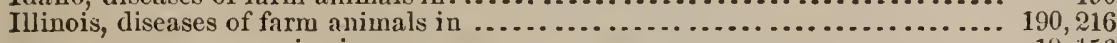

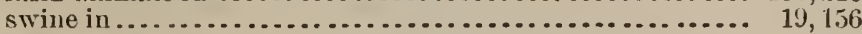

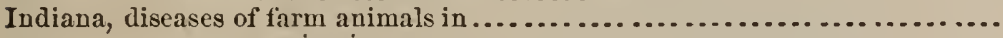

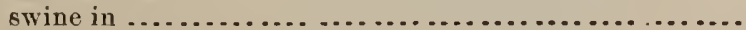

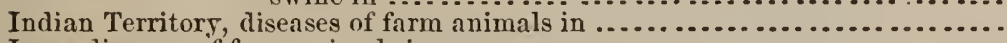

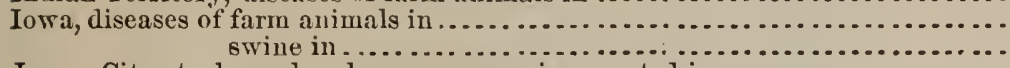

Jerser City stock-yarls, pleuro-pneumonia reported iu .......................

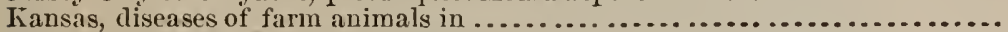

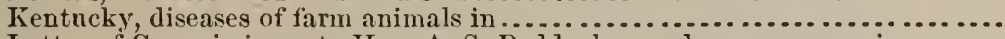

Letter of Commissioner to Hon. A. S. Paddock, on pleuro-pneumonia........

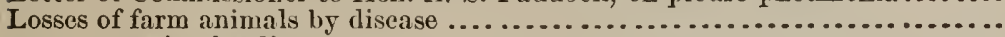

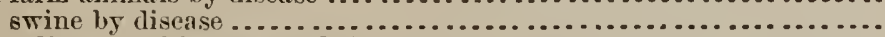

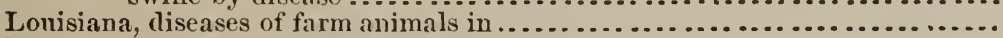

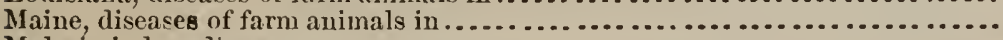

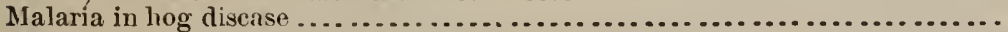

Maryland, diseases of farm animals in . . . . . . . . . . . . . . . . . . . . . . . . .

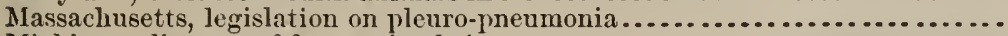

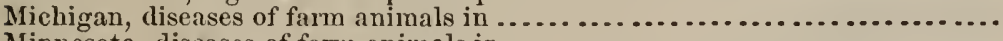

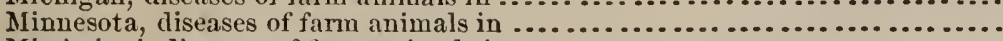

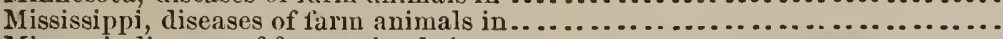

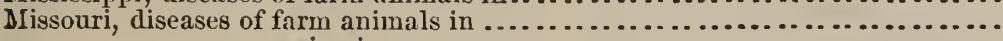

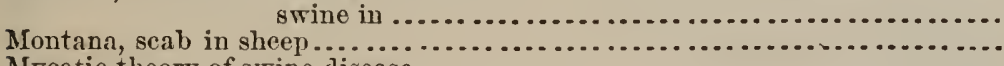

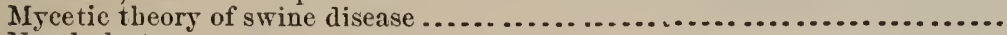

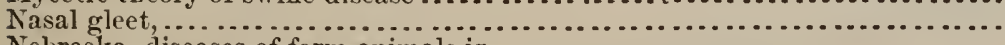

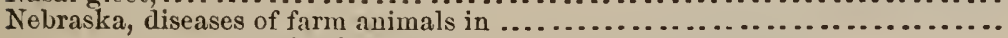

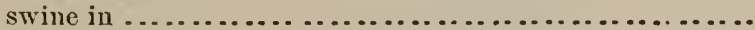

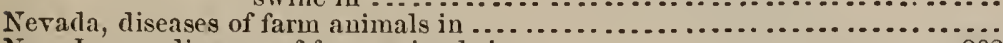

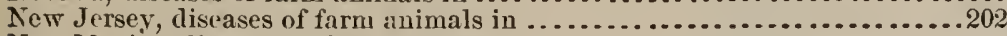

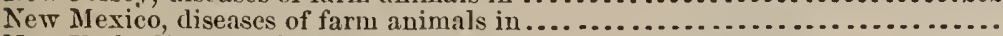

New York, diseases of firm animals in . . . . . . . . . . . . . . . . . . . . . . . . . . .

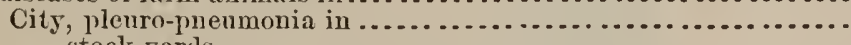

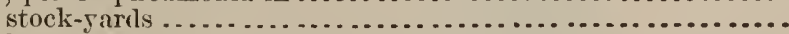

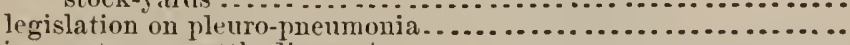

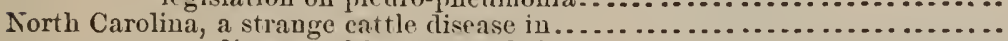

diseases of farm animals in ..............................

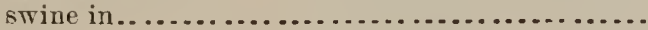

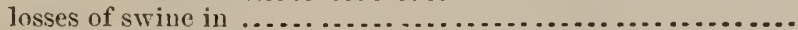

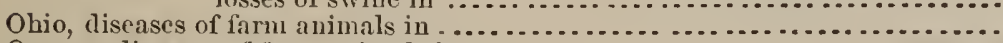

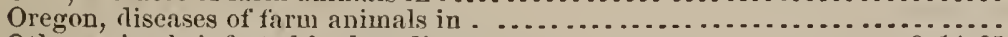

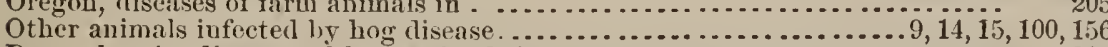

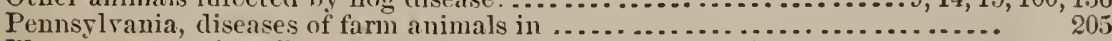

Pleuro-pneumonia, affected auimals should be promptiy lilled ............. 239 in and around New York City ..................... 237, 240

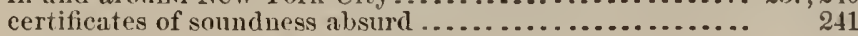
cirenlar of the Secretary of the Treasury ............... 226

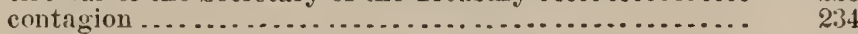
correspondence of Commissioner with Secretary of the Treasury. ....................................... danger of infecting our u fenced stock-ranges ........... 229, 239 inoculatiou .............................. 238

trying to cure infected animals ............... $\quad 239$

English "contagions disenses" act .................... 232

gradnal exteusion west ward ........................ 228

history, nature, symptoms, and treatinent ............... 242

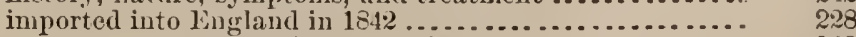

United States in $1843 \ldots \ldots \ldots \ldots \ldots \ldots \ldots \ldots \ldots . . . \ldots \ldots$

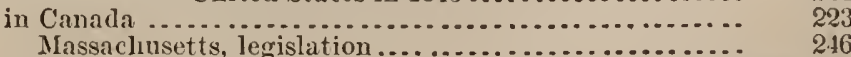

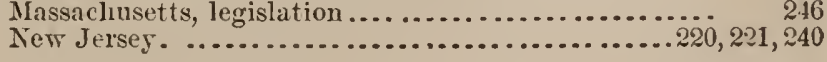




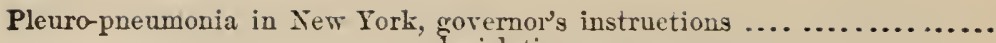

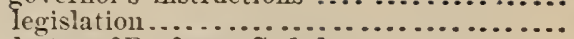

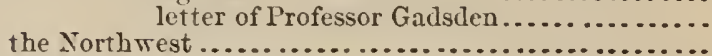

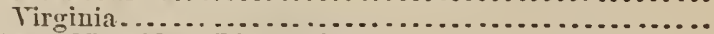

letter of President Liantard...........................

Professor Billings .........................

Professor Law ................................

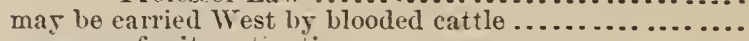

measures for its extinetion..........................

must be stamped out .................................

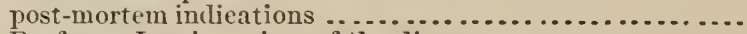

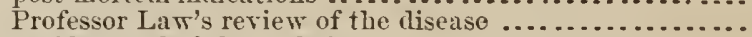

rapid sprearl of the malady ...........................

rules of the British Govermmeut against ...............

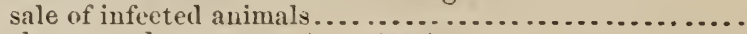

the general goverument must act ........................

the great dlanger of our stock interests ...............

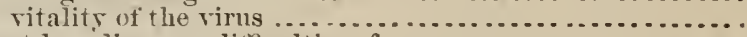

Quarantining agaiust log disenses, litficulties of . . . . . . . . . . . . . . . .

Rinderpest, British Gorermment rules against. ........................

letter to the Commissioner from Professor Gadsden.................

Sclerostomum dentatum

Secretary of the Treasure, eorrespondence of Commissioner with ...........

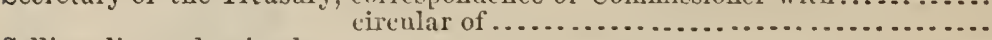

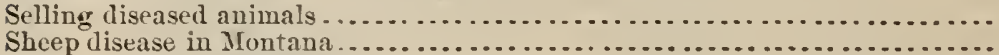

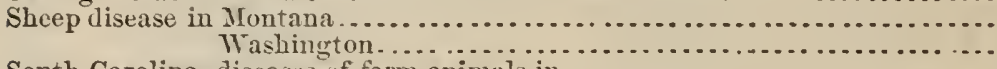

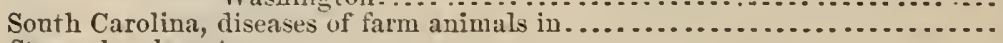

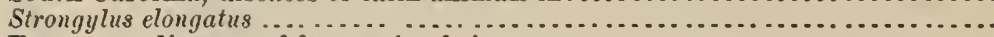

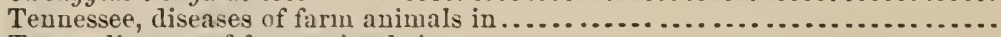

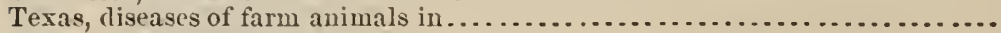

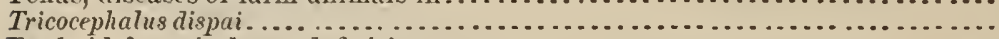

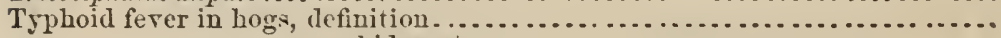

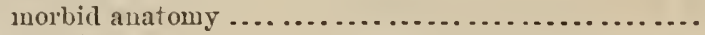

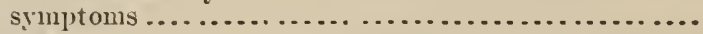

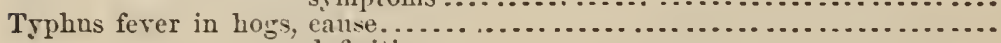

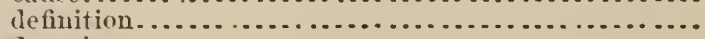

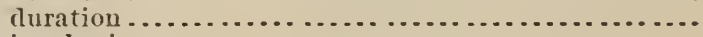

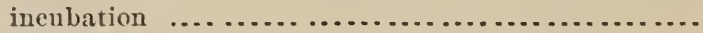

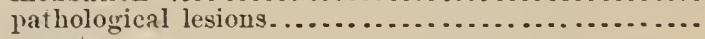

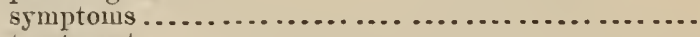

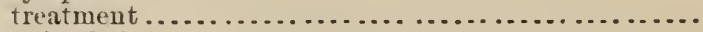

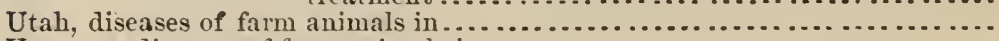

Vermont, diseases of farm animals in . . . . . . . . . . . . . . . . . . . . . .

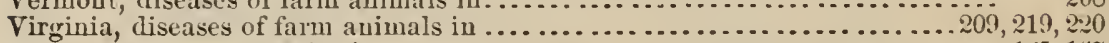

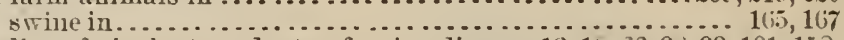

Virus, continued vitality of rirmlent products of swine disease. $13,16,3 j, 93,99,101,158$,

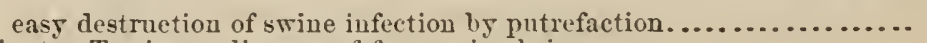

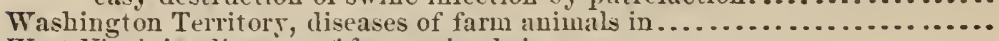

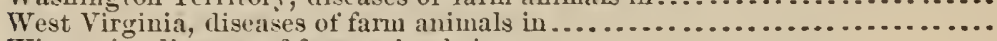

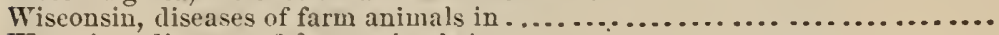

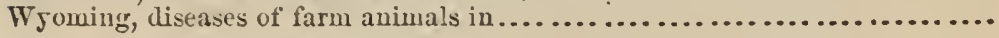







$$
\text { - }
$$


